

\section{Cornell University Library}

The original of this book is in the Cornell University Library.

There are no known copyright restrictions in the United States on the use of the text.

http://www.archive.org/details/cu31924090288600 




CANADA

DEPARTMENT OF MINES

Hon. Martin Burrell, Minister; R. G. McCunnell, Deputy Minister.

GEOLOGICAL SURVEY

William McInnes, Dirfecting Geologist.

MEMOIR 104

No. 3, Biological Series

\title{
Birds of Eastern Canada
}

\author{
BY \\ P. A. Taverner
}

111

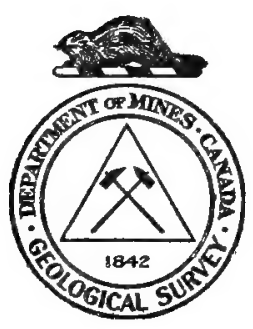

OTTAWA

J. DE LABROQUERIE TACHÉ

PRINTER TO THE KING'S MOST EXCELLENT MAJESTY

1919 

Introduction. . . .

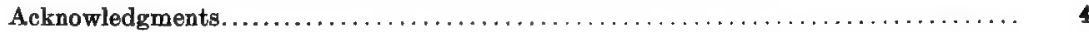

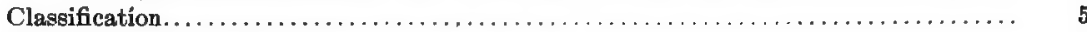

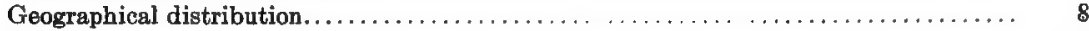

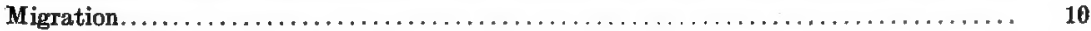

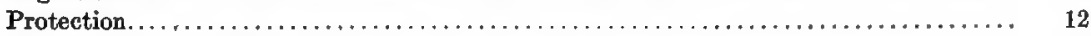

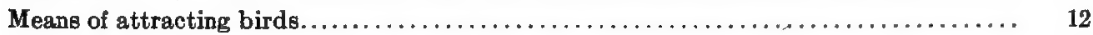

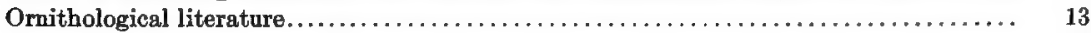

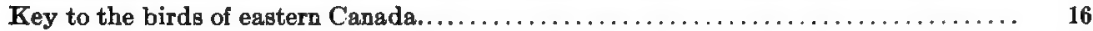

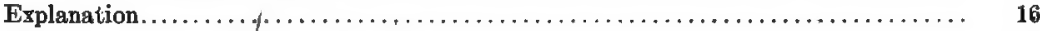

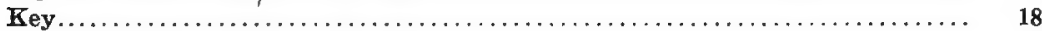

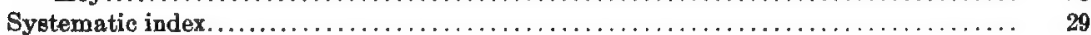

Descriptive ornithology $\ldots \ldots \ldots \ldots \ldots \ldots \ldots \ldots \ldots \ldots \ldots \ldots \ldots \ldots \ldots \ldots \ldots \ldots \ldots \ldots \ldots \ldots, 41$

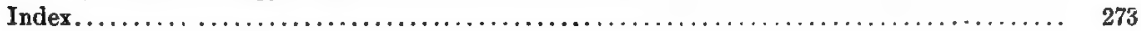

\section{Illustrations.}

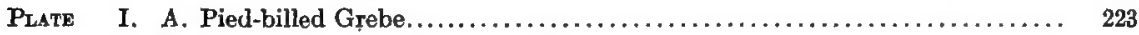

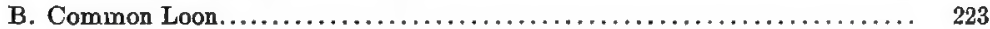

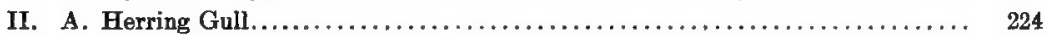

B. Common Tern.................................... 224

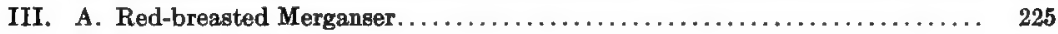

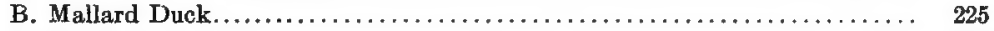

IV. A. Black Duck ........................................ 226

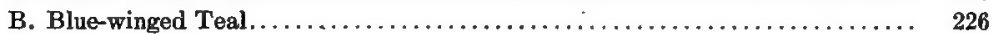

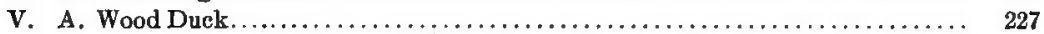

B. Canada Googe..................................... 227

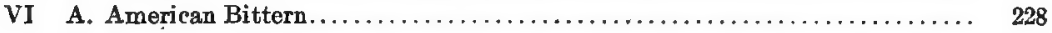

B. Great Blue Heron.................................. 228

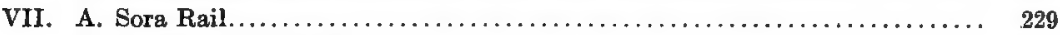

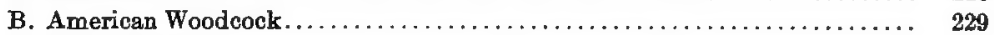

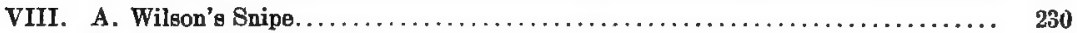

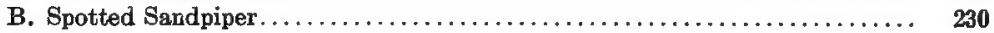

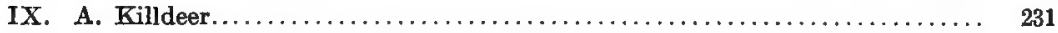

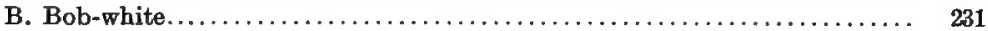

X. A. Spruce Grouse. ..................................... 232

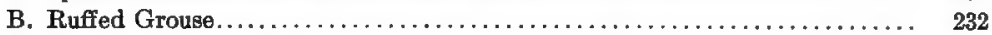

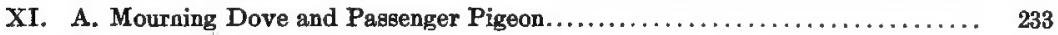

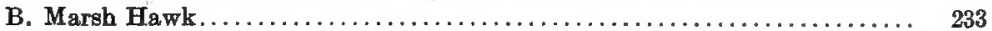

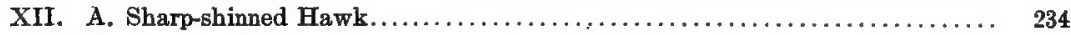

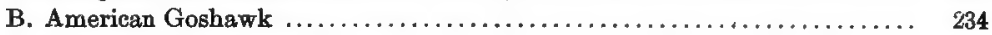

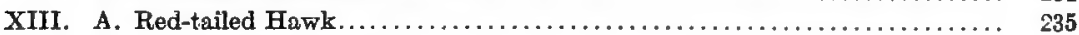

B. Red-shouldered Hawk. . . . . . . . . . . . . . . . . . . . . . 235

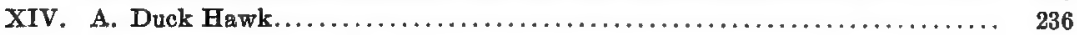

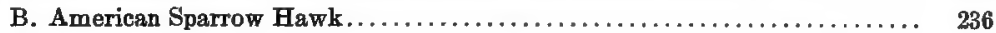

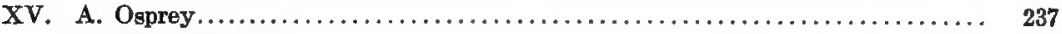

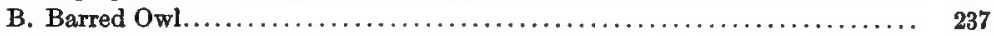

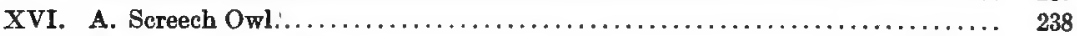

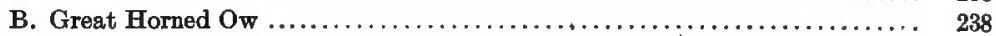

XVII. A. Black-billed Cuckoo; Yellow-billed Cuckoo....................... 239

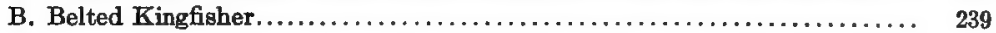

XVIII. A. Downy Woodpecker.................................. 240

$57172-1 \frac{1}{2}$

B. Arctic Three-toed Woodpecker............................. 240 
PAGE

XIX. A. Yellow-bellied Sapsucker................................. 241

B. Pileated Woodpecker.................................... 241

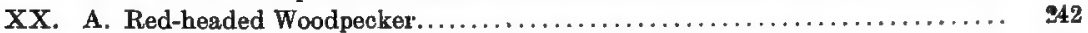

B. Flicker. . . . . .

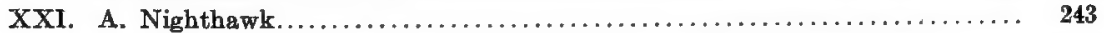

B. Chimney Swift.................................... 243

XXII. A. Ruby-throated Hummingbird............................. 244

B. Kingbird . . . . . . .

XXIII. A. Phoebe $\ldots \ldots \ldots \ldots \ldots \ldots \ldots \ldots \ldots \ldots \ldots \ldots \ldots \ldots \ldots \ldots \ldots \ldots \ldots \ldots \ldots \ldots \ldots \ldots .245$

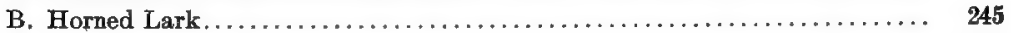

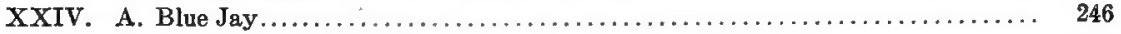

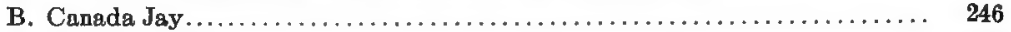

XXV, A. American Crow ...................................... 247

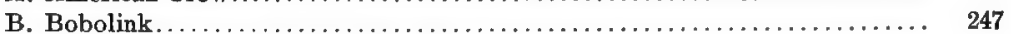

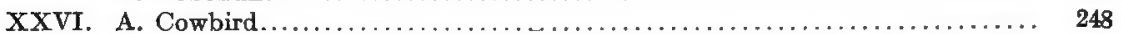

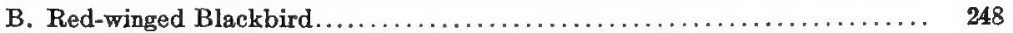

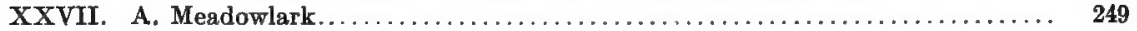

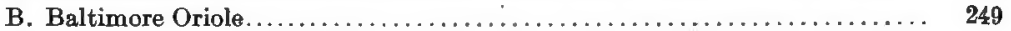

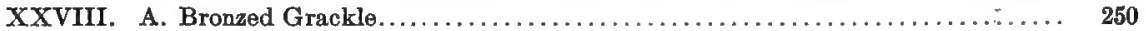

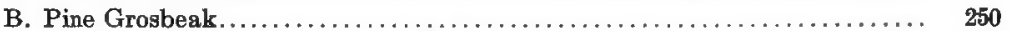

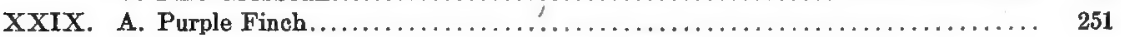

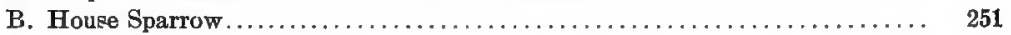

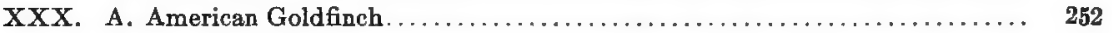

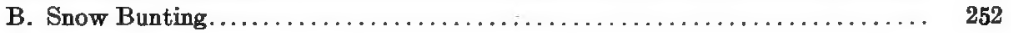

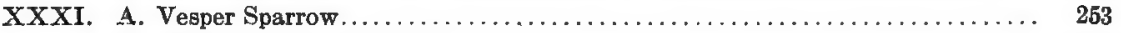

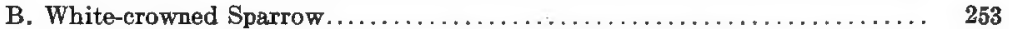

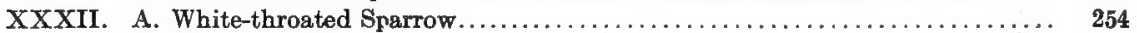

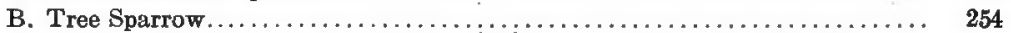

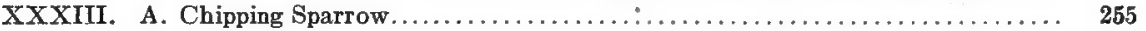

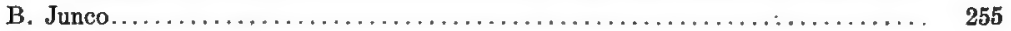

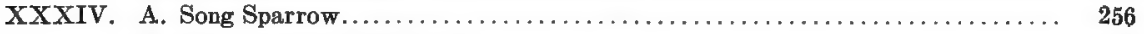

B. Rose-breasted Grosbeak............................... 256

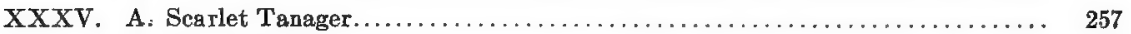

B. Purple Martin ..................................... 257

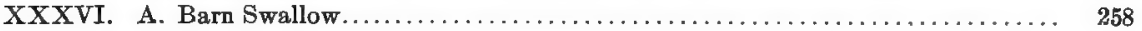

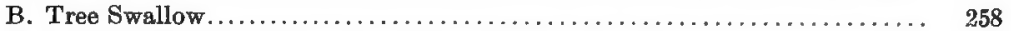

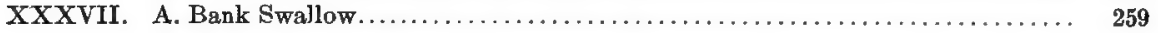

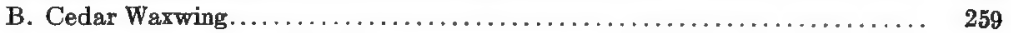

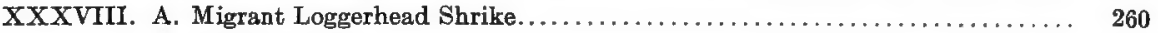

B. Red-eyed Vireo...................................... 260

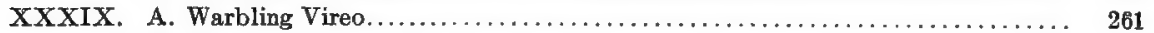

B. Black and White Warbler............................. 261

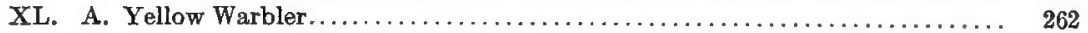

B. Black-throated Blue Warbler........................... 262

XII. A. Myrtle Warbler.................................. 263

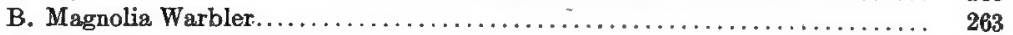

XLII. A. Blackburnian Warbler.................................. 264

B. Black-throated Green Warbler.......................... 264

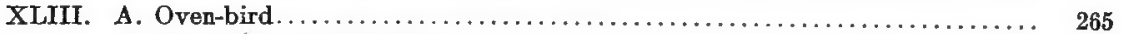

B. Northern Yellow-throat.............................. 265

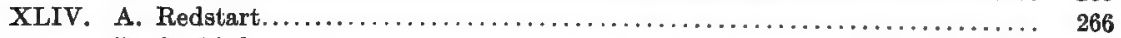

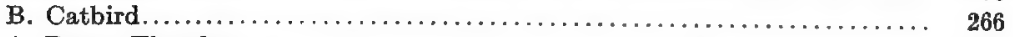

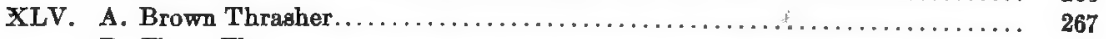

B. House Wren....................................... 267

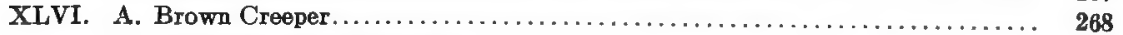

B. White-breasted Nuthatch............................ 268

XLVII. A. Chickadee...................................... 269 
B. Golden-crowned and Ruby-crowned Kinglets................... 269

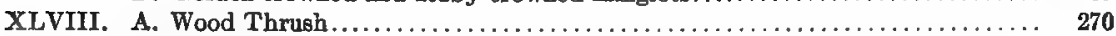

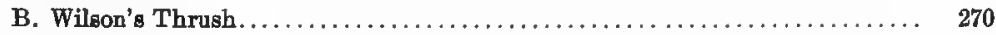

XLIX. A. Grey-cheeked and Olive-backed Thrushes....................... 271

B. Hermit Thrush........................................ 271

L. A. American Robin...................................... 272

B. Bluebird................................................... 27

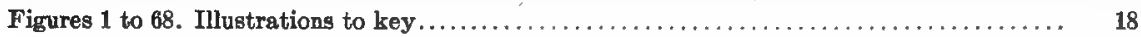


,

. 


\title{
Birds of Eastern Canada.
}

\section{INTRODUGTION.}

\author{
OBJECT OF THE BOOK.
}

Of late years there has been a great awakening of interest in the subject of natural history. More and more people are beginning to realize the pleasure and profit that can be derived from observation of common natural objects. In this growing field of nature study, few subjects have attracted so much popular attention as birds and few forms of life appeal so strongly to the æsthetic sense. They are beautiful; they arouse curiosity; their elusiveness piques the imagination; and by presenting constantly new aspects they never become commonplace.

The ornithological side is one from which the problems of nature can be successfully attacked from so many standpoints and in so many ways that there is interesting and valuable work for all to accomplish according to individual taste or opportunity. Those who incline towards systematic work can split their definitions as finely as human powers of observation permit. The animal psychologist can develop his problems as far as ingenuity can devise methods for experimentation. The ordinary nature lover can observe and note as painstakingly as opportunity permits; he can record information of scientific as well as popular interest, take pleasure in observing passing beauties, train his powers of observation, and acquire a knowledge that greatly increases his capacity for appreciation of nature. Even the unsentimental, practical man, who has little outward sympathy with abstract beauty, has his attention attracted by the evident economic value of birds.

The "Birds of Eastern Canada" has been written to awaken and, where it already exists, to stimulate an interest, both æsthethic and practical, in the study of Canadian birds and to suggest the sentimental, scientific, and economic value, of that study; to assist in the identification of native species; and to furnish the economist with a ready means of determining bird friend from bird foe that he may act intelligently towards them and to the best interest of himself and the country at large; to present in a readily accessible form reliable data upon which measures of protective legislation may be based; to point out some of the pitfalls that have caught the inexperienced in the past; and to suggest methods for their future avoidance.

SCOPE OF THE BOOK.

This work covers all the birds that the ordinary observer is likely to meet with between the Atlantic coast and the prairies north of the International Boundary. This region forms a natural zoological area (see Distribution, page 8), including what may be called the eastern woodlands of Canada, a fairly homogeneous section, physically, geographically, and zoologically. The prairies are radically different in character and, consequently, exhibit an entirely different aspect of bird life. The birds of 
the open are naturally different from those of the woodlands; hence Manitoba has been taken as the western boundary of the zoological area dealt with in this book.

Although not a scientifically complete check-list of the birds of Eastern Canada, this book is nearly so. A few species whose Canadian status is doubtful, and some of extreme rarity or of accidental occurrence, have been disregarded. The utmost freedom has been used in this respect and species have been admitted freely upon the basis of expediency; some as being of probable.occurrence and to be looked for, others as illustrating some point of general interest more pointedly than regular native species, and some because in the past they have been confused with commoner forms.

\section{PLAN OF THE BOOK.}

The systematic arrangement (see Classification, page 5, and nomenclature, page 7) used are those of the Check-list of the American Ornithologists' Union, third edition, 1910. Though this arrangement is acknowledged to be somewhat imperfect and its details tentative, it is that upon which most of the recent American bird literature is founded and is the one in common use in North America.

In the treatment of subspecies a departure has been made from current practice, which the writer believes to represent more accurately the facts of nature and modern concepts. Species have been treated as aggregations of subspecies, each of equal rank and importance, and not, as is customary, as species with subordinate sub-species dependent upon them. The species is first given as a whole, including its subspecific races, and under a subhead mention is made of the special subspecies that occur within the geographical scope of the work. This has caused no confusion or change except in the use of vernacular names in which the reader will find a few departures from those given and authorized by the American Ornithologists' Union. In the scientific nomenclature the true relative importance of species and subspecies has been expressed; but the common names have not heretofore always reflected this conception of subordination and this fact in many cases has caused the use of definite subspecific terms when it was by the very nature of the case impossible to determine their correctness or when it was unadvisable to recognize them. Thus there has been a tendency to attach unwarranted importance to these minor distinctions in popular as well as scientific estimation. In the correction of this condition certain adaptations of common names have been necessary, but as little change as possible from accepted practice has been made. Older terms have been revived wherever possible, but as current names have also been given no confusion should result. It has, in some cases, been necessary to apply the recognized type subspecific name to the whole species and adopt a new one for the form so robbed. In doing this it was advisable that as little change should be made in current usage as was consistent with the end in view. Therefore, except where good reasons prevented, the new subspecific name was formed by prefixing an adjective to the specific term hitherto applied to it. Each departure from accepted practice has been decided upon its own merits. Though there can be little doubt as to the advisability of the principle of the reform, the manner of carrying it out has been the subject of much thought, considerable consultation with others, and some hesitation in individual cases. 
The Horned Lark is one example of this problem. The type subspecies Otocoris alpestris alpestris has generally been known as the Horned Lark regardless of the fact that any one of the fourteen or more other geographical races have an equal claim to the name and that it is the only one for the species as a whole. The obvious course is to call the typical subspecies, Otocoris alpestris alpestris (only typical in the sense of being described first and not on account of any taxonomic superiority to other forms), Eastern Horned Lark and to apply the name Horned Lark to the whole collection of co-ordinate subspecies, making it synonymous with the scientific binomial Otocoris alpestris.

The Migrant Shrike offered other difficulties. The logical proceeding would be to call the whole species Louisiana Shrike, from its scientific name ludovicianus. This would, however, introduce an unfamiliar name recognizable by only a few. The species has, therefore, been called here the Loggerhead Shrike and the form of eastern Canada the Migrant Loggerhead, on the assumption that a geographical term such as southern could be applied to the type race to which Loggerhead has hitherto been restricted.

It would be too much to expect that the result attained will satisfy everyone; the writer hopes, however, that it will be accepted until the American Ornithologists' Union committee takes the matter up and makes authoritative decisions.

In the following pages the number and vernacular name, with as little modification as possible, have been taken from the American Ornithologists' Union check-list and appear first as a specific heading in heavy type. Following, in smaller type, are the more common local names by which the species has been or is known in various localities. The French equivalent is then given, preceded by the contraction, "Fr.". These formal French names have been adapted from "Dionne's Les Oiseaux de la Province de Quebec" and are followed when possible by vernacular terms in current use in French-speaking sections. Many of them were furnished by Dr. C. W. Townsend who has had considerable ornithological experience in the eastern provinces. Where French terms are missing, there is as far as the writer is aware no accepted French name.

The Latin specific name follows in italics and is always binomial.

Preceded by the initial " $L$ " the length of the species is next given in inches and decimals of an inch. The length of a bird is determined by measuring it, in the flesh, in a straight line from the tip of the bill to the end of the longest tail feather, the bird being stretched only enough to straighten the neck curves. The measurements given are those of the average adult male and indicate the comparative size of the species under consideration. They are not for specific identification, as in most species there is more or less individual and sexual variation.

Only an outline description of species is given and where there are illustrations the description is omitted and the reader is referred to the illustration instead.

Under "Distinctions," an attempt is made to bring out the salient points by which the species, when in hand, may be separated from other similar forms, and the work of other authorities has been freely drawn upon to supplement the writer's observations. Many of the distinctive points are naturally only superficial, but all are, as far as possible, reliable.

Under the heading "Field Marks," the features by which the species may be recognized in life are mentioned. In these the writer has been 
guided largely by his own experience and has stated the points that seem most characteristic to him. In species with which he has had little experience in life he has relied upon others.

Under "Discussion," as many facts of general interest relating to the species have been included as the space allows or the importance of the species warrants. Scattered among the various species, where applicable under this head, numerous matters are discussed and general laws governing zoological life stated. Many of these apply to a number of species and some might well be repeated under each specific heading were it not for the constant repetition that it would necessitate. An attempt has been made to encourage a wholesome protective attitude from an æsthetic view point.

"Nesting" is merely a brief description of the nest and its situation. Much of this is drawn from other authors, especially from the invaluable "Handbook of Birds of Eastern North America."

Under "Economic Status" is given a summary of present knowledge of the species in their relation to man. Most of this is drawn from the admirable work done by the United States Biological Survey. Of necessity only a brief outline of the data upon which conclusions are founded can be given and the reader is referred to Ornithological Literature on page 13, for greater details.

Under "Distribution", it has been deemed best to give the distributions in such general and well understood terms that all can get at least a general conception of the ranges of the species. The result may be a little vague owing to the lack of sharply defined boundaries of the ranges, but the centres of distribution are made clear. For definite ranges the reader is referred to the "Catalogue of Canadian Birds" by John and James M. Macoun, issued by this department in 1909 .

Throughout it has been the endeavour to avoid the use of technical terms, substituting familiar words wherever possible. Some technical terms, however, have no general vernacular equivalent and a glossary of these is given on page 219 , for the benefit of those who are unfamiliar with them.

\section{ACKNOWLEDGMENTS.}

The writer wishes to acknowledge valuable assistance received in the course of his work from the following sources:

Mr. Frank Chapman, whose "Handbook" has been invaluable in filling out gaps in the writer's personal experience; in suggesting ideas of construction, and plan and methods of execution. of birds.

The United States Biological Survey for data on the economic relations

Mr. J. H. Fleming, of Toronto, and Mr. W. E. Saunders, of London, who have been untiring in giving advice and assistance from the time of the inception of this work until its completion.

Frank Hennessey, of Ottawa, and Claude Johnson, of this department, who are responsible for the illustrations; the former for the coloured pictures and the latter for the line details of the key.

James M. Macoun, of this department, who has been a constant source of helpful advice, and has assisted in preparing the following pages for the printer's hands. 
To these, as well as to a multitude of other private and published sources I wish to express thanks for aid and assistance.

\section{CLASSIFICATION.}

The first step in any science is that of classification. The present system of generic grouping of species was first advanced by Linnæus in his epoch-making "Systema Naturæ" and has since been followed consistently by zoologists. By this, species are grouped together in genera according to fundamental structural relationships and not accidental resemblances. The fact that upon the discovery of the laws of evolution these relationships were found to agree with lines of descent proved the logic of the system and gave it an added meaning. Thus the various specific members of a genus can be conceived as having descended from a common specific ancestor; the genera of a family from a common generic one, etc.

Dealing only with existing North American birds, they may be divided into a number of Orders, which are the largest groups with which the Canadian ornithologist has direct concern. Orders are divided into Families, Families into Genera, and Genera into Species. These divisions may be again subdivided into Suborders, Subfamilies, Subgenera, and Subspecies whose positions in the scheme are evident from their titles.

Though the limitations of book construction necessitate the presentation of the classification scheme as a linear succession of forms following one another in single file, it should be borne in mind that the system is not linear in conception. The component species instead of following a single line of relationship and sequence from the lowest to the highest present many parallel or divergent lines of equal or subordinate rank. The class Aves or Birds may be represented by a tree, the height of the tree representing time in geological ages from the earliest at the bottom to the present near the top. The trunk should be shown as double at the base; one stem would be a short dead stump and would represent the fossil toothed birds which became extinct before present geological time; the other, large and thrifty, would represent the modern untoothed forms. This in turn would divide into two main branches a short way from the base and would represent the two subclasses, the Raft-breasted and the Keel-breasted birds. The former would be represented by much the smaller branch, whereas the latter would divide and subdivide into branches representing first, orders; next, families; then, genera; and finally species.

The value of these divisions, that is, the amount of differentiation sufficient to raise a group of genera to a family, or a collection of families to an order, is a matter for experienced individual decision as there is no authoritative ruling upon the subject. However, there has gradually grown up an approximate agreement on this subject, though the constant tendency among specialists has been to make finer and finer distinctions and to multiply the number of the various groups.

The smallest division generally accepted is the Species. Though everyone has a more or less accurate conception as to what a species is, whether it be called by that name or another, no satisfactory definition has ever been constructed for it. It is what is commonly known as a 
"kind of an animal". Thus the horse is a different "kind" or species from a donkey, a bluebird from a robin. They are sharply marked off from each other, regularly breeding together within the species only and producing like species as offspring. Distinct species do not commonly interbreed, but, when they do so, they form crosses or hybrids that are usually sterile. $\mathrm{Up}$ to comparatively recent years no smaller division was recognized, but with intensive study of material it has become evident to advanced students that within the species there is considerable individual and geographic variation.

Individual variation is the natural difference that may occur at any time between members of common parentage such as amongst full brothers and sisters. Just as like begets like so within certain limits like begets unlike for no two creatures are ever exact duplicates. This is individual variation, usually small and irregular in appearance and direction, but sometimes persisting progressively generation after generation in one direction and forming the basis upon which present day evolutionists explain the origin of new species. Individual variation, however, is disregarded in classification, unless it has proceeded far enough to produce marked and constant differentiation over a definable natural group of a species.

Geographical variation can be regarded as the result of a common tendency of individual variation acting over a whole community of individuals tending towards a common goal and is held to be induced and directed by local climatic and other conditions. Thus we often find that within a widespread species all individuals inhabiting certain localities have characteristics that separate them from those of the surrounding areas. Individuals in a dry desert country are apt to be smaller and lighter in coloration, whereas those in a warm, moist country are usually larger and darker. These differences are sometimes marked and obvious; at other times they are so slight as to be noticeable only by comparison of large numbers of specimens and can be detected only by averages. Thus there is every degree of differentiation, due to geographical habitat, from pronounced departures from type, of almost specific value, to the finest shades of differentiation that skilled specialists can distinguish and which are inappreciable to the ordinary eye. The outstanding fact, however, that prevents the most marked geographical variation from full specific standing is that these minor forms intergrade and in intermediate localities every shade of differentiation between the extremes can be found. Between species this gradual merging of character is not supposed to occur, and however fine the distinctions may be, the divisions should be sharp and defined. We, therefore, recognize these intergrading variations due to or based upon geographical distribution as Geographical Races, Varieties, or Subspecies, the latter term being now in best current use, and we regard them as species in the making before the connecting stages binding them to the original stock have disappeared, owing to the growing sterility between the extreme variants. Except in such rare cases of physical isolation, as where an oceanic island habitat precludes continuous distribution, we take, in practice, the existence of intergrades as we evidence of subspecific status. Besides these divisions of taxonomic value there are a few other variants that, owing to their erratic occurrence, cannot be recognized in our classification. These are "Albinos," "Melanos," and "Dichromatic Forms." 
Albinism, or unusual whiteness, is the sporadic occurrence of white individuals, in species that are normally otherwise coloured, and may occur in almost any species. It may be either perfect or partial and is due to lack of pigment or colouring matter in the feather or skin substance. It can be regarded as a manifestation of physical weakness and is said to be induced, among other things, by close inbreeding. A good test as to whether a pure white coloration is albinism or is normal is the colour of the pupils of the eyes. In albinos the pupils are pink in colour, as the lack of normal colour in the retina allows the blood coloration to show.

Melanism, or unusual blackness, is due to an excess of pigment. A good example of melanism is the Black Fox, which is a melanic variant of the common red species.

Dichromatism is the term applied to occurrence of two different types of coloration in a single species, irrespective of sex, age, or season. Thus the Screech Owl occurs in both red and grey phases (see Plate XVI A). They breed together indiscriminately and the offspring may be of either coloration. The Rough-legged Hawk and the Jaegers occur in light and in almost black phases; the difference between dichromatism, and melanism in these cases is slight.

Hybrids form another departure from specific type. They are the offspring of parents of two distinct species. It is only occasionally that such matings are fruitful, and when they are the offspring is generally sterile. Hybrids occur most often among ducks, especially with the Mallard as one of the parents.

Every North American bird has a common or vernacular name authorized by usage and recognized by the leading ornithologists and there is seldom necessity for using the scientific nomenclature. However, it is well for all who are interested in birds to familiarize themselves with as many of the scientific names as possible, as they are not only necessary in more advanced work, but they are of practical use in grasping the general relationships between various species.

The present Binomial System of nomenclature was introduced by Linnæus, the great Swedish botanist, and embodied in his Systema Naturæ, tenth edition, 1758, which is the authority accepted by American ornithologists. In this system each species is given a double name, the first term being that of the genus to which it belongs, the second that of the species. Generic names are not duplicated within the sphere of zoology and specific names never within the genus. Thus, the American Robin is Planesticus migratorius; that is, that species of the genus Planesticus which is named migratorius. Other species of Planesticus have other names than migratorius.

The three objects of scientific nomenclature are exactitude, universality, and permanence. To this end the naming of zoological material is subject to strict laws whose principles are universally accepted and applied according to strict codes. Under these laws the scientific name of a species is not a matter of personal preference, but is fixed, so that few or none can dispute it, and no changes can be made in scientific nomenclature except such as are necessary to correct current mistakes in the application of the laws of the code. With increased knowledge it has become necessary to depart slightly in letter, though not in spirit, from the strict bi- 
nomial system of Linnæus, and by adding a third term as name of the subspecies to make it.a trinomial one. Wherever a three-term name is used, it is that of a subspecies of the original binomial form. The first specimen described, or the first specimen to which a name has been attached, is regarded as the so-called "Type" form. Therefore, in dividing a species into subspecies the form which was first named as a species becomes automatically the type race, and its subspecific name is formed by a repetition of its specific name. Thus the American Robin that was first described and specifically named by Linnæus in 1766 as migratorius when mentioned subspecifically in distinction from the Southern Robin or the western one becomes Planesticus migratorius migratorius. The Western Robin first separated from it by Ridgeway in 1877, was named by him as Planesticus migratorius propinquus, and the Southern Robin by Bac' elder in 1900, is Planesticus migratorius achrusterus. In practice, where the generic or specific names are evident from the context, it is customary to indicate them by initial, as $P$. migratorius, or $P$. m. migratorius.

Subspecific varieties are divisions of the species and, except in special lines of work, or where special exactitude is necessary, of minor importance. As these subspecies are also often based upon points of difference only perceptible to the most experienced observers, they generally lie outside the sphere of interest of the average amateur observer.

\section{GEOGRAPHICAL DISTRIBUTION.}

The broader facts of the geographical distribution of life are patent to the most casual observer. The primary divisions of distribution, the Tropics, Temperate, and Arctic zones are obvious, but closer study shows that within these broad associations minor and less obvious ones can be detected. In America, north of the gulf of Mexico, there are three life regions, roughly following the above, called the Tropic, the Austral, and the Boreal regions. These are subdivided into life zones each characterized by its own peculiar assemblages of plants and animals.

The Tropic region is sufficiently characterized by name and need be only mentioned.

The Austral region corresponds roughly to the popular geographical conception of the Temperate zone. It is divided into three life zones, the Lower Austral, the Upper Austral, and the Transition zones. The Lower Austral might be designated as subtropic and extends north including the gulf and the south Atlantic states, not occurring in Canada at all. The Upper Austral is the first that we are directly interested in in eastern Canada, it merely crosses the border on the lake Erie shore and includes the famous Niagara fruit belt. The frequent or regular occurrence of numerous southern species on Pelee point in Essex county, Ontario, marks the strongest development of this zone in the Dominion. It slightly touches our southern boundary again in Saskatchewan and perhaps some of the warmer valleys running into southern. British Columbia. The northernmost Austral or Temperate life zone is the Transition zone which includes the greater part of the more highly cultivated areas of Canada. It occupies the shores of the bay of Fundy, the upper St. Lawrence river, southern Quebec and Ontario, the lower sections of the prairie provinces, and a 
strip of sea coast in southern British Columbia and marks the limit of extensive cultivation.

The Boreal region is divided into the Canadian, Hudsonian, and the Arctic zones. The Canadian includes the remainder of the forested land north of the Transition and is mostly coniferous, continuing across the continent to the northern limit of general cultivation. The Hudsonian zone is in the more northern country of small shrubs or stunted tree growth unsuited to agriculture, and the Arctic zone extends across the barren grounds north to the pole.

These life zones based upon temperature and roughly following the lines of latitude, are, however, deflected from their natural east and west sweep by varying local conditions, the vicinity of cold or warm ocean currents, the presence of large bodies of water, elevation above the sea, the prevalence of cold or warm winds or mountain barriers to the same, and other causes. Thus instead of being even belts they are irregular and only roughly follow parallels of latitude.

Elevation is an important factor in the distribution of life depending upon temperature. In the tropics in ascending a high mountain, representatives of each zone between that of the surrounding lowland and the Arctic of the snow-covered peak, may be met with and appropriate assemblages of species will be found inhabiting each. The juncture of Arctic and Hudsonian zones at the straits of Belle Isle, in the same latitude as Lands End in England, illustrates the enormous effect of the cold Arctic current, coniing down from Davis strait, in contrast to the influence of the warm Gulf stream that dies against the English shores.

We can also observe minor groupings east and west based upon conditions other than temperature, these determining factors being mostly variations of humidity. Thus the life of the eastern woodlands is plainly different from that of the more arid plains of the prairie provinces and both are strikingly different from that of the moist Pacific slope.

Taking the eastern forms as typical in the ordinary acceptance of the word, comparable birds of the prairie will be found to be slightly smaller and considerably paler in coloration, whereas on the humid Pacific coast they will be larger and much darker in colour. Through these influences we, therefore, find in the west many subspecies of eastern forms. A comparatively few species range unmodified across the continent, many are represented east and west by two or more subspecies showing greater or less differentiation, and in other cases they are replaced by closely allied species or not represented at all.

In noting these faunal divisions, however, it must be remembered that as far as birds are concerned, these associations have to be based entirely upon breeding individuals. Birds travel so widely and along so many devious routes in their migration, that they may pass through several faunal areas spring and autumn though breeding in only one. Therefore, in determining the faunal zone to which any given area should be referred, such transients must be disregarded.

Though the distributions given under the specific headings following are rather vague and indefinite, many tend to follow similar general lines. Thus some are given as "the lower Great Lakes region"; these are probably Upper Austral forms. "Southern Ontario and Quebec" refers to Transition species, whereas "beyond dense settlement or to the limit of cultivation" would naturally be species of the Canadian zone. 
The following species are given as representative of what birds are to be expected in each zone:

Upper Austral
Cardinal
Orchard Oriole
Carolina Wren
Grasshopper Sparrow
Blue-grey Gnatcatcher
Dickcissel
Transition
Bobolink
Wood Thrush
Yellow-throated Vireo
Baltimore Oriole
Towhee
Cuckoo
Field Sparrow
Bluebird
Catbird

\author{
Canadian \\ Hudsonian Chickadee \\ Red-breasted Nuthatch \\ Olive-backed Thrush \\ Three-toed Woodpecker \\ Hermit Thrush \\ White-throated Sparrow \\ Canada Jay \\ Grey-cheeked Thrush \\ Slate-coloured Junco
Hudsonian
Rough-legged Hawk
Fox Sparrow
Northern Shrike
White-crowned Sparrow
Pine Grosbeak
American Pipit

\author{
Arctic \\ Ptarmigan \\ Snowy Owl \\ Snow Bunting \\ Gyrfalcon \\ Longspur
}

\section{MIGRATION.}

The migration of birds, their periodical and seasonal appearance and disappearance, is one of the most obvious phenomena of nature. The fact that many birds disappear in winter is common knowledge and has attracted attention for ages. Though once regarded as a mystery, and still far from being throughly understood in many of its details, we are beginning to wonder less but admire more as accurate knowledge gives place to vague speculation. To-day, where most of our northern species spend the winter is known and many of the routes by which they come and go have been mapped out. We know that on the whole they are governed by ordinary and well known, though perhaps highly developed, senses and common every day influences, and not by the mysterious powers and instincts once ascribed to them.

The fundamental cause of migration is obviousiy the waxing and the waning of the food supply. Birds leave the northern land of their birth because there is no other way by which to avoid starvation. Many species can withstand extreme cold but none can go long without food and though some bird food still remains in Canada throughout the winter, its amount is small and only sufficient for a limited population and even that supply rapidly decreases, or to the north is buried under deep snow. The cause of the sou ${ }^{+}$ward migration in the autumn then is obvious, but why should a bird leave the soft climate and plentiful food supply in the south to brave dangerous travel and finally find itself in a land where retiring winter still lingers and the danger of starvation is imminent. Many ingenious explanations have been advanced to account for this, longing or homesickness for the land of birth, hereditary memories of an ancient home enduring through geological ages, the seeking of special food for nestlings, and insufficiency of nesting sites in the southern areas, have all been given as possible reasons. However, it is unnecessary to advance a complicated or far-fetched explanation when a simple and direct one exists. If we remember that in the nesting season the bird population is increased many

${ }^{1}$ Most of the species of this zone also occur in the Upper Austral, but rasch their northern limit here. The occurrence of these with the absence of the apecies of bordering zones are the most marked characteristics of the Transition zone: 
fold by the birth of young; that though in winter there may be room for a considerable number of birds in the southern stations, the natural spring increase of population outgrows the supporting power of the land; and that just at this critical time the whole northern temperate region is thrown open to occupation with an abundance of food, the subject is mysterious no longer. In fact, it is only by migration that it is possible to use the supporting power of the temperate regions unless the birds fast or hibernate through the winters, to neither of which the avian nature takes kindly.

Though food supply is the fundamental or originating cause of migration we must look for other and more immediate impulses for an explanation of its methods to-day. Originally forced to and fro by hunger, the anuual movements now have become instinctive and take place before the situation becomes acute, the actual hunger pinch felt, or the physical system weakened by want.

The extent of the migrations of the different species varies. A very few species do not, in the true sense of the word, migrate at all. In other species the more northern individuals only recede from their stations, the southern remaining practically stationary, though in the majority of Canadian species the whole body moves south. The bird of greatest length of migration is doubtless the Arctic Tern, a bird that nests from the gulf of St. Lawrence to the polar regions and winters as far south as the Antarctic continent.

The methods of migration are nearly as varied as their extent. Some species drift along throughout the day from treetop to treetop, from wood patch to wood patch, gradually working their way in the desired direction. Others take long flights, some high in the air, others lower. Some travel altogether by day; others travel at night and we are only aware of their passage through accidental opportunities, their faint voices coming down to us from overhead in the darkness, or by their sudden appearance about us in the morning. They travel in flocks of single or mixed species, scattered groups, or as individuals.

Many species, if not all, follow more or less definite routes to and from their breeding grounds and some go and return by altogether different paths. Comparatively small bodies of water deflect some species from their course, others unhesitatingly cross vast reaches of sea, indifferent to nearby and convenient land passages that are made use of by closely allied species. In some species the older birds precede and in others the males may precede the females.

How birds find their way is still only vaguely understood, and individuals far out of their natural range and course show evidence of being as hopelessly lost as any other animal would be on unfamiliar ground. Certainly experience has much to do with it and undoubtedly young birds are largely guided by the movements of their elders which, it can be assumed, through previous experience, already know and can lead the way. We can understand how birds can follow great landmarks-large river systems, mountain ranges, or sea coasts in their journey, but no sense with which we are familiar explains how some species return unerringly to lonely oceanic islands over wastes of monotonous sea. It may be that they have a special sense which aids them in orienting themselves.

$57172-2$ 


\section{PROTECTION.}

In food habits, birds are eminently adaptable; seeds, plants, fruit, insects, flesh, or fish are all acceptable to various species and, consequently, nearly all regions have their quota of appropriate birds. A bird lives fast, its heart beats more rapidly than that of other animals, the blood temperature is higher, and it consumes an enormous amount of energy in flight. This feverish heat and strenuous exertion requires a correspondingly large amount of food, consequently the bird as an economic factor is one to be regarded seriously. Though it may be an exaggeration to say, as some writers have inferred, that the whole balance of nature depends upon birds and that without them the country would be a barren waste peopled only by insects, yet birds cannot be seriously reduced in number without the gravest results. The destruction of tons of weed-seeds and millions of insects must necessarily have a great influence upon human welfare and neglect of this fact must seriously react upon any community that fails to give proper protection to its birds.

However, the problem of the status of individual species of birds is not the simple thing that it superficially appears to be. More than a cursory examination is necessary and many things must be considered in order to arrive at the truth. Sometimes birds work in harmony with human welfare and sometimes against it. They may be directly beneficial at one season and harmful at another, or their indirect influence may alter the sum of their direct effects in a most surprising manner.

General impressions then as to whether a bird is beneficial or harmful require careful checking. Mere casual observation in life is never sufficient to determine even its food supply. Modern practice bases such conclusions almost entirely upon the examination of the stomach contents of wild birds taken throughout the year, which is the only evidence that is not subject to question. In this work the United States Biological Survey has examined and passed upon thousands of bird stomachs and the results of its researches are available to those who care to study and use them.

As one of the factors in the delicate balance of nature birds should be respected.

There are certain birds which from their size, habits, and general food value are regarded as legitimate game. The pursuit of these is invigorating sport and tends to the healthful welfare of the sportsman, teaching woodcraft, hardihood, out of door adaptability, and marksmanship. The true sportsman has a code of ethics of his own founded upon economic as well as humanitarian principles. He shoots nothing without giving it a fair chance and little that cannot be used as food. He is also careful not to deplete the game upon which his future sport depends. Restrictive measures have invariably followed rather than preceded the results that have made them necessary, the regulations that are enasted to-day should have been adopted yesterday and the consequence is that over much of the country, game is a thing of the past.

\section{MEANS OF ATTRACTING BIRDS.}

To anyone interested in birds, the pleasure of having them about the house and garden where they can be observed at leisure, is a very great enjoyment. A small garden patch can be made attractive to many species 
by proper methods. The effects of strict protection are well illustrated in some of the larger parks where the shyest waterfowl, finding there is nothing to fear from man, become almost as confiding as barnyard poultry. This is the case also with the smaller garden species. Next to freedom from disturbance by the human inhabitants protection from the domestic cat is necessary.

The supplying of food in winter is also important. Shrubs carrying fruit, suet hung in trees, and grain, broken nuts, and small fragments of dried meat sheltered from the snow, never fail to attract birds in the winter time.

In summer, when natural supplies are plentiful, food seldom has to be supplied, though a row of fruiting sunflowers or the seed heads of many garden flowers well repay the trouble they may cost to provide. A shallow pool of clean water is a never failing source of pleasure to nearly all the common garden birds. They both bathe in it and drink it and on a hot day it is no uncommon sight to see several birds awaiting their turns to enjoy the grateful coolness. The simplest form of bird bath is a shallow pan, set well out in the open and away from cover as a protection from eats. In cities where the trees are well cared for and dead wood promptly removed, certain species of birds are always hard pressed to find suitable nesting sites. There are at least half a dozen species naturally nesting in hollow limbs, that readily come to bird boxes of various kinds and a number of other birds can be occasionally induced to do so. Suitable boxes are described in some of the books listed on page 16. In many schools where manual training is taught the boys are encouraged to build bird houses. Scope is thus given to their natural inventive genius, and at the same time they become interested in the birds that occupy the houses.

\section{ORNITHOLOGICAL LITERATORE.}

North American ornithological literature is rich and varied, and perhaps no natural science can be studied with such efficient written aids either to beginner or advanced student as that relating to birds. A publication can be found to suit all stages of knowledge and almost any purse. The following list of books on the subject is recommended, the first named being specially suited to the requirements of the beginner.

Birds guides, by Chester K. Reed: Part I, Water and game birds east of the Rockies (including the hawks and owls); Part 2, Land birds east of the Rockies. Doubleday, Page and Company, Garden City, N.Y., price each, $\$ 1$ in cloth, $\$ 1.25$ in leather.

These are small, almost vest pocket editions in limp bindings, $3 \frac{1}{4}$ by $5 \frac{1}{2}$ inches, very convenient for carrying in the pocket in the field. They contain small, easily recognized, coloured illustrations of all the birds in both sexes, and brief descriptions.

Colour key and guide to the birds of eastern North America, by Frank M. Chapman and Chester K. Reed: 8 vo., Doubleday, N.Y., price $\$ 2.50$.

Similar in plan to above but more detailed and instructive.

A guide to the birds of eastern New York, by Ralph Hoffman: 8 vo., Houghton, Mifflin \& Co., price \$1.50.

A most desirable book, though dealing with an extralimited area it includes most of the birde of eastern Canada. It contains keys for the birds of each season based upon colour, detailed descriptions, and also many illustrations in blaek and white showing specific details and gives much informatiou of various kinds.

$57172-2 \frac{1}{2}$ 
The birds of Ontario, by Thomas Mcllwraith: 2nd edition, 1894, 8 vo., Wm. Brigge, Toronto.

An annotated list of all the birds known to the writer to occur in Ontario at that date, with descripticns and much information regarding habits, etc. Unfortunately it is now out of print and can probably only be obtained through second-hand book dealers who make a specialty of ornithological literature.

The handbook of the birds of eastern North America, by Frank M. Chapman: 12 mo., D. Appleton \& Co., price $\$ 3.50$.

This is an almost complete text book on the birds of eastern North America and is invaluable for the advanced as well as the beginning student. It contains detailed accurate descriptions of all plumages, measurements and migration dates, and an immense amount of interesting and valuable detail with a most valuable introduction on birds and bird study. As soon as a student is familiar with the rudiments of ornithology, he should supply himself with this handbook.

Key to the birds of North America, by Elliot Coues: 5th edition, 1903, vols. 2, large 8 vo., Dana Eates \& Co., price $\$ 12.50$.

This is perhaps the most generally accepted authority upon the subject of Amerisan birds. It is primarily intended for the advanced student but it contains a mass of information that can be found nowhere else and is a final court of decision to the majority of our working ornithologists.

The catalogue of Canadian birds, by John and James M. Macoun: 8 vo., published by the Department of Mines, Geological Survey Branch, Ottawa, 1909.

This is a complete list of all the species and subspecies of birds known to occur in Canada, Greenland, and Newfoundland, with their ranges both breeding and migratory as thoroughly stated as the condition of knowledge at the time of publication permitted. It is based largely upon the explorations and experiences of the authors, supplemented by knowledge from all available sources and contains considerable information regarding breeding habits but little else of popular interest. The'original English version is now out of print but the French translation is still available for distribution and can be obtained from the Department.

The birds of North and middle America, by Robt. Ridgeway: Bulletin No. 50, 8 vo., United States National Museum.

This is a monumental work planned in eight volumes but later extended to ten or more, of which seven are in print, the remainder to follow as rapidly as the work can be prepared. It is the latest and most detailed and scientific work on the subject but contains nothing on life histories or allied popular subjects. It is not for general sale but may be procured from second-hand book dealers or through the Department of Public Documents at Washington.

Besides these general works, the following, dealing with special divisions of birds, are recommended:

The Warblers of North America, by Frank M. Chapman: D. Appleton \& Company, price \$3.

The Water-fowl family, by Sanford, Bishop, and Van Dyke: The McMillian Co., price, \$2.

North American land birds by Baird, Brewer, and Ridgeway: Little, Brown \& Co., 3 vols.

Reprint of the original. The water-birds of the series was originally published in Memoirs of the Museum of Comparative Zoology, Harvard College, 1884, but is now out of print and very difficult to obtain.

\section{For general reading the following can be recommended:}

How to study birds, by Herbert K. Job: Outing Publishing Co., price, \$1.50.

The sport of bird study, by Herbert K. Job: Outing Publishing Co., price, $\$ 2$.

Wild wings, by Herbert $\mathrm{K}$. Job: Outing Publishing Co., price, $\$ 3$.

These are all intensely interesting books and contain a wonderful collection of photographs of birds from life.

Bird craft, by Mable Osgood Wright: MacMillian Co., price, $\$ 2.50$.

Many full page illustrations. Rambles of a Canadian naturalist, by S. T. Wood: Illustrated, J. M. Dent \& Sons, Ltd,
London and Toronto, 1916, price, $\$ 1.50$.

This is a series of short sketches and observations on the nature life about 'Poronto. They are well and sympathetically written-many, though not all of them, refer to birds.

The bird, its form and function, by C. William Bebee: Henry Holt and Co. 
This list could be extended indefinitely but probably sufficient has been mentioned.

On economic ornithological subjects the reader's attention is directed towards the immense amount of valuable literature published by the United States Biological Survey in their many bulletins, circulars, and reports. Though these were prepared primarily for use in the United States they apply to Canadian birds almost equally well. A complete list of them with priees can be obtained from the Superintendent of Public Documents, Washington. The prices are merely nominal. tioned:

of Canadian publications of this nature, the following may be men-

The birds of Ontario in relation to agriculture, by Chas. W. Nash: Ontario Dept. of Agriculture, Bulletin 173.

Of literature of local application in Canada only a few of many can be mentioned, for their name is legion and they are scattered throughout many publications, periodicals, proceedings, and reports.

Ontario :

The birds of Ontario, by Thomas McIlwraith, 2nd edition, 1894, 8 vols., Wm. Briggs, Toronto.

The birds of Toronto, by J. H. Fleming: Auk, vol. XXIII, pp. 437-453; vol. XXIV, pp. 71-89.

The natural history of the Toronto region. Birds by J. H. Fleming: Published by Canadian Institute, Toronto, 1913 , price, $\$ 2$ or $\$ 2.50$.

Quebec:

Les oiseaux de la Province de Quebec, par C. E. Dionne: Dussault \& Proulx, 1906.

The birds of Montreal, by E. D. Wintle: Drysdale \& Co., Montreal, 1908.

Nova Scotia :

Birds of Nova Scotia, by A. Downs, edited by Harry Piers: Proc. and Trans., Nova Scotia Inst. Sc., vol. VII, pp. 142-178.

New Brunswick :

A catalogue of the birds of New Brunswick, by M. A. Chamberlain: Bull. Nat. Hist. Soc., New Brunswick, No. 1, pp. 23-68.

Ornithology, like all other branches of science, has its own periodicals. The principal one of these in North America is the Auk, a quarterly magazine, which is the official organ of the American Ornithologists' Union. In addition to purely scientific papers, it contains hundreds of articles of interest to Canadians, including local lists copiously annotated with life history notes from all over the Dominion and descriptions of habits popularly discussed. Subscription is $\$ 3$ a year. Editor, beginning 1912, Witmer Stone, Academy of Science, Philadelphia, Pa., Office of Publication, 30 Boylston street, Cambridge, Mass.

The Wilson Bulletin, a bi-monthly magazine, is the official organ of the Wilson Ornithological Club and is devoted to the interests of the middle west. Subscription $\$ 1$ a year, edited by Lynds Jones, Oberlin, Ohio. Address, The Treasurer, P. B. Coffin, 3232 Groveland ave., Chicago, Ill. This is a less pretentious publication than the Auk, but contains much of interest to the general reader and publishes some of the most popularly, interesting articles on birds and their habits.

"Bird lore" is an avowedly popular, monthly magazine notable for its beautiful makeup and illustrations. It is the official organ of the National Audubon Societies and is devoted to the popular study and protection of birds. It is now in its eighteenth volume and is edited by 
Frank Chapman. Subscription $\$ 1$ per year. Address, Bird-Lore, Crescent and Mulberry streets, Harrisburg, Pa.

The Canadian Field Naturalist, the continuation of the Ottawa Naturalist, is a monthly (nine numbers a year) published by the Ottawa Field Naturalists Club, Editor, Arthur Gibson, Entomological Branch, Dept. of Agriculture, Ottawa, Ont. Subscription $\$ 1$ per year. Address C. L. Patch, Sec., Geological Survey, Ottawa, Ont. This publication contains a great deal of interesting zoological material and numerous notes and articles on the birds of Canada.

On the subject of protection and attraction of birds about the home, among the great mass of literature available, the following can be specially recommended:

How to attract and protect wild birds, by Martin Hiesmann: Witherby \& Co., London, 1s. $6 \mathrm{~d}$.

This is an extended account of the methods pursued by Baron Berlepsch in Germany and gives innumerable methods by which the end can be obtained on both large and small estates.

Wild bird guests, by Harold Baynes: E. P. Dutton \& Co., 1915, \$2.

This gives a most interesting and readable account of the method pursued by the writer and his friends whereby they made Meriden, New Hampshire, a veritable model bird village, where the birds became as familiar and friendly as household pets, coming when called and alighting freely upon the person. It is beautifully illustrated with innumerable photographs showing both methods and results.

The domestic cat, by Edward H. Forbush, State Ornithologist, Mass.: State Board of Agriculture, Bulletin No. 2, 1916.

This is an exhaustive treatment of the house cat in its relation to wild bird life.

Bird houses and how to build them, by Ned Dearborn: United States Department of Agriculture, Farmer's Bulletin No. 609. Address Department of Public Documents, Washington, D.C. Cost about ten cents.

On the subject of the English Sparrow as a pest the following can be recommended:

The English Sparrow in North America, by Walter B. Barrows: Bull. No. 1, U.S. Dept. of Agriculture, 1889 , pp. 405.

How to destroy the English Sparrow, by Ned Dearborn: Farmer's Bulletin No. 383, U.S. Dept. of Agriculture, 1910.

The English Sparrow as a pest, by Ned Dearborn: Farmer's Bulletin No. 493, U.S. Dept. of Agriculture, 1912.

These reports give the English Sparrow a fair trial and an honest conviction, and suggest various means of keeping its number under control.

KEY TO THE BIRDS OF EASTERN CANADA.

\section{Explanation.}

In zoological descriptions a "key" is a device through which a specimen can be gradually referred from larger to smaller groups by picking out salient characters and its specific identity thus finally fixed.

The key here published is a modification of one originated by $\mathrm{Mr}$. Frank Chapman and Ernest Thompson Seton and published in the former's "Handbook to the birds of eastern North America." It is hoped that it will be found of great assistance to the beginner. One advantage of this key is that it is independent of the varying characters of age, sex, or season, and may be used for juveniles and females as well as adult male specimens. 
The method of its use is as follows: given a bird in the hand of unknown species to determine its name. It is first compared with the first heading in small capitals numbered in Roman numerals-I, FEET FULLY WEBBED. If this description does not fit the bird, the next Roman numeral heading is referred to-II, FEET PARTLY WEBBED, or III, FEET WITHOUT PRONOUNCED WEB. Assuming that the latter correctly describes the bird under discussion, we refer to the headings of next lower rank, which are numbered alphabetically with capital letters, where we find the alternatives-F, Legs long, and G, Legs short. Sometimes it may be difficult to decide whether a leg should be regarded as long or short, and the various pictured details following may then assist determination. In this case the legs we decide are not remarkably long, no longer in comparison to size of the bird than are the legs of a chicken or sparrow; we, therefore, under $\mathrm{G}$, refer to a number of subordinate alternatives, distinguished by small initial letters- $\mathrm{k}$, feet chicken-like, strong and compact for scratching; l, feet strongly clawed for holding prey; $\mathrm{m}$, feet small and weak; $\mathfrak{n}$, feet small or medium-sized, solidly made and legs covered with horny scales or plates. Glances at various feet shown under each heading will assist in determination. Assuming a decision in favour of the last, we compare our specimen with the next alternatives, numbered with ordinary Arabic numerals-19, two toes in front; 20 , three toes in front. There can be little confusion here and we assume that our specimen having three front toes is one of the great body of perching birds. We, therefore, compare it with the following line detail drawings to see with which it agrees most closely. The bill is not wide and flat; it is, therefore, not a flycatcher; there are no ear-tufts or long hind toe and the nostril is not covered with feather tufts, therefore it cannot be either a Horned Lark, a Crow, or a Jay. The next picture, the Bobolink's bill, catches our eye and the sparrow bill in the next lot. A glance through the remainder shows that our bird must be a bobolink or one of the sparrows. The picture p. 247, and description of the former, is nothing like it; therefore, we turn to the sparrows, read the general sparrow description, and remarks on $p .161$, and then work through the pictures. After looking at all the illustrations we find that our specimen agrees with that of the Song Sparrow, and on reading over the distinctive characters we have our opinion confirmed. It has the sharply striped breast aggregated in the centre, and is without either the yellow stripe over the eye of the Savannah Sparrow or the white outer feathers of the tail, as in the Vesper. We are, therefore, confident that, starting with no other ornithological knowledge than that the specimen was an Eastern Canadian bird, we have been able to refer it to its proper species. 
Key.

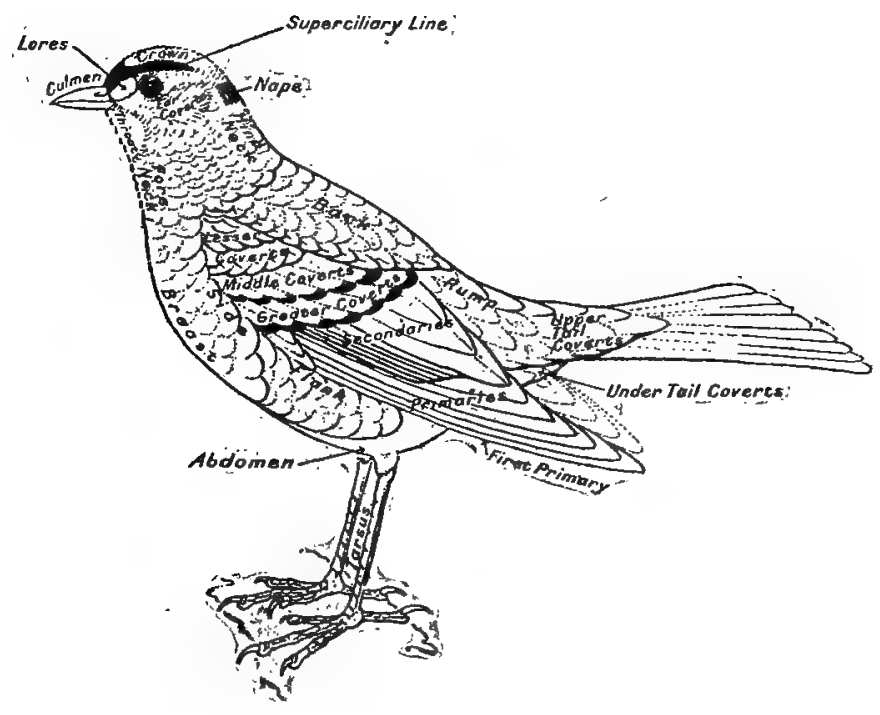

Figure 1.

Plumage areas of a typical bird.

I. Feet Fully Webbed-Two or three complete webs to each"foot.

A, Toes, four.

a, Tarsus flattened.

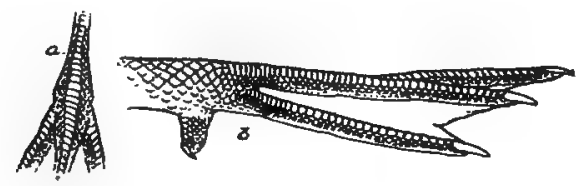

Figure 2.

Loons.... ............................. . . 44 .

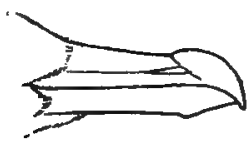

Figure 3.

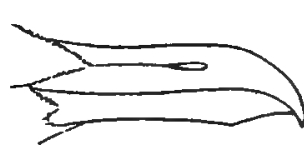

Figure 4.

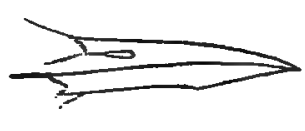

Figure 5.

b, Closed wing longer than tail, except in some Jaegers (Figure 3) and Terns (Figure 5), in which the rule only holds if the greatly elongated central tail feathers of the former or the outer ones of the latter are disregarded. Bills as shown

Long-winged Swimmers-Gulls, Tern, Jaegers.............. p. 48. 
c, Webs between all toes ( 3 webs)

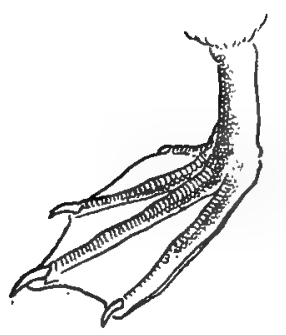

Figure 6.

Full-Webbed Swimmers-Gannets, Cormorants, etc.,........... 59.

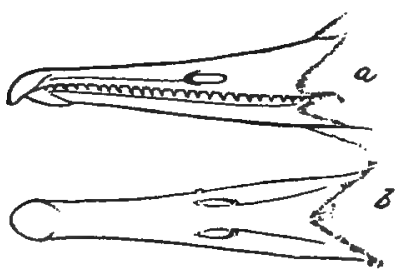

Figure 7.

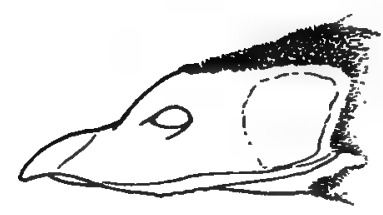

Figure 9.

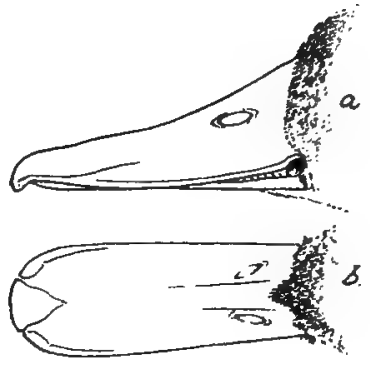

Figure 8.

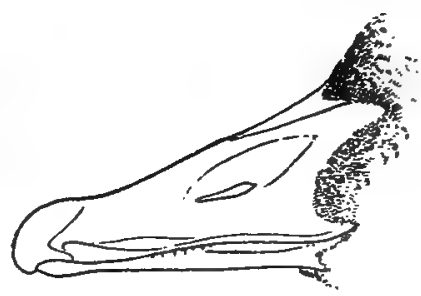

Figure 10.

d, Bill toothed or flattened (Duck-like).

Sieve-billed Swimmers-Mergansers, Ducks, Geese, and Swans.... p. 62.

e, Nostrils in tubes on top of bill.

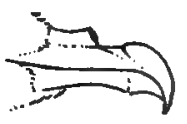

Figure 11.

Tube-nosed Swimmers-Petrels, etc................... 56 . 
B, Toes three (without hind toe), except Kittiwake (p. 50).

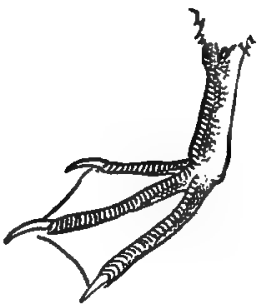

Figure 12.

Auks, Murres, etc. p. 45 .

II. Feet Partly Webbed-Webs reduced to scallops, bordering flaps, or small webs at base of toes. Toes four, "except as otherwise noted.

C, Tarsus much flattened; webs as shown.

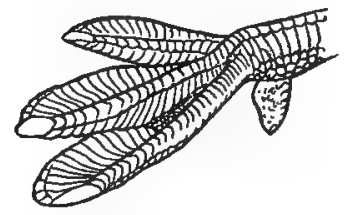

Figure 13.

Grebes. p. 42.

D, Bill extending in forehead and forming frontal plate.

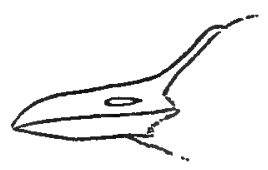

Figure 14.

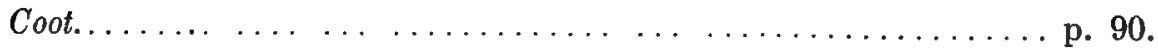

E, Small birds; bill long and slender; toes three or four.

f, Bill without hard terminal enlargement; toes four, except Sanderling (p. 97).

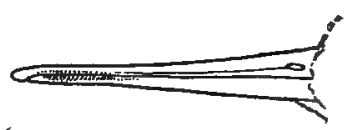

Figure 15.

Shore Birds-Phalaropes, Snipe, Sandpipers, Plover......... p. 90.

g, Bill with hard terminal enlargement; toes three, except Black-bellied Plover (p. 103).

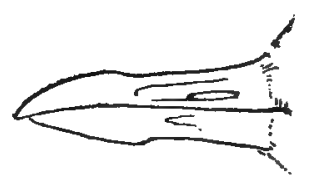

Figure 16.

Plover 
III. Feet Without Pronounced Web.

F, Legs long, for wading in water or mud; toes long, slender, and flexible at joints.

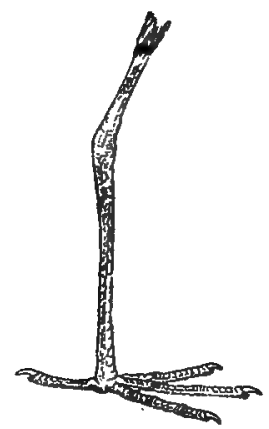

Figure 17.

h, Bill stout and horny; bare space about eyes.

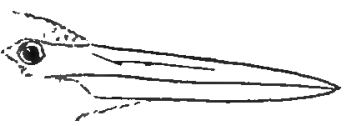

Figure 18.

1, Middle toe with comb.

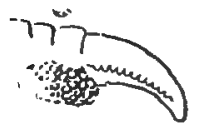

Figure 19.

Herons.

p. 80 .

2, Forehead bare.

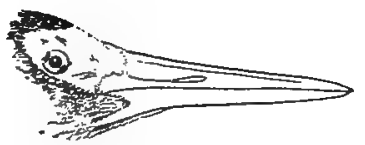

Figure 20.

i, Bills long, flexible, and evenly tapered.

3, Bill rather slender,
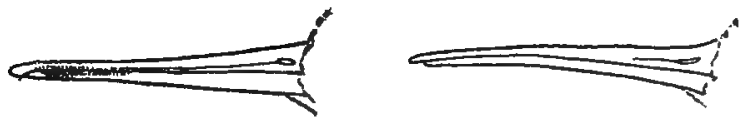

Figures 21 and 22. not markedly deeper at base than tip. Toes four, except Sanderling (p. 97).

Phalaropes, Snipe, Sandpipers p. 90 . 
4, Bill rather decidedly heavier at base than at tip.

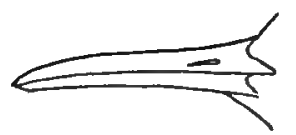

Figure 23.

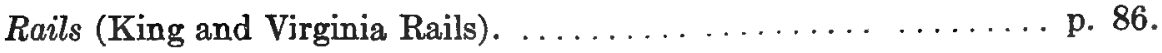

j, Bills short.

5, Bill soft at base ending in hard terminal enlargement. Toes three, except Black-bellied Plover. (p. 103).

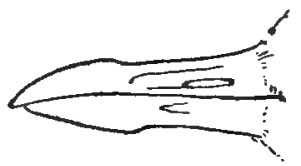

Figure 24 .

Plover.

p. 102.

6, Bill quite stout.

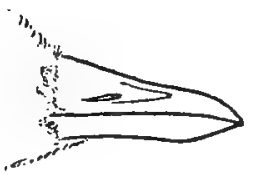

Figure 25.

Rails (Sora and Yellow Rails) ... . . . . . . . . . . . p. 88 .

7, Bill stout with frontal shield extending on forehead.

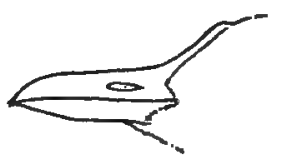

Figure 26.

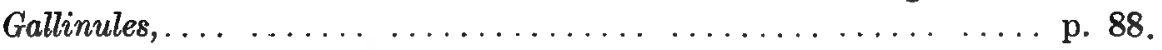

8 , Bill horny to base, wedge-shaped in profile, and appearing to be slightly turned up.

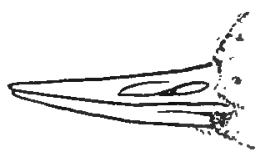

Figure 27.

Turnstone. p. 105.

G, Legs short for perching, walking, climbing, and living in trees or on land.

k, Feet chicken-like, strong and compact; toes less flexible; claws strong and blunt for scratching. Tarsus feathered or bare. With or without comb-like appendages on toes.

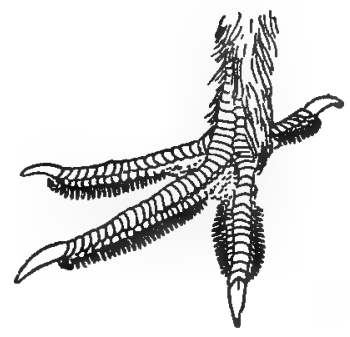

Figure 28. 
9, Bill rather conical; feathered to or about nostril.

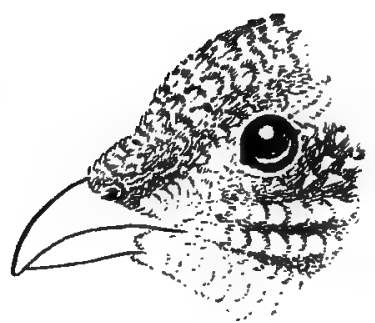

Figure 29.

Grouse and Quail............................ p. 106.

10, Bill hooked; neck and head bare.

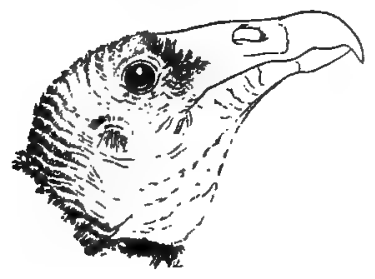

Figure 30 .

Vultures.... ........................... 114 .

1, Feet powerful for holding prey; claws long, strong, sharp, and curved. tarsus feathered or bare.

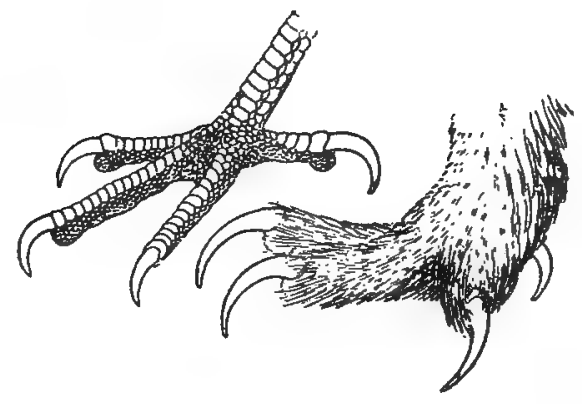

Figures 31 and 32 .

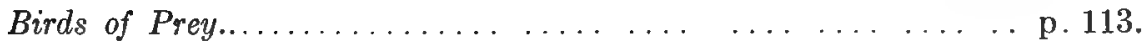

11, Naked cere at base of bill. Tarsus always (except Roughleg Hawk and Golden Eagle) bare. Toes always bare (Figure 31).

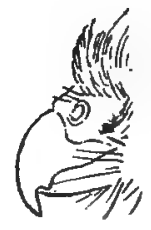

$a$

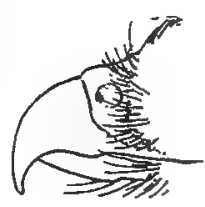

$b$

Figure 33 .

Hawks and Eagles............................. p. 116 . 
12, Cere hidden in feathers; eye in centre of more or less circular feather disks. Tarsus and toes feathered (Figure 32).

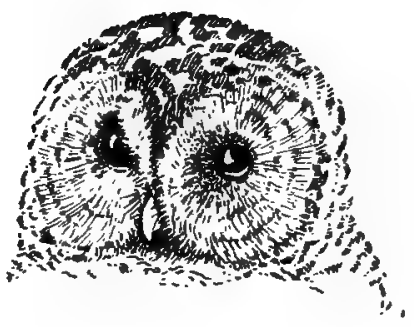

Figure 34.

Owls . p. 129

$\mathrm{m}$, Feet small and weak.

13 , Nostrils opening in a soft and somewhat swollen base.

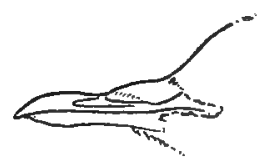

Figure 35.

Pigeons.

p. 111.

14, Two outer toes joined together for half their length.

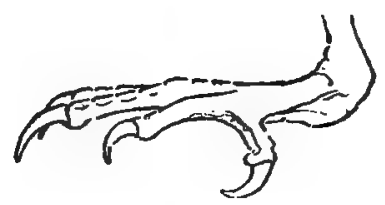

Figure 36.

Kingfishers.

p. 135 .

15, Two toes directed forward, two backward (see also Woodpeckers).

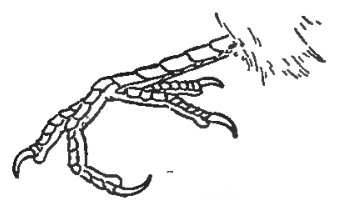

Figure 37.

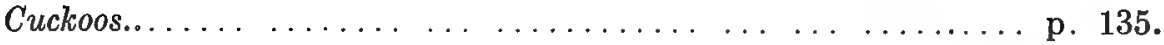

16. Bill very small; mouth enormous, opening to below eyes.

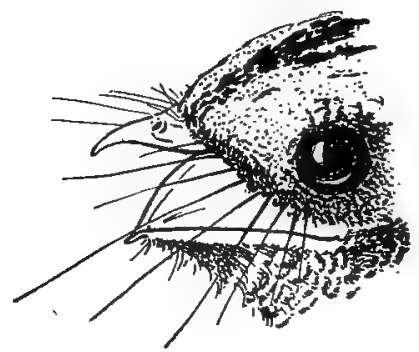

Figure 38.

Goatsuckers, Whip-poor-will, Nighthawks............... p. 143. 

17, Tail feathers ending in sharp
spines.

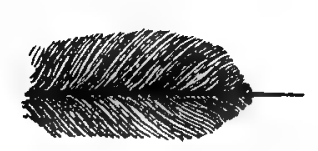

Figure 39.

Chimney Swift............................... 145 .

18, Bill very slender and awl-shaped. Exceedingly minute birds.

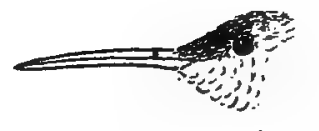

Figure 40 .

Hummingbird........................... 146 .

n, Feet, medium-sized or small, but not noticeably weak, flabby, or loose jointed. Legs covered with scales or plates.

19, Two toes in front, either one or two directed backwards. Bill chisel-shaped at tip.

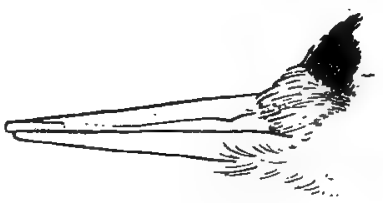

Figure 41.

Woodpeckers.

p. 138.

20 , Three toes in front; hind toe as well developed and as long as middle toe; claw on hind toe usually as long as or longer than that on middle toe.

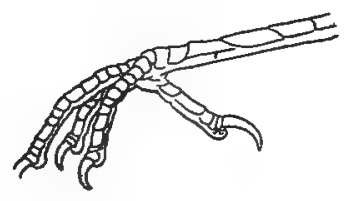

Figure 42.

Perchers................................ 147.

Recognition of Details of the Perchers.

Bill wider than high at base;

tip slightly hooked.
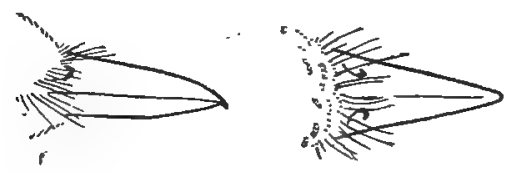

$a \quad$ Figure $43 . \quad b$

Flycatchers. p. 148.

Note ear tufts and long hind toe nail. Longspur and Pipit only other species having latter feature.

Horned Lark.

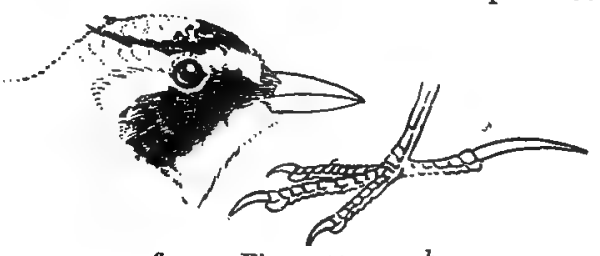

a Figure $44 . \quad b$ 
Bill stout, nostrils covered by bristly tufts.

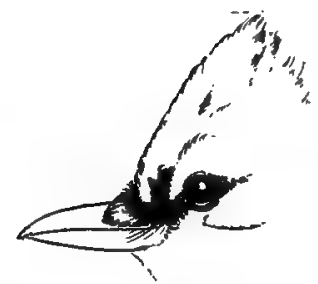

Figure 45 .

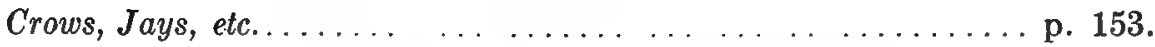

Keel of bill usually extending more or lesś up on forehead.

Cowbird and Bobolink (Fig. ure 46) have bills resembling the sparrow, see species.
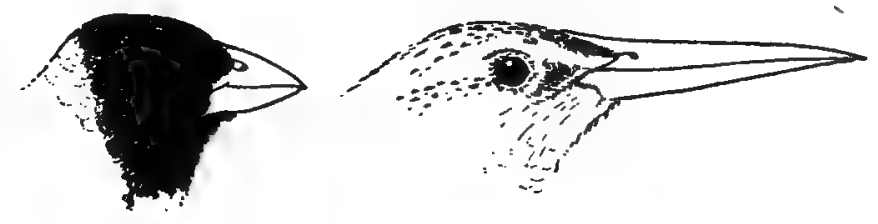

Figures 46 and 47.

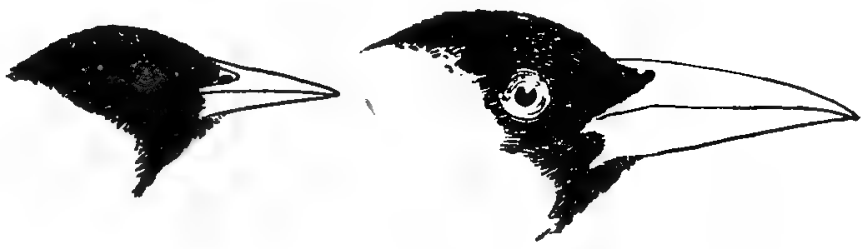

Figures 48 and 49.

Starlings.

p. 156.
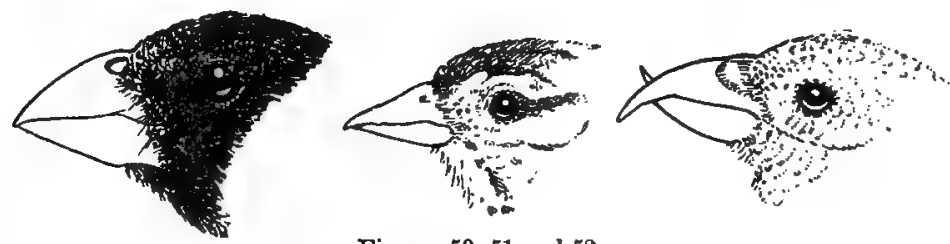

Figures 50, 51 and 52 .

Bill conical, stout for seed cracking. (Bills of Bobolink and Cowbird superficially similar, see descriptions.)

Sparrows................................ 161.

Slight or marked tooth on cutting side of upper mandible.

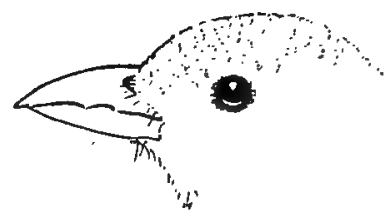

Figure 53.

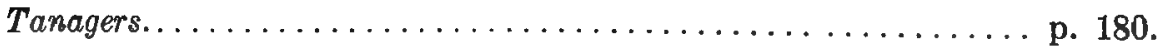


Bill very small, wide, and flattened at base.

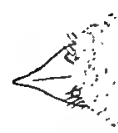

(a)

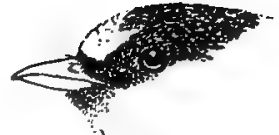

(b)

Figure 54.

Crest and black eye-band most conspicuous.

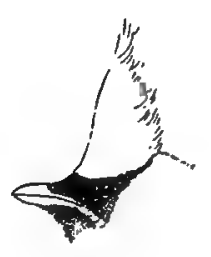

Figure 55.

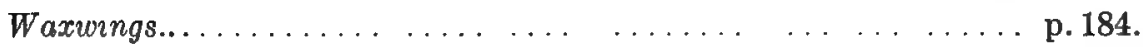

Tooth near tip of upper mandible.

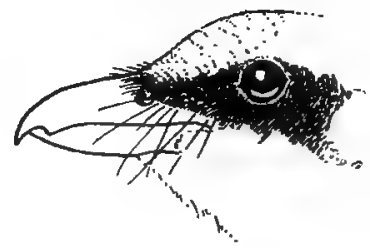

Figure 56.

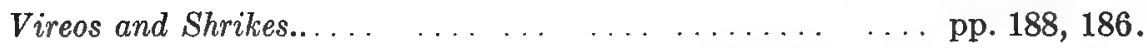

Small, brightly coloured birds. Olivegreens and yellows are perhaps the commonest colours, but blues, reds, and other colours are often present.

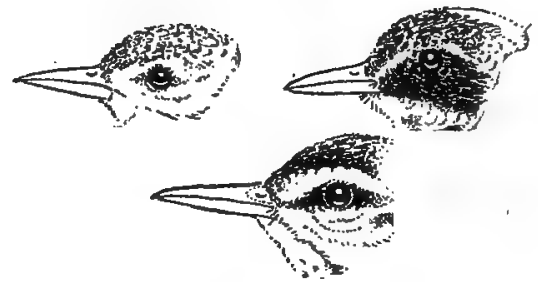

Figures 57, 58, and 59.

Wood Warblers... . . . . . . . . . . . . . . . . . p. 190

Fine sharp bill and long claw on hind toe.

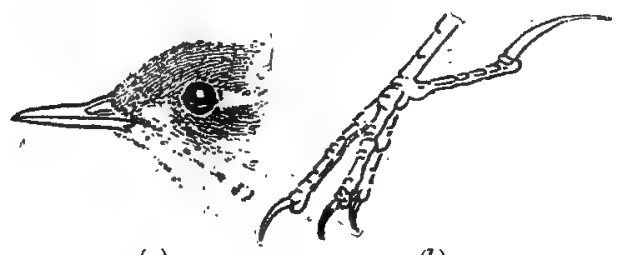

(a)

Figure 60.

(b)

Pipit . 

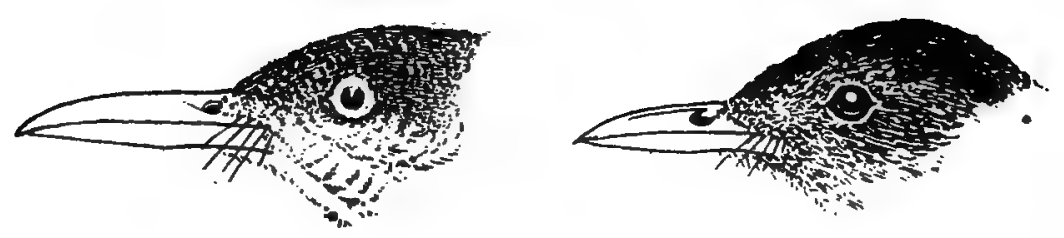

Figures 61 and 62.

Bills as shown. Thrasher large red-brown and white bird; Catbird even slate grey.

Thrasher and Catbird.

p. 205.

Small birds coloured in shades of wood-brown.

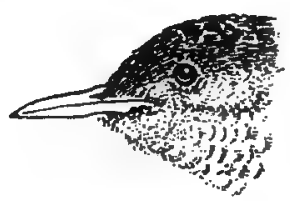

Figure 63.

Wrens.

(1)

p. 207.

Small birds in wood-brown colours. Tail long and stiff, feathers pointed at end.

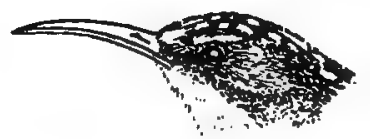

Figure 64.

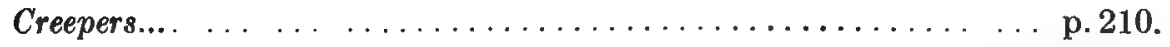

Bill pointing slightly upwards.

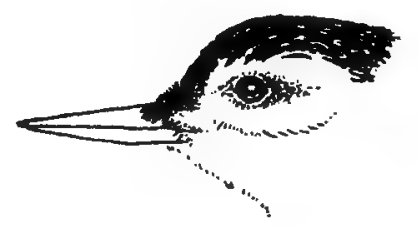

Figure 65.

Nuthatches................................. p. 210 .

Very small birds coloured in greys, white, and black.

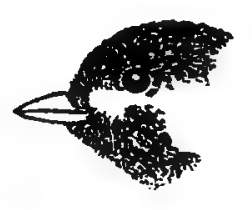

Figure 66.

Titmice. 
Very small birds, olive-coloured. Males with small, brightly-coloured crown patch.

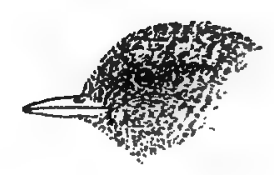

Figure 67.

Kinglets.

p. $213^{\circ}$

Medium-sized birds, coloured usually, except Robin and Blue-bird, in soft browns with more or less spotted breast.

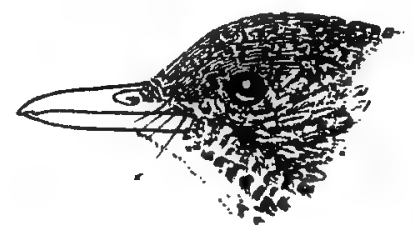

Figure 68 .

Thrushes

p. 215.

\section{SYSTEMATIC INDEX.}

Titles given in small capitals have special headings devoted to them; those in italies are mentioned incidentally in the text. Starred species are illustrated in colours.

Class........ vVEs, birds.

PAGE.

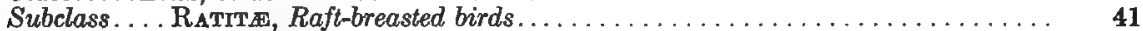

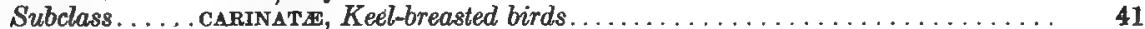

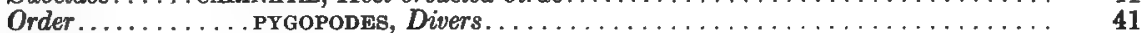

Suborder. . . . . . . . Colymbi, Grebes......................... 42

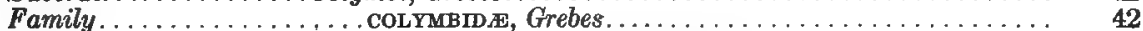

Western Grebe. . . . . . . . . . . . . . 42

HOLBCELL's GREBE. . . . . . . . . . 42

HORNED GREBE . . . . . . . . . 43

*PIED-BILLED GREBE. . . . . . . . 43

Family . . . . . . . . . . . Gavind Loons. . . . . . . . . . . . . . . . . . . . 44

${ }^{*}$ COMMON LOON............... 44

Family RED-THROATED LOON. . . . . . . . . . 44

PUFFIN . . . .

BLACK GUILLEMOT. . . . . . . . 46

Atlantic Guillemot.............. 46

Mandt's Guillemot. . . . . . . . . 46

COMMON MURRE............... 46

Atlantic Murre............... 46

THICK-BILLED GUILLEMOT . . . . . . 46

Brïnnich's Murre. . . . . . . . . . . . 46

RAZOR-BHLDD AUK .......... 47

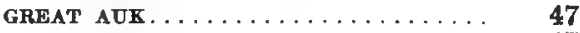

DOVEKTE. . . . . . . . . . . . . . . 47

$57172-3 \frac{1}{2}$ 
Order. . . . . . . . . . LoNGIPENNES, Long-winged Swimmers . . . . . . . . . . . . . . . . . 48

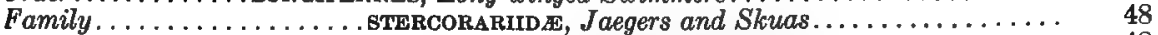

POMARINE JAEGER............. 48

PARAGTTIC JAEGER. . . . . . . . . . 49

LONG-TAILED JAEGER. . . . . . . . 49

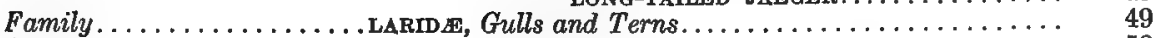

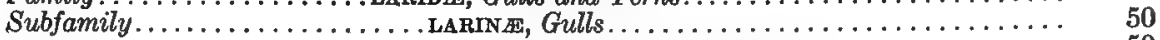

KTTTWAKE................. 50

Atlantic Kittiwake............. 51

GLAUCOUS GULL............... 51

ICELAND GULL................ 51

GREAT BLACK-BACKED GULL........ 51

* herring gull. . . . . . . . . . . . . . 52

RING-BILLED GULL... . . . . . . . . . . 53

BONAPARTE's GULL. ................ 53

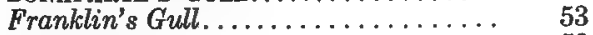

Laughing Gull. . . . . . . . . . . . . . . . 53

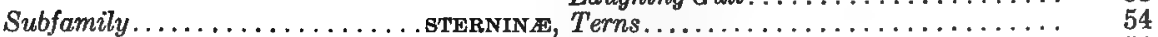

CASPIAN TERN.............. 54

FORSTER'S TERN.............. 55

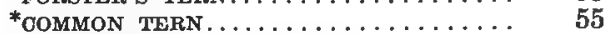

ARCTIC TERN ............... 55

BLACK TERN................. 56

American Black Tern............. 56

Order.......... Tobinares, Tube-nosed Swimmers................... 56

Family. . . . . . . . . . . . . Procellariide, Lesser Tube-nosed Sirimmers. . . . . . . . . 57

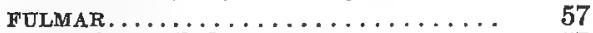

Atlantic Fulmar............ 57

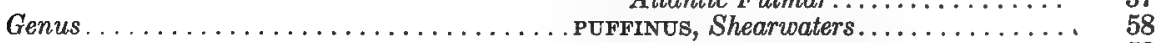

GREATER SHEARWATER. . . . . . 58

SOOTY SHEARWATER............ 58

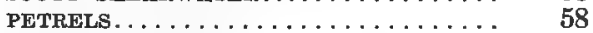

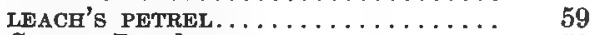

Stormy Petrel. ................... 59

WILSON's PETREL. .............. 59

Order. . . . . . . . . steganopoders, Full-webbed Swimmers. . . . . . . . . . . . . . . . . . 59

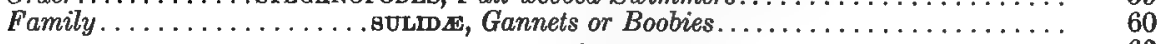

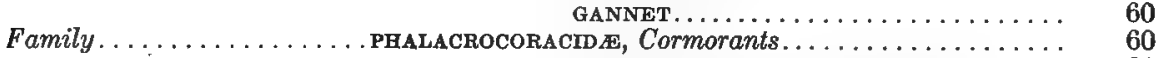

COMMON CORMORANT................... 61

DOUBLE-CRESTED CORMORANT......... 61

Eastern Double-crested Cormorant.. 61

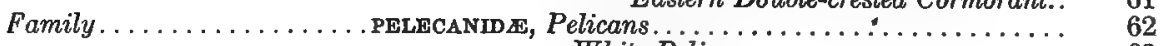

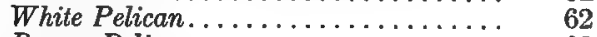

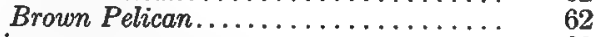

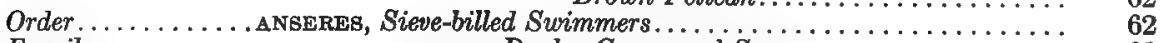

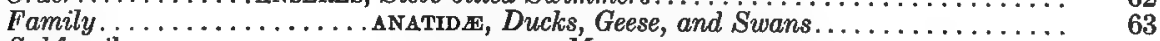

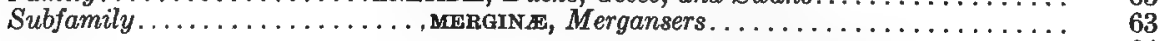

AMERICAN MERGANSER........... 64

*RED-BREAsted merganser.......... 64

HOODED MERGANBER. . . . . . . . 64

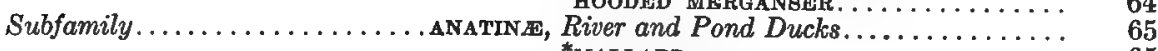

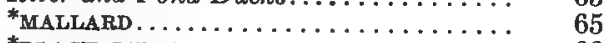

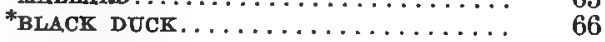

GADWALL. . . . . . . . . . . . 66

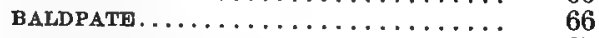

GRELN-WINGED TEAL. . . . . . . . . . 67

*BLUE-WINGED TEAL. . . . . . . . . . . . 67

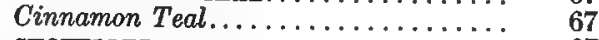

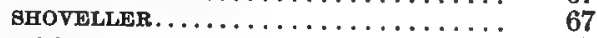

PINTAIL.................. 67

${ }^{*}$ woOd DUCK.................... 68 
Subfamily Foligulin

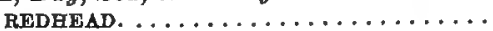

CANVAS-BACK...............

GREATTER SCAUP DUCK..........

LESBER SCAUP DUCK.............

RING-NECKED DUCK. . . . . . . . . .

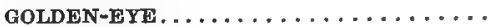

American Golden-eye............

BARROW'S GOLDEN-EYE...........

BUFFLE-HEAD . . . . . . . . . . . . .

HARLEQUIN DUCK............. 72

Genera.

. OOMATERIA and OIDEMIA, Eiders and

Scoters........................

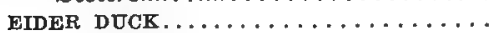

Northern Eider.............. 73

AMERICAN EIDER. ............ 73

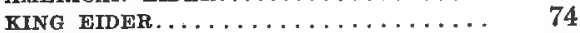

AMERICAN SCOTER........... 74

WHITE-WINGED SCOTER......... 74

SURF sCOTER............... 74

RODDY DUCK............... 75

Subfamily............. AnSERIN

sNow Goose.............. 75

Lesser Snow Goose............... 75

Greater Snow Goose................ 75

BLUE GOOSE.................. 76

WHITE-FRONTED GOOSE.......... 76

American White-fronted Goose ....... 76

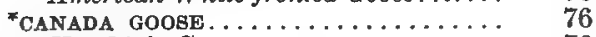

Hutchin's Goose.................. 76

BRANT,................. 77

American Brant................ 77

Black Brant.................. 77

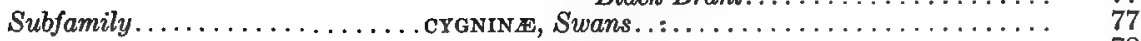

WHISTLING SWAN............ 78

THUMPETER SWAN............ 78

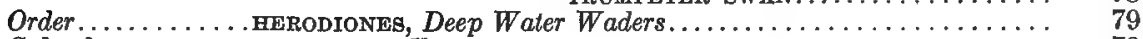

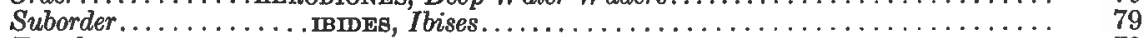

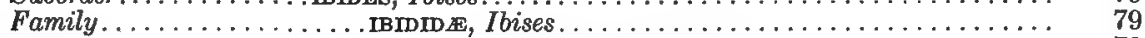

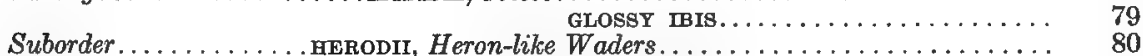

Family. . . . . . . . . . ARDEm A Herons and Bitterns............... 80

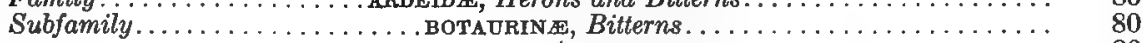

* AMERICAN BITTERN . . . .

LEAST BITTERN.............. 81

Cory's Least Bittern................. 81

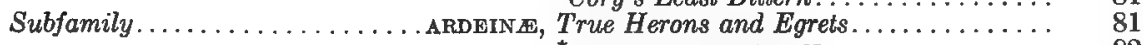

* GREAT BLUE HERON............... 82

Eastern Great Blue Heron.......... 82

WHITE HERONS............... 83

AMERICAN EGRET. . . . . 83

LITTLE BLUE HERON. . . . . . . 83

Louisiana Heron................ 84

GREEN HERON................ 84

Northern Green Heron................ 84

BLACK-CROWNED NIGHT HERON...... 85

Yellow-crowned Night Heron......... 85

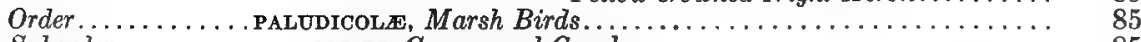

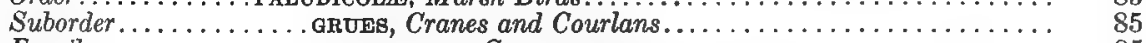

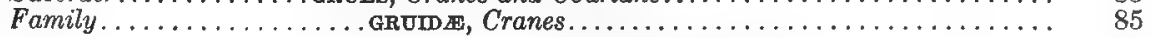

SANDHILL CRANE.............. 85

Little Brown Crane.................. 85

Whooping Crane................... $\$ 6$ 
Suborder.

RaLLI, Smaller Marsh Birds.

Family.

.... RALLIDs, Rail-like Birds. .

Subfamily

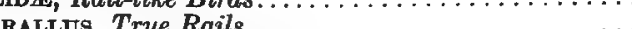

KING RAIL.

Clapper Rail. ..................

VIRGINIA RAIL.................

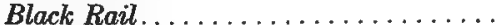

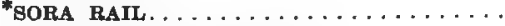

YELLOW RAIL................ 88

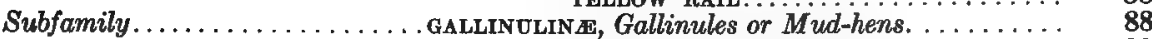
PURPLE GALLINULE. . . . . . . . . . 89 FLORIDA GALIINULE............ 89

Subfamily FULICINA, Coots

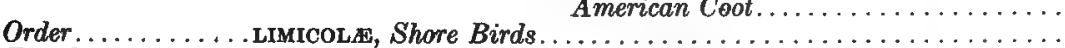

Family............. Phalakopodide, Phalaropes................. RED PHALAROPE................ NORTHERN PHALAROPE. . . . . . . . . WILBON's PHALAROPE..............

Family recurvirostrid as, Avocets and Stilts............ AMERICAN AVOCET. . . . . . . . . .

Family.

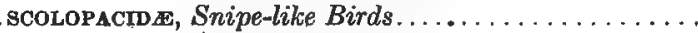

*american woodcock..............

*WILSON's SNIPE................

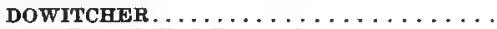

Long-billed Dowitcher. . . . . . . . . . GTILT SANDPIPER,............. KNOT . . . . . . . . . . . . PURPLE SANDPIPER............

Eastern Purple Sandpiper....... PECTORAL SANDPIPER............ WHITE-RUMPED SANDPIPER........ BAIRD's SANDPIPER. . . . . . . . . . LEAST SANDPIPER $\ldots \ldots \ldots \ldots \ldots \ldots$ DUNLIN....................

Red-backed Sandpiper.......... CURLEW SANDPIPER............. BEMIPALMATED SANDPIPER . . . . . . Western Sandpiper............

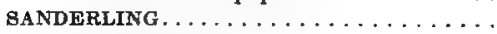
MARBLED GODWIT ............. HUDSONIAN GODWIT............ GREATER YELLOW-ILEGS ........... LESSER YELLOW LEGS. . . . . . . . . . . BOLITARY SANDPIPER........... Eastern Solitary Sandpiper.......

Genus. . ...................... NUMEnIUs, Curlews.............. 101

LONG-BILLED CURLEW . . . . . . . . . 101

HUDSONIAN CURLEW . . . . . . . . . 102

ESKIMO CURLEW . . . . . . . . . . . 102

Family.

Plover.................................. 


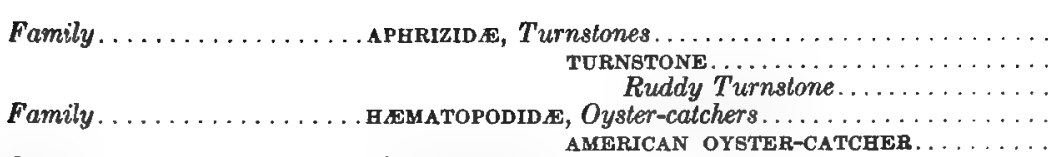

Order........... GaLlinds, Scralching Birds. .

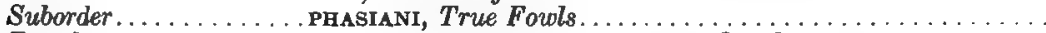

*RUFFED GROUSE. . . . . . . . . . . . 108 Canada Ruffed Grouse.......... 108

Genus. . LAgopus, Ptarmigan...............

WILLOW GROUSE ................ 110 Willow Ptarmigan............. 110 Allens Ptarmigan. . . . . . . . . . . 110

ROCK PTARMIGAN............... 110 Arctic Ptarmigan............... 110 Reinhardts Ptarmigan........... 110 Welsh's Ptarmigan............ 110

PRAIRLE CHICKEN............... 110 Northern Prairie Chicken........ 110

BHARP-TATLED GROUSE............ 111 Northern Sharp-tail............... 111 Prairie Sharp-tail................ 111

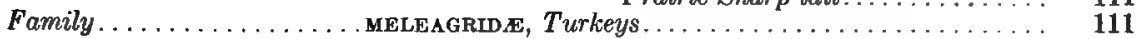

WILD TURKEY. . . . . . . . . . . 111 Northern Wild Turkey......... 111

Order.......... colvмвs, Pigeons and Doves........................ 111

Family................ CoLumbIDe, True Pigeons and Doves............. 111

* Passenger pigeon................. 112

* ModRnING dove...................... 113

Caralina Mourning Dove........... 113

Order.......... RaptoRes, Birds of Prey.......................... 113

Suborder............ SARCORHAMPHI, American Vultures..................... 114

Family . . . . . . . . . . . . . TURKEY VULTURE.............. 115

Northern Turkey Vulture.......... 116

BLACK VULTURE............... 116

Suborder............ FaLcones, Diurnal Birds of Prey................... 116

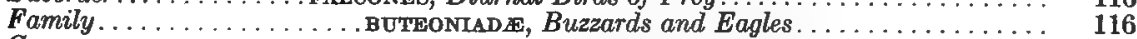

Genera.......................... ELANOIDEs and cIRcos, Kites and Harriers 117 SWALLOW-TAILED KITE. . . . . . . . . . 117

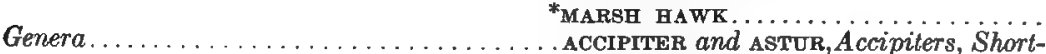
117 winged Hawks.................. 118

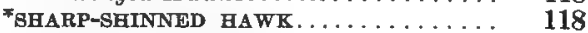

COOPER'S HAWK . . . . . . . . . . . 119

*aMERICAN GOSHAWK. . . . . . . . . 119

Genera.................... Buteo and ARCHIBUTEo, True Buzzards. 12

*RED-TATLED HAWK............. 120 Eastern Red-tail................. 121

${ }^{*}$ RED-SHOULDERED HAWK.......... 121

Eastern Red-shouldered Hawk. . . . 122

SWAINSON'S BAWK............. 122

BROAD-WINGED HAWK . . . . . . . . 122

ROUGH-LEGGED HAWK........... 123

American Rough-legged Hawk.... 123 
Genera.

AQULLA and HALIXTOS, Eagles.

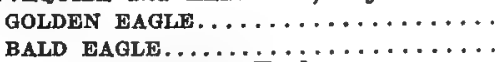

Northern Bald Eagle.

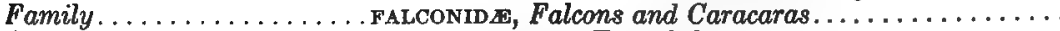

Subfamily.

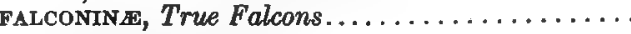

GYRFALCONS

WHITE GYRFALCON .............

125

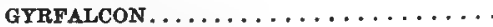

Grey Gyrfalicon..................

Black Gyrfalcon.

126

126

126

*PEREGRINE FALCON.............

Duck Hwak.

126

126

126

PIGEON HAWK.................

127

Eastern Pigeon Hawk........... 127

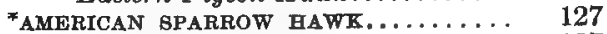

Eastern Sparrow Hawk. ........ 127

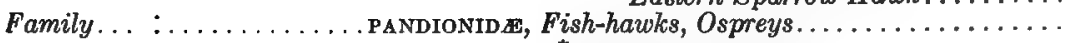

*OSPREY

American Osprey . ............... 128

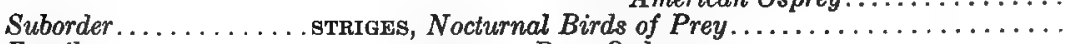

Family. STRIGES, Nocturnal Birds of

AmpRICAR Ban ow

Family.

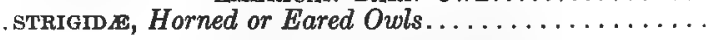

AMERICAN LONG-EARED OWL. . . . . .

AMERICAN SHORT-EARED OWL........

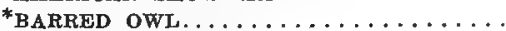

Eastern Barred Owl.............

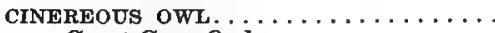

Great Grey Owl...............

ARCTIC SAW-WHET OWL.............

Richardson's Ool...............

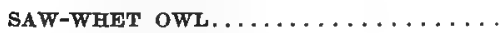

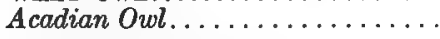

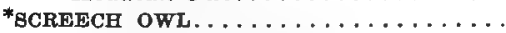

Eastern Screech Owl...........

* GReat hoRned owl. ............... Eastern Horned Owl........... Western Horned Owl............. Arctic Horned Owl................ Labrador Horned Owl..............

Order. . . COCCrges, Cuckoos and

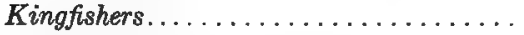

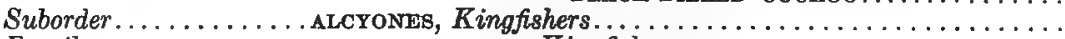

*BELTED KINGFLSEER . . . . . . . . . . 137

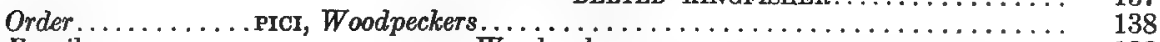

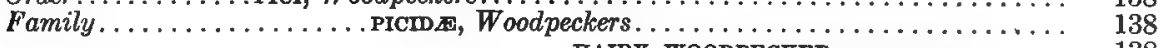

HAIRY WOODPECKER............ 138

Eastern Hairy Woodpecker......... 139

Northern Hairy Woodpecker...... 139

*DOWNY WOODPECKER............. 139

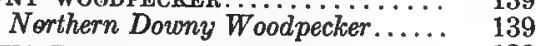

*ARCTIC THREE-TOED WOODPECKER...... 139

AMERICAN THREE-TOED WOODPECKER.. I40 Eastern Three-toed Woodpecker.... 140

*YELLOW-BELLIED BAPSUCKER........ 140 
Family. PICIDA.-Continued.

Order............. MACRochIREs, Goatsuckers, Swifts, and Hummingbirds........ 143

Suborder............ CAPRIMULGI, Goatsuckers..................... 143

Family. . . . . . . . . . . . CAPRIMULGID $\mathbb{E}$, Goatsuckers.................... 143

CHUCK-WILL's WIDOW . . . . . . . . 143

WHIP-POOR-WILL............. 143

Eastern Whip-poor-will.......... 143

*NIGHTHAWK................. 144

Eastern Nighthawk............ 144

Suborder............ CrpsenI, Swifts and Allies..................... 145

Family. . . . . . . . . . . MICROPODID $\mathbb{E}$, Swifts.................. 145

Subfamily................ CHATURINA, Spine-tailed Swifts.............. 145

*CHIMNEY SWIFT. ................. 145

Suborder........... TRocHIL, Hummingbirds...................... 146

Family . . . . . . . . . . . . TROCHILId

* $_{\text {RUBY-THROATED HUMMINGBIRD . . . . . . } 146}$

Order.......... Passeres, Perching Birds................... 147

Suborder.............. claMatoRes, Songless Perchers........................ 147

Family.............. TYRANNID $\mathrm{E}$, Tyrant Flycatchers.............. 148

SCISSOR-TAILED FLYCATCHER...... 148

* KINGBIRD................... 148

CRESTED FLYCATCHER. . . . . . . 149

*PHOEBE................... 149

OLIVE-SIDED FLTCATCHER . . . . . . 150

WOOD PEWEE................ 150

YELLOW-BELLIED FLYCATCBER...... 151

ACADIAN FLYCATCHER, . . . . . . 151

TRAILL's FLYTCATCHER. . . . . . . . . 151

Alder Flycatcher................... 151

Western Alder Flycatcher........ 151

LEAST FLYCATCHER. 152

Suborder........... oscines, Song Birds.......................... 152

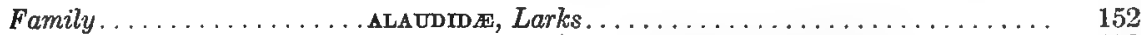

${ }^{*}$ HORNED LARK ............... 152

Eastern Horned Lark. . . . . . . . . . 153

Prairie Horned Lark............. 153

Hoyt's Horned Lark. . . . . ...... 153

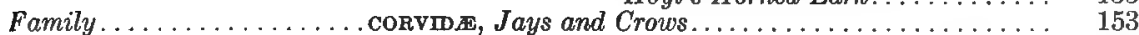

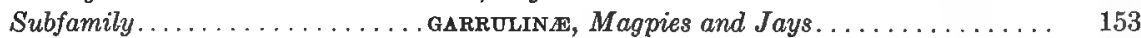

MAGPIE.................... 153

American Magpie................ 153

* BLUE JAT.................. 154

*CANADA JAY................ 154

Eastern Canada Jay.............. 154

Labrador Jay.................. 154

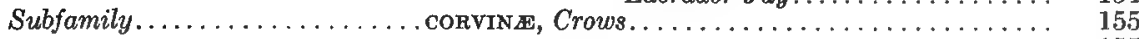

RAVEN........................ 155

Northern Raven............. $\quad 155$

*american crow.............. 156

Eastern Crow.................. 156

Family............... ICTERID, A merican Starlings................ 156

*BовоLINK................. 157

*Cowbird................ 157

YELLOW-HEADED BLACKBIRD ......... 158

* RED-WINGED BLACKBIRD . . . . . . . . . 158

Eastern Red-wing........... 158

Northern Red-wing............. 158 
Family

ICTERIDA.-Concluded.

PAGE

* MEAdowlaRK. . . . . . . . . . . . . 159

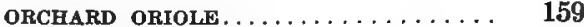

* BALTIMORE ORIOLE............... 160

RUSTT BLACKBIRD . . . . . . . . . . 160

CROW. BLACKBIRD.

*Bronzed Grackle................ 161

Purple Grackle............... 161

Family. . . . . . . . . . . . FRIngILLID s, Sparrows, Linnets, Finches, or Buntings.. 161

EVENING GROSBEAK.............. 162

Eastern Evening Grosbeak. . . . . 162

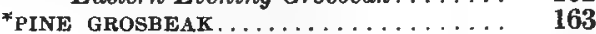

Canadian Pine Grosbeak. . . . . . . 163

*PURPLE FINCH............... 163

Eastern Purple Finch........... 163

*HOUSE SPARROW............... 164

CROssbill.................... 165

American Crossbill............... 166

WHITE-WINGED CROSSBILL . . . . . . . 166

ACANTHIS, Redpolls.............. 166

HORNEMANN's REDPOLL . . . . . . . . . 166

Greenland Redpoll............. 167

Hoary Redpoll. . . . . . . . . . . . . 167

REDPOLL LINNET . ................ 167

Common Redpoll............ 167

Holboll's Redpoll. ............. 167

Greater Redpoll. ............... 167

*AMERICAN GOLDFINCh. . . . . . . . . 168

Eastern Goldfinch............... 168

PINE SISKIN ................ 168

* SNOW BUNTING.............., 169

Common Snow Bunting. . . . . . . . . 169

LAPLAND LONGSPUR. . . . . . . . . . . 169

Eastern Longspur. . . . . . . . . . . 169

*VESPER SPARROW . . . . . . . . . . . 169

Eastern Vesper Sparrow......... 170

IPSWICH SPARROW. . . . . . . . . . 170

SAVANNAH SPARROW............. 170

Eastern Savannah Sparrow...... 170

GRASSHOPPER SPARROW........... 171

Eastern Grasshopper Sparrow..... 171

RENSLOW's SPARROW............ 171

Eastern Henslow's Sparrow....... 171

LECONTE'S SPARROW .............. 171

NELSON'S SHARP-TAIL............. 172

Prairie Sharp-tail.............. 172

Acadian Sharp-tail............. 172

LARK GPARROW............... 172

Eastern Lark Sparrow. . . . . . . . . 172

HARRIS' SPARROW.............. 172

${ }^{*}$ WHITE-CROWNED SPARROW.........

Eastern White-crowned Sparrow... 173

*WHITE-THROATED SPARROW......... 173

*TREE BPARROW ............. 174

Eastern Tree Sparrowo........... 174

${ }^{*}$ CHIPPING SPARROW . . . . . . . . . 174

Eastern Chipping Sparrow........ 174

CLAY-COLOURED SPARROW......... 175

FIELD SPARROW............... 175

Eastern Field Sparrow............. 175

*SLATE-COLOURED JUNCO........... 175

*SONG SPARROW................. 176

Eastern Song Sparrow. . . . . . . . 176

LINCOLN'B GPARROW.............. 177

Eastern Lincoln's Sparrow...... 177 


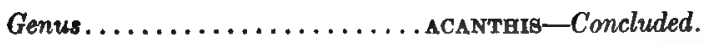

SWAMP SPARROW............... 177

FOX SPARROW................ 177

Eastern Fox Sparrow............. 178

TOWHEE.................. 178

Eastern Towhee.............. 178

CARDINAL.................... 178

Eastern Cardinal............. 178

*ROSE-BREABTED GROBBEAK. . . . . . . 179

BLUE GROSBEAK. . . . . . . . . . . . 179

Eastern Blus Grosbeak. . . . . . . 180

INDIGO BUNTING . . . . . . . . . . . . 180

DICKCISSEL. . . . . . . . . . . . . . . 180

Family........... TANGARId

${ }^{*}$ sCARLET TANAGER. . . . . . . . . . 181

SUMMER TANAGER ............. 181

Family............. HIRUNDINIDA, Swallows................... 182

*PURPLE MARTIN................. 182

Eastern Martin............. 182

CLIFP SWALLOW ............... 183

Eastern Cliff Swallow........... 183

* Barn gwaLlow................ 183

*TREe swallow.............. 183

*BANK SWALLOW............. 184

ROUGH-WINGED SWALLOW ......... 184

Family............. вомв FCILLme, Waxwings................... 184

BoHEMIAN WAXWING........... 185

* cedar waxwing................. 185

Family. . . . . . . . . . uannd $\mathbf{E}$, Shrikes, Butcherbirds............... 186

NORTHERN SHRIKE............ 186

*Loggerhead SHRIKe............ 187

Migrant Loggerhead............ 187

Family............ vireonide, Vireos or Greenlets................ 188

*RED-EYED VIREO . . . . . . . . . . . 188

Philadelphia vireo ........... 188

*WARBLING VIREO . . . . . . . . . . . . . 189

Eastern Warbling Vireo.......... 189

YELLOW-THROATED VIREO . . . . . . . . 189

SOLITARY VIREO . . . . . . . . . . . . . 189

Blue-headed Vireo............. 190

WHITE-EYED VIREO ............. 190

Northern White-eyed Vireo......... 190

Family.............. mNIOTILTId 4 , Wood Warblers.................. 190

${ }^{*}$ BLACK AND WHITE WARBLER........ 191

PROTHONOTART WARBLER.......... 192

Genus. . . . . . . . . . . . . . . vermyona, Worm-eating Warblers.... 192

WORM-EATING WARBLER. . . . . . . . 192

BLUE-WINGED WARBLER . . . . . . . . 192

GOLDEN-WINGED WARBLER . . . . . . . 192

NASHVILLE WARBLER. . . . . . . . . 193

Eastern Nashville Warbler. . . . . . . 193

ORANGE-CROWNED WARBLER . . . . . 193

Interior Orange-crown. . .......... 193

TENNESBEE WARBLER............ 193

PARULA WARBLER . . . . . . . . . . . . . 194

Northern Parula............ 194

Genus................................... ${ }_{194}^{194}$

CAPE MAY WARBLER ............. 194

*YELLOW WARBLER. . . . . . . . . . . 194

Eastern Yellow Warbler......... 195

*BLACK-THROATED BLUE WARBLER..... 195

Northern Black-throated Blue Warbler 195

* MYretle WaRBLER............... 195

*MAGNOLIA WARBLER............. 196

CERUlean warbler........... 196 
Genus.

DENDROICA-Concluded.

PAGE

CRESTNUT-SIDED WARBLER, ........

BAY-BREASTED WARBLER...........

BLACK-POLL WARBLER............

197

* Blackbutrnian warbler..........

*BLACK-TPROATED GREEN WARBLER.... KIRTLAND'S WARBLER . . . . . . . . PINE WARBLER. . . . . . . . . . .

PALM WARBLER, ..............

Interior Palm Warbler..........

Yellow Palm Warbler...........

PRAIRIE - WARBLER ...............

Genus........................ seruRUs, Wagtail Warblers..........

* ovenBIRD...................

NORTHERN WATER-THRUSH........

Eastern Water-thrush..........

Grinnell's Water-thrush..........

LOUISIANA WATER-THRUSH..........

Genera....

OPORORNIS and GEOTHLYPIS, Ground

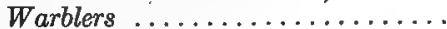

KENTUCK T WARBLER..............

CONNECTICUT WARBLER............

MOURNING WARBLER...............

MARYLAND YELLOW-THROAT..........

*Northern Yellow-throat..........

YELLOW-BREASTED CHAT............

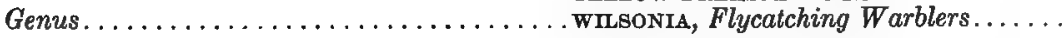

HOODED WARBLER...............

BLACK-CAPPED WARBLER............

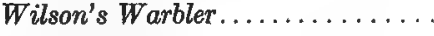

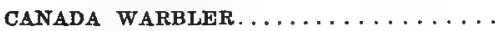

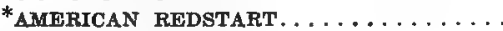

Family

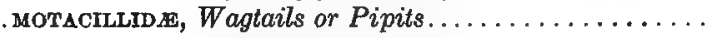

AMERICAN PIPIT................

Family

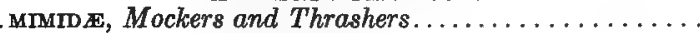

MOCKINGBIRD.................

Eastern Mockingbird...........

*CATBIRD. . . . . . . . . . . . . .

* Brown thragher. . . . . . . . .

Family

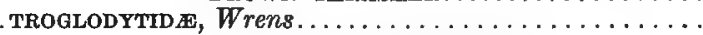

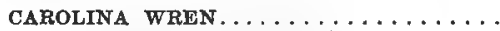

Northern Carolina Wren.........

BEWICK's WREN...............

Eastern Bewick's Wren............

197

198

198

198

199

199

199

199

199

200

200

200

201

201

201

201

201

201

202

202

203

203

203

203

204

204

204

204

205

205

205

206

206

206

207

207

207

207

208

208

${ }^{*}$ HOUBE WREN . . . . . . . . . . . . . .

Eastern House Wren............

208

208

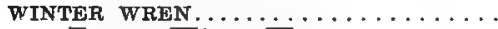

Eastern Winter Wren............

209

209

SHORT-BILLED MARSH WREN .........

209

LONG-BILLED MARSH WREN . . . . . . . . Eastern Marsh Wren...........

Family.............. CERTHIID , Creepers......................

"BROWN CREEPER..............

Eastern Brown Creeper...........

Family............. sitrid $\approx$, Nuthatches..................... 210

${ }^{*}$ CAROLINA NUTHATCH............. 211

White-breasted Nuthatch.......... 211

RED-BREASTED NUTHATCH........., 211

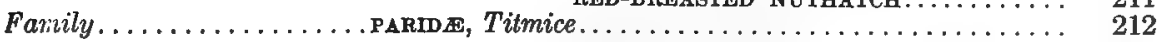

TUFTED TITMOOSE............... 212

* BLACK-CAPPED CHICKADEE . . . . . . . . 212

Eastern Chickadee.............. 212

Carolina Chickadee............... 212

BROWN-HEADED CHICKADEE........ 213

Hudsonian Chickadee............ 213

Acadian Chickadee.............. 213 
Family . BYLTIDDA, Old-world Warblers and Kinglets.

Subfamily.

$$
\text { . REGULINE, Kinglets........................ }
$$

*GOLDEN-CROWNED KINGLET.

${ }^{*}$ RUBT-CROWNED KINGLET........... 214

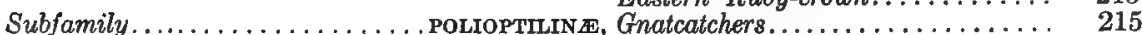

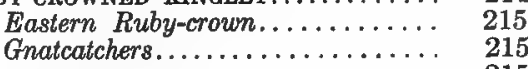

BLUE-GREY GNATCATCHER........ 215

Eastern Gnatcatcher........... 215

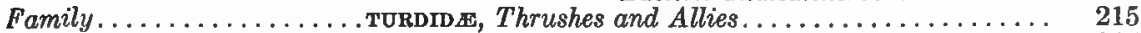

Subfamily................ TURones, True Thrushes................. 215

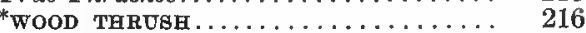

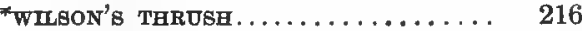

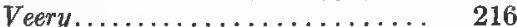

Willow Thrush.................... 216

*ALICE's THRUSH................ 216

Grey-cheeked Thrush.......... 216

Bicknell's Thrush............ 217

*OLIVE-BACKED THRUSH...... . . . . 217

Swainson's Thrush........... 217

${ }^{*}$ HERMIT THAUSH............... 217

Eastern Hermit Thrush... .... 217

*american robin.......... .... 217

Eastern Robin.............. 218

WHEATEAR. 218

Greenland Wheatear........... 218

*BLUEBIRD . . . . . . . . . . . . . . . 218

Eastern Bluebird............ 218 
. 1

: 


\section{DESCRIPTIVE ORNITHOLOGY.}

\section{GLASS-AVES, BIRDS.}

Birds, as a class, can be divided into toothed and toothless birds, although the former are now extinct and are known only by their fragmentary remains preserved as fossils. All modern birds are toothless. Some species, as the mergansers, are furnished with serrations in the horny bill that have a superficial resemblance to teeth (Figure 7, p. 19), but examination shows that these are not true teeth.

\section{SUBCLASS-CARINAT E. KEEL-BREASTED BIRDS.}

Present day, toothless birds are divided into two subclasses, the Ratita or raft-breasted birds and the Carinato or keel-breasted birds. The Ratite include the Ostriches and Emues which are without a keel to the breast bone for the attachment of wing muscles and are flightless. There are none in North America and they are, therefore, not dealt with here. The term keel-breasted is derived from the high, thin, keel-like projection from the middle of the breast bone, to which the powerful breast or wing muscles are attached.

Keel-breasted birds (subclass Carinato) are divided into numerous orders which are considered in the sequence adopted by the American Ornithologists' Union.

\section{Order-Pygopodes. Diving Birds.}

General Description. The Divers, as their name implies, are birds fitted for subaquatic pursuits. The hip joint is set far back on the body and the leg mechanism is better fitted for swimming than for walking. The tarsus, the visible part of the leg, is much flattened, (Figure 2, p. 18), and the toes are either partly (Figure 13, p. 20) or completely (Figures 2 and $6, \mathrm{p} .19$ ) webbed. The wings are small in comparison with the size of the body. The bill is straight and generally tapered, moderately long, but occasionally flattened and deepened, as in the cases of the Auks and Puffins; in the latter species this specialization reaches its bighest development in the order.

Distinctions. Toes, three or four entirely or partly webbed, tarsus flattened, tail inconspicuous or small.

Field Marks. Small wings and tail and straight, narrow, unduck-like bills. The Divers bear a superficial resemblance to ducks but where the ducks would fly the Divers dive.

Nesting. In the immediate vicinity of water on reedy shores or rocky ledges, or in crevices and holes in the ground.

In consequence of the peculiar leg construction, an unusually upright carriage of the body is necessitated when on land, and they walk with difficulty. Indeed some species are almost helpless on the ground and are unable to rise into the air except from the water, off steeply rising ground, or against a strong head wind. They swim and dive with ease and, though their wings are small in comparison to the size of the body, when once on the wing they fly with rapid beats, swiftly and strongly, in straight lines or long curves without evolution or manceuvring. 
Economic Status. The Diving Birds feed almost entirely upon aquatic life usually captured by diving and pursuit under water. Economically, they are of slight importance. The Canadian representatives of this order are divided into three families: the Grebes, Colymbida; the Loons, Gaviida; the Auks, Murres, etc., Alcidœ.

\section{FAMILY-COLYMBIDA. GREBES.}

General Description. Grebes and Divere with feet lobed and not fully webbed, and without perceptible tails. Instead of full webs extending from toe to toe, as in most swimming birds, the digits are provided with a scalloped edging of flat lobe-like flaps or processes hinged to the toe. These make excellent paddles during the stroke, and folding away, offer the minimum of resistance to the water on the return. Their wonderful diving ability has given these birds the common sobriquets of Hell-diver, Water-witch, etc.

Distinctions. Scalloped toe webs (Figure 13, p. ..), short tail, sharp pointed bill, and the peculiar silvery sheen of the feathers of the underparts.

Field Marks. Pointed bill and inconspicuous tail. Feet carried straight out behind when flying.

Nesting. In the reeds or rushes bordering sloughs or ponds, on either floating or stationary vegetable heaps.

Distribution. Grebes are distributed over the whole of Canada, and north well into the Arctic zone. In the breeding season they are generally more common on fresh than on salt water. There are three species of this family occurring regularly in eastern Canada; a fourth species, the Western Grebe, not further mentioned here, has been incorrectly recorded several times, and only one case of its occurrence can be substantiated.

Grebes are typically inhabitants of fresh ponds and lakes, though at times they frequent the sea in numbers. The adults are coloured in rather broad masses; the young show sharp stripes, especially about the head, indicating that the family has descended from a common striped ancestor. The grebe breasts, so much used for trimming and millinery purposes, are procured from birds of this family. The sacrifice of large numbers for this purpose and the drainage of many of their natural breeding grounds are continually reducing their numbers.

Economic Status. Feeding almost entirely upon water-inhabiting creatures they are of little direct economic importance. Considerable masses of feathers are often found in grebe stomachs, but no satisfactory explanation of their presence there has been offered. There is no evidence that they are remains of birds preyed upon.

2. Holbœll's Grebe. RED-NECKED GREBE. FR.-LE GREB À COJ ROJGE. Colymbus holboelli. L. 19. This is the largest of our Grebes. Summer adults have a rich chestnutred neck.

Distinctions. Size is usually sufficient to distinguish this Grebe. Juvenile birds generally have only a suggestion of the rufous neck.

Field Marks. Size will also separate it in the field from other Grebes; and the presence of a white wing patch and an unmottled back, from the Red-throated Loon with which it might be confused.

Nesting. On floating or stationary vegetable compost or marshy islands near the shores of freshwater lakes.

Distribution. Across the continent; breeding in the east, north of present settlement. In the prairie provinces and west it nests southwards to and across the United States border.

The bird, except in the west in the breeding season, is more commonly seen on large bodies of water than small. It is comparatively scarce in eastern Canada. 
3. Horned Grebe. FR.-LE GRbiBE CORNO. Colymbus auritus. L. 13.50. The Horned Grebe is about the same size as the Pied-billed Grebe mentioned next, but with a much sharper and more slender bill. The summer adult has a red neck (much like Holboll's), prominent ochraceous ear tufts, and a full projecting ruff on the cheeks from hindhead to throat. In the autumn and winter a shining almost black and white head contrasts with the duller coloration of the Pied-billed Grebe.

Distinctions. The juvenile, a plain, greyish-black and white bird, may be mistaken for the young Pied-billed Grebe, but can be distinguished by its shiny white forehead and breast, slender bill, and white wing patch.

Field Marks. Slender, sharp bill, white foreneck and wingpatch.

Nesting. Similar to the preceding.

Distribution. Across the continent, breeding locally within the borders of present settlement and northward, but more commonly west than east.

The Horned Grebe on migration inhabits the larger bodies of water and is less commonly seen on the small mud holes where the Pied-bill often occurs.

6. Pied-billed Grebe. DAB-CHTCK, HELL-DIVER, WATER-WITCH. FR.-LE GRìBE À BEC BIGARRe. Podilymbus podiceps. L, $13^{\cdot} 50$. Plate IA.

Distinctions. The Pied-bill can be separated from all other Canadian Grebes by its relatively heavier and stouter bill with its spot and its more strongly arched culmen, and from the juvenile Horned Grebe in any plumage, by its darker, less shiny foreneck, breast, and underparts, and the absence of a white wing patch.

Field Marks. Size and shape of bill, spot on bill, lack of white wing patch, and black throat patch in spring. forms.

Nesting. Along the marshy edges of ponds and lakes on stationary or floating plat-

Distribution. Across the continent, breeding from our southern borders northwards; probably any grebe found nesting south of a line drawn between Ottawa and Sault Ste. Marie will be of this species.

This is the common breeding grebe of eastern Canada, where it is found in the nesting season or during migration on nearly every pond or slough. It frequents clear, open water less than its relatives. The diving powers of the grebes are well known, and they are well developed in this species. Diving at the flash of the gun it is often safe under water by the time the shot reaches the spot it recently occupied. Even breech-loading guns are not always quick enough to eatch it, though the general use of smokeless powder has put it at considerable disadvantage. The grebes have the faculty of swimming either low or high in the water. By pressing the air from the thick soft plumage and by compressing that in the body cavities the grebe can increase its specific gravity, and gradually sink into the water until only the bill is above the surface, in which position it will hide and, barring accidents, escape the most prying eyes.

Economic Status. We have little accurate information as to the exact constituents of the food of the grebes. The Pied-bill, however, probably lives upon small fish and aquatic insects, supplemented more or less by vegetable matter. The fish, owing to the bird's habitat, are mostly mud-frequenting species of little economic importance. The insect content of its food probably consists largely of predaceous species like large water beetles that occasionally do some damage to fish fry. The vegetable matter is unimportant. On the whole, we can regard the Pied-billed Grebe as absolutely harmless except in the rare cases when it pays a passing visit to pools or ponds devoted to trout or other valuable fish culture.

$57172-4$ 
FAMILY-GAVIID正, LOONS.

General Description. The Loons are large divers with straight, sharply pointed bills and with the feet fully webbed (Figure 2, p. 18). In the adult state they are coloured in strikingly contrasting patterns, mostly black and white.

Distinctions. Larger than ducks and have shorter necks than geese. These points and the sharp pointed bill are diagnostic. Tails more evident than in the Grebes.

Field Marks. Size, length of neck, and bill. In flight, the feet are trailed behind the tail.

Nesting. On low shores in the immediate vicinity of water where they can dive directly into the water from the nest.

The Loons are probably even better divers than the Grebes but they rise less easily from the water, and unless there is a good breeze that they can face, require a long splashing start over the surface before being wing borne.

Economic Status. Their food is composed almost entirely of fish, but owing to the small number of loons in any given locality, their direct economic importance is small.

7. Common Loon. great NORThern diver. Fr.-Le PLONGeon à COlLLer. HUARD. Gavia immer. I, 32 . Plate IB.

Distinctions. The adult Common Loon is easily separated from other lopns by its marked coloration, but juveniles are somewhat more difficult to differentiate. Size and the lack of spots on the back will separate it from the Red-throsted Loon with which it is most easily confused.

Field Marks. Size and unspotted back of the juveniles as above. Most loons seen on our inland lakes are of this species.

Nesting. Close to the water on the boggy or rocky shores of inland lakes where when alarmed the loons can slide directly into the water. The rather bulky nest is built of decaying vegetable matter.

Distribution. Over the whole of Canada, breeding wherever conditions are suitable and often remaining in the wiater until the last open water is closed by ice.

Most frequenters of our waterways and lakes are familiar with the long loud laugh of the Loon. The loon has another call beginning low, rising high, and then dropping suddenly. It is often noisy at night or just before a storm and birds frequently call to and answer one another across the water.

Owing to the constant encroachments of settlement, and the consequent disturbance of its nesting places, the Loon has been growing scarcer of late years and in many of its old haunts it is seldom seen now except during migration. However, there are still great numbers of lonely lakes in the great uninhabited north where they can live and breed undisturbed, and the immediate loss of this picturesque species need not be anticipated. Proper local protection, enforced by an awakened public opinion, would undoubtedly restock our lakes and ponds with summer residents as well as augment the number that make passing visits.

Economic Status. Although the Loon is a large bird the capacity of its gullet limits the fish it takes to comparatively small sizes. This fact, taken in connexion with the small number of birds on the smaller lakes and the immense numbers of fish in the larger bodies of water, makes its depredations economically unimportant. The species, therefore, should not be destroyed.

11. Red-throated Loon. Le PLONGEON À GORGE Rovsse. Gavia stellata. L, 25. This is smaller than the Common Loon, and is without its intensely contrasted black and 
white back coloration. Its head and neck are grey and summer adults have a dull red throat pateh.

Distinctions. Adults can be distinguished from the Common Loon by size and coloration as above. Juveniles can be recognized by their finely spotted backs in distinction from the slightly grey marginations of the Common Loon.

Field Marks. Size and back coloration.

Nesting. Breeding habits similar to those of the preceding species.

Distribution. Ranges over the whole of Canada, scarce in the interior, more common on the coasts. Breeds in the east from northern Ontario, central Quebec, and New Brunswick northward.

Economic Status. Similar to the Common Loon in this respect, but of less importance on account of its smaller numbers.

\section{FAMILY-ALCIDA. AUKS, MURRES, AND PUFFINS.}

General Description. This family is composed of strictly maritime species of rare or only accidental occurrence on fresh water. Though most at home in the water they stand upright on land and walk about with considerably more ease than either the grebes or loons. Their bills are subject to a greater degree of variation than the aforementioned families, ranging from the straight tapering shape of the Murres to the deep compressed bill of the Puffin.

Distinctions. The obvious diver-like form combined with webbed feet and no hind toes (Figure 12, p. 20) is diagnostic.

Field Marks. General resemblance to ducks, but their short necks and pointed and sometimes deepened and narrowed bill are characteristic.

Nesting. Breed in large colonies, of ten of mixed species, on rocky islets or on inaccessible sea-washed cliffs. Build no nest but lay their eggs directly on the ground. Their eggs are unusually large for the size of the bird and markedly pyriform, as shape that causes them to roll in circles rather than in straight lines and lessens the danger of their falling from the bare, rocky, nesting ledges.

Distribution. Over our sea coast from our southern borders to the Arctic. They are only casual on fresh water, though one species has indulged in occasional abnormal, eruptive migrations to the lower great lakes.

This family frequents the open sea, coming ashore only to breed. They differ from the other divers in habitually using their wings under water as in flying. On the Labrador coast their eggs are much used by the fishermen for food.

Economic Status. Eating nothing but the smaller sizes of fish and crustaceans taken at sea, where the supplies are more than ample, there is little harm that these species can do.

13. Puffin. seia parrot. Paroquet. fr.-le macareux arctique. perroquet. Fratercula arctica. L, 13. The Puffin is a grotesque little diver, black above, white below, and with a grey face. It is notable for its absurdly deepened and flattened bill, nearly as high as long and highly coloured with reds and yellows.

Distinctions. Bill is always distinctive.

Field Marks. Bill can be recognized in life nearly as far as the bird can be seen.

Nesting. Breed in the crannies and cracks of rocky cliffs or burrow in the soil on lonely islets. Along the Canadian Labrador coast there are several "Paroquet" islands so-called from the great numbers of these birds breeding on them. However, the depredations of fishermen have sadly reduced their numbers and unless protective steps are taken they will shortly be exterminated.

Distribution. Puffins are distributed over the sea coast on both sides of the Atlantic from Canada and England northward far into the Arctic zone.

A sight of this bird is sufficient for recognition of the appropriateness of the names Parrot or Paroquet. Unlike other divers it stands up on its toes and is quite agile afoot.

$57172-4 \frac{1}{2}$ 
27. Black Guillemot. PIGEON. SEA PIGEON. FR.-LE GUILLEMOT NOIR. Cepphus grylle. L, 13. In summer the Black Guillemot is a small, coal black diver with large white wing patches and red feet. In winter the underparts are white and the feathers above are black but broadly tipped with white. The wings remain as in summer.

Distinctions. In summer the species cannot be mistaken for any other. In winter, the size and wing coloration are almost equally distinctive.

Field Marks. The characters above make easily recognizable field marks. cliffs.

Nesting. In cavities in the rocks or in openings in the rough talus at the foot of sea

Distribution. The Atlantic Guillemot is common along our Atlantic coast but is rarely if ever seen inland.

SUBSPECIES. There are two subspecies of the Black Guillemot in Canada, the Atlantic Guillemot, the type form, and Mandt's Guillemot, Cepphus grylle mandti, a northern race inhabiting Arctic regions and distinguished by having all the wing coverts white to the base instead of with a concealed dark wing bar. This form is given by the American Ornithologists Union check-list as a full species, but should probably be reduced to subspecific status.

The Black Guillemot is one of the commonest inhabitants of our sea coast and is known to nearly all who visit there. It is less gregarious than the other members of the family and usually nests alone and not in rookeries, though sometimes numbers are drawn together in localities by a community of interest.

30. Common Murre. FR.-MORMETTE. LE GUILlemot ORDINAIRE. MarMeTtes. Uria troille. L, 16. The Murre in summer is white below, with the head and neck dark, smoky, seal brown. The back and wings are black. In winter the throat is light, veiled with more or less greyish, and the brown is replaced on the head and neck with black more or less shaded with grey especially on the throat.

Distinctions. The Common Murre is very much like Brünnich's Murre and the Razorbilled Auk. Can be differentiated in summer from the former by the lighter brown coloration of the head and neck and by the fact that the back of the neck is not darker than the front. At all seasons it has a somewhat shorter and decidedly heavier bill. From the Auk it can be told by its bill which is not markedly flattened or deepened.

Field Marks. Bill sizes and neck coloration are the only field marks that can be given to separate the two Murres and in life these can only be seen under the most favourable circumstances. The birds are said to swim with level instead of up turned tail as does the Razor-bill. The difference between the latter's bill and that of the Murre, however, is quite obvious under ordinary conditions. egg.

Nesting. In large colonies amongst the rocks, making no nest and laying only a single

Distribution. Abundant along the eastern sea coast, never or rarely ever being found in the interior on fresh water.

SUBSPECIES. The Common Murre inhabits the northern parts of both Pacific and Atlantic oceans, being represented by different subspecies in each. The Atlantic Murre is the type form and is, of course, the one that occurs on our eastern coasts.

The number of Murres that will occupy a nesting ledge is sometimes remarkable. At the edge of the rocky shelves they gather as close as they can stand, like files of soldiers, bearing strong resemblance to the lines of penguins that are familiar to us in pictures.

31. Thick-billed Guillemot. BRüNNICH's MURRE. FR.-LE GUILLEMOT DE BRÔNNICH. Uria lomvia. L, 16.50 . This Murre is almost exactly similar to the preceding species.

Distinctions. Head and neck are darker and richer brown without the smokiness of the Common Murre and the neck is somewhat darker behind than in front. Bill is somewhat larger and noticeably heavier.

Field Marks. Longer, heavier bill and coloration of the head and neck will under exceptional visual conditions separate this bird in life from the Common Murre. Sharp and tapering instead of blunt and deep bill, and tail not turned up in swimming, should serve to distinguish it from the Razor-billed Auk. 
Nesting. Similar to the preceding species.

Distribution. Somewhat more northern than that of the Common Murre.

SUBSPECIES. The Thick-billed Guillemot occurs in the northern Pacific and Atlantic oceans but as distinct subspecies. Our eastern form is the type and is known as Brünnich's Murre.

Brünnich's Murre is the only member of this family that is found on the Great Lakes. The birds have at times come in hundreds on lakes Ontario, Erie, and tributary waters in late autumn and early winter, all in a starving condition, and none seem to survive or return to their sea homes. These occurrences are as yet inexplicable.

- 32. Razor-billed Auk. TINKER. FR.-GODD OR GUDD, LE PINGOUIN COMMUN Alca torda. L, 16.50. The Razor-billed Auk is of the same general appearance as the last two species.

Distinctions. Bill is considerably deepened and flattened (though not nearly as much so as in the Puffin); it is thus easily distinguished from the Murre especially in summer when a white line connects the eye and the base of the culmen, and the bill is crossed by a white band near the tip. Bill of the winter juvenile is less characteristic but may still be distinguished from that of the Murres. marks.

Field Marks. Deepened bill and, when swimming, cocked-up tail make good field

Nesting. Similar to that of the two preceding species but rather less gregarious.

Distribution. Frequents our Atlantic coasts north to the Arctic.

33. Great Auk. Gare-Fowl. FR.-LE GRAND PIngodin. Plautus impennis. L, 30. The Great Auk was the largest of the American Divers. Its wings were so reduced in size that though they made excellent swimming organs they were useless for other purposes and hence the bird was unable to fly. As the species is now extinct no further description is necessary.

This bird had become so well adapted to an aquatic life that flying was no longer necessary and consequently its wings became reduced to mere swimming flippers like those of the penguins of the Antarctic, and flight was impossible. Though as well able to live at sea as any fish or marine animal, land was as necessary to it for reproduction as to any other bird. Even then, if it had inhabited the very extremes of the Arctic regions for nesting purposes it would probably have survived; but lonely outlying rocks and islets about the British isles and, on our side of the ocean, south to Newfoundland, were its nesting places and immediately in the course of the fleets of hardy fishermen who early in our history flocked to our shores. To them, these then countless thousands of large sea birds inhabiting islets in the immediate vicinity of their fishing grounds, so helpless on land that they could be killed in unlimited numbers with sticks and clubs, were irresistible. They took full advantage of their opportunities and the story passes current that to save labour, gang planks were placed ashore from the boats and the unresisting birds were driven aboard in droves to be clubbed to death on deck. Of course no numbers could long resist such destruction and to-day the Great Auk is only an interesting memory and is represented by only individual specimens and fragments in a few favoured museums.

34. Dovekie. sea dove. Fr.-Le mergule nain. Alle alle. L, 8. The Dovekie is a diminutive Diver, the smallest of its family in eastern Canada. When in our waters it is generally black above and white on throat, cheek, and below.

Distinctions. Its size is enough to separate it from any other Diver in eastern Canada.

Field Marks. Size and extremely rapid wing beats make the best field marks.

Nesting. On cliff ledges in the far north. coasts.

Distribution. In summer in the far north in the eastern Arctic, in winter along the sea 
On our coastal shores and harbours this little bird should be looked for only in the winter. It flies with a very rapid wing motion.

\section{Order-Longipennes. The Long-winged Swimmers.}

General Description. The Long-winged swimmers are sea birds, with four toes and two webs, and with the wings longer than the tail if the excessively lengthened middle tail feather of some Jaegers and the equally elongated outer swallow tails of some Terns are disregarded.

Distinctions. Can be recognized as an Order by their long wings and bill characters (Figures $3,4,5$, p. 18) and are separated from the Tube-nosed Swimmers by the position of the nostrils which are in the sides of the bill and not in a tube on top (See Figure 11, p.19, for comparison).

Field Marks. No field marks can be given covering the order except length of wing and mode of flight.

Nesting. Usually breed on the ground or on cliff ledges, but there is little uniformity in their nesting habits.

Distribution. Some species are more or less common over all the waterways of Canada.

The long-winged Swimmers are wonderful fliers, being both tireless and agile on the wing. In habit they are fishers, scavengers, or pirates. There are only two families of the order in Canada; the Jaegers and the Gulls, the latter including the closely allied Terns or "Sea Swallows".

Economic Status. Being sea birds, the damage they do is slight and some of them are actively beneficial to man.

\section{FAMILY-STERCORARIID无. JAEGERS AND SKUAS.}

General Description. The Jaegers are predaceous sea birds. In colour they are dark brown and white. The family shows a peculiar dichromatism and all Canadian species occur in two colour phases, an almost evenly dark brown one and a dark or slaty brown with white or light head, neck, and underparts and an almost black cap.

Distinctions. The bills of the Jaegers (see Figure 3, p. 18) are characteristic, there being a distinct nail at the tip forming a well-marked hook, plainly separable from the remaining cere at the base of the bill. This character separates them easily from the Gulls, whereas the presence of nostrils and two instead of three toe webs (Figure 6, p. 19 for comparison), distinguishes them from the Cormorants which have bills similar in outline. The fact that the nostrils are not in tubes (Figure 11, p. 19) differentiates them from the Petrels which they otherwise resemble.

Field Marks. Jaegers are dark in colour above, have a quite conspicuous light band across the underside of the wing near the tip, and are hawk-like in flight. Two of the three species, in the adult state, show elongated tail feathers that are good recognition marks.

Nesting. On ground, in grass.

The occurrence of the two colour phases as well as every possible intermediate plumage, makes the identification of some of the Jaegers a difficult matter. Jaegers are pirates of the air; they pursue successful fishing birds and force them to disgorge the fish they have swallowed; and eggs and young birds in the nest are never safe from them.

Three Jaegars accur in eastern Canada and one Skua-the latter too rare and accidental, except off the outer Newfoundland coast, for further mention.

Economic Status. The Jaegers are not very numerous and except in far away, wild localities where numbers give them local importance, they are of little economic influence.

36. Pomarine Jaeger. Bo'sn. (BOATSWain). FR.-LE LABbe POMARIN. Slercorarius pomarinus. $\mathrm{L}, 22$. (Tail $9 \cdot 25$, projections of centre feathers beyond outer ones $4 \cdot 25$.) 
This is the largest of the Jaegers. It resembles the other two species in coloration so closely that its separation is difficult except by size and in adult condition. The species occurs in two colour phases and in all intermediate stages.

Distinctions. Elongated middle tail feathers of adult are wide and twisted at the tip so as to lie in a vertical instead of a horizontal plane.

Field Marks. The broad, elongated, twisted tail feathers are propably the best field marks.

Nesting. On ground, in grass.

Distribution. Breeds on the islands and mainland in the Arctic across the continent. Occurs on the sea coasts farther south, only as a migrant.

37. Parasitic Jaeger. FR.-Le LABBe PaRASITe. Stercorarius parasiticus. L, 17. (Tail $8 \cdot 25$, projection of middle feathers beyond outer ones $3 \cdot 25$.) This species occurs in two colour phases, a light, and a dark one. In the dark phase the general colour is dark brown slightly lighter below and with a black cap. In the light phase the underparts, breast, neck, and face are white, with black cap. Intermediate stages of coloration also occur.

Distinctions. The smaller size of this bird should distinguish it from the preceding in all plumages. In the adult, the middle tail feathers project only 3 inches beyond the others instead of 7 inches as in the next species and are slender instead of broad and twisted as in the last species. Immature birds of the Long-tailed species, not having the long tail feathers, are almost exactly similar to this species, and can best be distinguished by the colour of the shafts of the primary feathers. In the Parasitic, the shafts of the three first feathers are white and the remainder are progressively darker as they succeed each other on the wing. In the Long-tailed, there is an abrupt darkening of colour of the shafts after the third primary.

Field Marks. Small projection of the middle tail feathers as above and their not being twisted make a field mark of fair reliability in adult birds.

Nesting. On ground, on the moors and tundras of the north.

Distribution. Breeds in the Arctic across the continent and is much more common on the seaboard in migration than inland, where it is a very rare though possibly a regular straggler.

This is the only Jaeger that is likely to be met with in the interior on the Great Lakes. Other species have been recorded, but upon investigation, except in one instance, they have been found to be young birds incorrectly identified, usually on the ground of their lack of elongated tail.

38. Long-tailed Jaeger. FR.-LE LABBE $\lambda$ LONGUE QUEUE. Stercorarius longicaudus. L, 21. (Tail 13.25, projection of centre feather beyond outer ones 8.) Very similar in coloration to the preceding, but the long slender middle tail feathers project 7 or 8 inches beyond the others instead of only 3 .

Distinctions. The Long-tailed Jaeger although having nearly the measurements of the Pomarine, owing to the great tail length being included, is a much smaller bird than either of the other two species. Size should distinguish it. Juveniles are often confused with the Parasitic but the wing characters given under that species are diagnostic.

Field Marks. It is possible to separate only adult Jaegers in life; the long middle tail feathers being the best guide.

Nesting. Similar to that of the other Jaegers.

Distribution. Breeds in the Arctics of Europe, Asia, and America. Is only of rare occurrence on east coast.

Though the Long-tailed Jaeger has been recorded on the Great Lakes most of such occurrences are misidentifications of juveniles of the preceding species.

FAMILY-LARID 2 E. GULLS AND TERNS.

General Description. The Gulls and Terns are long-winged swimmers, easily separable rom the Jaegers by the shape and construction of the bill which shows a single continuous surface without distinct parts or joints (Figures 4, 5, p. 18). The colours of the adult are usually pure white, with white, pearl-grey, or black mantles, often with black wing tips, hood, cape, or cheek spots. 
Distinctions. Bill with continuous surface and sharp projecting angle on lower mandible is sufficient to diagnose the family in all plumages. Colours are quite characteristic, though some species during juvenility are evenly (over all) dark, approaching the dark phases of the Jaegers.

Field Marks. Coloration and flight characteristics are the best field marks.

Nesting. Gulls generally build on ground, on rocky ledges or flat shores, in either sandy, grassy, or marshy places; rarely, in trees.

Distribution. Gulls and Terns are distributed over all the world, usually near large bodies of water, but sometimes occurring far inland, for instance in our prairie regions.

\section{Subfamily-Larino. Gulls.}

General Description. With the family description in mind the Gulls can only be confused with the Terns, which follow (see p. 54).

Distinctions. Can be distinguished from the Jaegers by the bill and coloration characters. (See family description on previous page); from the Terns, by their more robust build and mode of flight. Bills especially are heavier and stronger (compare Figures 4 and 5, p. 18). As a rule, tails are square without evident fork. Though as much masters of flight as the Tern they have less agility and perform fewer aerial gymnastics. Young Gulls are often quite brownish and dark in coloration, in marked contrast to the adult. Young Terns are usually light in coloration.

Field Marks. Large birds of heavier flight than the Terns. Square tails and surface feeding habits; not diving from the wing and the horizontal earriage of the bill when flying (see Tern, p. 54) are the best guides by which to separate the Gulls from the closely allied Terns.

Nesting. On rocky shores or cliffs near the water in various localities, depending upon the species and their distribution.

Distribution. Almost cosmopolitan in range and few countries without representatives of the subfamily. In Canada about twenty-five species are known to occur, but some are only casual within the bounds of settled areas and are not discussed here.

Though Gulls are essentially sea birds they are at times found at considerable distances from large bodies of water and flocks often follow the prairie ploughman to search for insects in the newly turned furrows. They feed from the surface of the water, never diving, or glean from the shores, beaches, or fields.

Economic Status. Gulls eat anything in the way of animal matter, fish, crustaceans, molluses, insects, offal, and even when opportunity offers young birds and mice.

The amount of fish they consume is relatively unimportant, as it is usually only very abundant small species occurring in great schools that attract their attention; they are not patient fishers like the Herons. They search low tidal shores for crabs and shell fish, showing considerable ingenuity in breaking the hard shells and extracting the contents. The food supply from these sources is economically insignificant. The Gulls annually dispose of vast quantities of garbage and offal thrown into harbours and waterways; they frequent agricultural land for insect food and some species have been known to have been instrumental in stopping mouse and other small mammal plagues. The Gulls must be considered, therefore, to be beneficial and consequently should be protected, although they do sometimes destroy eggs and young birds.

40. Kittiwake Tickler. Fr.-LA MOURTTE a trois DoIGTs. Rissa tridactyla. L, 16. A small or medium sized Gull of the same general coloration as the Herring Gull (see p. 52). diagnostic.

Distinctions. Rudimentary condition or almost total absence of a hind toe is always 
Field Marks. Resembles so many other Gulls in general coloration that it can only be separated in life by close observation of minute characters under favourable conditions. In size, is smaller than the Herring and Ring-billed Gulls and larger than Bonaparte's Gull.

From the Herring and Ring-billed Gulls it differs by having black instead of fleshcoloured or yellowish legs and in lacking the small terminal white spots on the black primary tips. The bill is an even yellow in the adult, without the red spot of the Herring Gull or the black transverse band of the Ring-billed. Juveniles resemble Bonaparte's Gull very closely in having a black bill and similar colour pattern, but the forward edge of the outstretched wing is mostly black instead of conspicuously white. Juvenile Kittiwakes do not pass through a brown stage, as do the Herring Gulls, but resemble the adult in modified but similar coloration

Nesting. Makes a substantial and well built nest of sea-weed on small projections from the faces of perpendicular cliffs.

Distribution. A marine species, the Atlantic Kittiwake occurs only casually on fresh water or inland. Inhabits both sides of the Atlantic; breeding, in America, from the gulf of St. Lawrence north to well into the Arctics. It should be recorded on the Great Lakes only upon unimpeachable evidence.

SUBSPECIES. The Kittiwake occurs in distinct subspecific form on both the north Atlantic and north Pacific oceans. Our eastern form, the Atlantic Kittiwake, is the type and occurs in both Europe and America.

Economic Status. The food of the Kittiwake is probably similar to that of the other marine Gulls, but its smaller size renders it even less open to objection than some other members of its family.

42. Glaucous Gull. Burgomaster. Fr.-Le goÉland à manteat gladque. Larus hyperboreus. L, 28. The Glaucous Gull is one of the largest of the Gulls. In the adult, the mantle is only slightly tinged with grey; younger specimens are nearly pure white all over. It is the largest of the white-winged Gulls (those having no black on the wing tips). Birds of the year are only slightly barred with ashy or brownish grey.

Distinctions. Its nearly white coloration separates it from the Black-backed which it resembles in point of size.

Field Marks. Size, general white coloration, and lack of black wing tip make the best recognition marks in life.

Nesting. On ground, in the far north.

Distribution. Breeds along the circumpolar coasts and islands of both hemispheres. Occurs on our Atlantic coast in autumn and winter when a few individuals wander inland to lake Ontario and perhaps to lake Erie.

Economic Status. Being only a winter visitor to our coasts and rarely appearing inland, its economic importance is unappreciable.

43. Iceland Gull. FR.-LE GOÉLAND À AILES BLANCHES. Larus leucopterus. L, 24. The Iceland Gull is of about the same size as the Herring Gull, but with very light grey or white mantle and white wing tips-a smaller edition of the Glaucous.

Distinctions. Size, and white instead of black wing tips.

Field Marks. Size, wing tips, and general whiteness of coloration.

Nesting. On ground.

Distribution. Breeds in the Arctic regions of eastern America and western Europe. Visits our Atlantic coast in winter only, rarely straggling inland as far as lake Ontario.

Economic Status. As it is only a winter visitor on our sea coasts and accidental on the Great Lakes, it has little if any economic importance.

47. Great Black-backed Gull. SADDLE-BACK. COFFIN CARRIER. FR.-LE GOÉLAND ì MANTEAU NOUR. LIE GROS GOfLAND. Larus marinus. L, 29. A very large Gull, the adult with a distinctive black mantle.

Distinctions. Large size and black back are characteristic of the adult. Juveniles are brown instead of ashy or white as in the Glaucous Gull, more striped on back and less evenly coloured than the Herring Gull.

Field Marks. Large size and black back are good field marks for the adult. Size is the only describable distinction for juveniles in life. 
Nesting. On ground, nest of sea weed or vegetable fragments.

Distribution. Breeds on the Atlantic coast from Nova Scotia northward to the high Arctic. Owing to advancing settlement nesting localities have at present been reduced to the more isolated situations. Is a more or less regular but rather sparse winter visitor upon lake Ontario, but rarely wanders farther inland along the Great Lakes.

Economic Status. With similar feeding habits to those of the other Gulls, the superior size, strength, and numbers of the Black-backed Gull increase its powers for good or harm. The species is certainly not to be trusted in the vicinity of unprotected nests of other species, or even young birds, as both eggs and young are eagerly devoured when opportunity offers. To offset this, however, the opportunity to become an important pest is small except in a few localities, as on the Labrador coast where the Black-back breeds abundantly in close proximity to great numbers of Eiders and other sea birds. The damage it does on the Labrador coast, however, is small compared with the more serious and wanton waste of some of the fishermen.

\section{A.}

51. Herring Gull. Fr.-Le gof́LANd argenté. Larus argentatus. L, 24. Plate

Distinctions. Size and general coloration are generally sufficient to distinguish the Herring Gull from all other Canadian species, but as size alone is seldom a sufficiently reliable criterion when the contrasted species are not together for comparison, the following points will assist in accurate determination.

The juvenile Herring Gull is the darkest of the family, approaching the dark-phased Jaegers closely in this respect, but the bill shape and gull habits will prevent confusion with the Jaeger. In the adult, the black wing tips serve to distinguish it from any of the whitewinged Gulls and the small white terminal spots from the Kittiwake. The lack of a dark transverse bar on the bill distinguishes it from the adult Ring-bill. However, the juvenile Herring Gull at one stage, as the bill is turning from black to the yellow of maturity, shows a very similar mark and comparative size is then about the only distinguishing point of recognition.

Field Marks. Size and the colour marks above given are the best field guides. It is often very difficult, sometimes impossible, to separate the Herring and the Ring-bill in life when immature birds of either species are seen separately.

Nesting. On ground, or on rocky ledges or the flat tops of large isolated rocks, in nests of seaweed or waste vegetable matter.

Distribution. Found practically all over Canada, and common in the immediate neighbourhood of the larger bodies of water either fresh or salt. Breeds either generally or locally in all but the more southern sections of Canada.

The Herring Gull is the commonest of our Gulls. It is a wanderer and often seen on the smallest of our lakes, even at considerable distance from its nesting grounds. The Gulls that remain on the lower Great Lakes through the summer are immatures or non-breeding birds. In winter the species remains upon the larger waters until they are frozen over and often throughout the entire season, beating over the open water or perched on the floating ice. The Gulls haunt harbours for the offal and congregate in large numbers about sewer outlets. They have also learned that ships are abundant providers of toothsome scraps. Fishing stations are great attractions to them and there is almost certain to be a large flock in attendance about the cleaning tables on the shore. At the seashore, shell fish and crabs are eagerly sought for at low tide and the Gulls have learned the trick of carrying their hard shelled prey into the air and dropping it upon the rocks below, after which they descend and extract the savoury morsels from the broken case. In rough weather they congregate in numbers about foamy breakers off stormy points for the food that is brought to the 
surface. Occasionally they follow the immense schools of small fish that periodically visit our shores and take toll of the inexhaustible supply.

Economic Status. It will be seen from the above summary of the Herring Gulls food habits' that as scavengers they are important and should be protected.

54. Ring-billed Gull. FR.-LE Goḱland DE DELAWARE. MaUve. Larus delawarensis. L, 18.50. Like the Herring Gull (see p. 52) but smaller; the adult with the bill erossed near the tip with a transverse bar or ring.

Distinctions. Except when adult and ring on bill obvious, size is best guide to separation of this species from the Herring Gull. On the sea coast this species may be mistaken for the common but smaller Kittiwake. The presence of terminal white spots on the black wing tips serves to distinguish the Ring-bill. In juvenility, the brown coloration of the Ring-bill is in contrast to the lighter coloration of the young Kittiwake. It lacks the distinct terminal tail band of those birds and has flesh-coloured instead of black feet and legs. The absence of the sharp, narrow, black tail band and dark cheek patch, and great difference in size should be sufficient to differentiate it from Bonaparte's Gull in juvenile or winter plumage.

Field Marks. A careful study of the characters above will reveal the only good field marks known to the author.

Nesting. On ground in nest of grasses or vegetable material.

Distribution. Found over almost the whole of Canada. Breeds locally throughout its range in Canada except in the most southern parts of the Dominion in the lower Great Lakes region.

Economic Status. The food habits of the Ring-bill are similar in a general way to those of the Herring Gull, but the smaller size of the Ring-bill reduces its influence.

60. Bonaparte's Gull. FR.-LE GoÉLAND DE BONAPARTE. Lam philadelphia. $\mathrm{L}, 14$. Bonaparte's is our smallest eastern Gull. Its general coloration is similar to that of the Herring or Ring-bill but the adult has a black hood over the head and neck. Juveniles and winter birds are without the hood, but are marked with a veiled or indistinct dark ear spot.

Distinctions. The black hood serves to distinguish this Gull from all eastern species when in summer plumage. In western Ontario, Franklin's Gull may oscasionally be seen. It is a slightly larger bird with a red bill and almost black feet instead of black bill, coral red feet, and the exposed primary tips are mostly black instead of mostly white with small black tips. Juveniles may be recognized by their dark ear spot. They are distinguished from the Kittiwake which they somewhat resemble by the conspicuous amount of white on the forward edge of the outstretched wing and by the dark terminal tail band. Bonaparte's Gull may at times be confused with the Common Tern or other Terns, but its heavier build and action, and lack of any suggestion of a forked tail should make differentiation comparatively easy.

The Laughing Gull which occasionally occurs on our southern sea coast looks very much like this species, but the outer wing feathers are black instead of mostly white and jt is a breeder not a winter migrant. It is, however, so rare that its identification should be accepted with the greatest caution.

Field Marks. Size, black hood in summer adults, white on forward edge of wings, and the bill and feet colour on other plumages make the most valuable field characters for recognition in life.

Nesting. On stumps, bushes, or trees, sometimes as high as 20 feet from the ground.

Distribution. Breeds in Alaska and the far northwest, but occurs in winter or migration practically throughout Canada.

This little Gull is more often seen in passing or visiting flocks than the other species. It also haunts marshes and flooded lands more than they do and is rarely noted as a solitary individual. It shows a markedly communistic habit and flocks seem to be held together more by sociability than by a community of interest, as appears usually to be the case with other species of Gulls. 


\section{Subfamily-Sternince. Terns.}

General Description. The Terns, or Sea Swallows as they are sometimes called, are small gulls of a lighter and more graceful build and habit (see bill, Figure 5, p. 18).

Distinctions. The bill, lighter, and more slender than that of the Gulls, and the forked tail are characteristic of the Terns and will usually separate them without difficulty. All Canadian species have a more or less forked tail and all but one in summer adult plumage have a sharply defined black cap. The forking of the tails of young birds, though beginning to show early in their development, does not reach its maximum until after they leave for the winter; hence through the summer and autumn many individuals will be seen with much smaller forks than the measurements indicate.

Field Marks. The greater lightness of action on the wing and constant and rapid aerial evolution; the fact that Terns constantly dive from the wing, and the habit of commonly turning the bill straight down towards the water instead of carrying it on a line with the body are characteristic. The forked tails and black caps are also good recognition marks for adults.

Nesting. Whereas Gulls seem to prefer rocky shores upon which to breed, the Terns, except Forster's and the Black, favour sandy beaches, laying their eggs in a smooth circle of pebbles without other nest preparation.

Distribution. As a subfamily, Terns are more southerly in distribution than Gulls, though at least one species, the Arctic Tern, has been found as far north as man has ever gone. All our species migrate, nonk remaining in eastern Canada through the winter.

One has only to watch a flock of Terns feeding to recognize the appropriateness of the popular tern. Sea Swallow. Their active grace and dainty, pearl-like colours are a joy, $t$, the nature lover. Terns are on the whole less marine in their habits than Gulls and are not as often seen far from land. They haunt harbours, shores, and beaches, and live largely upon small fish caught near the surface by quick sudden dives from the wing, but they are not scavengers. In these dives the birds plunge in head first with a splash of white spray in which for a moment they disappear, but unlike Gannets and Cormorants they never go far under water.

64. Caspian Tern. Fr.-La sterne caspienne. Le grand esterlette. Sterna caspia. L, 21. (Forking of tail 1.50) ${ }^{1}$ The largest of our Canadian Terns. In colour very similar to the Common Tern (see p. 55).

Distinctions. Large size of this Tern is characteristic. There are two other equally large species, but they are too rare to require more than passing mention here. The Caspian Tern is as large as some of the smaller Gulls; but its bill though comparatively heavy for a Tern is too graceful and tapering to be gull-like. marks.

Field Marks. Characteristic Tern coloration, and habit and size make the best field

Nesting. On sandy beaches, or rocky or gravelly islands.

Distribution. A nearly cosmopolitan species. Found in the Old as well as the New World. Occurs rather irregularly all over Canada, but its known nesting stations are few and scattered over the continent from lake Huron to Labrador and the gulf of St. Lawrence.

The peculiarly disconnected and irregular distribution of this beautiful Tern suggests that it is a gradually disappearing species. This is greatly to be deplored as it is one of the most beautiful of our sea birds and it is to be hoped that careful conservation of its few remaining breeding stations will be inaugurated so that it will continue to adorn our waterways for generations to come.

Economic Status. Though feeding largely upon fish, the size of its prey is limited to small fry. The rarity of the species precludes its doing any appreciable amount of damage.

1This measurement shows the difference in length between the poiddle and outer tail feathers. A great part o the total length of these birds is in the greatly elongated outer tail feathers and these do not reach their maximum in juvenile birds. Hence this figure is given to correct the oftentimes greatly misleading nature of the usual length
measurement. 
69. Forster's Tern. Sterna forsteri. L, 15. (Forking of tail 4).' Closely resenabling the Common Tern (see next species) in size and coloration.

Distinctions. Forster's Tern lacks the delicate grey shading on the flanks and underparts characteristic of the Common Tern, and the outer feathers of the tail have the dark web on the inside instead of the outside of the shaft.

Field Marks. The pure white underparts are the most reliable field guides. The species is, however, so rare east of lake Huron that its identification in life should be based only on birds in the hand.

Nesting. On slight elevations in grassy marshes, in nests built of fragments of waste vegetation.

Distribution. Western or interior bird. At one time it nested on the Detroit river, but seems to have deserted that station and now as a brefuler must be sought for farther west.

These Terns frequent marshes rather than beaches and do not usually gather in flocks like the Common Tern. They should be looked for as individuals in flocks of other species.

Economic Status. Though fish eaters, their size and usual habitat prevent their being harmful.

70. Common Tern. wilson's tern. Fr.-LA sterne commune. Sterna hirundo. $\mathrm{L}$, 15. (Forking of tail, 3.0).$^{1} \quad$ Plate II B.

Distinctions. The dark, outer, instead of inner, webs on the outer, long tail feathers and delicate greyish, instead of pure white, breast and underparts distinguish the common from Forster's Tern. The grey of breast and underparts is rather less pronounced than in the Arctic Tern and the legs and feet are decidedly larger and heavier. The bill is usually dark in colour towards the tip, whereas that of the Arctic is evenly red. Juveniles are more or less washed with brownish above and have blackish bills. With adults in winter, the black cap is replaced by a more or less broken dark cape over hind head and upper hind neck. In this plumage Forster's Tern has a broad black streak across the eye.

Field Marks. Except in the few localities where other Terns are known to occur commonly it is always safe to conclude that this is the species seen. The pearly-grey underparts will usually distinguish it from Forster's Tern, but it is difficult to separate it from the Arctic Tern which, however, is only to be expected on our extreme eastern sea coast:

Nesting. Depression in sand on beach.

Distribution. A circumpolar species migrating to South America and Africa. More or less common all over Canada and breeding in favourable localities throughout its Canadian range.

This is the most abundant Tern of eastern Canada. Common about sandy shores, scarcer on rocky shores, it may be seen on any of our larger bodies of water, salt or fresh, throughout the summer. Its wonderful lightness of wing, graceful circlings, one instant hovering on rapidly beating wings stationary in the air as it regards some coveted prey below and the next dropping like a plummet with a sparkling splash, are constant delights to a seeker of the beautiful. Its shrill cry, harsh if taken by itself, blends harmoniously into the soft surge of the surf and remains in keeping with marine surroundings.

Economic Status. Though fairly numerous in suitable localities this species is too small to be seriously destructive.

71. Arctic Tern. Fr.-La sterne arctique. Sterna paradiscea. L, 15.50. (Forking of tail 4.50) ${ }^{\mathrm{I}}$ Closely resembling the Common Tern (see above) in size and colour.

Distinctions. The Arctic Tern has a little stronger greyish suffusion over breast and underparts than the Common Tern. Bill is red to tip and feet and legs are very small and weak. Its range separates it from Forster's Tern and there is only the Common and the Roseate with which it can be confused, but the latter is too rare in Canadian waters to be considered.

${ }^{1}$ See footnote, p. 54. 
Field Marles. Except the even red coloration of the bill, which is not an absolutely reliable guide, there is no field mark that can be described by which this species can be recognized with certainty. As in eastern Canada it is a sea coast species, it should be recorded on eyesight evidence only where it is known to occur commonly.

Nesting. Depression in sandy beaches.

Distribution. Nearly cosmopolitan, but of eastern and Arctic distribution in Canada and rarely if ever seen in the Great Lakes region. It is notable from having perhaps the greatest migration range of any species of bird. Though found in summer north close to the pole, it winters as far south as the Antarctic continent.

The remarks made under the heading of the Common Tern will very well apply here, bearing in mind that this species is regularly only of extreme eastern and Arctic distribution.

Economic Status. The small size of the fry it takes and the known abundance of such fish in the sea, renders this species as harmless as any of the other Terns.

77. Black Tern. FR.-LA. STERNE NOIRE. Hydrocheledon nigra. L, 10. (Forking of tail, $0 \cdot 8)^{1}$ The smallest of our Common Terns, dark slate-grey deepening to dull black on head, neck, and underparts.

Distinctions. The above diagnosis is sufficient to separate summer adults. Winter and immature birds have a dirty white face, throat, neck ring, and underparts and the grey above is suffused with more or less brownish. It is, however, always considerably darker than corresponding plumages of other species. This fact and its small size should be sufficient to differentiate it at all times.

Field Marks. Size and coloration make this species easy to recognize in life.

Nesting. On slight elevations such as old muskrat houses or floating debris in wet marshes, nest of vegetable matter.

Distribution. The American Black Tern is a bird of the interior, breeding from the Great Lakes region westward.

SUBSPECIES. The Black Tern occurs in both Europe and America in allied sub' specific forms of which the European is the type. The American Black Tern $H . n$. surinamensis is the only subspecies with which we are concerned.

This is a bird of the inland marshes. It is rarely seen on the larger bodies of water, but within its regular range no extensive expanse of watery marsh is without it. Its general habits are much like those of the other Terns.

Economic Status. The insect content of this bird's food is probably larger than that of the other Terns. In the south it is known to consume the larvæ of the cotton-boll weevil and probably retains some insectivorous habits with us. Therefore, we can venture to state that it is probably actively beneficial. At any rate the fish it takes, if any, are mud-inhabiting forms of small economic importance.

\section{Order-Tubinares. Tube-nosed Swimmers.}

General Description. Tireless fliers of the deep sea, of various sizes from the large Albatross to the small Petrel. Usually dull and evenly coloured birds. p. 19).

Distinctions. Nostrils are encased in tubes laid on top of the bill proper (Figure 10,

Field Marks. General flight habits and coloration. Familiarity with the various species is necessary to recognize members of the order.

Nesting. On ground or in burrows in out-of-the-way localities, often on rocky islets far out at sea to which they find their way in some mysterious manner that we cannot as yet explain.

iSee footnote, p. 54 . 
Distribution. As a family, they are birds of the southern hemisphere, for it is there that they reach their fullest develop nent in numbers of individuals and species. However, some inhabit the north far into the Arctics.

The Tube-nosed Swimmers are essentially marine, using the land only for breeding purposes. The whole ocean is their home and its lonely waste is sufficient for all their needs except that of rearing their young. They, therefore, as a class, rarely come into shallow water and are most commonly seen by the deep water sailor, the offshore fisherman, or the ocean voyageur. There are two families of the order: the Albatrosses, Diomedeido; and the Fulmars, Shearwaters, and Petrels, Procellariido; that are here called for convenience the Lesser Tube-nosed Swimmers owing to their inferior size. As there are no Albatrosses on our east coast we are concerned only with the Procellariida.

Economic Status. Owing to their pelagic habitat they are of little if any known economic interest.

FAMILY-PROCELLARIID AE. LESSER TUBE-NOSED SWIMMERS. FULMARS, SHEARWATERS, AND PETRELS.

General Description. See previous description.

Distinctions. Lesser Tube-nosed Swimmers are smaller than the Albatrosses and are the only members of the order found on our eastern coast.

Field Marks. General coloration and flight habits. Wings stiffly held straight out from the body and long steady glides on motionless wings (Fulmars and Shearwaters), or gently flitting close to the surface up one side of a wave and down the other with feet occasionally paddling along as if running on the surface (Petrels).

Distribution. The family is distributed over the oceans of the world from pole to pole. Though many species are regularly confined to the southern hemisphere they are great wanderers and the list of stragglers on our northern coasts is comparatively large. Of many species very little is known and our knowledge of several of them is confined to single or a few individual specimens that have found their way into collector's hands. Other species than those here listed may be found on our coasts or even occasionally on the Great Lakes in the interior, but their identification should be made with the greatest caution.

Economic Status. Though feeding almost entirely on fish and offal, their deep sea habitat renders them of little economic importance.

86. Fulmar. FR.-LE TULMAR. Fulmarus glacialis. L, 19. A large bird of gull-like coloration (light phase), or evenly dark, slaty grey (dark phase), and tube encased nostrils.

Distinctions. One of the larger of the Lesser Tube-noses, even grey or white and grey gull-like coloration.

Field Marks. Flight habits, stiffly-held outstretched wings, and long glides, together with light or grey coloration instead of dark brown as in the Shearwaters which approach the Fulmars in size, should usually render this species recognizable in life.

The Fulmar occurs in allied subspecific formo on both the Atlantic and Pacific oceans.

The Atlantic Fulmar is the type form.

Nesting. In large communities on ledges of rocky cliffs.

Distribution. The Fulmar is a bird of the north Atlantic, breeding in high latitudes and migrating to our southern coasts.

More often seen by sealers and whalers, the offal of whose trade attracts numbers of Fulmars. They are often seen by transatlantic travellers in mid-ocean or near the shores.

Economic Status. Of no economic importance. 


\section{Genus-Puffinus. Shearwaters.}

General Description. Tube-nosed Swimmers from 17 to 20 inches long. The nasal tubes are apparent but much less pronounced than in either the Fulmar or the Petrel.

Distinctions. The only two east Canadian species that the ordinary observer is likely to meet are either very dark or seem almost crow black from a distance.

Field Marks. The long narrow wings held stiffy at right angles to the body and the long glides of half a mile or more on fixed wings are distinctive. Their colour in browns should separate them from the Fulmar which is grey but has much the same fight habits.

Nesting. Very little is known of the nesting habits of the Shearwaters. Many of them nest in the southern hemisphere, migrating north in the summer.

Shearwaters are wonderful fliers, breasting the storms and gales with the ease and grace of swallows. They are rarely seen by the casual observer except from the decks of transatlantic steamers.

Economic Status. Gleaning from the surface of the high seas, taking small fish or such offal as is thrown from deep sea fishing or whaling boats, their economic influence is too small to be appreciable.

89. Greater Shearwater. FR.-LE GRAND PUFFIN, Puffinus gravis. L, 20. 'The larger of our two commoner Shearwaters, lighter below with under tail coverts ashy grey.

Distinctions. Its light colour below should separate this from the Sooty Shearwater; and its general brownness of back instead of greyness and its variegated colour differenti ate it from the Fulmar.

Field Marks. Flight habits as described previously, together with brown coloration and white underparts should separate this in life from either the Fulmar or the next species.

Nesting. There is little if anything known of the nesting habits of this species. Probably breeds in the southern hemisphere on lonely islets that have not been ornithologically investigated.

Distribution. Ranges over the whole Atlantic ocean from the Arctic to Cape Horn. Visits Canada irregularly in summer.

\section{Economic Status. Of no economic importance.}

95. Sooty Shearwater. Puffinus griseus. L, 17. The smaller of our two more common Shearwaters. Very dark brown, almost black, and but little lighter below.

Distinctions. Size, when possible to estimate or measure, and general dark coloration.

Field Marks. Flight habits as described under Shearwater and very dark, almost crow black, appearance in life are probably the best field distinctions.

Nesting. In burrows in the ground.

Distribution. The oceans of the southern hemisphere, migrating up our coasts in summer rather rarely.

The two Shearwaters and Wilson's Petrel are the only species of Canadian birds that are known to nest at the southern extremity of their migratory range instead of at the northern. Specimens seen here in the summer are migrants, not nesting birds.

Economic Status. Of no economic importance.

\section{Genera-Ocenanodroma, Oceanites. Petrels.}

General Description. The Canadian species of Petrel are small birds, scarcely as large as robins and of even dark brown coloration.

Distinctions. Small size, general sooty-brown coloration, and white rump.

Field Marks. Size, colour as above, and the habit of pattering up and down the waves as if walking on the water are diagnostic of the Petrels.

The origin of the name Petrel is after Peter who walked the sea of Galilee. The birds are also well known to sailors and voyageurs under 
the name of "Mother Carey's Chickens" and their appearance is said to presage a storm. In spite of their diminutive size they are met with far out at sea and are seldom seen by the longshoreman except in the vicinity of their breeding grounds.

Economic Status. The Petrels though feeding on fish are too small and their regular habitat is too far removed from man's usual activities to be of measurable economic importance.

106. Leach's Petrel. FR.-LE PATREL DE LEACH. Oceanodroma leucorhoa. $\mathrm{L}, 8$. A small, sooty-brown bird, very slightly lighter below, with a white rump. Tail forked about one-half an inch deep.

Distinctions. Forking of the tail, slightly lighter general coloration, and all black feet will separate this from Wilson's Petrel, the only one likely to be confused with it.

Field Marks. The slight forking of the tail is perhaps the surest specific guide in life.

Nesting. In burrows in the ground or under rocks.

Distribution. Inhabits both the north Pacific and north Atlantic oceans, breeding on the eastern side of the continent, from Greenland to Maine.

This is the only Petrel breeding on our coasts. It may be locally very abundant in the nesting season and its burrows may riddle the ground without the observer having a suspicion of its presence. It remains in its burrow through the day, but at night comes out in great numbers, wheeling about the deserted neighbourhood, uttering a low, wierd oft repeated little song with most eerie effect.

\section{Economic Status. Of no economic importance.}

109. Wilson's Petrel. Mother CAREY's chICEeN. FR.-LE PETREL DE WILSON. Oceanites oceanicus. L, 7. A slightly smaller bird than Leach's Petrel, of same general colour but averaging slightly darker, less forked tail, and with toe webs mostly yellow instead of all black.

Distinctions. Smaller size, slightly darker coloration, square instead of forked tail, and the yellow foot webs will separate this Petrel from Leach's. The Stormy Petrel also is said to occur off the Atlantic coast, but is too rare to be considered here. Unimpeachable evidence of its occurrence is desirable. It is recognizable by having the white rump feathers tipped with black.

Field Marks. Square instead of alightly forked tail is probably the most reliable guide to the specific identity of this Petrel in life, but accurate observation is necessary to make the distinction.

Nesting. In ground burrows or rock crevices.

Distribution. From the Antarctic to Labrador and to the British Isles across the Atlantic.

Wilson's Petrel is notable as being one of the very few North American species that nest at the southern end of their migratory range. Hence individuals seen here in the summer time are migrants and do not breed.

\section{Order-Steganopodes. Totipalmate Swimmers. Full-webbed Swimmers.}

General Description. Birds with webs between all four toes, making three webs instead of the usual two as in other orders (Figure 6, p. 19).

Distinctions. The feet characters are always distinctive.

Canadian Totipalmates are divided into three families: Sulido, the Gannets; Phalacrocoracider, the Cormorants; and Pelecanido, the Pelicans. There are other families that have occurred or may occur accidentally in Canada but are too rare to be included here. 
Economic Status. This order, being composed of large birds, all fisheaters, and many of them frequenting inshore or inland waters in considerable numbers, is open to a certain amount of suspicion as to its economic effect. However, no step should be taken against any species until careful investigation has proved its necessity.

\section{FAMILY-SULIDA. GANNETS OR BOOBIES.}

General Description. Large birds, mostly white when adult, bill sharp and straight without hook or pronounced throat or gular pouch.

Distinctions. The bill characters of this family serve to distinguish it from all excepting Tropic Birds, one species of which has been taken off Newfoundland. As the Tropic Birds, however, have enormously elongated middle tail feathers there is little chance of confusion, even if they were not too rare in our waters to merit detailed consideration here.

The Gannets are strictly marine birds never seen away from the sea except as stragglers. The family on the whole is tropical and only one species occurs in Canada.

117. Gannet. SOLAN GOOSE. FR.-LE FOU DE BASSAN. (OLD FRENCH-J. CARTIERMORGAUD) MARGOT. Sula bassana. L, 35. A completely-webbed swimmer with straight bill without pronounced hook or conspicuous throat or gular pouch.

Distinctions. The bill characters are distinctive. The adult is pure white except for the black primaries and a rich creamy suffusion over the crown and hindneck. The young bird of the year is greyish-brown, lighter below, and each feather has a small white $V$ at the tip that gives an even mottling over all. Several intermediate spotted stages occur between these plumages.

Field Marks. Dazzling white body and black wing tips of the adult are distinctive. The habit of diving from the wing, entering the water head first like an arrow, and remaining under an appreciable length of time is also characteristic. Terns dive from the wing but they rise again almost immediately and seldom completely disappear from sight like the Gannet. Even were it otherwise the great difference in size would be diagnostic. weed.

Nesting. In large communities on the rocky shelves of sea cliffs; nests made of sea-

Distribution. Both sides of the north Atlantic, breeding in Canada only on Bird Rock off the Magdalen islands, and on Bonaventure island, Gaspe county, Quebec, both stations being in the gulf of St. Lawrence.

The Gannet had at one time a much wider and commoner distribution than now, nesting as it did on many of the rocky islets on both sides of the north Atlantic. Of very slight value either for food or other uses, except in the most primitive communities, it has been driven from one breeding station after another until in the New World only two remain and, unless prompt measures are taken, these will likely go the way of the others.

Economic Status. Though the Gannets have been accused of doing considerable damage to fishing interests their harmful effects have been much overestimated. The greater part of the life of the Gannets is spent on or near the deep sea. When they come inshore for breeding purposes they can make very little impression on the mighty shoals of herring and other fish they pursue.

\section{FAMILY-PHALACROCORACID更. CORMORANTS.}

General Description. Large birds of black or very dark coloration, with bills ending in a decided hook and with a small throat or gular pouch.

Distinctions. Bill and small gular pouch are diagnostic. 
Field Marks. In life the Cormorants look somewhat similar to Loons, but have a distinctive wing action more easily recognized than described. In flight the Cormorant carries its neck outstretched and its feet hidden under the long tail, instead of trailing them behind like the Loon. On the water, it is easily recognized by its plainly visible tail, and even dark coloration.

A cosmopolitan family, only two species of which are found in eastern Canada.

119. Gommon Cormorant. FR.-Le CORMORAN oRdinaIre. Phalacrocorax carbo. L, 36. See family description previously given.

Distinctions. With the family description in mind, this species can easily be distinguished from all but the one following. The adult of this species has a flash of white at the base of the gular pouch and another on the flank. In other plumages, its superior size and fourteen instead of twelye tail feathers are diagmostic. The absence of crest even when adult is not a reliable guide for the determination of the species (see next species).

Field Marks. Unless size or the white marks are obvious it is rarely possible to separate the two Cormorants in life.

Nesting. Similar to that of the next species.

Distribution. The northerm hemisphere of all three continents. In Canada, it is closely confined to the eastern coast and is rarely seen inland.

Though called "Common" Cormorant this is the rarest of our eastern Canadian Cormorants. The species occurs on the European coast and was given the name "Common" because of its abundance about the British Isles.

Economic Status. Owing to its rarity it is of little economic importance in Canada.

120. Double-crested Cormorant. Fr.-LE CORMORAN À AIGRETTEs. Phalacrocorax auritus. $\mathbf{L}, 30$. See family description on previous page.

Distinctions. This species is likely to be confused with the preceding one only. In adult plumage the absence of any white at the base of the gular sac and on the flanks is diagnostic. In other plumages, size and the presence of twelve instead of fourteen feathers in the tail must be relied upon. Early in the spring the filamentous crests on the sides of the head instead of a ragged nuff as in the previous species are characteristic; but these features are lost early in the season, before nesting begins, and hence are usually of little help in determination.

Field Marks. Though Cormorants can be easily recognized by the characters given under the family heading, size and the presence or absence of the white spots are about the only features that serve to separate the two species in life.

Nesting. On the ground amongat rocks, or on cliff ledges, occasionally in bushes or low trees, in rather bulky structures of sticks or weeds.

Distribution. The Double-crested Cormorant breeds on the gulf of St. Lawrence and on lakes in the prairie provinces. It is a rather uncommon though perhaps regular migrant on the Great Lakes.

SUBSPECIES. The Double-crested Cormorant occurs in both the New and Old Worlds. Those of North America are divided into four subspecies, of which within the range of this book there is only one, the Eastern Double-crested Cormorant, the type race.

This is the most common Cormorant of eastern Canada. Unlike the previous species it is not strictly maritime and is found on fresh as well as salt water. It captures its prey by diving and pursuit under water. Unlike the Gannet it never dives from the wing but first alights on the surface and then goes under with a serpentine, gliding movement like a loon. It remains under water not longer than forty seconds as a rule.

Economic Status. The danger of jumping at conclusions based upon superficial observation or common report was well illustrated by the out$57172-5 \frac{1}{2}$ 
come of a study of the food of these birds in the neighbourhood of the Gaspe salmon rivers. ${ }^{1}$ Though commonly accused of damaging the salmon fisheries by devouring the small fish and fry, careful examination of about thirty specimens showed that the hundreds of birds present were eating fish of no economic value and no salmonoid remains were found in them. Probably the eels, sculpins, and other fish taken by the Cormorant make the species beneficial rather than harmful to the salmon, and probably more than compensate for the few valuable fish that it occasionally takes. This is a good example of the caution that is necessary before condemning any species of birds.

\section{FAMILY-PELECANIDE. PELICANS.}

General Description. Large bird with a very long, flattened bill and enormous throat or gular pouch.

Distinctions. The enormous throat pouch, holding a gallon or more, and the long flattened bill are always diagnostic.

These extraordinary birds are of too rare occurrence in eastern Canada to be specifically dealt with here. There are two species that have been occasionally taken, the White Pelican, Pelecanus erythrorhynchos a western form, that may be looked for towards the Manitoba boundary and westward, but in the east only as stragglers; the Brown Pelican, Pelecanus occidentalis, a southern bird of only accidental occurrence in Canada. The descriptive names are sufficiently explanatory to differentiate them. The White Pelican is practically pure white with black wing tip in all plumages; any other pronounced colours are indications of other species.

\section{Order-Anseres. Sieve-billed Swimmers. Lamellirostral Swimmers.}

General Description. Swimming birds with four toes and two webs, having bills with a hooked or flat nail at the tip and furnished with tooth-like projections or thin laminæ on the sides (Figures $7,8,9,10, p .19$ ) through which they strain the water from their food.

Distinctions. As above.

Field Marks. The outstreched neck, obvious tail, and rapid wing beats of the ducks and geese are familar to most of us. In the water some species bear superficial resemblance to the divers, but the straight, narrow, unduck-like bills of the latter, the obvious tails of the ducks and their general readiness to fly instead of diving when disturbed should make differentiation easy.

Nesting. Usually on ground, sometimes in hollow trees, and rarely in deserted crow's and other large nests, but seldom far from water. The young are able to run about and take to water as soon as hatched, but how they are brought to the ground from a tree nest some 20 or 30 feet in the air is a subject upon which a considerable difference of opinion exists.

Distribution. The Anseres are of world-wide distribution. In America the great majority of the species breed north of the International Boundary. They can, therefore, be regarded as birds of northern distribution. In winter some few remain in Canada as long as there is open water and others journey south, even to the warm waters of the Carolinas, the gulf of Mexico or beyond.

The order Anseres contains but one family-Anatidoe composed of the Mergansers, Ducks, Geese, and Swans, and comprises, therefore, the great bulk of the larger wild fowl pursued by sportsmen. One of the greatest sources of confusion in distinguishing the various species is the occurrence

1"The Double-crested Cormorant, Phalacrocorax auritue, and its relation to salmon industries on the gulf of St. Lawrence", Dept. of Mines, Geol. Burv., Can., Mus. Bull. No. 13, Biological Series No. 5, 1915. 
of what is called the eclipse plumage. Contrary to the rule that generally governs plumage changes, many of these species moult all their wing quills at once and are, therefore, flightless until refledged. During this period of comparative helplessness many males assume a peculiar plumage of less conspicuous character than that normally worn, usually approcahing that of the female. During this time the birds withdraw to the innermost recesses of their habitats and hide so closely as to be seldom seen by the casual observer. By the time the shooting season opens most have come out of the eclipse, but the few that still retain traces of it are sufficiently numerous to increase the number of plumages to be recognized and to complicate their differentiation. ${ }^{1}$

Economic Status. Anseres is, economically, one of the most important orders of birds; not, as in the case of other birds, so much on account of their food habits, for these are largely of negative influence in human affairs, as in other ways. In the early days of settlement of the country they furnished a most important food supply to the struggling inhabitants and even now the total annual number killed by sportsmen is an imposing addition to our food resources.

\section{FAMILY-ANATID在. DUCKS, GEESE, AND SWANS,}

General Description. As this is the only family included under the order Anseres the descriptive matter under the previous heading applies here and need not be repeated.

The family is divided into five subfamilies: the Mergina or Mergansers; Anatida or River Ducks; Fuligulince or Sea Ducks; Anserinœ or Geese; and the Cygnina or Swans. For the characters of these see under proper headings following.

\section{Subfamily-Mergince. Mergansers. Fishing Ducks. Saw-bills.}

General Description. Fish-eating ducks with a more cylindrical, tapering, and less spatulate or flattened bill, than the other ducks (Figure 7, p. 19). The cutting edges of the mandibles have a series of serrations giving foundation for the popular name "Sawbill". The nail on the tip of the bill forms a small but evident hook. The hind toe is developed into a flat paddle or fin-shaped lobe similar to that of the Sea Ducks but quite different from the hind toe of the River Ducks which follow. The males are brightly and strikingly coloured, mostly in black and white. The females are dull coloured with reddish heads and necks. Most plumages have crests. In the females and young birds the crests are ragged and without well-defined shape.

Distinctions. The bill is always diagnostic and easily distinguishes the Mergansers from the Sea Ducks which resemble them in the character of the hind toe.

Field Marks. Evident duck-like form combined with the long, slender, cylindrical, and slightly hooked bill.

Nesting. Mergansers are mostly river haunters in the breeding seasons, nesting either on ground or in hollow trees.

Distribution. A small family, most of its species inhabit the northern hemisphere.

Mergansers feed upon fish and shell-fish captured under water by diving; for this method of feeding their hooked and serrated bills are admirably adapted. They are, during the breeding season, mostly freshwater frequenters though they visit the sea sometimes in large numbers. They

\footnotetext{
${ }_{1}$ Another common source of confusion is the prevalence of a red rust coloration that of ten oceurs on various parts of the head or body and is common to many species of Anseres. It is due to an iron deposit from the water the birds nhabit, and should not be regarded as normal plumage coloration.
} 
are not very desirable table birds, though some young autumn birds, properly cooked, are not to be altogether despised.

Economic Status. Mergansers eat fish and, in certain waters, such as at the heads of salmon streams, they may do appreciable harm. Ordinary trout streams are too small for these species, and as no careful examination of stomach contents has been made they should not be condemned without more exact knowledge.

129. American Merganser. SAW-BILl. GOOBANDER. SHELLDRAKE. BHELLDUCK. FR. LE HARLE D'AMERIQUE. Mergus a mericanus. L, 25. Of the same general appearance as the next species (Plate III A), but the males without crest or reddish breastband.

Distinctions. See next species.

Field Marks. General coloration and the lack of crest or breast-band in the male are distinctive. When flying, the long, outstretched head and neck and generally greycoloured back will separate the females of these two Mergansers from other Ducks having white wing patches.

Nesting. In hollow trees or rock cavities near water; nest of grasses, etc.

Distribution. Common across the whole continent, nesting throughout eastern Canada except in the most southern parts.

The American Merganser is a bird of small wather than large waters and hence is less common on the larger lakes or the sea than the Redbreasted. Otherwise remarks under that species will apply to the American Merganser as their habits are similar.

\section{Economic Status. See under subfamily heading.}

130. Red-breasted Merganser. SAW-BILL. FISHDUCK. SHELLDUCK. SHELLDRAKE. FR. - LE HARLE À POITRINE ROUSSE BEC SCIE. Mergus serrator. L, 22. Plate III A.

Distinctions. The ragged erest, and reddish breast-band separated from the head by a conspicuous white collar, are sufficient to diagnose the male of this species. The female and the juveniles of this and the last species are much alike. The bill is, however, considerably lighter in build and the nostrils are slightly nearer the base than in the American Merganser. The head is not as rich a brown and the upper throat only a lighter shade of the same colour and not white as in that species.

Field Marks. The crest and breast-band of the adult male and the lack of the white upperthroat in the females and young birds will separate the Red-breasted from the American Merganser. The grey appearance of the back and the length of the outstretched head and neck will diagnose the species as a Merganser against other Ducks having white wing patches.

Nesting. On ground near water, sometimes in trees.

Distribution. Occurs more or less commonly over the whole of Canada, nesting whereever found except in the more southern parts.

A bird of the open waters, hence more often seen on the open lakes and the sea than the preceding species.

Economic Status. See subfamily heading.

131. Hooded Merganser. FR.-LE PETIT HARLE. Lophodytes cucullatus. L, 17.50. The smallest of our Mergansers. The male is a most striking black and white bird with rich chestnut flanks. Its distinctive ornament, the hood, is a flat disk-like crest springing from the base of the bill, arching over the crown, meeting the neck at the base of the head, and coloured mostly pure white with a narrow black edge. The female is a much duller coloured bird with brownish-fuscous body, lighter below, and with a ragged, slightly reddish crest, in shape similar to that pictured in Plate III A.

Distinctions. The hood of the male is unlike anything else worn by American birds. The female can always be distinguished from other Mergansers by its small size. 
Field Marks. Hood of the male and reddish crest and size of the female.

Nesting. In hollow trees.

Distribution. Across the continent but scarcer in the east than in the interior. Breeds locally wherever found in Canada.

The Hooded Merganser is a bird of the interior, of quiet ponds and woodland streams. It is the most edible of the Mergansers; this fact, combined with the clearing of the forests and too little restriction on shooting, is probably the cause of its growing scarcity to-day.

Economic Status. It is doubtful if any serious charge can be substantiated against the Hooded Merganser.

\section{Subfamily-Anatince. River and Pond Ducks.}

General Description. Typical ducks with flattened spatulate bill furnished with flat nail tip and straining laminæ or plates along the inner margins (Figure 8, p. 19) instead of tooth-like projections (Figure 7,p. 19). Feet with a snall though well formed hind toe, not modified into a flat lobe or fin-like appendage.

Distinctions. Bill will separate the River Ducks from the Mergansers and the hind toe as above from the Sea Ducks.

Field Marks. Under the most favourable conditions of view the bill will separate the Anatino from the Mergansers. The greater length of neck and more slender bodies are slight and rather uncertain guides to separate them from the Sea or Bay Ducks. The members of the subfamily are more easily recognized in life by species than as a class.

Nesting. On ground with the exception of the Wood Duck.

Distribution. As a class the Pond and River Ducks are more abundant in the interior than on either coast.

As their name implies, the River and Pond Ducks frequent our smaller inland waters more than they do the larger ones. They feed from the surface by "tipping" and reaching under the water. The food is gathered in the bill and the water squeezed out, the laminæ of the bills retaining the solid portions.

Economic Status. They are strictly water birds and vegetable and insect feeders, consequently their food habits are not a menace. It has lately been shown that Ducks feed largely upon mosquito larvæ and that the good they may do in this direction is of surprising magnitude. By actual experiment a pair of ducks in a small pond did more to reduce these pests in it than a considerable school of goldfish. As game, they are of great importance, see p. 12.

132. Mallard. GREEN-HEAD. GREY DUCK. FR.-LE CANARD ordinaIRE. Anas platyrhynchos. I, 23 . Plate III B.

Distinctions. The male cannot be mistaken for any other wild duck though many domestic strains approach it closely. The female is often regarded as belonging to another species and is sometimes called Grey Duck. There are several other ducks approaching her in coloration but the purple speculum with the white bar both before and behind the speculum will always distinguish her.

Field Marks. Green head and white neck ring are conspicuous recognition marks for the male. The speculum with its white bars will identify the female in life. Her tail has also a general whiteness in flight that is quite characteristic.

Nesting. On ground usually, in high grass or reeds not far from water, though occasionally at considerable distance inland.

Distribution. Distributed over practically the whole of Canada but less common in the extreme east. Breeds throughout Canada except where disturbed by settlement.

This is the "Wild Duck" par excellence, and is known as such to the sportsman of the Old World as well as the New. It is the original stock 
from which our domestic varieties sprang and nearly any mixed flock will show the green-black heads, white collar, or recurved upper tail coverts denoting reversion to the original form. As well as being one of the best table birds it is one of the wildest of ducks, which latter accounts for the fact that it still breeds in limited numbers on the edges of civilization.

133. Black Duck. DUSKY DUCK. Black Mallard. FR.-Le CANARd NOLR. Anas rubripes. I, 22. Plate IV A.

Distinctions. The general dark coloration combined with size renders this species unmistakable among River Ducks.

Field Marks. Size, dark coloration, and a silvery sheen to the lining of the underwings that shows in flight. The absence of the white bar bounding the speculum behind will separate it from the Mallard.

Nesting. On ground, in grass near water.

Distribution. The Black Duck is a more eastern species than the Mallard and is not commonly found west of the Great Lakes. It breeds in eastern Canada wherever found.

Now that the Wood Duck is growing scarce the Black Duck is the commonest nesting Duck in the southern parts of Canada and the only one that can now be called a common breeder near the lower Great Lakes. Originally almost every little lake and pond raised its brood of Black Duck, but, owing to the drainage of the marshes and human interference with nesting, it is now practically restricted to the larger marshes or more inaccessible situations.

It is still in dispute whether or not there are two forms of the Black Duck. Late in the autumn a number of very large birds with red legs are taken. Whether these are subspecifically distinct has not been conclusively determined.

Economic Status. Though the Black Duck often, especially in the breeding season, haunts the edges of cultivated fields where it gleans what food it can find, it does little or no harm. There is little crop to damage at that season and, as at other times it confines its attention to aquatic life, there is no harm that can be charged against the species.

135. Gadwall. GREY DUCK. SPECKLE-BELLY. FR.- - CA CANARD CHIPEAU. Chaulelasmus streperus. L, 19-50. A finely speckled or vermiculated grey duck, of same general tone as the female Mallard, but with chestnut-red shoulders and a white speculum.

Distinctions. White speculum is always diagnostic. Females are otherwise likely to be mistaken for small female Mallards or Baldpates.

Field Marks. White speculum and general greyish appearance.

Nesting. On ground, in grass or under bushes.

Distribution. Nearly cosmopolitan. One of the rarest Ducks on the lower Great Lakes, nearly absent from the east coast, commoner to the west where it breeds.

137. Baldpate. AMERICAN WLGEON. FR.-LE CANARD D'AMERIQUE. Mareca americana. L, 19. A medium-sized, greyish Duck, The male has white shoulders and cap, and a broad green stripe through the eye, a black speculum with green reflections, and a soft wash of pink over breast and back.

Distinctions. The male is distinctive, the female might easily be mistaken for a female Mallard or Gadwall but for its black speculum and pure white underparts.

Field Marks. The white crown and green eye-bar are characteristic of the male; the white underparts and the abrupt ending of the brown breast against the underparts distinguish the female in life.

Nesting. On ground, in grass or under bushes.

Distribution. Ranges over nearly all of Canada; rare on the Atlantic coast, more common to the west.

Closely related to the Widgeon of Europe, which has occasionally been taken on our coasts and which it closely resembles. 
139. Green-winged Teal. Fr,-LA GARCELLE $\boldsymbol{\lambda}$ AILES vertes. Nettion carolinense. L, 14.50. The smallest of our Ducks. The male has a chestnut-coloured head, bar back from eye and speculum, iridescent green;finely vermiculated back, and spotted breast; nearly white below. The female is a dull-brownish bird considerably lighter below and has the characteristic green speculum of the species.

Distinctions. Size will always separate this little Duck from all others except the next species and the Bufflehead, but the presence of the brilliant green speculum will separate it from the latter and the entire absence of chalky blue on the shoulders from the former.

Field Marks. Small size together with green speculum and lack of chalky blue on shoulders are recognition marks for any plumage.

Nesting. On ground, near water.

Distribution. Distributed across the continent but scarce in extreme east. Breeds in eastern Canada occasionally and probably originally nested commonly in the lower Great Lakes region.

This is one of the daintiest of the Ducks. Its habit of flying in large flocks at great speed makes it well known to sportsmen. The European Teal also occasionally straggles to Canada but is very rare.

140. Blue-winged Teal. Fr.-LA sARCELle À ArLes BLeUEs. Querquedula discors. L, 16. Plate IV B.

Distinctions. Size will separate the Blue-winged Teal from any other Duck except the Green-winged and the Bufflehead and the light blue on the wings will do so in these cases. The Shoveller also has a similar blue on the wing, but the small size of the Bluewinged and the lack of the broad shovel bi|l distinguish these two species.

Field Marks. Small size, together with white face mark, dark underparts, and chalky blue on wings.

Nesting. On ground, amidst grass.

Distribution. Across the continent; now rather rare in the extreme east. It is one of the few species that still breed regularly though sparsely in the lower Great Lakes region.

A western Teal, the Cinnamon Teal, is occasionally reported from eastern Canada, but most of such records are based upon the Blue-winged heavily stained below with iron ${ }^{1}$ from the water.

142. Shoveller. SPOONBILL. FR.-LE CANARD sodchet. Spatula clypeata. L, 20. The male is strikingly marked, with a green-black head, white breast and line over wings, underparts rich chestnut, cutting in a sharp line against the breast. The shoulders are chalky blue and the speculum green. The bill widens out at tip to a broad shovel or spoon shape. The female is much like the female Mallard though distinctly smaller.

Distinctions. Shovel bill separates this species from all others in any plumage.

Field Marks. White breast, rich chestnut belly, blue on the wings, and size distinguish the male. The bill will distinguish any plumage and when it can be seen is perhaps the best means of separating the female from the larger female Mallard which it resembles.

Nesting. On ground in grass, not always in the immediate vicinity of water.

Distribution. This is a bird of the west. It occurs sparingly on the lower Great Lakes and only occurs farther east as a straggler.

143. Pintail. springtail. FR.-Le Canard Pilet. Dafila acuta. L, 28. A very long and slenderly shaped Duck. Head seal brown, foreneck and underparts white, back finely verwiculated in greys, speculum bronze-green bounded by a light chestnut line before and a white one behind. The tail is graduated with two greatly elongated middle feathers. Female is much like the female Mallard.

Distinctions. 'The long tail is diagnostic of the male, the Old-Squaw being the only other American Duck with anything like this feature, but otherwise the Old-Squaw is entirely different and is a Sea not a River Duck. The bronze-green speculum and its bounding lines of rufous and white are characteristic of any plumage. Young Greenwinged Teal show almost the same speculum features but the difference in size will obviate confusion.

\footnotetext{
iSee footnote, page 63 .
} 
Field Marks. Long slender head and neck and long-pointed tail make good field marks. The dark head and white foreneck and underparts are recogaition marks for the male.

Nesting. On ground, sometimes at considerable distance from water.

Distribution. Rare on the Atlantic coast, becoming commoner towards the west. Breeds from the prairie provinces north to the Arctic and formerly east to lake Erie.

144. Wood Duck. SUMMER DUCK. THE BRIDE. Fr.-LE CANARD HUPPE. Aix sponsa. L, $18 \cdot 50$. Plate V A.

Distinctions. With the illustrations as a guide there should be no difficulty in recognizing this species. The male even in eclipse plumage always retains a suggestion of the cheek markings.

Field Marks. This is the only common summer Duck in our southern sections having a pure white underbody. The white eye-ring of the female is quite conspicuous.

Nesting. In hollow trees or stumps in the vicinity of quiet water.

Distribution. Temperate North America as far north as southern Canada and across the continent; more common in the lower Great Lakes region than on either of our coasts or in the prairie provinces.

This is the brightest coloured and most beautiful Duck in America and perhaps in the world. The only species that can approach it is the Mandarin Duck of China which is often seen in confinement with it. The Wood Duck was originally the "Summer Duck" of our southern borders and almost every woodland stream and back-water pond had at least one pair; but, since the clearing of the land, the farmer's-boy-shot-gun combination has been too much for it. Its bright colours, the relative conspicuousness of its nesting places, and the ease with which it can be stalked or "jumped" in its more or less wooded haunts have made it an easy prey for even the inexperienced shooter and it is in great danger of being exterminated. A duck that alights in trees is more or less paradoxical to most European sportsmen, but this species does so commonly. It builds its nest in a hollow tree some distance from the ground, usually overlooking quiet oxbow pond or other dead water. How the young are brought to the ground is not authoritatively settled yet, and many conflicting reports are circulated regarding it; such as the old birds carrying their young in their bills or on their backs, or shoving them out to take chances with their little unfledged wings in fluttering to the ground. In some way they reach the ground at an early age and follow the mother about the reaches of the streams or other quiet waters, the male keeping nearby to give his family the benefit of his (moral) support in times of danger. Later they seek the marshes, which they inhabit through the autumn, leaving for the south before the first frost has chilled the waters.

As the Wood Duck takes readily to nesting boxes prepared for the purpose it would seem probable that its numbers could be increased in this way.

\section{Subfamily-Fuligulinae. Bay, Sea, or Diving Ducks.}

General Description. Heavily or compactly built Ducks with typically flattened or spatulate duck-like bill sometimes swollen or high at base (Figure 9, p. 19), but always with flattened nail at tip (Figures 8 and 9, p. 19). Hind toe modified into a flat, paddle, or fin-shaped lobe.

Distinctions. Bill will separate the Sea Ducks from Mergansers and hind toe from River and Pond Ducks.

Field Marks. Bill, when observed, will separate these from Mergansers though they are more easily recognized in life as species than as a subfamily.

Nesting. Usually on ground, though sometimes in trees. 
Dislribution. Although some representatives of this subfamily are found commonly on every water-way in Canada both species and individuals are more numerous on the coast than in the interior.

The Bay and Sea Ducks, though more at home in large open waters, often frequent the marshes and shallower waters for feeding. They are good divers, sometimes descending to astonishing depths for shell-fish or vegetable matter. They include some of the finest table species.

Economic Status. The direct economic importance of their food habits is even less than that of the other Ducks.

146. Redhead. FR.-LE Milouin À Tête Rousse. Marila Americana. L, 19. A rather large Duck with an even coloured, brick-red head and upperneck; black breast; grey back finely vermiculated with black; white below. Head of female duller in colour, even to dull grey-brown, and canvas-coloured back replaced by an even wash of brown sometimes without hint of fine vermiculation.

Distinctions. Male resembles the Canvas-back but back considerably darker and red of head does not come to shoulders as in that species. Females of these two species are even more alike, but shape of the bill is always diagnostic (See Canvas-back). Female also somewhat like those of Scaup and Golden-eye but distinguished by grey instead of white speculum or wing patch and absence of any white face mark. Ring-necked Duck has a similar speculum but is a much smaller bird and has the white face mark.

Field Marks. Colour of head and outline of head and bill. down

Nesting. Usually on land or elevated over water, nest of reeds with more or less

Distribution. Usually only a migrant east of the prairie provinces, though at one time a few bred locally in Great Lakes region; rare on east coast.

One of our finest Ducks and when fed on wild celery its flesh has as fine a flavour as that of the Canvas-back. It is rather less of an open water bird than many of the Sea Ducks and is often found on marshes and ponds.

147. Canvas-back. Fr.-MILOUIN AUX YEUX ROUGES. Marila valisineria. L. 21 A large Duck; male with dull brick-red head and neck; black breast; white below; back white with very fine dark vermiculations bearing a close resemblance to canvas and to which the species owes its name. In female the redness of head and neck is reduced to brownish-grey and the back is brownish.

Distinctions. Colours very close to those of comparable Redhead plumages; distinguished from Redhead by shape of bill which in Canvas-back is longer and heavier, springing from well up on forehead and giving an almost straight culmen line rather than a concave one as in Redhead. Male much whiter on back and the red comes down to the shoulders instead of stopping halfway down the neck. Young and females may possibly be confused with the Scaups, Ring-bill, or Golden-eye, but may be separated by superior size or the lack of white or grey on the wing or of white on the face.

Field Marks. Red or reddish, or reddish-grey head, lack of white on face or wing, and shape and outline of head and bill.

Nesting. Built over water, in nest of reeds lined with down.

Distribution. Of regular though not very common occurrence on lower Great Lakes east to lake Erie; rare on Atlantic coast but more common in western Canada where it breeds.

One of the best known and most highly esteemed of the Ducks. The Canvas-back is associated in the popular mind with terrapin and highliving. This gastronomic fame is largely due to the wild celery, Vallisneria spiralis, upon which it frequently feeds and from which its specific name is derived. However, many other Ducks feeding upon the same plant become equally palatable. On the Great Lakes the introduction of the German Carp has proved very destruetive to the once extensive beds of wild celery and wild rice both of which plants are extremely attractive to 
all kinds of Ducks. One of the first steps to attract Ducks to reservations and private waters should be the clearing out of carp and the planting of wild celery and wild rice Zizania aquatica.

148. Greater Scaup Duck. american gCAUP. BRoAd-BILL. GREATER OR I ARE BLUEBILL, FR.-MORILLON À TETE NOLRE. Marila marila. L, 18.50. A medium-sized Duck-male, white below; head, neck, and upper breast black; and a black and white vermiculated canvas-like back. Females without canvas-back; blacks reduced to reddish browns of various shades; white face mark at base of bill.

Distinctions. Greater and Lesser Scaups are of almost exactly similar coloration but can usually be distinguished by size, or by shape and size of terminal nail on bill. Nail proportionately wider and more nearly circular in the Greater. Head of adult Greater Scaup has greenish gloss instead of changing to slightly purple on crown. Reddish shade on heads of young and females sometimes quite noticeable, and they may be mistaken for the Canvas-back, Redhead, or sometimes the Golden-eye, but white spot at base of bill and across forehead, or white wing patch are always distinctive of the Scaups. Ring-necked Duck, which also resembles them, has grey speculum instead of white.

Field Marks. Almost impossible to distinguish the two Scaups in life. Males of both species in flight appear black on front third of body and on the remainder except tail, but including second. ry wing quills, white. White face mark at base of bill, as above, is best field mark fo' , umale.

Nesting. On ground, in grass near grassy ponds.

Distribution. Uncommon migrant and rare breeder on Atlantic coast; commo: on Great Lakes; neste in numbers in northwest.

The Greater Scaup is more of an open water bird than the Lesser is indicated by on: of its common names, but it often comes with other species into the marshes for wild celery and rice.

149. Lesser Scaup Duck. RIVER BROAD-BILL. LITTLE OR MARSH BLUEBILL. FR.-LE PETIT MORILLON. Marila affinis. L, 16.50. Almost exactly similar to the last but a little smaller. Crown of adult male has a purplish instead of greenish gloss as on other parts of head.

Distinctions. See previous species. only by size.

Field Marks. See previous species. Scaups in life distinguished from each other

Nesting. On ground, near grassy ponds.

Distribution. Slightly less common in eastern Canada than the preceding. Breeds in western Canada and occasionally farther east to Great Lakes.

This is one of the commonest ducks away from the seacoast and more of a marsh and small-water bird than the preceding.

150. Ring-necked Duck. RING-BILLED DUCK. FR.-MORILLON A collrer. Marila collaris. L, 16.50. Very close in coloration to preceding two species, but without the canvas-coloured back; with a light ring about bill near end, and faint brown or coppercoloured ring about neck.

Distinctions. Young Ring-necks and females may be mistaken for either the Scaups, Golden-eye, Redhead, or Canvas-back ${ }^{1}$, but may be distinguished from the Scaups by the grey instead of white speculum, the female by fine white eye ring, and from any of the other ducks by white face marks usually connected across chin.

Field Marks. Male can be told from the Scaups by its black back, and female by its white chin and fine light eye ring; and either, in adult plumage, by light ring on the bill.

Nesting. On ground, near grassy ponds.

Distribution. Scarce migrant in the east where it once nested occasionally; scarce on Great Lakes; breeds regularly in the west.

151. Golden-eye. WHISTLE-WING. Whistler. GREAT HEAD. FR.-IA BUCEPHALE D'AMfriQUE. PLONGEUR. Clangula Clangula. L, 20. A rather large, heavily built duck, strikingly coloured in black and white. The back and head are black; the remainder of the plumage, including a very conspicuous circular spot between the eye

${ }^{1}$ See footnote, p. 63. 
and the bill, and the wing patch are white. The female and young male are marked with light greys and blacks on the back, large white wing patches, and a seal brown head; the upperneck usually strongly contrasted with white or grey neck and breast.

Distinctions. In young and female plumages it may sometimes be confused with the Redhead, Canvas-back ${ }^{1}$, or the Scaups. In such plumages the lack of white face mark or its restriction to the sides of the face will distinguish it from the Scaups; the white wing patches from the Redhead and Canvas-back.

Field Marks. The striking black and white coloration of the male and the brown head and lack of face markings of most juveniles and the females. The large head, short neck, and loud whistling of the wings in flight are characteristic.

Nesting. In stumps or hollow trees.

Distribution. Golden-eyes inhabit most of the northern parts of the northern hemi- inepe. The American Golden-eye, the only New World representative of the species, is nerally distributed over most of Canada. A common migrant and locally a winter cident in eastern Canada, breeding sparingly in the eastern provinces but more comis inly in the northwest.

SUBSPECIES. The Golden-eye is divided into two subspecific races: an old World and a New World form-the latter the American Golden-eye. C. c. Americana wing the only one that occurs in America.

One of the best known of the larger ducks. A very hardy bird remaining on our waters in winter until they close with ice.

152. Barrow's Golden-eye. FR.-LE BUCEPHALE D'ISLANDE. Clangula islandica L, 20. Like the American Golden-eye, but the male has a crescrnt-shaped instead of a circular face spot. The head glossed with purple instead of green and the bill relatively higher at the base.

Distinctions. Males easily separated from the Golden-eye as above, but young birds and females of the two species more difficult to distinguish and shape of bill perhaps only reliable guide. Young males can be recognized by a slight lump in the forehead just at base of bill, which though not visible through the plumage can be plainly felt with the finger.

Field Marks. Exceptional circumstances may allow some of the above points to be recognized in life.

Nesting. In stumps or hollow trees when possible, otherwise probably in rock cavities or on ground.

Distribution. A bird of very unusual distribution; common near the eastern and western coasts but absent from most of the great interior; eastern birds probably breed in northern Ungava.

This is a more northern species than the former which it closely resembles in habits as well as appearance.

153. Buffle-head. SPIRJT DUCK, BUTTERBALl. FR.-Le PETIT BUCEPHATE. Charitonetta albeola. L, 14.75. A very small duck, almost as diminutive as the Teal, but coloured in striking contrasts of black and white. Male : white below and around base of neck, black above with an iridescent black head broken by a large white triangular patch with apex below the eye meeting its fellow along the nape. The feathers of the cheeks leagthened, making puffs on the sides of the face, hence its name. Female : white below and dull brownish-grey elsewhere except for a vague white spot on each cheek.

Distinctions. Male cannot be mistaken for anything else; female rather like the Scaup but can be distinguished by small size and dash of light extending from behind eye towards back of crown instead of a white patch at base of bill. One facial spot instead of two and the evenly light underparts will separate it from the female Harlequin which it also resembles.

Field Marks. Small size and white head spot for the male, and size, cheek spot, and white wing patch for the female.

Nesting. In a stump or hollow tree.

Distribution. A common migrant from the Atlantic coast westwards; breeds in the west and northwest.

The name Spirit Duck refers to its diving powers and the remarkable ease with which it disappears when wounded.

\footnotetext{
${ }^{1}$ See footnote, p. 63.
} 
154. Old-Squaw. SOJTH-SOUTHERLY. COWEEN. LONG-TAILED DUCK. OLD-WIFE. COCKAWEE. Fr.-Le CANARD À LONGUE QUEUE. Harelda hyemalis. L, 21. (Projection of middle tail feather beyond others, $4 \cdot 50-5$.) A medium-sized duck showing remarkable seasonal change of plumage. Male in spring has a seal-brown breast, neck, head, and back; an almost white facial mask; and ochraceous striping over wings and at base of hindneck. Winter plumage white, with black or dark brown breast, back, and line across shoulders; a spot of same colour over the hindcheeks and upperneck; white stripes over wings. In both seasons male has two greatly elongated middle tail feathers about 8 inches from base to tip and projecting 4 or 5 inches beyond other tail feathers. Plumage of female is intermediate between the above two plumages, showing mostly white without any sharp line between the dark of the breast and the white underparts as in males.

Distinctions. Males are characteristic; females may be confused only with those of next species, but are much lighter underneath and head is mostly white instead of mostly dark.

Field Marks. Long tail of the male, and head mostly white with dark cheek mark in juvenile and female plumages.

Nesting. On ground, near water hidden under bushes or grass.

Distribution. Breeds across the continent in the far north. More common on the coast or Great Lakes, than on smaller bodies of water.

This is, with us, essentially a winter duck. It haunts our harbours and often congregates about the mouths of sewers remaining as long as open water prevails, even throughout winter. It is a great diver and a fish-eater, but is nearly worthless as a table bird. It descends to great depths after food and is sometimes taken in the fishermen's nets far from land and at surprising depths-in one known case 90 feet.

155. Harlequin Duck. ROCK DUCK. LORD AND LADY. FR.-LE CANARD HISTRION. Histrionicus histrionicus. L, 17. A small duck appropriately named after particoloured Harlequin. Male's general coloration is from dull slate-blue to blue-black, but on this ground is arranged a striking series of crescents, stripes, circular spots, triangles, and a collar of pure white, each narrowly bordered with black that makes it stand out in striking contrast; a brilliant splash of rich chestnut adorns the flanks and borders the sides of the crown. Female very dull and subdued, all brownish with white spotting on abdomen aggregated into a not quite continuous and even middle area. An obscure white blotch in front of and below eye and another more sharply defined one over ear.

Distinctions. Male cannot be confused with that of any other species. Female resembles female Buffle-head in size and colouring, but has a more or less speckled belly instead of an evenly light one, two facial spots instead of one, and no wing patch.

Field Marks. Male is unmistakable. Female may be recognized by size and general darkness of coloration, scarcely lighter below; absence of a wing patch; and two light face patches.

Nesting. On ground, under rocks or driftwood or in hollow stumps.

Distribution. Only a migrant in the east, very rare in the interior though common in the mountains of the west where it breeds.

This is one of the prettiest of our ducks, coming next to the Wood Duck in point of beauty. Its proper home is in the brawling streams of the west and northwest where it is well known to the prospector and miner. In eastern Canada it haunts rocky bays and shores where it feeds largely on the sea fleas and small shrimps that throng the inshore salt waters.

\section{Genera-Somateria and Oidemia. Eiders and Scoters.}

Though not forming a recognized systematic division of ducks these two genera are peculiar and show enough common characters to receive special mention here.

General Description. Large sturdily built birds, the largest of our ducks. Male Eiders have broad masses of sharply contrasting colours and delicate tints; Scoters nearly all black, some with small accents of pure white. Both genera have swollen bills with strange excrescences and brilliant colorations (Figure 9, p. 19). 
Distinctions. General dark colorations unrelieved by much pattern of the Scoters; the bright coloration in broad masses of male Eiders; and finely and evenly barred tones of browns of females; size, build, swellings, and protuberances of bills of both sexes of most species are the most obvious characteristics.

Field Marks. General coloration and bills.

Nesting. On ground near water, sometimes under shelter of over'sanging rocks or bushes; nest lined with down from the parent's body. The eiderdown of commerce is obtained from the nests of the Eiders.

Distribution. Distributed over the whole of Canada, nesting in the north; most common on the coasts and the large bodies of water during migration.

These are "Sea Ducks" in the strict sense of the term, built for buffeting heavy weather and rarely coming in to the shallow pools or marshes. They feed on shell fish and marine life obtained by diving.

Economic Status. Their food habits have little economic interest to man, but in certain localities, as in Labrador, they furnish in themselves and their eggs, the bulk of the fresh animal food available. As the down is a valuable object of commerce the Eiders are of distinct and easily recognized value. They are being rapidly reduced in numbers, (see discussion of American Eider) and drastic steps should be taken for their conservation.

160. Eider Duck. FR.-L'EIDER DU NORD. Somateria mollissima. L, 23. Male: black below, cutting sharply against the white breast which is delicately suffused with vinaceous pink; white above; head white with nile-green suffusion from cheeks to nape; broad black bar through eye to hind head. Female : evenly coloured in a fine pattern of various browns, blacks, and light ochres arranged in broken bars around the body. Bill processes extending up either side of forehead in long fleshy tongues.

Distinctions. Male unmistakable; female may be separated from that of King Eider by feathering of crown not extending as far forward as rear end of the nostril. This species is much like the American Eider from which it can only be separated by size and shape of the bill processes on the forehead-in the Eider Duck they terminate acutely and are not rounded at the tips-and distance from point of feathering on side of bill to tip of process is less than in the American Eider.

Field Marks. Size and general coloration.

Nesting. On ground, nest built entirely of down.

Distribution. Eider Duck inhabits northern parts of Europe and eastern America. The Northern Eider is the more northern of our two similar Eiders (see next species). A strictly Atlantic bird breeding in the eastern Canadian Arctic and in Greenland.

SUBSPECIES. The Eider Duck is represented in America by a subspecies, the Northern Eider S. m. borealis. The European Eider, the type race, has never been recorded in America.

161. American Eider. FR.-L'EIDER D'AMtrique. Motak. Somateria dresseri. L, 23. Almost exactly similar to the preceding species.

Distinctions. Female may be mistaken for that of King Eider, but can be separated from it by the feathering of crown not extending as far forward as rear of nostril. It may not be specifically distinct from preceding species and either sex can only be separated from it by rounded ends of bill process on forehead and the fact that the distance from point of feathering on side of bill to tip of processes is greater.

Field Marks. Size and general coloration; cannot be distinguished from Northern Eider in life.

Nesting. On ground, sometimes under overhanging rocks or bushes, nest built of down plucked from the parent's breast.

St. Lawributionce.

In Scandinavia and Iceland the Eiders are semi-domesticated and the down derived from their nests is an important source of revenue. Though on the Labrador and gulf of St. Lawrence coasts there are immense flocks of these birds no attempt has been made to turn them to account except 
as food; but the numbers have been so rapidly reduced by reckless killing that only a small fraction of the original number remains. On these bleak and desolate coasts where fresh meat is scarce the Eiders should be conserved for food if for nothing else. An intelligent and far-seeing policy would conserve the Eiders for all time to come, supply a liberal amount of flesh food and eggs, and at the same time produce a crop of down worth in the markets far more than the carcasses of the dead birds.

So closely is this species related to the last that it would not be surprising were it eventually included together with the Northern Eider as a subspecies.

162. King Eider. KING DUCK. FR.-L'EIDER REMARQUABLE. Somateria spectabilis. L, 23. Male much like the preceding, but the back mostly black, cheeks nilegreen, top of head and hindneck light bluish-grey, and a black $V$ on the throat; bill is distinctive, the bright yellow fleshy forehead processes almost meet on the forehead where they widen out to nearly an inch across, forming a comparatively mountainous hump on the forehead. Female is without the great bill process and is coloured in the same browns and blacks in fine-barred pattern as are the other Eiders.

Distinctions. Male with its bill processes cannot be mistaken for any other species. Females resemble those of other Eiders but can be separated from two preceding species by feathering of crown extending as far forward as rear of nostrils.

Field Marks. Less amount of white on the back and bill processes of the male. Females cannot with certainty be distinguished from the other Eiders in life.

Nesting. On ground, nest lined with down.

Distribution. The most northern of our Eiders. Nesting across the continent along the coast and islands of the Arctic. Wintering along the gulf of St. Lawrence and New England shores. It is the only Eider that straggles in to the lower Great Lakes with any regularity.

163. American Scoter. BLACK SEA COOT. FR.-LA MACREUSE D'AMERIQUE. Oidemia americana. L, 19. Male all black; base of bill much swollen near forehead and bright yellow. Female without swollen bill; dusky all over, lighter below and with evident $\mathrm{d}$ arker cap contrasting in a sharp line against lighter cheeks.

Distinctions. Male is the only Canadian all black Duck unrelieved by any spot of colour. Dark cap of female is distinctive against other comparable species.

Field Marks. Evident blackness and yellow bill of male, and the lack of white spots or facial marks and the dark cap on the female.

Nesting. On ground, near water.

Distribution. Breeds in the far north across the continent; common in winter on our eastern coasts and not unusual on lower Great Lakes.

165. White-winged Scoter. WHITE-WINGED COOT. FR.-LA MACREUSE VELOUTEE. Oidemia deglandi. $\mathrm{L}, 22$. Dark brown, almost black, with white wing patches and a small white crescent under the eye; bill is swollen at the base rising more abruptly forward than shown in Figure 9, p. 19, and the upper mandible is coloured with bright red and white. Female even dull brown.

Distinctions. White wing patch is distinctive of any plumage of this species.

Field Marks. Large size, general and even darkness, and white wing patches.

Nesting. On ground, under or among bushes.

Distribution. Breeds in the higher latitudes across the continent; abundant on the coast in migration and is the commonest Scoter on the Great Lakes and in the interior.

166. Surf Scoter. BUTTER-BILl COOT. BOTTLE-NOSEd DIVER. FR.-LA MA CREUSE A LARGE BEC. Oidemia perspicillata. L, 20. Male all black with white patch across forehead and a triangle of same colour at base of head; bill greatly swollen (Figure 9 , p. 19) and coloured most strikingly with reds, yellow, and black. Female dull brown, lighter below and much like that of American Scoter.

Distinctions. White patches of the head are distinctive of male. Female can be told from that of the White-winged by lack of wing patches; and from the American by absence of cap and presence of two vague light spots on side of the face, one at base of bill and other over ear.

Field Marks. White on head of male and the two vague spots on face of female.

Nesting. In grass near water. 
Listribution. Of about the same distribution as last species, but perhaps more common on the coast and less so on the Great Lakes.

167. Ruddy Duck. FR.-LE CANARD ROUX. Erismatura jamaicensis. L, 15. A small duck. Male strikingly coloured, rich rufous-chestnut on neck, shoulders, back, and flanks; crown and back of head almost black, and cheeks and lower face white. Female small, dull greyish-brown, lighter on underparts and cheeks, and with a dark cap.

Distinction. Male is the only Duck that is largely red. Female can be told by the silvery grebe-like sheen of the underparts, and, in any plumage, by the stiff pointed tail feathers.

Field Marks. Size, short squatty shape, and thick neck. Its habit of occasionally carrying its tail erect and spread out fan wise is also a good guide, though some Scoters also are said to do this at times.

Nesting. In reeds over water.

Distribution. Nests in the prairie provinces northward; more common in migrations on the Great Lakes than on the coast.

\section{Sub-family-Aıserino. Geese.}

General Description. Geese resemble ducks, but are larger with a less flattened body and comparatively longer legs; bill (Figure 10, p. 19) is higher and somewhat more compressed at base, stouter and less flattened at tip, hardly to be termed spatulate but with the broad nail at tip characteristic of the order.

Field Marks. The strong flight of the geese is familiar to most. Size, coloration, and flight habits are the best field guides. Their hoarse honking voices so often heard during migration are also characteristic.

Nesting. On ground.

Distribution. Geese are of world wide distribution. The American species all breed well to the north, migrating through the interior as well as along the coasts.

The geese are more terrestrial and herbivorous than the ducks but they are equally at home on the water. They do not normally dive, but secure food from the bottom by tipping and reaching by means of their long neck. The sexes are alike and there is little seasonal change of plumage. The goose is an excellent table bird and for this reason and on account of its superior size it is much sought after by sportsmen. Geese are exceedingly wary and, though greatly reduced in number, have been able to take better care of themselves than many other large game birds.

Economic Status. Feeding largely upon grasses and frequenting cultivated areas in migration more than other members of their order they may do more harm than the ducks, but this has never been seriously held against them. Their value in other directions is so obvious that less complaint has been made against geese than against other species equally worthy of protection but whose usefulness though real is less obvious.

169. Snow Goose. Ladghing goose. Wavey. Fr.-h'ode Bianche. Chen hyperboreus. L, 23. A rather small goose, pure white with black primaries. Juveniles with more or less grey or greyish-brown washing locally or over all.

Distinctions. Cutting edges of mandibles are more or less bowed away from each other, exposing tooth-like serrations and giving the face that appearance from which the name, laughing, is derived.

Field Marks. Colour and evident goose-like fight and outline.

Nesting. On ground.

Distribution. The Lesser Snow Goose breeds on the Arctic coast and islands from Coronation gulf westward. It migrates down the interior of the continent, the Greater along the Atlantic coast.

SUBSPECIES. There are two subspecies of Snow Goose in Canada, the Lesser and the Greater, differing only in size; but as the two intergrade this is not an entirely reliable distinction. There is a difference based upon the comparative shapes and sizes of $57172-6$ 
the bills, but it requires specimens for comparison for its appreciation. Though often incorrectly recorded the Greater Snow goose is a very scarce bird. It is the extreme eastern form of the species and can only be expected along the Atlantic coast.

The name "Wavey" is a corruption of the Indian word "Wa-wa," meaning Wild Goose.

169.1. Blue Goose. FR.-L'OIE BLEUE. Chen coerulescens. L, 26. Slaty-grey body, wave-marked with lighter feather edges on back and more or less so below; slate colour strongest on wings and rump; head white. Juvenile similar but head and neck greyish-brown. The bill shows in slightly reduced degree the teeth serrations of, the Snow Goose.

Distinctions. The combination of white head contrasted with blue-grey wings does not occur in any other eastern American Goose.

Field Marks. White head and darker body probably best field marks.

Nesting. On ground.

Distribution. Seems to be confined in breeding season to the east of Hudson bay; a. rare migrant on the Great Lakes on its way to or from the Mississippi valley.

For a long time the Blue Goose was thought to be only a juvenile plumage of the Snow Goose, but is now recognized as a separate species.

171a. White-fronted Goose. FR.-L'OIE À FRONT BLANC. Anser albifrons. L, 27. Greyish-brown, darker on head and neck, lighter below, white patch about base of bill; light colour of underparts irregularly blotched with black aggregating in maturity into indefinite bands giving an immature effect to even adult birds.

Distinctions. Brown head and white face.

Field Marks. General brownness and white face mark.

Nesting. On ground.

Distribution. The White-fronted Goose is a nearly circumpolar species. The American subspecies breeds on the western Arctic mainland and islands. Migrates through the interior of the continent and is found rarely as far east as the Great Lakes.

SUBSPECIES. Our representative, the American White-fronted Goose A. a. gambeli, is a subspecies of the European White-fronted Goose from which it is said to be distinguished by its slightly larger size.

172. Canada Goose. WILD Goose. GReY Goose. FR.-LA BERNACHE do canadA, odtARDe. Branta canadensis. L, 35 . Plate V B.

Distinctions. Large size, black head and neck, white throat and cheek patch.

Field Marks. Black head and neck and white throat patch. A white V over the tail, displayed when flying, will separate the members of this genus from any of the larger ducks.

Nesting. On ground, occasionally in large deserted nests in trees.

Distribution. Breeds across the continent from the northern tree limit to the borders of settlement.

SUBSPECIES. The Canada Goose is divided into several geographical races. In the west, there is a small subspecies called Hutchins's Goose B. $c$. hutchinsi. It is said to have a different note and to be quite recognizable in life by experienced hunters. Its smaller size is an uncertain criterion but is the only distinction that can be given here. Its length averages under 25 inches. It is to be expected only as far east as Manitoba and its identification elsewhere should be made with great caution.

The goose is a wary and watchful bird, usually spending the day well out in the open water, coming in to the marshes and cultivated fields to feed at night or in the evening and unless disturbed remaining until well into the next day. While so engaged there is always at least one with long neck upstretched surveying the surrounding country for danger and an unobserved approach by even the most experienced stalker is next to impossible. On this account the Canada Goose has perhaps suffered less from hunters than other members of its order and until its remaining breeding grounds are invaded there is little danger of its being exterminated. 
It originally bred within the borders of our present inhabited areas but settlement has driven it from its more southerly breeding range. However, it still occupies large areas throughout northern Canada as far as the northern tree limits and as much of this territory will remain unsettled for many years the goose is assured of safe breeding grounds and is in no immediate danger of extermination. However, unless intelligent conservation principles are adopted in the future the Canada Goose will probably decrease as its breeding grounds are opened up.

173a. Brant. Fr.-LA BeRnache COMMUNe. Branta bernicla. L, 26. Much like the Canada Goose but smaller; head, neck, and upper breast black; a narrow broken collar of white on neck.

Distinctions. A small dark Canada Goose without face mark.

Field Marks. Small size, dark breast, and lack of face mark. The white V over tail, displayed when flying low, will also distinguish the Brant from any of the larger, black ducks but not from the Canada Goose.

Nesting. in ground, nest of grasses lined with down.

Distribution. As a species, circumpolar. The American Brant breeds in the eastern Arrstic region, migrating down the Atlantic coasts, rarely in the interior.

SUBSPECIES. The Brant is a circumpolar species. The New World form, the American Brant $B . b$. glaucogastra, is subspecifically distinct from the Old World bird which has never been recorded in America. The Black Brant B. nigricans of the west is characterized by having the black of the breast suffused over the underparts; but it occurs in eastern Canada only as an accidental stragglex.

The Brant is a small goose. It occurs on the lower St. Lawrence and the seacoast in flocks of hundreds but is scarce or only a straggler in the interior on the Great Lakes.

\section{Subfamily-Cygnince. Swans.}

General Description. Very large white Anatida; excepting perhaps the Whooping Crane or the Wild Turkey, the largest of American birds.

Distinctions. Size combined with colour is sufficient to diagnose the two Swans. Lores (space between eye and bill) unferthered. Bill begins high on the forehead, at base is almost rectangular in cross-section and tip is provided with a flat nail.

Field Marks. Size and colour: they are our only large, all white, birds. ${ }^{1}$

Nesting. On ground, nest of grasses lined with down plucked from parent bird.

Distribution. Most of the Swans are found in the northern hemisphere but are not entirely confined to it. In America, they now nest in the far north; though originally the Trumpeter, now verging on extinction, bred as far south as some of the northern United States.

From time immemorial Swans have figured largely in Old World folk-lore and the fairy tales of childhood are filled with references to them, but it comes with a little shock of surprise to many people to learn that even to-day wild Swans are actually common in Canada. Geese are wild and wary, but the Swan is even wilder and more wary. Its long neck allows it to feed in deeper water than other non-diving species and it keeps well out in deep water through the day, where unobserved approach is impossible. It rarely comes into the shallow marshes that may hide the huntsman and, therefore, it is rarely taken.

The common names of the Swans of the northern hemisphere are indicative of extraordinary vocal powers; thus in America we have the Whistler and the Trumpeter, and in Europe the Whooper and the Mute Swans. Peculiar and complicated modifications of the windpipe, in the form of

\footnotetext{
1Other large white birds occurring in Canada all have more or less black on flight feathers.
}

$57172-6 \frac{1}{2}$ 
various convolutions in special bony recesses of the breast bone or sternum, are, evidently, directly connected with the voice and their complexity increases directly with the quality of the voice as indicated by the above descriptive names; thus the Mute Swan is without any tracheal convolution and the highest complexity is reached in the Trumpeter and Whooper.

180. Whistling Swan. FR.-LE CYGNE D'AMfriqUE. Olor columbianus. L, 55. A very large, all white, bird.

Distinctions. The Whistler can only be mistaken for the Trumpeter Swan. Superficially it can be easily separated only by its inferior size. As Swans do not obtain their full development for a number of years, size may not always be an accurate test. There is a difference in the shape of the bill, but it is too difficult of characterization to be clearly described here. The convolutions of the windpipe in the breast bone makes the most satisfactory differentiation. In the Whistler the windpipe makes one horizontal loop over the floor of the sternum, whereas that of the Trumpeter has a perpendicular loop as well. The absence of a yellow spot on the lores of the Trumpeter has been given as diagnostic, but this is so often absent from even adult Whistlers as to be of no use for this purpose.

Field Marks. Size and complete whiteness. The two species cannot be readily distinguished in life except by those familiar with the voices of each.

Nesting. On ground, in nest of grasses, moss, etc., lined with down.

Distribution. Breeds in the far north across the continent west of Hudson bay; migrates through the interior; rare or absent on the Canadian Atlantic coast, but locally ommon on the large waterways of the Great Lakes region.

Owing to its extreme wariness and its breeding far in the north the Whistling Swan has not been seriously reduced in numbers during the past generation. Its larger relatives, the Trumpeters, whose breeding grounds well within the borders of settlement were early disturbed, is now on the verge of extinction.

The Swans rarely come into shallow marshes where cover may hide the huntsman. They are exceedingly wary and are rarely seen except in dense white flocks like ice floes far out in the open water or in flocks flying high overhead and beyond the reach of guns. Their regular migration is usually by night and usually silent, though sometimes extremely noisy. To such habits as these is probably due the fact that few even of our most experienced huntsmen know the Swan in life and fewer still can boast of having taken it. Though flocks of hundreds appear annually on lake St. Clair not more than two or three individuals are taken there each year.

The species also occurs in large numbers on Niagara river where on misty or foggy nights in the spring, they often drift down with the current into the swift rough waters of the rapids and are carried helplessly over the falls. This catastrophe has occurred several times within the last decade and hundreds of Swans have lost their lives in this manner, some have every bone in the body broken whereas others are only slightly hurt. The dead that are not drawn under the ice and carried off by the current are picked up, the dying clubbed, and those whose injuries are only slight are shot. As the birds do not seem able in the close quarters to rise above the sides of the gorge and show marked reluctance to pass beneath the bridges that span the lower pass, all are confined in the narrow waters below the falls where there is no escape. The flesh of the Swan is not very suitable for eating and the birds are of little value to those who take them except as curiosities.

181. Trumpeter Swan. Olor buccinator. L, 65. Very large, all white, bird. 
Distinctions. Only to be mistaken for the previous, which see.

Field Marks. Size and complete whiteness; the two Swans cannot be separated with certainty in life.

Nesting. On ground, in nest of grasses and down.

Distribution. A bird of the interior, breeding from the central of the northern tier of states northward.

Any Swan over 56 inches in length or over 20 pounds in weight is probably of this species. It was at one time a fairly common bird on the Great Lakes, but now is so rare as to be regarded as nearly or quite extinct there. Its breeding range, being considerably south of that of the Whistling Swan and well into what is now fully occupied farming territory, is probably the cause of its rapid extermination.

\section{Order-Herodiones. Deep Water Waders.}

General Description. Usually large birds with long legs, neck, and bill, fitted for wading and obtaining food below the surface in rather deeper water than the majority of waders. Bills may be either straight and sharp (Figure 18, p. 21) or gently curved and blunt as in the Ibises. Legs are bare for a considerable distance above the heel joint and all four toes are perfect, well-shaped, and adapted for perching as well as walking on soft ground and with only small rudimentary. webs or none (Figure 17, p. 21).

Distinctions. Birds of this order may be mistaken for either Cranes or one of the Shore-birds (Curlews). From the Cranes they can be distinguished by their feathered forehead. The Wood Ibis combines bare forehead and curved bill, but is of only possible occurrence in Canada. From any shore birds they can be distinguished by the bare space between the eye and the base of the bill.

The Canadian forms of the order are divided into two suborders: Ibides including Spoonbills and Ibises; and Herodii including Herons, Egrets, and Bitterns.

\section{SUBORDER-IBIDES. IBISES.}

This suborder includes two families: Spoonbills which do not occur in Canada, and Ibidida, only one of which occurs in the Dominion and that rarely.

\section{FAMI Y Y-IBIDIDAE. IBISES.}

General Description. Birds with long, decurved bill quite blunt at the point and the upper mandible grooved throughout its length.

Distinctions. Curved, blunt, and deeply grooved bill is characteristic. Claw of the middle toe may be broadened and roughened at the edge, but is not perfectly pectinate or furnished with well-formed comb-like teeth as in the heron-like Waders of the suborder Herodii (Compare with Figure 19, p. 21).

There is only one of these birds, the Glossy Ibis, that may be found in Canada and that only as a casual straggler.

186. Glossy Ibis. BLACK CURLEw. Plegadis autumnalis. L, 24. Practically an all black bird with chestnut, green, and purple reflections. Juvenile is brown with head feathers slightly margined with light and with greenish reflections elsewhere.

Distinctions. The Glossy Mbis looks much like a large Curlew, but its almost black or very dark coloration will distinguish it from the Curlew with ease. Its grooved bill (see previous family description) otherwise differentiates it.

Nesting. In reedy swamps or low bushes.

Distribution. Tropical and subtropical regions.

The Ibis is well known by name as one of the sacred birds of ancient Egypt, and as such is familiar to every general reader. The Glossy Ibis 
is allied to the Sacred Ibis of the Nile and shows some of its general characters. It appears only occasionally in Canada, along the southern border.

Economic Status. Of too rare occurrence in Canda to be of economic influence.

\section{SUBORDER-HERODII. HERON-LIKE WADERS.}

As this subordery is represented in Canada by only one family, Ardeida, the description under that headirg is sufficient.

\section{FAMILY-ARDEIDAE. HERONS AND BITTERNS.}

General Description. Heron-like birds with straight and very sharply pointed bills. Space in front of eyes bare. A peculiar feature with this suborder is the occurrence of "Powder-down tracts"-aggregations of peculiarly modified feathers giving off a dry powder of unknown use. These feathers are found on various parts of body hidden under the visible plumage. Claw of the middle toe is pectinate, that is, furnished with a series of well-defined comb-like teeth (Figure 19, p. 21), not merely roughnesses as in the Ibises.

Distinctions. This suborder might be mistaken for Cranes, but the feathered forehead is distinctive. Back of neck bare, the feathers of sides reaching around behind and hiding the bareness from casual observation. Hind toe very long and set level with the other toes and not slightly raised as in other waders.

Field Marks. Obvious heron-like outline, with long graceful neck, long sharp bill (Figure 18, p. 21), and lengthened legs (Figure 17, p. 21). Neck folded in flight, bringing head clase to shoulders, the legs trailing behind. The Cranes with which they may be confused in life carry their necks outstretched.

Perhaps no birds are so well known to the general public by common repute and observation as these, yet we seldom hear them correctly named. The terms Herons, Storks, and Cranes, are applied and misapplied indiscriminately. There are no Storks in Canada. The Cranes are of western distribution and are rarely seen in eastern Canada. The birds we generally hear called by the latter name are true Herons. The family is divided into two subfamilies: Botaurino, the Bitterns; and Ardeino, the true Herons and Egrets.

\section{Subfamily-Botaurina. Bitterns.}

General Description. Marsh inhabiting, heron-like birds of heavier and less graceful build and habit than the true Herons.

Distinctions. Though forming a well-defined subfamily they are difficult to define in a short non-technical diagnosis. In Canadian species, colour is the best and most easily recognized guide. Excluding Cory's Bittern, which is very rare (see under Least Bittern, p. 81), the Canadian species have large amounts of ochraceous yellow on them, a colour that is, in any extensive mass, absent from all our true Herons.

Bitterns are bog and marsh haunters. They do not frequent wide open reaches of water, but drop down in the middle or on the edges of grassor reed-grown marshes, stalking their prey by silent approach through the close cover.

190. American Bittern. MARSh HEN. T'HUNDER-PUMP. STAKE-DRIVER. FR.-LE BUTOR D'AḾ́rique. Botaurus lentiginosus. L, 28. Plate VIA.

Distinctions. With its general yellow coloration, alike in both sexes and all ages, the Bittern can be mistaken for no other Canadian species. The Least Bittern is the only other bird of like build showing mostly yellow, but its size is so small that there is no chance of confusion. Black line from sides of face may be present or absent regardless of sex, age, or season.

Field Marks. As the bird rises from the reeds or grass its long neck, dangling legs, and general yellowish coloration are easily recognized. At a distance, in firght, its outline, 
head drawn in to the body and legs reaching out behind, is so similar to that of the Herons that unless the light so falls as to show the colour, apparent size only differentiates them. reeds.

Nesting. On ground, in grass, hayfields, or reed-grown marshes, nest of grass or found.

Distribution. Common throughout the settled portions of Canada, breeding wherever

References to the lonely booming of the Bittern are frequently seen in English literature. We can hardly say that our American Bittern "booms," but its note is most peculiar and is unique amongst American bird notes. The common names, "Thunder-pump" and "Stake-driver," are applied in reference to the strange noises it makes. Near a marsh one may hear a sound as of some one driving a stake with a wooden maul into soft mud. There is the dull thud of the blow with a sucking liquid echo followed closely by a squdgy drive. At other times sounds are heard like some one frantically working a dry sucking pump that draws the water part way and refuses to lift it farther. These are variants of the Bittern's love song and contain no recognizable vocal qualities.

Economic Status. The Bittern is a bog haunter and eats frogs, crawfish, snakes, small fish, crustaceans, insects, and probably even young birds and mice. It eats little or no vegetable matter. Bitterns are quite harmless as a class and may be useful.

191. Least Bittern. FR.-LE PETIT BUTOR. Ixobrychus exilis. L. 13. Smallest heron-like wader found in Canada. Coloured in broad masses of creams, ochres, and Indian reds, with black or brown back and eap, depending on sex.

Distinctions. Owing to its small size and striking coloration, can be mistaken for nothing else in Canada except perhaps its very close and rare relative, Cory's Least Bittern I. neoxena. This latter bird has the creams and ochres replaced by seal or reddish brown and it is still undecided whether or not it is only a colour phase of the common form.

Field Marks. Small size and striking colours make the species unmistakable. Seldom seen except at close range when colour and size are evident.

Nesting. Generally over water, in nest on platform of dead rushes in a marsh or reed-patch.

Distribution. A common but rather local bird in the more southern parts of Ontario and Quebec. Breeds wherever found in Canada.

The Least Bittern frequents wet, cat-tail marshes, usually of rather extensive area, and is rarely observed except by those who invade its quiet precincts. The American Bittern is often seen winging its way from marsh to marsh, but the Least Bittern remains within its home swamp and rarely ventures beyond it. It is a silent bird and has little or no vocal attainments.

\section{Sub-family-Ardeino.. True Herons and Egrets.}

General Description. More slender and graceful birds than the Bitterns and, on an average, of larger size. Smallest are very little smaller than the American Bittern and none are as small as the Least Bittern. Colour makes the easiest differentiation.

Distinctions. Herons are usually coloured slate-blue or dull greens, but are sometimes white. Bitterns on the other hand have a pronounced yellow colour. Many Herons have long fine plumes on the crown, lower throat, or back, and all Canadian species when in full breeding plumages show the plumes to greater or less extent at one or more of these points; but they are usually absent in the autumn.

Field Marks. The characteristic outline in flight, with sharp pointed bill, head drawn in to the shoulders, and legs trailing behind, is common to both the Bitterns and Herons 
which are better recognized by species than as a subfamily. However, any such bird that is obviously not a Bittern is probably a Heron.

Nesting. Herons commonly build their nests in communities, usually in tree tops in wet forests, but sometimes in bushes or on ground.

The Herons are fishers of open shallows, haunting grassy bogs less than the Bittern. Instead of stalking their prey they remain motionless until it comes within reach.

194. Great Blue Heron. BLUE Grane. BLOE HERON. Fr.-LE Grand HíroN BLeUE. Ardea herodias. L, 42. Plate VI B.

Distinctions. The largest Heron found in Canada; the Sandhill Crane of the west is the only bird for which it may be mistaken. The fully feathered forehead is diagnostic. Compare Figures 18 and 20, p. 21.

Field Marks. Heron-like outline, size, and general coloration make the best field marks. Unlike the Crane that flies with neck outstretched the Great Blue Heron, like other Herons, travels with neck folded and head drawn into shoulders.

Nesting. Usually in large communities in wet woods, such as tamarack, ash, or elm swamps, in nest of large bulky structure of sticks in tree tops.

Distribution. Over nearly the whole of Canada, breeding wherever found.

SUBSPECIES. The Great Blue Heron is divided into several subspecies, of which the typical form, Eastern Great Blue Heron Ardea herodias herodias is the only one that occurs in eastern Canada.

The Great Blue Heron is a haunter of open, shallow water. It rarely frequents dense reed beds, though it is often found on their outskirts or on the edges of pools within them. It prefers wide shallow reaches of rivers, or open flats of marsh or tidal shores. It is a still-hunter, cautiously wading with almost imperceptible movements, or standing statuesquely regarding the water until its prey comes within reach when, with a lightning stroke of the sharp bill, the prey is secured. Herons, nesting in large rookeries in wet woods, have been peculiarly open to the senseless persecution that seems to follow all our larger birds. Wary and uspicious ordinarily, in the vicinity of their nests they lose much of their usual caution and, in the rookeries, the birds can be shot in numbers. Heronries are usually known to all the surrounding country and are in the breeding season often visited by the rural sportsman who kills the parent birds and leaves the young to die of hunger, although a landowner has occasionally sufficient public spirit to protect heronries on his property. The result is that this picturesque bird is becoming scarce. Heronries once destroyed in this manner are seldom if ever repopulated and new ones are rarely established. Birds breeding in communities are seldom driven away to new locations. They remain until the individuals composing them are exterminated. The Blue Heron is a harmless bird and should receive every protection possible.

Economic Status. The food of the Great Blue Heron is almost entirely animal in its nature consisting mainly of frogs, snakes, and small fish usually of no economic importance. Cranes frequent the fields for food but the Herons never do so. Occasionally Herons may visit trout streams where they meander through open meadows, but such cases are rare and insufficient for the condemnation of the species. Herons often frequent the pound nets of the fishermen, but the limited size of their gullets precludes their taking anything of economic importance and the suspicion of the net owners against them is unfounded. 


\section{White Herons.}

Though not forming a recognized systematic division of the Herons there are several species showing pure white plumages, that are distinct enough to warrant discussion.

In some of these species, the Egrets, white is the adult plumage, in others it is a dichromatic form; that is the species occurs in two colour phases, either of which is normal, and cannot be referred to either albinism or melanism or to sex, age, or season. In still other species the white is a plumage of juvenility or old age and is regularly assumed at the proper time. These white plumages were a source of considerable confusion in identifying species until they were fully worked out. All of the White Herons are of southern distribution and are rare in Canada.

196. American Egret. FR.-L'EGRETTE BLANCHe D'AMÉRIQUe. Herodias egretta. L, 41. Almost as large as the Great Blue Heron, but always pure white. In breeding season cascade of some fifty fine straight plumes originates in middle back region and festoons over lower back and tail.

Distinctions. Size, colour, and obviously heron-like outline.

Field Marks. As above.

Nesting. In communities, in nests of sticks in trees or bushes over water. straggler.

Distribution. The southern and Gulf states, appearing in Canada only as an accidental

The American Egret, with the Snowy Heron and some other species of like character, constitute the source of the well known "aigrette" or "osprey "plumes of the millinery trade. As these plumes are grown only in the breeding season and as the immediate neighbourhood of the breeding rookeries is the only place where these wary birds can be easily approached it is evident that the harvesting of the beautiful crop is accompanied by great cruelty. The defence is often made that the plumes are picked up after being shed by the parent bird. This is a doubtful plea, for if any one will search domestic poultry yards for good shed feathers he will quickly realize that recovered "aigrette" plumes will probably be few in number and of poor quality. The plea is more doubtful as the rookeries are situated in dense subtropical swamps where all below is mud and water and the undergrowth prevents close, systematic search. The plume hunter usually hides in the rookery and with a small calibre rifle shoots the birds one by one until the flock is exterminated. The plumes are torn from the bodies which are left to rot on the ground. The remaining young starve in the nests above. Local laws have been passed against killing the birds but without avail. A few years ago the waters of Florida and the Gulf states were made beautiful with the forms of these immaculate birds; to-day they have almost lost one of their greatest attractions as the birds are approaching extinction. As a last resort, a federal law has been passed in the United States prohibiting the importation of feathers for millinery purposes. A similar law has been passed in Great Britain and the colonies. Egrets are not the only species that have seriously suffered: tern and other sea birds, Birds of Paradise, and many insectivorous forms have been victims.

200. Little Blue Heron. FR.-LE PETIT héron BLEU. Florida ccrulea. L, 22. A beautiful and gracefully built small Heron. Adult has head and neck maroon-chestnut, remainder of body dark bluish-slate colour. Fine-pointed plumes over shoulders and on front of lower neck. Juvenile is almost pure white more or less washed with slate colour. 
Distinctions. Adult is distinguished by colour as described above. The white, young bird closely resembles the juvenile Louisiana Heron but can be differentiated by its greenish yellow legs and blue-slaty tips to the primaries.

Nesting. In communities, in nests of sticks in bushes or trees over water.

Distribution. Tropical America. Breeds in the southern and Gulf states. Of only accidental occurrence in Canada.

Birds of adult plumage seldom occur in Canada. The juveniles are the only ones that are to be expected to wander into our confines.

Economic Status. Too rare in Canada to have any economic importance.

201. Green Heton. FLY-UP-THE-CREER. FR.-LE HÉRON VERT. Butorides virescens. L, 17. Smallest of the common Herons. Back lustrous grey-green with short plume-like feathers draping over the wings. Face, sides of neck, and throat, as well as the underparts, rich chestnut. Head has a black cap lengthened into a small crest.

Distinctions. The above description may seem to resemble the last species, but the evident green sheen of back, absence of neck plumes, smaller size, and heavier build, prevent serious confusion. This is, moreover, a common species within its range and the one most likely to be met with in the Great Lakes region. Any comparable species is very rare.

Field Marks. Size and general coloration.

Nesting. Solitary and not in communities, in flimsy and open nest of sticks in bushes or trees usually over water.

Distribution. Moderately common in southern Ontario, but rare eastward. Breeds wherever found in Canada.

SUBSPECIES. The Green Heron is subspecifically divided, but the type form, Northern Green Heron, is the only species that occurs in Canada.

The Green Heron is not as prone to frequent open water as is the Great Blue Heron, nor grassy marshes like the Bittern. Alder thickets in drowned land, the bushy edges of quiet bayous, back waters of slack streams, and beaver meadows are their preferred habitat. They are more solitary than the other Herons at nesting time and though several pairs may occupy a peculiarly favoured locality it is community of interest that draws them together and not sociability.

Economic Status. The food of the Green Heron consists of crawfish, insects, frogs, and small fish. An accusation has been brought against it that it is harmful to certain fish, but as the bird is small and comparatively scarce and as its usual still water habitat does not bring it in contact with many valuable species, it cannot be regarded as a serious menace.

202. Black-crowned Night Heron. QUA-BIRD. SQUAWK. FR.-LE HERON DE NurT. Nycticorax nycticorax. $\mathbf{L}, 24$. Smaller than Great Blue and larger than Green Herons, more like Bittern in size. Adult plumage is recognizable at a glance. Body is white, softly shaded with tints of light grey. Back and crown black, one or two long, fine pencil-shaped plumes falling from the latter. Juvenile is an altogether different looking bird, greyish-brown stripes against whitish ground.

Distinctions. Adult is distinctive. Juvenile may, at a hasty glance, resemble the Bittern, but lacks any decided yellow tinge, and the plain simple colour-pattern is very different from the highly involved and finely vermiculated colour scheme of that bird.

Field Marks. Size, general coloration lacking strong yellow of the Bittern; often alights in trees, the Bittern never does so.

Nesting. Often in communities with Great Blue Heron, nest usually of sticks in trees, sometimes on ground.

Distribution. The Black-crowned Night Heron is a bird of irregular and local distribution. It is found in eastern Ontario, western Quebec, and Manitoba, in occasional colomies. In Ontario, from Kingston west, it is exceedingly rare. Even in the western peninsula of Ontario it is scarce. 
SUBSPECIES. The Black-crowned Night Heron occurs in both eastern and western hemispheres. The New World bird under the name of American Black-crowned Night Heron $N . n$. noevius is subspecifically distinct from that of the Old World.

This is a rather heavily built Heron which though not without some beauty and grace lacks the fine, slender lines of most of the Herons and resembles the Bitterns in build. Its habits are a composite of those of the Great Blue and the Green Heron.

The Yellow-crowned Night Heron Nyctanassa violacea, also, occasionally occurs in Canada, but is too rare to require more than passing mention. The adult is generally a slate-grey bird, sharply streaked on the back with black and has a conspicuously black and white head. The juvenile is so similar to the Black-crowned that it is distinguished with difficulty, but its head is darker than the back and there is no trace of rufous on the primaries, which close inspection reveals on the young Black-crown. Juvenile Yellow-crowns should only be recorded in Canada with caution.

Economic Status. Its food is similar to that of the Green Heron and its status is much the same.

\section{Order-Paludicolæ. Marsh Birds.}

General Description. This is a poorly defined order, including a number of families of waders that can be referred to neither the Herons nor the Shore Birds, but superficially resemble both. They are birds having four long, well-developed toes, without webs, and legs adapted for wading. They are best defined by subfamily description. The Canadian species are divided into two sub-orders: Grues, including Cranes, Courlans, etc.; and Ralli, including Rails, Gallinules, and Coots. Of the Grues only the family, Gruidre, Cranes, is represented in Canada.

\section{SUBORDER-GRUES. CRANES AND COURLANS.}

As the Courlan, family Aramida, does not occur in Canada, we are interested only in the one family, Gruidoe Cranes. As far as Canada is concerned, this suborder may be called the "Large Marsh Birds," a term, however, which has no other warrant than that of convenience.

\section{FAMILY-GRUIDA. CRANES.}

General Description. Large heron-like birds; dull, slaty-blue with rusty overwash; or pure white, with black primaries. All colours are in even, over-all, tints and the birds have no plumes nor crests.

Distinctions. Distinguished from the Herons by having the forehead and the space about the eye bare, or with a sparse sprinkling of peculiarly modified hair-like feathers and by the lack of pectinations on middle claw (see Figure 19, p. 21); bill is smaller proportionally than that of Heron but more heavily built, in both material and shape (compare Figures 18 and 20, p. 21).

Field Marks. Cranes fly with outstretched neck instead of with head drawn into the shoulders as do the Herons, and contrary to the habits of Herons they commonly feed in flocks on upland fields.

206. Sandhill Crane. Grus mexicana. L, 40. Very similar to the Great Blue Heron, but without plumes at any season. An even blue-grey colour all over with a washing of rusty red or brown, strongest in the juvenile stages.

Distinctions. Distinguished from the Great Blue Heron by its bare forehead, etc., as described under preceding heading (compare Figures 18 and 20, p. 21). Otherwise it can only be confused with the Little Brown Crane Grus canadensis, from which it can be distinguished only by size - the length of the latter species being about 36 inches and the 
ength of the Sandhill 40 inches. As specimens intermediate in size are not uncommon, differentiation of the species is not always easy; and both forms may occur in eastern Canada. Another Crane, the Whooping Crane Grus americana, found in the west, has occasionally occurred in eastern Canada, but its pure white colour, or white washed with rust colour, black primaries, and extremely large size-50 inches-make it easy of recognition.

Field Marks. Bare forehead coloured dull reddish, flight with neck outstretched instead of folded, and more upland habits.

Nesting. In wet marshy places, nest of waste vegetable matter. ward.

Distribution. Western Canada, breeding within the bounds of cultivation and north-

The Sandhill Crane appears to have been a more common visitor to eastern Canada, the Great Lakes region at any rate, in the early days than at present. It is now only a rare straggler east of the prairie provinces, though a few individuals still nest in southern Michigan and it is not impossible that a few may still be found occasionally in adjoining parts of Ontario.

Economic Status. Too rare in eastern Canada to have any economic importance. Though a more graminivorous feeder than the Herons and occasionally visiting cultivated ground in numbers in the migration season, it does little damag. ; for in the spring it comes early and in autumn it takes only waste grail. The insect part of its food is large.

\section{SUBORDER-RALLI. SMALLER MARSH BIRDS.}

As regards Canada, this suborder, comprising the Rails, Gallinules, and Coots, may be called Smaller Marsh Birds, as compaied with the larger Grues. They are not heron-like in form and cannot possibly be confused with the Cranes either in shape, habit, or size. Of this suborder only one family Rallidoe occurs in eastern Canada.

\section{FAMILY-RALLIDE. RAIL-LIKE BIRDS.}

General Description. Toes long and slender for the purpose of covering a large area of soft uncertain footing. The pedal characters are somewhat like those of the shore Birds but the hind toe is as long and well developed as the others and inserted on a level with them instead of being slightly elevated. In this respect they resemble the Herons, but can be distinguished from them by their unheron-like build and their feathered lores.

They are typical marsh birds, skulking in the long grass and reeds, running swiftly over yielding masses of half-floating vegetation, and preferring to hide rather than fly on the approach of danger. They all swim, some habitually and others on occasion. The family is divided into three subfamilies: Rallus, the true Rails; Gallinulina, Gallinules or Mud Hens; and Fulicince, Coots.

\section{Subfamily-Rallus. True Rails.}

General Description. Very flat-bodied birds, compressed laterally, adapted for slipping between close growing reeds and grasses; wings small, rounded, and comparatively weak; the whole structure of the bird is loose, giving the flexibility needed by habit and habitat, but not adapted for prolonged or strenuous effort.

Distinctions. Most easily recognized by negative characteristics: rail-like birds as described above that are neither Gallinules nor Coots; without the frontal shield on forehead of those birds (Figures 25 and 26, p. 22).

Field Marks. Rails rise from the grass at one's feet with a loose, feeble flight, legs dangling and neck outstretched. They rise with evident and hurried difficulty, fly weakly a short way over the marsh, and then suddenly collapse into it again. 
The Rails are skulkers and expert hiders in the grass. They thread the narrow runways between the clumps with mouse-like dexterity and speed. They rely on this ability to hide more than on flight to escape danger and will often allow themselves to be caught in the hand rather than take wing. A Rail will flush once in a seeming panic, but safely down again it can rarely be forced to wing a second time and in a small isolated clump of cover will seldom be detected except by a dog's keen nose. Rails can and do swim, but only occasionally and only for a short distance, as when passing from one grass clump to another they find the water too deep for wading.

Rails are very noisy, especially at night. Even in the day-time a sudden and unexpected noise will bring forth a chorus if their loud harsh cracklings from the marsh, though not a bird may b. seeri.

Our Canadian Rails can be divided into two divisions, a long-billed type and a short-billed type (Figures 23 and 25, p. 22). The first includes the King and Virginia, the two species having a similar coloration; the second includes the Sora and the Yellow Rails, having only a general resemblance in colour but similar stubby bills.

208. King Rail. Rallus elegans. L, 15. Long-billed; cheeks, neck, and breast cinnamon-rufous; back brownish-black, each feather broadly margined with an ochraceous shade of the breast colour, flanks barred with black and white. Juvenile similar, but colours veiled with black.

Distinctions. In Canada can only be mistaken for the similarly coloured Virginia Rail, but King Rail is much larger.

Field Marks. Loose rail-like flight as it gets up from the grass, size, general coloration, and long red-brown bill.

Nesting. In wet marshes, in nest of grass, etc.

Distribution. Rather southern distribution; comes regularly within our borders along the lower Great Lakes; breeds wherever found in Canada.

The King Rail can be taken as the type of the Long-billed Rails (Figure 23, p. 22). This type has a longer neck and a more graceful habit and build than the Short-billed type. This series is one of several among American birds where distinct species differ from each other in little else than size. Included with our.King and Virginia Rails in this series is the extralimital Clapper Rail of the more southern sea-board salt marshes, never occurring in Canada.

212. Virginia Rail. FR-LE RÂLE DE vIRGINIE. Rallus virginianus. L, 9.50. Smaller than the King Rail but otherwise similar to it.

Distinctions. Easily distinguished from the King Rail by its smaller size and from the Sora by its long reddish bill and general coloration. Young birds are overwashed with a considerable amount of black and have often been misidentified as Black Rails. The Black Rail is even smaller than the Yellow Rail (5.0) and has a short bill; no Canadian record of the Black Rail rests upon perfectly satisfactory evidence. It may, however, be looked for in the Great Lake region, especially in the neighbourhood of the St. Clair flats, where there is strong evidence of its occurrence, though a specimen has not yet been secured.

Field Marks. Size, coloration, long, reddish bill (Figure 23, p. 22), and typical loose rail flight as it rises from the marsh.

Nesting. In wet marsh, in nest of grass.

Distribution. Southern Canada across the continent and north to the present limits of cultivation. Breeds wherever found in Canada.

This is a far more common Rail than the King and to be expected in almost any marsh or very wet meadow within its range. Its habits do not differ essentially from those of the other Rails. 
Economic Status. Its waste land habitat precludes its taking anything of economic importance. Its food consists largely of insect life, marsh seeds, and vegetable matter.

214. Sora Rail. SORA, RALbird, CAROLina RAIL. FR.-LE RÂLE DE LA CABoline. Porzana carolina. L, 8.50. Plate VII A.

Distinctions. Distinguished from the Virginia Rail by its short conical bill (Figure 25, p. 22) and general coloration; and from the Yellow Rail by larger size and coloration.

Field Marks. Loose, dangling flight, as it rises from the grass, proclaims it a rail; short bill, general coloration, and lack of white on wings are characteristic of the species.

Nesting. On ground in wet marshes in nest of grass, etc.

Distribution. Of considerably more northern distribution than the Virginia Rail, but also ranging across the continent; breeding wherever found in Canada.

In the early days of settlement the Sora Rail was a common game bird; but the draining of the swamps and the ease with which large bags could at times be made by hunters, have greatly reduced its numbers. On the tidal marshes of some of the Atlantic states it is still regularly hunted in late autumn. This is, therefore, the best known of our rails and, though its numbers are greatly diminished from those given in old travellers accounts, it is still a moderately common bird. It does not need grounds quite as extensive for its habitat as the King or the Virginia Rails and at times the merest little slough will suffice a pair and their young for the season.

\section{Rail. \\ Economic Status. Not notably different from that of the Virginia}

215. Yellow Rail. FR.-LE RÂLE JAUNE. Coturnicops noveboracensis. L, 7. A smaller, short-billed rail, somewhat like the Sora. The coloration is also similar in effect, but the underparts are overwashed with ochraceous and the back feathers are transversed with a few fine white lines instead of being margined by them. It, also, has prominent white wing-patches that are characteristic of the species.

Distinctions. Distinguished from the Sora Rail by size and coloration.

Field Marks. Size and white wing-patches.

Nesting. On ground in damp edges of marshes, in nest of grass.

Distribution. More northern than the other rails, extending considerably beyond the limits of present cultivation; breeding wherever found.

This is the most expert of the Rails in skulking and hiding. As it is almost impossible to flush it, it may be far more common than we have reason to otherwise suspect. According to actual records, it is one of the rarest birds in Canada. Its habits do not seem to differ much from those of the other rails, except that it does not require as much water in its habitat and is more often found on the shoreward, grassy sides of the marsh rather than in the wet reedy locations.

\section{Subfamily-Gallinulinæ. Gallinules or Mud-hens.}

General Description. Rather large duck-like birds, but with long toes without webs either partial or entire; conical bill extended on the forehead in a plate or frontal shield (Figure 26, p. 22).

Distinctions. Distinguished from the ducks by lack of webs, and by shape of bill; and from the Coot by absence of toe lobes; otherwise quite closely resembles these.

Field Marks. Round, duck-like shape of body; habit when swimming; general blue or blue-grey coloration; red bill, and frontal shield; and long legs and toes of yellow or green. 
Quietly watching the open leads through the marsh, one sometimes sees a swimming bird of duck-like outline sitting high in the water with upturned tail and progressing with a series of graceful backward and forward jerkings of the head. This alone is nearly enough for recognition of the Gallinules; but the brilliantly-coloured bill and frontal plate, visible at considerable distances in the bright sunshine, will make recognition certain. Sometimes individuals are jumped by the observer, quietly poling along a narrow winding channel, when off they go spattering along the surface and making a great amount of disturbance until wing borne. The Gallinules swim habitually and with ease, but rarely venture out in open water like the Coots, confining themselves to the small pools in the marsh or to the clear leads or passages that thread them.

218. Purple Gallinule. Ionornis martinicus. L, 13. Resembles the Florida Gallinule, but neck and underparts iridescent with pronounced purplish-blue; frontal plate (Figure 26, p. 22) plumbous blue instead of red; and legs yellow instead of green. Juveniles are similar but reduced in tones and with only traces of iridescence.

Distinctions. Can only be mistaken for the Florida Gallinule, but above characters and absence of conspicuous white streaks on flanks are differences.

Field Marks. Gallinule or Mud-hen-like outline, decided blue iridescence, yellow legs, and all white under tail coverts.

Distribution. Tropical and subtropical America regularly north to the Carolinas.

Of only accidental occurrence in Canada. To be looked for only in the most southern sections.

219. Florida Gallinule. RICE-BIRD. MUD-HEN. RED-BILLED MUD-HEN. FR.GALLINULE DE LA FLORIDE. Gallinula galeata. L, 13.50. An almost evenly coloured, slate-blue bird; darker on head and a little lighter below, tinged with slightly iridescent reddish-brown; conspicuous white flank streaks and a small edging of same under tail; bill and frontal plate (Figure 26, p. 22) bright red; legs green with red garters just below the feathering.

Distinctions. Distinguished from Purple Gallinule by the characters mentioned above; from the Coot, which it closely resembles, by red instead of white bill and frontal plate, white flank lines, brownish back, and clean unwebbed toes.

Field Marks. Red bill and frontal plate, white flank streaks, brownish back, and all dark secondary tipg when flying.

Nesting. Usually on a slight eminence such as an old muskrat house in watery marshes, in nest of waste vegetable fragments.

Distribution. More northern than the Purple Gallinule, and regularly common in Canada only along the lower Great Lakes.

This is the best known Mud-hen of southern Canada. Its fairly large size and palatable flesh, due to its fondness for wild rice and other marsh seeds, renders it an object of pursuit by the sportsman. It requires more open water than the Rails, but in general resembles them in habits. It is a rather noisy bird, especially at night; and during the day joins the Rails in their chorus of surprise at unusual and unexpected disturbances. At times one bird will suddenly utter a volley of cackles, answered immediately by another, and another, and for a few moments the apparently deserted marsh is a small pandemonium of unexpected bird sounds.

Economic Status. Except as a game bird the Gallinule is of little account economically. 


\section{Subfamily-Fulicince. Coots.}

General Description. Rather large, duck-like birds, but with long toes furnished with membranous lobes; bill extends up on forehead in a white frontal plate or shield (Figure 14, p. 20).

Distinctions. Much like the Gallinules; distinctions given under description of species in following section.

221. American Coot. WHITE-BILLED MUD-HEN. FR.-LA FOULQUE D'AMÉRIQUE' Fulica americana. L, 15. An evenly coloured, slate-grey bird, darker on head, lighter below; bill and frontal plate (Figure 14, p. 20) white with solitary reddish-brown spots at top of plate and on tips of mandibles. Legs dull green and toes with bordering scallop of web-flaps (one to three lobes on each toe).

Distinctions. Distinguished from the Gallinule by white bill and the toe-webs.

Field Marks. Size, slate-grey coloration, white bill, and frontal shield and when flying the border of white secondary tips on the wings.

Nesting. Nest very similar to that of the Florida Gallinule.

Distribution. More northern than the Gallinules; found throughout Canada well into the cultivated area; breeds wherever found in Canada.

Unlike the Gallinules, which quietly leave our marshes in early autumn, the Coots remain until late in the season and, their numbers augmented by migrants from the north, gather in large flocks in small lakes and ponds where they are sometimes shot by the hunter who later finds them indifferent eating.

Economic Status. The Coot is more of a vegetable feeder than even the Gallinule, but, owing to its habitat, cannot be of economic importance except as a second-rate object of sport.

\section{Order-Limicolæ. Shore Birds, Snipes, Sandpipers, Plover, etc.}

General Description. Shore Birds constitute an order comparatively easy to recognize but difficult to briefly describe. All snipe or plover-like birds are included in this order. They have moderately to extremely long, delicately-formed legs for wading in shallow water and pond edges and neck and bill (Figures 15, 21, 22,23, pp. 20-22) to correspond. The toes may be either three or four in number, and are poorly adapted for perching. They may be without webs entirely, or with partial webs situated either at the bases of the toes, or forming scalloped or entire edgings to them (see Phalaropes). The hind toe when present is small, weak, and slightly elevated above the rest. The wings are long and pointed and the secondaries next to the body are lengthened.

Distinctions. Some Shore birds show superficial resemblance to the Rails, whereas others in certain characteristics (Curlews) may be mistaken for either Ibises or Herons, but can be distinguished from them by the small and elevated, or absent hind toe and the lack of bare skin between eye and bill.

Field Marks. General outline, habit, habitat, and flight, characteristics which are quite recognizable.

Nesting. On ground, except one species.

Distribution. The order, Shore Birds, is cosmopolitan and there are few areas in the world that some of its members do not occupy. The Old and New World forms of the northern hemisphere are closely related: some are identical, many are subspecifically related, and a few, such as the Turnstone, are found all over the world. Most of our northern species breed in the far north, some of them as far as exploration has gone, though a few nest on, and across, our southern borders.

The Shore Birds, in the days of their original abundance, were favourite game birds; now since their numbers have been so greatly reduced they are seldom systematically hunted, and only shot incidentally. Of the Shore Birds of eastern Canada, Woodcock and Wilson's Snipe are of the most interest as game. The representatives of the order found in eastern Canada are divided into six families: Phalaropodido, Phalaropes; Recur- 
virotrida, Stilts and Avocets, of only casual occurrence in eastern Canada; Scolopacido, Snipes and Sandpipers, constituting the bulk of our species; Charadriide, Plover; Aphrizido, Turnstones; and Haematopodido, Oystercatchers, once casual now probably extinct within our eastern borders.

Economic Status. Most of the order inhabit waste land and are of little economic influence; others, frequenting cultivated fields, are of greater importance and will be discussed under their specific headings. On the whole, however, the order is either harmless or actively helpful to man.

\section{FAMILY-PHALAROPODID平. PHALAROPES. SEA SNIPES.}

General Description. Small birds between 7.75 and 8.75 inches long, wader-like in form but with plumage dense and duck-like. This, combined with their toes bordered with web-lobes or edgings and flattened tarsi, makes them comparatively easy to recognize.

Distinctions. Small waders characterized as above. Cannot be mistaken for anything else.

Field Marks. Size, bill characteristics, and the habit of swimming and feeding in deep water. These are the only Shore Birds that habitually swim.

Nesting. On ground, nest lined with a few mosses or grasses.

Distribution. Northern and western. One species breeds in the lower prairie provinces, the other two along the Arctic coasts and adjoining islands. Regular migrants along the Atlantic coast of eastern Canada and down the Mississippi valley, but merely stragglers in the Great Lakes region.

The Phalaropes constitute a small anomalous family of Shore Birds whose true affinities are hardly well understood or settled. They swim with ease and are often found in the open water, even out at sea, where they are as much at home as any pelagic species.

Anomalous in structure and systematic relationships, they are equally so in habits. The female instead of the male is the bright-coloured representative of the family circle and she takes the initative in courting rites; makes the first advance towards her shy and modestly-coloured prospective mate and upon fulfilling her duties of egg deposition leaves the further cares of incubation and family raising to him.

Economic Status. Inhabit water or waste shores and are of little or no economic importance.

222. Red Phalarope. Gery PHALAROPE, WHALE BIRD. FR.-LE PHALAROPE ROUX. Phalaropus fulicarius. $\mathbf{L}, 8 \cdot 12^{2}$. Adult female is easily recognized by the even, dull reddish brown of the foreneck and underparts. The back is light ochre and black in stripes. The male is similar, but the colours veiled, broken, and less distinct. In winter this species is slate-grey above and white below.

Distinctions. The Red Phalarope can be easily distinguished from either of the other two members of the family by its bill and feet, the former comparatively broad and flat. Toes webbed at base and with projecting scalloped lobes on either side. See following species.

Field Marks. General habits and habitat. In breeding season colour is best mark of recognition. At sea this species is said to show more black on top of head and in wings than the other phalaropes. In other than full plumage the comparatively short and flattened bill is perhaps the best point for identification.

Distribution. Breeds along the whole Arctic coast of America, migrating down the sea coasts on either side; rare inland in Great Lakes region.

223. Northern Phalarope. RED-NECKED PHALAROPE. FR.-LE PHALAROPE HYPERBoREEN. Lobipes lobatus. L, 7.75. Adult female: upperparts, back of neck, and head dark slaty; throat and below, white; sides of neck meeting on front of lower neck, rich rufous, with lines of same along back over closed wing. Male similar but veiled and re$57172-7$ 
duced in colour. Winter birds light grey above, white below, with only faint suggestions of above coloration.

Distinctions. Bill very slender and awl-shaped, rather like Wilson's Phalarope but shorter; feet have small webs and scalloped fiaps, like Red Phalarope.

Field Marks. General colour and fine needle-like bill. Smallest of the Phalaropes of eastern Canada.

Distribution. Similar to the preceding.

224. Wilson's Phalarope. FR.-LE PHALAROPE DE wILson. Steganopus tricolor. L, 8.75. Beautifully coloured bird. Adult female has stripes of sharply contrasting colour arranged on head and neck. Crown of pearl-grey shading to white on hind neck and to grey again on shoulders. Black line through eye and down side of neck, changing to rich, chestnut-red which continues along side of back. Throat, white blending into delicate vinaceous on neck and breast to white again on lower parts. Male greyish-brown above and white below, with suggestion of the femaleg' brighter coloration.

Distinetions. Bill very long, 1.25 inches, slender and needle-like, an exaggeration of the last species. Toes not webbed but furnished with narrow, even edges of membrane.

Field Marks. Colour, size, and extremely long and slender bill.

Distribution. A mid-western and more southern species than the preceding, breeding in the prairie provinces and only of casual occurrence east on lower Great Lakes.

\section{FAMILY-RECURVIROSTRIDA. AVOCETS AND STILTS.}

General Description. Among the largest of the Shore Birds and recognizable by their strikingly contrasted colours and great length of legs and bill. This is carried to an extreme in the Stilts which, however, are entirely extralimital. The Avocet has occurred accidentaally within our borders east of the prairies.

225. American Avocet. FR.-L'AVOCETTE D'AMERIQUE. Recurvirostra americana. L, 16.50. Large and most striking Shore Bird, with warm vinaceous head and neck blending into white underparts; and fuscous and white in sharply contrasting masses on the back.

Distinctions. Very long, slender, tapering bill with decided upward curve in its outer half. This is always distinctive.

Nesting. A slight depression in the ground near water.

Distribution. A mid-western bird of the interior, breeding in the prairie provinces and only of accidental occurrence east of Manitoba.

This species is included only because of the occurrence of a few individual specimens east of the prairie provinces.

FAMILY-SCOLOPACIDAF. SNIPE-LIKE BIRDS. TIP-UPS, SANDPIPERS, ETC.

General Description. Small to medium Shore Birds, the Curlew being the largest species. Feet never entirely webbed nor toes furnished with web-flaps or web-margins. Some species have small webs between the base of the toes, giving rise to the term "semipalmated" or half-webbed. All but one species, the Sanderling, page 97, have four toes. The bills are long, slender, and tapering; usually straight (Figures 21, 22, p. 21) ; but sometimes down-curved; occasionally, as in the Godwits, page 98 , very slightly upcurved; rather flexible and usually slightly enlarged and sensitive at the tip.

Distinctions. Obvious Shore Birds, usually recognized by the above popular names. Bill does not taper to fine sharp point, like that of the previous families, and has not the soft base and horny tip of the Plover, but is soft and rather flexible throughout its length in contrast to the horny bills of the Turnstones and the Oyster-catchers.

Nesting. All except one species, the Solitary Sandpiper, page 99, nest on the ground, in slight hollows lined sparsely with the waste vegetable matter adjoining.

Distribution. Greater number nest in the far north, though a few species are found south of the United States border. They migrate down our coasts or through the interior according to species and distribution. Some of them have most interesting migration routes.

Among these birds are the Woodcock and Snipes of the wet woods and marshes; the Tip-ups, Teeters, and Sandpipers we see along the shores and streams, and the Curlews of the uplands. These species formed the great 
bulk of the wonderful flocks of Shore Birds that once thronged our shores. Breeding mostly far beyond the confines of cultivation the occupation of their nesting grounds by settlers has had only the slighest influence upon their numbers. The great reduction must be blamed upon indiscriminate shooting. As they fly in dense flocks they offer an easy target and eighty or more have been known to fall at one discharge of the gun, so that there is little wonder that they are now comparatively scarce.

Economic Status. Either perfectly harmless or actively useful according to habitat.

228. American Woodcock. FR.-LA BÉCAsse D'AMfRIQUE. BECASSINE. Philohela minor. L, 11 . Plate VII B.

Distinctions. Long bill (Figure 21, p. 21) and eyes situated high in the head, deadleaf colours of underparts, and rich browns of back are distinctive.

Field Marks. The bird's habitat, combined with long bill, size, and coloration in rich brown and dead-leaf tints render it easily recognizable in life.

Nesting. On ground amidst last year's dead leaves, with which its plumage harmonizes so well.

Distribution. Regularly in southern Ontario in the lower Great Lakes region, though occasional individuals straggle over a much wider range.

Woodcocks haunt moist or wet shrubbery, alder or hazel thickets, or the tangled edges of damp woods. They spring suddenly from the ground on being disturbed, rise erratically on peculiarly whistling wings, and passing just over the tops of the underbrush drop suddenly into concealment again a few rods beyond. It is well within the memory of the present generation that the thickets of southern Ontario swarmed with Woodcock; but now, owing to unrestrained shooting, the drainage and clearing of waste lands, and perhaps the depredations of the domestic cat, the Woodcock is a scarce, almost a rare bird. Unlike the Ruffed Grouse or Partridge, which requires considerable and virgin ranges, there is no fundamental reason why the Woodcock should not remain plentiful and give abundance of sport for years to come. Almost any small retired covert of damp shrubbery will suffice for its needs. The Woodcock leaves for the south very shortly after the open season begins and is not long subject to legitimate shooting. Next to man the cat seems to be its principal enemy and as the Woodcock lives and nests on the ground trusting to protective coloration and hiding to avoid danger, it is peculiarly open to feline attack.

230. Wilson's Snipe. JACK BNTPE. SNIPE. FR.-LA BÉCASSINE DE WILSON. Gallinago delicata. L, $11 \cdot 25$. Plate VIII A.

Distinctions. Unlikely to be mistaken for any other species in Canada, but the reddishbrown tail, whitening on the outer feathers, and barred with black, will distinguish it if necessary.

Field Marks. Habitat (open grassy meadows), long bill, peculiar cork-screw flight as it rises, combined with size, general coloration, and reddish-brown and whitish tail. The Woodcock and the Dowitcher, are the only other similar birds.

Distribution. Breeds across the continent, coming just within the bounds of cultivation and irregularly to our southern borders. Common throughout the Dominion.

231. Dowitcher. RED-BReasted SNIPE, ROBIN SNIPE. FR.-LA BÉCASSINE Rousse. Macrorhamphus griseus. L, 10.50. Spring adult-throat, foreneck, breast, and all underparts strongly reddish. Back and upperparts variegated with shades of same and dark brown. Autumn plumage dull greyish-brown on head, neck, upper breast, flanks, and back, variegated with browner on the latter; white below. Lower back always white. Intermediates of all above plumages occur.

$57172-7 \frac{1}{2}$ 
Distinctions. Same general appearance as Wilson's Snipe, but with red front and underparts in spring, and without the rich browns of that species in autumn. Bill is longer in comparison with size than any other bird except Wilson's Snipe. A very similar red breast occurs in the Knot, but the longer bill of the Dowitcher (L, 2.10-2.50 against $\mathrm{L}, \mathbf{1} \cdot 30$ ) is conclusive identification.

Field Marks. About the size and general outline of Wilson's Snipe, but with conspicuous white on lower back and more white on tail. Habitat also different.

Distribution. Breeds in the far north, west and probably east of Hudson bay. Scarce on Great Lakes, more common on coast. Our eastern migrants are supposedly Ungava breeders, but accurate data on this point are lacking.

SUBSPECIES. A slightly differentiated subspecies, the Long-billed Dowitcher $M . g$. scolopaceous occurs in the west. It is distinguished by its slightly larger size, longer bill, heavier spotting of breast, and more extensive red below. It is difficult to differentiate bright plumages, and birds and juveniles can rarely be told apart. The Long-billed Dowitcher is to be expected in eastern Canada only in the Great Lakes region and its occurrence should not be recorded unless the specimen has been well compared with authentic material.

\section{A bird frequenting mud flats rather than grassy meadows.}

233. Stilt Sandpiper. FR.- LA MAUBËCBE A LONGS PIEDS. Micropalama himantopus. L, 8.25. Brown markings on ground of dull white; underparts lighter and the dark arranged in uniform bars changing to obscure striping on the foreneck and to fine spotting on the throat. Autumn plumage shows no sign of this characteristic barring; back with various shades of brown in strong pattern, underparts nearly pure white, slightly veiled with ochraceous on breast and foreneck where it is faintly and obscurely spotted with dark.

Distinctions. The evenly barred underparts of the spring plumage are unmistakable. The autumn bird resembles several species. The length of the bill, $1: 50$, and of the tarsus, 1.60, are greater than those of any other Shore Bird of otherwise equal size. The Redbacked Sandpiper has a bill of almost equal length, but it is heavier and has less of an abrupt spatulate enlargement at the extreme tip.

Field Marks. Contrast of its small size and great length of bill. Upper tail coverts, instead of lower back as in the Dowitcher, are light in spring and white in autumn.

Distribution. Breeds on Arctic coast northwest of Hudson bay. In migration, probably more common in the interior than on the coast. Regular but rare in autumn on lake Ontario.

One of the rarest of eastern Shore Birds, sometimes associated with the Dowitcher and Yellow-legs on mud flats.

234. Knot. RED-BREASTED PLOVER. ROBIN SNIPE. FR.-LA MAUBìCHe à POITRINE Roणsse. Tringa canutus. L, 10.50. In spring-upper parts mottled with various shades of brown and ochre, throat, foreneck, and below strong dull rufous, lighter towards the tail. In autumn-light smoky grey, pure white below, breast and foreneck slightly darker with fine, obscured spotting.

Distinctions. Spring birds as regards size may be confused only with Dowitcher. The short bill, $\mathrm{L}, 1 \cdot 30$, as against $\mathrm{L}, 2 \cdot 10-2 \cdot 50$ of the Dowitcher, is conclusive differentiation. Autumn birds very similar to several species of like coloration. Even light grey coloration of back quite similar to that of the autumn Red-back, but in the Knot each feather is margined with faint line of lighter colour giving effect of a succession of semicireles, present in no other Shore Bird.

Field Marks. In spring-bill, shorter than that of the Dowitcher which it otherwise resembles, and greyish but not conspicuous white over tail. In autumn-light grey back, lighter towards tail, is best recognition mark.

Distribution. A circumpolar species of extraordinary migration range. Breeding on the Arctic circumpolar islands and ranging in winter to South Africa, Patagonia, and New Zealand, etc. Apparently less common in the Great Lakes region than on the Atlantic coast.

A bird to be found on sandy beaches as well as on mud flats. It is steadily decreasing in numbers like so many of its allies.

235. Purple Sandpiper. WINTER SNIPE, ROCK SNIPE. FR.-LA MAUBLेCHE POURPRGe. Arquatella maritima. L, 9. Greyish-black on back, including head and extending 
across front of neck and throat, and along flanks. Lighter on throat and darkest on back, white below. Over darker parts a faint suffusion of slightly iridescent purple more or less mottled with lighter feather edgings. Autumn plumage similar, but light feather margins more extensive. Legs and feet orange in spring.

Distinctions. The only Shore Bird with back so uniformly black.

Field Marks. In spring, general dark colour and short orange legs. In autumn, season of appearance is almost diagnostic as it comes very late, well into the winter, when other Shore Birds have left.

Distribution. The Eastern Purple Sandpiper probably breeds on the islands of the Arctic. In migration, more common on the sea coast than on the Great Lakes where it is very rare.

SUBSPECIES. The Purple Sandpiper occurs in both the New and the Old Worlds. The subspecies occurring on the eastern coast of Canada is the Eastern Purple Sandpiper, the type race.

A very late autumn migrant coming long after all other Shore Birds have deserted us. November and December are the months of its appearance. Its apparent rarity may be largely due to its coming after the shores are deserted by the gunner. It prefers rocky shores to either sand or mud.

239. Pectoral Sandpiper. grass SNIPE. FR.-LA MAUBÈCHe ì POITRINE CENDREe. Pisobia maculata. L, 9. Upper parts dark brown, each feather edged with shade of light ochre; underparts and throat white; lower neck and breast suffused with light brownish buff and closely streaked with dark brown.

Distinctions. Size and rather sharply streaked brownish buff front are distinctive. The White-rumped Sandpiper and Baird's Sandpiper may be somewhat similar in this respect, but rump of the former, and smaller size of both are evident.

Field Marks. Its usual grassy marsh habitat makes Wilson's Snipe the bird most likely to be confused with it, but the shortness of bill of the Pectoral Sandpiper is obvious. It appears as an even brown bird without light on rump or elsewhere above, much like a large Least Sandpiper.

Distribution. Breeds on the Arctic coast northwest of Hudson bay. Common migrant throughout eastern Canada.

The Pectoral Sandpiper, like Wilson's Snipe, is to be found in wet grassy meadows, or on mud flats, rarely if ever on sandy beaches. In the grass it lies well to a dog and sometimes furnishes good sport. On the breeding grounds it develops a neck-sac that can be blown up to an extraordinary extent and indulges in a flight-song that is unusual among the generally songless Shore Birds.

240. White-rumped Sandpiper. BONAPARTE's SANDPIPER. FR.-LA MAUBغेCHE A CRUPION BLANC. Pisobia fuscicollis. L, 7.50. Back and upperparts dark brown broadly margined with greyish and ochraceous-brown, the former predominating. Rump and all lower parts white, foreneck and upper breast sharply and finely striped with dark brown. In autumn, similar, but more ruddy-ochraceous on back, and front stripings more blended.

Distinctions. Size and white rump distinguish it from comparable species. The Hudsonian Godwit and Stilt Sandpiper have white upper tail coverts, but the former is much too large a bird to be a source of error and the latter's longer slender bill or barred breast are distinctive.

Field Marks. General size and colour, and conspicuous large white rump.

Distribution. Breeds on Arctic cosst west to near Alaskan border. In migration common on Atlantic coast, rather scarce in Great Lakes region.

This species frequents mud flats and rocky shores rather than sandy beaches. It often accompanies the flocks of Least and Semipalmated Sandpipers.

241. Baird's Sandpiper. Fr.-LA MAUBÈCHe DE BAIRD. Pisobia bairdi. L, 7.40. Back to top of head dark brown edged with light ochraceous; below and throat, white; band of light buff across chest; lower foreneck dimly striped with fine brown lines. 
Distinctions. Resembles White-rump, but with rump dark and a more buffy suffusion across front. Also considerably like Least Sandpiper, but larger.

Field Marks. Resembles large Least Sandpiper, with buffy breast suffusion.

Distribution. Breeds on Arctic coast across the continent. More common in migrations in the prairie provinces than on the coasts. Not uncommon in the Great Lakes region, scarcer farther east.

Sandy margins and mud flats seem equally attractive to this species. It is often found in company with Least and Semipalmated Sandpipers, though more independent of water than many of its family.

242. Least Sandpiper. MUD PEEP. GREEN-LEGGED PEEP. FR.-LA MAUBËCHE DH wilson. Pisobia minutilla. L, 6. Upperparts and crown, dark brown edged more or less broadly with various shades of ochraceous-buff and ruddy tints; white below. Across breast and foreneck a dark suffusion sometimes tinged with buff with more or less pronounced dark striping and spotting.

Distinctions. Distinguished by its extremely small size from all other species except the Senipalmated Sandpiper, and from that by the absence of webs between the toes.

Field Marks. Differentiated from the Semipalmated Sandpiper by the dark greenisb instead of black colour of the legs.

Distribution. Breeds in high latitudes across the continent as far south, in the east, as the Magdalen islands in the gulf of St. Lawrence. Common throughout eastern Canada in migration.

One of the most numerous of Shore Birds. Probably its diminutive size has protected it from the sportsman, though from its dense flocks numbers can be obtained at a single shot. It frequents sandy beaches and open mud flats and is a tame and confiding bird. It associates largely with flocks of other species, though when disturbed separates from them to rejoin the company later. It arrives and leaves earlier in the autumn than the Semipalmated.

243. Dunlin. RED-BACKed SANDPIPER. BLACK-HEART PLOVER. RED-BACK. AMERICAN DUNLIN. Fr.-LA MADBËCHe À DOS RoUx. Pelidna alpina. L, 8. Spring bird is too strongly marked to be mistaken for anything else. Back is dark brown so broadly edged with red-ochre as to be mostly red. A large more or less diffused, almost black spot occupies the abdominal surface. Bill slightly decurved (Figure 22, p. 21). Autumn bird is without these striking characteristics. Upper surface is almost uniform, light brownish-grey suffusing across breast and lower neck. Below, and throat, white.

Distinctions. Colour in autumn similar to Autumn Knot, but smaller size and lack of light semicircles of feather edges will always differentiate it even if occasional traces of spring plumage are not present. It may also suggest the Curlew Sandpiper, but the upper tail coverts are dark instead of greyish.

Field Marks. In spring - red back, and black spot below are evident. In autumneven grey back and, when flying, a line of white on the wing. Slight but distinct downward bend of bill also helps identification.

Distribution. Including the European form, the species is circumpolar. The American Dunlin, the Red-backed Sandpiper, nests on the Arctic coast locally across the continent. It is a common migrant throughout eastern Canada.

SUBSPECIES. The New World representative of the Dunlin is a subspecific race, the Red-backed Sandpiper or American Dunlin $P$. a. sakhalina, which is distinguished from the Old World form only by its slightly larger size.

This bird frequents sand-bars, mud flats, or salt meadows. It is among the latest of the Shore Birds to arrive both spring and autumn.

244. Curlew Sandpiper. Erolia ferruginea. L, 8. Small red-breasted Sandpiper. Autumn birds greyish-brown above and white below.

Distinctions. Resembles the Knot or Dowitcher in having red breast, but much smaller and of more slender build. 
Distribution. Breeds in Arctic Siberia. Of only casual occurrence in eastern Canada. More records from the Atlantic coast than inland, though there is one from lake Ontario.

An Old World form occasionally seen in the New World. Said to resemble the Red-back in habit, but too scarce in eastern Canada to be looked for as a regular visitor. Any record of this species should be founded on definite specimens and subjected to a rigid scrutiny.

246. Semipalmated Sandpiper. BLACK-LEGGED PEEP. FR.-LA MAUBíCHE SEMIPALMEE. Ereunetes pusillus. L, 6.30. Upper parts, including crown, dark brown edged with light ochraceous or buffy; all white below, with vague band of slightly darker across the chest with obscure streakings and spots.

Distinctions. Very similar in size and coloration to the Least Sandpiper, from which it cannot always be distinguished except by close examination. The toes, however, have small webs between their bases, giving the bird the name Semipalmated.

Field Marks. Differentiated from the Least Sandpiper by its slightly larger size, purer grey back, and whiter, more clearly lined breast. Legs and feet are black instead of dark olive green.

Distribution. Breeds along the eastern Arctic coast south to southern Labrador. Common in migration throughout eastern Canada.

Very similar in habit as well as appearance to the Least Sandpiper, page 96. The Western Sandpiper Ereunetes mauri is a closely allied form that may be only a subspecies of the Semipalmated Sandpiper. It is distinguished by a slightly longer bill and a larger amount of red on the back, especially on the hindhead. Its occurrence in the Great Lakes region is very doubtful.

248. Sanderling. FR.-LA SANDERLING. Calidris leucophoea. L, 8. In springupperparts, including crown, dark brown variegated with much light rusty ochre or white, or both. Below, white. Throat, neek, and upper breast overwashed with more or less reddish-ochre and spotted with brown. The details of these colourings are exceedingly variable. The back may show enough of the various colours to make it either generally greyish, ochraceous, or rusty, and the coloured and spotted throat may be nearly immaculately white. The autumn bird is similar without much buffy or any reddish or ochraceous tint, it is pure white below and in front, and often predominantly grey to light ashy above.

Distinctions. From traces to strong washes of rusty on neck and around head in the spring and the general whiteness in autumn. The Sanderling can be told from all other Sandpipers by having three toes instead of four.

Field Marks. Rufous suffusion about the head in some spring birds, general contrasting black and white appearance on the wing, and line of white along the bases of flight feathers in all plumages. The pure white breast in autumn is also characteristic.

Distribution. Breeds on the islands of the Aretic west to Alaska. A common migrant on sandy shores throughout eastern Canada.

A bird of sandy shores, seldom frequenting mud flats. One of the most beautiful and interesting of the small Shore Birds. It haunts the edge of the water, following each retreating wave, and rapidly running back again before the wave's return, threatened every moment to be engulfed in the surf but always just escaping. As the birds fly out over the blue water, the sun shining on their glistening plumage, they are a beautiful sight; at one moment turning their daintily coloured black and white backs and the next, as though moved by a single impulse, banking on a wide wheel and showing the pure glistening white of their underparts.

249. Marbled Godwit. FR.-LA Barge MARBrée. Limosa fedoa. L, 18. A very large Shore Bird; a general light buff, faintly pinkish shade all over, except throat which may be white. Back, hind-neck to crown, variegated with dark brown and light tints and the breast and flanks more or less barred with fine lines of the same dark colour. 
Distinctions. Similar to the Curlews in general appearance but bill slightly turned up instead of decisively turned down. Distinguished from the Hudsonian Godwit by fine, dark marbling on the pinkish buff of the primaries.

Field Marks. The Godwits are among the largest of our Shore Birds, practically equal to the Curlews in size. The bill not turned down will distinguish them from the Curlews.

Distribution. Breeds in the prairie provinces including some cultivated regions, migrates to both oceans, occurring casually in the eastern parts of the Maritime Provinces.

Never abundant in eastern Canada, this species is being sadly reduced in numbers like other large birds. Doubtless its habit of nesting within cultivated areas has had considerable to do with its disappearance.

251. Hudsonian Godwit. FR.-LA BARGE DE LA BAIE D'HUDSON. Limosa hoemastica. L, 15. In spring-upperparts, dark-brown to crown, marked with more or less greyish or buffy and touches of rusty; underparts, reddish-brown, more or less barred with dark and suffusing up foreneck. Autumn-upperparts unmarked brownish-grey; underparts, buffy-white or dingy white, breast greyer.

Distinctions. Distinguished from the Curlews by the slightly turned up instead of distinctly turned down bill; from the Marbled Godwit by the red underparts in spring, and at all seasons by the all dark, white shafted primaries without marbling. This species shows almost endless variations between the above plumages, but suggestions of the spring coloration are usually recognizable in all except young birds.

Field Marks. Large size, straight or slightly turned up bill, and white rump at base of black tail, will separate this from either the Curlews or the Marbled Grodwit which are the only species that are likely to be confused with it.

Distribution. Breeds in the northwest beyond civilization. Most common eastward from the prairies to the Maritime Provinces in autumn, and in the interior in spring.

The Hudsonian Godwit is a fine bird on the verge of extinction. As frequently happens, it seemed to disappear suddenly and before its growing scarcity was realized. It is doubtful whether shooting is altogether responsible for this condition. When a species is greatly reduced in numbers by any cause, an otherwise comparatively unimportant adverse influence may suffice to snuff it out unexpectedly. Protection is ineffective when delayed so long that the breeding stock is too greatly reduced for recovery.

254. Greater Yellow-legs. GREater tell-TALE. FR.-LA GRAND ChEVALIER ì PIEDS JAUNES. CHEVALIER OU PATTES JAUNES. Totanus melanoleucus. L, 14 . A rather large Shore Bird. Upperparts to crown dark brown to black with small white or grey markings and intrusive greyish feathers, giving a grey effect; without trace of buff or rufous. Underparts white, streaked on foreneck, breast, and flanks with distinct streaks or bars of the same dark colour as on the back; legs very long and yellow.

Distinctions. Size, yellow legs, and lack of any indication of buffy or rusty anywhere are marks of the two Yellow-legs. In young autumn birds the breast and neck marks may be veiled and indistinct. This and the next species distinguished only by size.

Field Marks. Long, slender yellow legs, entire lack of ochraceous colour, size, and the large amount of white or whitish on tail and rump. When once acquainted with it, its flight is quite recognizable.

Distribution. Breeds in high latitudes across the continent. In the east, south to Anticosti island and the north shore of the gulf of St. Lawrence; common in migrations throughout eastern Canada.

The Greater Yellow-legs is one of the best known Shore Birds. Owing to its size and comparative numbers it is much sought after by sportsmen and it seems to have withstood their attacks better than many other apparently equally well-adapted species. It prefers marshy shores and mud to open sand and may be seen far out on the flats wading about, thigh deep, in water too deep for smaller waders. Its clear flute-like tremolo whistle in a descending scale is a sound to accelerate the pulse 
of any true sportsman or bird student. This species does not seem as numerous and is certainly more wary than the Lesser Yellow-legs; otherwise this description will do for both.

255. Lesser Yellow-legs. LitTle teli-Tale. FR.-Le Petit chevalier À PIEds JAUNEs. Totanus flavipes. L, 10.75. Smaller edition of the last species.

Distribution. Breeds across the continent, in high latitudes. A common migrant tbroughout eastern Canada but not breeding there within cultivated areas.

256. Solitary Sandpiper. FR.-LE CHEVALIER SOLITAIRE. Helodromas solifarius. L, 8.40. Upperparts dark, almost black, with a slight greenish lustre accented by comparatively few small white spots; underparts and throat, white; lower neck, breast-band, and sides of flanks barred and striped with lighter shades of back colour; no tinge of buff or other shades. clusive.

Distinctions. Size and general coloration; the white, dark-barred, axillars are con-

Field Marks. Resembles both the Spotted Sandpiper and the Lesser Yellow-legs. Distinguished from the former by the lack of a white line on the spread wing and the conspicuously white barring on the tail; and from the latter by size, and black instead of white rump.

Nesting. For a long time the breeding habits of this species were unknown and the problem of its nesting was not solved until it was discovered that it used the deserted nests of perching birds in trees and bushes. The closely allied Green Sandpiper of Europe has the same habit.

Distribution. Breeds northward from well within the limits of cultivation; fairly common throughout eastern Canada as migrant or breeder.

SUBSPECIES. The Solitary Sandpiper is represented by two subspecies in Canada, only one of which, the Eastern Solitary, the type form, occurs in the east.

As implied by the name, this species is a rather solitary bird, being found as single individuals and pairs rather than in flocks even in migration time. It is a mud haunter and with the Spotted Sandpiper is the only wader that is commonly seen about such small waters as drainage ditches or along the edges of flooded woods.

258. Willet. Catoptrophorus semipalmatus. L, 15. A large Shore Bird; upperparts buffy-grey marked with darker; underparts, white suffused with light greyish buff; barred and striped with darker on flanks, breast, and foreneck; rump white.

Distinctions. Size, general lightness and greyness of coloration, conspicuous white wing-spot on primaries, white rump, and black axillars. The characteristic Sandpiper bill will distinguish the Willet from the Black-billed Plover which has also these rump and axillar details.

Field Marks. In size it resembles the Godwits more than anything else, but ashy greyness and the conspicuous white wing-spots are distinctive,

Distribution. Breeds to the south of us, originally from Virginia to Nova Scotia in the east, and locally westward to the central parts of the prairie provinces. Now very rare on the coast, irregular but slightly more common in the Great Lakes region, and fairly common to the west in parts of the prairie provinces.

SUBSPECIES. The species is divided into an eastern and a western subspecies, the latter based upon slightly larger size and greyer colour. The exact subspecific status of the Great Lakes bird is not quite satisfactorily established. In all probability the few that remain in the Maritime Provinces are Eastern Willets, whereas those of the Great Lakes may be the Western Willet, $C$. $s$. inornatus, or intermediates. Material on hand is too scanty to make definite pronouncements and unless the species recovers at least some of its original numbers we may never be able to satisfactorily locate the range boundaries of the two forms.

The Willet is another large and important species rapidly diminishing in numbers, a reduction due perhaps largely to its southern breeding range and inadequate protection. 
261. Upland Plover. BARTRAMIAN SANDPIPER, BARTRAM's PLOVER. FIELD PLOTER. FR.-LA MAUBÈCHE $\lambda$ LONGUE QUEUE. Bartramia longicauda. L, 11.50. Upperparts, dark; feathers deeply edged with buff which colour suffuses rather strongly over head, breast, and neck. Dark V-shaped markings on breast turning to bars on flanks and stripes on neck; underparts, dull, creamy-white.

Distinctions. Bearing in mind that this species is a Sandpiper and not a real Plover, the size and general suffusion of buff is characteristic. The inner web of the first primary, sharply marked with acute, dark, saw-teeth against a white ground for most of its length, is a character that occurs in no other comparable Canadian Shore Bird. The Hudsonian Curlew has a similar design but on a buff ground.

Field Marks. The Upland Plover on the ground is scarcely recognizable as a wader by those unfamiliar with it, resembling a long-legged grouse chick rather than a Sandpiper. In flight, however, it exhibits its true relationship. Size, general buffiness, and upland habitat are distinctions. Its beautiful long drawn whistle once heard can never be mistaken.

Distribution. Properly a bird of the prairie regions but probably spreading to the east when the forests were cleared away. It breeds in the more southern parts of eastern Canada and in the prairie provinces, appearing occasionally on the Atlantic coast as a migrant.

Though called a Plover in its accepted name, this species is a true Sandpiper. The term Bartramian Sandpiper is a more satisfactory name and the one that should be in general use instead of Upland Plover. Once considerably more common that at present in the Great Lakes region, it is now scarce or rare. The species nested in the cultivated sections and was exposed to the accompanying dangers of such localities: agricultural disturbances to nesting, the ever present small boy with his cheap shot gun, the pot-hunter, and the sportsman. Size and ease of approach have evidently been the cause of its disappearance, where the smaller and warier Killdeer has been able to survive under the same conditions. As indicated by its name this species has deserted the ancestral wet habitat of its family and taken to upland meadows and dry pastures. It is, however, rarely found at any great distance from some small body of water. It alights readily on fences, fence-posts, buildings, or trees on occasion.

Economic Status. Frequenting cultivated land, this species feeds largely on insects, grasshoppers, cut-worms, and other enemies to grass crops. It has been known to be of marked importance in reducing locust plagues, hence it must be classed among our most beneficial species and its presence should be encouraged.

262. Buff-breasted Sandpiper. FR. -LA MAUBìCHE À POITRINE JAUNÂTRE. Tryngites subruficollis. L, 8.50. Back and crown dark, feathers of lower back finely edged with cream; underparts white; throat, neck, breast, and flanks strongly suffused with buff, which colour tinges much of the upperparts.

Distinctions. Small size, and general buffy colour, underside of the inner webs of the primaries finely speckled with dark on white. The under-wing surface is beautifully marbled in a manner that is assumed by no other eastern species.

Field Marks. Small size and general buffy colour. It may appear on uplands like the Upland Plover, but the latter is much larger.

Distribution. Breeds on the Arctic shores of the extreme northwest, migrating down the Mississippi valley; hence it is very rare in the Maritime Provinces, scarce in the Great Lakes region, and more common westward.

Economic Status. What has been said of the Upland Plover is probably true of this species.

263. Spotted Sandpiper. PEWIT. TEETER. TIP-UP. FR.-LA MAUBÈCHE TÉ. L'ALOUETTE À BRAULE QUEUe. Actitis macularia. L, 7-50. Plate VIIIB.

TACHE- 
Distinctions. Adults have decidedly round breast spots and a slight greenish lustre on the back. Young autumn birds resemble the Solitary but are distinguished by white instead of barred axillars.

Field Marks. Size and distinct round spots on breast. When flying it may be distinguished from the Solitary Sandpiper, which it most resembles, by the white line along the edges of the secondaries and the much smaller amount of black and white barring on the tail. The flight, when the observer becomes familiar with it, is also quite characteristic.

Nesting. Slight hollow in ground at no great distance from water, in the shelter of a bit of shrub or grass.

Distribution. Breeds over the whole of eastern Canada to the northernmost parts of Ungava. Common throughout its range.

This is the commonest summer Sandpiper in Canada; occasional pairs are to be found along the smallest streams. It frequents all kinds of ground; sandy beaches, gravelly reaches, mud flats, or rocky shores. Almost any Sandpiper seen in summer near our waters may be put down as this species unless there are good grounds for other identification. Its habit of bobbing its body up and down occasionally, even when apparently at rest, or more rapidly when excited, has given it the common name "Tip-up". Its white-barred wings, peculiar flight, with a few quick beats followed by a short sail on decurved wings, and its loud triumphant "pewit-pewit-pewit" as it alights on the stream margin well ahead of the intruder are familiar to all observers. One can chase it from point to point for some distance from its home ground, when, joined by its mate, it will circle well around the disturber and return again to the place from which it started.

Economic Status. Though normally frequenting water edges it is often seen in the adjacent fields, running between the furrows of newly turned earth or rows of growing plants. Its food is mainly, if not entirely, insectivorous, hence it is beneficial to the farmer. The species has not suffered severely from shooting and seems to hold its own in the most cultivated sections.

\section{Genus-Numenius. Curlews. Fr.-Le Courlis, le Corbigeau.}

General Description. Large Shore Birds between $13 \cdot 50$ and 24 inches long. Coloured in various shades from cream to weak brown, mottled above, lighter and clear below, neck and breast finely striped and with more or less suffusion or suggestion of buff over all. The bills are long and curved decidedly downward.

Distinctions. Large size, decurved bill, and general buffy colour. Distinguished from the Godwits by down-curved instead of slightly up-turned bill.

Field Marks. Large size, and decurved bill, general buff colour.

Large size among birds is a distinct menace to their existence. The Curlews are a good example of this and unless intelligent measures to protect them are taken in the near future there will soon be none left. In the east the Curlews have almost disappeared, but in the west there is still a fair number left. The vegetable part of their food is largely wild fruit and in the Maritime Provinces they frequent barrens and upland bogs for bake-apple berries and cranberries. In cultivated fields, insects are their chief food and as many noxious species, including grasshoppers, are consumed their presence is decidedly beneficial to the farmer.

264. Long-billed Curlew. SICKLE-BILL CURLEW. FR.-LE COURLIS À LONG BEC. Numenius americanus. L, 24. The largest of the genus. The coloration of all the Curlews is quite similar, but the Long-bill is distinctly buff below instead of creanywhite (see previous heading). 
Distinctions. In well grown specimens the extreme length of bill (6 inches) of this species is diagnostic, but, as in numerous other species showing great specialization or size, growth continues for some time after apparent maturity and this feature is unreliable as sole guide. The crown, axillars, and primary characters, however, make good criteria for the Curlews. In this species the crown is dark, evenly spotted with light without aggregation into a median line, and the inner vanes of the primaries are marked with saw-tooth figures of dark on a light buff ground. The axillars are solidly coloured without bars.

Field Marks. For recognition as a Curlew see previous page- The Curlews cannot be separated in life with absolute certainty.

Distribution. Breeds in the prairie provinces and well to the south. It is recorded originally as a more or less common migrant on the Atlantic coast north to the Maritime Provinces, but does not occur there now; also recorded from the Great Lakes region but without supporting evidence. The general confusion of this with the Hudsonian Curlew is responsible for many known misidentifications and the species should in future only be recorded in eastern Canada upon the conclusive evidence of specimens.

265. Hudsonian Gurlew. FR.-LE CodRLIS de LA BAIE D'HUDSON. Numenius hudsonicus. L, 17. A smaller Curlew than the last, but larger than the next. Of same general coloration, but the Hudsonian less buffy than the Long-billed, the underparts being dull creamy; see Curlew heading, previous page.

Distinctions. Often diagnosed as the Long-billed, but can be easily distinguished from the other Curlews by the pronounced median stripe on the crown, instead of uniformly distributed spots, combined with the saw-tooth marks on the inner webs of the primaries, and the barred axillars.

Field Marks. For recognition as Curlews see Curlew, previous page. Curlews cannot be easily separated in life with certainty, but size and length of bill may help. This is the only species likely to be met with in eastern Canada.

Distribution. Breeds in the northwestern Arctic. Migrates down the Pacific coast, and across the continent to the Atlantic where it is more common than in the interior. A regular though not abundant migrant in the Great Lakes region.

This is the only Curlew of which we have any satisfactory evidence on the lower Great Lakes. It has learned from experience to be a wild and wary bird, and as it now occurs in numbers only in the extreme east not very many are taken.

266. Eskimo Curlew. Fr.-Le codruis DU NORD, CORBIgead des esquimadx. Numenius borealis. L, $13 \cdot 50$. The smallest of the Curlews. Of same general coloration as the Hudsonian.

Distinctions. Easily separated from either of the other Curlews by its smaller size and plain unmarked primaries, though the axillars are barred as in the Hudsonian, and the crown evenly spotted, without median stripe, as in the Long-billed.

Field Marles. See preceding species. This bird is, however, too rare nowadays for eyesight record.

Distribution. Breeds on the barren grounds of the Mackenzie district. Migrates in autumn across to Labrador and then down the coast. In spring it ascends the Mississippi valley.

Very close to extinction. Whether or not ill-regulated shooting was the chief cause of its great reduction in numbers, for old accounts speak of immense flocks, it was certainly contributory. This is another case of disappearance coming before realization of the necessity of protection and the apparent or threatened loss of a species that can never be replaced.

\section{FAMILY-CHARADRIIDA. PLOVER.}

General Description. Plover are rather more stoutly and compactly built than the Snipe-like birds. Their bills are shorter, soft at the base, but ending in a hard, horny tip, (Figure 24, p. 22). Hind toe lacking in all species except Black-bellied (p. 103) in which it is very small and almost rudimentary. 
Distinctions. With the above description the Plover are not likely to be confused with anything else.

Nesting. On ground in a slight depression usually lined with scanty grass, moss, other waste vegetation, or pebbles.

Distribution. In closely related or nearly identical forms the family is circumpolar in distribution, breeding mostly north of present settlement.

The Plover are well known to the sportsman. They average larger in size than the Snipes and some of them which feed in upland fields offer considerable sport.

Economic Status. As a family they frequent cultivated land more than other Shore Birds and hence are of somewhat greater economic interest. They are actively helpful to man.

270. Black-bellied Plover. BULL-HEAD. FR-LE PLUVIER $\lambda$ VENTRE NOIR, VANNEAO GRIS. Squatarola squatarola. L, 11. Spring plumage-back, almost black with many broad white feather-tips aggregated on wings; crown and hindneck, almost white; cheeks, throat, foreparts and breast to abdomen, pure black, often showing white feathers remaining from immaturity. Autumn plumage-back, weak brown with cream or yellowish feather ends to top of head; throat, foreneck, and underparts dull whitish with indistinct breast-band of veiled stripes. All intermediate plumages are taken within our boundaries.

Distinctions. Plover-like characters; will be mistaken only for the Golden Plover which it closely resembles. The presence of a small though well-formed hind toe is peculiar to this bird as it is our only Plover with a fourth toe.

Field Marks. Requiring separation only from the Golden Plover. Rather inconspicuous white band on the spread wing, axillars black, in strong contrast to background of underwing surface when flying, and white rump to be seen under favourable conditions.

Distribution. A circumpolar species breeding in America along the Arctic coast northwest of Hudson bay. More or less common in migration in suitable habitats throughout eastern Canada.

272. American Golden Plover. FR.-PLUVIer DORÉ D'AMErique. Charadrius dominicus. L, 10.50. Spring plumage - back almost black to top of head, with numerous yellow feather-tips, more scanty on crown; forehead and line over eye, descending to sides of breast, white; throat, foreneck, and all underparts solid black. Autumn plumage -above, dull brown with many cream to yellow feather-edge spots, aggregating on rump and crown; throat and face, white or whitish slightly spotted; breast and all below, faintly barred with dull white and light tints of the brown of the back. All intermediate plumages may be seen.

Distinctions. A slightly smaller bird than the foregoing but easily confused with it. The large amount of yellow on the back of spring plumage and the faint barrings of the breast and underparts in the autumn are characteristic. The absence of any trace of hind toe is diagnostic in any plumage.

Field Marks. Only needing separation from the previous species. Extended wing without any indication of white band; axillars smoke-grey instead of conspicuous black; rump not white.

Distribution. Breeds in the barren grounds from Hudson bay westward. It is said to have extraordinary migration routes. In the autumn it moves eastward to Labrador, then southward across the gulf of St. Lawrence to Nova Scotia, where it takes an over-sea route to Brazil without touching intermediate land unless storm-driven. From thence it works down to the Argentine pampas. In the spring it strikes western South America about Equador, crosses the isthmus of Panama and the gulf of Mexico, and follows up the Mississippi valley to its breeding grounds. That it takes this immense flight over the broad Atlantic without resting seems too remarkable to be true, but as it is not a proficient swimmer able to rest on the water at will, the evidence points towards this conclusion.

SUBSPECIES. The American Golden Plover is divided into two subspecies; only the Eastern Golden Plover, the type form, occurs in eastern Canada.

Once far more common than now. Within the memory of living sportsmen large flocks were regularly seen; now only occasional birds are met with. It is very closely related to the Golden Plover of Europe. 
273. Killdeer Plover. FR.-LE PLUVIER kILDIR. Oxyechus vociferus. L, 10.50. Plate IX A.

Distinctions. As the Killdeer is the largest of the Ringnecked Plovers it can hardly be confused with its smaller relatives. The double instead of single breast band also distinguishes it from them.

Field Marks. Size, two breast bands instead of one, striking ochraceous tail and rump, and distinctive call of "killdee-killdee-killdee."

Nesting. A mere hollow in the ground scantily lined with vegetable fragments.

Distribution. A species of remarkably wide range, breeding from the northern limits of cultivation in Canada to the gulf of Mexico. Rare or absent from vicinity of either coast.

A common summer bird over all Canada except in the sea coast districts. Its loud voice is familiar to all country residents and visitors. A true Shore Bird, it frequents the high dry uplands and cultivated fields, often nesting in the ploughed furrows amidst the crops. When its young are hatched, however, it usually leads them to water, some quiet nearby pool as a rule, and as soon as they are able to take care of themselves they unite in small scattered flocks. That this species has been able to survive and thrive in the midst of cultivation and civilization while other species apparently as well able to take care of themselves have succumbed, is probably due to its comparatively solitary habits and to its not general'p gathering in dense flocks, the pursuit of which is profitable.

Economic Status. Its food is largely insectivorous and through spring and early summer it frequents ground where it can do much good.

274. Semipalmated Plover. RING-NeCK PlOVEr. Fr.-LE PLUVIER SeMipalut. A gialitis semipalmata. L, 6.75. A small Plover of general resemblance to the Killdeer, but with one instead of two dark breast-bands and without the ochraceous rump and tail of that species. Autumn birds are similar, but the colours are washed out and with no clear black anywhere.

Distinctions. With size and the above description, can be mistaken only for the Piping Plover, but the back coloration is decidedly brownish in all plumages instead of smoke-grey or dry sand colour, the breast band is always broad, continuous, and wellmarked even in autumn, and the ear coverts behind and below the eye are always decidedly dark instead of pure white. Feet with small webs explain the accepted common name; the only Plover in Canada which is so provided.

Field Marks. Size and a single instead of double breast-band distinguish this from the Killdeer Plover, and the back, dark-coloured like wet sand, from the Piping Plover which is lighter and grey like dry sand.

Nesting. Slight hollow in the ground or shore refuse.

Distribution. Breeds in the high north across the continent; south, in the east, to the gulf of St. Lawrence. Common in migration in suitable localities in eastern Canada.

A pretty little Plover frequenting mud flats or sandy beaches indifferently. Closely related to the European Ring Plover and distinguished only by slightly smaller size and a few minor details.

277. Piping Plover. RING-Neck. FR.-LE PLUVIER CRIARd. Égialitis meloda. L, $7 \cdot 10$. Spring plumage - same markings as the Semipalmated previously described, but back in lighter colours. Back and crown light smoke-grey, a black bar across fore-crown, remainder, collar around neck, and forehead white; a black ring about neck, just below the white one, sometimes broken on the breast. Autumn birds-similar but without black neck ring and generally weaker in coloration.

Distinctions. Can be mistaken only for the Semipalmated but easily distinguished by the characters given under that heading.

Field Marks. Distinguished from the Semipalmated Plover by its lighter coloration, like dry instead of wet sand. Its melodious whistle is easily remembered when once heard.

Nesting. Depression in the sand made by the bird and containing only a few small pebbles, coarse grains of sand, or fragments of shell upon which the eggs rest.

Distribution. Breeds on sandy shores locally from the prairie provinces to the gulf of St. Lawrence and Sable island. 
A small Plover well called meloda. It is a sand-beach bird and never seen in grassy or marshy stituations. Some individuals have broken and others complete black breast-bands. The latter were for some time regarded as a subspecies but now all are included under the one form. The Snowy Plover, AEgialitis nivosa, has been taken on lake Ontario, but is probably not to be expected again. It is slightly smaller than the Piping, of same general coloration but with a dark aural or cheek patch, and only a spot of dark at the sides of the breast instead of a complete bar across it. A more southern and western bird and can only occur as a straggler.

\section{FAMILY-APHRIZIDA. TURNSTONES.}

General Description. Medium-sized Shore Birds with bill (Figure 27, p. 22) moderately short, horny for the terminal half, tip slightly flattened (in a horizontal plane) but not distinctly enlarged as in the Plover.

A small family of world-wide distribution. Only one species of this family in eastern Canada.

283a. Turnstone. RUDDY TURNSTONE. AMERICAN TURNGTONE. CARRIQUET PLOKER CALICO PLOVER. FR.-LA TOURNE-PIERRE À POITRINE NOIRE. TOURNE PIERRE. Arenaria interpres. L, $9 \cdot 50$.

Distinctions. A strikingly coloured bird. Back in rather broad masses of dull red, black, and white more or less intermixed. Rump and head white, the crown striped with brown or black. Underparts pure white, with black breast-band, extending up side of neck to face where it makes a circle through the eye and around a white loral spot. Autumn birds have the colours subdued and the back coloration lost or only faintly represented, but enough of the face and breast noarkings always remain to suggest the above diagnosis.

Field Marks. The peculiar pied coloration in red, black, and white of the spring plumage. In the autumn the white lower back and upper tail coverts separated by a dark bar.

Nesting. Depression in the ground lined with a few dead leaves or vegetable fibres.

Distribution. The Turnstone as a species has one of the widest distributions of any bird, there being few countries where it has not occurred. The American subspecies representative of the species, the Ruddy Turnstone, breeds from the Arctic coast west of Hudson Bay northward, and is more common on the Atlantic than the Pacific coast; locally common, in migration, in the Great Lakes region.

SUBSPECIES. The Turnstone is represented in America by a subspecies, the Ruddy Turnstone $A$. $i$. morinella, though the typical form is said to occur in western Alaska.

A bird of sandy, muddy, or rocky shores, but preferring the first. It is named from its habit of turning over small stones and pebbles on the beach searching for food beneath them, and it is astonishing what comparatively large stones it can move. It inserts its bill under the edge, gives a little fillip, and away goes the stone rolling or skidding over the beach to a considerable distance. It is a comparatively good swimmer. It differs from the Old World Turnstone only in slightly smaller size, less black on the upperparts, and the stronger coloration of the legs.

\section{FAMILY - HAMATOPODIDA. OYSTER CATCHERS.}

General Description. Large Shore Bird more heavily built than is usual in the order; bill stout and horny, flattened laterally (sideways) at tip. There is only one species that may perhaps occur in eastern Canada.

286. American Oyster-catcher. hæmatopts paluiatus. L, 19. Head, neck, and upper breast, black; back, olive-brown with contrasting white wing-patch and rump. All underparts, pure white; bill, large, bright red.

Distribution. Atlantic coast north to Virginia. Formerly to New Jersey and accidental to New Brunswick. Probably bred throughout its range. 
The northern range of this striking bird was once on our southern sea coasts. It has long been exterminated (?) in Canada and there is little chance of its occurring again.

\section{Order-Gallinæ. Scratching Birds.}

As the name implies, these birds are adapted for securing their food by scratching in the ground. The best popular representatives are the common barnyard poultry, but the order glides almost imperceptibly into the Pigeons on one hand and the Shore Birds on the other. They are well distributed over the world, being found in almost every country on the globe. In Canada we have only one suborder of the group, Phasiani, the true fowls.

SUBORDER-PHASIANI. TRUE FOWLS. GROUSE, QUAIL, AND PTARMIGAN.

General Description. This suborder is composed of birds with strong, compact feet, four toes, and blunt claws adapted for scratching in the ground (Figure 28, p. 22). Though best adapted for terrestrial life they perch readily in trees and often feed and roost there. Bills short, horny, and with strongly arched culmen (Figure 29, p. 23); nostrils set in a soft intrusion into the base of the bill; wings short and round. These birds rarely take wing except for short flights or to avoid immediate danger.

Nesting. On ground, eggs laid on the dead grass or leaves with-little or no preparation.

Distribution. Species of this suborder are found in all parts of Canada. The Ruffed and Spruce Grouse and the Turkey are birds of the woodlands; the Bob-white, Prairie Chicken, and Sharp-tail inhabit open or prairie country; and the Ptarmigan, the barren lands of the extreme north.

Three families of this order are represented in Canada. Odontophoridoe the American Quail, Tetraonidoe the Grouse, and Meleagridoe the Turkeys.

Economic Status. Their food is both insectivorous and vegetable-grains, buds, leaves, fruit, and insects being equally acceptable to them. As several species frequent cultivated fields their economic status is of interest to the husbandman and has been the subject of considerable investigation, the results of which show that some of them are among the most useful birds on the farm. The insect portion of the food of some species is decidedly important and very little complaint can be made against the other items as they are mostly waste or wild material of little or no consequence to the agriculturist.

Like most of our larger birds they have been greatly reduced in number, and should be strictly protected and their killing limited to the natural annual surplus, leaving an ample permanent breeding stock untouched. The Canadian representatives of this suborder are divided into three families: Odontophorido, the American Quails; Tetraonidoe, the Grouse; and Meleagridae, the Turkeys.

\section{FAMILY-ODONTOPHORIDA. AMERICAN QUAILS.}

General Description. The smallest representatives of the suborder in Canada. The nostril is partly covered with a fleshy scale and not as well hidden in the feathering as it is in the feathering of the Grouse. There is only one species of the family in eastern Canada.

The term "Quail" for our American birds is a misnomer. They are not Quails in the European sense but true Partridges. In their turn our "Partridges" are Grouse. These are examples of a common misapplication 
of Old World names to New World forms. There are many such cases, confusing to the beginner but too well established in vernacular usage to be corrected at this late date.

This family is of rather southern distribution reaching its maximum in number of both species and individuals in the southwestern states and Mexico.

289. Bob-white. AMERICAN QUAIL. Colinus virginianus. L, 10. Plate IX B.

Distinctions. Can be mistaken for no other bird in Canada. Size and coloration combined with evident fowl-like character are distinctive.

Field Marks. Small, partridge-like bird which rises suddenly from the ground and flies with rapid beats and loud reverberating wing-strokes.

Distribution. The Bob-white and its allied subspecies are distributed over eastern North America, north to and including southern Ontario.

SUBSPECIES. The subspecies of Bob-white native to eastern Canada is the type form-the Virginia Bob-white.

The Bob-white occurs in Canada only in southern Ontario where it is known to every country dweller. In the autumn the sportsman hunts it with dogs, in spring the ploughman and small boy find its nest in the course of their farm work, and all are familiar with its clear whistle-like call of "Bob-white," or as otherwise interpreted "More-wet." It is not a retiring species which withdraws into the deepest woodland recesses on the advent of cultivation; but it keeps to the clearings, hanging about woodland edges, shrubby fence-lines, or overgrown wastes in close proximity to the fields. When food is scarce it will often come into the barnyard and feed with the poultry. Open land is its feeding ground, the brush its refuge from danger. Before the country was cleared, the Bob-white was probably rare in Canada, but advancing settlement opened up new ground for the species. Even in the most southern parts of the country to-day the Bob-white remains precariously, fluctuating greatly in numbers, and it is evidently hardly suited for this northern limit of its range. It is prolific, however, and favourable winters and a few years of abstention from shooting increase its numbers many times; but coverts are almost invariably overshot and hard winters periodically reduce its numbers. The hardest natural conditions it has to combat are deep snow covering the food supply, and wet sleety weather which not only chills it but seals it under an icy crust when it seeks refuge in the snow at night. The Ringnecked Pheasant, rather extensively introduced as a sporting bird, is said with some supporting evidence to be inimical to it. In addition to the sporting value of the species it is deserving of every encouragement by agriculturists from a purely economic standpoint and for this reason might perhaps with advantage be withdrawn from our list of game birds.

It has been a common practice to repopulate depleted covers with birds imported from the southern states. Whether this introduction of stock, unacclimatized to northern conditions, has weakened the constitution of native birds is still undetermined. Several subspecies of the Bobwhite occur in the south and importation has left doubtful the real characters of our own original form, which to-day can only be judged from specimens antedating such introductions.

Economic Status. The bulk of the Bob-white's food is weed seed. The grain it eats is waste, gleaned from the ground. The insect content, $57172-8$ 
though not especially large, includes some species not ordinarily eaten by other birds and for that reason is specially important. It is one of the few birds that will eat the potato beetle.

\section{FAMILY-TETRAONID Æ. GROUSE.}

The Grouse have their nostrils hidden in feathers that occupy an ntrusive space in the base of the bill at the sides (Figure 29, p. 23). The tarsus is either completely or partly feathered, in the Ptarmigan the feathering includes the toes. The toes when unfeathered, are bordered on each side by a small fringe composed of individual horny scales or pectinations (Figure 28, p. 22), which are shed in midsummer. The Grouse comprise the bulk of our upland game birds and are great favourites of sportsmen. The sexes are alike or nearly so, and except in the Ptarmigans show slight seasonal variation in plumage and do not usually migrate. The Ptarmigan, which directly reverse each of these statements, are so well characterized otherwise that no confusion is probable. All species nest on the ground, making little preparation for the eggs. They lay unusually large sets of eggs, six to eighteen, and the young, chicken-like, follow the parent as soon as out of the shell.

298. Spruce Grouse. CANADA GROUSE, SPRUCE PARTRIDGE, FOOL HEN. FR.-LE TETRAS DU CANADA. Canachites canadensis. L, 15. Plate X A.

Distinctions. Easily distinguished by colour, etc., from the Ruffed Grouse which is about the only species in eastern Canada that can possibly be mistaken for it. In the extreme west there are forms that closely resemble it.

Field Marks. General bluish colour of the male. Absence of ruff or specialized neck feathers and the presence of the striking red comb over the eye, present in both sexes but more conspicuous in the male.

Distribution. Through the northern coniferous wooded regions of Canada, resident wherever found.

SUBSPECIES. The Spruce Partridge is divided into several geographical races, two of which, the Hudsonian Spruce Partridge Canachites canadensis canadensis, the type form, and the Canada Spruce Grouse C. c. canace, occur in eastern Canada. The former occupies the Labrador peninsula and the more northern ranges and the latter New Brunswick, southern Ontario, etc. They are too similar, however, to be differentiated in a popular work.

A northern bird of the spruce woods. Its super-confiding nature has given it the popular name of "Fool-hen" as, where not much disturbed, it can often be killed with a stick or with stones. Owing to its feeding largely upon spruce or evergreen buds its flesh is too strong for the ordinary civilized palate.

Economic Status. Being of northern distribution and living in the evergreen forests, it has no economic influence.

300. Ruffed Grouse. PARTRIDGe. BIRCH PARTRIDGE. FR.-LA GELLINOTTE A FRAISE. Bonasa umbellus. L, 17. Plate X B (Feet and bill, Figures 27, 28, p. 22).

Distinctions. The Ruffed Grouse, with its prominent soft, black ruff at the sides of the neck, large fan-shaped tail, and eye-like spots on the rump and lower back cannot well be mistaken for any other species.

Field Marks. Large size and fan-shaped tail.

Distribution. The Ruffed Grouse is distributed throughout the wooded areas of Canada north to the tree limits.

SUBSPECIES. Several geographic races of the Ruffed Grouse are recognized. The type form is of southern distribution and is replaced in eastern Canada by the Canada Ruffed Grouse Bonasa umbellus togata, characterized by a greyer or less red coloration. 
This is the "Partridge" of most Canadian sportsmen Dwelling in the deep woods amidst the underbrush, lying close, rising at the feet like a miniature explosion, and flying with great speed through the dim forest it tests the alertness and marksmanship of any sportsman. The Ruffed Grouse to-day is found only in the forest patches where cover and a considerable area give it protection and along the fringes of settlement where it still exists precariously.

Sudden weather changes are a serious menace to the Ruffed Grouse. Wet, cold springs are deadly to the young and sleet destroys much potential breeding stock in winter. In severe weather the Ruffed Grouse seeks shelter beneath the snow or allows the latter to drift over it. Should soft weather come followed by cold, as often happens, it is frozen under a crust which it cannot break and so succumbs.

The drumming of the Partridge is a familiar sound to all frequenters of the woods. It is a series of dull reverberating throbs made by the rapidly beating wings and has a peculiar all-pervading intensity which makes the direction of its origin difficult of location. The beats begin slowly, gradually increasing in speed until at the end of perhaps five seconds they run into each other and die away in a confused whir. The bird is usually strutting along a prostrate log when he pauses to drum. During the drumming the bird displays all its ornaments - tail, crest, and ruffs - and though standing upright and still, the wings are lost in a haze of speed. Two sources for this drumming noise are suggested, one that the wings are struck together over the back and the other that they are brought against the sides to produce the beat. Either or neither may contribute to the effect. The sound from the wings beating on the air as the bird rises to wing is quite similar in quality if not in intensity or meter, and the mere beating of the air seems sufficient to produce the effect. The action, of course, is the call of the male to the female, as is the display of the Peacock or the Turkey Gobler. Spring is the proper season for drumming, but it is indulged in more or less throughout the summer and with increased frequency again in the autumn. In the Canada Ruffed Grouse Bonasa umbellus togata, two well-defined colour phases appear which are not governed by sex, season, or locality. In one form there is considerable red; in an extreme example the ruffs are copper-coloured rather than black, the tail is strikingly red, and there is more or less of the same colour elsewhere. In the grey form, which is perhaps the most typical, the tail is decidedly grey, there is less red elsewhere, and the ruffs are black with a slight greenish sheen. All intermediate forms are met with.

Economic Status. As the species lives in woods nothing can be said against it even if, apart from its sentimental and sporting importance, little economic value can be claimed for it.

\section{Genus-Lagopus. Ptarmigan.}

General Description. The Ptarmigan are more northern Grouse, and notable for their remarkable seasonal change in plumage. In winter, they are pure white; in summer, barred with various shades of red, brown, and ochre, with the reddish usually prevailing. Their feet are feathered to the ends of the toes and they perform definite and long migrations, walking most of the way but occasionally taking flights from point to point or across such wide waters as Hudson strait. As, even in midsummer, irregular patches of white remain in their plumage, and, as their feet are always feathered to the toes, there is no chance of

$57172-8 \frac{1}{2}$ 
mistaking them. They are circumpolar in distribution and are found in both the Old and New Worlds. Like many other Arctic forms they extend well southward along mountain ranges where elevation carries northern conditions to lower latitudes. The Red Grouse of Scotland is an interesting Ptarmigan that has lost its ability to change to white in winter and retains its summer coloration throughout the year. There are two species in eastern Canada. Owing to the remarkable variability of the species, American Ptarmigan have been split up into a great number of subspecies only to be distinguished by a specialist with abundant material for comparison. Economically the Ptarmigan are of little importance except as a source of food supply to trappers, hunters, and prospectors in the far north.

301. Willow Grouse. WLLIOW PTARMIGAN. FR.-LAgOPEDE DES SAULES. Lagopus lagopus. L, 15. In winter, all white except the tail which is pure black. In summer, nearly evenly barred all over in black and various shades of brown, ochre, and rusty. Either rust or ochre may predominate.

Distinctions. In winter the all white head and absence of black line through eye distinguishes this from the Rock Ptarmigan. In summer, its superior size, especially well shown by a comparison of the bills, is the most easily recognized point of identification.

Distribution. The Arctic, across the continent, migrates south in winter to the frontier of civilization.

SUBSPECIES. The subspecies occurring over most of Canada is the type form, the Willow Ptarmigan. Another, Allen's Ptarmigan L. $i$. alleni, occurs in Newfoundland.

302. Rock Ptarmigan. FR.-LA LAGOPÈDE DES ROCHERS. Lagopus rupestris. $\mathrm{L}, 13$. In winter, all white except a black tail and line through eye to base of bill. In summer, very similar to preceding species.

Distinctions. In winter, black eye line. In summer, size, especially of bill, when compared with Willow Grouse is diagnostic.

Distribution. The Arctic, across the continent, in winter slightly more northern than the previous species.

SUBSPECIES. Three aubspecies of Rock Ptarmigan are recognized in eastern Canada: Reinhardts Ptarmigan $L$. $r$. reinhardti in the northern extremity of Ungava, Welsh's Ptarmigan L. r. welchi in Newfoundland, and the type form, the Arctic Ptarmigan, in the remaining areas.

305. Prairie Ghicken. Prairie hen. PINNated grodse. Tympanuchus americanus. L, 18. A Grouse of the same size as the Ruffed, coloured in shades of brown, light ochre, and white, but without the long fan-shaped tail and with the soft ruff replaced by a few long, straight, stiff feathers pointed downward over the shoulders. The barring on the underparts and breast is clear and sharp and is continued across the back and upper parts as well as below.

Distinctions. The above points easily distinguish this species from the Ruffed Grouse. From the next species, the Sharp-tailed Grouse, it can be as certainly distinguished by its breast barred instead of covered with V-shaped markings. Other distinctions are the presence of long stiff feathers on the sides of the neck and the stiff tail not ending in a point when closed.

SUBSPECIES. Two subspecies of Prairie Chicken are recognized. The form which occurs in Canada is the type race, the Northern Prairie Chicken.

This is the true Prairie Chicken of the western prairies, though in western Canada the name is popularly and incorrectly given to the next species described. It is included here only because an occasional bird has been taken in the southern parts of Ontario, to which it seems to have spread from the Michigan side of Detroit river where, once common, it is now rare and restricted to a few localities. Within the memory of the present generation in parts of the west it has gradually encroached upon and displaced the next species.

Economic Status. Too rare in eastern Canada to require much discussion here. In the west where it occurs in numbers it is of considerable economic importance, but no damage can be charged against it. 
308. Sharp-tailed Grouse. PIN-TAILED GROUSE. FR.-LA GELINOTTE A QUEUE AIGUE. Pedicecetes phasianellus. $\mathrm{L}, 17 \cdot 50$. Coloured in fine indefinite patterns of browns and white, or cream, on the upper parts, tending towards bars only across the shoulders; underparts pure white. Across breast each feather is bordered with a dark V-shaped figure which changes to a short bar as it ascends the neck and to fine spots on the creamy throat.

Distinctions. The V marks of the breast and the soft, sharp point of the closed tail are conclusive and easily recognized identification marks.

Distribution. A more northern species and less distinctly an open prairie form than the Prairie Chicken. Distributed across the continent north of present cultivated areas in the east, but is very local as there are large stretches of country where it is absent or rare. It comes south irregularly in autumn to the edges of settlement. In the prairie provinces it extends south to and across the United States border.

$S U B S P E C I E S$. The species is divided into several geographic races. Along the Manitoba boundary the Prairie Sharp-tail Pediacetes phasianellus campestris is likely to be found; elsewhere in eastern Canada the typical or Northern Sharp-tail.

In the west this is a prairie bird but it is locally being replaced by the previous species.

FAMILY-MELEAGRIDA. TURKEYS.

The largest of our scratching birds and so familiar from its domesticated form that it requires no detailed description. We have had only one species in Canada.

310. Wild Turkey. Meleagris gallopavo. L, 48.50. So nearly like our domestic Bronze Turkey as to require no special description.

Distinctions. The only bird from which it is necessary to separate the Wild Turkey is the tame or domestic variety. The latter originated from Mexican stock and in consequence always shows a little white on the end of the tail. The tail of the Wild Turkey ends in wood-brown.

Distribution. Originally distributed over the whole of eastern North America to Maine and southern Ontario.

SUBSPECIES. Several subspecies of Wild Turkey are recognized. The type form is found in Mexico. The Canadian bird is the Northern Wild Turkey Meleagris gallopavo silvestris.

The Turkey as a wild form occurred in Canada only in southern Ontario and has been extinct for a number of years. At present the Wild Turkey remains only in the most out-of-the-way wooded localities of the wilder southern states and even there it promises to vanish soon. There is probably considerable native wild blood in the domesticated turkey flocks along lake Erie and a number of specimens of so-called Wild Turkeys are obviously at least half-bred with domestic blood.

\section{Order-Columbæ. Pigeons and Doves.}

This order, of world-wide distribution, is variously divided by different authors. According to the system of classification of the American Ornithologists' Union all our American species are included in the one family, Columbida. They are the most typically pigeon-like in form and, therefore, may be called the True Pigeons.

FAMILY-COLUMBIDAE. TRUE PIGEONS AND DOVES.

Pigeons and Doves can in a general way be said to resemble the outline and actions of our familiar domestic stock. Characters more easily recognized than described. Systematically they can be recognized by their bills. These are hard and horny at the tip, which is very slightly enlarged 
and with the basal half furnished with a soft, slightly swollen membrane in which nostrils open (Figure 35, p. 24). The legs and feet are weak, fitted only for walking on small level areas or for simple perching. Our common domestic Pigeons, descended from the Rock Dove of Europe, show all the most distinctive characters of the family. There are no recognizable or taxonomic differences between the so-called Pigeons and Doves.

315. Passenger Pigeon. WILD PIGEON, FR.-LE PIGÉN voYAGEUR. Ectopistes migratorius. L, 16:29. Plate XIA.

Distinctions. The Mourning Dove is so often taken for this species that the two should be diagnosed with care. The Pigeon is a considerably larger bird; the breast is distinctly ruddy and the head and upper parts are slate-blue in the male. The female is without the strong blue on the back, but the head retains a bluish shade that is never present in the Mourning Dove, which is more evenly fawn coloured and has a small black spot on the side of the neck just below the ear.

Field Marks. As this species is now extinct, field marks are unnecessary.

Nesting. The Passenger Pigeon built a rough nest of sticks in trees, in large communities.

Distribution. Bred in the wooded sections of most of Canada east of the mountains and south to the middle states, wintered in the southern states and beyond.

The immense flocks of Passenger Pigeons that once darkened the air were one of the wonders of America. The descriptions of their number, if they were not circumstantial and well vouched for by men of undoubted veracity, would sound like wild stretches of the imagination: flocks, so dense that haphazard shots into them would bring down numbers, travelled rapidly with a front miles in width and so long that it took hours to pass a given point. Audubon estimates one such flock as containing over a billion birds, basing his figures upon the density and area of the congregation and not by mere guess. They bred in dense rookeries where their weight often broke the branches from forest trees. Trees containing their nests were cut down and though each nest contained only one squab there were so many that the pigs were turned in to feed upon them. Later, the netting of pigeons was the occupation of professional fowlers who shipped their proceeds by the car load to the centres of population. Of course, not even the immense numbers of the Passenger Pigeons could stand such attacks without diminution and gradually they decreased. To suggest a halt in the proceedings at that time, however, aroused nothing but amusement. Their numbers were held to be inexhaustible, but to-day the species is extinct and the last one, a captive bird, died in Cincinnati a short time ago. The last great rookery was near Petoskey, Mich. In the autumn of 1878 the birds left, but failed to return in any commercial number the following spring. For a few years afterwards occasional small flocks were seen and isolated rookeries were reported, but as the fowlers investigated each case it became apparent that the netting of pigeons as an occupation was a thing of the past. Thereafter, the birds became fewer and fewer each year until records of them disappeared altogether. There are occasional rumors even yet of flocks occurring in out of the way places, in the western mountains in Mexico or South America and elsewhere, but in each case, investigation has proved that the reports are based on other species or on misinformation. For several years a large reward was offered for news of a single nesting pair. Of course, the person who offered the reward was flooded with reports but not a single case stood examination, the reward was never earned, and was finally withdrawn. In the east, the Mourning Dove was the usual basis of report, in the west the 
Band-tailed Pigeon. Even yet circumstantial accounts appear from time - to time, vouched for by those who remember the bird in their childhood, but there is little doubt that the species is extinct.

316. Mourning Dove. Carolina dove. Fr.-La todrterelle de la Caroline. Zenaidura macroura. L, 11-85. Plate XI A.

Distinctions. Smaller size and of a browner fawn colour than the Passenger Pigeon, without marked red on breast or blue on back and with small black spot on side of neck below ear. Can only be mistaken for the previous species.

Nesting. The Mourning Dove builds a loose open platform of sticks in the lower branches of trees or the upper parts of bushes. Nests alone and not in communities.

Distribution. Breeds along our southern borders in eastern Canada, wintering locally in the most southerly parts and in the states just south of us to the tropice.

SUBSPECIES. The Mourning. Dove inhabiting the most of North America is the Carolina Mourning Dove $Z$. $m$. carolinensis, which is the only subspecies generally recognized as occurring in Canada. The type form is entirely extralinital.

Though the Passenger Pigeon has disappeared entirely, the smaller Mourning Dove still exists and probably has greatly increased with the clearing of the country. The general food habits of the two birds were much alike except in the proportion of the various food elements. The Mourning Dove eats mast readily, but it formed the principal food of the Pigeon which was, therefore, more of a woodland bird. The Mourning Dove is of more solitary habits and rarely goes in tlocks of any size. It nests entirely alone. This may be a large factor in its continued existence where its larger and originally more numerous relative has failed. Disease could not spread through the ranks as thoroughly and any other calamity that might affect individuals or small bodies, would not involve the species as a whole. In many sections the Dove is regarded as a game bird, but such status is not usually recognized by law. Great numbers are killed, however, incidental to other sport, in spite of legal protection, and the life of the species is not an undisturbed one. It, is, however, a strong and thriving race and is in little immediate danger.

Its long mournful note of "Oh-woe-woe-woe" is well known and has given the name to the species. It has a peculiar quality like that produced by blowing softly into the neck of an empty bottle.

Economic Status. Though feeding largely upon mast (acorns, beechnuts, and such soft-shelled tree-fruit) it eats grain readily and a considerable amount of insect food. Most of the grain it takes is waste, and seed properly planted and covered is absolutely safe from it for it never scratches. No serious unpreventable harm can be substantiated against it and the good it does is positive.

\section{Order-Raptores. Birds of Prey.}

General Description. Flesh-eating birds with four well-developed toes (Figures 31 and 32, p. 23): each armed with strong sharp claws or talons for seizing and holding prey. Bill is hooked (Figures 30,33 a and b, and 34, pp. 23 and 24), and the base covered with a soft skin or cere in which the nostrils are situated. The Birds of Prey differ from the generality of birds in that the females are considerably larger than the males. This is probably due to the greater strain placed upon the female in feeding her young, which, demanding strength, weight, and endurance rather than fineness and technic, necessitates a greater degree of these qualities in the female than in the male who, while he may assist his mate, has not the final responsibility for the growing family.

Distribution. Raptorial birds are distributed over all the world except the Antarctic continent, where their place is taken by Skua, Gulls, and other rapacious sea-birds. 
Though the classification of this order is far from satisfactory and probably will eventually have to be revised, American practice divides our species into three suborders: Sarcorhamphi, the American Vultures, distinct from those of the Old World; Falcones, the Diurnal Birds of Prey; and Striges, the Nocturnal Birds of Prey or Owls.

Economic Status. Perhaps no birds are better known and at the same time so generally misunderstood in their economic relations as these. All know of the Hawks, Owls, and Eagles and their flesh-eating propensities, but few realize that amongst them are some of man's best friends and that the popular policy of killing them on sight is a mistaken one. Some do considerable damage, but to include all in the condemnation merited by the few is a grave economic error. The first family, the Vultures, are repulsive birds, but as scavengers entirely useful, and no valid complaint can be lodged against them. Of the other two divisions, the diurnal and nocturnal rapaces, their varying status is the cause of much misconception. Fortunately in regard to these birds we can speak with authority based upon actual data and not mere speculation. The United States Biological Survey made a thorough study of the food habits of American Hawks and Owls, basing its conclusions upon the examination of some 2,700 stomachs taken in all seasons of the year in various parts of the United States and Canada. The whole is embodied, with the data for its substantiation, in a report, "The Hawks and Owls of the United States" by Dr. A. K. Fisher, ${ }^{1}$ though compiled in and for an adjoining country all Canadian species are treated and the results are as applicable to Canada as to the United States. As some of the less harmful species do not occur in Canada the percentages below will have to be slightly corrected for our use, but not seriously enough to perceptibly modify the general conclusions. Only six of the seventy-three species studied are injurious. Of these, three are extremely rare in Canada and one is altogether a fish-eater. Of the remainder, 56 per cent of the stomachs examined contained mice and other small mammals, 27 per cent insects, and only $3 \frac{1}{2}$ per cent poultry or game birds. Dividing the raptorial birds of eastern Canada into groups according to their economic status we find that three species are wholly beneficial and absolutely harmless; sixteen are mainly beneficial, doing decidedly more good than harm; four are about balanced in their effect; and six are positively harmful. Only three of these latter are common enough to warrant consideration and only two, the Sharp-shinned and Cooper's Hawks, numerous enough in the thickly settled communities to be noticed. The Goshawk is a more northern species whose distribution overlaps the edges of settlement on the north. What can be regarded as a just balance between good and evil is difficult to decide; the loss of a chicken is definite, easily estimated in value; the absence of the mice and insects taken by a predaceous bird is a vague benefit that is difficult of realization or appreciation.

\section{SUBORDER-SARCORHAMPHI. AMERICAN VULTURES.}

This suborder is composed of the American Vultures which are systematically quite distinct from those of the Old World. One family only is represented in Canada, Cathartidoe the Turkey Vultures. Vultures

'See also "The Hawks of the Canadian prairie provinces in their relation to agrieulture," Geol. Surv., Can., Mus. Bull. 28, 1918. 
are carrion feeders, relying upon dead meat and not capturing living prey unless it is in the last stages of exhaustion. Ordinarily, they touch nothing but decaying flesh. This is usually regarded as a matter of choice, but may be a necessity, as their feet are not formed for grasping and the bill is comparatively weak. They may, therefore, be unable to break into large sound carcasses and are forced to await the decay which renders the subject less refractory.

\section{FAMILY-CATHARTIDA. TURKEY VULTURES.}

General Description. Large birds, uniformly nearly black in coloration. Bill is comparatively long and less strongly hooked than in remainder of the Raptores (Figure 30 , p. 23). Head and upper neck are bare of feathers and have a superficial general resemblance to those of the turkey, but are without wattles or warty excrescences. Feet resemble those of a chicken rather than a hawk. Claws are blunt and the whole foot is poorly adapted for seizing or holding prey.

Distribution. Vultures are essentially birds of the warmer regions. They enter eastern Canada only along the most southern boundaries.

Vultures cannot be observed to advantage in Canada. In the southern states they are more common and can be seen every hour of the day floating on motionless wings high in the air, searching the country below with telescopic eye for carrion. When an animal dies (or even before) it is sighted and a black form drops from the sky beside it; shortly it is joined by another, and another, and soon where not a bird was previously to be seen many are struggling about the unclean feast. Though dissection shows very highly developed nostrils, scent does not seem to guide them to any appreciable extent. Experiment indicates that the eyesight alone is relied upon for locating food. The flight of the Vultures is one of the wonders of the physicist. The Vultures hang suspended in the air or even rise until beyond the bounds of human vision, without visible effort. On motionless outspread pinions they glide in great ascending spirals, mounting higher and higher, and then, always circling, maintain their positions for hours at a time, apparently without a single wing stroke. Many explanations of the phenomenon have been offered but all so far advanced fall just short of conviction. In Canada we have only one species of regular though limited distribution. Another is of casual occurrence only.

Economic Status. The Vultures are not birds of prey in the usual acceptation of the term, for they do not kill what they eat but feed entirely on carrion. They have been accused, and perhaps justly, of accelerating death at times, but they never attack an animal that is not in the last stages of dissolution. In Canada the species is of little economic importance, but in the south their scavenging is an important safeguard to the health of the more careless communities and in many typical places they are rigorously protected by law for sanitary reasons.

325. Turkey Vulture. TURKEY BUZzARD. Cathartes aura. L, 30. An all dark bird, nearly black, with head and neck naked or in juveniles covered with greyish brown, fur-like down.

Distinctions. This species can only be confused with the next, but as the ranges of the two in Canada do not overlap there is little likelihood of misidentification. The base of the bill is bright red in the adult and the head and neck dull red. The under surface of the wings is without silvery sheen. 
Field Marks. The naked head and neck make the best field mark of the Vultures. The red colour of these parts identifies this species.

Nesting. On ground, usually in a hollow log.

Distribution. Over most of North America north to the Canadian line which, in the east, it only crosses in southern Ontario. A few may come in from Manitoba more or less regularly.

SUBSPECIES. The species occupying most of North and South America is subspecifically divided. The form occurring north of Mexico is the Northern Turkey Vulture Cathartes aura septentrionalis.

Economic Status. Being a carrion feeder no harm can be charged against the species.

326. Black Vulture. FR.-LE VAUTOUR NOIR. Catharista umubu. L, 24. Very like the Turkey Vulture, but slightly smaller.

Distinctions. Distinguished from the preceding by the neck, head, and base of the bill being black instead of red or pink.

Field Marks. The general blackness of the bare head parts and a silvery sheen to the under-wing surface are diagnostic in life. The tail is shorter and the bird looks blacker than in the Turkey Buzzard.

Distribution. A bird of more eastern distribution than the Turkey Vulture. Regular from Virginia south, straggling across our borders occasionally in the Maritime Provinces.

Of too infrequent occurrence in Canada for more than passing mention. It is to be expected occasionally only in the Maritime Provinces.

\section{SUBORDER-FALCONES. DIURNAL BIRDS OF PREY.}

General Description. Bill strongly hooked from the base (Figure 33, p. 23), where it is eovered with a swollen cere or mass of yellow waxy-looking tissue in which the nostrils appear. This tissue is distinctly softer than the bill proper and usually yellow in colour. The feet are powerful and furnished with strong claws or talons for capturing and holding living prey (Figure 31, p. 23).

Distinctions. The members of this suborder differ from the Vultures in having the bill shorter and more strongly hooked and the head feathered instead of bare (compare Figures 30, 33, p. 23); and from the next suborder, the Owls, in lacking distinct facial disks (Figure 34, p. 24) about the eyes which are so set in the Owls as to look directly forwards instead of from the sides of the head as in most birds.

These are the birds generally recognized as the Hawks and the Eagles. They are represented in Canada by three families: Buteonida, the common Buzzard Hawks and the Eagles; Falconidee, the true Falcons and Caracaras; and Pandionidee, the Ospreys or Fish Hawks.

FAMILY-BUTEONID无. BUZZARD HAWKS, KITES, HARRIERS, BUZZARDS, AND EAGLES.

General Description. Hawks of various sizes, most easily described as being neither Falcons nor Ospreys.

Distinctions. Wings are short, round, and concave except in the Kites and Harriers, and their flight is comparatively heavy. Bill (Figure 33b, p. 23) is without notches which make, as in the Falcons, distinct tooth-like (Figure 33a, p. 23) projections to the cutting edge. The feet (especially under-surface) have no distinct, sharp, hard corrugations for holding slippery prey, as in the Ospreys or Fish Hawks.

This family is composed of a number of well-marked genera, each comparatively easy of recognition. These comprise the bulk of our common birds of prey. Though truly raptorial in character they have not the bold spirit, the address in attack, or the iron endurance of the true Falcons and hence were called "Ignoble Hawks" by the old falconers. 


\section{Genera-Elanotdes and Circus. Kites and Harriers.}

The Kites are birds of southern distribution and only one species has ever been taken in Canada.

327. Swallow-tailed Kite. FR.-LE MILAN A QUEOE D'ARONDE. Elanoides forficatus. L, 24. (Projection of outer tail feathers beyond middle ones 8 inches). A rather small Hawk which measures large because of the great elongation of its outer tail feathers which extend 8 inches beyond the middle ones. Wings and tail pure black; all remainder, including head, shoulders, and upper back, white. A bird strikingly coloured in intense black and white, with the deeply forked tail and long pointed wings of a Barn Swallow. It is hardly possible to mistake this for any other species.

Distribution. Tropical and semitropical America, appearing very rarely along our southern border.

A most beautiful species, but too rare in Canada to receive more than passing reference here.

Economic Status. Its principal food is insects, snails, and reptiles; it never touches mammals or birds.

331. Marsh Hawk. Marsh harrier. Fr.-LE BUSARd des Marars. Cïrcus hudsonius. L, 19. Plate XI B.

Distinctions. A partial and incompletely feathered eye-ring merely suggestive of those of the Owls, is distinctive of the species. The general gull-like colours of the adult male and the warm reds of the juveniles are characteristic.

Field Marks. General coloration and the white rump which shows conspicuously in flight are the best field marks. Its long pointed wings and long narrow tail give it a falcon-like outline in flight, but its action is entirely different.

Nesting. On ground in a dry spot of the marshes, or in a hay field.

Distribution. The whole of the United States and Canada north to near the Arctics. Breeds throughout Canada.

One of our commonest Hawks, found almost anywhere in eastern Canada. It haunts the open marshes, meadows, and fields and is to be seen beating up and down, quartering and covering the ground like a well-trained bird-dog. For an instant it hovers over its intended prey and then drops upon it, rising a moment later to alight on a fence-post or other similar slight elevation to devour its captive. The young birds are unsuspicious, but the blue adults are amongst the wariest of birds and fall to the gun comparatively seldom.

Economic Status. Of 116 stomachs examined, 7 contained poultry or game birds, 34, other birds; 57 , mice; 22 , other mammals; 7 , reptiles; 2, frogs; 14, insects; and 1, indeterminate matter. Thus of 144 food contents 41 were harmful, 93 useful, and 10 neutral. Of the 41 harmful items, only 3 were domestic fowl and the remainder wild stock, consisting of 46 individuals of considerably less value than the domestic varieties. The 99 mice and other mammals included about 117 individuals. The insects were mostly locusts, grasshoppers, and beetles. The balance is evidently in favour of this species which is incapable of taking any fowl but small ones and then only when they wander away into its habitat. Keeping spring chickens close about the premises is an almost perfect protection against this bird. Haunting marshes, grassy meadows, and tangled fence-rows as it does it is the nautral enemy of field mice and probably does more to keep their numbers within bounds than any other single natural influence. 
Genera-Accipiter and Astur. Accipiters. Short-Winged Hawks.

General Description. Hawks with short rounded wings and long tail.

The Accipitrine Hawks are woodland birds which beat about the tree tops or along the edges of the woods; they do not habitually soar high in the open. They take their prey by surprise and quick attack rather than by open pursuit. Their short wings and long tail, giving rapid bursts of speed and quite flexible evolution, are well adapted for such manœuvres but not suited to sustained effort.

Economic Status. These are the only common species of Canadian Hawks for which little good can be claimed. They are active and spirited and though without the great strength and endurance of the true Falcons do far more real damage than their larger and heavier ratives. The term "Chicken Hawk" popularly applied to any small bitwk receives its meaning from these birds. They never eat carrion but alw dys make fresh kills, rarely if ever returning to partly devoured prey. Fortunately the two commonest species are the smaller and their capacity for damage is reduced in consequence. The one large and powerful memitre of the group, the Goshawk, is of more limited distribution and except in occasional winters is rarely seen in the more settled parts of southern Canada.

332. Sharp-shinned Hawk. CHICKEN HAWK. FR.-L'GPERVIER BRUN. Accipiter velox. L, 11·25. Plate XII A.

Distribution. As a rule, size will distinguish the Sharp-shinned Hawk from all except the Sparrow Hawk, but its evident non-falcon characters will prevent confusion. A large female will measure closely to a small male Cooper's Hawk of which it is a perfect miniature in coloration. It differs from that species in having a square instead of a rounded tail, when closed the outer feathers being quite as long as the inner ones instead of obviously shorter. The tarsus is also comparatively thinner and more slender, a difference that is quite perceptible on comparison of specimens.

Field Marks. The short, round wings, long tail, and flight by a series of alternating quick even strokes and short sails will mark this species as an Accipiter. Its tail being square instead of round is a guide to identification from the Cooper' $\mathrm{H}$ awk, but size is the most reliable difference.

Nesting. In trees, usually conifers from 10 to 40 feet up.

Distribution. Over nearly the whole of North America, north, probably, to the tree imits. It breeds in eastern Canada everywhere except in the most southern parts of the lower Great Lakes region.

This is the second smallest Hawk we have. It has not the sustained strength or persistency of the "Noble Falcons", but it is active and agile. It makes bold dashes at its prey, but on missing the stroke seldom follows it up by pursuit and almost never strikes on the wing, as the "Noble Falcons" do.

Economic Status. This is the species that should have been called "American Sparrow Hawk" instead of the little Falcon which has been so-named. It is a close relative, and the American representative of the European Sparrow Hawk which is also an Accipiter. The name would suit this bird excellently as the smaller sparrows and other birds are its favourite food.

Of 107 stomachs examined, 6 contained poultry or game birds; 99, other birds; 6 , mice; and 5 , insects. This gives 105 harmful food contents against 11 good ones. The mice consisted of no more than 9 individuals, but the small birds numbered 115, from Kinglets to a Mourning Dove in size. This makes a strong case against this otherwise rather interesting 
species. One good word can be said for this little hawk, it is fond of the English Sparrows and takes toll of their flocks about the smaller towns and cities. Pelee point on lake Erie is a famous Sharp-shinned resort in the autumn, and great numbers of Thrushes, Vireos, Sparrows, and other small birds annually fall victims to these active little freebooters.

333. Cooper's Hawk. CHICKEN HAWK. Fr.-L'GPERIER DE COOPER. Accipiter cooperi, L, $15 \cdot 50$. Similar to the Sharp-shinned Hawk, but larger.

Distinctions. A small, male Cooper's Hawk may come very close in measurement to a large female Sharp-shinned, and a large female to a small male Goshawk. Cooper's Hawk can be distinguished from the sharp-shinned by its rounded instead of square tail and its comparatively shorter and heavier tarsus. At no age is it like the adult Goshawk in coloration, but juvenile plumages are very similar. The best guide to separation other than size is the feathering of the tarsus; about one-third is covered in Cooper's Hawk and about one-half in the Goshawk. It may also resemble young plumages of the Red-shouldered Hawk, which see. It may also be easily confused with the juvenile Broad-winged Hawk, but has the first four instead of the three outer primaries abruptly narrowed or emarginated.

Field Marks. Accipiter outline and size are the best field guides. The round instead of square tail will help distinguish this from the Sharp-shinned. Coloration of the adults is the only field mark besides size to differentiate from the Goshawk.

Nesting. In trees, much like the Sharp-shinned Hawk, but seldom in conifers. States.

Distribution. From the northern borders of settlement south throughout the United

An even worse species than the Sharp-shinned as its larger size gives it greater power and capacity for damage. Showing an almost equal spirit it seeks larger prey and even a fairly well-grown chicken is not safe from it. Adult fowls are rarely attacked unless feeble.

Economic Status. Of 94 stomachs examined, 34 contained poultry or game birds; 52 , other birds; 11 , mammals; 1 frog; 3 , lizards; and 2, insects. The mammals consisted of rodents, mostly harmful, but one a Grey Squirrel; making a total of 87 food contents against the species, 12 in its favour, and 4 neutral. As it is a comparatively common Hawk throughout much of the settled parts of the country it is certainly a menace and is responsible for much of the popular ill-repute of the order as a whole.

334. American Goshawk. BLUE PaRTRIdGe HAWK, HEN HAWK. FR.-L'AUTOUR À tête NoIRe. Astur atricapillus. L, 22. Plate XII B.

Distinctions. Adults, with their characteristic slate-blue coloration and fine vermiculation, are not to be mistaken for any other American bird. The juveniles, however, are very similar to other young Accipiters and a small male will sometimes approach in size to a large female Cooper's Hawk. In such case, the tarsus feathered for one-half instead of one-third its length and the slight tinge of buff to the white of the underparts of this species will distinguish the forms.

Field Marks. Adults are distinguishable by coloration. Juveniles can be recognized by their size and Accipiter outline of long tail and short, round wings.

Nesting. In trees.

Distribution. Breeds across the continent within the borders of settlement. Its winter migratory movements are usually of small extent, though it occasionally visits our southern borders in considerable numbers. Paralleling the case of the Snowy Owl such flights are likely to contain mostly adults, though, normally, juveniles are much the commoner south of the breeding distribution. It is probable that these occasional flights are caused by the periodic failure of rabbit food in their usual habitats.

SUBSPECIES. The American Goshawk is divided into two subspecies, but only the typical form, the Eastern Gashawk, occurs in eastern Canada.

The American representative of the Old World Goshawk or "Goose Hawk", which seems to be the original name. It was the only shortwinged Hawk regularly used in ancient falconry. It was flown at hares, 
partridges, and such ground game, which its long tail and short wings allowed it to follow through rapid turnings and twistings, whereas its size allowed it to kill quite large game. It was not, however, regarded as a thoroughly sportmanlike bird as it lacked the spirit and energy of the longwinged Falcons and its use lacked the excitement and interest of the "Noble Hawks".

Economic Status. Fortunately this bird is only an irregular winter visitor into our least settled sections. Otherwise it would be a serious menace to the poultryman. Of 20 stomachs examined, 9 contained poultry or game; 2 , other birds; 10 , mammals; 3 , insects; and 1 , a centipede. Of the 10 mammals, 3 were rabbits and 1 a grey squirrel, both of which can be regarded as useful. This gives a total of 15 harmful food items against 9 useful and 1 neutral. There can be no question as to the harmful status of this species. Its size gives it ample power to take pullets and even wellgrown hens, and such large game as Ruffed Grouse is its favourite food. Though the real home of the Goshawks is in the more northern forests along the edge of the cultivated sections, when they once establish themselves near a farmyard they are likely to visit it daily. They dash suddenly over or around a building into the middle of the poultry flock, seize their victim, and are off with it before the owner can protect his property.

\section{Genera-Buteo and Archibuteo. True Buzzards.}

General Description. Heavily built Hawks of medium or large size, the bill without notches or teeth (Figure $33 \mathrm{~b}, \mathrm{p} .23$ ). The wings are rather short and round and the tail long and ample, spreading out in a broad semicircle. Genus Buteo has clean tarsi, but those of Archibuteo are feathered to the base of the toes. Buzzards.

Field Marks. Round wings, and broad, ample tail make the best field marks of the

These are the true Buzzards. The Turkey Vulture is called Buzzard in the south, but incorrectly so. The Buzzards lack the dash, speed, and spirit of either the Falcons or the Accipiters and confine themselves to humbler game and slower, heavier methods of hunting. They are the common high-flying Hawks of summer, can be seen circling for hours high in the air, and are little given to dashing about the thickets like the agile Accipiters. With the exception of the Broad-winged, their characteristic habitat is the wide open, though they usually nest in the forest.

Economic Status. On the whole their mousing and insectivorous habits more than compensate for some undeniable damage done by individuals of a few species. Though the Buzzards include some of our largest Hawks, the harm they do does not begin to compare with that done by the smaller Accipiters. Indeed the very largest species of the group, the Rough-legs, are the most harmless. Their principal food is mice, other small mammals, reptiles, and insects and the size of many of these guarantee that the good they do is on a large and important scale.

337. Red-tailed Hawk. HEN HAWK. FR.-LA BJSE À QUEUE RoUSSE. Butee borealis. L, 20. Plate XIII A.

Distinctions. Our largest common Hawk; usually to be distinguished from all others by size. The Rough-legged, which is its equal or superior in this respect, can be easily distinguished by its feathered tarsus. Broad red tail is distinctive of the adult. Juveniles vary only slightly from the Red-shouldered Hawk of equal age but are larger. Except for 
this the best distinction between them is the lack of any indication in this species of reddish on the shoulders or upper wing coverts and the presence of a roughly circular, unspotted, area on the breast.

Field Marks. Adults can be recognized specifically in life by the red tail, and all ages generically by their characteristic Buzzard outline of short wings and broad, ample, round tail. Juveniles are only likely to be mistaken for the Red-shouldered; from these the white breast and the voice are probably the most reliable guides. The call of the Red-shouldered is identical with some of the Blue Jay calls. The notes of the Redtailed are similar, but different enough in quality and execution to be recognizable after having once been heard.

Distribution. Eastern North America north to near the tree limit. Breeds in Canada wherever found.

SUBSPECIES. The Red-tailed Hawk is represented in Canada by several subspecies, but only the typical form, the Eastern Red-tail, is to be looked for in the east.

Nesting. High up in trees in the larger woodland patches.

The Red-tailed is a shy and a cautious Hawk. It is more often seen sailing in great circles high overhead than close by. It requires larger and wilder woodland patches than the Red-shouldered for its headquarters in summer, though like that species it hunts in the surrounding open.

Economic Status. This large, fine bird occupies a debatable position of usefulness and so much depends upon local conditions and the personal characteristics of individuals that no hard and fast conclusion respecting it can be laid down. Of 473 stomach examinations, 54 contained poultry or game birds; 51 , other birds; 278 , mice; 131 , other mammals; 37 , batrachians or reptiles; 47 , insects; 8 , crayfish; 1 , centipede: and 13 offal. Of the "other mammals" 16 were rabbits or grey squirrels. "This gives us about 121 food items against and 464 for the species, and there are 48 that can be regarded as neutral besides the 13 of offal that can only be listed as favourable. It should also be borne in mind in studying these food contents that those birds coming closest to the farmyard are the most likely to be shot and have their stomachs examined. Hence there is a certain amount of unfavourable selection against the species as a whole in the choice of evidence, that should be allowed for.

The species is, on the whole, exceedingly useful and does considerably more good than harm. Individuals, however, frequently get into the habit of regularly visiting the poultry yard. These are nearly always young birds of the year in search of easy prey. The old birds are usually too cautious for this. There can be no question that such individuals should be eliminated as quickly as possible, but it certainly cannot be maintained that a generally useful species should be systematically persecuted for the bad habits of a few. In economic ornithology it is a good rule, when the evidence is delicately balanced, to give the bird the benefit of the doubt.

339. Red-shouldered Hawk. CHICKEN HAWK. FR.-LA BUSE à MANTEAU ROUX. Buteo lineatus. L, 18.30. Plate XIII B.

Distinctions. The reddish underparts of the adults. Juvenile plumage may be similar to the young Red-tailed, but its inferior size and the presence of at least an indication of rufous on the shoulders or wing-coverts and the spotting of centre of breast will distinguish it.

Field Marks. With its characteristic Buteo outline and habits it is not likely to be confused with any other species than the Red-tailed. The lack of red tail and the ruddy underparts will distinguish adults. For juveniles the voice and size are probably the most reliable guides. The notes of this species are so like certain calls of the Blue Jay that they can be differentiated with difficulty. The Red-tail's screams are of similar nature, but quite distinguishable. 
Nesting. In trees, 35 to 75 feet from the ground.

Distribution. Over eastern North America north to the limits of settlement. Breeds in Canada wherever found.

SUBSPECIES. Several subspecies of the Red-shouldered Hawk are recognized, but only one, the Eastern Red-shouldered, the typical form, occurs in eastern Canada.

This is probably the most common Hawk in eastern Canada. It is similar in habit to the Red-tailed except that it does not insist upon deep woods for its nesting habitat but will build in almost any little patch of woodland, sometimes in surprising proximity to settlement.

Economic Status. This species is, fundamentally, very similar in its food habits to the Red-tailed, but being a much smaller and lighter bird the damage it can do is proportionately less, whereas its good offices are scarcely if at all impaired. Of 206 stomachs examined, 3 contained poultry; 12 other birds; 102 , mice; 40 , other mammals; 20 , reptiles; 30 , batrachians (frogs, etc.); 92, insects; 16, spiders; 7, crawfish; 1, earthworm; 2, offal; and 3 , fish. It will thus be seen that its diet is varied. Whether the shrews, frogs, reptiles, and spiders are to be counted for or against the species is open to some doubt, but the large number of mice and insects against 3 of poultry and 12 birds obviously acquits the species of the charge of doing much damage.

342. Swainson's Hawk. FR.-LA BUSE DE swaInson. Buteo swainsoni. L, 20. Of about the same size as the Red-shouldered. It may occur either in a nearly black phase, a light one, or any intermediate stage between. The characteristic light plumage shows an evenly brown back, head, and upperparts, white underparts with a band of vinaceous across the chest, and slight indications of bars of same colour on flanks.

Distinctions. Many birds have the ends of their primaries suddenly reduced in width as if a shaving had been taken from the edge with a pocket-knife. In this species the three outer primaries are thus attenuated or emarginated. In the Red-shouldered Hawk, for which certain plumages might be mistaken, four of the primaries are emarginated.

Distribution. The prairie provinces and westward. North to the Arctics, wandering casually to the lower Great Lakes.

This species occurs in eastern Canada only as a rare straggler from the west and should be identified with the greatest care. Though a prairie bird, its habits are too similar to the last species and it is too rare to require detailed mention.

343. Broad-winged Hawk. F'R.-LA BUSE DE PENSYLVANIE. Buteo platypterus. L, 15.89. The smallest of our Buteos. Adult-brown above, underparts all barred with reddish brown and white in rather coarse pattern. Juveniles-brown above with more or less white irregularly scattered through; below, white with brown stripes on breast to throat and bars on flanks and legs.

Distinctions. Size will distinguish this species from the young Red-shouldered Hawk which juveniles may resemble. Three attenuated or emarginated primaries instead of four will differentiate it from both that species and the Cooper's Hawk with which it also might be confused.

Field Marks. Size, general coloration of adults, and its long, fine, sharp call like the drawn-out squeak of a rusty barn-door hinge are good field characters.

Nesting. In trees 25 to 70 feet from ground.

Distribution. Eastern North America northward to the bounds of settlement. Breeds locally in eastern Canada in all except the most southern parts of Ontario and far south in the Mississippi valley.

Local in distribution and prefers the wilder sections.

Economic Status. Of 57 stomachs examined, 2 contained small birds; 15, mice; 13 , other mammals; 11 , reptiles; 13 , batrachians (frogs, etc.); 
30 , insects; 2, earthworms; 4, crawfish. Without further analysis this evidence is sufficient to free this species from any stigma of being harmful.

347a. Rough-legged Hawk. FR.-LA BUSE PATTUE D'AḾrique. Archibuteo lagopus sancti-johannis. L, 22. The largest of our true Hawks. It occurs in two phases: one all dark, almost black; and the other light, of almost infinite variety of colour tone and pattern. All intermediate stages occur. The most common form is brown above more or less mixed with ochre, especially about head, and ochre below with dark abdominal band and stripes on breast and throat. The tarsus, being feathered to the toes, is the basis of the common name and is characteristic of the genus.

Distinctions. Large size and the feathering of the tarsus to the base of the toes is diagnostic.

Field Marks. Large size, broad masses of black below, tail white at base (not a white rump), and prominent black wrist marks on the under surface of the wing are all good field marks.

Nesting. In the far north on ground, on rocky ledges, or in trees.

Distribution. As a species, inhabiting the northern portions of the northern hemisphere. The American form is found from Mexico to the Arctic. Breeds on or near the barren grounds.

SUBSPECIES. The Rough-legged Hawk is represented in the New and Old Worlds by two subspecies. The one peculiar to America is the American Rough-legged $A$. $l$. sancti-johannis, and is only distinguished from the European and Asiatic bird by its slightly lighter colour and the greater rarity of the black phase.

This large Hawk is only a migrant in settled Canada to or from the barren grounds of the north. It is a bird of large marsh expanses and can be seen beating over the grass until late in the evening something after the style of the Marsh Hawk. Usually, however, it is observed high in the air working its way gradually, with many pauses and circlings, to or from its breeding grounds. Owing to the dichromatism of the species an almost infinite variety of plumages may be found.

Economic Status. Though our largest Hawk, it is the least harmful one. Of 45 stomachs examined, 40 contained mice; 5, other mammals; 1, lizard; 1, empty. A record like this is enough to condemn the indiscriminate killing of Hawks. The feet of the Rough-leg are weak and incapable of holding large prey; it is, therefore, a mouse-hawk par excellence. It also feeds on grasshoppers and has been known at times to do most excellent work controlling plagues of these destructive insects.

\section{Genera-Aquila and Halizemtus. Eagles.}

The Eagles are our largest Birds of Prey. Size alone will differentiate them from the Hawks. Any Bird of Prey over 30 inches long or 6 feet in extent is an Eagle. Contrary to usual conception, the Eagle is not the noble bird of prey usually pictured. It is typically an overgrown Buzzard. Much of its quarry is of large size, but it is rarely dangerous to human interests. In some sections young lambs are occasionally threatened, but in eastern Canada Eagles can be looked upon more as scavengers than anything else, taking little of economic value and subsisting mostly on offal.

349. Golden Eagle. FR.-L'AIGLE DoRE. Aquila chrysaetos. L, 30. A large, darkbrown Eagle, the head suffused with faint ochraceous suggesting the name golden and the basal half of tail with broken greyish bars against dull white. Tarsus feathered to the toes. 
Distinctions. The Golden Eagle is altogether different from the adult Bald Eagle, but very similar to the juvenile. It can, however, in all plumages be identified by its feathered tarsus, the latter species having at all times bare, bright yellow legs.

Nesting. On cliffs, rock ledges, or in trees.

Distribution. Over the temperate region of both hemispheres. In America, it ranges over all the north country excepting the northern extreme, extending south into Mexico in the western plains and mountains and down along the high lands of the east. Practically only a straggler in the Great Lakes region.

The Golden Eagle is too rare in eastern Canada to receive more than passing mention here. It is a magnificent bird and having less of the scavenger and robber in its nature it fits the popular conception of the king of birds better than does its close relative the Bald Eagle.

Economic Status. The economic view of this bird must be largely affected by local conditions. It feeds principally on mammals and its large size allows it to take those of considerable weight. Most of its food is naturally wild stock-ground-hogs, rabbits, and rodent pests-but newly-born animals are taken on opportunity. In the western sheep country the depredations of numbers of Golden Eagles may be serious, but are never so in the east. Fortunately the species is too rare in eastern Canada to cause strong objection to it; in fact to see an average of a single bird a year would be rather remarkable. Therefore, the occasional presence of one of these magnificent birds in the east can be looked for with pleasure rather than alarm. On occasion the species devours carrion, but does not seem to depend upon it as its relative the next species does.

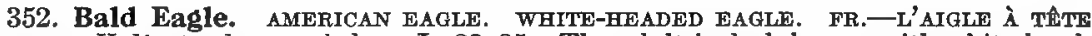
BLANCBE. Halioetus leucocephalus. L, $32 \cdot 85$. The adult is dark brown with white head, neck, and tail. The juvenile is all brown with more or less suggestion of the coming white, depending upon age.

Distinctions. Though very similar in juvenile plumage to the Golden Eagle, the unfeathered yellow legs will always identify it.

Field Marks. The Eagle outline and great size are quite characteristic when one is familiar with them. The great hooked bill, the culmen which projects in a straight line with the crown and fills the whole of the forehead are plainly visible and quite recognizable. The white of the head and tail are unmistakable recognition marks for the adult and on account of the large scale of the details the juvenile can be told from the Golden with greater ease than would naturally be expected. The golden-tawny of the upper neck of the Golden is often quite conspicuous though absent on the Bald. The somewhat whitish or mottled tail of the Golden shows from below a dark terminal tip, in perceptible contrast with the base, from 2 to 4 inches deep depending on age; whereas the tail of the juvenile Bald is all dirty white with little or no distinet terminal band but presenting an aspect of even mottling at all stages. Any Eagle observed in eastern Canada should be tentatively identified as of this species unless there are definite and positive reasons for declaring it as Golden.

Distribution. Over the whole of the United States and Canada except the extreme Arctic coasts.

SUBSPECIES. The Bald Eagle is divided into two subspecies, only one of which, the Northern Bald Eagle $H$. l. alascanus, is known to occur in Canada. The typical race is of more southern distribution.

Though the Golden Eagle is typically an inhabitant of the mountains and high lands, the Bald Eagle is a bird of the water side and is seldom found far from that element. Though once a typical species of the eastern landscape it is yearly growing rarer, until now in most localities the sight of one is an event of some importance. The Bald Eagle is a harmless species. The damage it does is very small and as a characteristic wild feature of our lake landscape this picturesque bird should be preserved. 
Economic Status. Of 15 stomachs examined, 1 contained game; 5, mammals; 9 , fish; and 2 , carrion. In examining these data it is observable that the 6 stomachs containing mammals and game are winter specimens and, except one, were taken at a distance from water. Had the natural breeding and summer grounds of the Bald Eagle been the source of the specimens here studied, the mammals and game would probably have been replaced by fish, for this forms the great bulk of its food. The food is taken in various ways. The bird dives for fish in true Osprey manner when necessary, but it usually picks them up dead from the shore or, where Ospreys are common, takes the fish from them by force. To do this it pursues and badgers the successful fisher until the prize is dropped, which by a lightning-like swoop is caught in the air and carried away in triumph. It is, as a rule, hardly equal to the capture of the quicker birds, but wounded or hurt ducks or game are eagerly picked up from the marshes. When opportunity offers the Bald Eagle eats offal without compunction.

It will be seen that Bald Eagles in reasonable numbers cannot be any great menace to mankind. Poultry is rarely touched. The fish they take is only a bagatelle, being mostly waste or surplus from a great abundance. Their scavenging is actively beneficial and they should be encouraged rather than repressed.

FAMILY-FALCONIDAS. FALCONS AND CARACARAS.

The Family Falconidee consists of two subfamilies, the True Falcons Falconince and the Caracaras Polyborinoe. The last named subfamily is of southern distribution and only one Caracara has been taken in Canada.

\section{Subfamily-Falconina. True Falcons.}

The Falcons were known to the old falconers as the Noble or Longwinged Birds of Prey and, on account of their great spirit, strength, and address, were the chosen birds for use in hunting. Their long wings give them great speed and their endurance permits them to maintain it. They are bold and strong and capture their prey by sudden swoops when possible, but unlike the Accipiters are not discouraged when their stroke misses. Their first object is to rise above the prey, which they do by means of a long spiral climb. Once above their prey they drop like a bullet upon it striking with their powerful talons as they do so.

The flight of the Falcons is quite recognizable, quick strokes with pointed wings and with very little sailing. Seen in the hand, the upper mandible furnished with a tooth (Figure 33a, p. 23) will always separate the Falcons from other Hawks. Fortunately, none but the smallest and most harmless of the subfamily is common within cultivated areas and those that size makes important are either very rare or are confined to the far north where their depredations can do the husbandman no harm. Even those that do occur occasionally about cultivation are generally wild and wary enough to keep away from the immediate vicinity of habitation.

\section{Gyrfalcons.}

General Description. Large falcons 20 to 22 inches in length, usually of very white eoloration. Their large size distinguishes these birds from all others of the subfamily.

$57172-9 \frac{1}{2}$ 
The Gyrfalcons were most highly regarded for hunting by the falconers of old and by the exacting laws of the times their use was restricted to persons of the highest rank. They combine all the spirit and hardihood of the smaller species with greater size and strength and hence were adapted for the largest game to be taken with birds. The Gyrfalcons are of far northern distribution in Canada and are very rare within the limits of settlement, rarely troubling poultry yards or game coverts; otherwise a war of extermination would probably have to be waged against them as they are undoubtedly very destructive.

In Canada there are two species. They are circumpolar in distribution, occurring in the northern parts of both the Old and New Worlds.

353. White Gyrfalcon. FR. - IE FAdCON BLANC. Falco islandus. L, 22. A very large falcon, mostly pure white with small but sharp markings of light brown.

Distinctions. The general whiteness and the lack of markings on the under tail coverts will differentiate this from the next species. Its large size and obviously falcon-like characters will identify it as a Gyrfalcon.

Nesting. On rocky cliffs.

Distribution. The Arctic regions. Breeds in Greenland and the adjacent parts of America. Only a casual visitor in the settled parts of Canada.

None of the Gyrfalcons are common in the settled parts of Canada and, therefore, will not be discussed in detail.

354a. Gyrfalcon. Fr.-(in part) Le FAdCON NOIR. Falco rusticolus. L, 20. Similar in size to the White Gyrfalcon and of much darker coloration. Slaty-brown above, more or less margined or barred with cream or white. Head and underparts white or creamywhite, striped with colour of back.

Distinctions. In the White Gyrfalcon white greatly predominates, whereas in the lightest of this species white and slaty-brown are about equal in mass and in the darkest the brown greatly preponderates. The under tail coverts are always somewhat streaked.

Nesting. On cliffs or in trees.

Distribution. The Arctic regions of the northern hemisphere; only an accidental straggler within settled districts.

SUBSPECIES. The American representative of this species has been divided into three subspecies or geographical races, based upon the degree of dark coloration; the Grey Gyrfalcon F.r.rusticolus, the type form, the Gyrfalcon $F$. r. gyrfalco, and the Black Gyrfalcon $F, r$. obsoletus. Some of these subdivisions are perhaps based upon age plumages or individual variation and may be found to be unnecessary. The names suggest the difference in colour of the forms. The first has the head broadly streaked with dark against an almost white ground, the second has an almost solidly dark head and the dark of the back heavily margined with lighter, and the third has an almost black back and the underparts so heavily streaked as to be almost black.

356. Peregrine Falcon. duck haWk. bUllet hawk. fr. - Le fadcon pèrlerin. Falco peregrinus. L, $16 \cdot 50$. Plate XIV A.

Distinctions. The colouring shown in Plate XIV A, the comparative size, and the true falcon-like character of the bill and wing should serve for the recognition of this bird.

Field Marks. The long, sharp falcon wings, coloration, and size are distinctive. The flight also is easily recognized - a quick flapping of the wings with little sailing.

Nesting. Usually on the ledges of rocky clifts, occasionally in hollow branches of tall trees.

Distribution. It ranges over most of the Arctic, temperate, and subtemperate regions of the northern hemisphere, nowhere common but living in scattered pairs and returning to the same locality year after year.

SUBSPECIES. The New World form under the name of Duck Hawk F.p. anatum, is the only representative of the species occurring in America.

The American representative of this species is a subspecies of the famous Peregrine Falcon of the Old World, which next to the Gyrfalcon was the most desirable hunting hawk of the falconers, and our Duck 
Hawk is almost if not quire indistinguishable from the European bird. Although distributed over most of the northern hemisphere it is everywhere a rare and more or less casual visitor or breeder.

Economic Status. The size of the prey which this bird can take is remarkable. Even the Mallard Duck, weighing perhaps three times as much as the falcon, is often struck down. Around a nest found by the writer in the Muskoka district, were the remains of several full grown Ruffed Grouse that must have been carried bodily to it. An examination of the stomach contents of 16 specimens, gave the following result: 7, contained poultry or game birds; 9 , other birds; 1 , mice; and 2, insects. Fortunately it is as wary as it is spirited. Adults usually confine themselves to the fields and marshes where they can do little direct damage.

357. Pigeon Hawk. FR.-La FAdCon Des PIgeons. Falco columbarius. L, 10. A small falcon. Adult male: dark slate-blue above, bluest on lower back and rump. Below, streaked with brown on an ochraceous ground, the stripes aggregating slightly on lower breast. Juveniles: similar but back brown instead of slate. Adult females: intermediate.

Distinctions. True falcon characters; the generally dark coloration and the small size of this hawk are characteristic.

Field Marks. The falcon flight and outline, in conjunction with small size and dark coloration, are distinctive.

Nesting. In hollow limbs of trees or on cliff ledges.

Distribution. All of North America and to northern South America. Breeds southward to the borders of cultivated land in eastern Canada.

SUBSPECIES. There are several subspecies of the Pigeon Hawk in Canada, but in the east there is only the type form, the Eastern Pigeon Hawk.

In spirit and action this is a miniature of the Duck Hawk, but is a far commoner bird than nay of the Falcons previously mentioned. This species also was used in court falconry.

Economic Status. As indicated by its name the Pigeon Hawk pro bably preyed largely upon Wild Pigeons. Nowadays, however, it follows smaller game as a rule. Of 51 stomachs examined, 2 contained young chickens; 41 , small birds; 2 , mice; and 16 , insects. It will be seen from this record that the Pigeon Hawk is destructive to small wild bird life but is not large enough to seriously aff ct the poultryman. It often follows Shore Birds and seems particularly fond of the Black-bellied Plover. Though more numerous than the Duck Hawk it is still nowhere a common bird.

360. American Sparrow Hawk. FR.-LE FAUCON EPERTER. Falco sparverius. L, 10. Plate XIV B.

Distinctions. The coloration of this bird renders it unmistakable for any other species.

Field Marks. With its falcon-like outline and small size it can not be mistaken for any bird except perhaps the Pigeon Hawk. Its more slender shape and longer tail will separate it readily when the striking colours are not distinguishable.

Nesting. In deserted Woodpecker's holes or natural cavities in dead stub.

Distribution. Most of North America, from beyond the settled areas to the gulf of Mexico. Breeds wherever found in Canada.

SUBSPECIES. Two subspecies of the American Sparrow Hawk are recognized in Canada, but only the type form, the Eastern Sparrow Hawk, occurs in the east.

This is the only falcon that is common in Canada. It is a beautiful bird-the brightest coloured of any of our Birds of Prey. The open fields are its hunting ground and the topmost dead branches of solitary 
trees in fields or along fence rows are its chosen observation points. It beats about over the meadows and on sighting its prey hovers for a moment on quickly beating wings, like a Kingfisher, and then drops upon its quarry.

The name Sparrow Hawk should properly belong to the Sharpshinned; this is recognized in the Old World where the name Sparrow Hawk is applied to a small Accipiter closely resembling that species. Grasshopper Hawk would be a far better descriptive name for this little falcon as grasshoppers form a large part of its food. When taken young from the nest this little falcon is easily tamed.

Economic Status. Although a hawk, this bird is one of the most efficient and valuable protectors of the farm. Of 291 stomachs examined, 1 contained a game bird (Quail); 53, other birds; 89 , mice; 13, other mammals; 12 , reptiles or batrachians (frogs, etc); 215, insects; and 29 , spiders. Of the birds examined, 43 were taken in the winter months, from December to April. Of specimens taken in seasons when insects are available only 10 stomachs contained birds. This record shows that birds are killed by the falcon from necessity rather than choice. The "other mammals" are mostly harmful rodents, with a very few shrews. The insects are usually grasshoppers which do great damage and are difficult to control. From the above evidence it is obvious that the Sparrow Hawk is beneficial and should be protected.

\section{FAMILY-PANDIONIDA. FISH-HAWKS. OSPREYS.}

The Fish-hawks or Ospreys are a family of raptorial birds subsisting entirely upon fish, which they capture in shallow water by diving. Other members of the order eat fish, but usually only as scavengers or by stealing from fish-catching birds. As there is only one species of Fish-hawk in America, no general discussion of the family is necessary here.

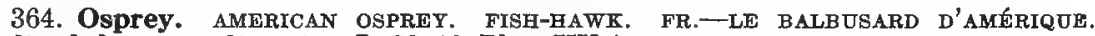
Pandion halicetus carolinensis. L, 23-10. Plate XV A.

Distinctions. The coloration of the Osprey is quite distinctive. Its pale blue legs, and feet much roughened with sharp horny processes, especially on the soles and grasping surfaces, are decidedly characteristic.

Field Marks. The large wing-expanse of this bird is responsible for the common mistake of calling it an eagle. It is, however, much smaller than either of the eagles and its white underparts will distinguish it from them.

Nesting. A great mass of sticks in trees or on the ground, which, as it is added to year after year, finally becomes almost as large as a small baycock.

Distribution. The Osprey occurs in most of Europe, Asia, Africa, and in America south to northern South America. The American Osprey breeds in Canada locally in all except the southern sections.

SUBSPECIES. The Osprey, inhabiting both the New and Old Worlds, is divided into subspecific races, of which the American Osprey $P . h$. carolinensis is the American representative. Its separation from the European form is based upon characters too slight for discussion here.

The Osprey is a most picturesque bird. Sailing at a height over the water it pauses a moment and then drops suddenly, not straight down like a plummet, as the Gannet does, but in a long spiral, striking the water feet first with wings raised high over its back. There is a splash of white spray and it rises in the air, a fish clasped in its rough talons, and is away to its aerie. The Ospreys frequent broad shallows, tidal flats, and shallow bays where water is not too deep for shallow diving, 
rather than deeper water where they would have to depend upon chance surface-frequenting fish. In the Great Lakes region the species is growing rarer. Its great bulky nest is added to year after year until it assumes such proportions that it becomes a landmark for the country around and invites constant attack from human nest-robbers, so that it is now only in the more retired localities that it can breed undisturbed. It is still numerous along the Atlantic coast and gulf of St. Lawrence, but inland it is rare.

Economic Status. Though the food of the Osprey is entirely fish the antipathy that fishermen have for it is rather exaggerated. Feeding as it does in shallow waters it takes few fish of economic importance. On the coast, flounders, tom cod, and other small species form the bulk of its food. On the freshwater lakes, sun-fish, perch, and suckers seem to be its staples. The number of game or marketable fish it catches is undoubtedly small. In eleven stomach examinations there were none. Trout streams are not attractive to the species and most of the valuable fish like bass and pickerel usually lie too deep for it to catch.

\section{SUBORDER-STRIGES. NOCTURNAL BIRDS OF PREY. OWLS.}

The Owls are easily recognized. The cere hidden in the feathers of the face, and the striking facial disks or feather rings about the eyes (Figure 34, p. 24) are distinctive to the most casual observer. They are mostly nocturnal, the Hawk Owl and the Snowy Owl being the only eastern Canadian species that habitually hunt in daytime. Even the nocturnal owls, however, see quite well by day. They may be momentarily dazed when brought suddenly from dark to bright light and some species repose such confidence in immobility to escape detection as to allow themselves almost to be caught in the hand. The feathers are a most interesting character in owls. They are peculiarly soft and cling together in a way that keeps the air from passing through the small interstices and ensures the silent flight characteristic of the suborder. An Owl can pass so closely as to fan the face with its wing and yet be inaudible.

Two families are represented in Canada: Aluconida the Barn Owls, represented by one species which is an accidental visitor from the south; and Strigidee known as the Eared or Horned Owls, though many of them are without these ornaments, including all the other Canadian species.

\section{FAMILY-ALUCONID开. BARN OWLS.}

The Barn Owls, sometimes called the Monkey-faced Owls from the heart-shaped character of the united facial disks, are represented in Canada by only one species and that species is rare. The middle claw is pectinated, having comb-like teeth on its inner edge like the Herons (Figure 19, p. 21) and the inner toe is as long as the middle instead of being slightly shorter as in the Horned Owls.

365. American Barn Owl. MONKEY-FACEd owL. Aluco pratïncola. L, 18. General ground colour a reddish ochre, lighter below, facial disk dull white with an outer edging of darker ochre to brown. Back to top of head frosted over with ash-grey with numerous small eye spots outlined in black. Underparts, throat, and around face sprinkled with scattered round dark spots. 
Distinctions. The strongly and well outlined heart-shaped facial disk, soft yellow coloration with a suggestion of pink, and the tarsi almost bare of feathers are distinctive.

Nesting. In towers, steeples, or holes in barns, banks, or trees.

Distribution. From the gulf of Mexico to the middle Atlantic states across the continent. It occurs in Canada only as a straggler along the southern border.

This is the American representative of the ruin-haunting European owl so familiar in song and story. It is a wonderfully efficient mouser and a most valuable bird, but is rare in Canada.

\section{FAMILY-STRIGIDA. HORNED OR EARED OWLS.}

The family is known as "Horned" from the tufts of feathers projecting from the forehead in some of the species, though not in all. The feet are feathered to the ends of the toes (Figure 32, p. 23). The family includes all the Canadian owls except the Barn Owl previously described.

366. American Long-eared Owl. Fr.-LE HIBOU À OREILLES LONGUES. Asio wilsonianus. L, 14-80. A medium sized owl rather similar in coloration to the Great Horned Owl (p. 133), but much smaller and of more slender build.

Distinctions. Although the colouring is suggestive of the Great Horned Owl, the difference in size serves to distinguish the two. From the Short-eared Owl, which is of abont equal size, it may be distinguished by the prominent horns or ear tufts which spring close together from the forehead, by the general lack of stripes in its coloration, and by the conspicuous amount of black and white suffused over the body colour.

Field Marks. The prominent horns standing nearly straight up from the middle of the forehead and the rusty brown facial disk differentiate this species from the next, the only species for which it might be mistaken.

Nesting. In trees, usually in deserted crows' nests or hawks' nests 20 to 40 feet from the ground.

Distribution. Throughout temperate North America, north to about the limit of cultivation.

Evergreen or alder thickets on the edges of marshes or ash swamps are the preferred habitat of the species. During migration it is sometimes found in companies, resting by day in the dark recesses of wet woods.

Economic Status. Of 92 stomachs examined, 1 contained a game bird (Quail); 15, other birds; 84, mice; 5 , other mammals; and 1, insects. From this record it is evident that the species is not seriously destructive. Its mousing proclivities are sufficient to give it a claim to protection and its small size and nocturnal habits prevent its interference with young poultry.

367. American Short-eared Owl. MARSH OWL. FR.-LE HIBOU À OREILLES cotrTEs. Asio flammeus. L, 15.50. A medium sized owl with short, hardly visible eartufts. General colour ochraceous with considerable white lining on face, with sharply defined stripes of brown over all, narrower below and broader and more diffused above.

Distinctions. The general light buff colour and the stripes of this bird are distinctive. The horns may be inconspicuous; when visible they rise, as do those of the last species, from between the eyes and stand upright. The lack of any black and white pattern in the coloration serves to distinguish this species from the Long-eared.

Field Marks. The buff colour is the best field mark.

Distribution. Nearly cosmopolitan. Occurs everywhere in Canada, breeding locally wherever found.

This bird is a true marsh owl and is slightly more diurnal in its habits than many of its relatives. It is often seen in the dusk of the evening beating over the marshes in strong and hawk-like flight. As it lives in the 
marshes or along their brushy edges, a great number annually fall under the guns of sportsmen.

Economic Status. Of 97 stomachs examined, 11 contained small birds; 77, mice; 7, other mammals; and 7, insects. From this record and from the fact that the marsh edges, waste patches, and fence rows which this species haunts, are the reservoirs from which small rodent pests spread over cleanly cultivated land, it is evident that this is a most useful species and that killing it is reducing one of the most efficient checks upon innumerable pests.

XV B.

368. Barred Owl. FR,-LA CHOUETTE DU CANADA. Strix varia. L, 20. Plate

Distinctions. It is almost impossible to mistake this owl. The only other hornless owl at all resembling it is the Great Grey Owl. The Barred Owl can be differentiated by its smaller size, black instead of yellow eyes, and by the well-defined striping and barring below. This and the Barn Owl are the only owls with black eyes.

Field Marks. Size, absence of ear tufts, and general grey-brown colour with bars on the breast.

Nesting. In hollow trees or in deserted crows' nests or hawks' nests.

Distribution. Eastern North America from the edge of settlement south to Kansas and Georgia.

SUBSPECIES. There are several subspecies of the Barred Owl, two of which occur in Canada. The form found throughout eastern Canada is the type, the Eastern Barred Owl.

Though apparently a fairly large bird the Barred Owl when stripped of its feathers is comparatively small. Added to this it is a bird of gentle nature and lacks the keen aggressiveness of some of its relatives. Its notes are loud, the wierd hooting carrying far in the still night air.

Economic Status. Though fowls have been known to roost repeatedly without harm in trees from which Barred Owls hooted every night, it is usually regarded as an enemy and killed indiscriminately. Of 189 stomachs examined, 5 contained poultry or game; 13 , other birds; 46 , mice; 18, other mammals; 4, frogs; 1, a lizard; 2, fish; 14, insects; 2, spiders; and 9 , crawfish. The fowls, only two cases, can be regarded as accidental as they were both taken in January, when they would ordinarily be full grown and beyond the powers of this weak owl to kill. The status of this bird is most satisfactory.

370. Cinereous Owl. Great grey owl. Fr.-LA ChoubTte Cendrete. Scotiaptex nebulosa. L, 27. Of much the same general grey tone as the Barred Owl, but considerably larger than that bird.

Distinctions. By measurement and in appearance the largest of our owls, but when stripped of its great abundance of soft feathers a surprisingly small bird. Like the Barred Owl in general coloration and lack of horns; but with yellow instead of black eyes and having the coloration of the breast and underparts diffused and without a defined pattern of stripes and bars.

Field Marks. Size, grey coloration, and lack of breast bars.

Nesting. In trees.

Distribution. The forest of the north across the continent; an occasional winter migrant within the bounds of cultivation.

SUBSPECIES. The Cinereous Owl occurs in the northern parts of both the New and Old Worlds, but is represented in each by distinct subspecies. The European form is the Lapp Owl S. n. Lapponica, and the American is the Great Grey Owl, the type race.

This owl is only an occasional visitor in the settled parts of Canada. 
Economic Status. The economic effect of this bird as far as it goes is a beneficial one. Data on its foods are rather scanty. Of 9 stomachs examined, 1 contained a small bird; 7 , mice; and 4 , other mammals. It is evidently an efficient mouser.

371. Arctic Saw-whet Owl. RICHARDSON's OWL. FR.-LA NYCTALE DE RICHARDson. Cryptoglaux funerea. L, 10. A small, hornless, grey owl. Ashy-brown above with round white spots, whitish below vaguely striped. The colour pattern is soft and the design vague and diffused.

Distinctions. This species resembles the Screech $\mathrm{Owl}$ in size and general grey colouring, but in nothing else; it has not the horns of that species and the colour pattern shows no sharpness anywhere. The colour scheme shows too little distinction from that of the Saw-whet to be clearly differentiated here. Its decidedly larger size, however, will characterize it.

Field Marks. It is too rare to identify by such slight field marks as could be suggested. Nesting. Usually in holes in trees.

Distribution. The northern woods to the limit of trees from the Mackenzie River valley eastwards.

SUBSPECIES. This is a European as well as an American species, but the form inhabiting the New World is subspecifically separated from that of the Old World under the name of Richardson's Owl C.f. richardsoni.

This species is perhaps the rarest of the Canadian Owls, and within the boundaries covered by this work is only an occasional and irregular winter visitor.

Economic Status. Though too rare to have any noticeable economic influence it must be regarded as a beneficial species. Of 9 stomachs examined, 1 contained a small bird; 7 , mice; and 4 , other mammals.

372. Saw-whet Owl. aCadian owl. Fr.-LA Nyctale d'acadie. Cryptoglaux acadic. L, 8. A very small owl. Above, colour is warm ashy-brown vaguely marked with inconspicuous white spots especially about the back of the neck, changing on the head to fine sharp stripes which join in a line over the facial disk. Below, white, with light brown streaks and a vague tendency to form a solid breast-bar. A rare plumage of this owl was long thought to indicate a distinct species which was given the name Kirtland's Owl, It is now, however, understood to be but an evanescent juvenile plumage of the above. though the cause of its rarity is not known. Above, it is solid brown, rather redder than the adult, and extending across breast in a rufescent band; below, even ochre. The facial disk on outside of the eyes is almost black, in striking contrast to the white over and between eyes.

Distinctions. In ordinary plumage so nearly like Richardson's Owl in colour as to be separated from it only by size. Being without horns or any sharply marked colour pattern it can be easily distinguished from the Screech Owl.

Field Marks. Very small size and lack of horns are the best field marks.

Nesting. In holes in trees, sometimes natural, at other times those made by wood. peckers or squirrels.

Distribution. Most of temperate North America. Its breeding is irregular and usually in the northern parts of its range or at high elevations farther south.

SUBSPECIES. There are two subspecies of the Saw-whet Owl occurring in Canada; but only one, the Acadian Owl, the type form, is ever found in the east.

This diminutive owl is the smallest of the Birds of Prey in eastern Canada. It haunts the dark tangle of cedar and tamarack swamps, passing the day close against the trunk of a tree where its plumage blends indistinguishably into the bark. It has such great reliance in its protective coloration that it will allow close approach and can at times be almost taken in the hand. It takes its vernacular name from its call notes which are said to resemble the sound made by filing or whetting a saw. 
Economic Status. Of 19 stomachs examined, 1 contained a sparrow; 17 , mice; and 1, a moth. With this record the species should be given protection.

373. Screech Ow1. FR.-LE HIBov Macul任. Otus asio. L, 9.40. Plate XVI A.

Distinctions. The species is dichromatic, that is, it occurs in two well marked colour forms irrespective of sex, age, or season. One form is rich brown with shades of grey and white, and the other has the grey replaced by bright rufous. The plumage pattern of each is the same. Many intermediate stages occur. In apparent size it comes between Richardson's and the Saw-whet Owls, but the presence of well-defined horns from the sides of the crown and the sharply defined figures of its colour pattern are characteristic.

Field Marks. Size, and the distinct horns are the best field guides.

Nesting. In hollow trees.

Distribution. All temperate North America. Breeds in Canada wherever found.

SUBSPECIES. The Screech Owl is divided into a great number of subspecies, some nine geographical races being recognized in North America by the American Ornithologists' Union check-list. The only one found in eastern Canada, however, is the type form - the Eastern Screech Owl.

Although called the "Screech Owl", the notes of this bird are melodious and soothing with a tinge of melancholy, and contain nothing harsh or grating. The most common call is a long, soft, tremolo whistle on a descending or even scale. Occasionally it consists of low croons, gurgles, and other quiet and conversational notes. Although inoffensive, these small birds show surprising courage in defence of their young. At night they will sweep down on the head of an intruder with a startling, hollowsounding "whoo-whoo" and snapping of the bill. Just before striking, however, they wheel away to gather momentum for a return. Such attacks while disconcerting are far from dangerous. The habit of nesting in old hollow apple trees on the farm where its mousing is of the most immediate importance makes this bird most valuable to the husbandman.

Economic Status. The official finding on the food of the Screech Owl is warrant for its protection. Of 212 stomachs examined, 1 contained poultry; 38 , other birds; 91 , mice; 11 , other mammals; 2 , lizards; 4 , frogs and toads; 1 , fish; 100 , insects; 5 , spiders; 9 , crawfish; 7 , miscellaneous; 2 , scorpions; and 2, earth worms. The poultry item must be regarded as an accidental occurrence, as the bird represented, a pigeon, would be exceedingly large prey for this bird.

375. Great Horned Owl. FR.-LE DUC DE VIRGINIE. Bubo virginianus. L, 22. Plate XVI B.

Distinctions. Our only owl over 15 inches in length wearing horns. Its ochraceous, and black and white coloration is distinctive.

Field Marks. Large size, ochraceous colour, and prominent ear tufts.

Nesting. Usually in abandoned hawks' nests or in hollow trees.

Distribution. In various subspecies the Great Horned Owl ranges over all of North America. The ranges of the subspecies in Canada are sufficiently indicated by their names.

SUBSPECIES. The Great Horned Owls of North America are split up into a great number of geographical races or subspecies, some of which occur as migrants in eastern Canada. The Arctic form $B$. v. subarcticus is nearly white in colour with the ochre and rufous of the common variety almost absent and the black pattern much reduced. The Western Horned Owl $B . v$. pallescens is about intermediate between the Arctic and the Eastern Horned Owl, the type form shown in the illustration. The Labrador Horned Owl $B . v$. heterocnemis is a very dark form. As these intergrade with each other indistinguishably and overlap in range in migration, exact subspecies designations should only be made with great care and, except in extreme plumages, only after comparison with duly authenticated specimens. 
The Great Horned Owl is the evil genius of the woods. Winding silently in and out through the shadowy foliage, it is master of all except the larger animals. The animosity the crows show the Great Horned Owl must be based upon bitter experience.

Economic Status. The economic status of this bird depends upon where it lives. In the deep woods away from settlement it is, of course, harmless and only the wild creatures it preys upon are affected by it. In settled districts this bird is to be guarded against in every possible way. Of 110 stomachs examined, 31 contained poultry or game birds; 8, other birds; 13 , mice; 65 , other mammals; 1 , a scorpion; 1 , fish; and 10 , insects. The evidence is, therefore, decidedly against this owl. There is no danger that restriction will result in its extermination since it is perfectly able to take care of itself and there are large sections where the species can hold sway over the wilderness without molestation.

376. Snowy Owl. FR.-LF HARFANG. Nyctea nyctea. L, 25. A large, white owl with short, sharp, dark-brown barring practically all over and without perceptible ear tufts. Adult birds which have reached maturity may be almost immaculate.

Distinctions. The only owl that is markedly white, except the Arctic Horned Owl which sometimes approaches it. The lack of horns or ears, however, is diagnostic.

Field Marks. Nearly white bird without ear tufts.

Nesting. On ground.

Distribution. Aretic regions of North America, migrating south in winter to the Iatitude of the Great Lakes across the continent.

This is a winter visitor in the settled parts of Canada. It frequents frozen marshes and lake shores and is typically a bird of the open. Usually the birds that come from the north are heavily marked juveniles, but occasionally flights occur in which the very white and almost unspotted adults are in the majority. Probably the juveniles are naturally greater wanderers than the adults which migrate far from their home grounds only when driven out by a scarcity of food or attracted south by a great abundance of rabbits.

377. Hawk Owl. Fr.-LA CHOUETTE ÉPERvìre D'AMERIQUE. Surnia ulula • L, 15. A medium-sized owl of somewhat hawk-like build and habits. Above, rich, warm brown variously spotted with white. All underparts and breast, sharply and regularly barred with brown and white. A rich seal brown line bordering the outer sides of the facial disks and meeting in the throat. Facial disk not as perfect as in most owls.

Distinctions. The less flattened and less typically owl-like face, long tail, and sharp and regular barring of the underparts are distinctive.

Field Marks. Diurnal habits, general coloration, and long tail are good field marks. Any owl seen hunting in the daytime or perched in commanding position in full daylight is probably this species, though the Long and Short-eared both do so occasionally.

Nesting. In evergreen trees or in holes in dry trunks.

Distribution. The northern wooded parts of the continent, occurring within the settled regions only rarely in winter.

SUBSPECIES. The Hawk Owl occurs in both the New and Old Worlds as allied subspecies, the type being European. The American Hawk Owl S. u. caparoch is the snly form found in Canada.

This is the most strictly diurnal of Canadian owls. It is very hawklike in action and form, being of more slender and lighter build than other members of its family. It may often be seen perched on the tip of a dry tree trunk, reminding one very much of the Sparrow Hawk both in outline and in the distinctive way in which it jerks its tail. 
Economic Status. This is a northern bird which occurs within the bounds of cultivation only in winter and rarely. Few data are available upon its food, but without doubt it is a mouser as it is too small to prey upon larger animals.

\section{Order-Coccyges. Cuckoos and Kingfishers.}

Systematic zoologists are not agreed on the classification of these birds. The present American Ornithologists' Union check-list (1910 edition) recognizes these as composing a full order and divides the Canadian representatives into two suborders: Cuculi, including the American Cuckoos and extralimital families, and Alcyones, the Kingfishers. Distinctive characters are most easily described under the subfamily and specific headings.

\section{SUBORDER-CUCULI. CUCKOOS, ETC.}

This suborder is represented in North America by only one family, Cuculide, comprising the Anis and two groups of Cuckoos.

\section{FAMILY-CUCULID无. AMERICAN CUCKOOS.}

A family represented in North America by three subfamilies, only one of which occurs in Canada-Coccyzince, the American Tree Cuckoos.

\section{Subfamily-Coccyzine. American Tree Cuckoos.}

General Description. Birds with weak feet and yoke toes, two toes directed forward and two backwards (Figure 37, p. 24). The bills are rather long, gently curved, and sharp pointed. The plumage is soft and thin, lacking in cohesion, and has the soft silky feeling associated with many tropical species. The tail is long, soft, and graduated.

Distinctions. May be distinguished from the Woodpeckers, which also have yoke toes, directed two and two, by the difference in the bills and tails. In the Woodpecker the bills are straight, stout, the tip chisel-pointed, and the tail is rather short, very stiff, and bristle-like at the tip.

The Cuckoos are largely tropical in distribution. The two Canadian cuckoos are outliers from the main body of species in warmer latitudes. They are possessed of a sensuous tropical grace and air that are out of keeping with northern climes. This is exhibited in their lithe, sinuous carriage, full round deep throat, long graceful tail, and thin but soft and silky plumage. They haunt hot and humid jungles of shrubbery, and flit across the open spaces with a silent undulating flight that seems in harmony with their exotic nature. English literature is rich in reference to the Cuckoo, but little that is said is applicable to the Canadian Cuckoo. The latter is not an early arriving species and comes in spring with a quietness and a silence that hides its presence for some time after arrival. Its notes, too, are entirely different from those with which European writers have made us familiar. The calls of our birds are less musical but have a charm of their own and a wildness and unusual quality in keeping with their natures. The two Canadian species are very much alike in their calls; a loud startling "Kaow-kaow-kaow" is one of the most characteristic and one that, on the still summer air, can be heard for a quarter of a mile or more. Again they have a "Kuck-kuck-kuck" note like a big clock beating seconds, that has not the range of the above but has considerable carrying power. 
In regard to their parental duties, our birds show considerable more realization of responsibility than the European. They are slightly parasitic in their habits, that is, they occasionally drop their eggs in the nests of other birds and shelve upon them the cares of raising their young, but the practice is not common. The old English word "Cuckold" refers to and is based upon this habit of the European bird. This is not a common practice with the American, as it is with the Old World species, and is perhaps only accidental.

Economic Status. Cuckoos are almost entirely insectivorous, but occasionally take small amounts of wild fruit. Their great value lies in the fact that they show special fondness for certain insects that other species rarely touch. Hairy caterpillars which, on account of their bristly coatings, are safe from most fastidious birds are regularly eaten by Cuckoos. The interior of a Cuckoo's stomach will be found to be lined with a coating of spiny caterpillar bristles set in the walls and projecting from them like fur.

387. Yellow-billed Guckoo. FR.-LE COJCOU À BEC JAUNE. Coccyzus americanus. L, 12.20. Plate XVII A.

Distinctions. The Yellow-billed Cuckoo may be mistaken only for its relative the Black-billed. The yellow on the bill, from which it gets its name, is the easiest means of identification. Additional distinguishing marks are a broad area of suffused cinnamon on the wings, that is conspicuous in flight, and considerably more white on the ends of the tail feathers.

Field Marks. The long flexible outline in flight and the general coloration make this bird recognizable as a Cuckoo. The yellow lower mandible, cinnamon wing marks, and the large amount of white on the tail fix the species.

Nesting. Loose structure of sticks not far from ground.

Distribution. This species is of rather more southern distribution than the next, but the data seem to point to its increase in numbers and range within the past thirty years. Its range just overlaps the southern borders of Ontario, Quebec, and New Brunswick.

SUBSPECIES. There are two races of this species recognized in Canada. The Eastern Cuckoo, the typical form, extends west to the plains.

388. Black-billed Guckoo. FR.-Le COđCOđ À BEC NOIRE. Coccyzus erythrophthal mus. L, 11.85. Plate XVII A.

Distinctions. Can be distinguished from the Yellow-billed by its all-black bill, lack of cinnamon on the wings, and the smaller amount of white tips on the tail.

Field Marks. The above make the best field marks available for the species. The characteristic Cuckoo flight and outline are easily recognized.

Nesting. Loose structure of sticks not far from ground.

Distribution. A bird of wider and more northerly distribution than the yellow-hilled Cuckoo; irregularly in the more settled parts of the country south of the gulf of St. Lawrence and west to the Manitoba line.

\section{SUBORDER-ALCYONES. KINGFISHERS.}

The Kingfishers form a well-marked group represented in nearly all parts of the world. Though evidently adapted to catching fish some have given up their ancestral habits and watery habitats to live in the woods on insects and earthworms. However, all these departures from type are extralimital and mostly tropical; the well known Laughing Jackass of Australia is a large aberrant Kingfisher. The North American Kingfishers are all included under one family, Alcedinidoe. 
FAMILY-ALCEDINID AE. KINGFISHERS.

As there is only one species of the family in Canada the description given under the species will serve for the family.

390. Belted Kingfisher. FR.-LE MARTIN PECHEUR. Ceryle alcyon. L, 13.02. Plate XVII B.

Distinctions. The great ragged crest and slaty-blue back of the Kingfisher cannot be very well confused with any other American bird. The weak feet, three toes in front, the two outer (Figure 36, p. 24) joined for half their length, and the peculiar clumsy grasping surfaces are diagnostic of the Kingfishers.

Field Marks. The ragged crest and large head, general coloration, and habit of sitting motionless on a perch overhanging the water or diving into it with a splash make the Kingfisher easily recognizable in life. bank.

Nesting. Usually on ground at end of a tunnel driven in the face of an exposed earth

Distribution. All of North America, breeding wherever found in Canada.

All frequenters of Canadian waters know the Kingfisher. It sits motionless on a commanding perch over the water watching for the fish below. Suddenly it dashes off, hangs suspended a moment in the air, and then drops with a resounding splash into the water, rising a moment later with a luckless fish in its capacious bill, and is off around the bend of the stream. Within its daily range the Kingfisher knows every perch and branch from which it can get a comprehensive view of its fishing grounds and returns to them again and again. Streams are not its only habitat; it frequents lakes and ponds and even the seashore. The Kingfishers fish sometimes at considerable distances from their nests as they are often seen in country where earth banks such as they require for nesting are few. However, they are adaptable and sometimes use the most unexpected substitutes, such as the earth clinging to the roots of an overturned tree, or the sides of a drainage ditch.

Economic Status. The Belted Kingfisher lives upon small fish, and whether or not this constitutes a grave economic offence is a question that cannot be answered offhand. The minnows caught by this bird along our larger streams, ponds, or lakes are certainly not of importance, but when Kingfishers frequent small preserved trout streams they may possibly commit rather serious depredations. Their effect on the larger salmon waters is less clear. Ordinarily the fish they take are small perch, shiners, chub, and other minnows that frequent the surface or shallow warm water. The number of young game fish that are taken cannot be great. On waters given to the culture of trout the question is different. The fish taken there are comparatively well grown and even if they are not very numerous the Kingfisher cannot be looked upon with friendly eyes by the angler.

On the salmon streams the Kingfishers are regarded with strong disfavour and the guardians are usually busy reducing their number with gun and trap on every possible occasion, and even offer bounties upon their heads and nests. How far this is justified is questionable. In many of these streams the fish have little other food than the smaller of their own species. The large fish, except the spring run of breeders, are all busy eating the small ones. The fry evidently live on micro-organisms and plankton, the fingerlings upon the fry, the parr upon the fingerlings, and so on. The fingerlings are those taken by the Kingfishers. Now if the final number of adult salmon depends on the fingerling, if the fingerling 
is the critical stage in the salmon's life beyond which its chances for survival are greatly increased, the Kingfisher can possibly commit appreciable depredation; but if on the other hand this critical point occurs later, during the sea life of the fish for instance, the effect of the taking of even a considerable number of fingerlings will be negligible. At any rate it will take several Kingfishers to equal the damage done by one comparatively small fish in the waters frequented by the salmon. It would seem, therefore, that the good and evil in the case of the Kingfisher nearly balances.

\section{Order-Pici. Woodpeckers.}

The world wide order Pici is a rather heterogeneous division including numerous subdivisions and there is little uniformity of opinion as to their exact relations. In Canada there is only one family of the order-Picida, the Woodpeckers.

\section{FAMILY-PICIDE. WOODPECKERS.}

General Description. The Woodpeckers are an easily recognized family. They have either three or four toes, as in the Cuckoos, two permanently directed forward, ending in well hooked claws for clinging to the rough bark of trees. In one group, the Three-toed Woodpeckers, one of the hind toes is absent. The bill is straight, stout, and chisel-shaped at the tip (Figure 41, p. 25). The tail is well developed; not remarkably long but stout and ending in stiff bristles that are worn and frayed by pressure against rough bark.

Distinctions. Feet, bill, and tail characters make reliable distinctions.

Field Marks. Tree climbing habits; and flight by series of quick wing strokes with slight pauses between, causing a waved course like a succession of festoons.

Nesting. In holes excavated in trees or stubs.

The Woodpeckers are well known for their ability to cling to perpendicular or overhanging surfaces. The stout chisel-shaped bill is admirably adapted to drilling into wood whence the larvæ of borers or other insects are extracted. The tongue is modified into a long, extensible spear furnished with a sharp point and armed with minute barbs to assist in holding the impaled prey and withdraw it from the wood. The hyoid or tongue bones are so long that in the normal position of rest they wind up over the base of the skull along the crown and in some species penetrate the nostrils beneath the bill-sheath and finally rest their ends near the tip of the bill. As a further aid, large salivary glands secrete a sticky fluid for the tongue to which small insects stick and are caught as with bird lime. A few species, for example the Sapsuckers, have the tip of the tongue frayed out into a sort of brush that is evidently used in gathering up the sap.

Economic Status. Of the general usefulness of the Woodpeckers, with the exception of the Sapsuckers, there can be little doubt. They are almost entirely insectivorous. They pursue wood-boring grubs by drilling holes even in apparently healthy trees and hence they are beneficial not harmful.

393. Hairy Woodpecker. FR.-LE PIC CHEVELU. Dryobates villosus. L, 9.40. Almost exactly like the next species, but larger. Plate XVIII A.

Distinctions. The Downy Woodpecker is the only species with which this is likely to be confused. Size is the best point for differentiation, but the white of the outer tail feathers being solid instead of barred with black, is diagnostic.

Field Marks. The spotted black and white coloration to mark the genus and the size to separate it from the Downy. 
Nesting. In holes drilled in dead stubs or living trees.

Distribution. The Hairy Woodpecker in its various sub species is found over all the wooded parts of Canada, breeding everywhere except perhaps in the most southern portions of Ontario.

SUBSPECIES. The species in eastern Canada is divided into two geographical races, the Eastern Hairy, the type form, and the Northern Hairy, D. v. leucomelas. The latter is the one usually but incorrectly given as the bird of southern Canada. It is of slightly larger size and of more northern distribution, only occasionally coming down into settled districts in winter and perhaps never appearing in the Lower Great Lakes region.

The Hairy Woodpecker gets its name from the white feathers of the back, which fall over the black borders in a loose disconnected way faintly suggestive of hairs. It is one of the common woodpeckers and quite typical of the family in its habits. It is not as familiar about houses or orchards as the Downy Woodpecker, preferring the woods to orchard or shade trees.

Economic Status. Insects constitute 77 per cent of the food of this species; they are mostly beetles, but include ants, scales, and sawflies; 22 per cent is vegetable, almost entirely wild fruit.

394. Downy Woodpecker. FR.-LE PIC MINULE. Dryobates pubescens. L, 6.83. Plate XVIII A.

Distinctions. The Downy can be separated from the Hairy Woodpecker by its smaller size and the black barring on the white outer tail feathers.

Field Marks. Size is the best field mark.

Nesting. In holes drilled in dead trees and stubs.

Distribution. The Downy Woodpecker with its various subspecies occupies all of temperate America, breeding in Canada wherever found.

SUBSPECIES. The species is divided into several geographical races. The form of eastern Canada, the Northern Downy D. p. medianus, is separated from the type form only by a slight difference in size.

The Downy Woodpecker is our commonest woodpecker. It comes close about the house and is quite at home in the orchard and among the shade trees of towns and parks. As it is resident in Canada throughout the year it is of particular value to the husbandman.

Economic Status. Being the most fearless of the woodpeckers and coming close about the fields and houses where it is most needed, it is an invaluable bird. Peering into every crack and crevice of shade and fruit trees and drilling for deeper lying insects it well complements the work of the little Chickadee and Nuthatch. In fact, these three species often travel in company in the winter and there is little in the food line that is overlooked when the three species work together. The food of the Downy Woodpecker is similar to that of the Hairy Woodpecker, but, as would be expected from its smaller size and its more common presence in summer, includes more of the smaller insects. The various scale insects make a larger item in its food and it takes more moth caterpillars, including the Tent Caterpillar and those of the Codling Moth.

400. Arctic Three-toed Woodpecker. BLACK-BACKED WOODPECKER. FR.-LE PIC ARctique. Picoides arcticus. L, 9.50. Plate XVIII B.

Distinctions. A woodpecker with three instead of four toes and a solidly black back.

Field Marks. Except the Red-headed, the only solidly black-backed woodpecker in eastern Canada. The all black back for specific, and the yellow crown patch of the male for generic recognition. Plate XVIII B.

Distribution. The northern coniferous forests, west to the prairie provinces.

$57172-10$ 
A bird of the northern coniferous forest, seldom coming under the notice of the ordinary observer, except towards the verge of present settlement where it is of regular occurrence.

Economic Status. This woodpecker is of growing importance for the protection of the coniferous forest from introduced and other insect pests which have greatly increased in recent years.

401. American Three-toed Woodpecker. LADDER-BACKED WOODPECKER. FR.- LE PIC D'AMERIQUE. Picoides americanus. L, 8.75. Almost exactly similar to the Arctic Three-toed, but with the middle of the back barred with white.

Distinctions. The yellow crown of the male is distinctive of the Three-toed Woodpeckers. This species can be distinguished from the Arctio by the white-barred instead of solid black back. Except the Red-bellied, the only woodpecker in eastern Canada with a barred back.

Field Marks. Yellow crown of male and the black and white barring in the middle of the back.

SUBSPECIES. The form occurring in eastern Canada is the Eastern Three-toed Woodpecker, the type race of the species. In the west, other forms occur.

A much rarer bird than the preceding, but of similar habits, status, and distribution, and extending into the western mountains in subspecific form.

402. Yellow-bellied Sapsucker. FR.-LE PIC MACDIf. Sphyrapicus varius. L, 8.56. Plate XIX A.

Distinctions. The well-defined red cap just covering the top of the head will usually distinguish this species. Some females have a black crown, but the general coloration is always recognizable even in young birds, although in them it is veiled and indicated rather than expressed.

Field Marks. The red cap of both sexes and red throat of the male are the most conspicuous field marks. In other plumages the broad white bar that shows along the wing and the black gorget below the throat are distinctive.

Nesting. In holes in dead trees.

Distribution. Eastern North America from well north of cultivation, southward. Breeds everywhere in eastern Canada excepting in the most southerly portions.

SUBSPECIES. The eastern form of the Yellow-bellied Sapsucker is the type race-the Eastern Sapsucker. In the extreme west another subspecies occurs.

The Sapsuckers have departed somewhat from their ancestral woodpecking habits. Although numerous during migration through southern Canada, they are scarce breeders in the lower Great Lakes region though common elsewhere.

Economic Status. This is the only bird of the family that seems to be harmful. The harm is done in quest of sap, by girdling the trunks and branches of orchards and other smooth barked trees with rows of small squarish pits regularly spaced in horizontal lines penetrating both outer and inner barks to the sap-wood beneath. Several trees may be so tapped and visited in turn as the sap exudes. Though it is primarily the sap which is sought, the insects attracted are also eaten, for though sap is a large item in the Sapsucker's diet, animal food is also necessary.

Although the damage to trees so girdled is not nearly as great as might be expected, they are sometimes permanently injured and even killed. All are weakened and a lodgment prepared for fungoid growth and insects. Unless severely and repeatedly attacked, however, most survive and completely recover. Even forest growth suffers considerable damage; valuable timber trees are attacked and the consequent burr 
growths and wood stains in the manufactured lumber, marking the old, healed attacks of the Sapsucker, reduce the marketable value of the lumber products. The whole question of the damage done by Sapsuckers has been exhaustively discussed in a United States Biological Survey Bulletin, No. 39 , "Woodpeckers in relation to trees and wood products," by W. L. McAtee. Under the heading of defensive measures against Sapsuckers the author advises a limited use of the gun where the species is doing appreciable harm, or the use of poison. If the gun is used care should be taken that only Sapsuckers are killed and it must be remembered that with poison, Hummingbirds and other small birds, especially warblers, are likely to suffer also.

405. Pileated Woodpecker. COCK-OF-THE-WOOD. FR.-LE PIC A HUPPE ÉCARLATE. Phlcotomus pileatus. L, 17. Plate XIX B.

Distinctions. The size of this woodpecker makes identification easy. It can be confused with no other Canadian Woodpecker.

Field Marks. Large size, striking, red crest, and the white on the outspread wings.

Distribution. Once ranging over all of eastern Canada it is now practically confined to the wilder parts and the wilderness of the north.

SUBSPECIES. The Pileated Woodpecker is divided into two subspecies, of which only the Northern Pileated $P$. $p$. abieticola occurs in Canada.

On account of the wanton destruction of this beautiful bird which was once of wide distribution, it is now to be found only in the quiet of the north woods. The colloquial name "Cock-of-the-woods" has been locally corrupted into "Woodcock", and its use for this species is a source of confusion and misunderstanding. The Pileated Woodpecker is not a legitimate object of sport; it will not "lie to a dog", cannot be hunted by sportsman-like methods, and is too small for use as food, but has great value as a forest preserver. It should, therefore, be rigidly protected for economic as well as sentimental reasons.

Economic Status. The Pileated Woodpecker is now restricted to the wildest sections. It is mainly beneficial in the protection of forest trees and, therefore, its greatest value is to the lumberman. Its food is much the same as that of the other woodpeckers, but its superior strength enables it to dig deeply and exhume larvæ and insects that are safe from a less powerful bird.

406. Red-headed Woodpecker. FR.-LE PIC A TÊTE ROJGE. Melanerpes erythrocephalus. L, $9 \cdot 75$. Plate XX A.

Disinctions. The bright red head and contrasting broad masses of black and white body-plumage are easily recognized.

Field Marks. The striking coloration of this species makes it easily recognizable.

Nesting. Generally in holes in dead stubs and occasionally in telegraph and other such poles.

Distribution. A bird of rather southern distribution, only regularly and commonly entering Canada on the southern border along the lower Great' Lakes.

The Red-headed Woodpecker is one of the familiar species about orchards and wood lots. It is, therefore, well known wherever it occurs. The Red-headed has rather less of woodpecker habits than the forms hitherto considered, or it has evolved other flycatcher-like traits in addition to its ancestral ones.

Economic Status. The Red-headed eats fewer larvæ and grubs than other species, and more useful, predaceous ground-beetles. However, $57172-10 \frac{1}{2}$ 
the balance between good and evil is in its favour, for although it eats some fruit, May beetles or June bugs and weevils form a large part of its food. It has been accused of eating fruit and without doubt the charges have some foundation, but careful study has shown that these cases are local and confined to limited areas and perhaps to certain individuals.

409. Red-bellied Woodpecker. FR.-LE PIC DE LA CAROLINE. Centurus carolinus. L, 9.50. Entire back and upperparts sharply and regularly barred with black and white. Whole back of neck to shoulder and, in the male, the top of head, bright red. All remainder and below ashy white with slight olive tinge. Abdomen slightly tinged with red.

Distinctions. The even barring of the whole back and the red colour of the crown and rear neck are exsily distinguished.

Distribution. From the gulf coast to northern United States, occurring as a straggler to the north of the boundary in southern Ontario.

This Woodpecker is of rare and local occurrence in Canada. Its economic status is good although it is fond of wild fruit and occasionally turns its attention to cultivated varieties.

412. Flicker. GOLDEN-WINGED WOODPECKER. HIGHHOLE, HIGHHOLDER, YELLOWHAMMER. FR.-LE PIC DORE. Colaptes auratus. L, 12. Plate' XX B. yellow.

Distinction. A large Woodpecker with the under surface of the wings and tail bright

Field Marks. General Woodpecker-like actions; size; yellow underwing surfaces and white rump conspicuous in flight.

Nesting. Nests in holes excavated in dead stubs, usually in the open, rarely if ever in dense woods. The peculiar inter-relation of distinct species is well illustrated by this bird. Its deserted nesting-holes are made use of by many other species which are incapable of excavating their own. Sparrow Hawks, Tree Swallows, Crested Flycatchers, and some other useful species are thus directly dependent upon Woodpeckers, especially Flickers, for nesting sites. There are many other such cases in nature of interdependence; some are obvious and well known, some we surmise, and others may be that we do not and cannot at present even suspect. This is a cogent reason for caution in disturbing the established order of nature.

Distribution. The Flicker in its various subspecies is distributed all over eastern North America, north to the tree limits. It breeds wherever found in Canada.

SUBSPECIES. The Flicker is divided into several subspecies, the eastern Canadian variety being known as the Northern Flicker $C$. a. luteus.

The most familiar of the Woodpeckers to the general public, as is indicated by the great number of vernacular names that have been appplied to it; only the principal ones are given above. The loud "Flicker, flicker, ficker", of the male and the piercing "Peiu-u" of both sexes are well known and easily recognized sounds. Though a true Woodpecker the Flicker is a pronounced ground feeder and is especially fond of ants, of which its food is often largely composed. It delights to cling to a hollow reverberating tree trunk and beat out rattling tattoos that can be heard for great distances. This noise seems to be made as a call to its mate or may sometimes be from pure exuberance of spirits. The reproductive powers of the Flicker are phenomenal. By taking away the eggs as they are laid it has been known to lay thirty or more in a season. It seems to be able to keep up the deposition until the set is completed.

Economic Status. Ants constitute nearly half the food of the Flicker. The remainder of its insect food consists of both beneficial and harmful species, but the latter noticeably predominate. It takes some fruit, grain, and mast; but on the whole must be considered to be beneficial rather than harmful. Perhaps the worst charge that can be made against 
the species is its scattering of the seeds of the poison oak and ivy and so aiding in the spread of these harmful plants.

\section{Order-Macrochires. Goatsuckers, Swifts, and Hummingbirds.}

In this order are grouped a number of birds that after further investigation may be rearranged. The present classification of the American Ornithologists' Union is avowedly tentative and adhered to only until a permanent system can be agreed upon. The various suborders of the division are more easily recognized by their differences than by their agreements, and those points in which they differ will be emphasized in the following descriptions.

\section{SUBORDER-CAPRIMULGI. GOATSUCKERS.}

This is a widely distributed suborder divided into a number of families. A description of the one family represented in North America will serve for the recognition of the native species.

\section{FAMILY-CAPRIMULGIDA. GOATSUCKERS.}

General Description. The Goatsuckers have flattened heads, very small bills, and enormous mouths, with gape extending to behind the eye (Figure 38, p. 24). The feet are small and very weak and the middle claw pectinated or furnished with comblike serrations as in the Herons (Figure 19, p. 21). The plumage is very soft in texture and coloured in wood browns, neutral buffs, and grey.

Distinctions. The above characters should be sufficient to characterize this family as they are dissimilar to those of any other Canadian birds.

The Goatsuckers were given their name from an old but mistaken belief that they sucked the milk from the goats in the pastures over which they were seen to wheel and circle, and their immense mouths and pink throats gave support to the popular impression. In truth the birds that frequented the pastures were hawking for flying insects that had been attracted by the animals. The birds of this family are nocturnal or crepuscular. They feed entirely upon insects caught on the wing and seldom come to ground except to nest or for repose. Their feet are too small and weak to clasp a branch securely and in perching they normally sit on large branches, lengthwise of them instead of crosswise, as do most birds.

416. Chuck-will's Widow. FR.-ENGOULEvent DE, LA CAROLINE. Antrostomus carolinensis. L, 12. A large Whip-poor-will. See next species.

Distinctions. Size; it is a considerably larger bird than the Whip-poor-will; the long bristles about the mouth with hair-like branches at their base instead of being clean and bare throughout their length.

Distribution. The southern states. Of accidental occurrence within our borders.

The basis for the inclusion of this bird here is the taking of a specimen at Pelee point on lake Erie and another at Pictou, Nova Scotia. It is rare and is similar to the Whip-poor-will in appearance, habits, and notes.

417. Whip-poor-will. Fr.-L'ENgodlevent CRIARd. Antrostomus vociferus. L, 9.75. Coloured in soft indefinite patterns of wood-browns and greys with suggestions of rufous and ochre. There is little broad pattern in the colouring, but much fine detail. On the underparts there is only a faint suggestion of barring, and the coloration of the whole bird is like that of a great brown moth. 
Distinctions. Only to be mistaken for the Nighthawk or the very rare Chuck-will'e Widow. It is easily distinguished from the Nighthawk by the following points: th; throat is dark instead of white; there is a narrow white collar across the base of the throats the final half of the tail feathers, except the middle pair, is white in the male and tipped with buffy white in the female. The spread wing shows no white spot.

Nesting. Eggs are laid directly upon the ground or on dead leaves.

Distribution. Common throughout most of the settled parts of eastern Canada, scarcer in the extreme east, and more common in undisturbed than in highly cultivated sections.

SUBSPECIES. Two subspecies of Whip-poor-will are recognized in North America, of which the Eastern Whip-poor-will, the type form, is the only one occurring in Canada.

There is no other sound in the Canadian woods as poetically mournful as the reiterated call of the Whip-poor-will. The translation of bird notes into words usually requires a stretch of the imagination, but this bird says "Whip-poor-will, whip-poor-will" with unusual distinctness. For a calling station it selects a perch on a fallen tree-trunk, a bare branch, the roof of a building, or even a tent pole. It returns to its various stations regularly on successive nights and seems to visit each in turn. Between periods of calling the bird hawks and wheels through the tree tops in large interlacing circles, sometimes swooping towards the ground in a long pendulum-like swing. In the daytime it seeks the ground in some quiet patch of underbrush where it passes the time at rest. When disturbed by an intruder it rises with a loose, poorly controlled flight that gives no indication of its wonderful command of the air at other times, flutters a short distance over the tangle, and drops again to earth.

The Whip-poor-will is often regarded as identical with the Nighthawk. This is a not unnatural mistake when they are not seen side by side as they are quite similar enough to be confused.

Economic Status. The Whip-poor-will feeds largely upon nightflying beetles, especially May beetles or June bugs.

420. Nighthawk. Mosquito Hawk. BULL-BAT. NIGHT-JAR. FR.-L'ENGOULEvent D'AMḱR IQUE. Chordeiles virginianus. L, 10 . Plate XXI A.

$D^{i}$ stinctions. The Nighthawk and the Whip-poor-will are often mistaken for one another. This species, however, can be distinguished from the Whip-poor-will by the following characters: the throat is white instead of dark, there is no white collar below the throat, and the long mouth-bristles are lacking. The tail is slightly forked instead of round and has little or no white except a narrow subterminal bar. The underparts are distinctly barred and the wings have a white spot at the base of the primaries instead of being all black.

Field Marks. The Nighthawk flies about in daylight and in the early evening, whereas the Whip-poor-will never hawks about in the open until evening. A white spot in the wing shows in flight very plainly, resembling from a little distance a clear cut shot hole. The sudden and perpendicular dive. in the air with hollow booming accompaniment is also distinctive of the species.

Nesting. A clear spot on the ground-usually the bald tops of flat rocks in the open. Eggs laid directly on ground with little or no preparation. Often utilizes the flat gravel roofs of buildings.

Distribution. North and South America, north to the tree limits, breeding in Canada wherever found.

SUBSPECIES. Several subspecies of Nighthawks are recognized in Canada, but the only form occurring in the east is the Eastern Nighthawk, the type form.

Though called Nighthawk this bird has no relation to the Raptores in habit, structure, or outward appearance. Its large eyes directed slightly forward sometimes causes it to be mistaken for an owl by casual observers. This species nests to some extent on the flat gravel roofs of buildings. 
These graceful aeronauts may be seen over almost any city or town as evening draws on, beating about on long, strong wings with slow, powerful, but slightly erratically timed beats. At intervals one will mount in steep spirals higher and higher, and then face earthwards and come nearly perpendicularly down like a falling stone. As it falls a hollow dull tremolo buzz is heard. Just before the observer thinks the bird must dash to the ground it catches itself and glides off safely to repeat the operation. Its notes are not musical, though from the high upper air its hoarse squawking voice comes down softened and harmonized by distance.

Economic Status. Of few birds can more good or less harm be told than of the Nighthawk. Its food is wholly of insects and it takes most of it on the wing, high in the air where many of the insects are mating and at a time when their destruction does the most good. It is a surprisingly small bird when stripped of its thick coat of soft feathers, but requires a great amount of food. A list of the species taken by it includes great numbers of ants, June bugs, squash beetles, chinch bugs, leaf-hoppers, and other obnoxious species. The habit, common in some places, of using this bird as a live target by gunners when practicing is inexcusable and those guilty of it should be rigorously prosecuted. It should be realized that every offence against the laws protecting insectivorous birds is something more than a technical offence against an impersonal state; it is a direct blow at the welfare of the whole community.

\section{SUBORDER-CYPSELI. SWIFTS AND ALLIES.}

A widely spread suborder consisting of one family of which in eastern Canada we have only a single species.

\section{FAMILY-MICROPODID\&. SWIFTS.}

The North American Swifts are divided into two subfamilies, only one of which, the Spine-tailed Swift Choeturince, is represented in eastern Canada.

\section{Subfamily-Chœeturinæ. Spine-tailed Swifts.}

The Swifts are a group of birds superficially resembling swallows, but structurally very different from them, the similarity being brought about by common requirements and not by relationship. A description that is applicable to the whole subfamily is given under the specific heading following.

423. Chimney Swift. FR.-LE martinet des Chemines. Chotura pelatica. I, 5.43. Plate XXI B.

Distinctions. The even, sooty-brown colour lightening on the throat and becoming darker towards the vent, is almost sufficient for recognition. The projection of the shafts of the tail feathers (Figure 39, p. 25) beyond the webs as sharp stiff spines is a positive identification mark.

Field Marks. The peculiar, long, narrow, and rather elub-shaped wings, well shown in the illustration; the nearly continuous quick beating; the dense dark coloration; and the habit of entering chimneys, are distinctive and characteristic.

Nesting. Originally in hollow trees or clefts in rocks, now over most of the range of the Chimney Swift, in unused chimneys. The nest is a firm structure of twigs cemented together with a natural glue furnished by the salivary glands. The edible nests so much in demand by Chinese epicures, are composed of the cement from a closely allied Swift.

Distribution. Eastern North America, north to the limit of cultivation. Breeds in Canada wherever found. 
This is an interesting species, swallow-like in outward appearance and food-hunting habits yet structurally distinct from the Swallows. Ii is an odd example of parallel development of widely separated characters induced by similarity of requirement. Its habits have entirely changed since the advent of the white man and, forsaking hollow trees, it is now practically dependent upon chimneys for sites in which to build its nest. The winter home of the Chimney Swift is unknown. The mystery, however, should not be exaggerated, as there are numbers of Swifts in the western hemisphere looking very like this one and the bird has probably been overlooked in its winter quarters or confused with closely allied forms. The Swift spends much time on the wing and seldom comes to rest except in a chimney or hollow tree. In the autumn, before migration, great numbers gather totogether and at evening seek the shelter of some ample chimney where they pass the night. They may be seen just before dusk flying about in complicated patterns near the chosen chimney, and as the sun sets, circling, until as they throw the wings straight up over the back and drop fluttering into the stack, one rapidly following another, they appear to pour in like a miniature maelstrom. The birds cling to the perpendicular walls of the chimney by hundreds, in masses like lumps of soot. Occasionally one with insecure hold drops a few feet, loosening as it does so, others below; there is a momentary flutter of wings and a small chorus of fine sharp chippings until they find new holdings and settle for the night.

\section{SUBORDER-TROCHILI. HUMMINGBIRDS.}

These tiny, insect-like birds with brilliant flower-like coloration, unbird-like flight, and wonderfully varied form, are a typically American order. In a way, they occupy much the same position in the New World as the Sun Birds do in the Old World, but the similarity between the two is superficial and not one of relationship. Many species are highly specialized and exhibit some of the strangest forms in the bird world, including crests, ruffs, fans, and muffs, exaggerated tails, long plumes, and enormous swordlike and fine awl-shaped bills, but their most striking feature is the brilliant metallic colorations on various parts of the body, that gleam in the sun. They feed largely upon the nectar of flowers. The tongue is very long and protrusive as in the Woodpeckers, with its sides curled over towards the middle to form a double tube frayed into a brush-like tip which makes a most efficient organ for sucking liquids. Numbers of small insects, however, are taken with the nectar and, from feeding experiments on captives, they seem to be necessary to the bird's welfare. They are usually minute forms taken from the flowers from which the nectar is obtained.

Hummingbirds as a group are tropical and subtropical species and increase greatly in number to the south, though one species in the east ranges well to the north.

\section{FAMILY-TROCHILID \&. HUMMINGBIRDS.}

As there is only one family of Hummingbirds, represented in eastern Canada by a single species, see preceding and succeeding headings for description.

428. Ruby-throated Hummingbird. FR.-LE COLIBRI À GEORGES RUBIs. Archilochus colubris. L, 3.74. Plate XXII A. 

distinctive.

Nesting. In a beautiful structure covered with bits of lichens and cobwebs, saddled on the top of a branch.

Distribution. Eastern North America north to the limits of present cultivation.

Hummingbirds fly forwards, backwards, sideways, or remain perfectly stationary in the air with equal ease-another instance of parallel development-a bird flying like an insect yet in structure strictly bird-like. The wings vibrate with a rapidity that can only be measured by the tuning fork method used with insects. This system of flight is fundamentally different in method from that of other birds and consequently the wings differ from the usual type. They are long, narrow, non-flexible, and the keel of the sternum is immensely deepened to give support to the great muscles that move them. In proportion to its wing spread a Hummingbird has a breast keel nearly three times larger than that of a pigeon, a bird of average flight, or forty times larger than that of an albatross.

Economic Status. When it is remembered that some of the smallest insect pests are the most destructive, we can realize that possibly the economic importance of the Hummingbird may be greater than suspected. Besides nectar, its food seems to be composed of small flies, gnats, minute bees, wasps, and other flower-haunting and pollen-eating forms. Apparently no harm can be charged against the species and it may do good out of all proportion to its size.

\section{Order-Passeres. Perching Birds.}

The order Passeres, Passerine or Perching Birds, is the largest and most important division of modern birds. The lower and more generalized types of birds have in the past been in the ascendant; but to-day the highly specialized Passeres are dominant; they constitute nearly if not quite half of our present living forms and are put at the head of the classification by systematists. They have a greater number than any other order, of characters that are common to themselves but special in relation to other orders, for instance, the highly developed larynx or singing organ, with complicated muscular control and many other special characters. Generally, a bird may be referred to this order by a process of elimination, as not belonging to any of the previous orders. The feet (Figure 42, p. 25) are not webbed, the hind toe is as long as the middle one, and the whole foot is well adapted for perching. The bill is hard and horny, without cere or soft base, and the nostrils do not communicate with each other as in some of the other orders. Two suborders are represented in Canada: Calmatores, the Songless Perchers; and Oscines, the Song Birds.

\section{SUBORDER-CLAMATORES. SONGLESS PERCHERS.}

This suborder is constituted upon a basis of anatomical structure. The name Songless Percher is not intended to indicate that the birds are silent, but that they are less tuneful than the Oscines, with a larynx less highly specialized. Only one family of this suborder occurs in Canada, the Tyrannidee or Tyrant Flycatchers. 
FAMILY-TYRANNIDA. TYRANT FLYCATCHERS.

General Description. The Tyrant Flycatchers are most easily recognized among Canadian birds by their bills (Figure 43, p. 25) which are comparatively long, somewhat flattened and broadened at the base, wider than high, and slightly hooked at the extreme tip.

Field Marks. Easily recognized in life by their characteristic habits and attitudes which soon become familiar to the discerning observer. When perching they usually sit in an upright attitude, quite still except for an occasional spasmodic jerking of the tail. On observing a passing insect they dash out and capture it in the air with a nimble evolution and quick snap of the bill.

The Flycatchers are one of the most difficult families to identify specifically. Some of them are strongly characterized, but of the commonest ones, several species are so nearly alike as to puzzle the experienced ornithologist when they are silent or not in normal habitats. In identifying thern in life, attention should be paid to their notes. These and the type of habitat in which they are observed are good guides to differentiation in the case of the more puzzling species.

Economic Status. Their food consists almost entirely of insects, caught on the wing, for which the broad bill is well adapted. As they take most of their food in the air near the ground they catch varieties of insects not taken by other birds. The species found in their stomachs include beetles, flies, wasps, crane flies, ants, grasshoppers, tent caterpillars, and moths. Indeed, nearly all the harmful species of insects are found in their crops and they must be classed as highly beneficial.

443. Scissor-tailed Flycatcher. Muscivora forficata. L, 13 (about). (Tail, 9.) This Flycatcher is an occasional wanderer within the borders of Canada, from subtropical America. It is unmistakable - a light, ash-coloured bird about the size of a Kingbird, with darker wings, scarlet or orange cap and the same colour under the wings, and with a great tail 8 to 9 inches long, split to a depth of 6 inches or more, which, when the bird is at rest, opens and closes like a pair of gcissors. Strangely enough one of our best authenticated records comes from York Factory on Hudson bay. With this record before us, it is difficult to state positively what species may or may not be found anywhere in Canada.

444. Kingbird. BEE MARTIN. FR.-LE MOUCherolle DE LA CAROLINE. Tyrannus tyrannus. L, 8.51. Plate XXII B.

Distinctions. The black and white coloration, orange crown patch showing in moments of excitement, and the black tail conspicuously tipped with white as if dipped in white paint.

Field Marks. Easily recognized in life by the above marks. The orange crown, however, is rarely seen. In life, the head and tail appear to be dead black in colour in strong contrast to the pure white below.

Nesting. In trees, 5 to 40 feet above the ground; the nest a well built structure of weed stalks, grasses, and waste vegetation lined with plant-down, rootlets, and fine grasses. The fact that the bird not uncommonly nests in orchards and near cultivated fields is much in its favour. found.

Distribution. North America north to near tree limits. Breeds in Canada wherever

The Kingbird is a familiar species, coming close around houses and orchards, and the presence of a pair nesting close by is one of the best preventives of the depredations of hawks or crows. None come anywhere near the Kingbird's home, without being vigorously challenged. The Kingbird flies at the intruders with an energy that is surprising in so small and weak a bird. It cannot do them any real harm, but drives them away and its outcries give wide notice of the impending danger. Owing to 
its small size and agility in the air, it can attack a large enemy from any quarter and is practically safe from counter attacks from anything heavier and less agile.

Economic Status. The name Kingbird is of obvious application, but the other term applied to it, "Bee Martin," naturally raises suspicion as to its feeding habits. It is accused of catching honey bees, and most circumstantial accounts of its doing so are given credence. The record given below shows that the charge of taking bees is to some extent true, but it shows also that the bees caught are mainly drones that can well be spared. The old story of the Kingbird opening its brilliant crest to decoy the bee within reach under the impression that it is a flower may be dismissed as groundless folk-lore, though it has received wide circulation and acceptation. Of 624 Kingbirds' stomachs examined by the United States Department of Agriculture in 1911, 22 contained a total of 61 bees: 51 of which were drones; 8 , workers; and 2 were indeterminate. The remainder of the food consists of other insects, including many noxious forms and a little wild fruit and berries.

452. Grested Flycatcher. Great CRested FlyCATCHer. FR.-LE MOJCHERolle $\grave{\Lambda}$ HOPPE. Myiarchus crinitus. L, 9.01. Olive-brown above, turning to rufous on the inner webs of the tail. Throat and upper breast, ash-grey. Underparts, sulphur-yellow. Distinctions. The above coloration is distinctive. No other Flycatcher in eastern Canada is similarly coloured.

Field Marks. The bright yellow colour below and the long rufous tail are the most striking recognition marks. The loud, hoarse cry, a long drawn "wheeeep" and a lower "whip-whip-whip," are very characteristic though sometimes mistakable for the notes of the Olive-sided Flycatcher.

Nesting. In holes abandoned by woodpeckers. The bird shows a remarkable preference for cast snake skins as nesting material. Scarcely a nest of the species but contains one or more.

Distribution. Eastern North America. In Canada all along the southern border, breeding wherever found.

A Flycatcher of the woodland tree tops. Its voice is constantly heard in the summer, but rarely at any distance from dense forest.

Economic Status. Beetles, locusts, ants, crickets, flies, and moths constitute the bulk of its food. It takes more parasitic wasps and beetles than most birds but not enough to counterbalance the pests it destroys.

456. Phoebe. BRIDGE PEWEe. Fr.-LE MOUCherolle BRUN. Sayorris phoebe. L, 6.99. Plate XXIII A.

Distribution. The small, greenish Flycatchers are perhaps the most difficult of American birds to separate. Fortunately each has a typical habitat and characteristic note which form good guides to differentiation. The Phoebe is the largest of these puzzling little birds and the most easily recognized. It is most likely to be confused with the Wood Pewee, but examined in the hand, the larger and stouter legs and feet of this species are easily recognizable.

Field Marks. The head of the Phoebe seems a little darker and in stronger contrast to the body than in the other Flycatchers. The sideways sweep of the tail is characteristic and in adults the lack of wing bars. The note, however, a quickly uttered Phoe-be with a strong accent on the first syllable, is the most easily recognized field mark. The Wood Pewee's note is long-drawn and that of the Least is short and explosive.

Nesting. A large structure of mud, moss, and grasses under bridges, the overhang of buildings, or ledges of rock. found.

Distribution. Eastern America, north to near tree limit. Breeds in Canada wherever

No place suits the Phoebe so well for nesting as the flat timber or projecting ledges of an old bridge over some little stream where the air 
over the water abounds in insect food. In many parts of the country scarcely a bridge but has its pair of Phoebes in the summer. However, the mud nests are not restricted to bridges but are plastered on the slightest projection under the eaves of an outbuilding or even under the family porch. It is a friendly, familiar bird and comes close to man wherever it finds a welcome. Unfortunately its great nests are occasionally the dwelling place of innumerable parasites, in other words bird-lice. The usual course when they appear is to knock the nest down with a stick and apply boiling water. The application of common insect powder to the nest is better. This will kill the parasites and help to retain about the house this easily domesticated and attractive bird.

459. Olive-sided Flycatcher. FR.-LE MOdCHEROLle AdX COTÉs OLIVE. Nuttallornis borealis. L, 7.39. Much like a large Phoebe, but with less olive and with extensive masses of dark colour on either side of the chest.

Distinctions. In the hand the conspicuous dark patches at the sides of the chest, and the dark under-tail coverts with light tips will separate this species from the Phoebe which it resembles. At the sides of the back, usually concealed under the closed wings, though occasionally displayed over them, are patches of fine silk-like plumage of pure white or cream colour. These will distinguish the Olive-sided from any other species.

Field Marks. In life the Olive-sided looks more like a dark breasted Kingbird than a Phoebe or other Flycatcher. The dark chest areas separated by a line of white, however, distinguish them with comparative ease. When the white silky feathers show over the wings at the sides of the lower back, as sometimes occurs, the species cannot be misidentified. The call notes are somewhat similar in tone and execution to those of the Crested Flycatcher, but a little attention and experience will enable the hearer to distinguish between the two.

Distribution. North America. Breeds in Canada from the tree limits to the boundaries of regular cultivation.

This is typically a bird of the burnt ridges of the north. Its favourite perch is the top of a tall lone stub in the open, from which its loud, penetrating voice is heard far and wide. In migration it is rather scarce and local in distribution and though great numbers pass through the populous southern counties it is usually regarded as a scarce migrant.

Economic Status. It is too rare in settled districts to have great economic value, but it is distinctly beneficial.

461. Wood Pewee. FR.-LE MOUCHerolle VERDÂTRE. Myiochanes virens. L, 6.53. Very similar in coloration to the Phoebe but smaller.

Distinctions. The Wood Pewee can be separated from the Phoebe and other Flycatchers of comparable size by its short tarsus and long wings, these being decidedly longer than the tail.

Field Marks. The Pewee never flirts its tail as does the Phoebe. The sides of the breast are also slightly darker, giving a better defined and narrower light median line. Its best identification mark, however, is its call-note which is much like that of the Phoebe but drawn out into a long pee-e-weee without appreciable accent but with a rising inflection at the end. The female varies the call by dropping the last note, making it pee-e-e-e.

Nesting. A well made but slight structure of fine fibres and rootlets covered with lichens and saddled on a branch, 20 to 40 feet from the ground.

Distribution. It is distributed over nearly all of eastern North America west to the prairies, breeding in Canada wherever found.

The long-drawn plaintive pee-e-we of this bird is a characteristic sound of the open woodlands in the spring, and after other birds have relapsed into mid-summer silence one still occasionally hears the mournful note. 
Economic Status. The food of the Wood Pewee is quite similar to that of the other Flycatchers, but modified, of course, by its woodland habitat. As it is not retiring and frequents open groves and orchards freely, it is of direct benefit to the agriculturist.

463. Yellow-bellied Flycatcher. Fr.-LE MOdChERolle À VENTRE JAUNE. Empidonax flaviventris. $L, 5 \cdot 63$. Similar to the Wood Pewee and the Phoebe in colour, but smaller than either and with the browns and olives of those species replaced by distinct olive-green and the whites by dull sulphur-yellow.

Distinctions. The distinctly yellow colour of the whole bird makes this the most easily recognized of the small Flycatchers.

Field Marks. The yellow colour, especially on the throat, is the best sight mark. The notes te-pee- $a$ are distinctive - three syllables, with accent on the middle one. Its pe-wick is something like the name call of the Phoebe, but the first syllable is not accented.

Nesting. On ground; nest built of moss and lined with grasses.

Distribution. From the Great Plains east and north to the edges of cultivation. Breeds in Canada along the northern boundary of its range, not in the lower Great Lakes region.

Another woodland Flycatcher; but one that is less confined to large timber. Thickets bordering heavier woods seem to be its favourite locality.

Economic Status. Food habits very similar to those of the other small Flycatchers. Its normal station on the edges of woods bordering cultivated land makes it of value to the agriculturist.

465. Acadian Flycatcher. LITTLE GREEN-CRESTED FLYCATCHER. Empidonax virescens. L, 5.63. A small Flycatcher of about the same size as the Yellow-bellied, Traill's, and LeastFlycatchers; smaller than the Wood Pewee; and much smaller than the Phoebe. In colour, like the Phoebe but distinctly olive-green above and more yellowish below. Wing-bars rather prominent.

Distinctions. This species agrees so closely in size and coloration with Traill's and the Least Flycatchers as to make identification most difficult. It is not so yellow in colour as the Yellow-bellied, there being no pure yellow on it anywhere, but it is the yellowest and greenest of the other small Flycatchers. It is very rare in Canada and new records should be accepted only on the authority of experts.

Distribution. Eastern North America north to the borders of Canada along the western end of lake Erie.

466. Traill's Flycatcher. FR.-LE MOUCHEROLLE DES AULNES. Empidonax trailli. L, 6.09. A small Flycatcher, slightly larger than the Yellow-bellied or the Least and of almost identical coloration to the latter and the Acadian.

Distinctions. The back is browner than in the Acadian and without its decided suggestion of green. From the Least, size is sometimes the only means of differentiation.

Field Marks. Colour or size details are of little use in the field determination of this or the next species. Habitat and call notes are, however, reliable. Traill's Flycatcher is a bird of the alder, willow, or raspberry thickets, and overgrown marsh edges; the Least Flycatcher is a woodland bird; and though either may be occasionally found in other habitats the surroundings are usually a good guide to identification. The call notes, however, make recognition easy. Traill's are ee-zee-e-up with stress on the second syllable and the Least utters quickly an explosive che-bec that is sometimes repeated several times.

Nesting. In a crotch of small growth near the ground; in nest of coarse grasses, plantdown, and fibres lined with grasses.

Distribution. Traill's Flycatcher as a species inhabits nearly all of North America. The eastern subspecies, the Alder Flycatcher, is found from the east coast of Canada west across the mountains.

SUBSPECIES. Two subspecies of Traill's Flycatcher occur in Canada. The eastern form, the Alder Flycatcher $E$. $t$. alnorum, is the only one that occurs within the area under consideration. The Western Alder Flycatcher $\mathbb{E}$. $t$. trailli is a more southern and western form. 
Economic Status. Similar to that of the other Flycatchers. Its food is almost entirely insects, the species destroyed being mostly those frequenting waste land.

467. Least Flycatcher. CHEBEC. FR.-LE PETIT MOJCHEROLLE. Empidomax minimus. L, 5.41. The smallest of our Flycatchers. In general coloration of the Phoebe-like flycatcher type and almost indistinguishable from the Acadian and Traill's.

Distinctions. Browner on back and without the distinct green suggestion of the Acadian, but almost identical with Traill's in colour, from which it can somretimes only be separated by size. Its habitat in woodland localities instead of shrubby wastes offers a suggestion as to its identity and its call note is different from that of any other species. This call is a quick explosive che-bec, sometimes repeated several times, with a not distant resemblance to a series of hacking coughs.

Nesting. Usually in a crotch 15 to 30 feet from the ground; in nest of plant-down, fine wood fibres, rootlets, and long hairs.

Distribution. Throughout Canada west to the mountains and north beyond oultivation. Breeds in Canada wherever found.

This is a bird of the orchard and the trees about the house, overgrown fence-lines, and other familiar localities where close proximity to cultivation makes its services of noteworthy benefit.

Economic Status. The food of the Least Flycatcher does not differ materially from that of the other members of the family, but its familiarity and confidence bring it close to man where its useful qualities have the maximum influence.

\section{SUBORDER-OSCINES. SONG BIRDS.}

The suborder Oscines is a large division of birds, placed at the head of the list as exhibiting the highest development of the class $A$ ves. It includes a great number of families and species, the exact relationships of many of which have never been satisfactorily defined. According to present American usage the suborder begins with the Larks and ends with the Thrushes which are regarded as constituting the most highly developed family. The characters differentiating the Oscines from the Clamatores are technical and anatomical and beyond the scope of a popular consideration of the subject. As might be gathered by the name the high development of the vocal organs and muscles attached are important points in the classification. The members are more easily recognized from family descriptions than under this more general heading.

FAMILY-ALAUDID更. LARKS.

The Larks comprise a large family of wide distribution. The systematic distinctions that characterize the family are rather technical, and as there is only one species in Canada to consider, they will be described under the species on the next pages.

474. Horned Lark. SHORE LARK. FR.-L'AlOUETTE ORdINAIRE. Otocoris alpestris L, 7·75. Plate XXIII B.

Distinctions. The long hind toe nail (Figure 44b, p. 25), is one of the distinctive marks of the Larks. However, this is shared with the Titlark (Figure 60, p. 27), and the Longspur ; the latter, however, is a sparrow having the typical conical sparrow bill, very different from that of the Larks. The yellow throat, with black gorget below, and the erect-like horns or crest tufts, are distinctive of the Horned Lark (Figure 44a, p. 25). marks.

Field Marks. The colour marks above and the horns make easily recognizable field 
Nesting. On ground, in nest of grass often amidst snow drifts in early spring.

Distribution. The Horned Lark in its various forms ranges over all of North America.

SUBSPECIES. The Horned Lark is divided into many geographical races or subspecies. It has a very wide range in North America and living under many and varied conditions has developed in different parts of the country along different lines. Thus the desert form is small and pallid or bleached, whereas the northeastern, which is the type form, is large and strongly coloured. The commonest form in eastern Canada is the Prairie Horned Lark 0 . a. praticola. Originally when the country was well wooded this was probably the prairie form, and did not occur in eastern Canada. The making of clearings, artificial prairies, has permitted it to come east, where it is to-day the breeding form. In the north, east of Hudson bay, occurs the typical or originally described form $O$. a. alpestris at present without a recognized common name and here called the Eastern Horned Lark. This is a large bird with a strong suffusion of yellow over the face and eyebrow line. As the average difference is only about half an inch in total length and as all intermediate sizes occur it can be seen that the differentiation between the forms may be somewhat difficult. An attempt to show the difference in coloration is made in the illustration. The Eastern Horned Lark occurs within the settled districts of eastern Canada only as a winter migrant and is rare except in the Maritime Provinces where it is probably the common winter form. Another race, Hoyt's Horned Lark O. a. hoyti, is a northern form, breeding west and northwest of Hudson bay. It is about as large as the Eastern and has the general coloration of the prairie form. The brownish instead of greyish ear coverts should identify it, but the difference is not great. This form occurs occassionally in the lower Great Lakes region as a winter migrant.

The distribution of the various races and their migrations in Canada have not been completely worked out and the difficulty of exact determination is so great that no subspecific determination should be made without expert assistance and a good series of authenticated specimens for comparison.

The Horned Lark is a bird of the open, frequenting bare fields, beaches, or roadways. In the winter the seeds of weeds left projecting from the snow are its main food supply, and numbers frequent travelled roads for the weeds that grow at their sides and for the partly digested grain dropped by the horses. Occasionally large winter flocks appear. It is in such cases that the rarer migrant forms should be looked for.

\section{FAMILY-CORVIDA. JAYS AND CROWS.}

The Crow family is very large and diverse, including many beautiful and highly coloured birds; indeed the famous Bird of Paradise is closely related to this family. The bill (Figure 45, p. 26 ) is the most easily distinguished character. It is moderately long and stout with a well arched culmen. At the base are tufts of dense, stiff, bristle-like feathers pressed close to it and covering the nostrils. The Woodpeckers and the Titmice have a suggestion of this, but the latter are all small and the former well characterized otherwise. They are not songsters in any sense of the term; their voice is hoarse and raucous, but the complexity of their vocal organs is very great and some of them can be taught to articulate words. They are amongst our most intelligent species and by some authors have been put at the head of the whole avian list.

$$
\text { Subfamily-Garrulino. Magpies and Jays. }
$$

Medium-sized birds, many of them brilliantly coloured and with ornamental crests and flowing tails. They can be most easily recognized under their specific headings.

475. Magpie. american magrie. Fr.-PIE d'amerique, Pica Pica. L, 15.20. (Tail 10.) Only slightly larger in body than a Blue Jay but much longer owing to the 
great tail some 10 inches long. Strikingly coloured in sharply contrasted masses of black and white. Head, neck to upper breast, back, tail, and much of wings, black, glossed with green on wings and tail. A conspicuous white bar on shoulders over wings. Inner webs of primaries, lower breast, and below, all white.

Distinctions. Easily recognized by the very long tail and the strong black and white contrasts in colouring.

Distribution. As a species the Magpie occurs in the north temperate regions of both the New and Old Worlds. The American form is properly a bird of the west, regularly coming to the central prairie provinces and occurring occasionally farther east.

SUBSPECIES. The American Mapgie is a subspecies, under the trinomial P. $p$. hudsonia, of a species common to both New and Old Worlds, and differs from the European form in slight details only. This is a matter for experts.

The Magpie is with some doubt included among the native birds of eastern Canada. The species is common in the far west and we have a number of records in the Maritime Provinces and lower Great Lakes region as well substantiated as is possible without specimens. In 1879 a number of Magpies imported from England were liberated at Levis opposite Quebec. Some of the records may refer to descendants of these introduced birds and not to natives. Specimens for the determination of these eastern birds are greatly desired. The species is too rare to require economic discussion.

477. Blue Jay. FR.-LE GEAI HUPPÉ. Cyanocitta cristata. L, 11.74. Plate XXIV A.

Distinctions. Well characterized by crest and colour.

Field Marks. The predominance of blue in the general coloration, the white tail borders, and the crest. The flight of the Blue Jay is easily recognizable. Its numerous calls are distinctive, ranging from the loud raucous jay-jay, through its barn door squeak, to many quiet conversational chuckles.

Nesting. Nest of twigs and rootlets 10 to 20 feet from the ground.

Distribution. Eastern America from the borders of settlement to the gulf of Mexico. Breeds wherever found in Canada.

The Blue Jay is alert, inquisitive, and mischievous. A strange noise in the woods or a moving figure attracts him and he steals quietly up to it; on discovering an enemy he flees shrieking away in exaggerated fright. In this way Jays have spoiled many careful stalks and caused great annoyance to hunters. In the autumn he is provident, and gathers acorns which he carefully stows away in bark crannies and like places. Whether he ever returns to his stores may be open to some doubt.

Economic Status. Economically the Blue Jay occupies a doubtful place; in food habits it is omnivorous, eating in turn, insects, fruit, acorns, grain, eggs, or young birds. Undoubtedly acorns in their season form its staple food. It is a bird that should be discouraged about the orchard when other more useful birds are nesting.

484. Canada Jay. WHISKEY JACK. MOOSE BIRD. MEAT BIRD. CAMP ROBBER. Fr.-LI GEAI DU CANADA. Perisoreus canadensis. L, 13. Plate XXIV B.

Distinctions. Size; soft, neutral-grey coloration with black cap and white forehead are distinctive. The juvenile, rather rarely seen in early plumage, has an evenly dark head and neck. All have loose, fluffy, ragged plumage.

Field Marks. Size, even grey coloration, and white forehead and face.

Nesting. Nests of twigs and fibres, closely felted with fur and feathers into a compact deeply-cupped structure which serves as a protection to the eggs which are sometimes incubated at a temperature of 30 below zero Fahrenheit.

Distribution. The northern coniferous woods across the continent.

SUBSPECIES. The Canada Jay is divided into a number of very slightly differentiated subspecies. In eastern Canada, the Eastern Canada Jay, the type form, is the generally distributed one, with Labrador Jay $P$. c. nigricapillus inhabiting Newfoundland and the Ungava peninsula. 
The Canada Jay has most of the characteristics of the Blue Jay in an exaggerated form. Every camper in the northern woods knows Whiskey Jack. No sooner is a new camp fire lighted than it appears, looking expectantly for waste scraps. The offal from dressed game is eagerly sought and hardly has the sound of the rifle shot died away before the Whiskey Jack is on hand and expectant. Vocally the bird has all sorts of surprises for the uninitiated. In fact, in its proper habitat any bird sound that cannot be referred to any other possible species may be tentatively attributed to the Canada Jay.

Economic Status. A bird of the unbroken forests, and only rarely seen in populated areas. Its status is probably very similar to that of the Blue Jay, but its retired habitat removes it from any conflict with the agriculturist.

\section{Subfamily-Corvino. Crows.}

The Crows form a well marked subfamily of remarkably similar appearance. They are common almost everywhere and a reference to Plate XXVA is sufficient description. The European Rook belongs to this division.

486. Raven. FR. - LE conbeat. Corvus corax. L. 22. Like the Crow (Plate XXV A) but larger.

Distinctions. The Raven is in general appearance a very large Crow. The most obvious distinction is the long pointed shape of the feathers on the throat, each lying distinct on the other and not softly blended together as in the Crow.

Field Marks. In addition to size, which is always an uncertain criterion in wide open spaces, the voice is the most certain guide. The croak of the Raven is hoarse and rattling, not clear and distinct like the caw of the Crow. However, young Crows have notes almost indistinguishable from those of the Raven and where both species occur, vocal characters are not always reliable guides. When one sees a Raven one can easily imagine marked characteristics of form and flight, but it must be confessed that they seldom become obvious to the ordinary observer until after the identity has been determined.

Nesting. Usually on cliff ledges, sometimes in trees; in nest of sticks.

Distribution. The species is found in both the Old and the New World far into the polar regions, where its black coat against the general whiteness sounds a warning against too ready tendency to stretch the protective coloration theory to cover the whole of animated creation. It once occupied all of Canada, but now is restricted to the most unsettled parts in the north and southward along the mountain ranges of both coasts to well into the United States.

SUBSPECIES. The Raven is divided into several geographical races. The European is the type form. In Canada, we have the Northern Raven C. c. principalis. The differences between them are slight.

The Raven is traditionally a bird of ill-omen. Sombre of colour, dismal in voice, solitary and wild of habit, it fills in the north the place of the Vulture in the south. The Raven holds aloof from the haunts of men. As civilization has advanced into the primeval vastnesses, the Raven, unlike its close relative the Crow, has retired and is to-day what it was in the beginning, a bird of the wilderness. Knowing only the physical requirements and food habits of the two species, one would naturally think that the Raven could thrive as well under civilization as the Crow. It is omnivorous and can adjust itself to almost any food supply. It is hardy and can live in climates and under conditions where its weaker congener can not exist, yet for some unexplained cause, the Crow increases and the Raven disappears when settlement advances.

$57172-11$ 
Economic Status. The Raven eats both animal and vegetable food, but has a strong partiality for the former. It seeks the offal from the hunter's dressed game, or the game itself if it is available. It lurks about the outskirts of bird rookeries and makes dashes for eggs and young. By the sea it searches the shores at low water for crabs and other sea life and for anything edible that may be washed up. Avoiding cultivation as it does it has little direct influence on the crops.

488. American Crow. FR.-LA CORNEILLE D'AMÉRIQUE. Corvus brachyrhynchos L, 19.30. Plate XXV A.

Distinctions. May be mistaken for Raven but distinguished from it by size and the absence of the long, pointed, lanceolate feathers on the throat.

Field Marks. General appearance, with which one soon becomes very familiar.

Nesting. In trees; in nest of sticks.

Distribution. All of temperate North America.

SUBSPECIES. Two subspecies of American Crows occur in Canada, but in the east we have only the type form, the Eastern Crow.

Whereas the Raven retreats before the advance of civilization, the Crow increases. It is omnivorous, feeding readily on anything from carrion to freshly sprouting corn. Without doubt the Crow has increased enormously in the country since the removal of the forests, and probably its advent in eastern Canada was coincident with the arrival of the white man. The Crow is a partial migrant. Most of the birds go south in winter, but slaughter-houses and garbage dumps in the neighbourhood of cities and towns have induced numbers to become permanent residents.

Economic Status. The economic status of the Crow cannot be summed up in a few words. It undoubtedly does much good but it also does much harm. Moreover the harm is concentrated and easily measured whilst the good is scattered and not easily estimated. The detailed results of nearly a thousand stomach examinations and testimonies from all over North America are published in Bulletin No. 6 of the United States Department of Agriculture, by W. A. Barrows and E. A. Schwarz. The greatest complaint against the Crow arises from its fondness for sprouting grain, especially corn. Corn was found to constitute 29 per cent of its annual food and strangely enough, from May to August, constituted only from 8.4 to 17.7 per cent and was greatest in December, 48.2 per cent, when the grain must have represented gleanings from the bare fields. Insects form a large part of the Crow's food and balancing the useful with the harmful species, the result is obviously in the bird's favour. Mice and other rodents and reptiles are also eaten very extensively and are preferred to all other food. In the autumn, mast (acorns, beech-nuts, etc.) is eagerly sought. Judged by food habits alone, therefore, the Crow is a valuable bird. However, this is not all the tale, for the Crow does harm that cannot be overlooked. It matters little to a farmer that the Crows destroy all the cut worms in a field if they also pull all the grain. On the whole, there seems to be no very good reason for extending any greater measure of protection to the Crow; it is in no danger of extinction and probably needs to be controlled.

\section{FAMILY-ICTERIDE. AMERICAN STARLINGS.}

This family includes the Blackbirds, Orioles, and Meadowlarks, which are the American representatives of the European Starlings. They are closely related to the Sparrows and clear differentiation cannot be made 
between them in a popular description. Most of them have rather long, pointed, tapering bills (Figures 46, 47, 48, 49, p. 26) and some have the middle of the culmen running up in a short keel on the forehead. The Bobolink and the Cowbird have quite sparrow-like bills, but they are shortened Icterine rather than Passerine bills. These species can also be easily separated by their marked colour patterns.

494. Bobolink. SKUNK BLACKBIRD, RICEBIRD. FR.-LE GOGLU. Dolichonyx oryzivorus. L. $7 \cdot 25$. Plate XXV B.

Distinctions. The spring male in its striking piebald plumage is unmistakable. The female and the autumn birds of either sex show no colour relation to the spring male and are easily confused with some of the sparrows (bill, Figure 46, p. 26). The newly plumaged autumn birds are yellowish-buff in colour, unstriped below and heavily striped above. The spring female, more worn and faded and slightly olivaceous, looks much like a female House or English Sparrow, but the decidedly streaked back and crown and the buffy line over the eye are distinctive.

Field Marks. The male in spring needs no special mention of field marks for recognition; the streaks and yellowness of other plumages and the buffy eye and crown stripes are good recognition marks. These with habitat and general actions should prevent confusion.

Nesting. On ground; nest built of grasses.

Distribution. North America, wintering in South America; in eastern Canada, along the southern border breeding wherever found.

The Bobolink in spring and summer is a bird frequenting the hay and clover fields. It can be seen any summer's day perched on the surrounding fences or launching into the air on quivering wings, pouring forth its song of ecstasy. Later in the season the rollicking male doffs his parti-coloured gayness for the duller ochre and brown stripes of the female. His song is replaced by metallic clinks, and with hundreds of others of this species joined together in flocks he seeks the marshes until autumn. On leaving Canada for his winter home in South America he stops for a time in the rice fields of the Carolinas and here he is hailed not as Bobolink, the merry songster, beloved for both practical and sentimental reasons, but as the plaguy "Rice Bird" that settles upon the crops in thousands and causes decided damage. In the south he is shot and sold for food in great numbers.

Economic Status. The Bobolink in Canada is an irreproachable bird who charms us with his song and whose bad habits have yet to be discovered. In May and June, 90 per cent of its food consists of injurious insects, and 10 per cent of weed seeds with a few useful insects. In July and August a very little grain is added. ,Yet this bird is regarded as a pest in the southern States.

495. Cowbird. cow Blackbird. Fr.-L'Gtournead ondinatre. Molothrus ater. L, 7.92. Plate XXVI A.

Distinctions. A small Blackbird with a seal black head and neck. The female is ashy-brown, lighter on throat, and can be distinguished from any of the sparrows, which she resembles in having a conical bill, by the even, unmarked coloration.

Field Marks. Small Blackbird with short conical bill, a harsh rattling note, and grating squeak.

Nesting. Eggs laid in the nest of other, usually smaller species, on the ground or in low situations.

Distribution. Over most of North America. In Canada north to the limits of cultivation. Common except in the extreme coastal provinces of the east.

The Cowbird is our only habitually parasitic bird. It never builds a nest or incubates or cares for its young. In the absence of nesting birds it takes the opportunity of depositing one of its own eggs in the unguarded

$57172-11 \frac{1}{2}$ 
nest. Uusally the birds so imposed upon accept the foreign egg without protest, at other times there is strong objection and final resignation. In a few cases, the nest is deserted or a new nest is built over the offending egg, as is sometimes done by the Yellow Warbler. On incubation an interesting case of adaptation is shown. The Cowbird's egg usually hatches a few hours before those of the original occupant of the nest and consequently the changeling is strong and well grown when the proper occupants of the nest break their shell. It can monopolize the food, thus increasing the difference in strength, and is able finally to hoist its competitors from the nest to perish on the ground while it receives the attention that should have been given to the whole brood. Thus practically every Cowbird means the destruction of at least one brood of another species and probably the Cowbird must be considered one of the greatest enemies of the species imposed upon. Once the foster parents accept the intruding egg they do not make any distinction between it and their own. The Cowbird receives its name from its habit of following cattle, evidently attracted by the flies and insects which gather about those animals.

Economic Status. From a study of their food, Cowbirds would seem to be purely useful birds. They consume large amounts of weed seeds and harmful insects and only small quantities of grain or fruit, the former largely waste and the latter wild. Their effect upon other equally useful birds, however, puts a different complexion on their activities. Practically every Cowbird raised to the fledgling stage means the elimination of a nest full of other species. Perhaps the economic effects of the changelings equal those of the individuals they displace, but the substitution cannot be looked upon with equanimity.

497. Yellow-headed Blackbird. FR.-L'ǴTOURNEAd ì TÊTE JAUNE. Xantho cephalus tanthocephalus. L, 10. A Blackbird with white wing patches on the primaries, and yellow head, neck, and breast. Female similar, but brownish rather than black; brightness of yellow reduced, and white lacking on the wings.

Distinctions. Above characterization unmistakable.

Distribution. Western North America to northern parts of prairie provinces. Only of accidental occurrence in eastern Canada.

A marsh or swamp bird rare in eastern Canada.

498. Red-winged Blackbird. SOLDIER BLACKBIRD. FR.-L'ÊTOURNEAU À AILES Rovges. Agelaius phoniceus. L, 9.51. Plate XXVI B.

Distinctions. All male plumages have at least suggestions of the red shoulders, though sometimes they are reduced to scattered spots of orange. The female is always distinguishable from any other Blackbird by her sharply streaked coloration.

Field Marks. The male is plainly characterized by its red shoulders, and the bird can be recognized in all plumages by its characteristic notes, the most common one, only uttered by the male, being well rendered into " $\mathrm{O}-k e-l e e$ " or " $\mathrm{O}-k e-r e e$ " with a rising inflection at the end.

Nesting. In well made structure of rushes and grass tied 2 or 3 feet above the water to reeds, cat-tails, or low bushes in swampy places.

Distribution. As a species, the Red-wing is distributed over all of North America north to the limit of trees.

SUBSPECIES. The Red-wings are divided into a number of subspecies. The common one in eastern Canada is the type form, the Eastern Red-wing. In the western end of Ontario we probably get the Northern Red-wing A. p. arctolegus from the central northern regions. It is characterized by somewhat larger size, but correct differentiation can only be made by the expert.

No marsh in eastern Canada is typical without one or more pairs of Red-wings chasing each other or clinging to the cat-tails, the mal es 
spreading their wings and tail and screwing themselves into constrained attitudes as they squeeze out their clear "O-ke-ree" with a roll on the last syllable, in sight and hearing of the females. In the spring the Blackbirds usually arrive in large flocks of mixed species which keep together a few days and then separate. The Red-wings repair to the marshes and before the reeds begin to grow they settle down to their domestic arrangements. When the family cares are over for the season all Blackbird species unite again in flocks that darken the sky, roosting together in the marshes when possible and scattering through the day in groups of various sizes which frequent the harvest fields.

Economic Status. The character of its food makes the Red-wing decidedly beneficial. Weed seeds and injurious insects form 80 per cent of its food and grain about 15 per cent. In July and August more grain is eaten, and in the early days of settlement when the acreage under cultivation was small and Blackbirds many they were a serious menace to the crops.

501. Meadowlark. FR.-L'Étournead DES PRÉs. Sturnella magna. L, 10.75. Plate XXVII A.

Distinctions. Unmistakable for any other species in eastern Canada. (Bill, Figure 47, p. 26).

Field Marks. The striking, yellow breast with sharp black necklace is unmistakable. Flying, the white outer tail feathers and peculiar manner of flight are good recognition marks. The familiar clear, long whistle of the Meadowlark is characteristic.

Nesting. On ground, nest of grasses, usually arched over like an oven.

Distribution. Eastern North America north to the limits of cultivation.

The clear call of the Meadowlark is often the first indication of the coming of spring. Coming with or sometimes even before the Robin and the Bluebird, it haunts upland pastures and from the top of an isolated tree or fence-post, pours out its rich, clear, far-carrying calls.

Economic Status. The Meadowlark is one of the farmer's most valuable assistants. Living close to the ground it attacks most of the worst crop foes. Its food is made up of 75 per cent insects, 12 per cent weed seeds, and 13 per cent grain nearly all taken in the late autumn and early spring months and obviously owing to the scarcity of insects. This bird should receive absolute protection.

506. Orchard Oriole. Icterus spurius. L. 7.32. A small Oriole, like the Baltimore (Plate XXVII B) with the orange of that bird replaced by zeal brown and with a black tail. The female is an even dull green. The young male is like the female, but has a black throat.

Distinctions. The seal brown and black coloration of the male is unmistakable. The female has a certain resemblance to the female Tanager, but is smaller and of more delicate shape and has a fine pointed, unnotched bill. (Compare Figures 48 and 53, p. 26.)

Field Marks. Colour, size, and voice somewhat like that of the Baltimore Oriule, but richer and with characteristics of its own.

Nesting. Nest woven of green grass hanging from a crotch. A beautiful structure, not as elaborate nor as deeply bagged as that of the Baltimore.

Distribution. A more southern species than the Baltimore Oriole, occurring in Canada regularly along the lake Erie shore and occasionally north to the southern end of lake Huron.

The Orchard Oriole is commonly met with only along the southern borders of Ontario and in habits is quite similar to the Baltimore. 
507. Baltimore Oriole. HANG-NGST, GOLDEN ROBIN. FR.-L'ORIOLE DE BALTIMORE Icterus galbula. L, 7.53. Plate XXVII B.

Distinctions. Coloration.

Field Marks. The striking flashes of golden orange and the rich contralto voice are absolute identification marks. The species can only be confused with extralimital forms.

Nesting. The nest of the Baltimore Oriole is one of the avian curiosities. It is in the form of a bag woven of fibres, plant down, hairs, and string and hangs from the end of long drooping branches. With her sharp, awl-like bill the female Oriole thrusts a fibre into the side of the nest, then reaching over to the inside pulls it through, tugging to make all tight and solid, another fibre is thrust in and the process repeated until when complete the nest is so knitted, woven, and felted together that though tossed at the end of long flexible whip-like branch tips through summer and winter storms, it remains intact for several years.

Distribution. Eastern North America north to the bounds of dense settlement.

Open country with scattered groves and occasional large isolated elms is the ideal habitat of the Baltimore Oriole. It obtains its name from its brilliant orange and black livery, the colours of Lord Baltimore, under whose patronage the state of Maryland was first settled and in whose honour the bird was named by the early settlers.

Economic Status. The food of the Oriole consists mostly of insects, including, in order of numbers, caterpillars, click beetles, of which the pestilent wire worms are the larvæ, May beetles, and grasshoppers. Very few predaceous beetles are taken. The amount of vegetable matter is smail. This species, therefore, ranks very high as an insect destroyer. Complaints are sometimes made that the Oriole spoils fruit and it has been accused of puncturing grapes for the juice. It is not the amount which it tákes that is objected to but the quantity of fruit that is spoiled, for it goes from bunch to bunch puncturing many and consuming little. This, however, seems to be a very local and perhaps an individual habit and except in vine country is of comparatively small importance. In Canada, the Baltimore Oriole leaves shortly after mid-August and before the autumn fruit season is well advanced, so that grapes are usually too green to be attractive to it. Hence, though it cannot be wholly exonerated from the charges which have been made against it, the damage done by the Oriole in Canada has certainly been greatly exaggerated. The good the bird does is constant and important, the harm is occasional and slight.

509. Rusty Blackbird. RUSTY GRACKLE. FR.-LE MAINATE COULEUR DE ROUILLE. Euphagus carolinus. L, 9.55. About the size of a Red-wing, but all black with green reflections and with straw-coloured eyes. In the autumn the feathers are broadly edged with rusty, lighter on the crown and head. The female is a nearly evenly dark grey bird with traces of rusty marks in spring, much more extensive in both sexes in autumn when they form a well-defined, reddish cap and a light eyebrow line.

Distinctions. Small size compared with the Crow Blackbird, the only other comparable species with light coloured eyes; even blackness or rusty overwash tending towards a light line over the eye, and straw-coloured eye.

Field Marks. Size, coloration, and straw-coloured eyes.

Nesting. In coniferous trees or on ground, in nest of grasses or moss.

Distribution. Eastern and northern North America; usually breeding just north of the cultivated areas in Canada.

The Rusty Blackbird visits us in great numbers spring and autumn, joining and forming a considerable part of the large flocks of mixed Blackbirds that are seen about the fields and marshes. The name Grackle which is commonly applied to the two yellow (nearly white) eyed Blackbirds is doubtless derived from the sound of their harsh, crackling notes. 
511. Grow Blackbird. BRONZed GRACKLE. FR.-L MaINATE BRONZE. Quisculus quiscula. L, 12. Plate XXVIII A.

Distinctions. Large size complete iridescent blackness, and straw-coloured eyes.

Field Marks. The all black body, straw-yellow eyes, and size are good field marks. When flying the long tail is "boated", that is spread and turned up at the sides so that a cross section through it would be U-shaped. This is a most characteristic feature and easily seen in outline against the sky.

Nesting. Usually in communities in coniferous trees; nest a large bulky mass of grass and mud.

Distribution. All of temperate North America east of the Rockies. The Bronzed Grackle occupies the Canadian section of the range overlapping that of the Purple south of our borders.

SUBSPECIES. The species is divided into three subspecies. The Canadian bird is the Bronzed Grackle Q. q. aeneus. The type form, the Purple Grackle, is a more southern bird that so far has not been taken in Canada, though it should be watched for along our outhern borders. It can be recognized by the feathers of the back showing semicircular purple iridescence instead of being an evenly metallic brass. The third form is found in Florida.

The Crow Blackbird is a gregarious bird and likes to nest in company with its own kind. Evergreens are its favourite nesting trees and it often takes possession of ornamental rows edging gardens. With its metallic colours and yellow eyes it is a brilliant and striking bird. It walks with comical pomposity over the lawn, or uncouthly gesticulates while it emits unusually discordant noises.

Economic Status. Through the months the bird is in Canada, insects constitute $29 \cdot 7$ per cent of its food and vegetable matter $70 \cdot 3$ per cent. The insects include useful predaceous species, but not in large numbers. The vegetable matter contains about 48 per cent of grain and domestic fruit, the remainder being wild fruit, mast, and weed seeds. Much of the grain is waste, and the total cultivated fruit is only 2.9 per cent. On the whole the work of the Bronzed Grackle is beneficial but its numbers should not be allowed to greatly increase. As it is an inveterate nest robber it is a poor bird to have about the house if other more attractive species are desired.

\section{FAMILY-FRINGILLIDA. SPARROWS, LINNETS, FINCHES, OR BUNTINGS.}

General Description. As represented in Canada this is generally an easily recognized family. It is composed of small birds, no Canadian species being over $8 \frac{1}{2}$ inches in lengthwith unnotched conical bill adapted for cracking seeds, and the gape of the mouth usually decidedly turned down (Figures 50, 51, 52, p. 26). This latter feature is not equally well developed in all species and some of the American Starlings, as previously described (p. 156), exhibit it strongly; but having other marked characters they can be easily distinguished from the Sparrows.

Distinctions. The bill is the best point of recognition; that of the ordinary domesticated Canary is of the characteristic sparrow type. The birds most likely to be mistaken for members of this family are the Bobolink (Figure 46, p. 26) and Cowbird (p. 157) of the previous family and the Tanagers, of the next one. These are all easily separated by their striking colours (see under specific headings.) The Tanagers show notches in the cutting edges and tip of the mandibles which make them easy to recognize (Figure 53, p. 26). In one group of Sparrows, the Crossbills, the tips of the bill cross each other (Figure 52, p. 26); in another, the Grosbeaks, the bill is very large and heavy (Figure 50, p. 26).

The sparrows form the largest and most important family of the Perchers, and are probably the most important family of birds in the world. They are found everywhere except in Australia and are represented in all 
habitats from wet swamps, grassy uplands, and brushy thickets to dry plains and sand dunes. The terms Sparrow, Linnet, Finch, and Bunting are almost synonymous and are applied to various species irrespective of their relationship. The name Sparrow is, therefore, a very broad one and can be applied to many species of very different rank and value. It is to 'be regretted that one objectionable introduced form should have cast discredit upon a large family which includes many beautiful as well as useful birds and some of great sweetness of song. The most typical feature of the Sparrows in popular estimation is a plain earthern coloration, but some of the brightest of plumages are found amongst them and in place of the commonly expected Sparrow chirp are some remarkable vocal achievements. The Sparrow can be divided roughly into ground species, tree species, winter wanderers, and Grosbeaks. Superficially observed, the first are dull in appearance, but, on close examination, often show beautiful colour harmonies. The tree species are often very brightly coloured. The winter wanderers usually exhibit a large amount of dull reds. The Grosbeaks, recognized by their great, heavy bills (Figure 50, p. 26) are highly coloured. This is not a scientific subdivision but as the recognition of Sparrows is difficult to the amateur any classification that will help is of use.

514. Evening Grosbeak. FR.-LE GROS-BEC À COURONNE NOIRE. Hesperiphona vespertina. L, 8. One of the largest Sparrows with the very large powerful bill which is typical of the Grosbeaks (Figure 50, p. 26). It is coloured in broad masses of strong yellow with black wings, tail, and crown and a white band over the wing. The female is similar, but duller in colour with an ashy wash over all.

Distinctions. Size, bill, and large amount of yellow. The female retains enough yellowish showing through the ashy to be easily recognized. The yellow or yellow-green colour of the bill is diagnostic of all plumages. For a comparison of the female with the Pine Grosbeak, see that species.

Field Marks. Size and yellow coloration. As it is a winter visitant only, it cannot be confused with other birds.

Nesting. In trees; nest of small twigs lined with bark, hair, and rootlets. The nest has been seldom seen.

Distribution. Central and western North America, south along the mountains. Migrating east irregularly in winter.

SUBSPECIES. The Evening Grosbeak is divided into an Eastern and Western subspecies; only the former, the type form, occurring in eastern Canada. The breeding grounds of the eastern bird are still to be accurately determined.

This is only an irregular winter wanderer in eastern Canada. Sometimes years will pass without the bird being seen and then suddenly it appears everywhere. The causes of these irregular appearances have not been definitely deterisined. Whether the birds are driven from their usual winter ranges by lack of food or are attracted to others by an unusual abundance cannot be stated. Food is probably the determining factor.

Economic Status. The Evening Grosbeak, coming only in winter, can do very little harm. Its favourite food is the seed of the Manitoba Maple left hanging on the trees, or the fruit of the Mountain Ash or Rowan trees. The fact that the Manitoba Maple has in recent years been planted extensively in all parts of Canada may affect the migration habits of this bird. Almost any dried winter fruit is taken and it delights to remove the seeds from old rotten apples left hanging through the winter. 
The charge that it damages trees by picking off the buds may contain an element of truth, but cannot be seriously considered as a source of appreciable damage.

515. Pine Grosbeak. FR.-LE GROs-BEC DEs PINS. Pinicola enucleator. L, 9.08. Plate XXVIII B.

Distinctions. From descriptions, the females of the Pine and Evening Grosbeaks might possibly be confused as they are both grey overwashed with yellow; but the yellow in the Pine Grosbeak is stronger, especially on head and rump, rather rusty instead of clear lemon, and is superimposed on the body colour instead of seeming to show vaguely through. The dark bill of the species is also diagnostic.

Field Marks. Size, dark grosbeak bill, and general red of adult males. The majority of the birds which visit Canada are in the dull female plumage, hence the general effect is that of a flock of large, dull slate-coloured birds warming to yellow on head and rump in favourite lights, accompanied by an occasional red individual. The ordinary notes are ridiculously small and fine for so large a bird, though it also has a clear, loud whistle.

Nesting. In coniferous trees; in nest of twigs and rootlets.

Distribution. As a species, confined to the northern parts of the northern hemisphere. The Canadian Pine Grosbeak breeds in the coniferous forest of the north, west to the Mackenzie river, migrating to settled sections only in winter.

SUBSPECIES. There are several subspecies in Canada, the eastern form, the Canadian Pine Grosbeak $P$. e. leucura, being the only one which comes within the scope of this work.

These are irregular winter visitors from the north. Their presence with us can rarely be anticipated, though they may occur any winter almost anywhere in eastern Canada. They are frequenters of coniferous trees, but are fond of Mountain Ash or Rowan berries and the fruit of the sumach.

Economic Status. As the Pine Grosbeak spends the summer in the northern woods and only visits settled sections in winter, the damage it can do is reduced to a minimum. It eats wild and waste fruit left hanging on the trees so that its economic effect is too slight to be appreciable. It has been accused of destroying fruit buds, but the damage it thus does, if any, is very slight. There is every humanitarian reason for protecting the species and no serious charge can be brought against it.

517. Purple Finch. Hefling. FR.-LE PINSON POUPRE. Carpadacus purpureus L, 6.22. Plate XXIX A.

Distinctions. Size and general coloration of male are distinctive. Female is streaked in olive-browns, but the general evenness of the olive cast to the coloration, and abundance of streaks below are quite characteristic. The bill is rather larger for the size of the bird than in other species except the Grosbeaks.

Field Marks. Size, general coloration, sometimes resembling a small Pine Grosbeak, and striking song are the best field marks.

Nesting. In coniferous trees; in nest of twigs, grass, and rootlets.

Distribution. As a species it occupies all America between Mexico and Canada. In eastern Canada it extends north to the extreme limit of regular settlement. Along the southern borders it is a regular winter visitor breeding less commonly than farther north.

SUBSPECIES. The Purple Finch is represented by two subspecies; the eastern Canadian form, Eastern Purple Finch, is the type of the species.

The Purple Finch, though so-called, is not purple; "magenta" would better describe its coloration. It is one of our finest songsters and is occasionally caged for that purpose. Like its allies, the Pine Grosbeak and the Crossbills, when kept in captivity it loses the bright redness of its plumage and assumes a ruddy yellow, so peculiar and characteristic that escaped caged birds can be recognized on sight. The song is a con- 
tinued and clear warble like that of a glorified Warbling Vireo, but more rapidly delivered. The young male in the autumn sings almost as well as the adult.

Economic Status. The Purple Finch eats largely of buds and fruit. The fruit eaten in eastern Canada is trifling, as the species is not numerous in summer-time in fruit-growing sections. The bird retires from the southern borders to less cultivated sections in the breeding season. The fruits it takes are mostly waste winter left-overs and wild forms as it is specially fond of Mountain Ash or Rowan berries. The charge that it eats buds is more serious, but so far has been based upon general assertions not substantiated in the east by results of stomach examinations. It is possible that at times the Purple Finch can do considerable local harm picking off the fruit buds of the coming year. That it does so to an extent to cause uneasiness to the fruit grower has yet to be proved.

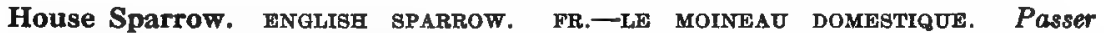
domesticus. L, 6.50. Plate XXIX B.

Distinctions. Black bib of the male is distinctive. Females have a slight olive suggestion and might be confused with the female Purple Finch were it not that they are unstreaked below. The female or autumn plumages of the Bobolink are somewhat suggestive of this plumage, but the pronounced streakiness above and the general yellowness are quite distinctive of the Bobolink. With a little observation of the species in our streets or barnyards, no one need ever confuse this species with anything else.

Field Marks. The characteristic notes and chirrups of the House Sparrow make the best recognition mark in, the field.

Distribution. Originally distributed over all of Europe and most of Asia. Now found through North America to the limits of settlement.

This bird is not native to America, but is one of our most undesirable importations from Europe. In spite of its obvious seed-eating habits and structure, it was originally introduced as a caterpillar destroyer. It does, of course, like nearly all birds, sometimes eat caterpillars, but does not approximate in this direction the capacity of the birds it has displaced. Being a bird of cities and barnyards most of its activities are in localities where there is plenty of food of non-insectivorous character, garbage, waste grain, etc. In the autumn, it makes excursions into the country and visits fields in large flocks, mostly after harvest when waste grain is abundant, but occasionally before, and then causes considerable loss. Its food habits thus are harmful or not according to circumstances and perhaps the balance on the whole lies well in its favour. The principal other objections to the House Sparrow are three in number. It drives more useful species away, it is very dirty about buildings, and it is suspected of spreading poultry diseases.

The House Sparrows drive other birds away by three methods: monopolizing the food supply; occupying their nesting places; and by pugnacious and bulldozing habits. During the nesting season while the young are being fed they come into direct competition with other species depending for the support of their young on the same insect forms (the young of all Passerine birds require insects, though those of this species are not long dependent upon them). Thus far perhaps they may be nearly as useful as the forms they displace, but most of the displaced birds are continuous insect hunters and the House Sparrow only a seasonal one. After nesting duties are over they again turn their attention to waste material and become of smaller importance, whereas the superseded birds 
continue to be useful through the season. The House Sparrows are with us through the winter, showing no tendency to migrate, hence they are on the ground in the early spring, and when our native summer residents, which are with only one or two exceptions more or less migratory either as species or individuals, arrive, they find the most attractive nesting sites already occupied. The difficulty of keeping Sparrows out of nesting boxes is proof enough of this situation. They are quarrelsome, also, and though, when once established, most native species are quite able to hold their own against aggression, they do not like the constant turmoil in which they must engage when in the vicinity of the House Sparrow. It is far easier to avoid than combat them. Hence few other birds care to live in their immediate neighbourhood.

The nests are great, bulky, untidy masses of straw and grasses and the tendency of these birds to fill down-spouts and load every projecting architectural feature of buildings with litter makes them objectionable. Added to the nesting habits of the House Sparrows, their congregation in numbers throughout the whole year in sheltered corners under cornices and porches causes accumulations of filth that is exasperating to the householder. To-day one of the important problems in architectural offices is to design satisfactory detail that will not harbour sparrows, whose dirt disfigures the most careful design and disintegrates the material of which the building is composed. The last charge, that of carrying disease, is not the least of the charges against the species. Feeding familiarly with the hens and freely flying about from one poultry yard to another they have every opportunity to be effective disease carriers. That they carry disease has not been definitely proved, but its possibility and likelihood are obvious. The fact that turkeys are to-day so subject to the ravages of the blackhead which has spread rapidly over the country, whereas on some of the coastal islands of Massachusetts from which the House Sparrow is absent they can be raised with old time ease, is more than suggestive.

Without doubt the introduction of the House Sparrow into America was a mistake. It was known in its original home as a rather undesirable species and unfitted for the work it was brought over to perform. In this country, removed from the natural checks that kept it under control, it has multiplied beyond all reason and though its objectionable features have increased, its commendable ones have not. However, the House Sparrow is here to stay. It has been legislated against, and large sums have been spent in the endeavour to control it, but without avail. Local endeavour has reduced the numbers from time to time, but only to have new hordes pour in from the surrounding country when the effort has spent itself. Constant effort will keep the numbers reduced but only continent-wide persistent effort will destroy them altogether. Traps, poison, and systematic destruction of the nests are the most satisfactory means of control. Poison is effective, but care must be taken that it is used only in the seasons and places where no other species have access to it. Wire fabric traps that are always set and will catch numbers at a time are the most satisfactory. A good type of such trap has been described by the United States Biological Survey in Farmers Bulletin 493.

521. Crossbill. FR.-LE BEC-CRoIsf D'AMGRIQUE. Laxia curvirostra. L, 6.19. A medium-sized Sparrow with the bill tips prolonged and crossing each other when closed 
(Figure 52, p. 26). The male is dull red, brighter on rump; females and juveniles similar with the red replaced by greenish or yellow. No wing bars.

Distinctions. The crossed bill is distinctive of the Crossbills; the lack of white wing bar designates this species.

Field Marks. Small winter bird often in large flocks. Notes somewhat similar to those of Goldfinches, but individuals show red coloration. Climbing, almost parrot-like, habits.

Nesting. Usually in coniferous trees; in nest of twigs and grasses lined with moss and rootlets.

Distribution. The coniferous forests of both hemispheres. The American Crossbill breeds north of dense settlement and southward along the mountain ranges east and west. Irregularly common in winter in southern Canada.

SUBSPECIES. The American Crossbill is a subspecies of the Crossbill, an Old as well as New World species, and bears the trinomial name L. c. minor.

The Crossbills are also birds that irregularly come out of the north to southern Canada in the winter, reoccur commonly for successive seasons, and then vanish perhaps for years.

Economic Status. This species feeds almost entirely upon coniferous seeds-pine, hemlock, and cedar; berries of the climbing bittersweet and seeds of rotten apples on the trees are also taken. The speed and skill with which the seed is removed from pine cones makes one think that the crossed bill is necessary for this work until one finds normally billed species doing the same thing with equal ease.

522. White-winged Grossbill. FR.-LE BEC-CROIsÉ A AILES BLANCHES. Laxia leucoptera. $\mathrm{L}, 6 \cdot 05$. Similar to preceding species, but with white bars on wings.

Distinctions. Perhaps a little brighter in coloration than the American, but showing considerable variation in tint and shade. The white wing bars and crossed bill are always diagnostic.

So similar to the preceding in habits and occurrence that no special discussion is necessary.

\section{Genus-Acanthis. Redpolls. L, 5-5 -50.}

General Description. Small sparrows with short, sharp bills; crown with a dull crimson cap; a suffused black chin spot; back and flanks streaked with browns, ashy, and white. Adult males have rosy breasts and the rump more or less tinged with pink; suggestions of this tint show in other plumages.

Distinctions. The small crimson cap is always distinctive.

Nesting. In low shrubs; nest of grasses lined with hair, often white rabbit or fox fur, feathers, or plant-down.

Distribution. Circumpolar and Arctic in breeding range, migrating south irregularly in winter.

There are two species of Redpolls in eastern Canada, divided into five subspecies, all so nearly alike that it requires special experience to differentiate them accurately. The dividing line between species is very fine, the subspecies intergrade and, as considerable individual and age variation exists, it is only by attention to small details that they can be separated.

The distinctive characters are given more as suggestions than as final differentiations.

\section{Economic Status. See Red poll Linnet.}

527. Hornemann's Redpoll. Acanthis hornemanni. L, 5. Light-coloured Redpolls with white or rosy unspotted rump. Adults with feather edgings light so that a typical bird looks like a Common Redpoll seen through a white veil. 
Distinctions. The unspotted rump is the most constant and easily recognized specific character.

Distribution. Arctic and subarctic parts of the northern hemisphere. The Greenland Redpoll breeds in Arctic Europe, Greenland, and perhaps adjoining America. The Hoary breeds in Arctic America east to Ungava and in adjacent Asia.

SUBSPECIES. Hornemann's Redpoll is divided in America into two subspecies; a large form, the Greenland Redpoll, the type form; and the Hoary Redpoll $A$. $h$. exilipes. They are most easily separated by size, the former having a wing measurement of $3 \cdot 37$ and the latter of 3.

In general habits so nearly like the next species, which is much more common, that separate discussion is unnecessary. This species is generally so rare in settled districts that its identification must be made with great caution. During occasional winters this species occurs in greater or less numbers with large flocks of the Common Redpolls, but there is no regularity in their visits.

528. Redpoll Linnet. FR.-SIZERIN \& TÊTE ROJGE. Acanthis linaria. L, 5-5.5. A rather dark Redpoll with rump more or less heavily streaked and not noticeably frosted with white.

Distinctions. The streaked rump is the most easily recognizable character.

Distribution. Northern part of northern hemisphere. The Common Redpoll breeds across the northern parts of the American continent, south in the east to the gulf of St. Lawrence. Holboll's breeds in America on the west Aretic islands and the Greater in Greenland.

SUBSPECIES. The species is divided into three subspecies: the Common Redpoll $A$. l. linaria, which is commonest in fact as well as name; Holboll's Redpoll $A . l$. holballi, a slightly larger form; and the Greater Redpoll $A$. $l$. rostrata, the largest of the species. There are small differences visible to the eye of the expert in the bills and details of coloration, but size is, on the whole, the best criterion, though it should not be entirely relied upon as intergrades occur. The wing of the Common Redpoll should be 2.9 inches, Holboll's 3.0 with slightly longer bill, and the Greater 3.5 with bill shorter and stouter, However, in identifying Redpolls it should be remembered that the Common is the only one likely to be met with and no other determination should be made unless confirmed by expert opinion.

With more or less regularity our winter fields and waste lands are taken possession of by immense flocks of tiny sparrows, feeding on the weed tops which project from the snow or perching in the low trees and bushes nearby. From the throng comes a subdued but constant twitter from many little throats, no one of the birds producing a song in the usual sense of the word, but collectively making an undercurrent of low music that is distinctly agreeable. The round, fluffy, heavily plumaged bodies, the little, rich crimson cap, and the occasional flash of rosy breast and pink rump declare them Redpolls. They are tame and unsuspecting little fellows and if the observer conducts himself discreetly they may at times alight all about him or even upon his person with as much indifference as if he were a stump or some other inanimate feature of the landscape. They remain until just as the spring breakup is due when they vanish until another winter. Their winter wanderings are irregular and erratic.

Economic Status. Coming in flocks of large numbers and searching weed tops diligently the Redpolls should be hailed by the farmer with pleasure, not only for their pretty ways but also for the evident good they do in destroying weed seed. One cannot go over the ground where they 
have fed and examine it closely without being impressed with the amount of good work they have done. Their tracks are seen everywhere in the snow and every little weed-top seems to have been scrutinized with microscopic eye. Considering their numbers and that they come in the coldest weather, it is evident that their presence must have a marked deterrent effect upon the following season's weed crop.

529. American Goldfinch. Thistlebird, Wild GaNary. Fr.-Le ChardonNerbt JAUNE. Astragalinus tristis. L, 5.10. Plate XXX A.

Distinctions. In summer, male with its strongly contrasting yellow body and black wings, tail, and cap is most characteristic. In winter, the colours are less distinctive but there is always a suggestion of yellow about the throat, head, and back, if not elsewhere, and the wings and tail remain a decided black though with more or less buffy or white edgings on wing bars.

Field Marks. In habit, disposition, and the general quality of their notes, winter Goldfinches resemble Pine Siskins or the Crossbills. They can be distinguished from the former by their lack of streakiness and from the Crossbills by the absence of red, lighter coloration, and white rump.

Neating. Nest of grasses and plant down lined with the latter.

Distribution. As a species, throughout the United States and southern Canads north to the limits of settlement. The Eastern Goldfinch extends west to, and including, Manitoba.

SUBSPECIES. The American Goldfinch is divided into three recognized subspecies, only one of which, the Eastern Goldfinch, the type form, occurs in eastern Canada.

One of the merriest of summer birds, sometimes remaining through the winter in the more southern parts of Canada. It is a great lover of fluffy white thistle and dandelion seed-heads and can often be seen plucking the down, cutting off the fruiting end, and letting the airy tops float away on the wind. Its song is as pleasant as its bright appearance as it sits on some lone elevation and sings " sweet-sweet-chewit-chewit-chewit" or goes speeding off through the air with a merry flock with their cheerfully repeated per-chico-pee. The American Goldfinch, though a relative of the Old World bird of the same name, is an entirely different species, named, as the original settlers named many birds, from various fancied or real resemblances to the familiar forms known at home.

Economic Status. A bird of no bad habits and many good ones. Weed seeds are its staple food, but grain is rarely touched. If the House or English Sparrows do not exhaust the supply prematurely, sunflower seed heads are a neverfailing attraction to Goldfinches and a supply of these along the back fence will ensure their constant attendance through the autumn and winter. Insects are taken more or less and some fruit, usually wild species, as no complaint is made of any damage done to cultivated varieties.

533. Pine Siskin. FR - LE CHARDONNEERT DES PINS. Spinus pinus. L, 5 Small, goldfinch-like birds striped with olive-brown on a dull white ground sometimes. slightly tinged with yellowish; lighter below and with a lemon-yellow spot and suffusion on the wings.

Distinctions. General streakiness and suffused yellow wing spot.

Field Marks. Goldfinch-like habits and voice and general streakiness.

Nesting. In coniferous trees; nest of twigs and rootlets lined with plant down.

Distribution. The north coniferous woods across the continent, migrating to settled districts in winter and locally breeding there.

A winter visitor to the more southern sections of Canada. Very fond of coniferous evergreen trees. 
Economic Status. As it is only a winter visitor to settled Canada and shows strong partiality for the fruit of coniferous trees, it is a neutral species, doing perhaps no great good but certainly no harm.

534. Snow Bunting. snowflake. Fr.-LE Plectrophane DE Neige. Plectrophenax nivalis. L, 6.88. Plate XXX B.

Distinctions. Sharply contrasting black and white colouring with most of the feathers heavily bordered with rusty, especially on the head, back, and breast-band. Through the winter the rusty borders gradually wear off and the breeding plumage of black and white results without moult. The general scheme of colouring of the Snow Bunting is found in no other Canadian bird.

Field Marks. Gregarious ground sparrows showing large amounts of white on black wings when flying. and fur.

Nesting. On ground in moss, nest of grass, rootlets, and moss lined with feathers

Distribution. Circumpolar Arctics. In Canada, breeding from the edge of barren grounds northward across the continent.

SUBSPECIES. Though the Snow Bunting is divided into several subspecies, in eastern Canada only the type form, the Common Snow Bunting, occurs.

Winter visitors in southern Canada, feeding on the weed-tops that project from the snow in open fields and rarely perching in trees. A flock alights in the weed-spotted snow and gradually works across it, the rear of the flock rising up from time to time like a flurry of snow and pitching ahead, the process being repeated until the whole field is covered.

536. Lapland Longspur. FR.-Te PLECTROPHANE DE LAPONIE. Calcarius lapponicus. L, 6י25. A gregarious, winter sparrow frequenting open fields. Males-dark brown above sharply streaked with buff to crown of head, with a rufous collar across back of neck, cheeks, throat, and bib black. Flanks streaked with black, brown, and buff. White, below. Females and juveniles are similar, but with the black on the face and throat replaced by suffusions of brown and buff or showing only vaguely in scattered irregular feathers. The nail of the hind toe is greatly elongated as in the Horned Lark (Figure 44, p. 25).

Distinctions. In habits the Longspur may be mistaken for Snow Bunting, but the sharply streaked back, lack of white on the wing, and the elongated hind claw are distinctive. The lack of ear tufts, the absence of yellow on the throat, and the sparrowlike bill will separate it from the Horned Lark. Large size, ground habit, and occurrence in winter in flocks will distinguish the Longspur from any other sparrow of similar coloration.

Field Marks. The lack of white masses on the wings will distinguish the Laplnd Longspur from the snow Bunting, and the lack of ear tufts and yellow throat from ahe Horned Lark, the birds with which it is most likely to be confused in life.

Distribution. A circumpolar species coming down into settled districts only in winter' In America it breeds in high latitudes across the continent.

SUBSPECIES. In the east', only one subspecies of Lapland Longspur, the Eastern Longspur, the type form, ever occurs.

Similar in habits to the Snowflake and often accompanying flocks of Snowflakes and Horned Larks.

540. Vesper Sparrow. GRASS FINCH. BAY-WINGED SPARROW. FR.-LE PINSON A AILEs BAIEs. Pocecetes gramineus. L, 5.75. Plate XXXI A. A dull coloured ground sparrow softly streaked with shades of brown, above; below, white, with suffused streaks on the flanks, across the breast, and on the sides of throat. Shoulders, brownish rufous.

Distinctions. The Vesper can be separated from other earth-coloured sparrows by its red-brown upper wing coverts or shoulders, and the white on the outer tail feathers.

Field Marks. The Vesper Sparrow is easily mistaken for the Song Sparrow in life, but the lack of the central breast spot caused by the aggregation of the streaks and the presence of the white outer tail feathers visible in flight are distinctive. The Junco, an evenly dark grey bird, is the only other comparable species having such a tail mark. 

within.

Nesting. In grass on ground in nest of grasses, rootlets, and hairs, finer grasses

Distribution. Distributed, as a species, over all of temperate North America. Breeding wherever found in Canada.

SUBSPECIES. Though eastern and western subspecies of the Vesper Sparrow are recognized, only the Eastern Vesper Sparrow, the type form, occurs in eastern Canada.

The Vesper Sparrow is comparable with the Song Sparrow in its habits, song, and general appearance. It is less a bird of the brush, however, and usually frequents the edges of fields, or where there is slight cover as in the vicinity of ditches or roads. Its song is similar to that of the Song Sparrow, but can be readily distinguished from it by the educated ear.

Economic Status This is one of the most beneficial of the Sparrows. It feeds farther afield than most of the common summer Sparrows and takes a greater percentage of insects than they, and large quantities of weed seeds. Some grain is found in its stomach, but under circumstances that point to its being waste from the stubble or roadways. The Vesper Sparrow, therefore, should receive every possible protection.

541. Ipswich Sparrow. Passerculus princeps. L, 6.25. Like a large and very pale Savannah Sparrow (see next species).

Distinctions. Distinguished from the Savannah Sparrow by larger size, and light coloration; in autumn also, by an almost complete lack of yellow on the bend of the wing and in front of the eye. Distinguished from the Vesper Sparrow by light coloration, lack of red on shoulders, and, in spring, by yellow on the bend of the wing and in front of the eye. Distinguished from the Song Sparrow by its lighter colour and, in spring, by the yellow as above.

Field Marks. A very pale sparrow about the size of a Vesper Sparrow.

This bird has a limited and isolated distribution. Its only known breeding place is Sable island, about 60 miles south of Cape Breton. In winter it migrates down the Atlantic coast never wandering far inland. It is of small economic importance.

542. Savannah Sparrow. FR.-L PINSON DES PRÉs. Passerculus sandwichensis. L. 5.68. A rather small sparrow striped above with brown, ashy, and intermediate shades. Below, white with sharp brown streaks on the breast, flanks, and in some cases on the throat. Yellow on the bend of the wing and a spot in front of the eye. Autumn birds are generally overwashed with buffy and the markings are softer and more diffused.

Distinctions. The Savannah Sparrow can be distinguished from the Song Sparrow by the yellow spots in front of the eye and on the bend of the wing and by the lack of the aggregated streaks which form a spot in the middle of the breast of the Song Sparrow. From other allied sparrows of the Grasshopper and Passerherbulus groups it can be told by the sharply defined streaks on white ground beneath.

Field Marks. The Savannah Sparrow can be recognized in the field by the yellow line over the eye and by its notes. Its song is a fine, insect-like tsip-tsip-you-re-e-e-e-e-e-you, the first notes often too faint to be heard and the whole with a peculiar far-carrying intensity and high pitch that leaves one in doubt whether it is close at hand or very far away. It resembles a similar song of the Grasshopper Sparrow, but the latter omits the final note.

Nesting. On ground, in nest of grasses lined with finer material.

Distribution. America, north to the Arctic coast. The Eastern Savannah Sparrow $P$. s. savanna occupies eastern North America west to the prairies, when it is displaced by a western form.

SUBSPECIES. Our form, the Eastern Savannah Sparrow, P. s. savanna, is a subspecies of which the type form occurs in the Aleutian islands. There are several other geographical races but the differences between them are too slight for popular recognition.

A bird of damp meadows and waste land, where the grass grows in rank and coarse bunches and water lies close to the surface; or of sandy 
barrens where the grass and weeds grow in scattered clumps. It runs in the grass like a mouse and rises with a low quick flight, often before a good view of it can be obtained. It is an interesting little bird, but is so inconspicuous as to readily pass unnoticed by the casual observer.

Economic Status. Besides great quantities of weed seeds the Savannah Sparrow consumes more insects than most sparrows and more beetles than any other sparrow. The insects taken include a great number of weevils and other harmful forms. Although usually inhabiting waste places it also frequents cultivated land often enough to make it a most efficient helper to the agriculturist.

546. Grasshopper Sparrow. YELLOW-WINGEd SPARROW. Ammodramus savannarum. L, 5.38. A small, grass-haunting sparrow. Back marked with fine, short streaks of brown, ashy, and light buff in indefinite pattern; dull white below, with a light buffy wash across the breast fading away on the sides of the throat. A yellow spot in front of the eye; upper wing coverts and the bend of the wing yellow or yellowish.

Distinctions. The yellowish upper wing coverts are distinctive of the species. The unstriped and unspotted breast will separate it from most of the other small grass sparrows.

Field Marks. This species can be distinguished from most of the other small sparrows by its unstreaked, faintly buff-coloured breast. Its song is like the last part of the song of the Savannah Sparrow, without the final syllable, and dies gradually away like $b z-b z=b z$ $z-z-z-z$.

Nesting. On ground, in nest of grasses, arched over.

Distribution. United States to South America; regularly crosses the Canadian border only in the vicinity of lake Erie.

SUBSPECIES. The Eastern Grasshopper Sparrow is a subspecies A.s. australis. The type form is extralimital. Another subspecies occurs in the west.

This sparrow is to be looked for in grassy fields along with the Bobolink and Meadowlark, but is very local in its distribution.

Economic Status. A rare sparrow of little economic importance, but, at least, harmless.

547. Henslow's Sparrow. Passerherbulus henslowi. L, J. A very small grass sparrow. Back of head and lower neck yellowish-olive, and back vinaceous; both colours streaked with short strokes of brown. Below, white, finely streaked across breast and on flanks with dark brown. Bill large for the size of the bird and tail feathers pointed. breast.

Distinctions. Olive and vinaceous ground colour of upper parts and fine streaking of

Field Marks. A small bird that runs in the grass and is very difficult to flush. Rises with a quick, low zig-zag flight and drops back into the grass with unexpected suddenness. The best identification character in life is its note, a fine penetrating se-slick of such light volume as to be almost inaudible close at hand, yet decided enough to have considerable carrying power.

Nesting. On ground, in nest of grass exceptionally well hidden.

Distribution. The Eastern Henslow's Sparrow occurs in eastern Canada only in southern Ontario. Another subspecies is found in the west.

SUBSPECIES. The eastern form of Henslow's Sparrow is the Eastern Henslow's Sparrow, the type subspecies of the race.

One may be in the midst of quite a colony of Henslow's Sparrows without knowing it, as they are rarely seen unless attention is directed to them by their notes. Waste grass-grown meadows are their favourite habitats.

548. Leconte's Sparrow. Passerherbulus lecontei. L, 5. A very small and elusive grass sparrow. Above, crown dark brown with light buff median stripe, nape vinaceous with buff-grey stripes, back dark brown with sharp light buff stripes. Below, white suffused with ochre on breast, throat, and cheeks.

$57172-12$ 
Distinctions. The contrasting light buff median stripe, vinaceous nape, and dark brown back.

Nesting. On ground, in nest of fine grass.

Distribution. Central North America. A prairie form of only accidental occurrence within the limits covered by this work.

The species has been recorded only once in eastern Canada, at Toronto. Owing to its mouse-like habits it is most difficult to find or to recognize when seen, and, therefore, may be more common that it is thought to be.

549. 1. Nelson's Sharp-tail. FR.-LE PINSON A QUEUE AIGUE. Passerherbulus nelsoni. L, 5.9. A small grass sparrow. Above, median line of crown slaty-blue bordered with dark brown, with an ochre line over eye. A faint slaty and olive band across nape and shoulders. Back sharply striped with rich brown and light buff with a light slaty overwash. Below, white with ochre breast extending more or less to the cheeks and flanks and lightening on the throat. Breast sometimes, and flanks always marked with indistinct darker stripes.

Distinctions. Slaty median crown stripe and long, strong stripes on back.

Field Marks. The general strong buff or yellow coloration below, the yellow line above the eye, and the faint streaking of breast.

Nesting. On ground; in nest of fine grass.

Distribution. Eastern America, mostly in northern United States and southern Canada. The type form is confined to the prairies and the other to the Atlantic coast.

SUBSPECIES. Nelson's Sparrow is divided into two subspecies, the type form, Nelson's Sharp-tailed Sparrow, a prairie race; and the Acadian Sharp-tailed Sparrow $P . n$. subvirgatus, an extreme eastern race. The Acadian Sharp-tail is confined to the salt marshes of the east corst of Prince Edward Island and below the gulf of St. Lawrence. Its breast and throat are lighter, buff rather than ochre coloured, and distinctly though faintly streaked on breast. The colouring of the back is fainter and more diffused and the slaty median line wider and in less contrast to the brown. There is little chance of confusion between them for the races can be divided geographically with considerable certainty. Nelson's Sharp-tail is only of casual and accidental occurrence in the Great Lakes region, whereas the Acadian is practically confined to the vicinity of salt water.

The Sharp-tailed Sparrows are marsh-haunting birds, running and hiding in the grass and refusing to take wing until absolutely forced.

552. Lark Sparrow. Chondestes grammacus. L, 6-25. A very striking and conspicuously marked sparrow. Above, striped with brown and buffy brown; below, white with buffy flanks. Crown, chestnut-brown with conspicuous light median line; ear coverts chestnut-brown in strong contrast to the white face; and three sharp black lines, one through eye, one from lower mandible to ear coverts, and one down sides of throat. Outer tail feathers and ends of all except the middle ones, white.

Distinctions. The bright reddish brown ear coverts contrasting with black and white face are certain distinguishing characters of the species.

Field Marks. The strongly marked head and face and the large amount of white in the tail make easily recognized field marks. hairs.

Nesting. In low trees or bushes, in nest of grasses lined with fine grass, rootlets, and

Distribution. The Mississippi valley westward. The Eastern Lark Sparrow, the type form, extends from the Great Plains east and north into southern Ontario. Another subspecies occurs in the west.

SUBSPECIES. The eastern subspecies of this bird is the Eastern Lark Sparrow, the type form of the species.

The Lark Sparrow is rare in eastern Canada. It is to be looked for in open brushy wastes and along the wooded edges of fields.

553. Harris' Sparrow. Zonotrichia querula. L, 7.50. A large sparrow, streaked with brown and ashy brown, above; white, below. Crown, face, throat, and front neck solid black fading into stripes on flanks.

Distinctions. In adults, the black face as if dipped in ink which had spread over crown and throat. 
Nesting. On ground under dwarf birch, in nest of grass. Nest rarely discovered.

Distribution. The prairie regions of America, north to the edges of the Barren lands.

This bird may be more common in western Ontario near the Manitoba line than is supposed, but that is the only section in which the species may be looked for. One has been recorded from London, Ont., but this was, of course, accidental.

554. White-crowned Sparrow. Fr.-LE PINSON ג COURONNE BLANCHE. Zonotrichia leucophrys. L, 6.88. Plate XXXI B.

Distinctions. Only likely to be mistaken for the White-throated Sparrow, the next species, and can be distinguished from it in any plumage by the absence of the yellow spot in front of the eye and, in the adult form, by its nearly even grey throat instead of the strongly white throat of that species.

Field Marks. The white crown and lack of white throat or yellow spot in front of the eye. In life, the back has a grey rather than a reddish cast.

Nesting. On ground or in low bushes, in nest of grass and fine vegetable fibre, rootlets, etc.

Distribution. North America from tree limit south. Our Eastern White-crowned, the type of the species, extends to the western prairie province, where its place is taken by a subspecies, Gambel's Sparrow Z.i. gambeli.

SUBSPECIES. Though three subspecies of this species are recognized in Canada, only one, the Eastern White-crown, the type form, occurs in the east.

One of the most beautiful of the sparrows. Though it lacks gaudy colours, its sharply contrasting black and white crown and grey throat and neck give it distinction. Its song too is sweet, having much of the clear quality of that of its near relative, the White-throat, but unhappily it is usually heard at its best only in its northern breeding grounds.

Economic Status. Though only within the bounds of cultivation for about two weeks in the spring and autumn it does good work while there. Weed seeds form a large part of its food, ragweed and grass seed being in large proportion. Insects form only a small part of its food.

558. White-throated Sparrow. CANADA WHITE-THROAT. PEABODY-BIRD. FR.LE PINSON 1 GORGE BLANCHE. Zonotrichia albicollis. L, 6.74. Plate XXXII A.

Distinctions. In adult plumage it is most likely to be taken for the White-crown previously mentioned, but its distinctly white throat and the yellow spot in front of the eye are distinctive. Young birds are apt to be mistaken for the Swamp Sparrow, but the yellow spot and redder coloration of the back will always separate them.

Field Marks. The White throat, yellow lores, and reddish instead of greyish back will readily distinguish adults from White-crowns. Juveniles are rather more difficult to identify from several other species, but if neither the yellow loral spot nor the vague white throat sometimes suggested by the Swamp Sparrow are recognizable, the greater redness of the back will usually suffice for identification.

Nesting. On ground or in low bushes; in nest of coarse grasses, rootlets, and moss lined with finer grass.

Distribution. Eastern North America to near the tree limits on the north. Breeds everywhere it is found in Canada except in the most southern portions.

This is the most famous songster of the northern woods. At its best the song is a clear, flute-like, slowly measured whistle which has been very well put into words. Hard-times-can-a-da-can-a-da-can-ada or Poor-Bill$P e a-b o-d y-P e a-b o-d y-P e a-b o-d y$. The White-throat is a brush-wood bird; tangled thickets or brush piles in the vicinity of open ground are its favourite haunts. Throughout most of the cultivated sections of Canada the bird is a migrant only and its best song is rarely heard. In the autumn when the young birds fly south the notes are heard in a softened, shortened version.

$57172-12 \frac{1}{2}$ 
Economic Status. The White-throat is a valuable bird. It is important as a destroyer of weed seeds, especially of ragweed, and consumes a considerable number of insects and a little wild fruit. As the species comes down in great numbers to the thickly cultivated sections in early autumn, its effect on the succeeding season's weed crop must be pronounced.

559. Tree Sparrow. FR.-LE PINSON DE montagne. Spizella monticola. L, $6 \cdot 36$. Plate XXXII B.

Distinctions. Much like the Chipping and Field Sparrows, but larger and the bill yellow with dark tip instead of black as in the former, or cinnamon as in the latter and with a semi-concealed dark spot in the middle of the breast.

Field Marks. Red-brown cap, prominent white wing-bars, ashy-grey throat, and dark spot in middle of the evenly coloured unspotted breast.

Nesting. On or near ground, in nest of grasses, rootlets, and hair.

Distribution. Eastern North America. Breeds in the far north beyond the limits of civilization; winters in northern United States.

SUBSPECIES. Eastern and western subspecies of the Tree Sparrow occur in Canada. The former is the type form and the only one that occurs within the region covered by this work.

Among the hosts of sparrows that congregate in the shrubbery in the autumn or return early in the spring, is the Tree Sparrow. In the southern parts of the Dominion it sometimes remains all winter, but is a migrant elsewhere. It is a natty little bird and its modest song in the early spring is most welcome after the long silent winter.

Economic Status. The Tree Sparrow is valuable for its destruction of weed seeds and seems to have no bad habits.

560. Chipping Sparrow. CHIPPIE, HAIR BIRD. FR.-LE PETIT PINSON À COURONNE Rodsse. Spizella passerina. L, 5.37. Plate XXXIII A.

Distinctions. A familiar bird, separable from the Swamp and Tree Sparrows which, like it, have red caps, by size; and from them and the Field Sparrow by its black bill and the black stripe through the eye. Juveniles have streaked heads and closely resemble the Clay-coloured Sparrow, a western bird that occasionally may be confused with them in far western Ontario. The Chipping Sparrow, however, has a slaty instead of an olive-buff rump.

Field Marks. A small, slim sparrow with red cap, unstreaked breast, and a black line through the eye. Its long drawn out song, a series of unaccented chirps running into each other in a single sustained trill, is very characteristic.

Nesting. In trees or bushes, in nest of grasses, rootlets, and fibres plentifully intermixed with long hairs. The amount of horse hair used in the nest is the origin of one of this bird's popular names.

Distribution. Eastern North America to well north of civilization. Breeds in Canada wherever found.

SUBSPECIES. The form of the Chipping Sparrow occurring in eastern Canada is the Eastern Chipping Sparrow, the type form. Another subspecies occurs in the west.

The Chipping Sparrow is rarely absent from the vicinity of suburban or village homes, coming close to houses and frequenting the orchard and shade trees, the front yard, and even the door step. It does not fear man, but though not avoiding him it escapes notice through its quiet and unobtrusive habits.

Economic Status. The Chipping Sparrow is a greater insect eater than most of the family. In fact, through June, 93 per cent of its food is composed of insects, only 1 per cent of which are beneficial species such as predacious beetles and parasitic wasps. The average for the year is 38 per cent of insects, and for the months spent by the bird in Canada, the 
average must be considerably higher. The vegetable matter consumed consists of small weed seeds in which those of crab grass, lambs quarters, and ragweed predominate. It will be seen that a bird having these desirable qualities and coming into the immediate vicinity of the garden is most useful and one to be encouraged in every manner possible.

561. Clay-coloured Sparrow. Spizella pallida. L, 5.20. A small sparrow with upper parts streaked in light buff and dark brown to crown, where a whitish median stripe is indicated. A faint collar of slaty suffusion about the back of the neck. White below, slightly tinged with buff on flanks.

Distinctions. On account of size and habits only likely to be mistaken for the Chipping Sparrow; but the back is lighter than in that bird and more clay-coloured, and the rump instead of being faintly slaty is slightly olive-buff.

Nesting. On ground or in bushes, in nest of grasses lined with hairs.

Distribution. The interior of America. It is a prairie form extending north to the limits of the prairie provinces, and only of accidental occurrence in eastern Canada, except perhaps in the country adjoining the Manitoba boundary.

A bird of the west; of rare occurrence in the western limits of the region treated of in this work.

563. Field Sparrow. FR.-LE PINSON DES CHAMPs. Spizella pusilla. L, 6.68. A small sparrow of the same general colour as the Chipping, but with the colours subdued, suffused, and blended. The red crown is darker and inconspicuous and there is no line of black through the eye. The bill is cinnamon coloured instead of black.

Distinctions. The above distinctions are sufficient to distinguish this bird.

Field Marks. Dull reddish crown, lack of facial marks other than a touch of red on ends of ear coverts, and cinnamon-coloured bill. The song is its most easily recognized characteristic and when learned is the best means of identification.

Nesting. On ground or in low bushes, in nest of rather coarse grasses, weed stalks, and rootlets, lined with fine grasses and hair.

Distribution. Eastern America; in Canada including most of the settled sections, but rather local in distribution and unaccountably absent from some localities well within its range.

$S U B S P E C I E S$. The Field Sparrow is divided into an eastern and western subspecies; the former, the type form, is the only one occurring in eastern Canada.

The Field Sparrow is an inconspicuous bird and though often very common is so like a Chipping Sparrow with worn plumage that it may be mistaken for it. It is a bird of the open fields and fence rows and though not shy or unusually retiring, must be looked for and listened for to be found.

Economic Status. Very much like the Chipping Sparrow in food habits, taking a few more useful insects though not enough to perceptibly affect its usefulness.

567. Junco. GRAYBIRD. BLACK SNOWBIRD. FR.-PINSON NIVEROLLE. Junco hyemalis. $\mathrm{L}, 6 \cdot 27$. Plate XXXIII B. Distinctions. Solid dark slate-grey above and on breast, cutting sharply against the
white underparts.

Field Marks. Sharp line of the dark breast against the white below, and white outer tail feathers which show in flight.

Nesting. On or near the ground in nest of grasses, moss, and rootlets lined with finer grasses and long hairs.

Distribution. As a species, all of America to the tree limits. The Slate-coloured Junco extends west to Alberta.

SUBSPECIES. The Juncos are divided into a number of subspecies, only one of which, the Slate-coloured Junco, the type form, occurs in eastern Canada. 
The Junco with its black breast, light coloured bill, and white bordered tail is conspicuous amongst the large flocks of sparrows passing through or tarrying in the spring and autumn.

Economic Status. The effect of the Junco on agriculture is almost wholly beneficial. During its stay in the more settled sections it consumes large quantities of weed seeds. The insects it takes are mostly harmful Little or no exception can be taken to it as it does no perceptible damage. to crops or fruit.

581. Song Sparrow. Fr.-LE PINson Chantedr. Melospiza melodia. L, 6.30. Plate XXXIV A.

Distinctions. Rather like the Vesper Sparrow in size and general coloration, but darker and more decided in tone; lacks the white outer tail feathers. The breast streaks are also sharper and darker brown and aggregated in the middle into a well-defined spot. The lack of the yellow stripe over the eye separates the Song from the Savannah Sparrow and the sharply streaked breast from any of the other sparrows of comparable size and habit.

Field Marks. Sharply striped breast and central spot. The absence of the white outer tail feathers will guard against confusion with the Vesper Sparrow, and longer tail, lack of yellow lores, voice, and general attitude distinguish the Song Sparrow from the Savannah.

Nesting. On ground, more rarely in bushes, in nest of coarse grasses, rootlets, dead leaves, strips of bark, etc., lined with finer grasses and sometimes long hairs.

Distribution. As a species, the Song Sparrow inhabits all of America to the tree limits. Our eastern form extends west to the central prairie provinces.

SUBSPECIES. The Song Sparrow is a wide ranging species and has been divided into many subspecies, twenty being recognized in North America and a number more proposed. Most of these are western forms originating in the broken land of the Pacific coast where isolated colonies and varied conditions have favoured numerous departures from type. In eastern Canada the form recognized is the Eastern Song Sparrow $M$. m. melodia, the type race.

It is difficult to form a just and unprejudiced estimate of the standing of the Song Sparrow in the avian chorus. Its little medley of chirps and trills makes a sustained song of some duration and to those who listen to it sympathetically it has a gladness, brightness, and sweetness of tone that is difficult to surpass. The bird is almost omnipresent. It lives in the shrubbery close about the house and is one of the familiar bi rds of the garden. It haunts the thickets on the edge of the wood-lot or bordering little streams or rivulets. The deep woods and the clean open fields are the only places where it is generally absent and even there it sometimes surprises us with a burst of liquid song.

Economic Status. The great numbers of the Song Sparrow render it most important to the agriculturist. An analysis of its food shows that only 2 per cent is composed of usseful insects and 18 per cent of harmful insects. Waste grain constitutes 4 per cent and weed seeds 50 per cent. The remainder is composed of wild fruit and other unimportant material. It is seen from this that the Song Sparrow is of considerable economic importance. Investigation has shown that one-quarter of an ounce of weed seed a day is a fair estimate of the amount consumed by a seedeating sparrow. For the nine months the Song Sparrow is with us in the average eastern Canadian locality the consumption amounts to four and a quarter pounds per individual per year. Allowing seventy-five Song Sparrows per square mile as a very conservative estimate of population we get a total for the southern cultivated parts of Ontario of over eleven thousand tons of weed seed destroyed annually by this one species. 
583. Lincoln's Sparrow. FR.-LE PINSON DE LINCOLN. Melospiza lincolni. L, 5'75. Like the Song Sparrow but with a belt of buffy across the breast which is marked also with small, fine spots.

Distinctions. The above distinctions will separate Lincoln's from all other sparrows it may be confused with.

Field Marks. A good view will show the faint buff breast and fine spotting. Otherwise it is with difficulty separated in life from the Song Sparrow. The back is rather greyer than the Song Sparrow and this often arouses a suspicion of the presence of Lincoln's Sparrow that may be confirmed by other characters.

Nesting. Similar to that of the Song Sparrow, on ground.

Distribution. The species is distributed all over America, breeding in the northern coniferous woods.

SUBSPECIES. Eastern and extreme western Lincoln's Sparrows can be differentiated into two subspecies. The form occupying the territory here treated is the Eastern Lincoln's Sparrow M. $l$. lincolni, the typical race.

Though a rare sparrow it is an interesting one. It has reduced hiding in brush to as fine an art as any bird. When first disturbed it hops to a branch, where it obtains a good view, regards the intruder for an instant, and then dives into the tangle and is gone. The most diligent search thereafter gives no more than a fleeting glimpse of a brown shadow disappearing into the nearest brush pile. The species is a passing migrant through the settled sections of Canada and is rare.

584. Swamp Sparrow. FR.-LE PINSON des Marars. Melospiza georgiana. L, 5'89. Much like the Song Sparrow, but of stronger and less blended coloration and without any distinct breast streaks or markings.

Distinctions. The Swamp Sparrow is difficult to separate from several other forms comparable in both colour and size. It may be distinguished from the Song Sparrow, most likely to be confused with it, by the unstreaked breast, and, in adult birds, by the red crown. Young autumn birds strongly resemble juvenile White-throats but lack the faint yellow loral spot, are not as evenly ruddy on the back, and usually have a suggestion of an ashy bar across the shoulders at the base of the neck, an ashy cast to the crown, and eyebrow lines that are absent in that species. It can be told from the Tree Sparrow by the lack of the dark middle breast spot or of the white wing-bars.

Field Marks. Its resemblance to a Song Sparrow without breast streaks, the lack of the yellow loral spot of the White-throat or the wing-bars of the Tree Sparrow. In summer when the Tree Sparrow is not present the red cap is distinctive. grass.

Nesting. Nest similar to that of the Song Sparrow, on ground, sometimes in the

Distribution. North America east of the prairies, breeding in most of the inhabited parts of Canada.

As its name implies this is a bird of the swamps and marshes. The long grass and shrubby edges of marshes are its typical haunts. Late in the autumn it joins the large mixed flocks of sparrows in the brush heaps and tangled fence rows and then comes into closer contact with man.

Economic Status. The food habits of the Swamp Sparrow are not very different from those of other comparable sparrows. Owing to its living in waste places it is not important.

585. Fox Sparrow. FR.-LE PINSon FAdve. Passerella iliaca. L, 7.26. A rathe r large sparrow. Above, bright reddish-brown, solid on tail and rump but with dull slaty showing through the red on hind neck and crown. Below, white heavily spotted and streaked with red like back, on sides of throat, across breast, and on flanks. The throat is almost free from markings and the spots tend to aggregate on the breast in a centre spot.

Distinctions. Rather large size and gene ral bright foxy red coloration are distinctive.

Field Marks. Rich red coloration, especially on rump and tail. The Hermit Thrush has a similar appearance as it flies, but the upper back is more olivaceous.

Nesting. On ground or in low trees and bushes, in nest of coarse grasses lined with finer grass, hair, moss, and feathers. 
Distribution. As a species the Fox Sparrow ranges over all of North America north to the tree limits. The Canadian form, the Eastern Fox Sparrow, the type, extends west to the foot of the Rockies, where its place is taken by a number of other subspecies.

SUBSPECIES. The Fox Sparrow is a highly variable and plastic species and numerous well marked subspecific forms can be distinguished. The one occupying eastern Canada is the Eastern Fox Sparrow $P$. $i$. iliaca, the typical race.

This sparrow remains within the limits of civilization only for a few days spring and autumn. Occasionally in spring it greets us with a song of full clear tone that is equalled by few other birds and hardly surpassed by any.

Economic Status. It is with us hardly long enough or in sufficient numbers to be of great importance to the agriculturist. It eats a little more fruit than the majority of the sparrows, but at the seasons of its visits little cultivated fruit is available and the insect and weed seed portions of its food are such that it need cause no anxiety.

587. Towhee. FR.-LE PINSON AUX YEUX RoJGEs. Pipilo erythrophthalmus. L, 8 35 . Male, all above pure black including tail, head, throat, and breast where it cuts in a sharp line against the clear white of the underparts. Broad reddish or bay flanks. A few white feather edges on the flight feathers and considerable white in tail margins. Female, similar but with the black replaced by reddish brown.

Distinctions. Owing to its large size, long tail, and striking coloration the Towhee can hardly be mistaken for any other bird. Young birds do not have much indication of these distinctive colours, being a vague, generally rusty colour, faintly and brokenly striped; but the long tail, size, and general outline are usually sufficient for recognition.

Field Marks. With a good view of the black or brown head and back, and the red flanks, the speciés can hardly be mistaken. As it dashes away into the underbrush the strongly accentuated black and white of the wings and tail of the male, or the reddish brown and white on the tail of the female are easily recognizable.

Nesting. On or near ground, in nest of dead leaves and strips of bark, lined with fine grasses.

Distribution. Eastern North America, from southern Canada to the gulf. Occurs in Canada only along the southern border and is common only in the lower Great Lakes region.

SUBSPECIES. The Towhee of eastern Canada, $P$. e. erythrophthalmus, is the Eastern Towhee, the type race of the species.

The Towhee is a bird of brushy wastes or wood edges, where its distinctive note "Chewee" or "Te-wee" is a familiar sound. It delights to perch on the top of a sapling standing alone in the underbrush and sing its clear "dick-yoo, chiddle-chiddle-chiddle". On being disturbed it drops straight down into the underbrush, its black and white uniform flashing an instant, then vanishes in the tangle, whence it peers about uttering its usual "chi-wee" in inquisitive accents. In feeding it scratches over the surface like a hen, making the dead leaves fly in all directions.

593. Cardinal. RED-BIRD. CARDINAL GROSBEAK. Cardinalis cardinalis. L, 8.25. A large sparrow and a typical Grosbeak. The male is bright cardinal red with a black splash about the base of the bill and throat. Both sexes have a decided crest as prominent as that of the Blue Jay. The female is warm buff in colour, almost white below and olive-buff on the back, the wings, tail, and crest approaching the rosy colour of the male. The black face and throat of the male are faintly indicated.

Distinctions. Absolutely unmistakable for anything else. The Pine Grosbeak may suggest the Cardinal, but the red is never as solid and brilliant and it is without the crest or the striking black face mark. The Scarlet Tanager is as brilliantly red, but is without crest or face mark and the wings and tail are black.

Field Marks. The brilliant all red coloration of the male, the flash of warm reddish on the wings and tail of the female, and the prominent crest and large red bill in both sexes.

Nesting. In bushes, in nest of twigs, rootlets, and strips of bark, lined with grasses and rootlets. 
Distribution. The Cardinal in its various subspecies has a wide distribution in the United States and the type form crosses the Canadian border commonly along the western end of lake Erie, occurring as scattered individuals and in isolated communities there and in adjoinging localities. The Eastern Cardinal, the one here considered, is the type form of the species.

The Cardinal Grosbeak is not generally distributed in Canada, but is a permanent resident wherever it is found and its gorgeous colouring and brilliant whistling give an added interest to nature. It may surprise many that this southern bird ever occurs in Canada, but in some sections along the lake Erie shore it is not only regular but common. It should be rigorously protected for its beauty as well as for more material reasons.

Economic Status. The Cardinal feeds largely upon locusts, cicadas, potato bugs, rose chafers, plum and cherry scales, cutworms, weevils, and other destructive pests. In addition, it takes weed seeds in considerable amount and some wild fruit. There is no evidence that it damages cultivated varieties.

595. Rose-breasted Grosbeak. FR.-GROS BEC ̀̀ POITRINE Rose. Zamelodia ludoviciana. L, 8.12. Plate XXXIV B.

Distinctions. The male with his black back and rose-coloured bib is unmistakable. The female is the only sharply streaked Grosbeak in eastern Canada. Young autumn males are much like the female, but have a slight rosy suffusion showing through the buff colour of the breast. They vary considerably, but indications of the more pronounced spring plumages can usually be seen.

Field Marks. A full view of either sex with their characteristic colorations and large bills is distinctive enough. The black-backed male with contrasting white rump and wing-bars can be recognized at a glance even as it vanishes in the brush. The female, if not clearly seen, may be mistaken for the much smaller female Purple Finch; but the unstriped underparts, more heavily marked head with conspicuous line over the eye, and more prominent white wing-bars usually serve for its identification.

Nesting. In bushes or trees 5 to 20 feet above ground, in nest of fine twigs, weed stalks, and rootlets.

Distribution. Eastern America, north to well beyond settlement. Breeds in Canada wherever found.

The Rose-breasted Grosbeak is one of our most beautiful birds and best songsters. It prefers tangled thickets interspersed with open spaces and large tree clumps. It frequents thickets along rivers, edges of woodland abutting on clearings, overgrown fence lines, and sometimes orchards.

Economic Status. If the number of Rose-breasted Grosbeaks could be greatly increased on the farms the potato bug scourge would soon disappear. This bird is one of the few that eats the potato beetle and it takes them in both adult and larval stages. One-tenth of the contents of the stomachs examined consisted of potato bugs and this species is equally efficient against other insect pests. To increase the numbers of Rose-breasted Grosbeaks may be difficult, but the next best thing is to conserve what we have, protect them from preventable destruction, and see that suitable nesting corners are left in waste corners of the farm and woodlot. In carrying out plans for clean cultivation and the elimination of waste places, care should be taken that bits of shrubbery are left to afford shelter for birds which without these sanctuaries must disappear. The preservation of the birds will more than compensate for the small losses entailed.

597. Blue Grosbeak. FR.-LLE GRos-BEc BLEJ. Guiraca carulea. L, 7. A small Grosbeak, coloured like a large Indigo Bunting, but not quite as bright and with chestnut-rufous bars on wing and shoulder. 
Distinctions. The plumages in seasonal and sex variation closely follow those of the Indigo Bunting, from which it can be told by size and its Grosbeak bill. In mixed plumage it may resemble the Bluebird even to the reddish breast, but the bill is entirely unlike the bill of that bird. (See Figure 50, p. 26).

Field Marks. The above will suggest field marks, but the Blue Grosbeak is too rare in Canada to safely rely on sight identification.

Distribution. Eastern North America, in the north stopping normally considerably short of the Canadian border.

SUBSPECIES. The subspecies of the Blue Grosbeak to be expected in Canada is the eastern form, the Eastern Blue Grosbeak, the type race of the species.

The records of this bird's occurrence in Canada are too fragmentary for the species to be expected otherwise than as a rare and accidental straggler. It can only be hoped for in the southern parts and perhaps the southern coast.

598. Indigo Bunting. FR.-LE PINson INDIgo. Passerina cyanea. L, 5.59. A rather small sparrow; the male, brilliant blue all over, the female nearly uniformly buffy rust colour with occasional faint suggestions of the blue of the male, slightly whitiah below with faint and indistinct stripes. Autumn birds show intermediate stages between the above coloration or with stronger reddish rust.

Distinctions. The Indigo Bunting is our only all blue bird; the Bluebird, the only comparable bird, has a reddish breast. The even, almost unvaried dull rusty colour of the female and juvenile distinguishes them from other species.

Field Marks. The all blue colour of the male and the even reddish of the females and juveniles.

Nesting. Generally in the crotch of a bush 2 to 3 feet above ground, in nest of grasses, dead leaves, and strips of bark, lined with fine grasses, rootlets, and long hairs.

Distribution. North America east of the plains and north well into Canada.

The Indigo Bunting commonly frequents brushy overgrown wastes, burnt land, or slashes. It has a pleasing song.

Economic Status. Our knowledge of the food of the Indigo Bunting is not complete. There is little doubt that it has the'usual food habits of its family; and it is credited with doing good work against the Browntailed Moth. It is undoubtedly as worthy of protection as the others of its kind.

604. Dickcissel. Spiza americana. L, 6. Back striped with dark brown and ruddy buff changing to solid dull red on wing coverts; hind neck slate-grey to crown where it is strongly tinged with yellow; cheeks igrey with pure yellow eyebrow line. White below; breast pure yellow and throat with a sharply defined black throat-patch or bib.

Distinctions. The yellow breast and black throat, slightly suggesting a small Meadowlark, are distinctive.

Distribution. Eastern America, mostly in the interior and central portions. In eastern Canada, irregularly across our borders in southwestern Ontario.

This beautiful open field species is rare in Canada. A few have appeared for a short series of years in the region at the west end of lake Erie and then vanished to reappear some years later.

$$
\text { PAMILY-TANGARIDAM. TANAGERS. L, 7.25-7.50. }
$$

General Description. Brilliantly coloured birds with bills resembling those of sparrows but slightly elongated, with an evenly curved culmen, a slight notch in the upper mandible opposite the tip of the lower one and a tooth and notch in the middle of the upper cutting edge (Figure 53, p. 26). In some species the notch is too slight to be seen without careful examination.

Distinctions. Besides the bill features above, the eastern Canadian species can be easily recognized by colour. The spring males are birds of brilliant red coloration, the females and autumn birds are dull warm yellows or greens with no sharp, detailed mark- 
ings and little variety in colour except in the even masses of the wings and tail. Spring males can only be compared with the Cardinal in colour, the autumn birds and females only with the female Orioles, but the lack of crest of the Tanagers will easily separate them from the Cardinals and the bill characters from either the Cardinals or Orioles.

The Tanagers are a typically American family that reaches its highest development in the Tropics and is only regularly represented in eastern Canada by one species. As a family the Tanagers are so closely related to the Sparrows that the status of some extralimital species is still undetermined.

608. Scarlet Tanager. RED BIRD. FIRE BIRD. WAR BIRD. FR.-LE TANGARA 6Carlate. Piranga erythromelas. L, 7.25. Plate XXXV A.

Distinctions. Excepting the next apecies, the Summer Tanager, the Scarlet Tanager is only comparable with the Cardinal, but it is easily recognized by its lack of crest, slighter and longer bill, and black wings and tail. The even green of the female is distinctive, being approached only by a few much smaller Warblers and the Orioles. The autumn male is like the female, but with black wings and tail.

Field Marks. Brilliant scarlet colour, with black wings and tail in the male and the even green coloration and size in other plumages.

Nesting. Usually near the extremity of a branch, about 20 feet above the ground, in nest of leaves, strips of bark, etc.

Distribution. Eastern America north to near the limit of settlements.

The Scarlet Tanager shows remarkable seasonal and sexual plumage changes. In the spring the sexes are so entirely different that one wonders at their specific relationship, and in the summer the brilliant scarlet male gradually assumes the dull green of his mate.

The Scarlet Tanager is a bird of light woodlands, where large timber grows with a sprinkling of small underbrush below, but in spring it occasionally visits the orchard. On arrival in spring the Scarlet Tanager is a most conspicuous object, but as the trees put on their leaves it becomes cautious in exposing itself and if it were not for its distinctive note "chipchur" that directs attention to it, it would be most difficult to find. The song is cheerful, rythmical, and fairly sustained, something like a robin's but more connected and not quite so clear.

Economic Status. The food of the Scarlet Tanager consists mostly of insects and fruit. The insects are usually woodland species and their destruction is of importance to the forester and fruit grower. The fruit eaten is mostly wild, in fact most birds prefer wild to domestic fruit and given an abundance of the former seldom eat the latter. The Scarlet Tanager does no serious damage.

610. Summer Tanager. SUMMER RED-BIRD. Fr.-TANGara Vermulon. Piranga mubra. L, 7.50. Much like the Scarlet Tanager, but with red instead of black tail and dull brownish wings edged and tinged with red; the females bear the same relation to the male as do those of the Scarlet Tanager.

Distinctions. The wings and tail are different from those of the Scarlet Tanager and the red is more rose-coloured, less brilliant and lighter below than on the back. The female is a warm orange-green of quite a different shade to the cold greenish of the allied female. She bears a fairly close resemblance to the female Baltimore Oriole, but the evenly coloured, unmarked back and wings and the Tanager bill make separation easy.

Distribution. Southeastern United States and north to the latitude of southern Ohio. Has been recorded in Canada near the southern boundary along the lower Great Lakes and in New Brunswick and Nova Scotia.

The Summer Tanager is an accidental straggler in Canada, from the south, along the lower Great Lakes and in Nova Scotia and New Brunswick. 
FAMILY-HIRUNDINIDE. SWALLOWS.

General Description. Mostly small birds, wings very long and pointed; feet small and weak, unsuited to walking; head flattened and bill very short with deep gape (Figure 54, p. 27).

Distinctions. Superficially resembling the Goatsuckers, but much smaller and of different type of coloration. More apt to be confused with the Chimney Swift than with any other species, but without the spines at the end of the tail feathers.

A world-wide family, of aerial habits, seldom coming to the ground except for nesting material. Their feet are weak and suitable for alighting only on small twigs, telegraph wires, and similar perches. They take their food on the wing and can often be seen sweeping over ponds, slightly furrowing the still surface as they drink. They are skilful nestmakers and build. a remarkable variety of forms from bottle-necked structures of kneaded mud to holes tunnelled in earth banks.

Economic Status. Flying insects constitute almost the entire food of the Swallows. Sailing high or low in the air as food results justify, the Swallows attack many winged insects which are otherwise almost unmolested. Over grain fields and about barnyards where insect eating birds are few the Swallows congregate and give efficient assistance to the agriculturist. They are sometimes dirty when they nest in numbers under eaves and in similar situations, but instead of merely knocking down the nests, suitable nesting sites should be provided about the farm buildings where they can congregate without offence. A large flock of Swallows about the barnyard is of very great advantage to the farmer.

611. Purple Martin. Fr.-L'HIRONDelte Potrpres. Progne subis. L, 8. Plate XXXV B.

Distinctions. The largest of our swallows. Size and iridescent blue black coloration of the male Martin should be sufficient for the separation of the species.

Field Marks. Size, colour, almost falcon-like manner of flight, and the voice make good field marks.

Nesting. Under primeval conditions in hollow trees. In civilization in artificial bird houses, cavities in cornices of buildings, etc. They are sociable nesters and prefer to build in communities of their own kind.

Distribution. North America. A western subspecies occupies the Pacific coast. The eastern form, which is the type race, frequents the most of the settled sections of eastern Canada.

SUBSPECIES. The subspecies of the Purple Martin that occurs in eastern Canada is the Eastern Martin P. s. subis, the type form.

Through the day the birds scatter over the country, returning at frequent intervals with food for their young. At evening all return to the house they occupy and retire within its shelter for the night. The young remain for a considerable time in the nest and even after their first flight old and young return to the nest at night. Martins are domestic and sociable birds and greet each other with welcoming gurgles and chatterings. Each is interested in the other's family affairs and there is a constant interchange of visits between neighbours. They rarely quarrel among themselves but show a united front to common enemies, especially the English Sparrow. A colony can hold its own against that pest very well indeed, after it has established itself. A Martin house should contain several rooms about 8 by 8 inches, weather and draft proof at all points except the door which should be about 2 inches in diameter and $1 \frac{1}{2}$ inches from the floor. The house should stand 15 to 20 feet above the ground, up well in the open, and in such a manner that it can be lowered for cleaning. 
There are indications that the Purple Martin is growing fewer in numbers. Old colonies from time to time are broken up and few new ones take their places. The Martins return to their summer quarters very early in the spring and at times suffer severely from late frosts and cold rains which stop the flight of insects and deprive them of the necessary large and constant amount of food.

Economic Status. The Martin like the other Swallows is a bird with no bad habits, and with so many good ones that every effort should be made to aid its increase.

612. Cliff Swallow. eave swallow. mud swallow. FR.-L'Hirondelle à Front Blanc. Petrochelidon lunifrons. L, 6.01. Similar in general coloration to the Barn Swallow (Plate XXXVI A), but different in detail and without the long, deeply forked tail.

Distinctions. Throat, richer in colour and more reddish brown than that of the Barn Swallow; the brown colour extending in a narrow band across the back of the neck and with a black spot in the middle of lower throat instead of a broken black bar across breast. Forehead sharply contrasting creamy white instead of reddish. Rump light reddish. Below, dull white. Tail, almost square.

Field Marks. The white forehead and reddish rump make the best field marks. The square tail will separate it from all Barn Swallows except juveniles which have not yet grown the fork.

Nesting. A typical nest is built entirely of mud carried in little pellets in the bill and on the feet. The mud is mixed with saliva and plastered pellet by pellet on the wall under the eaves of some building. The nest is first a shelf built out from the wall, then saucer-shaped and then cup-shaped, in any of which states it may be left as finished. In the best examples the sides are continued until the nest assumes the shape of a round flask with the neck drawn over and pointing outwards.

Distribution. America. In eastern Canada to well north of civilization.

SUBSPECIES. The subspecies of the Cliff Swallow occupying most of North America and all of Canada is the Eastern Cliff Swallow P. l. lunifrons, the type form of the species.

Originally a cliff dweller as the name implies, within the confines of civilization this Swallow now nests almost entirely on barns and other buildings. It is often of rather local distribution, different colonies nesting in many cases in widely separated groups of farm buildings.

613. Barn Swallow. FR.-L'HIRONDELle Des Granges. Hirundo erythrogastra. L, 6.95. Plate XXXVI A.

Distinctions. Broken black bar across the chest beneath the reddish throat, black rump, and, in adult, long forked tail are distinctive of the species.

Field Marks. Rufous tints beneath and black rump are good field marks; also, in the adult the long forked tail and in juveniles the white in the tail.

Nesting. The nest is far from being the beautiful structure the Cliff Swallow builds. It is largely made of mud mixed with grasses, lined with grass and feathers, and set on a support such as a rafter or beam; but of ten the slightest projection will be utilized as a foundation upon which to build. Some farmers ensure the presence of the birds about the place and induce them to nest where they will be unobjectionable by furnishing small supports for their nests close under the eaves of their barns or inside where they will be sheltered but can do no damage.

Distribution. America. Probably not quite as northern as the preceding species.

This is the Swallow commonly nesting in barns and outbuildings. It not only builds under the eaves but enters the building and occupies the interior. Its long "swallow tail" assists in making it perhaps the most graceful of all the Canadian swallows.

614. Tree Swallow. WHITE-BELLIED SWALLOW. FR.-LE HIRONDELLE BICOLORE. Iridoprocne bicolor. L, 5.90. Plate XXXVI B. 
Distinctions. The even blackness with pronounced steely reflections of the upper parts and pure whiteness below are distinctive.

Field Marks. The pure unmarked whiteness of the underparts make an easily recognized field mark. Young birds have the black above replaced with dull brown and a suggestion of suffused brown on the sides of the breast, but this never forms a continuous band across the breast as in the Bank Swallow.

Nesting. In old woodpecker's holes in dead stubs, hollow trees, or bird boxes. Lined with grasses and feathers.

Distribution. America north to near the limit of trees.

Though normally using woodpecker's holes in dead stubs over the water the Tree Swallow is easily induced to nest in boxes in the garden. The beauty of its bright iridescence and the grace of its flight make ample payment for the work of preparation, even if its presence were not an important safeguard against insects in the garden. The continued existence of the species is threatened through the growing scarcity of natural nesting sites unless an effort is made to supply the nests artificially.

616. Bank Swallow. SAND MARTIN. FR.-L'HIRONDELLE DR RIVAGE. Riparia riparia. L, $5 \cdot 20$. Plate XXXVII A.

Distinctions. Dull brown instead of iridescent coloration of back, and white underparts with distinct dark breast-band are distinctive. The band is always full and complete and the white pure. The complete breast-band will separate the Bank from the young Tree Swallow; and from the Rough-winged in which the white is not pure and the breast and throat are evenly suffused with ashy brown.

Field Marks. The white underparts crossed by a conspicuous dark bar makes the best field mark.

Nesting. Nearly every one has seen how quickly the exposed sides of a sand or gravel pit excavation become pitted with the small nesting holes of these swallows. Too often the heedless small boy digs them out. Not only is this dangerous to the boy from the possibility of the bank caving, but it is striking a direct blow at the existence of one of the farmer's best friends.

617. Rough-winged Swallow. Stelgidopteryx serripennis. L, 5·75. Much like the Bank Swallow in general coloration, but with the breast and throat suffused with light ashy-brown instead of being crossed with a sharp brown band.

Distinctions. The above difference, together with the absence of much pure white below and any white on throat are diagnostic. Grown birds have the small outer web of the outer primaries converted into a series of fine recurved hooks almost too small to see with the naked eye, but obvious to the touch as the finger is drawn along the edge towards the tip. Young birds do not show this well, sometimes not at all, and various stages of its development appear. It is present in some degree in all spring specimens.

Field Marks. The best field mark by which to separate the Rough-winged from the Bank Swallow is the evenly suffused breast instead of the white one with broad dark bar. In watching a mixed flock the Rough-wings can usually be picked out by the slightly redder or rusty-coloured back which seems more conspicuous in life than in the hand.

Nesting. Similar to the Bank Swallow, but more solitary and perhaps more given to nesting in crevices in rock piles, cliffs, or masonry.

Distribution. America. North to across the Canadian border in the lower Great Lakes region.

The Rough-wings belong to a genus widely scattered over the world, all exhibiting the peculiar modification of the wing which cannot be accounted for in the present state of our knowledge.

\section{FAMILY-BOMBYCILLID $A$. WAXWINGS.}

The Waxwings are striking birds, distributed over the northern parts of both the New and Old Worlds. They are represented in America by two species so well characterized in form and colour and so nearly alike that 
description here is unnecessary. There is remarkably little seasonal or sex variation and Plate XXXVII B and Figure 55, page 27, designate them plainly. The shafts of the secondaries and sometimes those of the tail are enlarged at the tips into brilliantly-coloured appendages having a close resemblance to bits of sealing wax.

618. Bohemian Waxwing. WANDERING CHATTBRER. FR.-LE JASEUR DE BOHÈME. Bombycilla garrula. L, 8. Almost exactly similar in form and colour to the Cedar Waxwing, but larger; the secondaries are tipped with white and most of the primaries with white or yellow or both; there is likewise a small white wing bar. The under tail coverts are chestnut and the abdomen greyish without the yellow suffusion.

Distinctions. No further distinctions are necessary; the Cedar Waxwing is the only species with which it can be confused.

Field Marks. Their trim figures and conspicuous crests easily identify the Waxwings. The white or yellow on the wings and the chestnut under tail coverts are the best specific field marks.

Nesting. In trees, in nest of twigs, roots, moss, etc.

Distribution. Northern sections of the northern hemisphere. In America, breeding in the far north, northwest of Hudson bay, visiting settled districts irregularly in winter.

Their irregular wandering habits in winter have given these birds the name "Bohemian" which in this sense is synonymous with "wandering." They are northwestern birds, but come into cultivated sections of eastern Canada occasionally in winter, as does the Evening Grosbeak. They are too rare to have any great economic influence. Their favourite food is the dried waste fruit that hangs through the winter.

619. Cedar Waxwing. Cedar bIRd, Carolina waxwing, cherRy BIRd. hR.LE JASEUR DU cìDRF. Bombycilla cedrorum. L, 7.19. Plate XXXVII B.

Distinctions. With the illustration the Cedar Waxwing can hardly be mistaken for any other species except the Bohemian. For distinctions see that species. This is the only Waxwing to be seen in eastern Canada in summer and the most probable one, in the southern sections, in winter.

Field Marks. The natty shape and bearing and the conspicuous upstanding crest are easily recognizable field marks. The note, a fine sharp wheeze, is distinctive and soon learned. See previous species.

Nesting. Often in fruit or shade trees, in a bulky structure of strips of bark, leaves, grasses, twigs, rootlets, moss, etc., lined with finer materials of the same nature.

Distribution. America, north in Canada to and somewhat beyond the limits of regular cultivation.

The Cedar Waxing is one of the familiar birds of the orchard. It builds in the fruit trees in the summer and is rather too well known in the vicinity of early ripening cherries. In the winter it seeks the various kinds of old dried fruit left hanging on the branches. The coloration is soft and harmonious with just enough accent of contrasting colour to give character. The peculiar smooth, silky texture of the plumage seems to cause the feathers to cling together so that they always lie smoothly and never seem awry. The red-sealing-wax-like processes in which the shafts of the secondaries and sometimes the tail feather end, common to this and the Bohemian Waxwing, are unique amongst American birds and give an added touch of individuality.

Economic Status. About 13 per cent of the Waxwing's food is noxious insects, the remainder largely fruit. The greater part of the fruit is wild and of no economic importance, in fact, as with most birds, wild fruits are evidently much preferred to cultivated ones. However, when early 
cherries ripen before wild forms the damage Waxwings can do is considerable. The same amount of fruit distributed over many later trees might pass unnoticed, but when the damage is concentrated upon the earliest and most valuable part of the crop the loss is keenly felt. The protection of early fruit from the depredations of this and a few other species of like habit is a subject that has received considerable attention. To shoot all birds visiting the orchard is one solution, but a very poor one. It gives only partial protection and has to be repeated each season; for as long as any remain in the vicinity the annual increase will undo the results of previous efforts. Besides, the entire community is deprived of the valuable assistance of a number of species in order that a certain amount of early fruit may be protected. A cover of netting is generally cheaper than shooting. As the birds prefer wild to cultivated fruit early ripening wild fruit trees in waste corners and along fences provide inexpensive protection. The Russian Mulberry and Service-berry and later, the Black-currant, Mountain ash, Raspberries, and Blackberries, Sumach, Alder, Wild grape, Bittersweet, Nightshade, Snowberry, and Elders will serve the purpose.

\section{FAMILY-LANIID正. L. 9-10 -32. SHRIKES. BUTCHER-BIRDS.}

General Description. The Shrikes are medium-sized passerine birds of raptorial nature. They are easily recognized by their bills which are plainly hooked at the tip and furnished with a notch and tooth near the end of the upper mandible (Figure 56, page 27). The two species which occur in Canada are very similar in coloration and differ in minor characters only (Plate XXXVIII A).

The Shrikes are interesting examples of passerine or seed and insecteating birds adapted for a predatory life. The true raptores, the Hawks, etc., which also prey upon the higher living forms, have powerful feet with which to secure their food and hold it while they tear it with their bills. The Shrikes are without these efficient grasping and holding limbs, having in fact feet no stronger than those of a sparrow or blackbird of equal size. They, therefore, seize prey with their bill and, to hold it while feeding, have evolved the habit of impaling it upon strong thorns, etc.; this habit gives them the popular title of Butcher-bird. Shrikes are bold, spirited birds and quite as daring and capable in proportion to their size as any of the true birds of prey. The family is large and widely distributed. Only one genus is represented.in America and two species in North America.

621. Northern Shrike. BUTCHER-BIRD, FR.-LA PIE-GREICHE BOREALE, Lanius borealis. L, 10.32. Similar to the Loggerhead Shrike, (Plate XXXVIII A) but larger and with a series of fine wavy lines or vermiculations faintly showing across most of the underparts.

Distinctions. General coloration and notched bill will distinguish this as a Shrike. Size and the distinct vermiculations below will characterize it as the Northern Shrike.

Field Marks. The sharply contrasted amount of black and white on the wings and tail, the grey upperparts, and the black band through eye. Any Shrike seen in eastern Canada in winter between October and March will be of this species.

Nesting. In low trees or bushes in nest of twigs, grasses, etc.

Distribution. Northern America, breeding beyond regular settlement across the continent, south in winter.

The Northern Shrike is the bolder and more energetic of our two species. It is a northern breeder and is only seen in cultivated sections in the winter where it follows the flocks of Snow Buntings, Redpolls, etc. It has shown 
some tendency to come into cities and villages in pursuit of the House or English Sparrow, in which work it is to be encouraged in every way. Dry, mummied mice and birds occasionally found pinned to thorns and barbs of wire fences or hanging from the close forks of twigs are usually the work of this species.

Economic Status. Though thoroughly raptorial in habit the Northern Shrike cannot be said to do a great amount of damage. It is not common enough within settlement to be a serious factor in the small bird life of the fields. It catches numbers of mice and probably its attacks on them and on the House or English Sparrow compensate for the seed-eating birds it takes.

622. Loggerhead Shrike. MIGRANT SHRIKE, BUTCHER-BIRD. FR.-Lanius ludovicianus. L, 9. Plate XXXVIII A.

Distinctions. This species can hardly be mistaken for any thing but the Northern and it is considerably smaller than that species. The adult is without the fine vermiculations of the breast and in the juvenile they are only faintly suggested. A summer and not a winter bird in Canada.

Field Marks. The clear white and light grey of the body plumage, black wings, and tail strongly accentuated with white, and the black band through the face are distinctive of the Shrikes. Any summer Shrike within the cultivated sections will be of this species.

Nesting. Nest of strips of bark, small twigs, and vegetable fibres lined with fitted wool and feathers.

Distribution. As a species, North America north to the limit of cultivation. The migrant Shrike occupies eastern North America north of the gulf states and west to the prairie provinces.

SUBSPECIES. The Loggerhead Shrike, like many other wide ranging species, develops various local characteristics in different parts of its diversified range, each forming a recognized subspecies. The form occupying eastern Canada is the Migrant Shrike, $L . l$. migrans separable from the type subspecies in the southern states or the White-rumped of the west by only slight differences of colour and proportions.

The Loggerhead is a bird of open, brushy pastures and hillsides. Thorn-apple trees, cropped and trimmed by cattle until dense and repellent are its favourite nesting sites and in such neighbourhoods it can usually be seen on some commanding perch, such as the tip of a dead sapling or a telegraph wire, keenly regarding the surrounding country. The impaling of prey is not quite as strongly developed a habit in this species as in the previous one, probably because it is more insectivorous and can handle much of its smaller prey without so doing. At any rate evidence in the shape of remains stuck on thorns is decidedly rare in haunts where the species is common and where it would be expected to be numerous. The song of the Loggerhead Shrike is quite musical and pleasing, but the call notes are harsh and discordant.

Economic-Status. The food habits of the Loggerhead are similar to those of the Northern Shrike, differing only as would be expected in a smaller and weaker bird and a summer rather than a winter resident. Thus we find fewer birds and mammals and more insects are taken, indeed during the height of the insect season the latter seem to constitute the greater part of its food. Early in the season great numbers of beetles are eaten, useful and harmful forms being about equally divided in numbers. Later, grasshoppers and crickets form a large proportion of the food, but numbers of caterpillars, many of them hairy, cutworms, some wasps, 
spiders, and other insect forms are also taken. The food of the species throughout the year is regarded by the United States Biological Survey as being beneficial in the ratio of 4 to 1 .

FAMILY-VIREONIDA. VIREOS OR GREENLETS. L, 4·75-6.23.

General Description. Small, warbler-like birds generally coloured in greens and white with more or less yellow in softly suffused masses and without much definite marking. The bill is perceptibly notched and hooked at the tip much like that of the Shrike (Figure 56 , page 56), but is on a much smaller and much lighter scale.

Distinctions. The Vireos are most apt to be mistaken for warblers which in habit, size, and general coloration they resemble. The bills, however, are stouter, more strongly arched on the culmen, higher for the width, and more evidently hooked and notched at the tip. The Yellow-breasted Chat has a bill that might answer this description in outline, but it is not hooked nor has it any indication of notch at tip.

Field Marks. In addition to specific markings, which form the best guide to species, the Vireos can be recognized by their warbler-like habits but slower and more sluggish movements, peering under leaves and gleaning from the branches and twigs with less activity.

The Vireos constitute a small family peculiar to America. Three genera occur in Canada, represented by six species.

Economic Status. Economically the Vireos can be treated together as they are similar in their food habits. 'Their food consists of 91 per cent of insects and the remainder of fruits. The latter are almost without exception wild varieties. The insects taken are among the most harmful, including scales and other close lying species that no birds but the careful, close-peering Vireos ordinarily seek. They are among our more useful birds.

624. Red-eyed Vireo. PREACHER-BIRD. TEACHER. FR.-LE VIRío AUX YEUX Rodaes. Vireosylua olivacea. L, $6 \cdot 23$. Plate XXXVIII B.

Distinctions. The Red-eyed can be distinguished from other Vireos by its superior size, the lack of yellow, the grey confined to the crown, and the white eyebrow line bordered with dark both above and below. The iris is red, but this can only be seen on very close examination.

Field Marks. The markings of the face of the Red-eyed makes the best field mark. The white eyebrow bordered with darker colour and the lower line through the eye can usually be seen as the bird peers through the leaves at the intruder.

Nesting. Suspended from between the forks of a small branch 5 to 15 feet above the ground in pensile nest or hanging-cup, woven of strips of bark, dead wood fibres, paper, plant down, or birch bark lined with fine materials.

Distribution. North America to near the limit of trees.

The Red-eyed Vireo is one of the commonest frequenters of our groves and woods. Its song, a leisurely repetition of slight variants of the same phrase with pauses between, and continued ad libitum, can be heard in the tree tops almost anywhere in Canada and has given the species the name of Preacher-bird.

626. Philadelphia Vireo. FR.-LE viréo DE PHILADELPHIE. Vireosylva philadelphica. $\mathrm{L}, 4 \cdot 75$. Almost exactly similar in coloration to the Warbling Vireo (Plate XXXIX A) but more generally suffused with yellow on breast, flanks, and below.

Distinctions. The Philadelphia can always be separated from the Warbling Vireo by the length of the first primary feather. In this species it is nearly as long as the second, whereas in the Warbling it is reduced to a rudimentary condition and is barely threequarters of an inch in length.

Field Marks. In life it looks like a Warbling Vireo with unusually yellow breast and underparts. 
Nesting. Suspended from a branch about 8 feet from the ground in pensile nest of fibres and birch bark.

Distribution. Eastern America. More northern in breeding range than the Warbling and only a migrant in most of the settled sections of Canada.

Usually a rather rare little Vireo and too inconspicuous to be often seen or recognized by the ordinary observer.

627. Warbling Vireo. FR.-LE vIReo GRIS-OLIVE. Vireosylva gilva. L, 5.80. Plate XXXIX A.

Distinctions. The even unmarked coloration and small size will distinguish the Warbling from any other Vireo except the Philadelphia. The lack of yellow overwash in front and below will usually be diagnostic. The final test of the species, however, is the small rudimentary condition of the first primary which is hardly three-quarters of an inch long instead of one and three-quarters.

Field Marks. The almost pure white underparts instead of the yellow suffusion of the Philadelphia makes the best recognition mark from that species and the small size and dull even coloration from other Vireos.

Nesting. Suspended between the forks of a small branch 15 to 50 feet above the ground in pensile nest of fine bark strips and plant fibres, smoothly and firmly interwoven and lined with pine needles and hairs.

Distribution. As a species, occupies all of temperate America; the Eastern Warbling Vireo extends west to the prairie provinces.

SUBSPECIES. The Warbling Vireo is divided into an eastern and a western subspecies. The Eastern Warbling Vireo V. g. gilva, the type of the species, is the only one met with in eastern Canada.

The Warbling Vireo, hidden in leafy tree tops, is more often heard than seen. Its song is very different from that of the Red-eyed, being continuous and not composed of disconnected phrases.

628. Yellow-throated Vireo. FR.-LE VIRÉ À FRONT JAUNE. Lanivireo flavifrons. L, 5.95. Head, cheeks, and back greenish; rump and tail slaty; breast and throat bright yellow; below white; wings with two distinct white bars.

Distinctions. The bright yellow breast and throat of this species is distinctive. The Solitary and the White-eyed are the only other Vireos with wing bars. In the former the bars are white as in the breast, in the latter the bars are yellowish. In coloration the Yellowthroated Vireo is very similar to the Pine Warbler, but there is much less white on the underparts of the latter species, the yellow suffusing and covering most of it instead of stopping almost sharply at the breast line.

Field Marles. The bright yellow throat and breast are distinctly recognizable and prevent confusion with any other native Vireo. The voice, similar to that of the Redeyed but with the phrases following each other less rapidly 2 to 3 seconds apart instead of about one per second, will distinguish it from others of its family or from the Warblers.

Nesting. Suspended from a forked branch 10 to 80 feet above the ground, in pensile nest of strips of bark, plant fibres, etc., lined with fine grasses and covered externally with lichens, spider webs, etc.

Distribution. Eastern North America. Common in eastern Canada only in the southern parts of the lower Great Lakes region.

A woodland and orchard bird. Besides its characteristic song it is a maker of many queer noises and has an extensive vocabulary.

629. Solitary Vireo. BLUE-HEADED VIREo. FR. - LE VTREo À TÊTE BLEUE. Lanivireo solitarius. $L, 561$. Back greenish shading into bluish ash on head and adjacent parts of cheeks; white loral spot and white ring about eye; all underparts white with suffusion of yellow on flanks; wings with two whitish bars. distinctive.

Distinctions. The ashy blue head with conspicuous white lores and eye-ring are

Field Marks. The bluish head with conspicuous white eye-ring and lores and pure white throat make conspicuous field marks.

Nesting. Suspended from between the forks of a small branch 5 to 10 feet above the ground, in pensile nest of wood fibrea, bark strips, and pine needles, plant down, etc.

$57172-13 \frac{1}{2}$ 
Distribution. As a species the Solitary Vireo extends over all of the United States and Canada north to the extreme limits of settlements. The Blue-headed, the eastern representative of the species, ranges west to central Alberta.

SUBSPECIES. The Solitary Vireo is divided into several subspecies, only one of which, the Blue-headed Vireo L. s. solitarius, the type form, occurs in eastern Canada.

A pretty little Vireo and a common inhabitant of woodland and orchard during migrations. The song is similar to that of the Red-eyed, but an attentive ear can easily distinguish between them.

631. White-eyed Vireo. Vireo griseus. L, 5.27. A small Vireo like the Warbling but of much richer green colour on back and with yellow loral mark and eye-ring; iris white. Throat and underparts almost pure white; strongly yellow on flanks; wings have two yellowish bars.

Distinctions. White iris, yellow eye-ring and loral mark, strong yellow on flanks, and white breast and abdomen.

Field Marks. This species is too rare in Canada and too similar to other species to be recorded on eyesight observation alone.

Nesting. Nest usually similar to that of the Red-eyed.

Distribution. All forms of the species are southern. The eastern White-eyed occurs in the eastern United States north to New York and Massachusetts and is only accidental in Canada.

SUBSPECIES. The White-eyed Vireo is represented by several subspecies, the type form, the Northern White-eye V. g. griseus being the only one which occurs in Canada.

A bird of the south noted for its remarkable voice. This species is included here on the basis of a few records scattered along the southern borders of Canada.

\section{FAMILY-MNIOTILTIDE. WOOD WARBLERS. L, $4 \cdot 25-7 \cdot 44$.}

General Description. Small birds, only one Canadian species being over $6 \cdot 28$ inches long and very few over 5.75. They are usually bright coloured woodland and treetop birds though a few inhabit the ground and the grass. They are, as a family, difficult of diagnosis and the genera can be most easily recognized by the bills (Figures 57, 58, 59, p. 27) though considerable familiarity with the species is necessary to recognize the generic characteristics.

Field Marks. No reliable field marks which cover the whole family can be given. However, after a little experience with them their small size, bright colours, and sprightly actions are easily recognized. They are most likely to be confused with the Vireos.

Nesting. The nesting habits of the family are various, some build in trees, from down near the ground to well up towards the tops of the taller trees, others on the ground or in grass, and some in holes in dead stubs, etc.

Distribution. Most of the warblers breed in the northern spruce woods beyond the limits of general settlement. A few nest in the more cultivated sections and some just cross the International Boundary. All are migratory and spend the winter, according to species, from northern United States south to the Amazon country of South America.

The American Wood Warblers constitute a large family peculiar to the Americas. In fact they divide the honours in point of numbers with the sparrows. The Warblers are the delight of the amateur bird observer. So small that few but the enthusiast ever see them, but so numerous and brilliantly-coloured that their discovery opens up a new world of interest to the beginner. The sexes are usually dissimilar and there is considerable seasonal change in plumage. This, multiplied by the large number of species makes the task of identifying all of them seem almost hopeless to the beginner. It is not, however, as difficult as it seems at first. The spring males are usually distinctly marked and as many of them are furnished with descriptive names their differentiation is comparatively simple. 
As the females and autumn birds almost invariably retain suggestions of the characteristic spring markings of the males the difficulty is really less than is generally anticipated. Of course, puzzling specimens occur which give even the experts some difficulty, but it is usually an alternative between two species, which can be settled by giving attention to one or more small details. In studying the warblers the observer is advised to first become familiar with the spring males. When the males of the common species are known, a comparatively easy matter with such strongly characterized forms, most of the females are recognized without much difficulty as they usually carry a subdued reflection of their mate's brighter colour pattern. In the autumn, most juveniles resemble the females closely enough to make recognition not so very difficult. There are thus comparatively few plumages besides the spring males that have to be learned individually. The Canadian Warblers represent twelve genera, seven of which are represented by single species only. Dendroica has sixteen species, Vermivora five, and three others are represented by three species each. The generic details of the most important will be discussed under their proper headings.

Though called "Warblers" their song should as a rule hardly be dignified by such a term. With few exceptions the songs are only insignificant little notes without much prolonged continuity, but as they are often specifically distinctive the student is advised to pay close attention to them, for when the great warbler migrations are on, the presence of a new or rare species is often first made known by a single unfamiliar sound directing attention from the many to the one that would otherwise escape notice.

Economic Status. The Warblers are highly insectivorous. A few take more or less seed and a little fruit, the latter almost invariably wild, and no complaints have been made against any of the family. Their effect, therefore, is wholly beneficial. Being active they reach all kinds of insect habitats from the axils of highest flung leaves to between blades of grass on the ground, and as they are small they are satisfied to take insects and insect eggs that are too insignificant or too well hidden to receive the attention of larger birds.

636. Black and White Warbler. BLACK AND WHITE CREEPER. FR.-LA FAUVETTE NOIRE ET BLANCHE. Mniotilta varia. L, 5.30. Plate XXXIX B. There is little plumage variation.

Distinctions. A small black and white warbler which creeps about holes and branches like a woodpecker. In the autumn the colours of the young bird are similar to those of the adult but slightly veiled and have small washes of buff and less black on the throat. It is only to be mistaken in spring for the Black-poll but the white median stripe on the crown instead of all black can distinguish it from that species.

Field Marks. Its creeping habits, strong black and white coloration with median crown stripe. In the autumn it is the only all black and white warbler to be seen in eastern Canada.

Nesting. On ground at the base of a stump, $\log$, or rock, in nest of strips of bark, grasses, etc., lined with rootlets and long hair.

Distribution. Eastern North America; breeds in most of Canada north to well beyond the settlements.

This is one of the earliest warblers to arrive in the spring and one of the easiest to identify at any time as it is always well marked and there is little difference in seasonal or sexual coloration. 
637. Prothonotary Warbler. Protonotaria citrea. L, 5.50. A golden yellow warbler, bright rich chrome or golden on head and most of underparts and with greyish wings, tail, and rump. There is little plumage variation.

Distinctions. The only warbler with an intense even golden head, neck and breast without wing-bars. The Pine and Wilson's Warbler have green or black crowns; the Yellow Warbler is without the grey wings and tail and is lemon yellow rather than or ange or golden.

Field Marks. The Prothonotary is too rare a species in Canada to record from living specimens.

Nesting. In a hole in a stub or stump in nest of rootlets, fine twigs and moss, plant down, or feathers.

Distribution. Mississippi valley north barely to Canadian boundary which it only crosses accidentally in the lower Great Lakes region.

This is only included in the Canadian list on the basis of a few accidental occurrences in the lower Great Lakes region. It is a bird of drowned lands, and of bushes standing in dead water.

\section{Genus-Vermivora. Worm-eating Warblers.}

The genus Vermivora is a group of small slightly built warblers in which the following characters are most easily recognized. The bill is small, sharply pointed, almost spine-like, and the culmen line is straight or almost concave rather than convex or slightly arched (Figure 57, p. 27). The tails are solidly coloured and without white spots.

639. Worm-eating Warbler. Helmitheros vermivorus. L, 5.51. Dull olive above; head buffy with conspicuously contrasting dark brown lines through the eye and bordering crown. There is little plumage variation.

Distinctions. The only warbler with this distinctive dark and buffy head marking. The bill is rather heavy for a warbler of this genus.

Field Marks. Too rare in Canada to trust to sight record for identification.

Nesting. On ground; nest of rootlets, leaves, and bark.

Distribution. Eastern United States; only one record in Canada, in southern Ontario.

A bird of wooded banks or swampy thickets, feeding near the ground.

641. Blue-winged Warbler. Vermivora pinus. L, 4.80. A green warbler with yellow forehead, throat, breast, and underparts; a fine black line through eye and bluegrey wings and tail. Two white wing-bars. Female similar but duller. Little plumage variation.

Distinctions. The bright yellow face and underparts with black eye stripe and bluegrey wings with white bars are distinctive.

Field Marks. Too rare in Canada to rely on field marks for identification.

Nesting. On ground generally in or at the border of second growth in nest of bark and leaves lined with fine strips of bark and tendrils, firmly wrapped with leaves.

Distribution. Eastern North America; regularly stopping south of the Canadian border and only accidentally crossing it in southern Ontario.

Though taken only once in Canada this is a most interesting species as it hybridizes with the next species, the Golden-Winged, forming puzzling hybrids that were long regarded as separate species under the names of Lawrence's and Brewster's Warblers.

642. Golden-winged Warbler. Vermivora chrysoptera. L, 5.10. A blue-grey warbler; male, white or very light grey below darkening on the flanks, with yellow cap and 'wing-patch and black cheeks and throat. Female similar to male but somewhat reduced in brightness and the blacks represented by dark grey. There is little age or seasonal plumage variation.

Distinctions. The blue-grey body, yellow wing patch, and black throat and eyepatches are distinctive. 
Field Marks. The above marks are easily recognizable in life. The black throat somewhat suggests the Chickadee but the other marks make it easy to separate them.

Nesting. On ground or in bushy fields or second growth in nest much like that of Blue-winged Warbler.

Distribution. Eastern United States; regularly crossing our borders only in southern Ontario along lake Erie and the lower corner of lake Huron.

Usually found in shrubby wastes or the bushy edges of woodland. To be expected only in southern Ontario.

645. Nashville Warbler.

FR.-LA FAUVETTE DE NAGHVILLE. Vermivora rubricapilla. $\mathrm{L}, 4 \cdot 77$. A yellow and green warbler with a greyish head and a more or less concealed chestnut crown patch. Sex, season, and age plumages varying only in intensity of yellow and the amount of chestnut in cap. In females the cap may be entirely concealed by the grey edgings of the feathers and occasionally it may be altogether absent.

Distinctions. The unmarked green above and yellow all below to tail, but brightest on throat and breast; and the grey or greyish head and cheeks are distinctive. This greyish head and hind neck may not be marked but is always present as a slight differentiation from the green back. When present the chestnut crown (not orange-rufous as in the Orange-crowned Warbler) is an unmistakable specific character.

Field Marks. Bright yellow, unstreaked underparts and grey head and cheeks.

Nesting. On ground in partial clearings or tree grown pastures in nest of grasses and moss lined with finer grasses and fine rootlets.

Distribution. Eastern North America. In Canada north to beyond the settlements. The Eastern Nashville Warbler extends west to near the mountains.

SUBSPECIES. The Nashville Warbler is divided into the Eastern Nashville, the type form, V.r. rubicapilla, and an extreme western one the Calaveras Warbler.

This warbler is most likely to be found in open shrubbery and the small growth that lines country roads.

646. Orange-crowned Warbler. FR.-LA FAUVETTE À COURONNE orangé. Vermivora celata. L, 5. A dull yellowish, grey-green warbler with a concealed orange-rufous crown-patch. Very little sexual difference. Immatures are without the erown spot and the brightness of the yellow below is reduced to almost the colour of the back.

Distinctions. Similar to the Nashville but without the grey or greyish on the head. The crown spot when present is still more concealed than that of the Nashville and of ten entirely hidden until the feathers are separated to show their coloured bases. The yellow throat is duller than in the Nashville. The juvenile bird is an almost evenly greyish green bird with faint suggestions of ashy to it and rather similar to the immature Tennessee but without the faint light eyebrow line ; it is more evenly coloured, and without any suggestion of white below.

Field Marks. Like a very dull coloured Nashville Warbler or a juvenile Tennessee without the faint eyebrow line.

Nesting. On or near the ground in nest of leaves and fine grasses.

Distribution. Central and western America. The Interior Orange-crown breeds from Alaska to Manitoba and is only a migrant through eastern Canada.

SUBSPECIES. The species is divided into three subspecies. The Interior Orangecrown V.c. celata, the type form, ranges west to the mountains.

One of the rarest of the regular Eastern Canadian Warblers. Eyesight alone is hardly reliable for records in eastern Canada.

647. Tennessee Warbler. FR.-LA FAUVETTE DU TENNESSEE. Vermivora peregrina, L, 5. Back of male green, underparts nearly pure white. Head and hind neck ash-grey, suffusing on cheeks. White eyebrow line and suggestion of dark line through eye. Females and juveniles have the grey head and hind neck replaced by the green of the back which suffuses more or less as dull yellow or greenish yellow over breast and underparts. The eyebrow line is always visible as a lighter coloration of the green.

Distinctions. The general green and white coloration and light eyebrow line are the best distinctions in any plumage.

Field Marks. General coloration as above, with light eyebrow line and without wingbars, tail patches, or the whitish spot at base of primaries of the Black-throated Blue Warbler. 
Nesting. In moss on ground in small, dense, coniferous growth in nest of fine gress, rootlets, and long hairs.

Distribution. Eastern America, probably to the northern tree limits. Usually a rare migrant through our settled sections but locally common.

A rather rare warbler in most sections of eastern Canada. In migration usually found well up in the trees.

648. Parula Warbler. BLUE YELLOW-BACKed WARBLER. FR-LA FAUVETTE D'AMérIQUE. Compsothlypis americana. L, 4.73. Above and sides of face and neck blue, almost bright blue, with yellow suffusion over middle of back. Below white, throat and breast clear yellow with a vaguely defined black (or bluish-black), and rufous band across breast. Females and juveniles are duller, without the breast band, and with the yellow more or less suffused over all upperparts but strongest in middle of back. White wingbars in all plumages.

Distinctions. The blue back, either pure or overwashed with yellow, wing-bars, and yellow breast and throat are always distinctive.

Field Marks. See just above.

Nesting. In hanging bunches of Usnea (the old man's beard) or other hanging lichens.

Distribution. Mostly eastern America. The Northern Parula occupies the northern part of the specific range to the limits of present settlement; not breeding in the lower Great Lakes region.

SUBSPECIES. The Parula Warbler is divided into a northern and a southern subspecies. The Canadian form, the Northern Parula C. a. usneo, is named from the lichen in which it builds its nest.

\section{Genus-Dendrotca. Woodland Warblers.}

The genus Dendroica is composed of warblers of slightly sturdier build than Vermivora. The bill is longer and the culmen more decidedly arched (Figure 58, p. 27). The tail, except that of the Yellow Warbler, has a considerable amount of white.

650. Cape May Warbler. FR.-La fadvette dU CaP May. Dendroica Tigrina. L, 5. Male: throat, breast and most of underparts bright yellow finely and sharply striped with black on lower throat, breast, and flanks. A chestnut patch in the middle of the cheek cuts sharply against the yellow. Top of head black continuing as elongated spots on the yellow-green of back. The rump is yellow and the wing has a large white patch. Female: Olive-grey above, dirty white below warmed with yellow suffusion across breast which is faintly striped with dark. Rump yellowish and white wing-patch replaced with vague bars. Juvenile: similar to spring birds but less bright; male without chestnut cheeks. Females: even dull olive-grey, slightly yellow on rump; dull white slightly olive below, faintly streaked with soft dark lines, and with faint washes of yellowish olive on breast and flanks.

Distinctions. Males are distinctive with their tiger-like colours of yellow with black stripings. Adult females show enough of the male's pattern to be recognizable. Juvenile females are more difficult to recognize. However, all show at least an appreciable yellowness on the inner parts of the feathers on the sides of the neck just behind the ears. This slight tinge sometimes shows in life when the bird turns its head but with the bird in the hand the feathers must be separated to show it.

Field Marks. Adults and juvenile males are distinctive. Juvenile females can be recognized by the peculiar fine, dim striping of breast against a slightly buffy, light olive-grey ground or by the concealed yellow spot on sides of the neck as described above.

Nesting. On low branches in small trees in pastures or woodlands in partly pensile nest of twigs and grasses fastened together with spider web and lined with horse hair.

Distribution. Eastern America west to the prairies and north to beyond settlements.

One of the most beautiful of the warblers; usually regarded as rare but locally growing commoner. It is a woodland treetop species but often seen in orchard and shade trees.

652. Yellow Warbler. SUMmer Yellow Bird. FR.-LA FaUVeTte JUANe. Dendroica astiva. L, 5.10. Plate XL A. 
Distinctions. The Yellow Warbler is apt to be confused with few other species. Its tail, with yellow on the inner vanes of the feathers, will distinguish it from all other evenly yellow or green species.

Field Marks. The even and uniform bright yellow of spring birds is unmistakable. Some dull females are more green than yellow but the green-edged wings and yellow tail, lack of colour contrasts, size, and actions of the bird are easily recognized.

Nesting. In an upright crotch in bushes and small trees in nest of fine fibres and a large amount of plant down, lined with plant down and sometimes long hairs.

The Yellow Warbler is one of the few species that sometimes refuses to incubate Cowbird's eggs. Instead of throwing out the intruding egg, however, it builds a new nest over the old one, burying it and its entire contents, including often some of its own eggs, in the foundation of the new structure, in which another set of eggs is deposited.

Distribution. Nearly all of North America. The Eastern Yellow Warbler inhabits all of Canada except the Pacific slope.

SUBSPECIES. The Yellow Warbler is divided into four subspecies; the Eastern Yellow Warbler D. aestiva which occupies most of Canada, is the type of the species.

This is the commonest breeding warbler in southern Canada. It shares with the Goldfinch the popular name of Wild Canary, but the lack of black will determine it at a glance. It is found in shrubby localities in open country or along stream or marsh edges. It is a common visitor to the garden and its cheery little song is very pleasing. In the autumn the Yellow Warbler is one of the first species to leave. Shortly after July it disappears and by mid-August only a few stragglers are left. It goes before many observers begin to think of autumn migrations and thus details of its autumn movements are difficult to gèt.

654. Black-throated Blue Warbler. FR.-FAUVETTE BLEUE $\grave{A}$ GORGE NOIR. Dendroica corvlescens. L, 5.28. Plate XL B.

Distinctions. The male, so descriptively named and strongly marked, is very distinctive. The female, however, especially in autumn, is more difficult to distinguish, it may resemble either the juvenile of the Tennessee, the autumn Black-poll, or the Bay-breast. The streaked back and wing-bars, however, of the latter two are absent. They are darker and more greyish-green than the Tennessee above and more buffy below. An indistinct and partly concealed white or light spot at the base of the primaries is always diagnostic of females of this species.

Field Marks. The male is distinctive. The female in any plumage can usually be recognized from all other evenly coloured dull green warblers by the sometimes very faint light spot at the base of the primaries, which shows far more conspicuously in life than would be expected.

Distribution. Eastern North America, breeding in the north, south to the borders of civilization.

SUBSPECIES. The black-throated Blue Warbler is divided into two subspecies of which we have only one in Canada, the type form $D$. c. ccerulescens, the Northern Black-throated, though occasionally specimens closely approach the southern variety, Cairn's Warbler D. c. cairnsi, in having a suggestion of black spots on the back.

655. Myrtle Warbler. YeLLOW-RUMPED WARBLER. FR.-LA FAUVETTE ì CROUPION JAUNe. Dendroica coronata. L, 5-65. Plate XLIA.

Distinctions. A very easily recognized species. All plumages have at least suggestions of the yellow crown, rump, and side marks. The juveniles are largely rusty brown above and have more or less of a wash of same colour across breast with the streaks only slightly indicated.

Field Marks. The yellow rump is always distinct and bright and makes the most conspicuous field mark. Its presence and the side and crown marks of the same colour, sometimes indistinct in autumn but always present, make reliable identification guides in life.

Nesting. In coniferous trees 5 to 10 feet above the ground in nest of vegetable fibre lined with grasses.

Distribution. Nearly all of North America north to tree limits. Breeding just beyond the dense settlements. 
An early warbler to arrive in spring and the last one to depart in autumn. At times in the latter season the brushy wastes, roadsides, and the overgrown fence lines are filled with Myrtle Warblers each showing, as it darts away, its distinct yellow rump as proof of its identity.

657. Magnolia Warbler. BLACK AND YeLLOW WARBLer. FR.-LA FAUVETTE $\lambda$ Tête CENDRét. Dendroica magnolia. L, 5:12. Plate XLI B.

Distinctions. The bright yellow breast and underparts sharply striped with black, black cheeks, and greyish upperparts are perfectly distinctive in the spring. Autumn birds have recognizable reflections of the adult plumage but the breast markings are absent and those of flanks reduced. The head and cheeks are evenly greyish and the back greyish shaded with green to the rump which is suffused with yellow.

Field Marks. The yellow below and on rump will separate the Magnolia from all warblers but the Cape May. The latter's yellow breast is sharply and more evenly striped with black and it has the chestnut ear patch. Close examination of the Magnolia in autumn plumage always shows a vague, light ashy bar across the upper breast. The tail is also a good identification mark. The characteristic white marking of the tails is well back from the tip and rather extensive, giving, when seen from below, the appearance of a white tail broadly banded with black.

Nesting. In coniferous trees 3 to 6 feet from the ground in nest of fine twigs and leaf stems lined with hairlike rootlets.

Distribution. Eastern North America north to tree limits; breeds mostly north of general cultivation.

One of the most beautiful of the warblers, on migration coming into shade trees and orchards where its rich coloration makes a pleasing combination with the blossoms.

658. Cerulean Warbler. Dendroica cerulea. L, 4.50. Male: sky-blue and white. Above, all blue with fine black markings on back and sides of crown. Below, pure white with blue breast-band and flank stripes;wing-bars white. Female: even dull greenishblue above, white below, more or less stained with greenish and yellow suggestions. Juvenile similar but yellower all over.

Distinctions. The male is unmistakable. Other plumages have a peculiar bluish, instead of olive or yellowish, green above that is quite characteristic. The Juvenile with its yellowish-greenish underparts is somewhat similar to the young Tennessee, having a similar eyebrow stripe, but its white wing-bars and tail patches will separate it.

Field Marks. The blue of the adult and the bluish sheen of other plumages. Otherwise like a juvenile Tennessee but with wing-bars and white in tail.

Nesting. In a tree 20 to 60 feet above the ground in nest of fine fibres bound with spider's web, lined with strips of bark fibres and with a few lichens on the outer surface.

Distribution. Eastern United States except the coast; north along lake Erie to just within Canadian territory.

Too rare in Canada to be expected regularly except in a limited area in southern Ontario.

659. Chestnut-sided Warbler. FR.-LA FAUVETTE DE PENSYlvanie. Dendroica pensylvanica. L, 5.14. Male: Crown yellow; back black and grey in stripes, overwashed with yellowish green; below white with chestnut bands along flanks; two white or yellowish wing-bars. Juvenile: an almast even yellowish-green above, white below, cheeks grey; usually with suggestions of the chestnut sides of the male.

Distirations. Superficial attention to the above description might confuse this species with the Bay-breasted but the white throat is distinctive. Spring birds with their yellow cap, chestnut sides, and white underparts; and autumn birds white below, yellowish green above, and yellowish wing-bars are easily recognized.

Field Marks. The white underparts and peculiar lemon yellowness of the green above are good recognition marks even in plumages where the characteristic markinge do not show.

Nesting. In bushes some 3 feet from the ground in nest of strips of bark, leaf stems, etc., lined with tendrils and rootlets. 
Distribution. Eastern North America west to well into the prairie country and north to beyond settlement. Nests locally almost wherever found in eastern Canada except in the extreme southern portion.

The Chestnut-sided is usually found in dry brushy clearings, second growth, and raspberry tangles.

660. Bay-breasted Warbler. FR.-LA FAUVETTE à POITRINE Bale. Dendroica castanea. L, 5.63. Male: finely striped with dull olive-ochre and black above; underparts white; top of head, throat, foreneck, and flanks bay colour (reddish chestnut); forehead and cheeks black; a light ochre spot on side of neck. Female has all these characteristic marks obvious enough for recognition but veiled and dimly indicated. The autumn birds, however, are entirely different; above, yellowish-green faintly striped with dark, below, white, more or less tinged with yellowish or buffy greenish; the bay of the sides is often indicated by a slight ruddy warmth or by individual, fully coloured feathers.

Distinctions. Spring birds are distinctive enough. Autumn specimens resemble the juvenile Black-poll so closely that often they can be separated only with difficulty even when in the hand. The Bay-breast almost invariably has a certain amount of warm ochre on the flanks which is lacking in the Black-poll and the under tail coverts are cream instead of pure white. The presence of wing-bars will distinguish these two species from any other plain greenish warbler.

Field Marks. The adult male is distinctive in colour. The spring female always shows enough of the bay breast for recognition. Adult autumn birds also usually have a trace of the bay on the flanks and the warm ochreish of these parts can usually be seen in juveniles. When these characters fail to distinguish the species, however, close attention will show that the breast colour is perfectly even and sharp eyes or good glasses will usually reveal very faint dark stripings showing on the sides of the breast of the Blackpoll. None of these marks, however, can be seen except under the most favourable circumstances, but in mixed flocks one can usually tell the proportion of each species with fair accuracy.

Nesting. In coniferous trees 5 to 20 feet above the ground in nest of grasses and plant fibres lined with plant down and long hairs.

Distribution. Eastern North America west to across the prairies and north to the tree limits. Breeds beyond regular cultivation.

The Bay-breast in spring migration prefers brushy growth in sandy wastes, roadsides, etc., but often comes close about the house in shade trees and the orchard. The similarity of the autumn Bay-breast and the autumn Black-poll, a bird in full plumage totally different, is one of the interesting phenomena of bird coloration. The autumn plumages of these two birds were at one time confused with each other under the name of Autumnal Warbler.

661. Black-poll Warbler. FR.-LA FAUVETTE RAYEE. Dendroica striata. L, 5.56. Male: black and white stripes with a solidly black crown; finely lined with black and grey on back; below all white with black from base of bill down sides of neck breaking into stripes on flanks; cheeks white. Female: greenish above; white below washed with greenish on throat and breast but with enough of the black striping showing more or less vaguely to make the bird recognizable as the female of the above. Autumn birds are almost indistinguishable from the preceding Bay-breast (see above).

Distinctions. The spring males with their clear black and white markings can be mistaken for nothing except the Black-and-White Creeper, but their non-creeping habits and the crowns solidly black, instead of with a broad white median stripe, easily separate them. The striping of the female is distinctive. The autumn birds can be told from the Bay-breast by their lack of ochre, bay, or buffy on flanks and their pure white undertail coverts.

Fietd Marks. The Black-poll is seen in three plumages: the male black and white; the female greenish, white below and more or less streaked with black; and autumn birds like Bay-breasts with faint stripes, visible only to sharp eyes or with good glasses, showing through the yellowish flanks.

Nesting. Generally in spruce trees about 6 feet above the ground in nest of twigs, mosses, rootlets, etc., lined with fine grasses and tendrils.

Distribution. Nearly similar to that of the preceding species. 
The Black-poll Warbler is one of the latest warblers to arrive in the spring, usually after most of the other migrant hordes have gone north.

662. Blackburnian Warbler. FR.-LA FAUVETTE DE BLACkBURN. Dendroica fusca. L, 5.25. Plate XLII A. The black upperparts and flaming orange throat are distinctive in the case of the adult male. In the female the orange colour of the throat though faint is easily recognizable. The young in the autumn are like the adult female although the young females are duller in colour, the throat and breast only retaining a faint yellow colouring.

Distinctions. Adult and autumn males are unmistakable. Autumn females may be confused with autumn Black-polls and Bay-breasts but the clearer yellow on the throat, the absence of a greenish tinge below, and the dark ear coverts with conspicuous buff eyebrow line are diagnostic characters.

Field Marks. The bright orange or warm yellow confined to throat and breast and orange-yellow or buff eyebrow stripe, in contrast to the dark cheeks and crown, make the best field marks.

Nesting. In coniferous trees 10 to 14 feet or more above the ground in nest of fine twigs and grasses lined with grasses and tendrils.

Distribution. Eastern North America west to the prairie provinces; breeding mostly north of dense settlement.

The male Blackburnian has the bright plumage commonly associated with the tropics rather than with our colder climates. The species asso('iates with many other warblers in the treetops of the open woods or orchard.

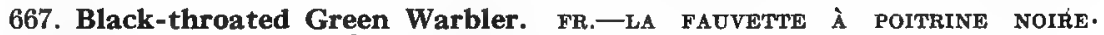
Dendroica virens. L, $5 \cdot 10$. Plate XLII B.

Distinctions. A green warbler with bright yellow cheeks and sharply contrasting black throat and breast. In females and juvenile males the black is almost wanting or indicated only by vague interrupted black suffusions which are stronger on the breast. In young females the black is reduced to dull cloudings at the sides of the breast and flanks. In all plumages the underparts are white and the back and crown clear, even green. Bright yellow predominates on the cheeks.

Field Marks. For juveniles, the green back, yellow cheeks, and white below. For adults, the black throat and breast contrasting with yellow face and white below.

Nesting. In coniferous trees 5 to 30 feet above the ground in nest of small twigs and moss lined with rootlets, fine grasses, and tendrils.

Distribution. North America, west to the mountains. Breeding in eastern Canada wherever cedar or evergreen thickets are found except in extreme southern portions.

A striking bird, fond of scrubby evergreen when available but is also found in the orchard and in hardwood tree-tops.

670. Kirtland's Warbler. Dendroica kirtlandi. L, 5·75. Blue-grey above heavily striped with black on back, and finely striped on crown. All below, except under tail, pale yellow with black stripes on sides of breast and flanks. Females and juveniles similar but duller, and breast stripes broken and forming spots.

Distinctions. Kirtland's Warbler resembles the Canadian Warbler, but is larger; the yellow is paler and the black stripes are on the flanks and do not tend to make necklace suspended from the ears as in that species; and the back is marked with black instead of being clear grey. The only other warbler that might be mistaken for it is the Magnolia but the black does not cross the breast as it does in adult Magnolias, and there is no yellow or greenish on the back or rump.

Field Marks. The species is too rare to be accepted on eye identification alone.

Nesting. On ground at foot of pine or oak trees in nest of soft bark, strips of vegetable fibre, and grass lined with fine grass, pine needles, and hair.

Distribution. Winters in the Bahama islands. The only known breeding station is a limited section of the jack-pine plains in the northern part of the lower peninsula of Michigan. The species has only been taken twice in Canada, both specimens being taken in the lower Great Lakes region. Its nest should be looked for in the Bruce peninsula of Ontario and around the Great Lakes west to the lake Superior country. 
In the winter this species is confined within a limited oceanic island habitat and is an instance of the difficulties in the way of abnormally increasing the numbers of native species. It is evident that we can never have in the north a greater number of Kirtland's Warblers than can live through the winter on the Bahama islands.

671. Pine Warbler. FR.-LA FAUVETTE DES PINS. Dendroica vigorsi. L, 5.52. A dull green warbler, the green changing to dull yellow on throat and breast with greyish or brownish wings and tail and faint wing-bars; in high plumage rarely becoming fairly bright yellow on throat and breast. There is little sexual or seasonal change.

Distinctions. Very similar to the Yellow-throated Vireo but greener in colour and with the yellow below stronger and more extensive. The white abdomen is inconspicuous. The bill is lighter and warbler-like instead of being stout, hooked, and of Vireo type. From the Yellow Warbler it can be separated by its duller colour and the contrast between its wings and tail and body. Its preference for pine trees is at least suggestive of its identity.

Field Marks. A dull green warbler, yellow on breast with greyish brown wings, white wing-bars. Canadian specimens are usually somewhat soiled and bedraggled in appearance. Almost invariably found in pine trees.

Nesting. In pine trees 10 to 80 feet above the ground, in nest of strips of bark, leaves, plant fibres, etc.

Distribution. Eastern North America, west to the prairies and north to the limits of the pine woods; breeding in Canada mostly beyond settlement.

The preference for pines, which this bird shows, is striking. It is rarely, if ever, found away from them. In consequence, it is likely to have its plumage more or less soiled with pitch which gives it a dull and worn appearance. Bright, clean birds of this species are rare with us.

672. Palm Warbler. FR.-La fauvette ì couronne rousse. Dendroica palmam. L, 5.25. A dull or greenish warbler. Male: all underparts bright or suffused yellow; cap reddish-chestnut. The breast and flanks are streaked more or less with rufous and a yellow eyebrow line contrasts with dark cheeks and red cap. Females similar but colour subdued. Juveniles and autumn birds are greyish brown above; buff below with faint streaks, almost white on throat and suffused with distinct yellow increasing to pure yellow on undertail coverts. There is a blended yellowish rump patch in all plumages.

Distinctions. The yellow underparts and red cap are unmistakable in all spring birds. In autumn the vaguely striped underparts, brown back, and yellow undertail coverts are distinctive.

Field Marks. The habitual, andpiper-like upward jerk of the tail will distinguish this from all other warblers with yellow underparts except the Prairie Warbler. The bright yellow confined to the undertail coverts, light throat, and vaguely striped buff breast of the juveniles will assist in separation of the species from comparable forms.

Nesting. On or near the ground in boggy ground or sphagnum barrens in nest of coarse grass, lined with fitted feathers.

Distribution. Eastern North America west to the prairies and north to near tree limits; breeding mostly beyond the bounds of civilization. The Yellow Palm Warbler is of eastern distribution west to the eastern Ontario boundary. The Interior Palm Warbler occupies the remainder of eastern Canada.

SUBSPECIES. The Palm Warbler is divided into two subspecies, the type form, the Interior Palm Warbler D.p. palmas um, distinguished in adult spring plumage from the Yellow Palm Warbler D.p. hypochrysea by the smaller amount of yellow and the reduced brilliancy of the underparts which are slightly tinged with greyish. The two forms, however, are too similar to separate without specimens of both for comparison.

A ground-haunting bird. On migration to be looked for in low, scrubby, and sandy wastes. In breeding season in mossy bogs.

673. Prairie Warbler. Dendroica discolor. L, 4.75. A green and yellow warbler. Throat, cheeks, and all underparts of male bright yellow; a black line through the eye, a black wedge below the ear coverts, and a succession of black lines along the sides of the breast and flanks. Middle of back has a saddle of reddish spots. Female similar but occasionally almost or quite without the reddish on back. Juveniles similar but colours 
reduced and veiled, the underparts yellow, brightest on breast, and the black lines on the face, side of breast, and flanks only indicated.

Distinctions. The fine black, facial marks against bright yellow, their sharp continuation along flanks, and the reddish back spots are the best distinguishing features of adults. In juveniles the underparts brightest on breast rather than throat or elsewhere and the indications of stripes on the sides instead of in the middle of breast make the easiest recognition characters.

Field Marks. Too rare in Canada to be recorded by sight unless the observer has had considerable experience.

Nesting. In briery bushes, in nest of plant fibres and plant down lined with rootlets and long hairs.

Distribution. Eastern United States, north rarely, though perhaps locally regular across the Canadian border in the lower Great Lakes region.

The Prairie Warbler prefers dry, sandy, or open second growth wastes. From the data on its occurrence in Canada it should be looked for nesting in the neighbourhood of the lower end of lake Huron.

\section{Genus-Seiurus. Wagtail Warblers. L, 6.04-6.17.}

Birds of the genus Seiurus look more like Thrushes than Warblers as is indicated by the popular names of Golden-crowned and Water Thrushes that are sometimes given them. They are, however, true warblers of woodland habits; ground birds, walking instead of hopping; of large size for warblers; brown or dark olive coloration above, white below with the breast heavily streaked. They can be mistaken for thrushes either in life or in the hand but by attention to specific characters they can be easily distinguished.

674. Ovenbird. GOLDEN-CROWNED THRUSH. Fr.-LA GRIVE COURONNEE. Seiurus aurocapillus. L, 6.17. Plate XLIII A.

Distinctions. The partly concealed dull golden crown patch bordered with brown will always determine this species.

Field Marks. Though very thrush-like, there is generally little probability of actual confusion between this species and the thrushes. Its pure white throat, foreneck, and underparts with little or no suffusion of other colour and the sharply contrasting stripes rather than spots of the breast are easily distinctive.

Nesting. On ground, in a bulky structure of coarse grasses, weed stalks, leaves, and rootlets; covered over with leaves and with the entrance at the side, like an oven, from whence the specific name is derived.

Distribution. Wooded sections of North America east of the Rockies, north to beyond settlements; breeds in Canada wherever found.

It is a woodland bird, usually common wherever open timber is interspersed in the heavier woods. Its common song Teacher-teacherteacher - teacher, beginning low and ending very loud is a familiar woodland sound and once heard will be remembered.

675. Northern Water-thrush. WATER-THRUSH. FR.-LA GRIVE DES RUISSEATX. Seiurus noveboracensis. L, 6.04. Dark olive brown above, yellowish white finely and sharply streaked with dark below, disconnected lines on throat, breast, and flanks. A buffy blended line over the eye and a fine, sharp, dark one through it.

Distinctions. Easily distinguished from the Oven-bird by the finer, more evenly distributed striping, darker coloration, yellowish underparts, and the lack of crown patch. From the Louisiana Water-thrush it may be told by the buffy instead of white line over the eye, the yellowish instead of buffy or creamy underparts, and the presence of spots on the throat.

Field Marks. The Water-thrushes can be told in life by their habitual upward jerking of the tail as they walk or stand, much similar to the actions of the common Spotted Sandpiper. The two Water-thrushes can be told apart by the difference in the colour details given above. 
Nesting. In a mossy bank or in the roots of a turned-up tree, usually near or over water, in nest of moss lined with tendrils and fine rootlets.

Distribution. North America north to the limits of settlement. Breeds in Canada wherever found except in the extreme southern parts.

SUBSPECIES. The Water-thrush is divided into an eastern and a western subspecies, the Eastern Water-thrush $C . n$. noveboracensis, the type form, ranges westward to southern Ontario where it intergrades with Grinnell's Water-thrush $S$. n. notabilis which occupies the country to the west.

The favourite home of the Water-thrush is in wet cedar swamps.

676. Louisiana Water-thrush. Seiurus motacilla. I, 6.28. Dark olive brown above, buffy-white below finely streaked with sharp dark disconnected lines from upper neck to breast and flanks. A sharp, white line over the eye and a fine blended dark line through it.

Distinctions. Easily separatedfrom the Ovenbird by lack of coloured crown streak; very similar to the Northern Water-thrush but separable by slightly larger size, buffy rather than yellowish underparts, and by the whiteness of the face markings.

Field Marks. The Louisiana Water-thrush has the jerking tail habit of the Northern Waterthrush and can only be distinguished from it in life by attention to the differences given above.

Nesting. Similar to that of the Water-thrush. Ontario.

Distribution. Eastern United States, only appearing in Canada in southwestern

Very similar to the Northern Water-thrush in habits as well as in colour and form. It is, however, a bird of more southern distribution than it and is of only rare occurrence in Canada.

\section{Genera-Oporornis and Geothlypis. Ground Warblers. $\mathrm{L}, 5 \cdot 40-5 \cdot 56$.}

The Ground Warblers are rather larger than the Woodland Warblers but considerably smaller than the Wagtail Warblers and have comparatively stout legs and short wings. Their colours are largely green and bright yellow. They inhabit low shrubbery and are seldom seen far above the ground.

677. Kentucky Warbler. FR.-LA FAUVETTE DU KENTUCKY. Oporornis formosus L, 5.40. Greenish above; all underparts clear yellow; forehead black, shading off on mid crown; bright yellow eyebrow line hooking around eye. A sharp black patch extends from base of bill, including lores and most of ear coverts, to side of neck. Female and autumn birds similar but duller, the black face mark being more or less veiled though still visible.

Distinctions. Coloured much like the Prairie Warbler but with the black leaving only a narrow eyebrow line in front of the eye instead of a largely yellow cheek and without flank stripes. Somewhat similar to the Canadian Warbler but with back greenish instead of grey and without breast markings of any kind.

Field Marks. Too rare in Canada to be identified in life by sight.

Nesting. On or near ground in bulky nest of twigs and rootlets firmly. wrapped with several thicknesses of leaves and lined with fine rootlets.

Distribution. Eastern United States, not reaching the Canadian border except as an accidental straggler.

This species has been taken in Canada on only a few occasions. It can be reasonably looked for only in the most southern sections in the region of the lower Great Lakes.

678. Connecticut Warbler. Oporornis agilis. L, 5.40. A greenish warbler. Male: clear lemon yellow below; face and throat to upper breast even bluish-grey with a fine white eye-ring. The female is similar but grey paler. Juveniles have the grey replaced by a lighter buffy shade of the back coloration. 
Distinctions. This species is so like the Mourning Warbler that at times they can be separated only with difficulty. Adult males, having a conspicuous eye-ring and perfectly even grey throat and breast, are distinctive enough. Females can be told by the eye-ring and by having the top of the head strongly suffused with the olive of the back and not showing clear grey. Juveniles when they show the eye-ring are usually quite distinctive, though Mourning Warblers of similar age have an indication of it. When the eye-ring is not conclusive evidence the difference in the colour of the throat and breast, a buffy olive instead of an even lightening and greying of the pure yellow below, is a good guide.

Field Marks. The evenly grey throat and white eye-ring of adults and the buffy olive throat and buff eye-ring of the juveniles. Both this bird and the Mourning Warbler walk instead of hop.

Nesting. On ground in nest of dry grass.

Distribution. Eastern North America west of the Alleghanies. It appears to breed along the edge of settlement in Canada but data is lacking. It is regular in migrations only locally along the shores of lake Erie and lake Ontario.

The Connecticut is one of the rarest of our regular warblers. It is a late arrival in the spring and is so retiring that it is seldom seen in the autumn. There is not sufficient data to determine whether it is very local in its migratory range or has been overlooked. It is to be looked for near the ground in waste brush.

679. Mourning Warbler. FR.-LA FAUVETTE de PHILAdelPHIE. Oporornis philadelphia. L, 5.63. A greenish warbler. Male: clear lemon-yellow below; whole head, neck, and breast bluish-grey with semi-concealed black spots on breast and throat giving a fancied resemblance to crape which suggests the common name. The female is similar but the grey lighter and without the crape markings on breast, thus resembling the male of the Connecticut. Juveniles have the grey of the crown, etc., replaced with the body green and the yellow of the underparts extends up neck to throat slightly modified by lighter and greyish tinges.

Distinctions. The Mourning Warbler can usually be distinguished by the crape on the breast or by suggestions of it, the greyness of the crown, and the lack of eye-ring, though juveniles sometimes have faint eye-rings. See previous species.

Field Marks. The black crape of the breast and lack of eye-ring for adulte and the lack of sharp distinction between the breast, throat, and underbody yellows for juveniles.

Nesting. On or near ground in nest of strips of bark and other fibrous materials lined with hair.

Distribution. Eastern North America mostly west of the Alleghanies. Breeds along the northern bounds of settlement west through the wooded sections of the prairie provinces.

One of the late spring warblers and one of the earliest to return in the autumn, going through before many observers are on the watch for migrant warblers and thus usually slipping by unobserved. The latter half of August is the time to watch for the Mourning Warblers. By the first of September most of them have gone.

681. Maryland Yellow-throat. FR.-LA FAUVETTE TRICHAS. Geothlypis trichas. L, 5·33. Plate XLIII B.

Distinctions. The adult male with its black mask is easily recognized and needs no special characterization. Juvenile males have sufficient indications of the mask to be easily recognizable. Adult females and juveniles are very much alike. They can be recognized by their even coloration above, warm yellow throat, buffy white underparts washed with darker on flanks, and undertail coverts yellowish. They are most likely to be mistaken for the Mourning or Connecticut juveniles but the sharp division between throat and cheek colours, the brightness of the throat, and the general warmer yellow tint will separate them. They have been confused with the Nashville and the Tennessee but the grey rather than buffy or ruddy-olive head and crown of the former and the nearly white breast instead of distinct yellow of the latter should make separation easy. 
Field Marks. In addition to coloration, the marshy habitat, hiding habits, and characteristic actions of the Maryland Yellow-throat soon become familiar to the observer. Its scolding wren-like note is easily recognized.

Nesting. On or near ground in bulky nest of strips of bark, coarse grasses, and dead leaves lined with fine grasses, tendrils, and rootlets.

Distribution. North America north to the limit of settlement. The Northern Yellowthroat, our eastern Canadian subspecies and the type form, breeds west to the prairies and south to Virginia, being replaced in both directions by other subspecies.

SUBSPECIES. The Yellow-throat is divided into a number of subspecies only one of which, the Northern Yellow-throat $G$. $t$. trichas, the type form, is found in eastern Canada.

The particular haunts of the Maryland Yellow-throat are damp marshes where the wire grass grows long and clumpy. It regards its immediate neighbourhood as its own particular property and resents human intrusion vigorously. The usual song of the Yellow-throat is one of the characteristic sounds of the damp meadows. It has been poetically translated as witchery - witchery - witchery, which gives a close approximation to it.

683. Yellow-breasted Chat. Icteria virens. L, 7.44. The largest and least warbler-like of its family. All upperparts and cheeks green; lores black bordered above and below with white; throat to breast bright clear yellow; underparts white; bill comparatively shorter and stouter than that of any other warbler.

Distinctions. Size is sufficient to distinguish the Chat at all times but its colours are equally characteristic.

Field Marks. Large size, bright yellow foreparts, and black lores bordered above and below with white make striking field marks.

Nesting. In a crotch near the ground in rather bulky nest of coarse grasses, leaves, and strips of bark lined with finer grasses.

Distribution. Eastern United States and just across the Canadian boundary in southern Ontario along lake Erie.

The Chat frequents tangled thickets and brushy wastes, coming and going unseen but not unheard. It is a rare bird in Canada and is found regularly only in Essex county, Ontario, along the border of lake Erie.

\section{GENUS-WILSONIA. FLYCATCHING WARBLERS. $\mathrm{L}, 5 \cdot 0-5 \cdot 67$.}

Small warblers largely coloured yellow. Bill slightly flattened or widened at base suggesting that of the flycatchers and with well developed bristles about the mouth. In these respects like the Redstart but not as extreme. The Redstart, however, being without much or any clear yellow, can be easily distinguished.

684. Hooded Warbler. Wilsonia citrina. L, 5-67. Male: green above and bright yellow below; entire head and neck black with a bright yellow mask similar in shape to the black one of the Maryland Yellow-throat. The female is without the black except for an indistinct patch on rear head and the yellow mask blends softly into the yellow of throat and underparts.

Distinctions. The adult male of this species is too distinctive for confusion. The yellow face with dark hind crown of the female is also easily recognized.

The Hooded Warbler is included here on the basis of a few Canadian records in the lake Erie region of southern Ontario.

$57172-14$ 
685. Black-capped Warbler. WILSON's WARBLER. WILBON'B BLACK-CAPPED WARBLER. FR. - LA FAUVETTE DE WILSON. Wilsonia pusilla. L, 5 . A small green warbler. Male is all bright yellow below with a sharply defined black cap on crown. The sexes are similar but some juvenile females are entirely without the cap, and in others it is present but less perfect than in adults.

Distinctions. The black cap and all green and yellow coloration are distinctive of the adults and young males. When without the cap the vague yellow eyebrow stripe is eharacteristic.

Field Marks. The small size, all bright yellow and green with black cap or traces of it, or having yellow eyebrow line when the cap is absent.

Nesting. On ground in nest made almost wholly of fine grass lined with a few hairs; nest deeply cupped and quite substantial for a warbler.

Distribution. North America. The subspecies Wilson's Warbler occurs in Canada, extends west to the central prairie region, and breeds from the northern settlements to the tree limits.

SUBSPECIES. The blackmcapped Warbler is divided into three subspecies all of which occur in Canada though only one, Wilson's Warbler W. p. pusilla, the type form oocurs in the east.

A very pretty little warbler usually found in willows or in similar trees and bushes near the water.

686. Canada Warbler. canadian flucatcher. FR.-La FaUVETte dU Canada. Wilsonia canadensis. L, 5.61. Male: even grey above slightly marked with black on crown; all below bright yellow except undertail coverts which are white, yellow proloral line and eye-ring; black lores extending down sides of neck and forming a necklace of short stripes across upper breast leaving throat elear yellow. Female is similar but necklace and black reduced, though usually remaining strong enough to retain the easily recognized specific character. Juveniles are like the female but the necklace almost obliterated only showing in vague, suffused, and interrupted cloudings.

Distinctions. The even grey above without markings and yellow below with the black necklace marks either sharp, dim, or suggested.

Field Marks. See distinctions.

Nesting. In mossy banks or under roots in nest of strips of bark and bits of dead wood wrapped in leaves and lined with fine rootlets.

Distribution. Eastern North America west to near the foothills and north to the limit of large trees; breeding occasionally and locally in southern Canada except in the most southern parts and regularly north from the edge of settlement.

A bright active warbler with some flycatching habits. Its typical habitat is similar to that of Wilson's Warbler, but it is more often found higher in the trees.

687. American Redstart. FR.-LA FAUVETTE $\lambda$ QUEUE ROUBse. Setophaga ruticilla. L, 5.41. Plate XLIV A.

Distinctions. A perfectly characteristic bird in all plumages. No other warbler has anything like this combination of orange-red and black, the former replaced in female by similar yellow or white patches on tail and wings. Juveniles have a slight yellow suffusion over breast and are without the wing blotch but that of the tail is always present. Some young males in the spring look like females but with irregular patches of the perfect male plumage showing on throat.

Field Marks. Colour is the most easily noted distinction but even in black silhouette the manner in which the long tail is thrashed about soon becomes familiar and distinctive.

Nesting. In the crotch of a sapling in nest of fine strips of bark, fibres, and plant down lined with tendrils and fine rootlets and nearly always covered outside with silvery bark strips.

Distribution. North America north to the limit of large trees. Breeding in Canada wherever found.

The brilliancy of a high plumaged Redstart against the dark green of the trees is a constant source of pleasure to even the most blasé observer 
and is a sight that never loses its charm. Its sprightly movements, constant fluttering, and spreading of wings and tail give it a vivacity that few other species exhibit. Like many other American birds the term Redstart was given it by early settlers who bestowed upon it the name of a familiar old World form though the resemblance is far from close.

\section{FAMILY-MOTACILLIDAE. WAGTAILS OR PIPITS.}

There is only one species of this family in eastern Canada and for the family characters the reader is referred to the specific description following.

697. American Pipit. TITlark. FR.-LA Farlodse D'amerique. Anthus rubescens. L, 6.38. A ground-coloured and ground-haunting bird; bill very warbler-like; hind claw elongated like that of the Longspur and the Horned Lark (Figure 60, p. 27, compare with Figure 44, p. 25). Adult spring male: greyish above, purest on head and growing slightly olive on rump; back faintly mottled with dark feather centres; pinkish buff below, with sparse fine breast stripes of brownish grey, tending to form a necklace across breast and extending along sides; wings brown with faded feather edges. Autumn birds and females in spring: even dull olive slightly mottled above; buffy white below with diffuse and more or less aggregated spots descending sides of throat and extending across breast and along flanks.

Distinctions. The fine warbler-like bill together with the long hind claw are distinctive. The only other birds with such a claw are the Horned Larks and the Lapland Longspur, but the horns of the one and the sparrow-like bill (Figure 51, p. 26) of the other make differentiation simple.

Field Marles. A ground-coloured bird seen in the open in settled parts of Canada in the spring and autumn, often in large scattered flocks like the Snow Bunting and Horned Lark. Its even coloration, constant habit of tail dipping, and the conspicuous white outer tail feathers are good field marks.

Nesting. On ground in nest of grasses.

Distribution. North America; breeding in high latitudes beyond the tree limits.

A spring and late autumn migrant, occurring sometimes in large flocks and feeding in open meadows, ploughed fields, or on dry sandy uplands and shores. On its breeding grounds it has the Skylark-like habit of mounting and singing high in the air and descending in a perpendicular dive like a falling stone.

Economic Status. Coming as it does while the fields are bare and returning after the harvest, its food is necessarily confined to weed seeds and early or belated insects. Its effect must be beneficial.

\section{FAMILY-MIMID床. MOCKERS AND THRASHERS.}

$$
\text { L. } 8 \cdot 94-11 \cdot 42 \text {. }
$$

The imitative faculty of the Mockingbird that has given the family its name is well developed in Canadian representatives. The family is peculiarly American and like many of the subdivisions of the order Passeres is difficult to diagnose in non-technical language. The birds are rather large, as shown by the above measurements. The Catbird and Mockingbird are of even shades of stone-grey and the Thrasher bright rufous brown above with heavily spotted whitish or creamy underparts and an unusually long full tail. They are all good mockers and diversify their song with imitations of all the common sounds around them, including the songs of other birds, and are capable of effects that are rarely equalled by the most famous songsters of either the New or Old World. Any one of $57172-14 \frac{1}{2}$ 
these species is a sufficient and crushing answer to the charge that there are no song birds in America.

703. Mockingbird. FR.-LA GRIVE POLYGotTe. Mimus polyglottos. L, 10.50. A large Catbird in appearance without black cap or red under the tail; almost white below and with large amounts of white in wing and tail.

Distinctions. The above characters will separate the Mockingbird from the Catbird. It closely resembles the Shrikes in coloration but is without the conspicuous black patch across the eyes.

Field Marks. General greyness and white patches on wing and tail with absence of black face mask.

Nesting. In thickets of coarse twigs and weed stalks in nests lined with rootlets and shreds of cotton.

Distribution. Southern United States north into Canada at the western end of lake Erie. This is the only locality where the species has obtained what approaches an established foothold in Canada. A few pairs have been known to summer there for the last decade.

SUBSPECIES. The Mockingbird is divided into southeastern and southwestern forms-the former, the common Mockingbird, the type race of the species, being the only subspecies to be expected in Canada.

The species is rare in Canada. It is very similar to the Catbird and most of what is said of that species applies with even greater force to the Mockingbird, for it is in many ways only a glorified Catbird and is probably the finest native singer in America.

704. Catbird. FR.-LA GRIVE DE LA CARoline. Dumetella carolinensis, L, 8.94. Plate XLIV B.

Distinctions. This evenly grey bird can be confused only with the Mockingbird and the black cap, red undertail coverts, and lack of white on wing, tail, or below are distinctive.

Field Marks. Even grey colour; black cap and call-notes, especially the cat-like "meouw" from which the bird derives its name.

Nesting. In thickets or densely foliaged shrubs in nest of twigs, grasses, and leaves ined with rootlets.

Distribution. Eastern North America; in Canada including most of the more densely gettled sections.

Though inferior to the Mockingbird the Catbird at its best takes a high position as a songster, though there is much individual variation in the excellence of its efforts. Its usual call-note like a cat's meouw, which it utters in the brush while it curiously investigates the human intruder, is well known to most country frequenters and by some queer twist of psychology has aroused a prejudice against it.

It is a frequenter of thickets and, like many other species frequenting such habitats where close observation can be made of dangerous objects with a minimum of danger to the concealed observer, its curiosity is well developed. On some tall spray rising out of the tangle it sits in the bright sun with its tail depressed and body held low to the perch, and pours out a medley of song. Phrase follows phrase in rapid succession and snatches of all the bird songs of the neighbourhood are intermixed with occasional harsher, mechanical sounds which are given with as much gusto as the more melodious ones. The Catbird is a most desirable neighbour.

Economic Status. The Catbird lives largely upon fruit in season, of which perhaps a third can be regarded as cultivated, but many insects are also taken. The fruits are small, soft varieties and it is very seldom if ever that perceptible damage is done. 
705. Brown Thrasher. FR.-LA GRIVE Rousse. Toxostoma rufum. L, 11.42 Plate XLV A.

Distinctions. The Brown Thrasher with its red-brown back and sharply streaked breast has the general outward appearance of a thrush, but its large size, ruddiness of the brown, and long tail are distinctive.

Field Marks. The bright red-brown back, sharply striped breast, long tail, and general carriage and habits.

Nesting. In thickets or on ground in nests of twigs, coarse rootlets, and leaves lined with finer rootlets.

Distribution. Eastern United States and southern Canada, except Atlantic coast, north including the sections of thickest settlements.

The Brown Thrasher is probably the best common Canadian songster.

Its song is very similar to that of the Song Thrush of Europe. It is a succession of phrases like that of the Catbird but without its occasional discordance and more liquid and mellow in tone. The notes are uttered close together and continue for several minutes, sometimes in great variety. Thoreau has translated some of them as "Drop it - drop it cover it up cover it up-pull it up pull it up." The repetition of each variation is one of the peculiarities of the song of the Brown Thrasher, by which it can be distinguished from the Catbird.

This is also a bird of the thickets, inhabitating open tangles, clumps of bushes in meadows, and the edges of woods and fence-rows. The Thrasher is rather more retiring than the Catbird and is less easily induced to come into the home grounds.

Economic Status. A decidedly useful bird, over one-half of its food being injurious insects, beetles, caterpillars, grasshoppers, etc. The remainder is largely fruit, a small part of which is probably cultivated and is mostly raspberries. On the whole it does little damage and much good.

\section{FAMILY-TROGLODYTID A. WRENS.}

The Wrens are small brown birds living close to the ground. Though diminutive in size they are very energetic and except when brooding or asleep are rarely still. They can be recognized by their small size, brown coloration, small stubby tail often thrown up over the back, and their restless habits, winding in and out amongst the densest brush piles more like mice than birds. The Wrens are a large family well distributed over the world but better represented in species in the New than in the Old World. Their habitat varies from watery swamps to dry uplands and from open thickets to deep dense woods. The family name Troglodytida, cavedwellers, is derived from their habit of nesting in holes.

718. Carolina Wren. Thryothorus ludovicianus. L, 5.50. The largest of our Wrens and the reddest, the back approximating the red of the Brown Thrasher, of a lighter yet distinctly warm tint below.

Distinctions. Size, comparative redness of back, and the distinct light eyebrow line are distinctive of this species.

Field Marks. The above distinctions make the best field marks. The Long-billed Marsh Wren has a similar eyebrow line but size, general colour, and habitat will prevent confusion with it.

Nesting. In holes in trees or stumps or in nooks and crevices about buildings, in bulky nest of grasses, feathers, leaves, etc., lined with finer grasses, long hairs, etc.

Distribution. Eastern United States, north intermittently into Canada in the western lake Erie section. For a number of years the species was quite common on Pelee point and on Pelee island, but since 1913 it seems to be becoming rarer.

SUBSPECIES. Of the three subspecies of Carolina Wren only one, the Northern Carolina Wren, the typical race, is to be expected in Canada. 
The Carolina Wren is the finest singer of the family. The song is not continuous or long but it has a peculiar flute-like, liquid quality and is of striking beauty. The species is rare in Canada and its song is heard either regularly or occasionally only in a few localities.

Economic Status. Too rare in Canada to have any perceptible economic influence.

719. Bewick's Wren. Thryomanes bewicki. L, 5. Similar to the House Wren but whiter below and tail longer, larger, and distinctly greyish. It has a light eyebrow line.

Distinctions. Characters given above will serve for the identification of the species.

Field Marks. A House Wren with long tail and loud, sparrowlike song.

Nesting. Nest similar to that of the House Wren.

Distribution. Eastern United States not reaching the Canadian border except as a straggler in southern Ontario.

SUBSPECIES. The eastern Canada form is the Eastern Bewick's Wren, the type race of the species.

This Wren is only a rare visitor from the south and has seldom been recorded from eastern Canada. It should only be recorded on the most trustworthy evidence.

Economic Status. Too rare a species in eastern Canada to be of economic interest.

721. House Wren. Fr.-Le troglodyte adon. Troglodyte aedon. L, 5. Plate XIV B.

Distinctions. This is the commonest Wren of eastern Canada. The even woodbrown back, throat and breast tinged with lighter brown; the almost white underparts; and the barring confined to the flanks will separate it from other native wrens.

Field Marks. The light underparts and longer tail will separate the House from the Winter Wren, and the even brown colour of the back and its habitat, from either of the Marsh Wrens.

Nesting. In a hole in a tree, bird-box, or similar places, in a nest of twigs, lined with grasses, feathers, etc. The House Wren will occupy any kind of a bird-house that is suitably placed. The English Sparrow can be kept away by making the entrance hole small, a oneinch auger hole is sufficient for a wren and will bar the sparrows entirely.

Distribution. As a species, all United States and Canada north to the edges of settlement. The eastern or type form, the Eastern House Wren, inhabits from the Great Lakes eastward.

SUBSPECIES. The House Wren is divided into eastern and western subspecies of which the former, the Eastern House Wren, is the type.

The House Wren is a most attractive bird about a garden; it steals around, under, and over everything; not a crack nor a crevice in the fence escapes its fine investigative bill and hardly a leaf stalk but at one time or another is carefully examined for insects. It has been charged with piercing and destroying the eggs of other species nesting in its immediate vicinity and undoubtedly sometimes does so, but the damage done in this way is probably an individual habit and perhaps not sufficient to warrant the taking of any very drastic preventive measures against the species as a whole.

Economic Status. As the food of the House Wren consists almost if not entirely of insects nothing can be said against it in that direction. Its small size causes it to deal with minute insects that are beneath the notice of larger birds and so it often controls pests before they are large enough to do damage or be attractive to other birds. 
722. Winter Wren. FR.-LE TROGLODYTE D'HIVER. Nannus hiemalis. L, 4.06. Of typical wren-like build and coloration. Much like the House Wren but smaller and darker below and more or less finely barred across the abdomen.

Distinctions. The complete barring below is distinctive of this species.

Field Marks. A small, very dark Wren with \& short tail; found in dense woods.

Nesting. In roots of a tree or a brush heap or in side of mossy log in nest of small twigs and moss lined with feathers.

Distribution. As a species, all of North America to tree limits; breeding throughout Canada in the coniferous woods except in the more southern sections.

SUBSPECIES. The Winter Wren, distributed over most of the continent, is divided into a number of geographical races or subspecies of which the type form, the Eastern Winter Wren, is the only one that comes within our geographical limits.

Only a migrant within most of the more southern sections of Canada this bird breeds commonly in the cool deep forest. Its song is nearly enough in spirit and character like that of the House Wren for the recognition of its relationship but has a fuller and richer quality and purer tone. Heard in the quietness of the still forest it has a wild woodland beauty possessed by no other native species.

Economic Status. Being a frequenter of the woodlands this bird does not come into close contact with man but its effects so far as they go are entirely beneficial.

724. Short-billed Marsh Wren. Cistothorus stellaris. L, 4. Much like the longbilled Marsh Wren but smaller and more finely streaked.

Distinctions. The two Marsh Wrens are the only wrens native to eastern Canada which have sharply striped upperparts. The Short-billed is the only one with a streaked crown.

Field Marks. A emall Marsh Wren with little or no redidsh tinge in the brown colouring and with a streaked head. Its notes are quite different from those of the Long-bill with which it is most likely to be confused .

Nesting. On wet ground, in nest, a ball of green grass woven near the top of grase dumps with a small circular entrance hole in the side.

Distribution. Eastern United States crossing into Canada in the east along lake Erie and adjacent country but more common in the prairie provinces.

The Short-billed Marsh Wren is local and irregular in its distribution; it may be present one year in a locality and absent the next, and little is really known of its distribution in Canada. It frequents damp, grassy marshes rather than wet swamps and is usually found in little colonies.

725. Long-billed Marsh Wren. FR.-Le TROGLOdYTE DES Marars. Telmatodytes palustris. L, $5 \cdot 2$. A richly coloured wren with an almost black mantle falling from hind neck over shoulders where it is streaked with white; all remainder, reddish brown above, creamy white below with flanks washed with the same colour as the back.

Distinctions. The variation and colours of back will distinguish the two Marsh Wrens from all others; the crown evenly coloured or with only a diffuse brown median stripe instead of numerous short, fine stripes will separate it from the Short-billed.

Field Marks. The locality which it frequents-wet, reedy, or cat-tail marshes-is usually sufficient for identification but the dark crown contrasting with the light eyebrow line is always specifically diagnostic.

Nesting. Near the top of the reeds or rushes in wide wet marshes, nest a ball of dead cat-tail leaves, grass, or reeds. Unlike many other marsh-haunters this species is not attracted by marshes of small size. A swampy pool a few yards across attracts the Redwing and perhaps a Rail or two but the Long-billed Marsh Wren demands a considerable area. An interesting trait of the Marsh Wren is the habit of building numerous mock nests near the one really occupied. The use made of these nests is not known but as many as eight or nine nests that can be reasonably attributed to the efforts of one pair may at times be found.

Distribution. As a species the United States and southern Canada. Our Eastern Marsh Wren, the type subspecies, occurs west to the Great Lakes region. 
SUBSPEC1ES. The Long-billed Marsh Wren is divided into several subspecies; the Eastern Marsh Wren, the only form in which we are directly interested in eastern Canada, is the type form of the species.

Wide wet swamps and quaking bogs grown with cat-tails or reeds are the places frequented by this wren.

\section{FAMILY-CERTHIIDA. CREFPERS.}

The name of the only eastern Canadian Creeper, the Brown Creeper, describes the bird very well. It is a small brown bird that creeps or climbs woodpecker-fashion on the trunks and larger branches of forest trees. It is smaller than any Canadian Woodpecker and the bill is comparatively long, light, delicately tapered, and sickle-shaped (Figure 64, p. 28), adapted for extracting small insects and insects' eggs from narrow cavities but not for chiselling in even the softest wood or bark to reach them. The tail is rather long and stiff and the claws are quite long and much curved.

726. Brown Creeper. american brown CREeper. Fr.-Le grimperead d'amgriQUE. Certhia familiaris. L, 5.66. Plate XLVI A.

Distinctions. The brown and white stripings, lacking in decided design; the fine, delicate, sickle-shaped bill and long stiff tail feathers, worn on the tips, are easily recognized distinctions of the species.

Field Marks. Our only small brown bird with pronounced tree-creeping habits.

Nesting. Behind the loose bark of trees in nest of twigs, strips of bark, bits of dead wood, moss, etc.

Distribution. As a species, occupying most of the northern hemisphere. In eastern North America the Eastern Creeper is the native subspecies, in Canada extending west as far as the prairie provinces and north to beyond settlement.

SUBSPECIES. The Brown Creeper occurs in the Old as well as the New World. The species is divided into several subspecies in America, only one of which, the Eastern Brown Creeper C.f. americania, occurs in eastern Canada.

Pressed tightly to the trunk of forest trees the Brown Creeper may be seen spiralling up the perpendicular trunk and industriously gleaning from every crack and crevice in the bark. Reaching the section where the branches begin to grow smaller and the bark smooth it drops down to the base of an adjoining tree and works upward again, never hurrying, never pausing, filling its stomach with small beetles, larvæ, and insect eggs. The skill with which this bird can cling to smooth surfaces is remarkable. The writer once knew a Brown Creeper to climb the polished corner of a black walnut bookcase with as much unconcern as if it had been the roughest barked oak in the woods.

Economic Status. The Brown Creeper is purely insectivorous in its habits and its constant microscopic attention to every little crevice in the rough bark must account for innumerable insect pests. Most of its work is done in the woods but as the bird frequently appears in the orchard and on shade and ornamental trees about the town and house the species has a powerful beneficial influence.

\section{FAMILY-SITTID居. NUTHATCHES.}

The Nuthatches are small, woodpecker-like birds in general habit but their toes are of the usual passerine type with three toes in front and 
one behind instead of the characteristic two and two of the Woodpeckers. The bills are somewhat like those of the Woodpecker in outline but without their chisel-shaped point and are set on a slightly up-tilted angle with the head giving a turned-up or retrousse appearance (Figure 65, p. 28, compare with Figure 41, p. 25). The colours of our species are characteristic. The name Nuthatch is derived from their habit of wedging nuts and other hard food into crevices and "hatching" or hacking them until an entrance is made. Though capable of considerable excavating in wood or bark they do not use their powers to delve deeply into trees but as a rule content themselves with flaking off the loose bark scales and searching the open cavities and seams.

727. Carolina Nuthatch. WhITE-BReAsted NUTHATCH. BIG QUANK. FR,-LA SITELLE DE LA CAROLINE. Sitta carolinensis. L, 6.07. Plate XLVI B.

Distinctions. With the illustration and family description this species can be mistaken only for the Red-breasted Nuthatch. It is, however, a larger bird and while there are traces of chestnut on the lower belly and undertail coverts and sometimes a slight wash on the flank, the breast and most of the underparts are pure white instead of being evenly washed with rufous or rusty. The sides of the face are solid white instead of having black ear coverts and distinct white eyebrow stripes.

Field Marks. The even blue-grey back and black crown are characteristic of the Nuthatches; the purity of the white below and lack of white eyebrow line separate the White from the Red-breasted.

Nesting. In a hole in a tree or usually a natural cavity, in nest of feathers, leaves, etc.

Distribution. As a species the Carolina Nuthatch inhabits all of temperate North America. Our eastern subspecies, the White-breasted Nuthatch, the type of the species, extends west to the prairie provinces in Canada and north to the limits of heavy forests.

SUBSPECIES. The Carolina Nuthatch is divided into several geographic races, only one of which, the White-breasted Nuthatch, the type form, occurs in eastern Canada.

The climbing and trunk creeping of the Nuthatches is a wonderful accomplishment. They travel upwards or downwards, forwards or backwards, perpendicularly or horizontally, or even clinging to the underside of branches like flies on the ceiling, apparently with equal ease. Their usual call note is a hoarse Quank Quank and they often travel in pairs and little groups along with Chickadees and Creepers.

Economic Status. One of the most useful birds. Although it pays much attention to forest trees it often comes to orchard and shade trees and as a member of the above-mentioned company which examines every part of the winter tree trunks for insects with microscopic eyes, it consumes great quantities of pests in adult, egg, or larval stages.

728. Red-breasted Nuthatch. LITTLE QUANK. FR.-LA SITELle DU CANADA. Sitta canadensis. L, 4.62. Like the White-breasted Nuthatch (Plate XLVI B) but smaller and with the underparts washed with rufous; black ear coverts, and with a white eyebrow stripe. bird.

Distinctions. Size and above colour differences will separate this species from any other

Field Marks. An evident Nuthatch, smaller than the previous species, and with a conspicuous white eyebrow line, all underparts obviously reddish.

Nesting. In hole in tree or stump, in nest of grasses.

Distribution. Rather more northern in breeding range than the preceding and a migrant in most of the cultivated sections of Canada. It ranges over most of North America north to near the tree limits.

A slightly more active bird than the preceding and more prone to forage about the tips of branches. Otherwise its habits are very similar. 
FAMILY-PARIDES. TITMICE.

The Titmice are birds of wide distribution in the northern hemisphere and are as familiar to European residents as to us. They are small birds with rather short but comparatively strongly arched bills (Figure 66, p. 28). Their plumage characters are usually easily recognized.

731. Tufted Titmouse. Baolophus bicolor. L, 6. The largest of our Titmice and without the characteristic Chickadee colouring. All above, an almost even stone-grey; white below slightly washed on flanks with rufous. A distinct almost Blue Jay-like orest.

Distinctions. The plain grey and unmarked coloration with striking crest are unmistakable distinctions and field marks. Its common note a loud clear Peetle-peetlepeetle is most characteristic but is very like one of the phrases of the Orchard Oriole.

Nesting. In old woodpecker's holes, stumps, etc., in nest of leaves, moss, strips of bark, feathers, etc.

Distribution. Canadian boundaries in the lower Great Lakes region.

The only Canadian records for the Tufted Titmouse are two noted on Pelee point in southern Ontario in the western Lake Erie country. It is rather common on the Michigan side of Detroit river and even on Grosse isle in midstream and should eventually be found on the Canadian side of the river though as yet we have no record of its occurrence there.

735. Black-capped Chickadee. ChICKAdeE. FR.-LA MÉSANGe a TÊTE Norr. Penthestes alricapillus. L, 5.27. Plate XLVII A.

Distinctions. 'This species can be mistaken in eastern Canada only for the Brownheaded Chicadee but is a far commoner and more generally distributed species.

Field Marks. The Chickadeers all field mark. Its shape, a round bundle of feathers with tail and hardly any neck, its sprightly habit, its penchant for hanging upside down while investigating the very tips of twigs, its colours, a black cap and throat, white cheeks, and soft grey back, and its note Chick-a dee-dee in which its name is so plainly pronounced, all proclaim its species on the instant.

Nesting. In old stumps, holes in trees, etc., in nest of moss, grasses, feathers, and plant-down.

Distribution. As a species, from about the centre of the United States north to the tree limits; the Black-capped Chickadee occurs from a little south of the Canadian line north, extending west to the prairie provinces where its place is taken by allied subspecies.

SUBSPECIES. Like other dominant and wide ranging species the Black-capped Chickadee under the various conditions of the continent divides in North America into several recognizable geographic races or subspecies. In eastern Canada there is only one form, the type of the species, the Eastern Chickadee. To the south occurs the Carolina Chickadee $P$. carolinensis, a closely allied but distinct species that may be looked for as accidental in the lower Great Lakes region, as it has been taken in Michigan immediately over the boundary. The specific distinctions, however, are too slight to be accurately defined here and records can only be based on specimens.

Of all the birds of field or woods the Chickadee is the cheeriest and merriest. The Chickadee is often the centre of a little host of mixed species of Warblers, Vireos, Kinglets, Nuthatches, and an occasional Downy Woodpecker and Brown Creeper. After the migrants have left for the winter the hardier ones remain casually together off and on until the spring breeding scatters the good-natured little company. The Chickadee has another song composed of only two notes of rather high register clear and whistle-like. The first is prolonged and the second shorter about two tones lower and has been translated as "Spring's here". 
Economic Status. Few birds are more useful to mankind than the Chickadee. Though small, it is constantly at work, and being with us all winter its good work is continued throughout the year. All insects are very small in their early stages and the little bird that devours a whole cluster of eggs at a gulp may benefit agriculture as greatly as a larger one that makes a meal from one or two large caterpillars or adult insects but scorns the minute ones. The prying habits of the Chickadee and its companions the Nuthatch, Creeper, etc., and their close examination of the small erevices where many insects hide or hibernate render their services of great value to the husbandman, especially in winter when insect enemies are scarce, and the total taken through the year by these allied species must be very great. These active little birds demand comparatively large quantities of food to resist the intense cold and the smallness of their game necessitates the consumption of innumerable individuals.

The Chickadee's food is 68 per cent insect and 32 per cent vegetable. The former comprises eggs, larvæ, chrysalids, and small insects, largely weevils, and includes some of the worst orchard and crop pests. The vegetable matter is largely small seed and wild fruit. No charges of damage to cultivated varieties have been advanced. Chickadees can easily be induced to come about the home grounds in winter and with a little coaxing become tame enough even to alight on the person and feed from the hand. A lump of suet fastened to a tree trunk is a never failing attraction to them and ensures their constant visits.

740. Brown-headed Chickadee. HUDSONIAN CHICKADEE. Fr.-LA MÉSANGE DU canada. Penthestes hudsonicus. L, 5.12. Similar to the Black-capped Chickadee but duller and darker in general tone; cap greyish brown of nearly the same colour as the back; throat patch present but veiled; flanks rufous tinted.

Distinctions. The brownish cap and back and general duller and less contrasted coloration.

Field Marks. A very dark Chickadee with coloration diffused and pattern lacking distinctness. Its characteristic Chickadee note is hoarse but otherwise similar to that of the common Chickadee.

Nesting. In holes in trees and stubs in nest of moss and felted fur.

Distribution. Northern America from beyond settlement to the tree limits.

SUBSPECIES. The Brown-headed Chickadee is represented by two subspecies in eastern Canada. The type form, the Husdonian Chickadee, extends to central Ontario, east of which it is replaced by the Acadian Chickadee $P . h$. littoralis which differs from it slightly in size and colour.

The Brown-headed Chickadee is so similar in habits to the Blackcapped that further description would be little more than repetition.

FAMILY-SYLVIIDAE. OLD-WORLD WARBLERS, KINGLETS, AND GNATCATCHERS.

An old world family represented in America by only a few species. Of these, the Old World Warblers, not to be confused with our Wood Warblers, do not occur in eastern Canada, the Kinglets are represented by two species, and the Gnatcatcher by one species. 


\section{Subfamily-Regulina. Kinglets. $L, 4 \cdot 07-4 \cdot 41$.}

General Description. The Kinglets are the smallest of Canadian birds except the Hummingbird. They are wren-like in their short round body but more like Chickadees in habits and actions. Their colours are dull olive-green, lighter below, and they have s aall, brilliantly coloured crown spots of red, orange, or yellow. The bill is small and straight, similar to but not as stout as that of the Chickadee (see Figure 67, page 29).

Distinctions. The Kinglets might be mistaken for some of the dull, evenly coloured warblers, but as all plumages except the female and juvenile Ruby-crowned have brilliant crown patches, this will usually prevent confusion and size should do so in any event.

Field Marks. Dull greenish coloration, chickadee-like restlessness, and custom of hanging head downward from pendant sprays are characteristic. Their fine, sharp conversational tsee-tsee-tsee's soon become familiar and are easily recognized.

748. Golden-crowned Kinglet. GOLDEN-CROWNED WREN. FR.-LE ROITELET HOPPE. Regulus satrapa. L, 4.07. Plate XLVII B.

Distinctions. Kinglets, so nearly alike in general coloration, can be easily separated by their crowns. The Golden-crowned has a black line over the eye that is absent in the Ruby-crowned and the crown spot is orange and yellow in the male or plain yellow in the female instead of ruby-red or even olive as in the Ruby-crowned.

Field Marks. The crown coloration and light eyebrow make the best field marks but, owing to the small size of the bird, considerable patience is sometimes necessary to distinguish these marks when the birds are constantly moving about high overhead in coniferous trees.

Nesting. Generally in coniferous trees. Pensile nest of green mosses lined with fine strips of soft inner bark, fine black rootlets, and feathers.

Distribution. As a species, northern North America. The Eastern Golden-crown ranges west to near the mountains, breeding in the coniferous belt north beyond settlement.

SUBSPECIES. The Golden-crowned Kinglet is divided into an eastern and western subspecies. The Eastern Golden-crown, the type form, is the only one that occurs in eastern Canada.

One often finds himself surrounded by a large flock of these little birds flitting in and out of dense foliage, darting hither and thither, utterly indifferent to the intruder's presence, and coming and going so quickly that it is difficult to note the specific characters. Some hang head downward from a swaying bunch of twigs and others work in and out on the branches and twigs, keeping up a continual interchange of fine sharp tsee tsee tsee.

The Golden-crown remains in southern Canada most if not all the winter. It is partial to evergreen trees and often frequents the ornamental. conifers about the house and in towns. It is fearless and trusting but unlike the Chickadee seldom becomes familiar.

Economic Status. The Kinglets are so largely insectivorous that they can be looked upon as most beneficial. They are small but their numbers, when they occur, more than make up for their small size and what is said of the Chickadee in this respect applies equally well to them.

749. Ruby-crowned Kinglet. RUBY CROWNED WREN. FR.-LE ROITELET $\lambda$ couronne rubis. Regulus calendula. L, 4.41. Plate XLVII B.

Distinctions. The Ruby-crowned is likely to be mistaken only for the previous species but the lack of black stripes on the head is always diagnostic.

Field Marks. In the quick movement of the lively flocks and the deep shadows of dense conifers it is sometimes difficult to catch the distinctive head marks of the Kinglets. It will be noted, however, that the Ruby-crowned has a habit of fluttering its wings oocasionally, in a few short quick vibrations, during momentary pauses while hopping about without flying. This will often suggest the species though it cannot be regarded as a certain proof of identity. 
Nesting. In coniferous trees, nest of moss and fine strips of bark neatly interwoven and lined with feathers, usually semi-pensile.

Distribution. Northern North America. In eastern Canada breeding north above settlement and slightly farther north than the Golden-crown.

SUBSPECIES. The Ruby-crowned Kinglet is divided into three subspecific races only one of which, the Eastern Ruby-crown, the typical form, occurs in eastern Canada.

This species is so nearly like the Golden-crowned Kinglet that little further discussion is necessary either of habits or economic status. The song of the Ruby-crowned, however, is one of nature's surprises. It is loud, clear, and full throated and is audible for a surprising distance, equalling in carrying power the song of the Purple Finch. When first heard it is almost invariably ascribed to some of the better singing sparrows rather than to this diminutive little bird.

\section{Subfamily-Polioptiline. Gnatcatchers. L, 4.05.}

A small family composed of only one genus and peculiar to America. The colour is in soft bluish-ash and white. The bill is superficially warblerlike but the first primary feather of the wing is small and almost aborted, being considerably less than half as long as the next, as is the case with the Warbling Vireo. Only one species occurs in Canada.

751. Blue-grey Gnatcatcher. Polioptila corulea. L, 4.05. All even bluish-grey above, wings dark, and tail black, the outer tail feathers white; below and face all white. Male has black line across forehead and over eye.

Distinctions. The small size, even blue and white coloration, and the short first wing quill are diagnostic.

Field Marks. Inhabiting treetops so high up that the colours are usually difficult to make out, the outline, with long narrow tail switched about much in the manner of the Red-start, and the characteristic rather hoarse call notes make the best recognition marks.

Nesting. Nest of tendrils, fine strips of bark, and fine grasses firmly interwoven and covered outside with spiderweb and lichens. It is chimney-like in shape, high with straight sides, and is one of the most beautiful American bird nests.

Distribution. Southeastern United States north to the Canadian border along lake Erie and the Detroit river.

SUBSPECIES. The eastern subspecies, the Eastern Gnatcatcher, is the typical form. A western subspecies occurs in the southwestern states.

This is a bird of the large tree forests where it usually lives and builds high up among the tree tops. As it is only regularly found in southern Ontario along western lake Erie and has been taken elsewhere in Canada only occasionally, it must be regarded as a rare bird in Canada.

Economic Status. Too rare in Canada to be economically considered.

FAMILY-TURDID $\$$ TH. THUSHES AND ALLIES.

This is a nearly cosmopolitan group systematically separated with difficulty from the last family, though the individuals described in the following pages are strongly enough marked to be easily recognizable. In eastern Canada only one subfamily is represented.

Subfamily-Turdina. The True Thrushes. L, 6.25-10.

Most of the Canadian Thrushes are easily recognized as such. Systematically they are plainly marked by the number of primaries and 
the scalation of the feet. As these are rather difficult features for the amateur to discern, it is perhaps easier to differentiate them by other more striking characters that apply to the representative of the group in eastern Canada. For this purpose they may be divided into the Thrushes proper and the American Robin, Bluebird, and Wheatear, the last very rare and the other two so well marked as to be recognized with ease. The Thrushes proper are medium-sized birds, brown above and white below, with the breast more or less spotted, except one species, the Veery, conspicuously so. Any Canadian bird of this description between 6.25 and 8.30 inches long, with the first primary very small and degenerate, belongs to this group. The Thrushes are all ground-haunting birds and usually more or less solitary. Their principal food is insects and soft fruit. The woodland species are of little direct economic importance, although their influence is beneficial. All the Thrushes of this group are very sweet singers.

755. Wood Thrush. SONG THRUSB. FR. - IA GRIVE DES BOTS. Hylacichla mustelina. L, $8 \cdot 29$. Plate XLVIII A.

Distinctions. Easily recognized as a Thrush, though having somewhat the general colour of the Brown Thrasher. The short tail, straight bill, and dark instead of light eye make good separation marks. From the other members of the genus it can be told by its larger size, the absolute whiteness of the breast, the sharper definition of the round spots, and the yellowish rather than reddish or olive tinge of the back, brightest on head.

Field Marks. The sharp spots on the pure white breast and the tawniness of the back make the best field marks.

Nesting. In saplings about 8 feet above the ground, in nest of leaves, rootlets, fine twige, and weed stalks firmly interwoven and lined with mud and fine rootlets.

Distribution. Eastern North America; north regularly to southern Ontario; occhsional or local in adjoining regions.

The Wood Thrush is a woodland bird of rather southern distribution; common in Canada only in the more southern portions.

756. Wilson's Thrush. VEery. CATHEdRAL-BIRD, FR.-LA GRIVE DE WILSON. Hylocichla fuscescens. L, 7.52. Plate XLVIII B.

Distinctions. In this Thrush the brown is almost as tawny as in the Wood Thrush but the back is evenly coloured and no brighter on head or tail than elsewhere. The breast spots are reduced to a vague series of darker spots down the sides of the neck and on a tinted area across the upper breast.

Field Marks. The even, light coloration of the back and the light suffused colour of the breast spots.

Nesting. On or near ground, in nest of strips of bark, rootlets, and leaves wrapped with leaves and lined with rootlets.

Distribution. The northern part of north America north to the limits of settlement.

SUBSPECIES. In Canada Wilson's Thrush is represented by two subspecies, the Veery, the type form, and the Willow Thrush of western distribution, coming east to Manitoba and only occasionally occurring in eastern Canada.

The Veery has a wide distribution within settled sections. Beyond the range of the Wood Thrush and before the other thrushes become numerous this species is common and its cascade of bell-like notes poured forth at sunset in the darkening bush are very pleasant to hear.

757. Alice's Thrush. GREY-CHEEKED THRUSH. FR.-LA GRIVE D'AliCE. Hylocichla alicia. L, 7.58. Plate XIIX A.

Distinctions. Although a distinct species, this thrush is so nearly like the next, the Olive-backed, as to be separated from it with some difficulty. The two can be distinguished from other thrushes by their even dark olive backs and heavily spotted breasts with spots suffused in places and running together. In the Grey-cheeked Thrush the sides of the face and spotting of breast are suffused with dull cold grey instead of a warm buff. 
Field Marks. Heavily spotted breast and evenly coloured back and tail will separate this from all but the Olive-backed. The lack of buff tones on the side of the face will differentiate it from that species though in actual field work it is only under the most favourable circumstances that this character can be made out with certainty and many specimens seen in the dark woods or the fleeting moments given for observation go unidentified.

SUBSPECIES. Alice's Thrush is divided into two geographical races: the Greycheeked, the type, and Bicknell's Thrush H.a.bicknelli. The latter in Canada is confined as far as we know now to the Maritime Provinces below the gulf of St. Lawrence, but the distribution of the two forms in eastern Canada is not well worked out.

Distribution. Northern North America; breeding mainly in Canada from the edges of settlement northward.

758a. Olive-backed Thrush. FR.-LA GRIVE DE swaInson. Hylocichla ustulata. L, 7.17. Plate XLIX A.

Distinctions. Evenly coloured back without colour variation on either head or tail and heavily spotted breast will separate this from all the thrushes but Alice's. The distinctly buffy cast of the cheeks instead of cold grey will differentiate it from that species.

Field Marks. Back and breast characters as above. The facial coloration which separates it from Alice's can only be seen under the most favourable conditions and many individuals usually go unidentified.

Nesting. In bushes or small trees about 4 feet above the ground, in nest of coarse grasses, moss, rootlets, leaves, and bark lined with rootlets and grass.

Distribution. As a species, all of North America; breeding mostly in Canada from the edges of cultivation northward. Swainson's Thrush extende west to the Rocky mountains.

SUBSPECIES. The Olive-backed Thrush is divided into two subspecies. The type race, under the name of Russet-backed Thrush, is a Pacific Coast form. The Eastern Olive-back or Swainson's Thrush H.u. swainsoni is the only one in eastern Canada.

In spring and autumn the open woods are invaded by great numbers of these evenly coloured, spotted-breasted thrushes on their way to and from their breeding grounds. They are rather wary and the numerical proportion of each species present can usually only be estimated.

759. Hermit Thrush. FR.-LA GRIVE solitaIRE. Hylocichla guttata. L, 7·17. Plate XLIX B.

Distinctions. Very similar to the last two but the tail reddish brown in contrast with the olive-brown of the back.

Field Marks. Brown back and white, spotted breast identifies it as a Thrush. The reddish coloration of the tail contrasting with the olive back serves for the identification of the species.

Nesting. On ground in nest of moss, coarse grasses, and leaves lined with rootlets and pine needles.

Distribution. As a species, all of northern North America. The Eastern Hermit Thrush extends westward to near the mountains and north to the tree limits, breeding usually just beyond the cultivated districts but irregularly to or near our southern boundary.

SUBSPECIES. The Hermit Thrush is a flexible and adaptable species represented in America by some six recognized subspecies. The typical form is an Alaskan race. Eastern Canada has only one subspecies, the Eastern Hermit Thrush H.g. pallasi:

The Hermit Thrush is one of our most famous singers. Unfortunately, it is usually silent as it passes through southern Canada and is heard at its best only in the northern coniferous woods.

761. American Robin. FR.-LE MERLE D'AMERTQUE, Planesticus migratorius. L, 10. Plate L A.

Distinctions. The robin is too distinctly marked and well known to require special description.

Field Marks. The robin is recognizable by those acquainted with the species, at great distances, when no colour is visible, by its outline, carriage, and manner of flight.

Nesting. Frequently in fruit or shade trees or about buildings, in nest of coarse grasses, leaves, rootlets, etc., with an inner wall of mud lined with fine grasses. 
Distribution. As a species all of North America, north to tree limits. The Eastern Robin covers all of Canada overlapping with the western form on the Pacific coast.

SUBSPECIES. The Robin is divided into three subspecies of which the Eastern Robin, the type form, is the only eastern Canadian representative.

The Robin has more intimate associations with man than perhaps any other bird. Its cheery voice is the harbinger of spring. Its song is the first heard in the morning and the last at night, and in the autumn when it has stripped the rowan tree of its last berry, and has disappeared we know that winter is upon us. Though named after a famous Old World bird, it only very superficially resembles the Robin Red-breast of England. The only points of resemblance are its red breast and confiding habits.

Probably the worst enemy of the Robin is the household cat. Nesting in readily accessible places young Robins are subject to many disturbances, often leave the nest before they are able to fend for themselves and so fall prey to the cat.

The spotted breast of the young Robin indicates its descent from a spotted ancestor and its relationship to the thrushes of the previous genus. In fact the young of most of the members of the family have spotted breasts.

Economic Status. Though the Robin is an efficient aid to the agriculturist, its fondness for fruit occasionally gets it into trouble with the small fruit raiser. Forty-two per cent of its food is animal, mostly insects, the remainder is composed largely of berries and other soft small fruits of which little more than 4 per cent is cultivated fruit.

765. Wheatear. FR.-LE TRAQUET MOTTEUX. Saxicola cenanthe. L, 7.01. A Titlark-like bird, light grey above, white below, warmed with buff colour on throat; a black band through the eye and a white rump. The female and juvenile are similar but duller and more evenly buff coloured.

Distinctions. The conspicuous and extensive white rump with the general colorations given above are distinctive.

Field Marks. With its showy white rump the bird looks like a partly albino Titlark.

SUBSPECIES. The subspecies of Wheatear that occurs in eastern Canada is the Greenland Wheatear S.o. leucorhoa.

This is a European bird of regular occurrence in Greenland and perhaps in the adjacent parts of Ungava but of only casual or accidental occurrence elsewhere in Canada.

766. Bluebird. FR.- LE ROUGE-GORGE BLEU. Sialia sialis. L, 7.01. Plate L B.

Distinctions. The only solidly blue bird with a reddish breast among Canadian species- the Indigo bird is blue but lacks the red breast. Females and juveniles are duller in colour and the breasts of young birds are spotted with brown but all have the characteristic blue backs. breast.

Field Marks. The bright blue coloration of the back and the earthy red of the

Nesting. In hollow trees, posts, or stubs or in bird houses, in nest of grasses.

Distribution. Eastern North America, west to the prairie provinces and north nearly to the bounds of settlement.

SUBSPECIES. The subspecies of Bluebird occurring in Canada is the typical race, the Eastern Bluebird.

The Bluebird arrives in the early spring with the Robin and the Meadowlark. It is a confiding bird building in the hollows of old apple trees, holes in fence-posts, bird boxes, or nests abandoned by Wood- 
peckers. It is characteristically a bird of the orchard and with a little encouragement will build in birdhouses in the garden where its gentle ways, pretty murmuring notes, and brilliant coloration make it quite an acquisition.

Economic Status. The Bluebird feeds mainly upon insects and is, therefore, highly beneficial. Weed seeds form an important part of its food and it eats some soft fruit, but practically no cultivated kinds are taken. Hence the Bluebird can be regarded as a consistently useful bird.

\section{GLOSSARY}

Albinism. The occasional and erratic occurrence of white specimens, either pure or partial, complete or in irregular spots, in species that normally are not white. It is nothing more than a freak caused by a deficiency of colouring matter in the plumage (p. 7).

Axillars or Axillaries. A fan-shaped group of feathers under the wing closing the space between the innermost flight feathers and the body when in flight.

Bars. In descriptions of bird coloration, bars designate lines drawn across the body and not parallel with the shafts of the feathers (see stripes).

Cere. A wax-like appearing swelling about the base of the upper mandible, present in some species, especially the Hawks. See Figure 33a and b, page 23.

Coverts. The feathers covering the bases of the larger flight and tail feathers. There are upper and under wing coverts and upper and under tail coverts. The upper wing coverts are divided into greater and lesser coverts, the former being the largest line immediately next to the flight shafts and resembling them to some degree in texture (Figure 1 p. 18).

Crepuscular. Pertaining to twilight.

Crown. The top of the head from the forehead to near the base of the skull.

Culmen. This may be called the ridge line of the bill. Viewed sideways, the line forming the top outline of the bill from the spring of the first forehead feathers to the tip is the culmen line. It is measured in a straight line, as with dividers, not following the curves as with a tape line (Figure 1, p. 18).

Dichromatism. The normal occurrence of two different colorations in the same species due to neither sex, season, nor age and only partly hereditary. Both colorations may occur in the same brood though the tendency is for like to produce like and one form may predominate in any given locality (see p. 7).

Emarginate. When applied to the shape of feathers indicates that more or less of one web is cut away as if a shaving had been removed with a jack-knife.

Extralimital. In describing distribution refers to the subject occurring without the geographical bounds of the area under discussion.

Family. In zoological classification is one of the larger groups of animals having enough mutual resemblance to be classed together and apart from all other forms. It is the next larger group to a genus and next smaller to an order or suborder. For example, all the Ducks, Geese, and Swans belong to the same family, Anatidæ (see p. 5).

Flanks. The sides of the body, below or under the closed wing. They are often covered by a loose group of feathers that may be laid at will either over or under the shafts of the closed wing (Figure 1, p. 18).

Genus (plural, genera). In zoological classification is one of the smaller groups of animals having enough resemblance to be classed together and apart from all other groups of like rank. It is a subdivision of a family or subfamily and next above a species. A genus is, therefore, a group of species, and a group of genera is a family (see p. 5).

$57172-15$ 
Gular Pouch. A pouch of bare skin depending from the under side of the lower bill between its Y-shaped arms and joining it to the neck below. Some species have only the merest trace of it, and others have it remarkably developed, though in most species it is entirely absent.

Hybrid. The offspring between parents of two different species-a " cross."

Iris. The coloured portion of the eye. The pupil, except in albinism, is always black and the surrounding circle of colour is the iris.

Lanceolate. Lance shaped, i.e., long and narrow with parallel edges or tapering gradually to a point.

Length. Abbreviated in descriptions by its initial $\mathrm{L}$ and given in inches and tenths of an inch. Length is taken in a straight line, as with dividers, from the tip of the bill to the end of the longest tail feather, the bird being laid out flat on its back and stretched just sufficiently to straighten the curves of the neck.

Lores. A small spot between the eye and the base of the bill (Figure 1, p. 18).

Mandibles. The two members forming the bill; thus there is an upper and a lower mandible.

Mantle. A term covering the back, shoulders, upper wing coverts, and secondaries. Applied more especially to the gulls where the even colouring of these parts suggests a mantle covering the whole upper part of the body and closed wings.

Melanism. The opposite of albinism. It is the more or less erratic occurrence of very dark or black individuals in a normally lighter-coloured species. It usually occurs less frequently than albinism though some species are more liable to it and it glides jmperceptibly into dichromatism in some cases. Albinism usually denotes a lack of virility. Melanism does not seem to be an evidence of weakness and hence melanistic strains have better chances of surviving. A melanistic animal is said to be a Melano (see page 7).

Nape. A small space at the back of the neck just below the base of the skull (Figure 1, p. 18).

Neck. The space between the throat and breast in front, and the hind head and shoulders behind. It is divided into fore neck and hind neck whose meanings are obvious (Figure 1, p. 18).

Order. In zoological classification a group of families having mutual resemblance enough to separate them from all other groups. It is next larger than the family and is the largest subdivision of birds that we have to deal with in Canada (see page 7).

Pectinate. Furnished with comb-like teeth. In ornithology usually applied to the claws of some species that are so furnished (Figure 19, p. 21).

Pelagic. Living largely or almost entirely a.t sea.

Pensile. Applied to nests when they hang suspended like a bag between the forks of a branch or other such support, with nothing supporting from below.

Primaries. The large flight feathers secured to the first joint of the wing from the wrist to the tip (see secondaries). (See Figure 1, p. 18.)

Race. As used here, practically synonymous with subspecies. In general, any group within a species exhibiting recognizable common characters differentiating it from others of the same species.

Rufous. Of a red or reddish colour.

Rump. The lower end of the back just before the root of the tail (Figure 1, p. 18).

Secondaries. The large flight feathers secured to the second joint of the wing between the wrist and the elbow (see primaries). (Figure 1, p. 18.)

Species. In zoological classification the smallest constant group. is the scientific 
term to denote what is understood in common language as a "kind of animal." Thus a house cat is a species, whether Maltese, tortoise shell, or tabby, the dog, whether greyhound or spaniel is another, and a horse, whether Shetland pony or draught, is a third (see page 5).

Speculum. A somewhat rectangular patch of contrasting colour on the centre of the upper surface of the wing. It of ten shows metallic iridescence and is a common feature of coloration in some families, as in the Ducks.

Stripes. In ornithological descriptions, stripes always run lengthways of the bird; lines if across the body are spoken of as bars (see bars).

Sternum. The breast bone. In a bird a deeply keeled structure to which the wing muscles are attached.

Subspecies. In ornithological classification, synonymous with geographical race or variety, denoting a division of the species usually correlated with geographic limitations. It differs essentially from a full species by showing intergradations with allied races of equal rank. Taking the horse as a representative species, the various breeds or strains, such as Arab, Clydesdale, or Shetland pony are subspecies (see page 6, for discussion).

Tarsus. The metatarsal bones of the foot fused together into a single bone. This is what we popularly regard as the bird's leg but is properly the foot, extending between the juncture of the toes and the end of the "drum stick." A comparison with the joints of the human leg will make it obvious that the knee is between the "drum stick" and the "second joint " of the fowl and that the first external joint on the bird corresponds with our heel, the "feet" being true toes.

Type. In zoological nomenclature the "type form" is that form first properly described and named and the specimen from which the description was written is the type specimen. It does not of necessity mean that the form is typical in the ordinary sense of the word, though for convenience it is assumed to be so (see page 8).

Vermiculation. In descriptions of plumage, vermiculation refers to fine, irregularly wavy lines suggesting the pathways of innumerable small worms, from which the word is derived.

Vinaceous. Wine coloured. A peculiar purplish pink shown or suggested in the coloration of some birds. 

$-$ 
Plate I.

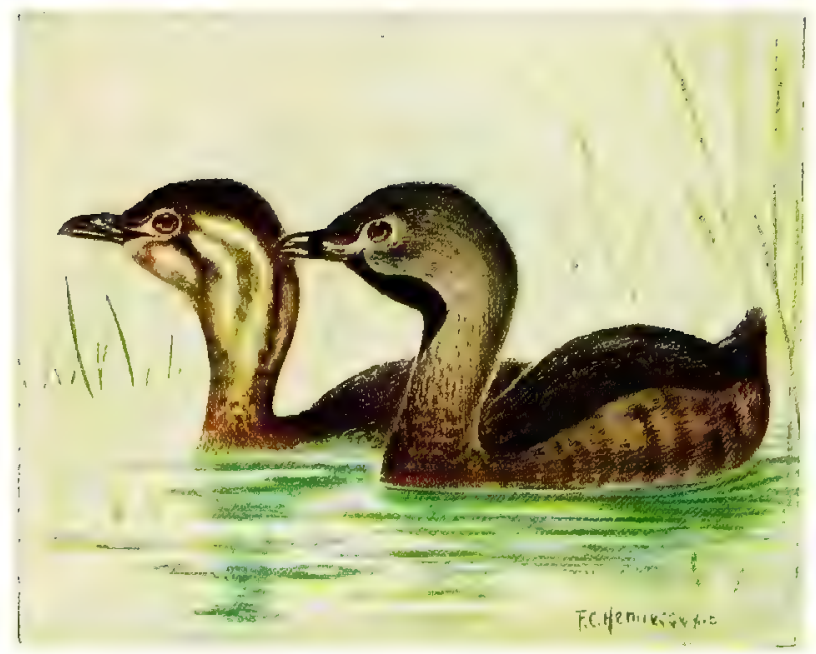

A. Pied-billed Grebe (p. 43 ).

Juvenile

Adult

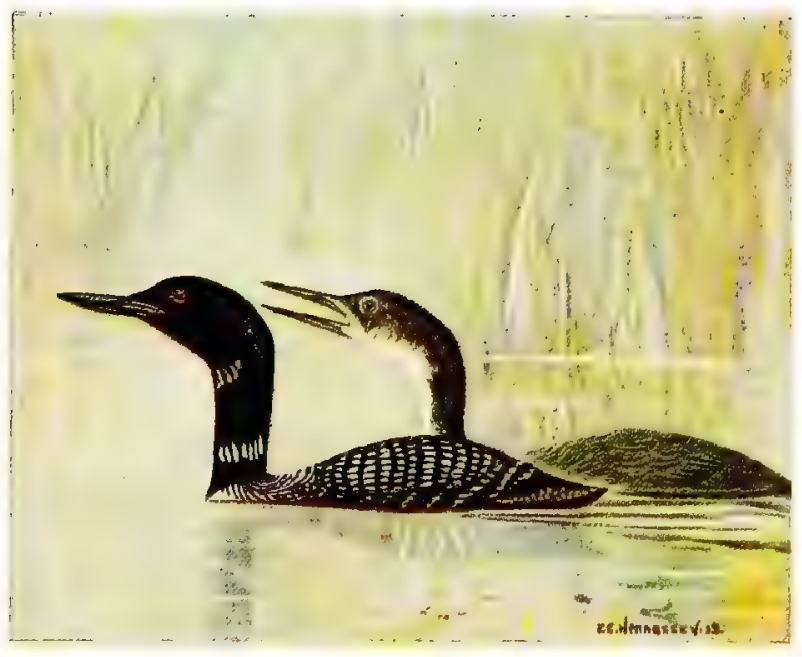

B. Common Loon (p. 44).

Adult Juvenile 


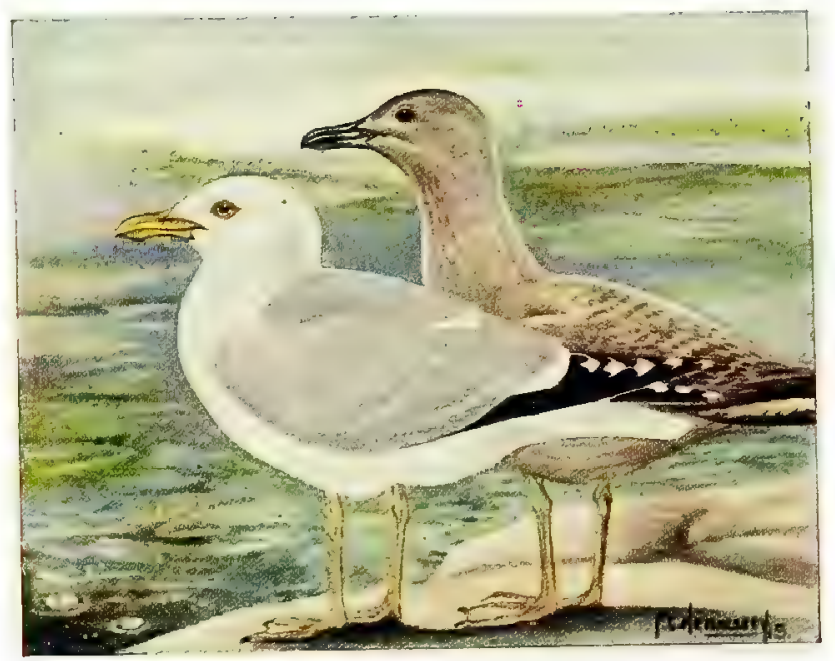

A. Herring Gull (p. 52).

Adult Juvenile

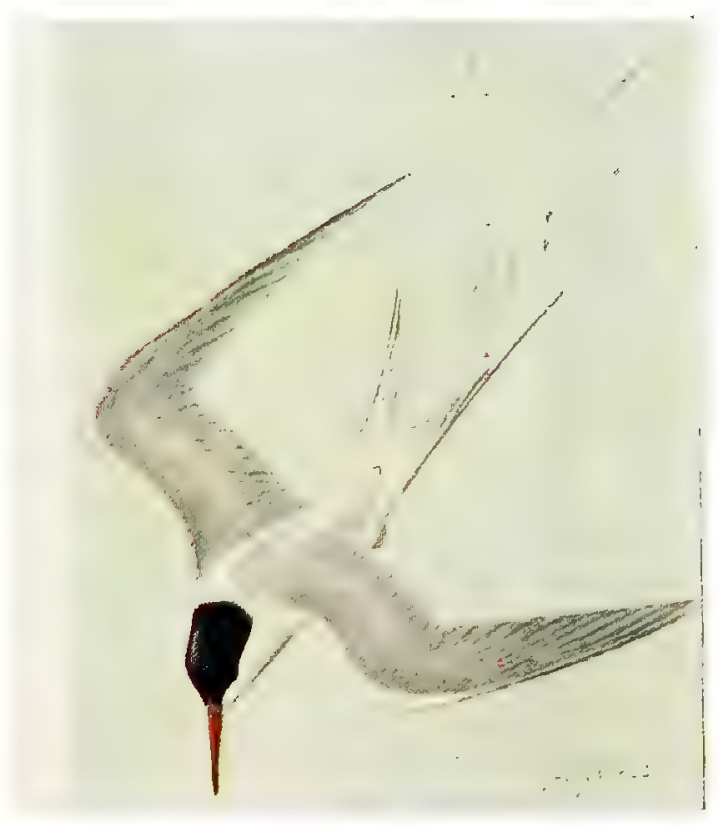

B. Common Tern (p. 55). 
Plate ill.

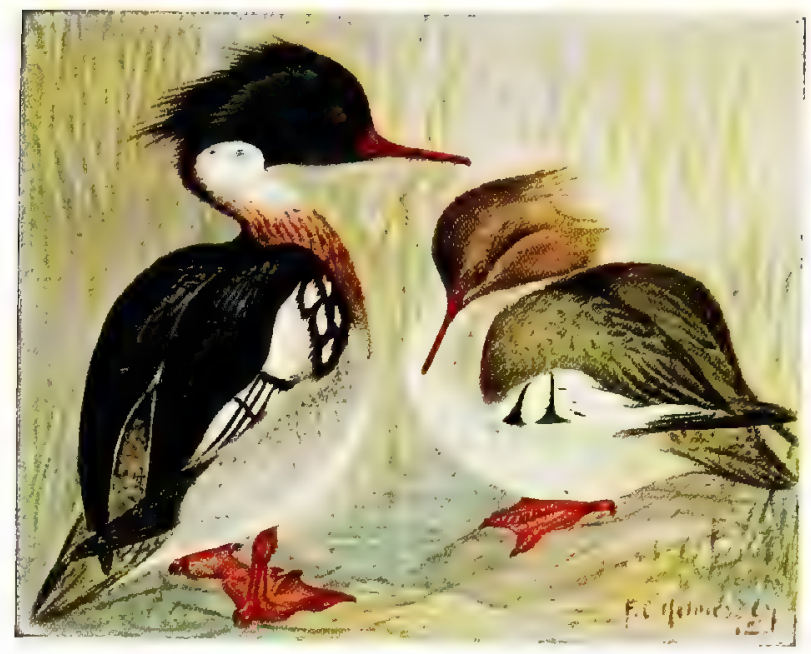

A. Red-breasted Merganser (p. 64).
Male
Female

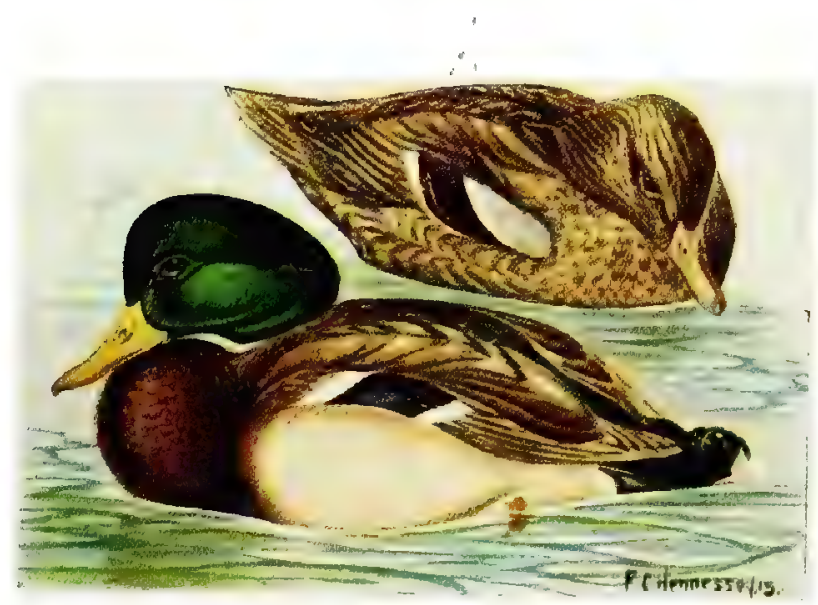

B. Mallard Duck (p. 65). 


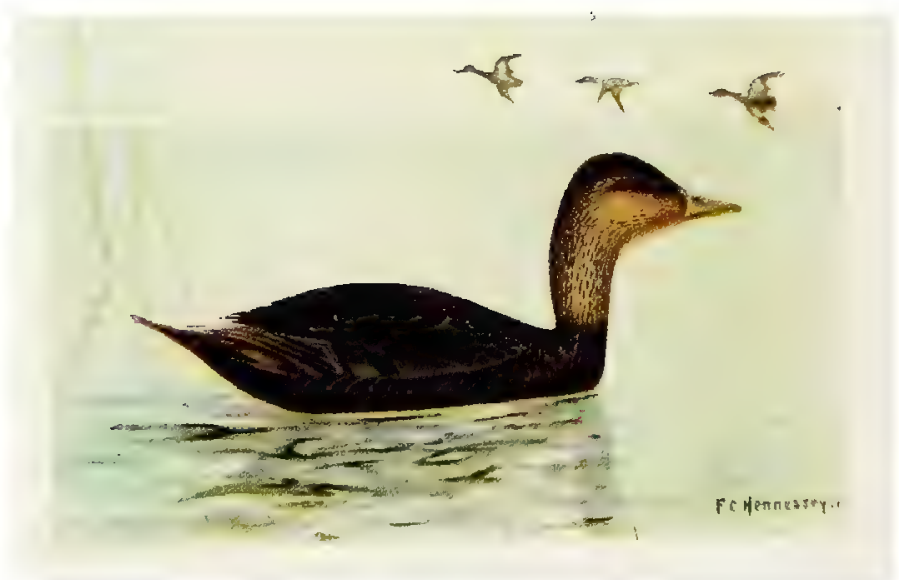

A. Black Duck (p. 66).

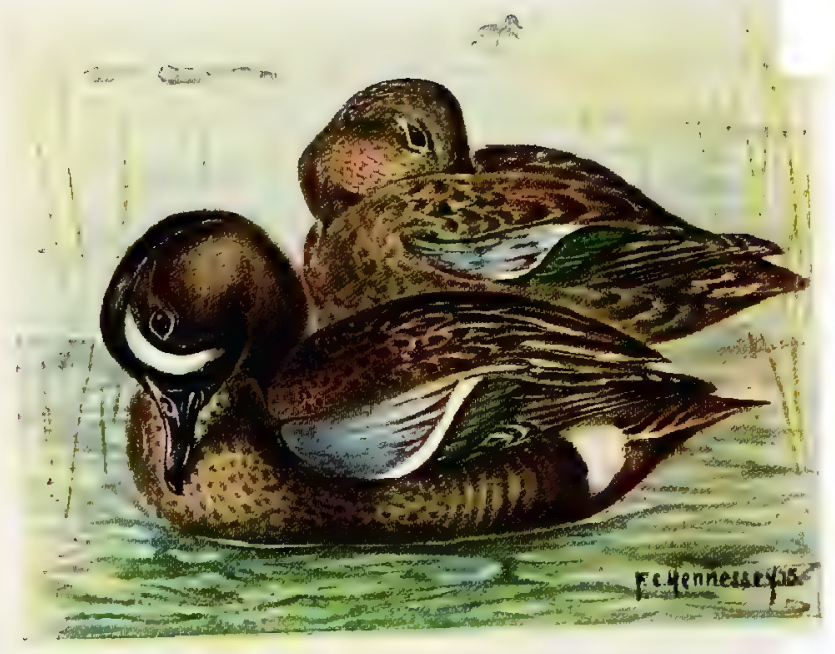

B. Blue-winged Teal (p. 67).

Male

Fernale 


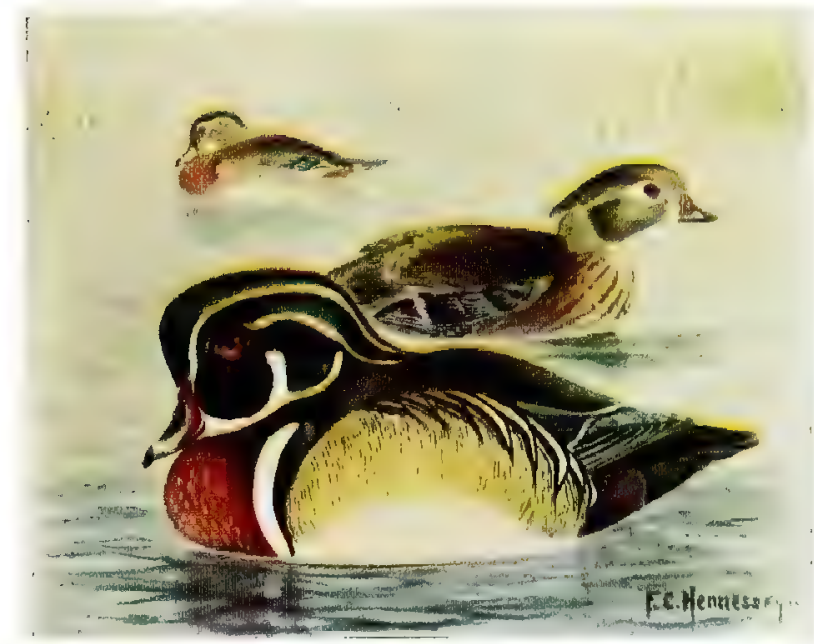

A. Wood Duck (p. 68), Male Female

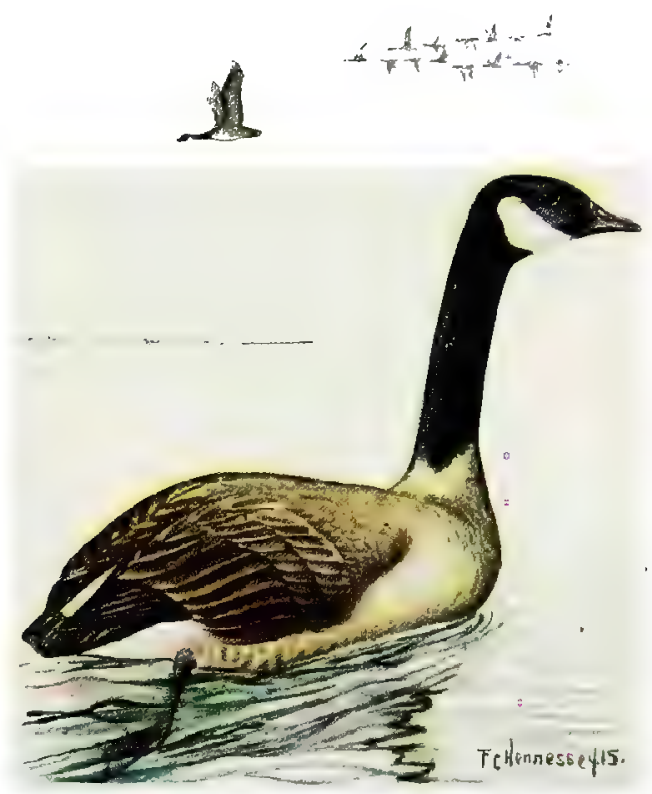

B. Canada Goose (p. 76). 


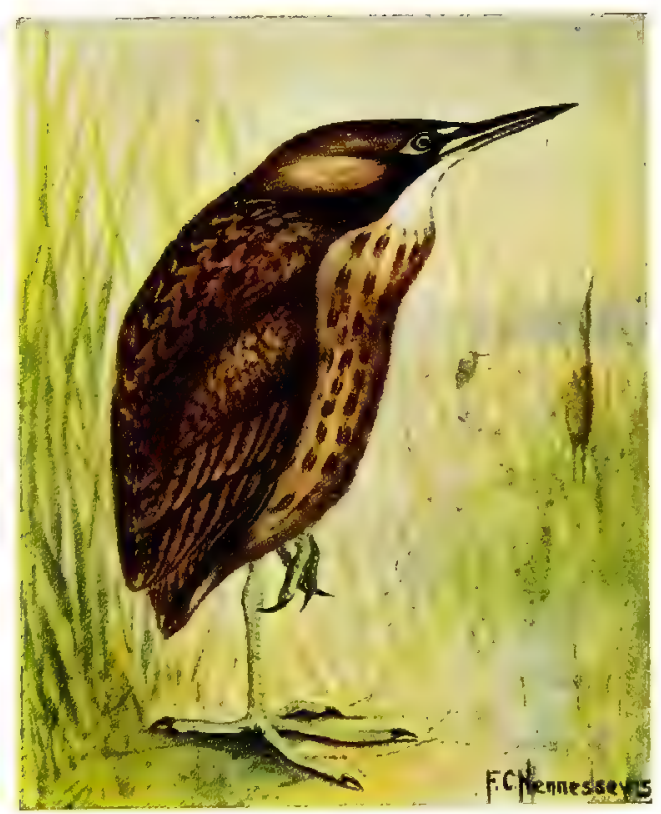

Plate li.

A. American Bittern (p. 80).

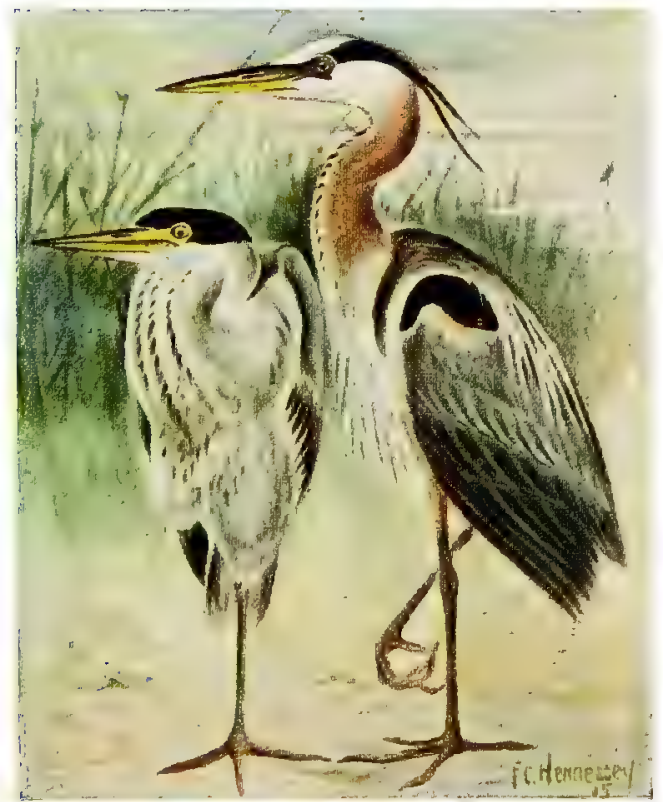

B. Great Blue Heron (p. 82) 
P'a ATE, VII.

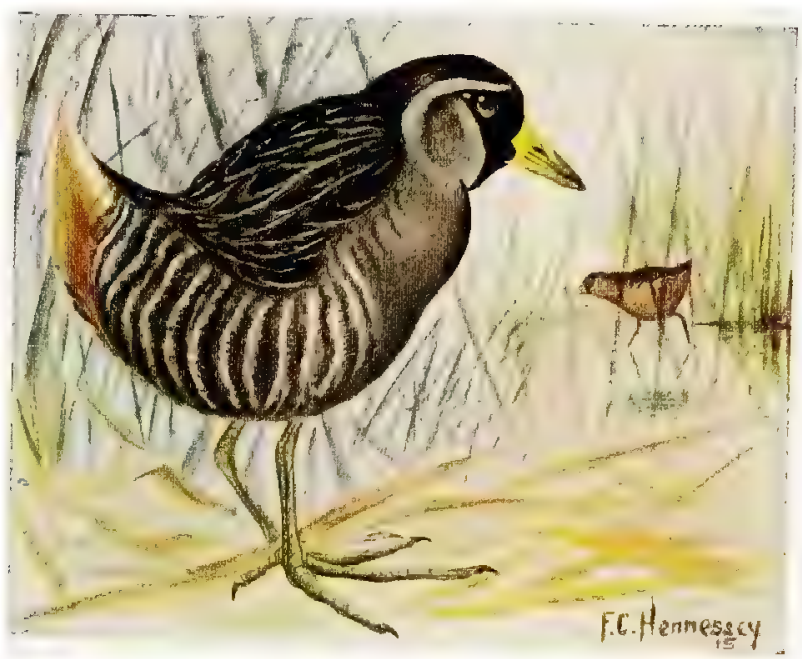

A. Sora Rail (p. 88).

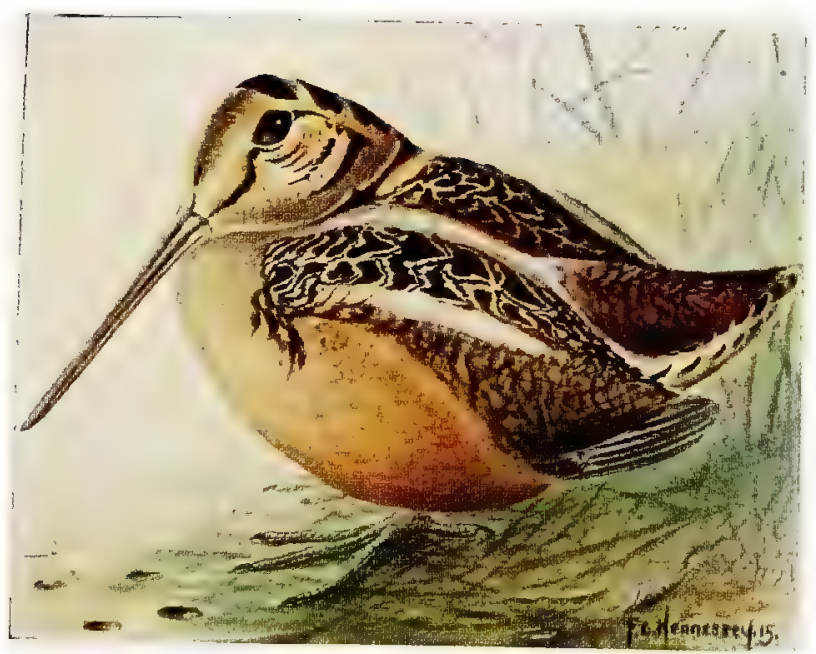

B. American Woodcock (p. 93). 


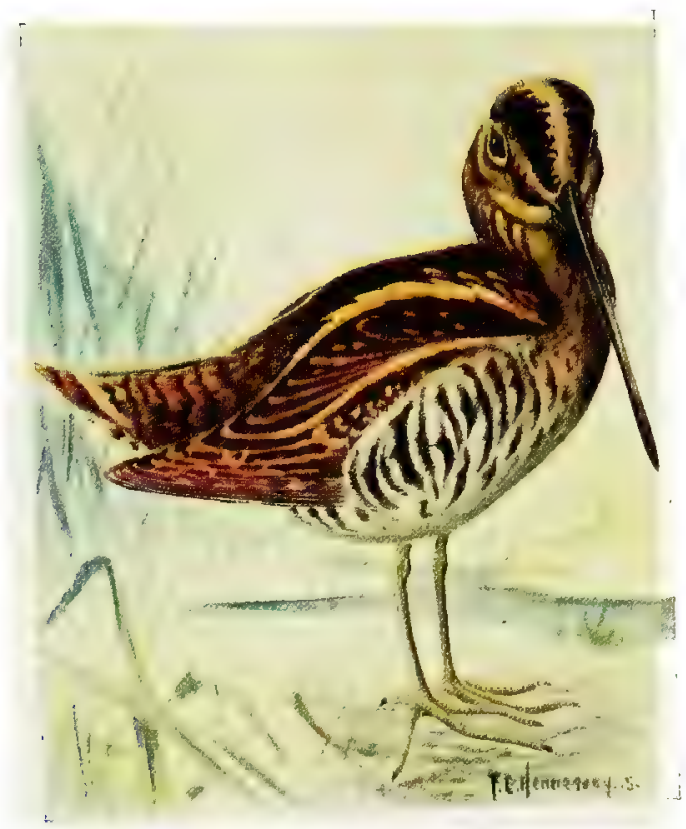

A. Wilson's Snipe (p. 93).

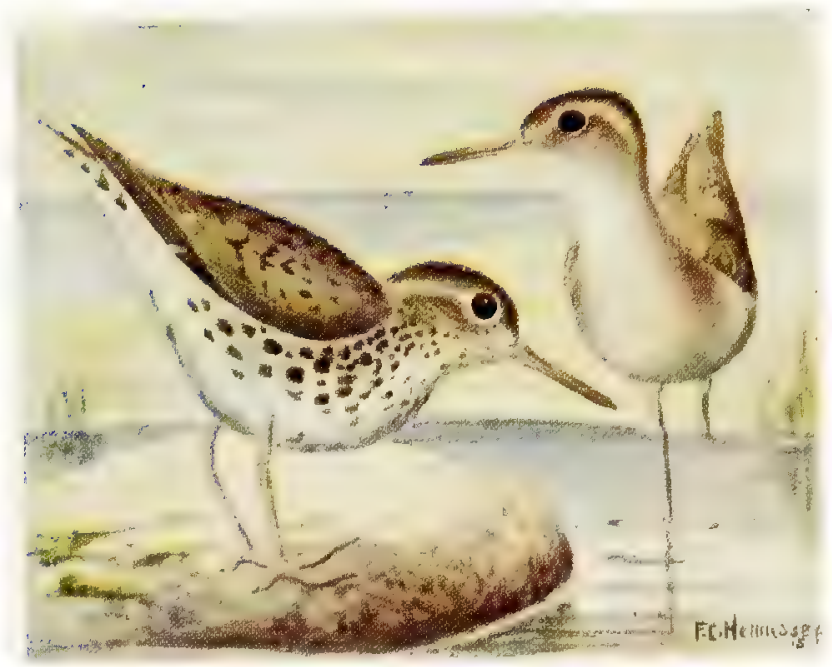

B. Spotted Sandpiper (p. 100). Adult Juvenile 
I'LAIEIX.

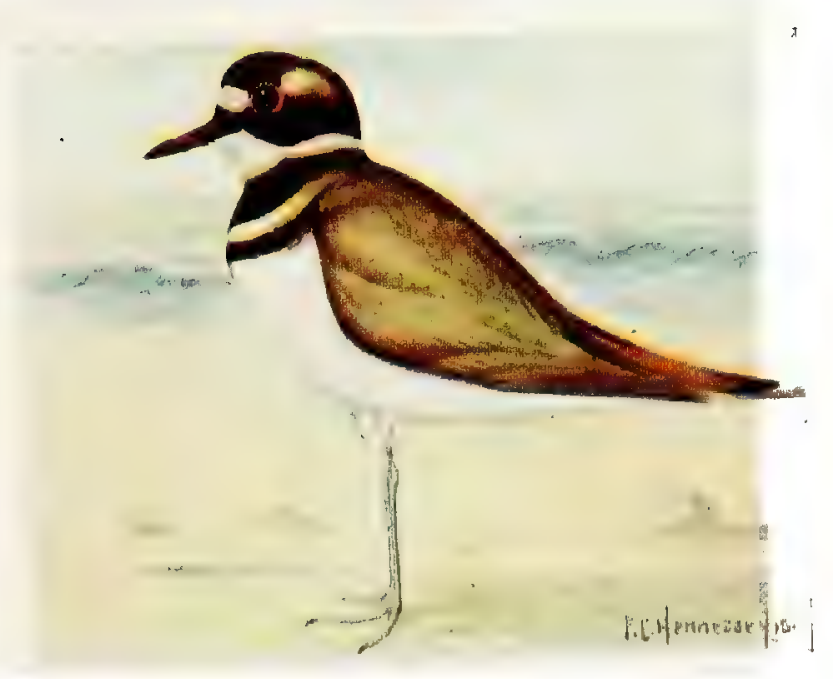

A. Killdeer (p. 104),

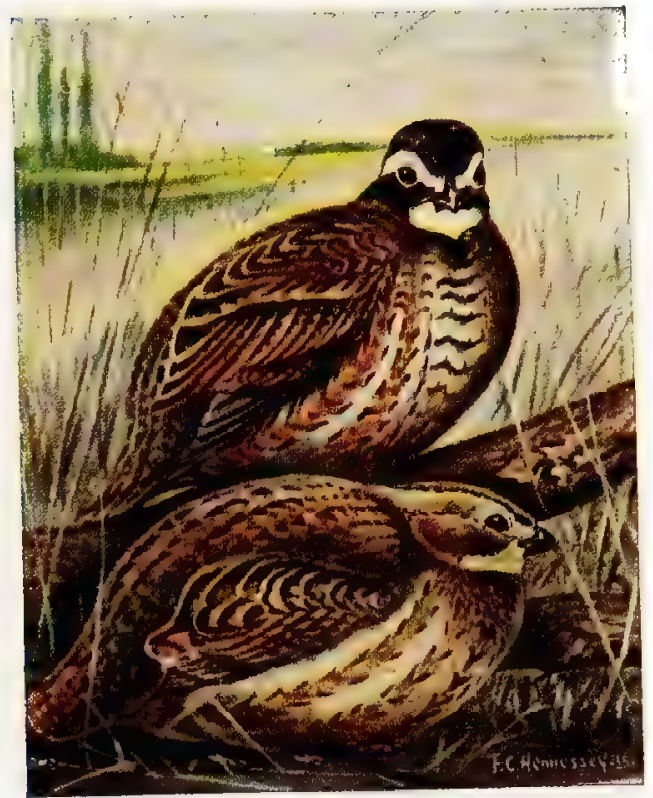

B. Bobwhite (p. 107).

Male

Female 


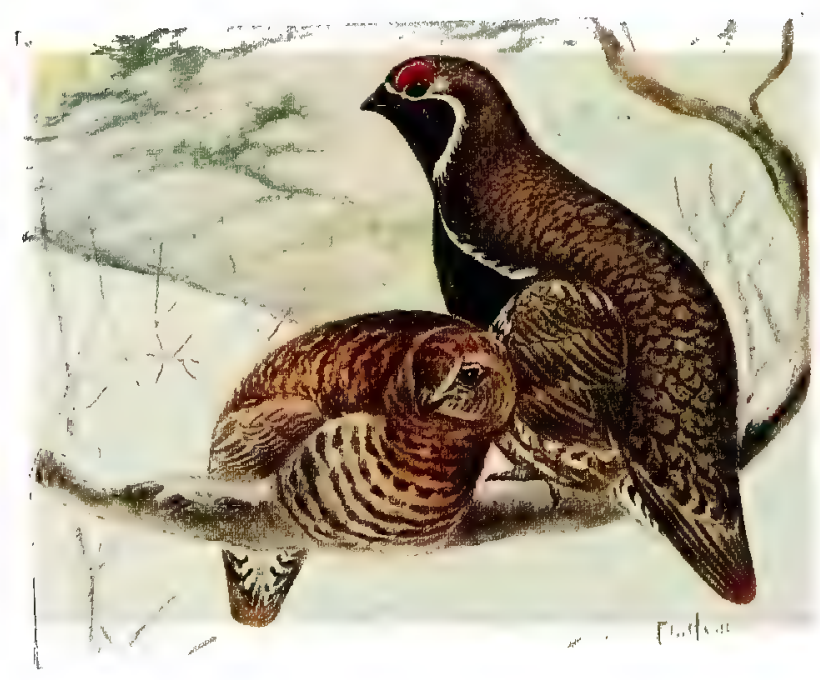

A. Spruce Grouse (p. 108).

Female Male

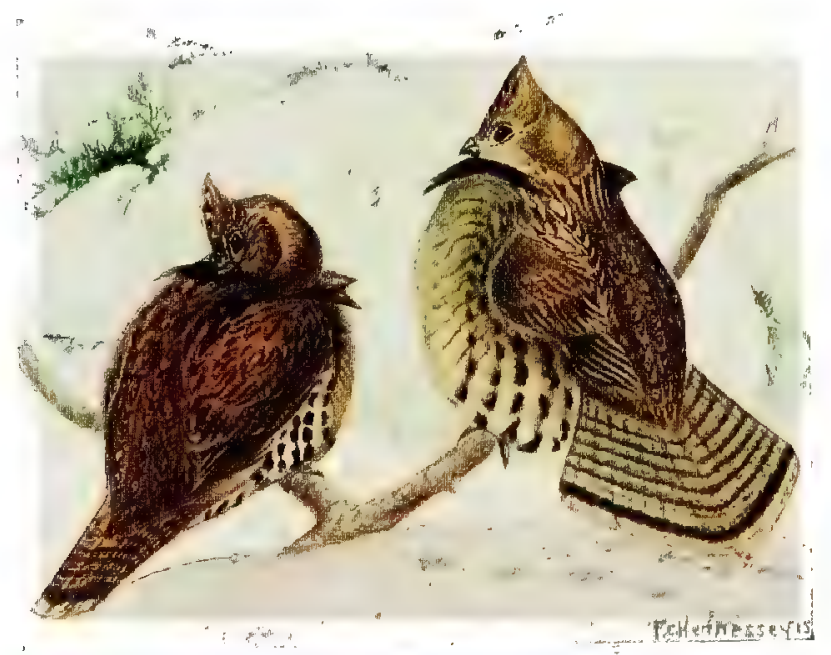

B. Ruffed Grouse (p. 108).

Red phase Grey phase 
P'Late XI.

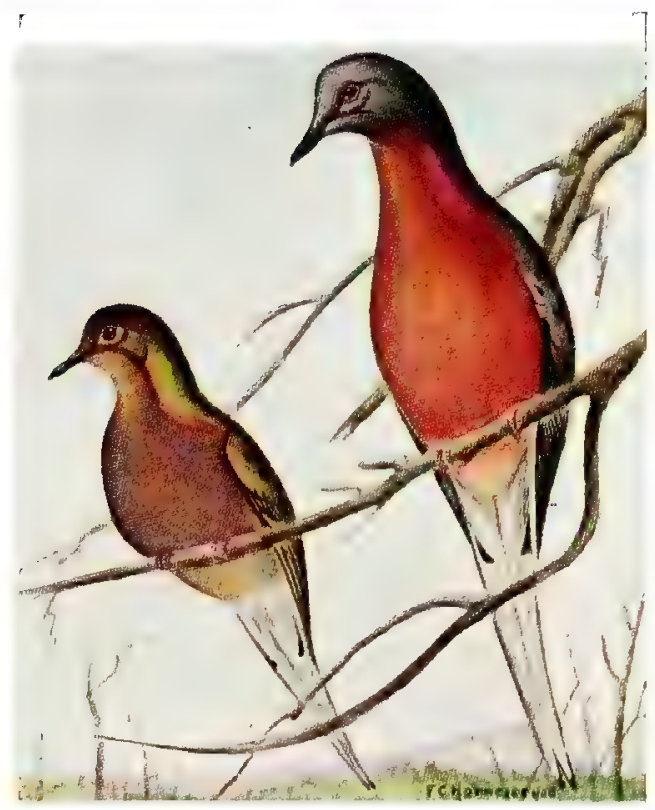

A. Mourning Dove and Passenger Pigeon (pp. 112 and 113).

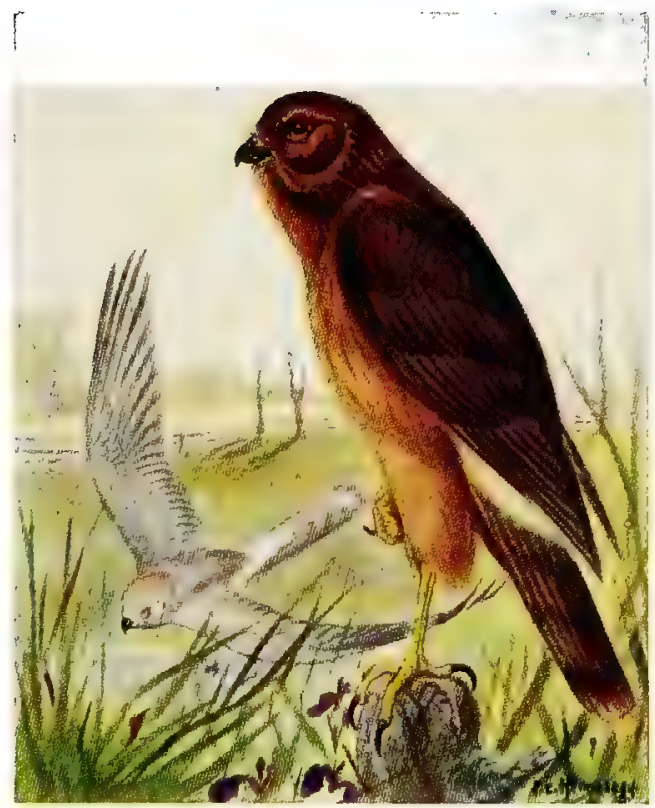

B. Marsh Hawk (p. 11\%).

Adult Tovenile 
Plate Kil.

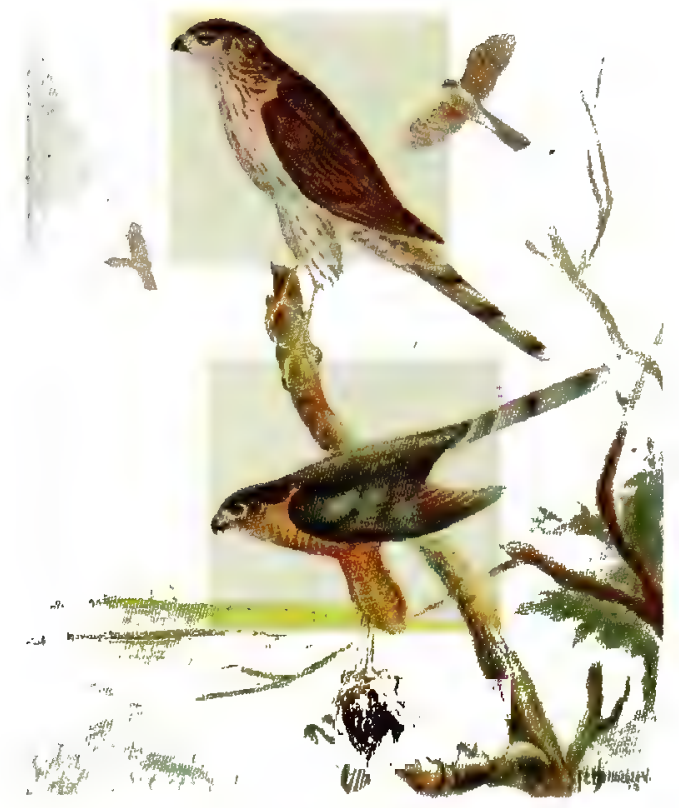

A. Slarp-shinned Hawk (p. 118). Juvenile female Adult male

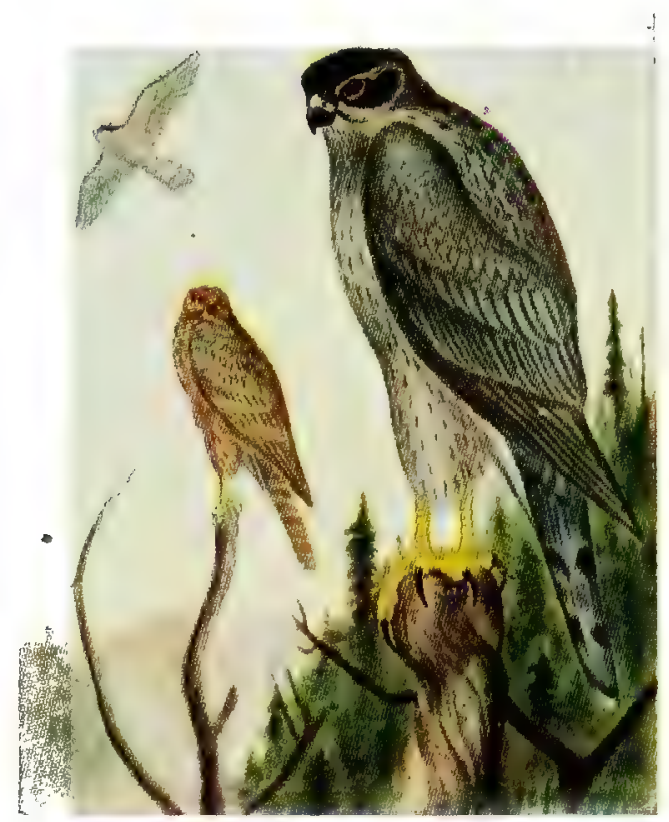

B. American Goshawk (p. 119). 
Plate XiII.

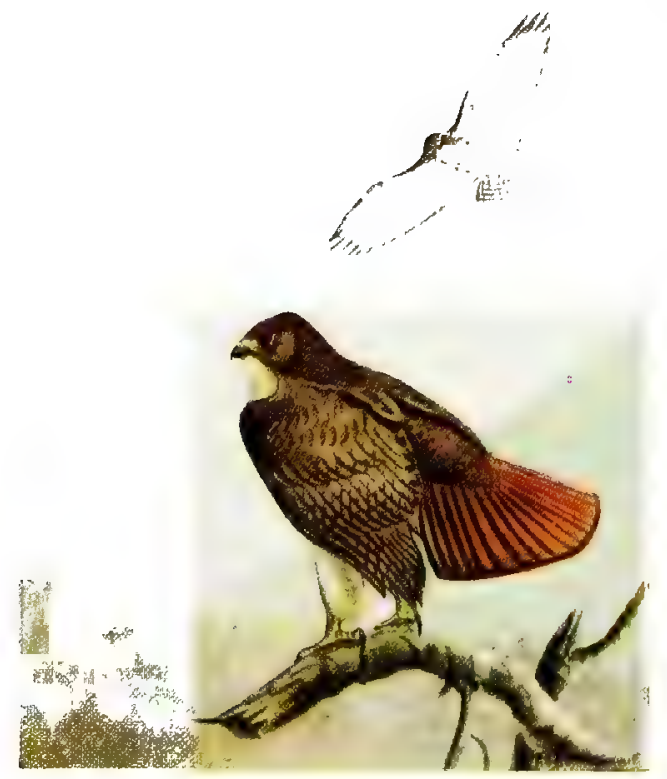

A. Red-tailed Hawk (p. 120).

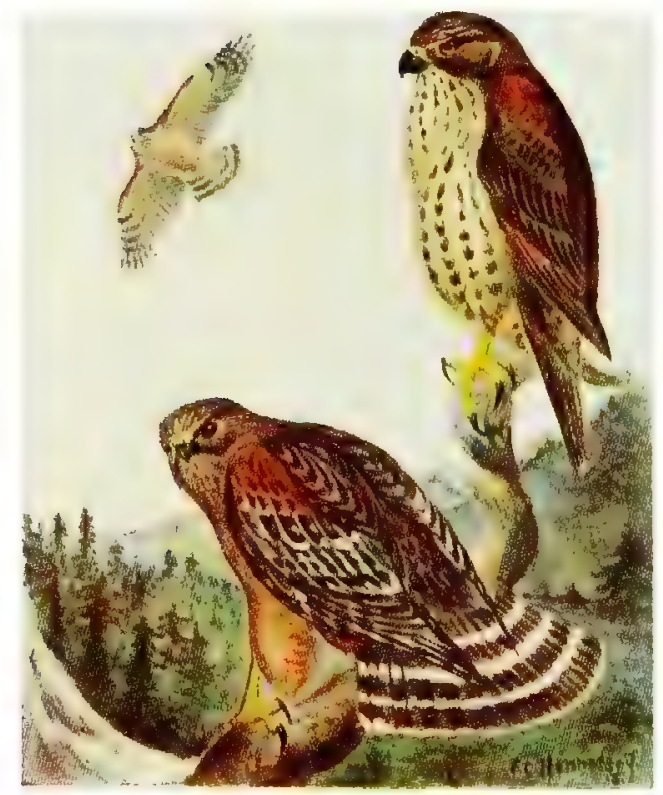

B. Red-shouldered Hawk (p. 121). 
Plate XIV.

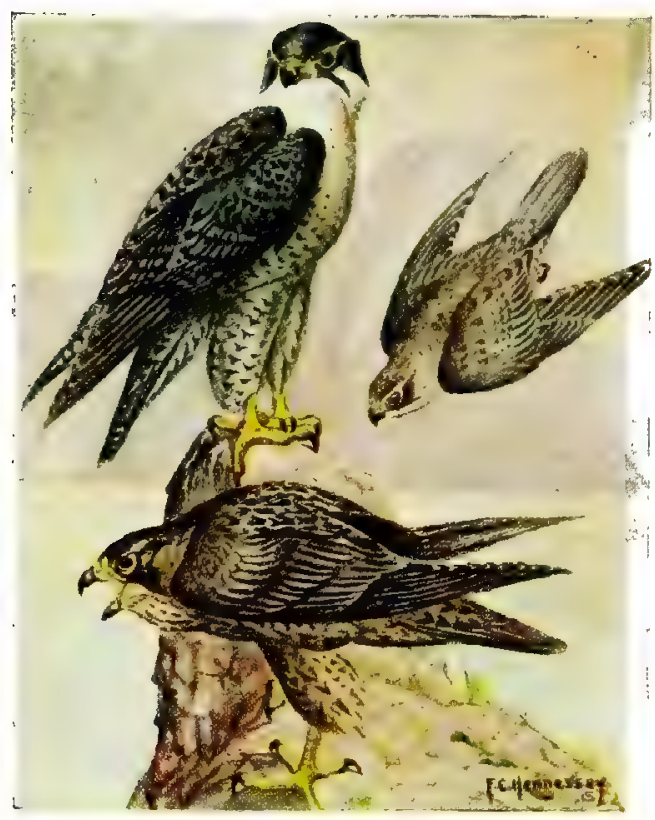

A. Duck Hawk (p. 126).

Adult Juvenile
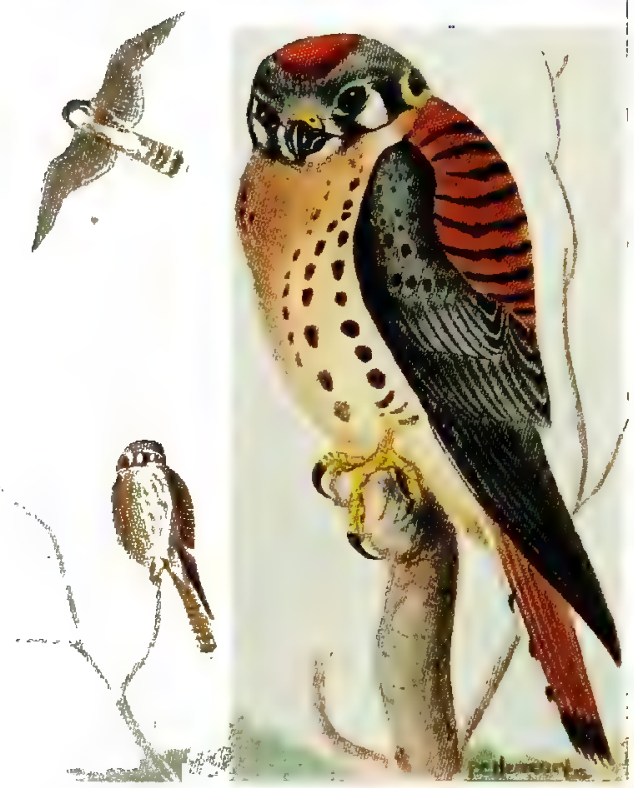

B. American Sparrow Hawk (p. 127). 
Plate XV.

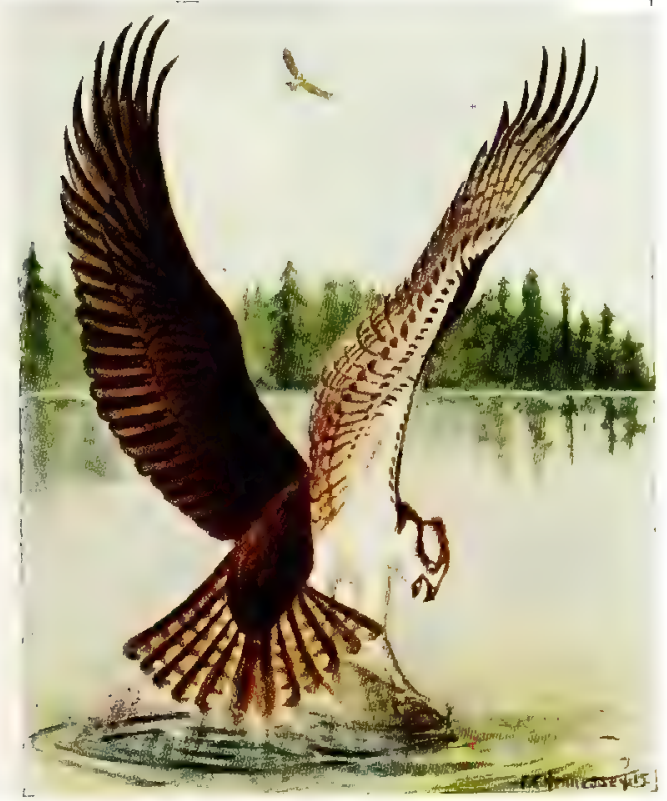

A. Osprey (p. 128).

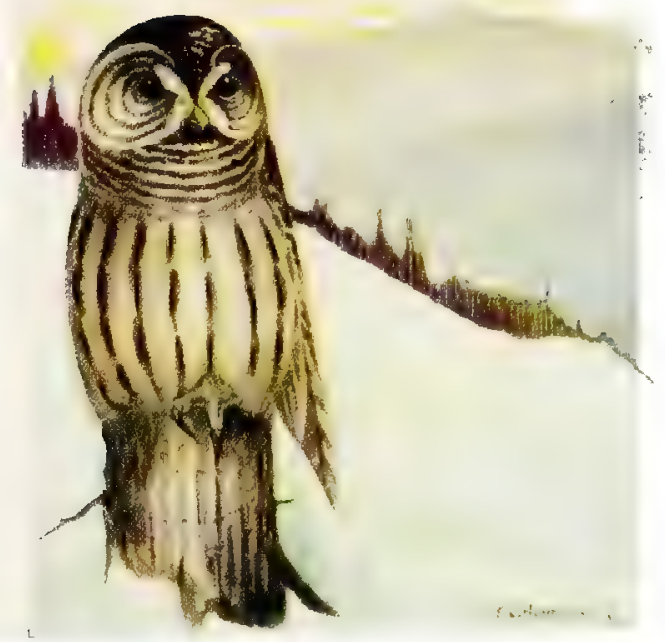

B. Barred Owl (p. 131). 
Plate XVI.

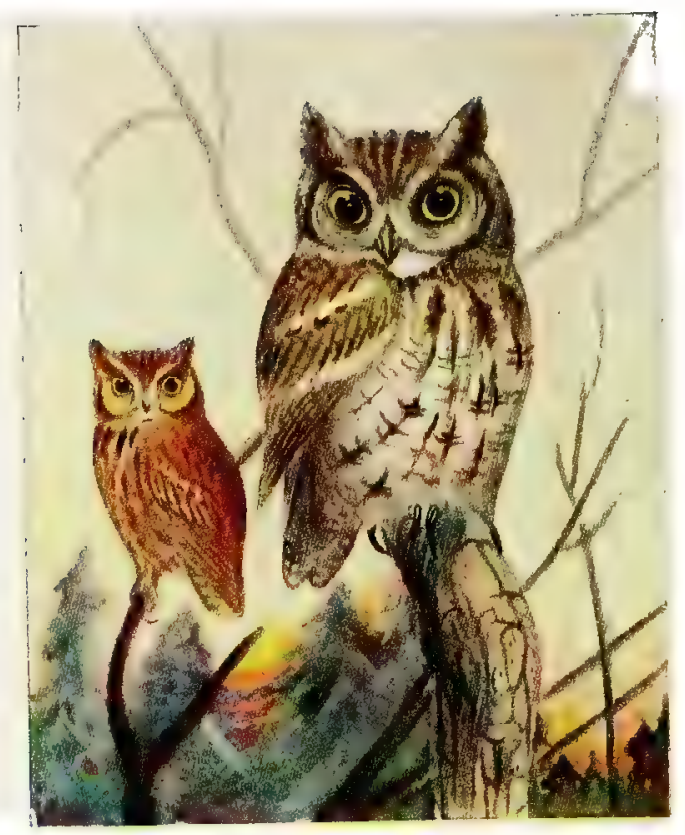

A. Screech Owl (p. 133).

Red phase Grey phase

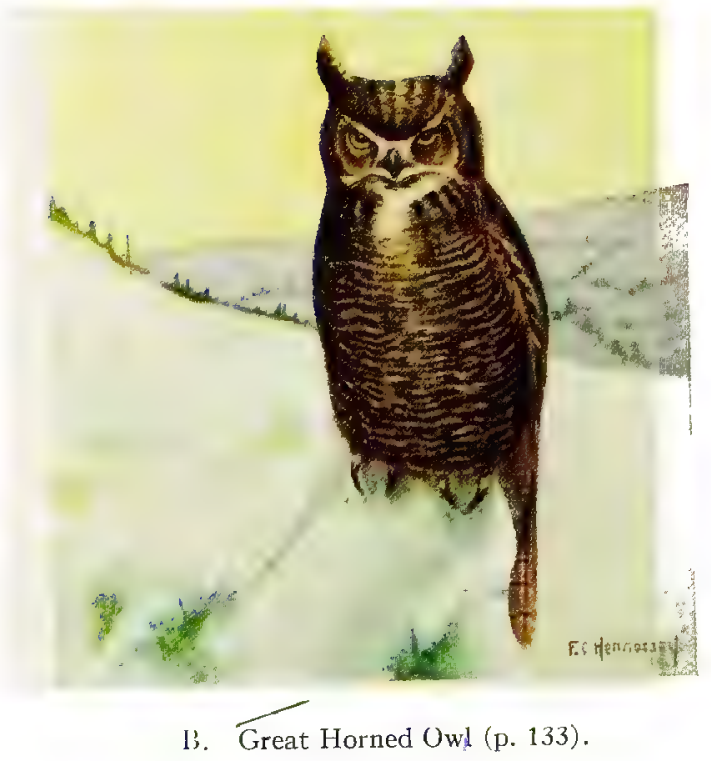




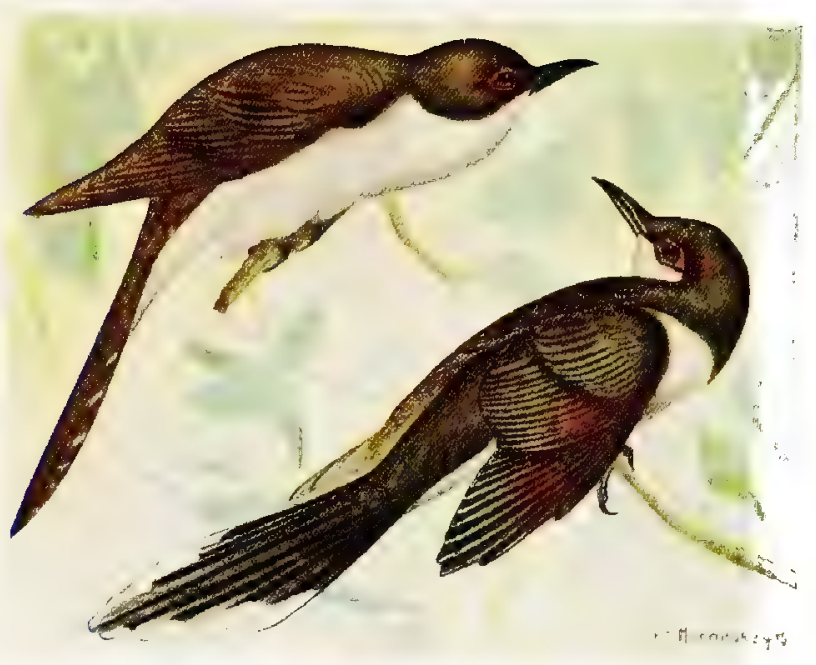

A. Black-billed Cuckoo (p. 136).

Yellow-billed Cuckoo (p. 136).

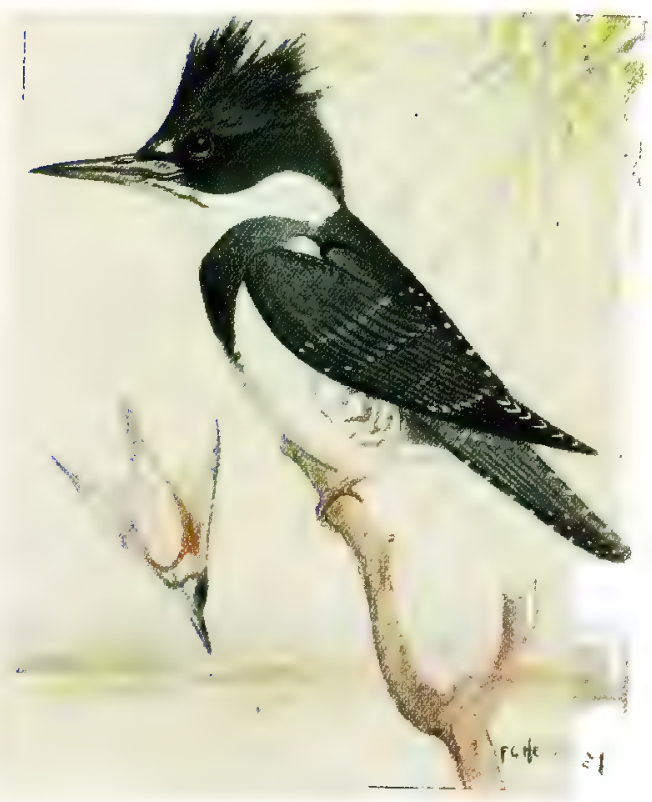

B. Belted Kingfisher (p. 137). 


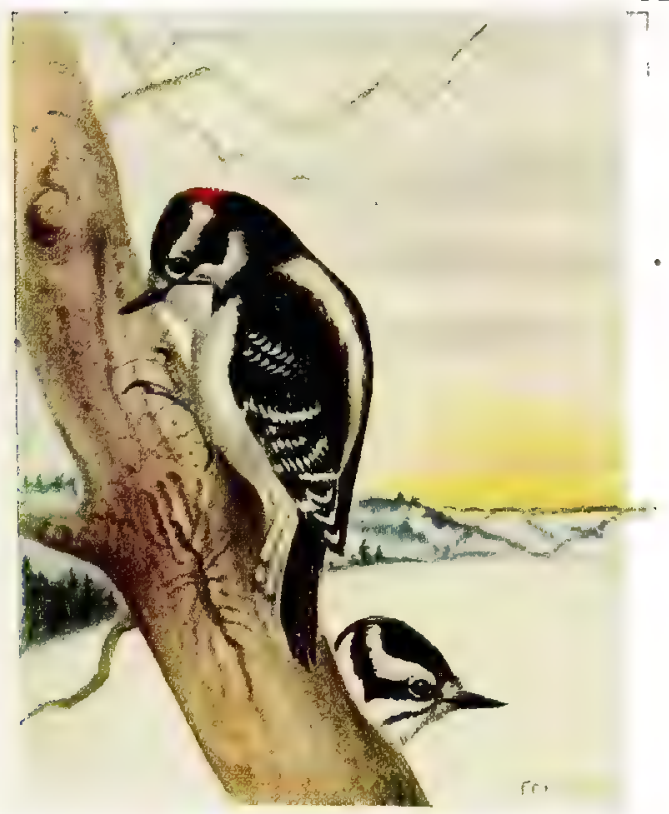

A. Downy Woodpecker (p. 139). Male Female

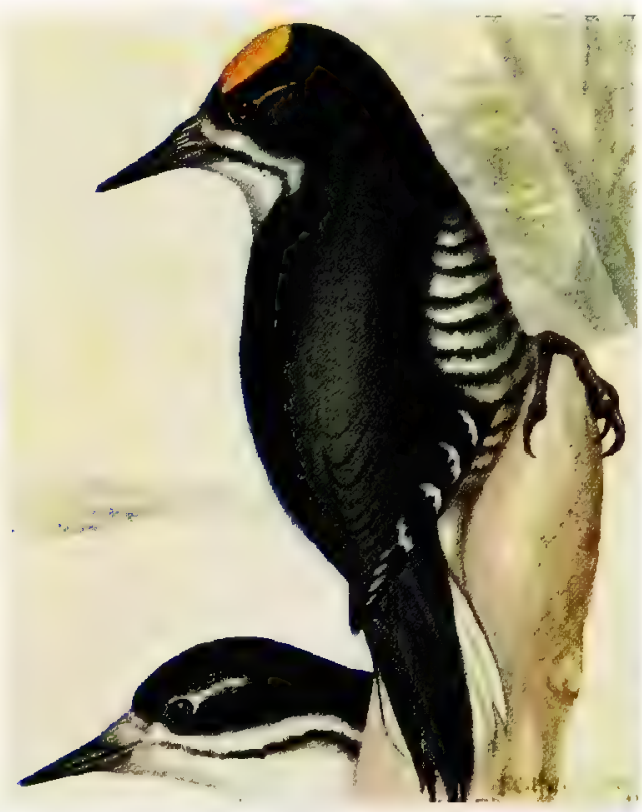

B. Arctic Three-toed Woodpecker (p. 139). 
Plate XIX.

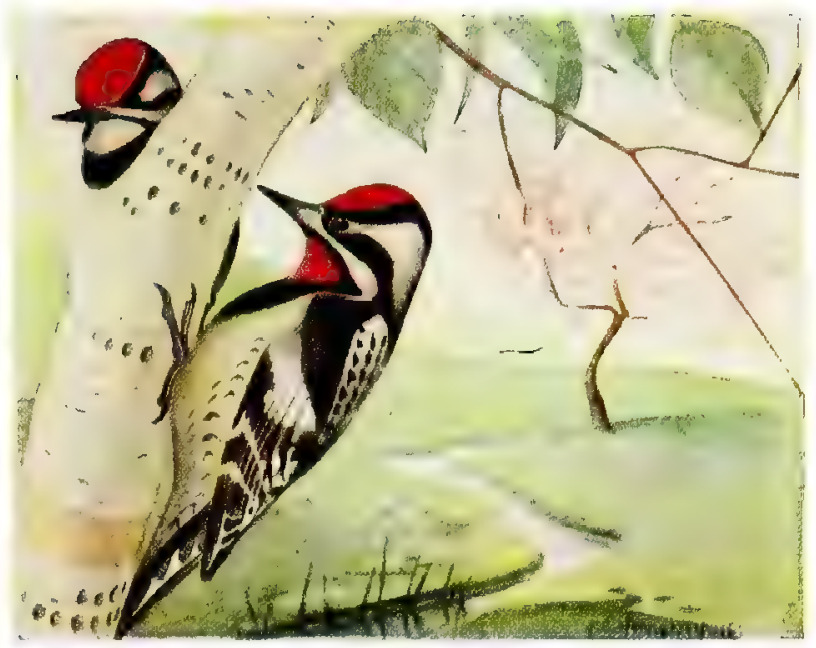

A. Yellow-bellied Sapsucker (p. 140). Female Male

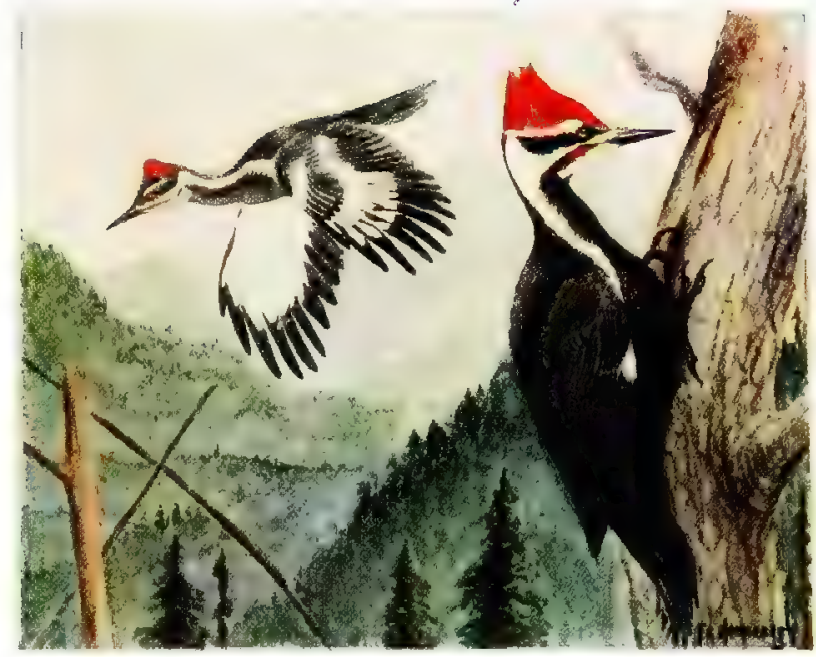

B. Pileated Woodpecker (p. 141). 
Plate XX.

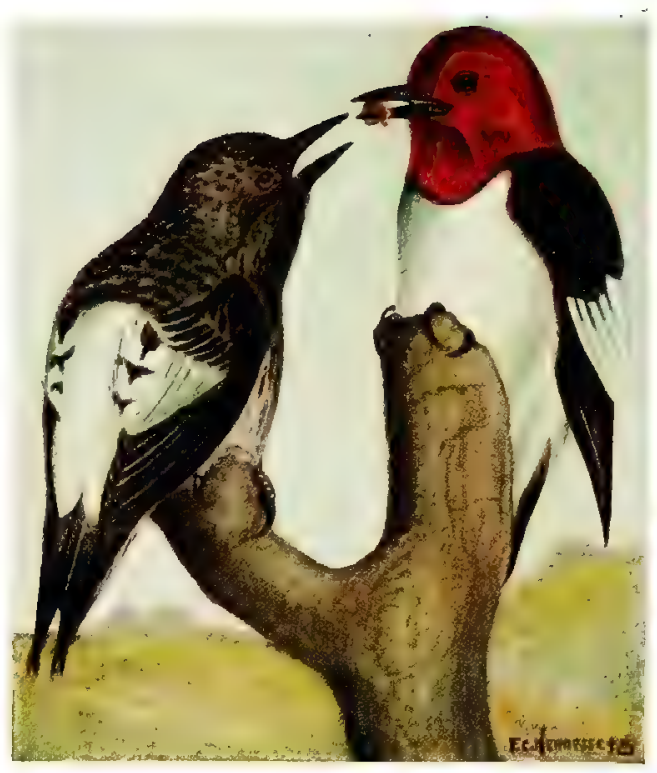

A. Red-headed Woodpecker (p. 141).

Juvenile Adult

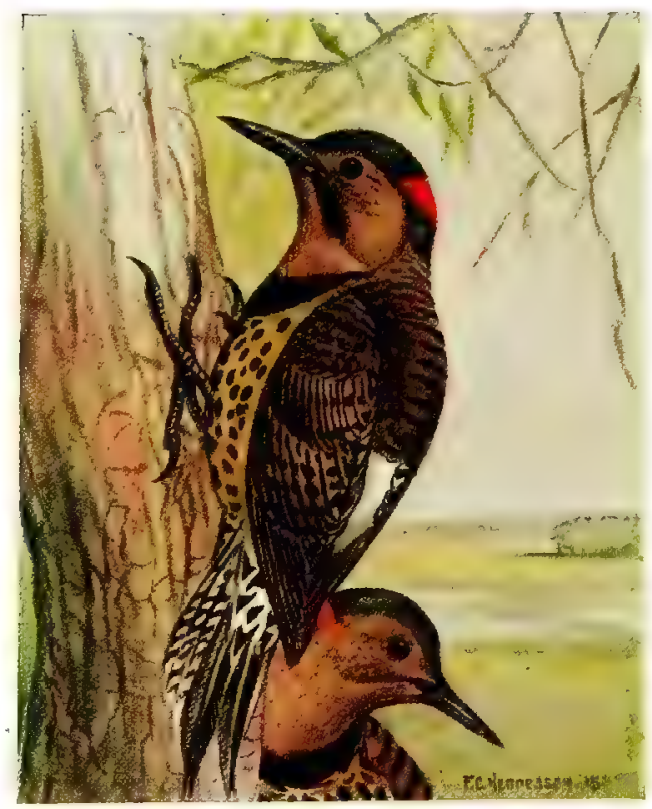

B. Flicker (p, 142). 


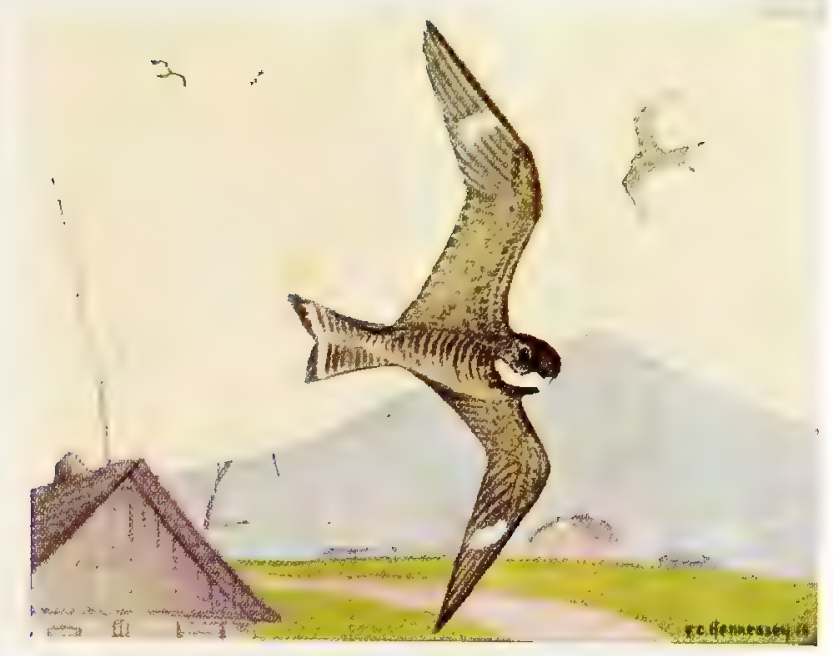

A. Nighthawk (p. 144).

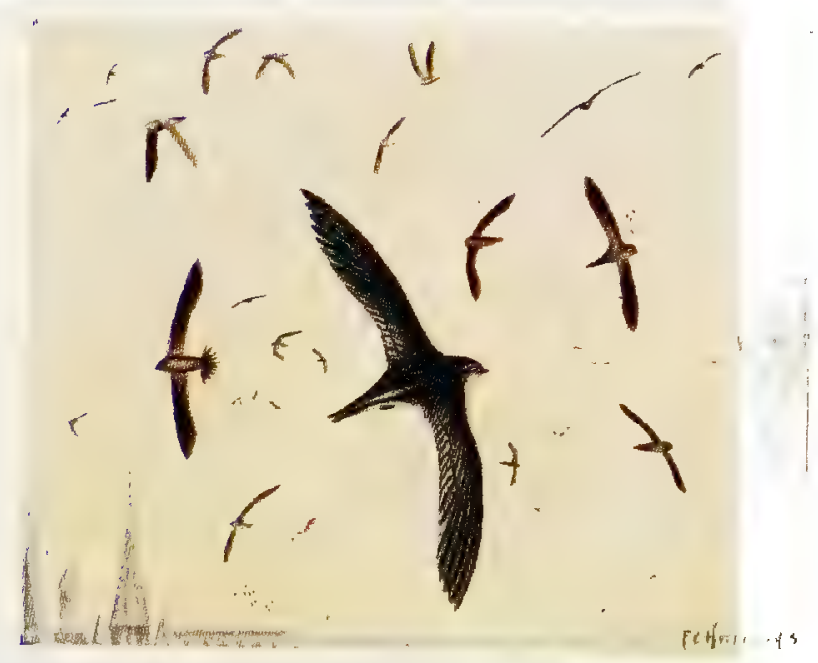

B. Chimney Swift (p. 145). 
Plate Xyil.

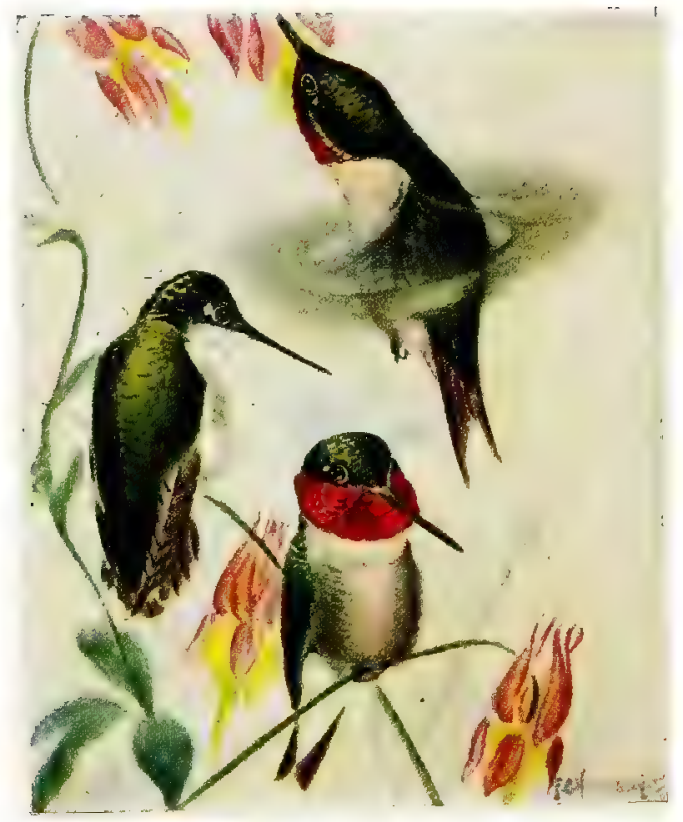

A. Ruby-throated Hummingbird (p. 146).

Female

Males

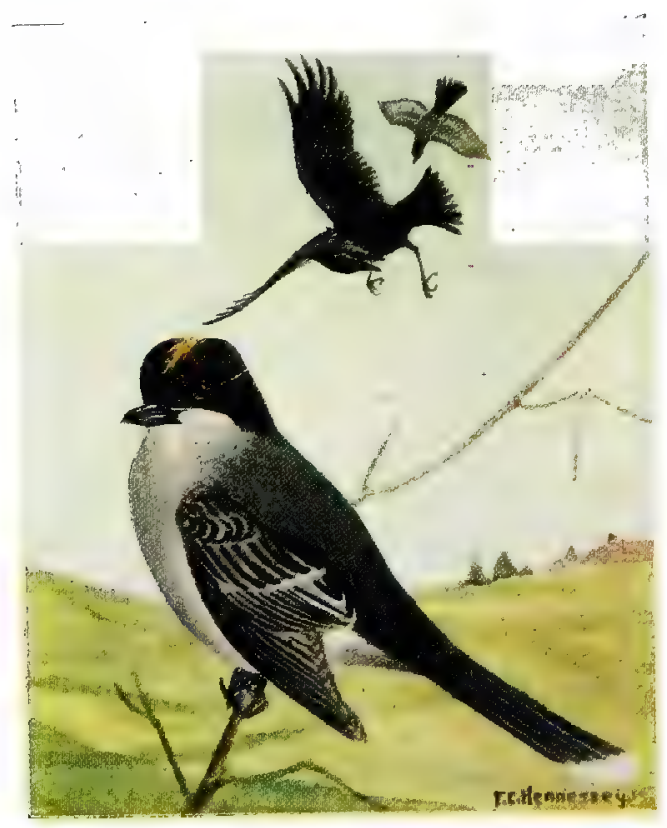

B. Kingbird (p. 148). 
Plate XXIII.

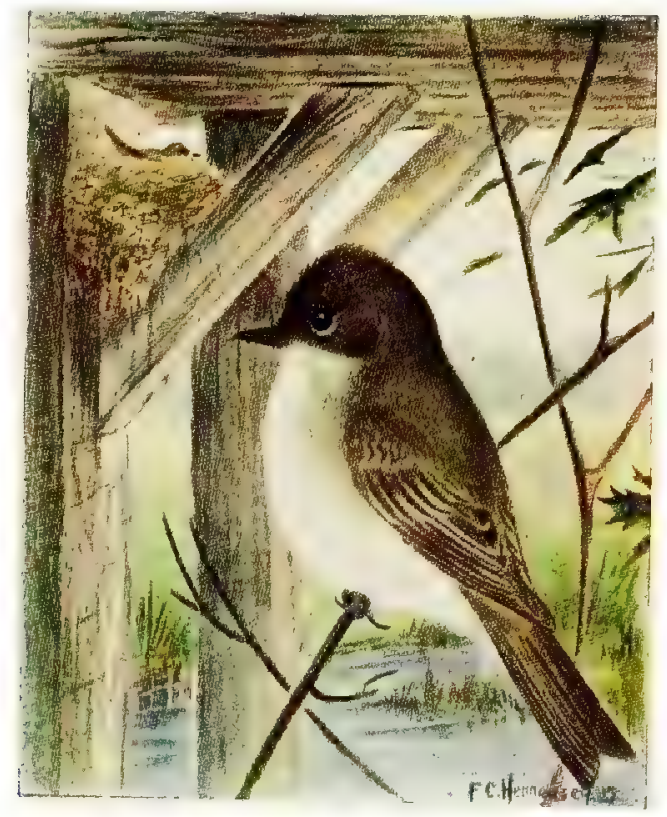

A. Phoebe (p. 149).

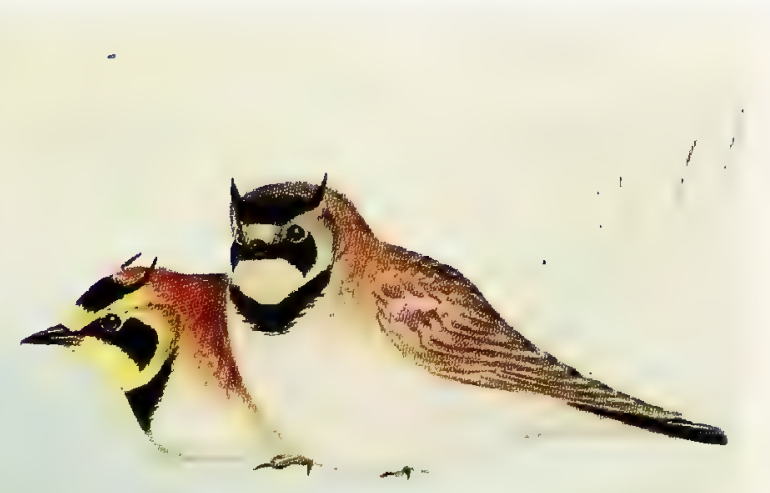

B. Horned Lark (p. 152).

Eastern Horned Lark

Präirie IIorned Lark 
Plate XXIV.

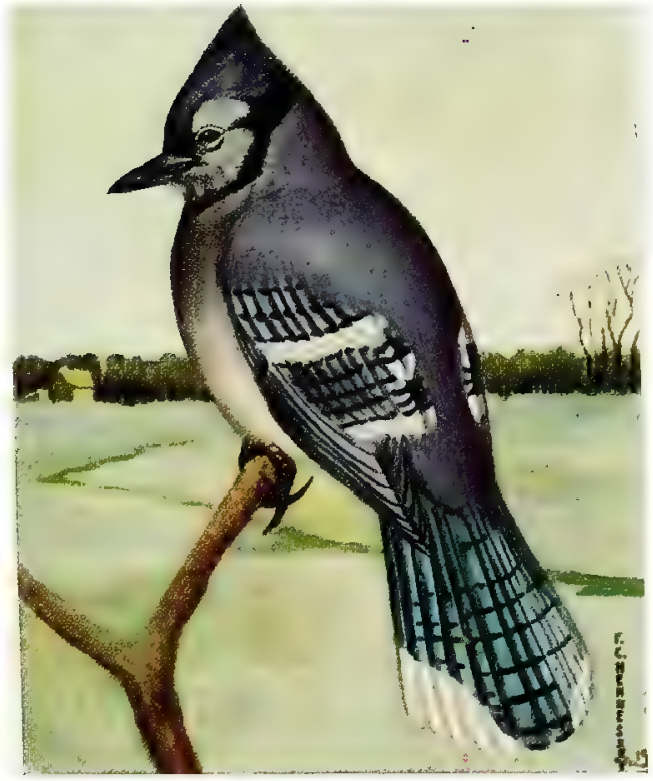

A. Blue Jay (p. 15t).

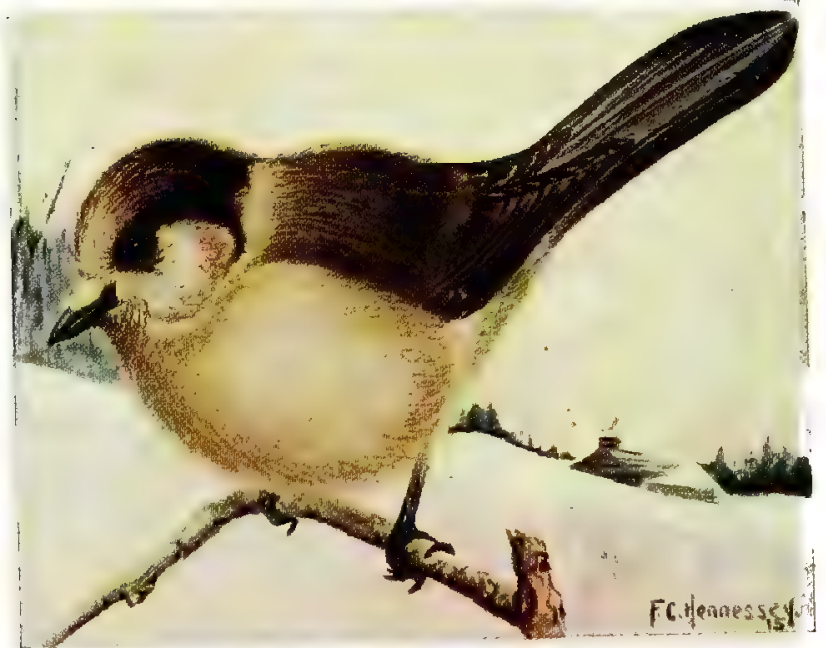

B. Canada Jay (p. 154). 
PLIL XXV.

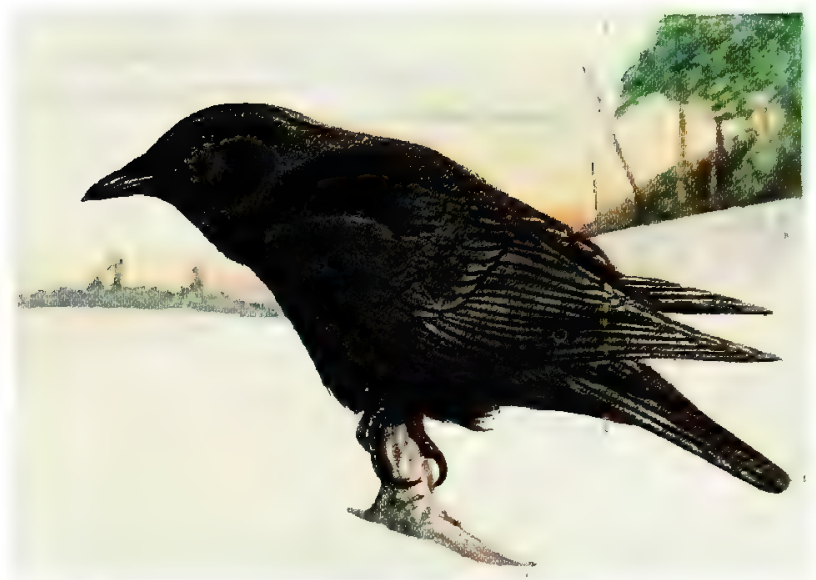

A. American Crow (p. 156).

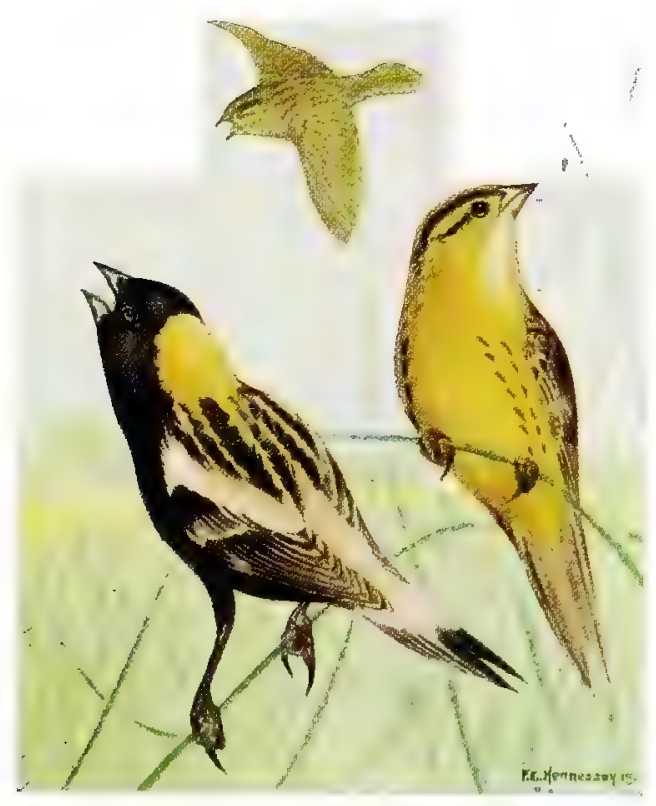

B. Bobolink (p. 157). 


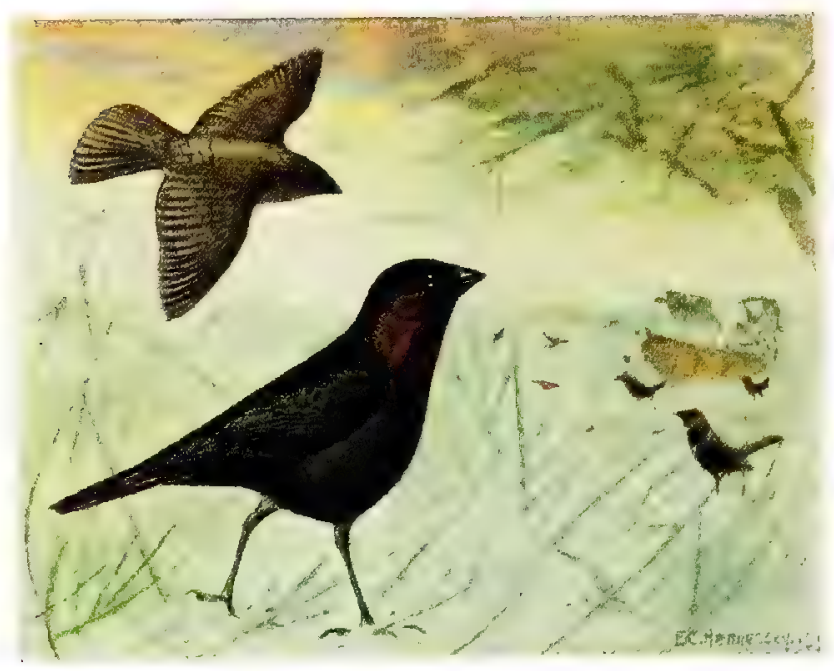

A. Cowbird (p. 157).

Female Male

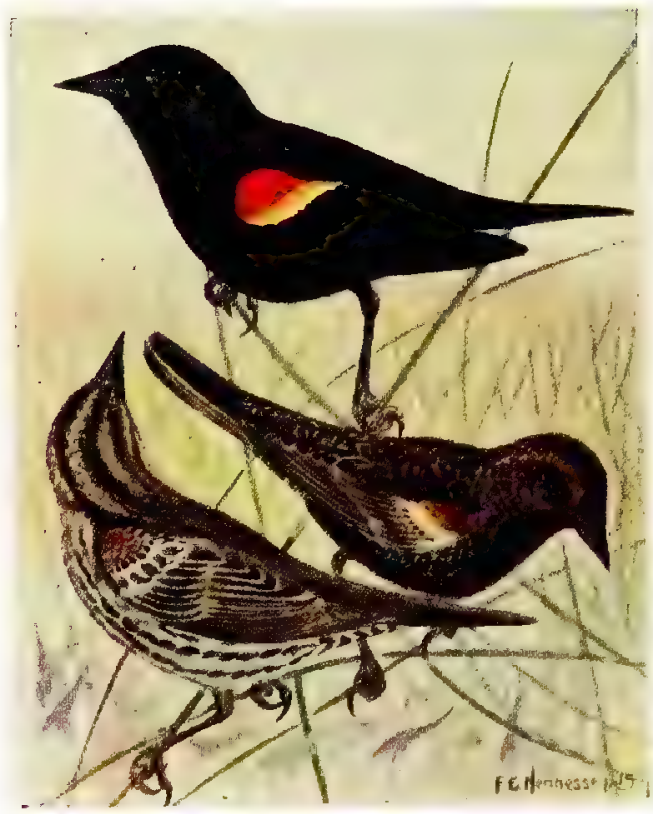

B. Red-winged Blarkbird (p. 158). Juvenile Male Female 


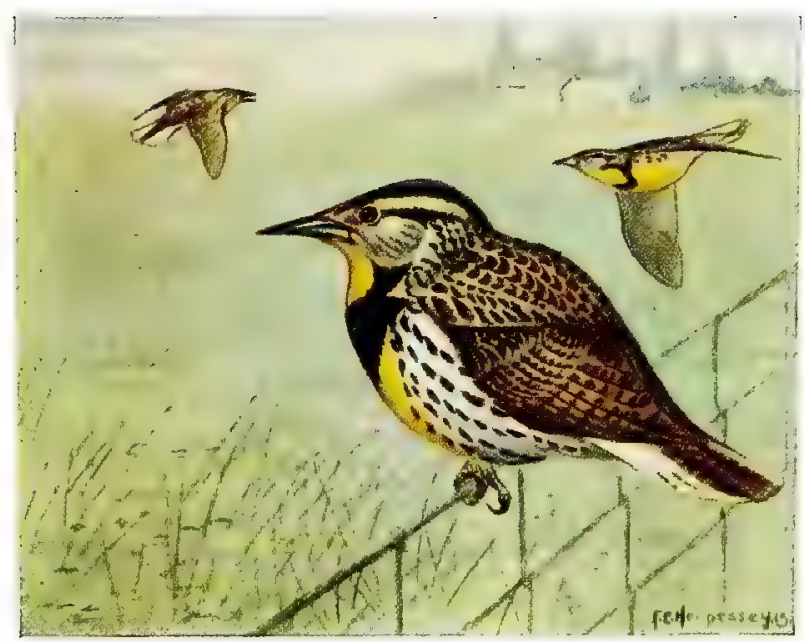

A. Meadowlark (p. 159).

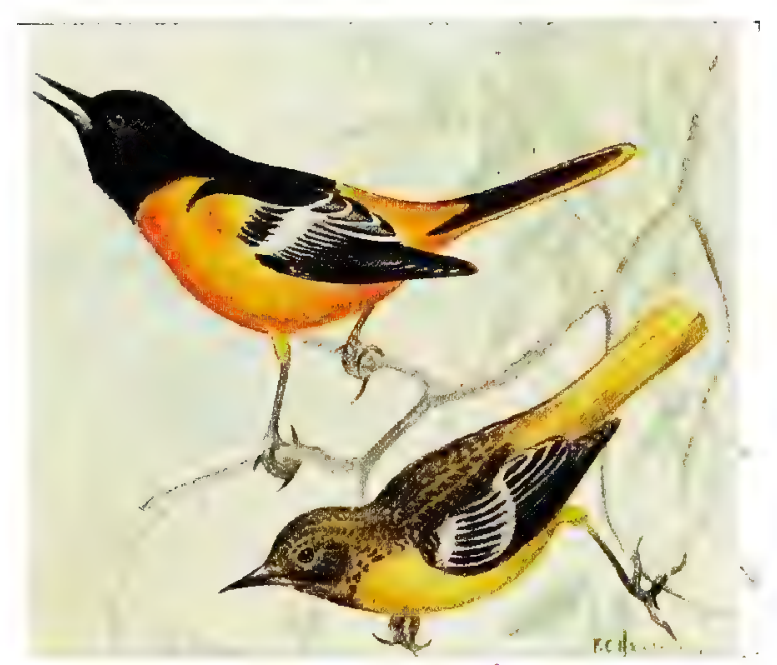

B. Baltimore Oriole (p. 160).

Male Female 


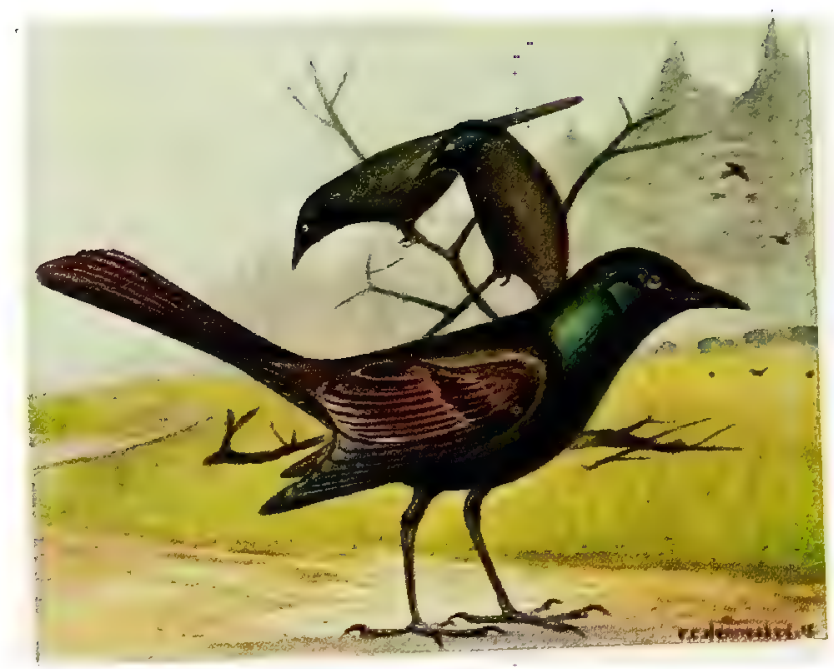

A. Bronzed Grackle (p. 161).

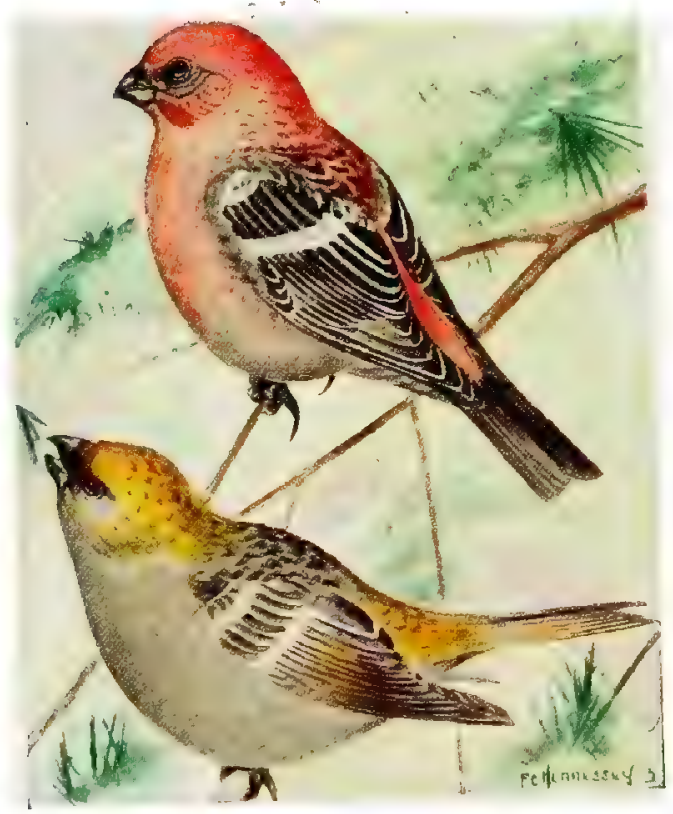

B. Pine Grosbeak (p. 163).

Female 
Plate XXIX.

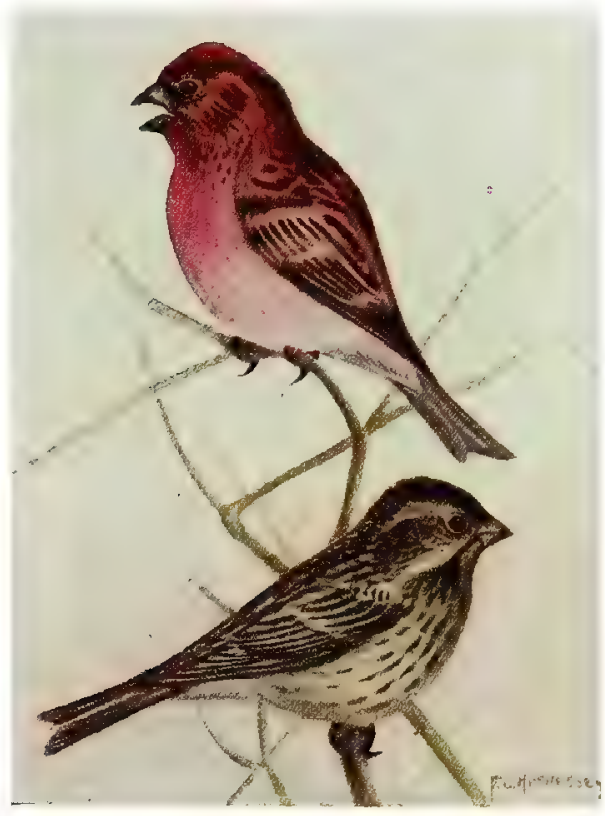

A. Purple Finch (p. 163),

Tale Female

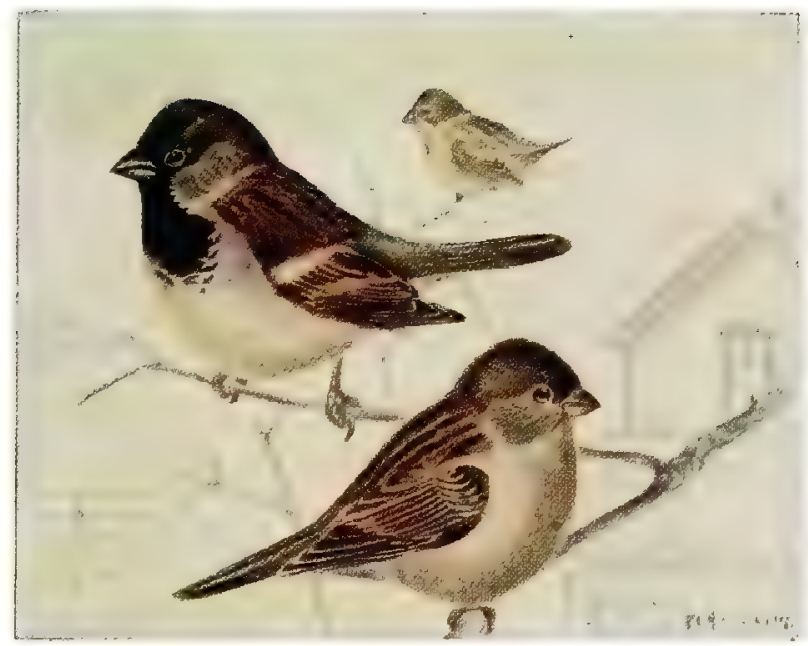

B. House Sparrow (p. 164).

Male Female 
Plate XXX.

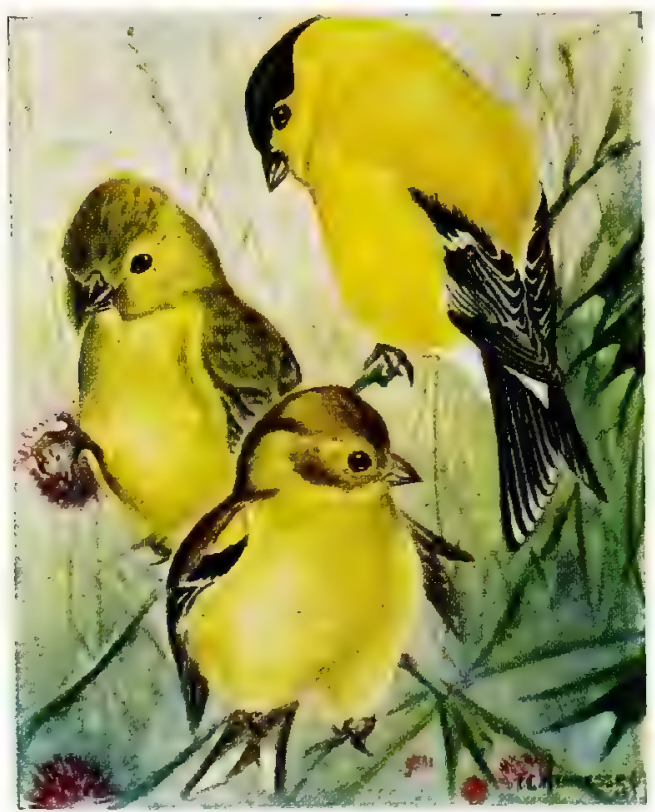

A. American Goldfinch (p. 168).

Juvenile Female Male

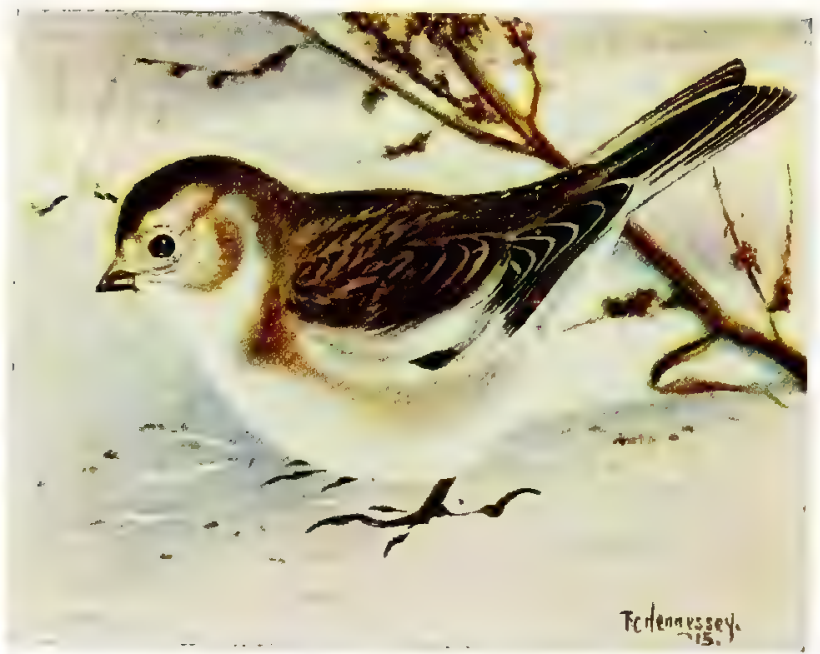

B. Snow Bunting (winter plumage) (p. 169). 
Plate XXXi.

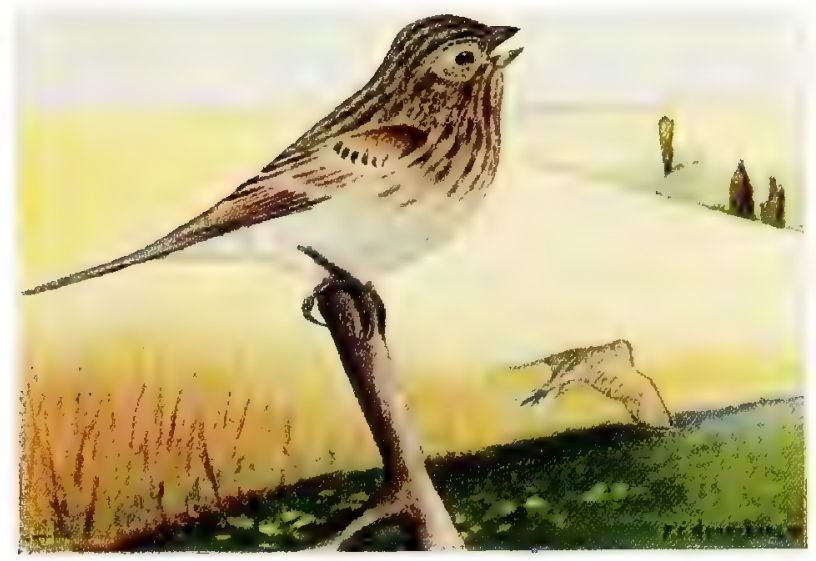

A. Vesper Sparrow (p. 169).

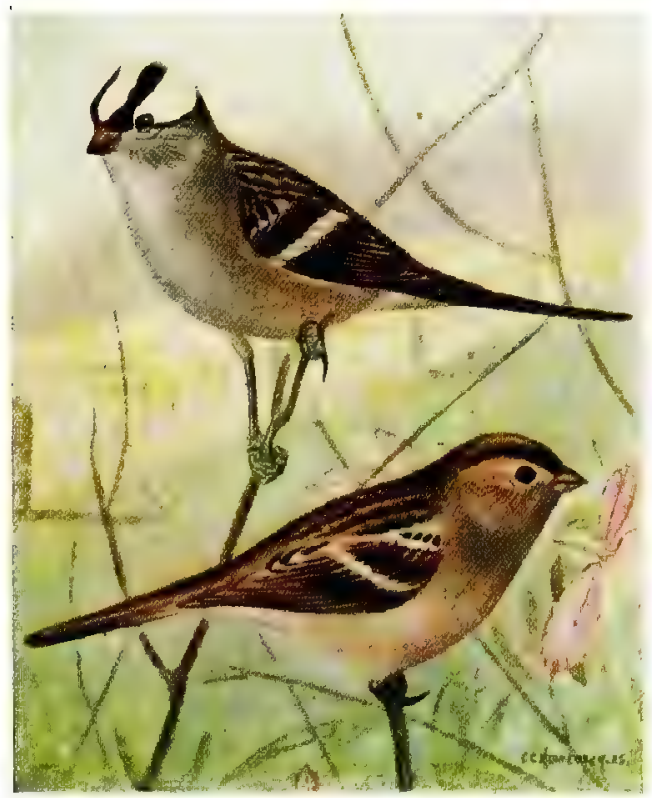

B. White crowned Sparrow (p. 173). 
I'LATE XXXII.

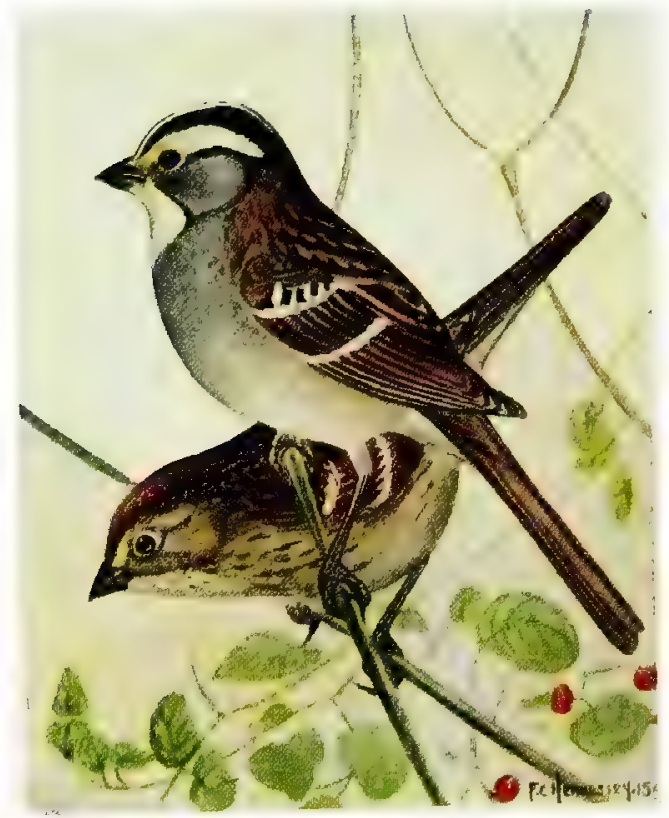

A. White-throated Sparrow (p. 173).

Adult Juvenile

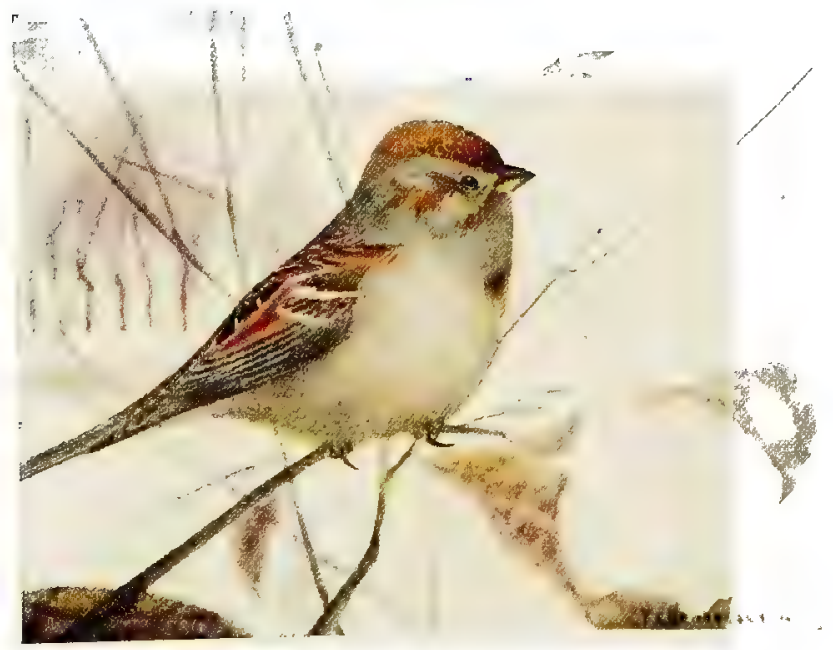

B. Tree Sparrow (p. 174). 
PLate xyxil.

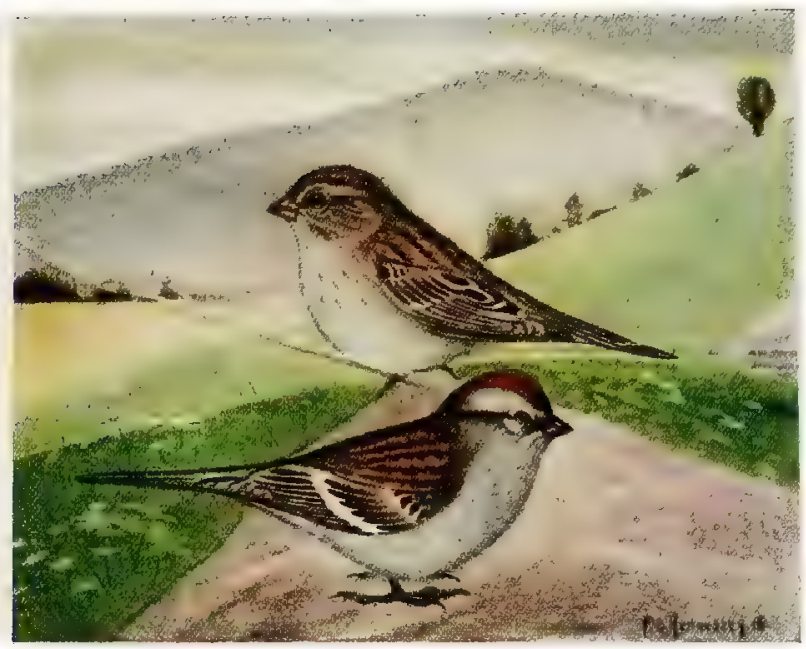

1. Chipping Sparrow $\left(\mathrm{p}_{*}=17+1\right.$

Juvenile

Adult

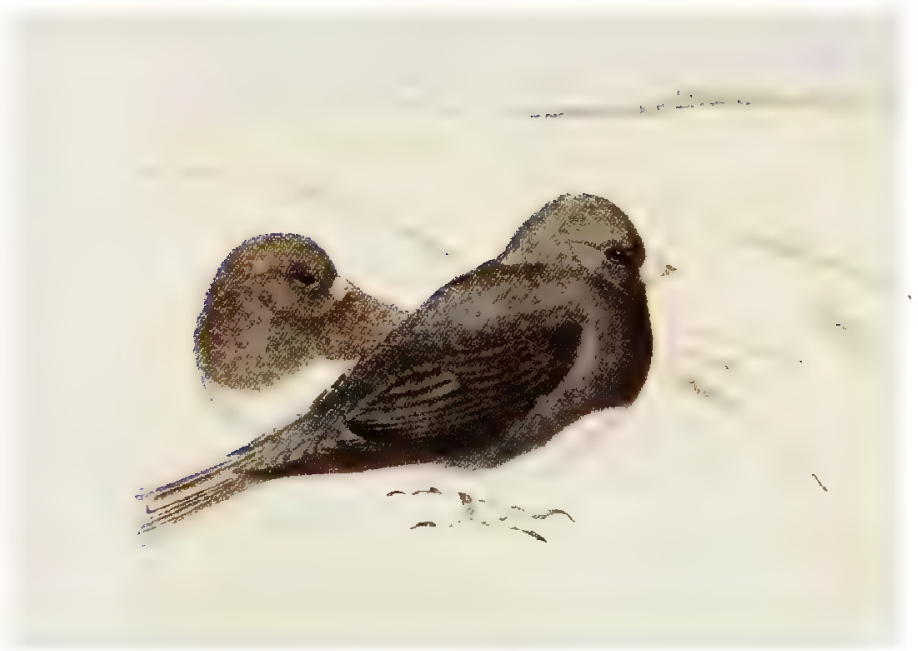

B. Junco (p. 17.5).

Female Male 
Plate NXXil.

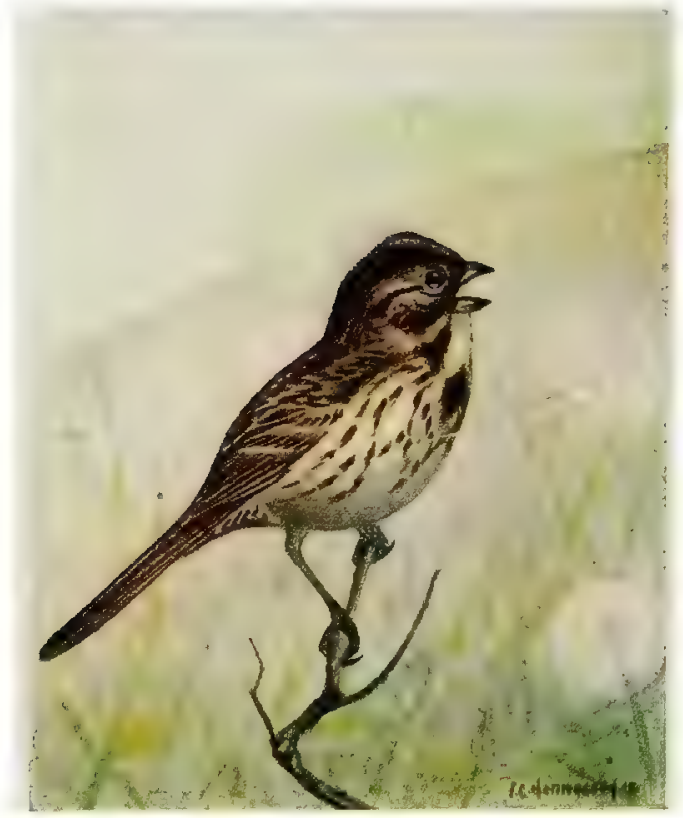

A. Song Sparrow (p. 176).

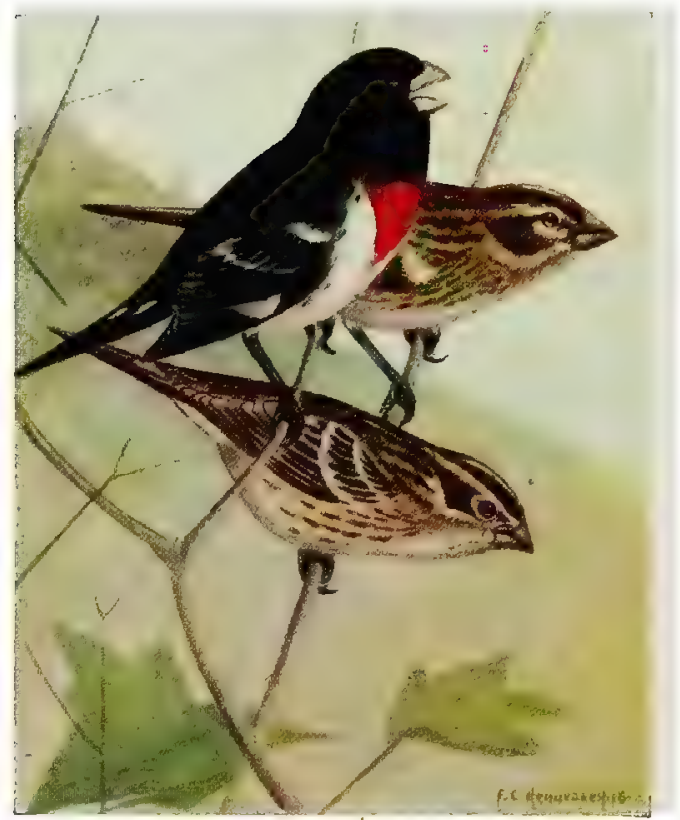

I3. Rose-lreasted Crosbeak (p. 179). 
PLATE XXXV'.

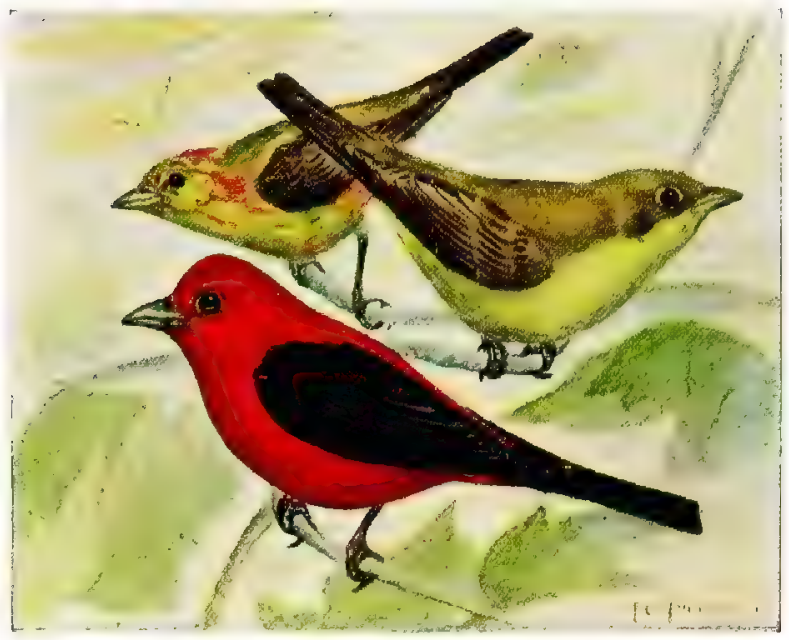

A. Scarlet Tanager (p. 181).

Male clranging to autumn plumage

Male Female

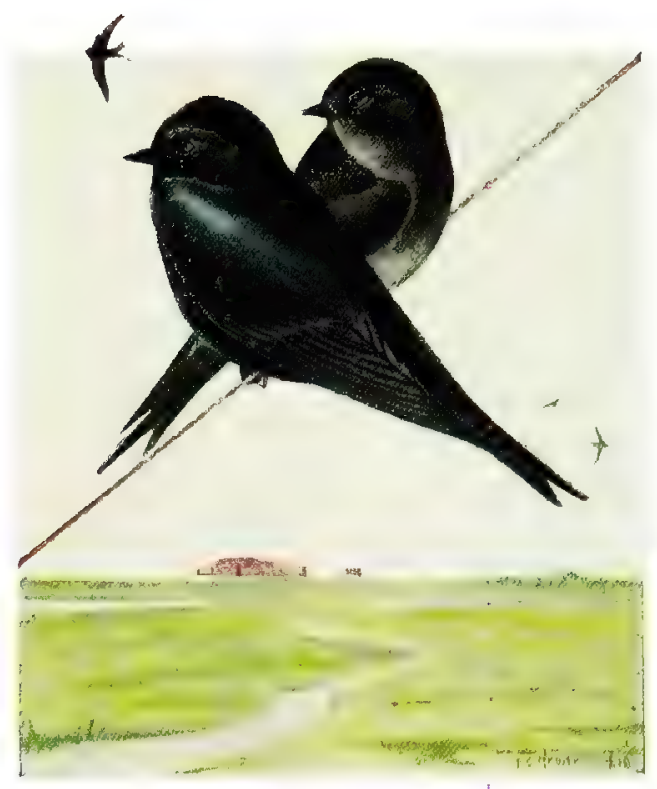

B. Purple Martin (p. 182).

Male Juvenile 
Tlate XXXVI.

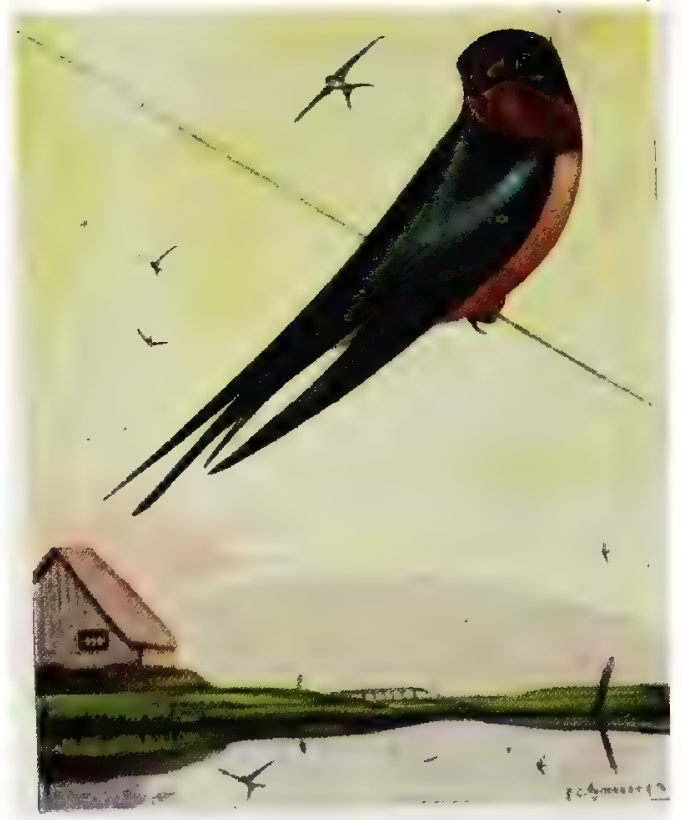

A. Barn Swallow (p. 183).

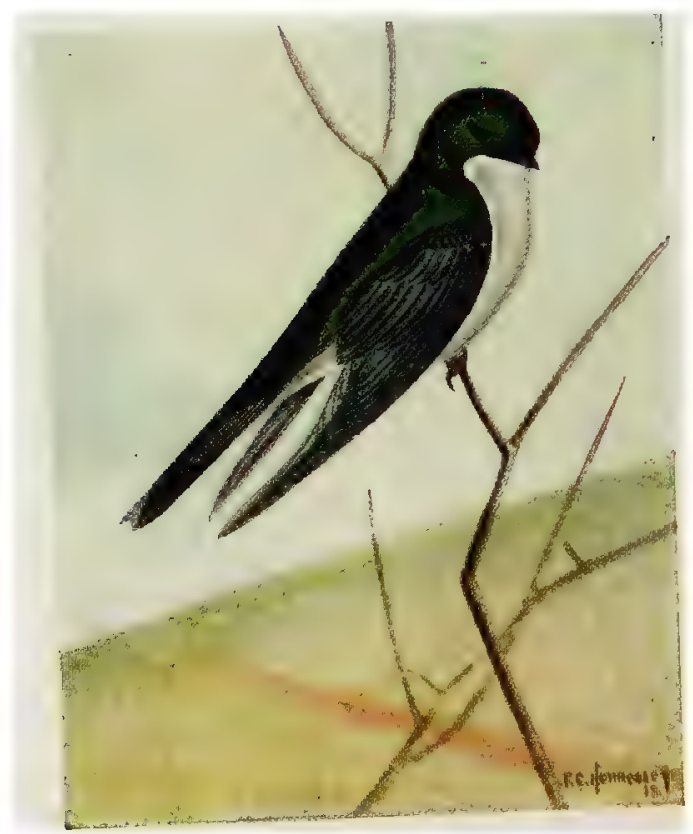

B. Tree Swallow (p. 183). 


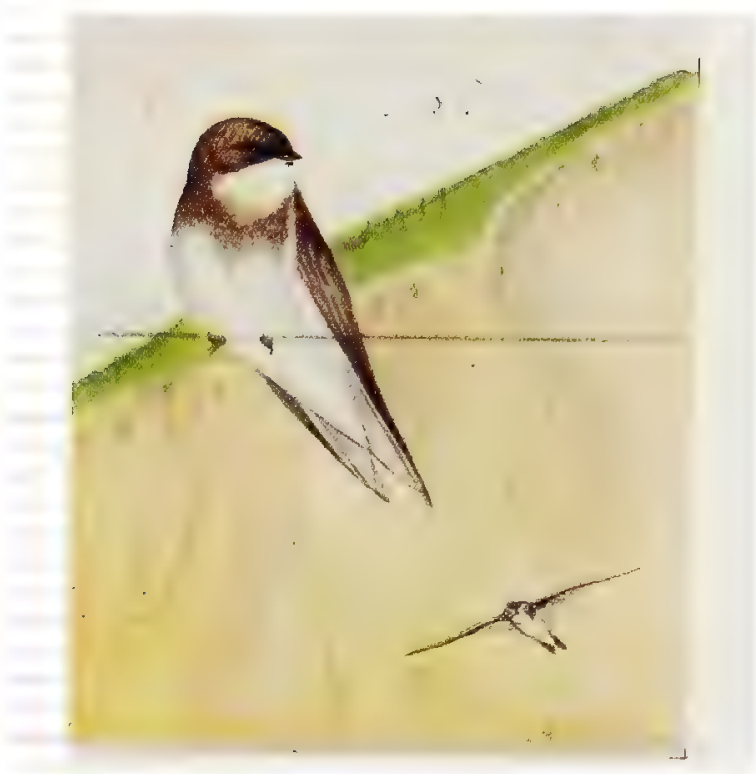

A. Bank Swallow (p. 184).

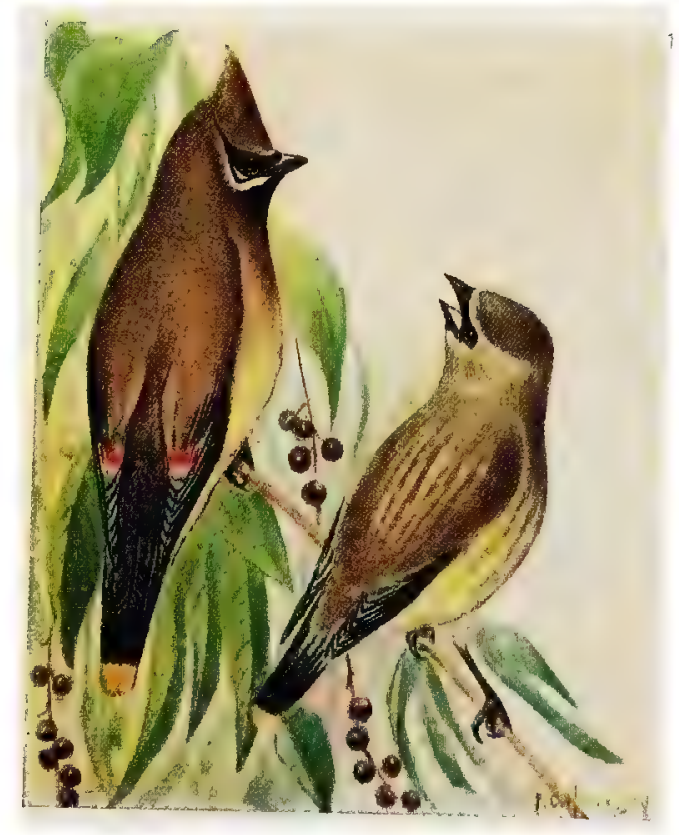

B. Cedar Waxwing (p. 185).

Adult

Juvenile 


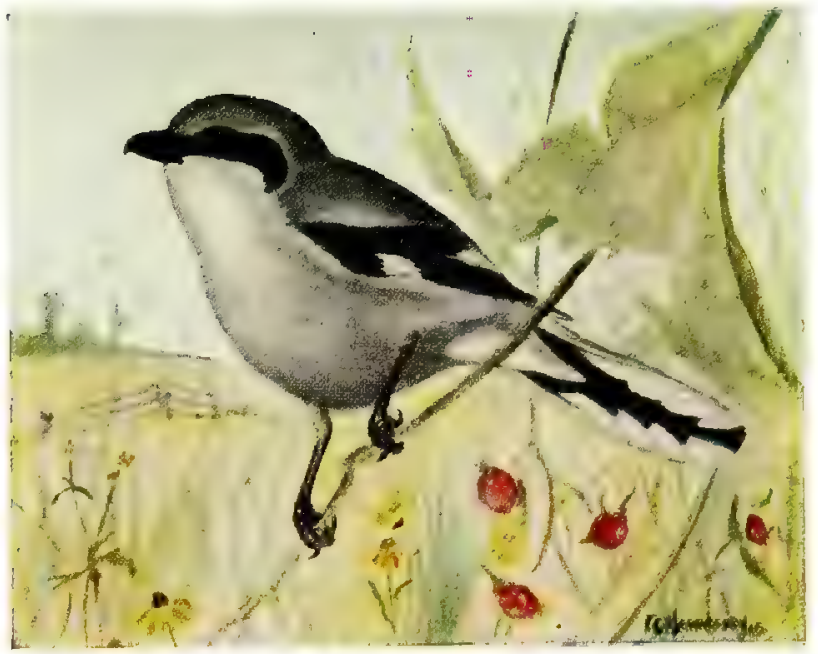

A. Migrant Loggerhead Shrike (p. 187).

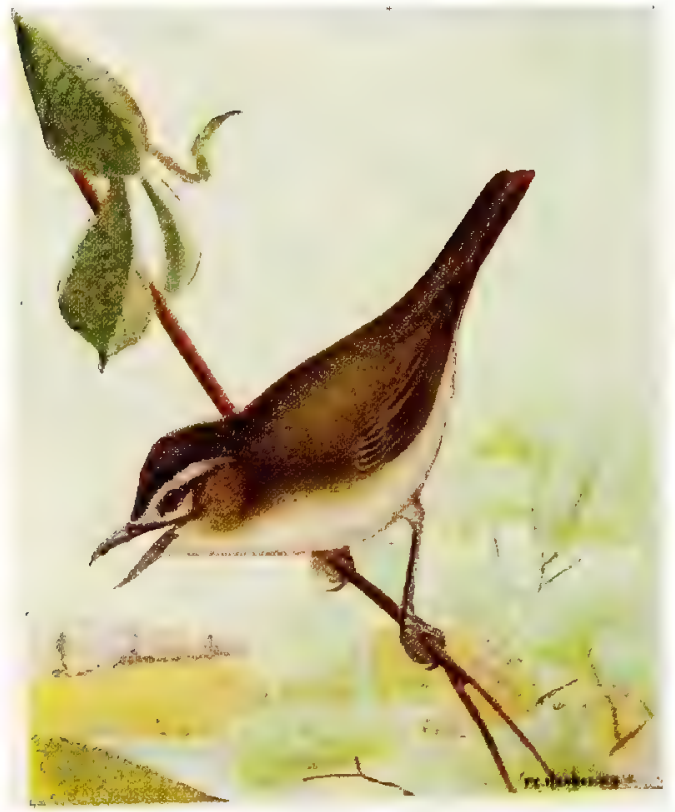

B. Red-eyed T'ireo (p. 188). 


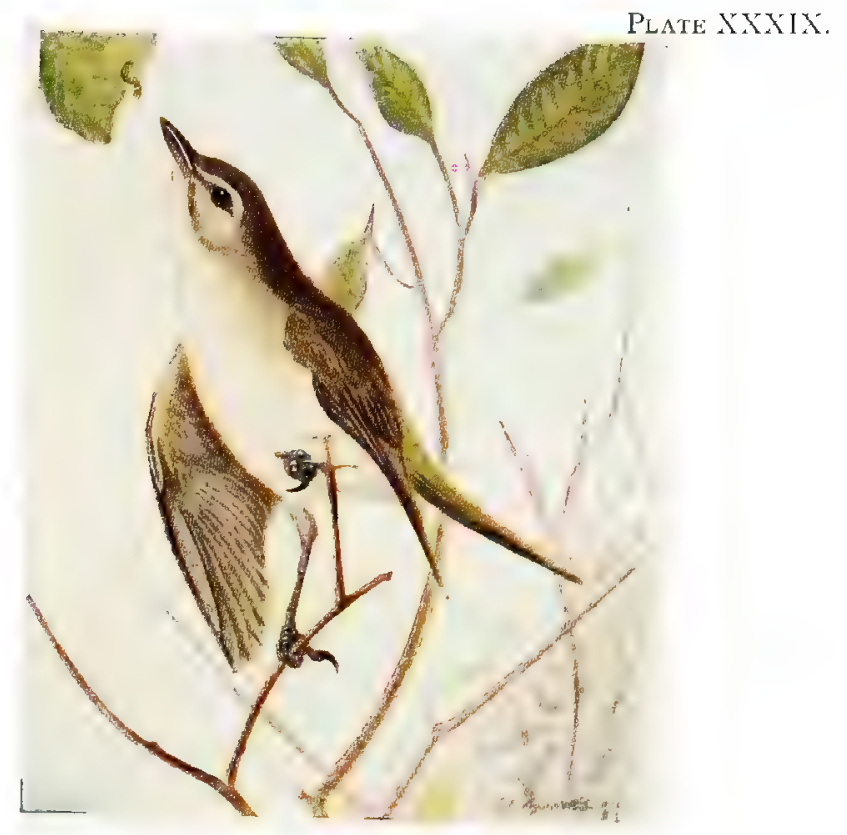

A. Warbling Vireo (p. 189).

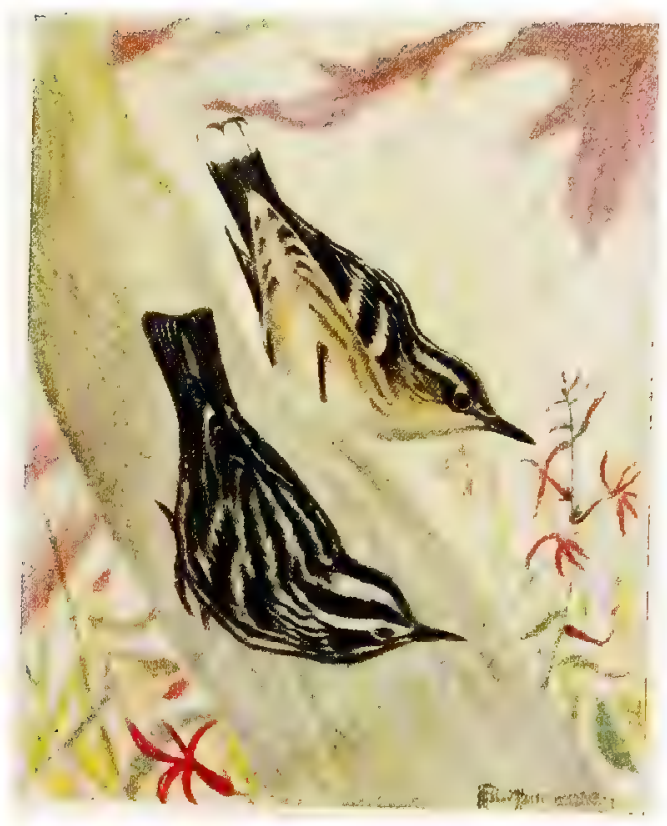

B. Black and White Warbler (p. 191). 
Plate XL.

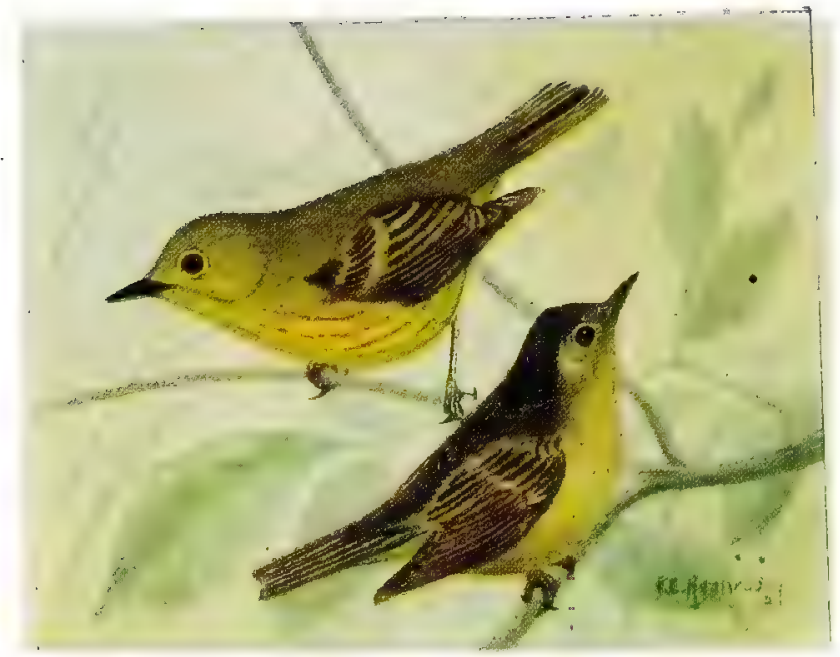

A. Yellow Warbler (p. 194).

Male.

Female

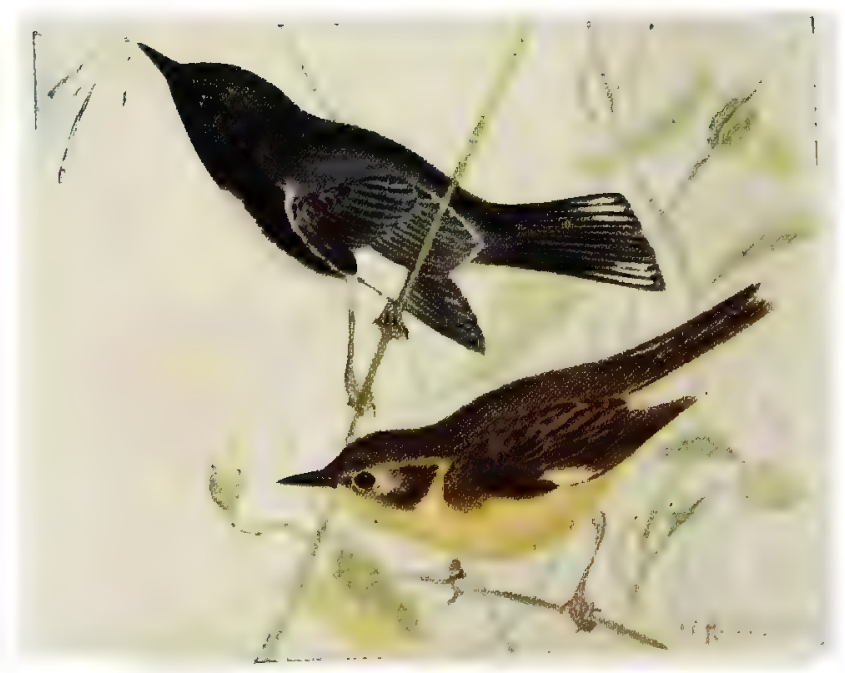

B. Black-throated Blue Warbter (p. 195).

Male

Female 
Plate Xli.

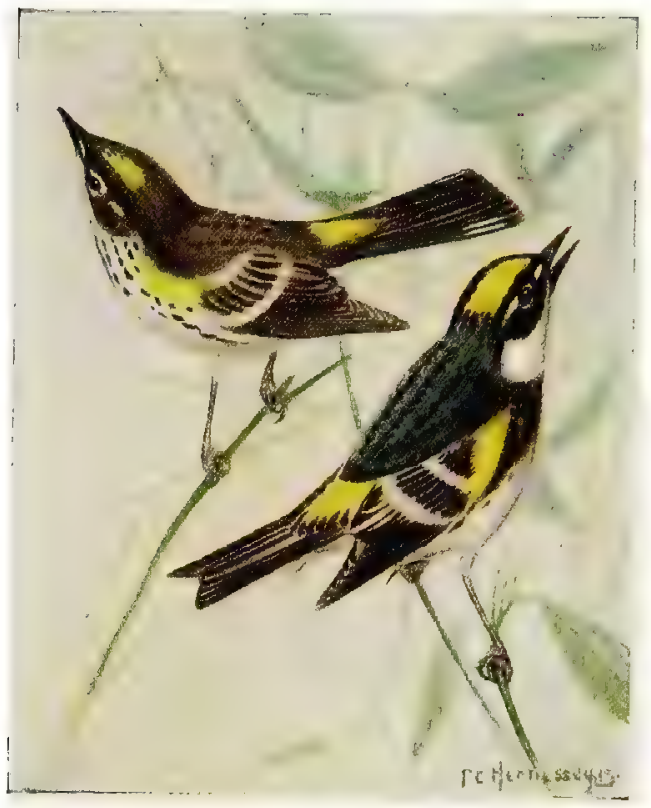

A. Myrtle Warbler (p. 195).

Female Male

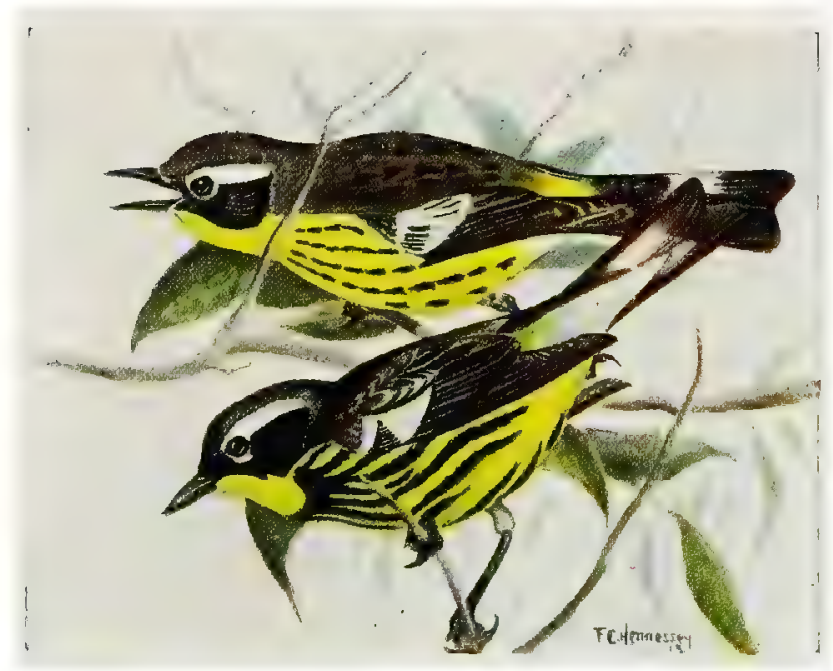

B. Magnolia Warbler (p. 196).

Female

Male 


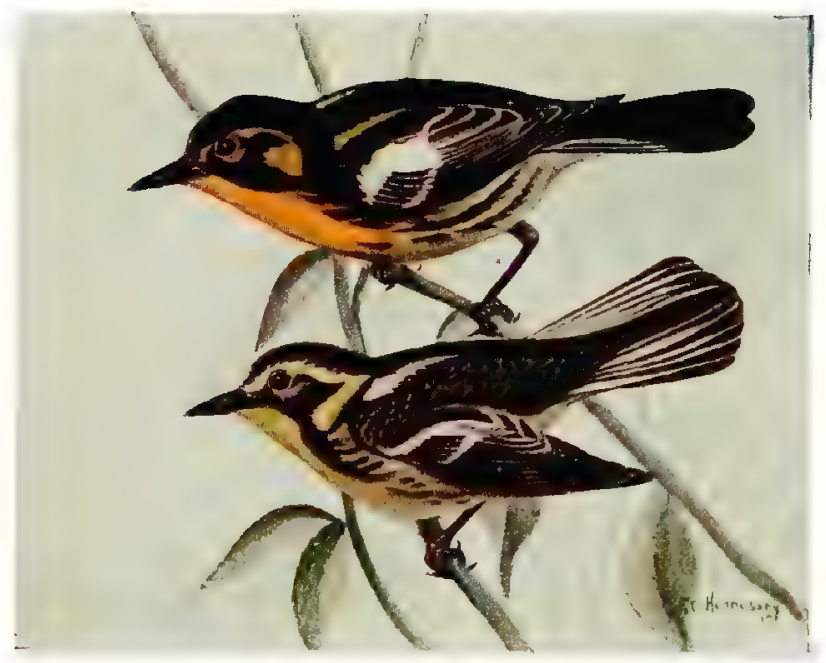

A. Blackburnian Warbler (p. 198).

IIale Female

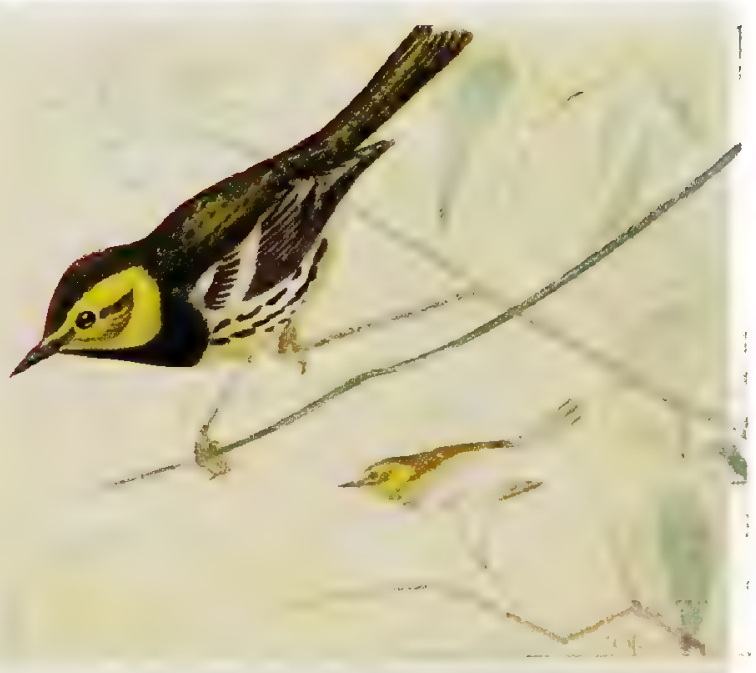

B. Black-throated Green Warbler (p. 198). 
Plate XlliI.

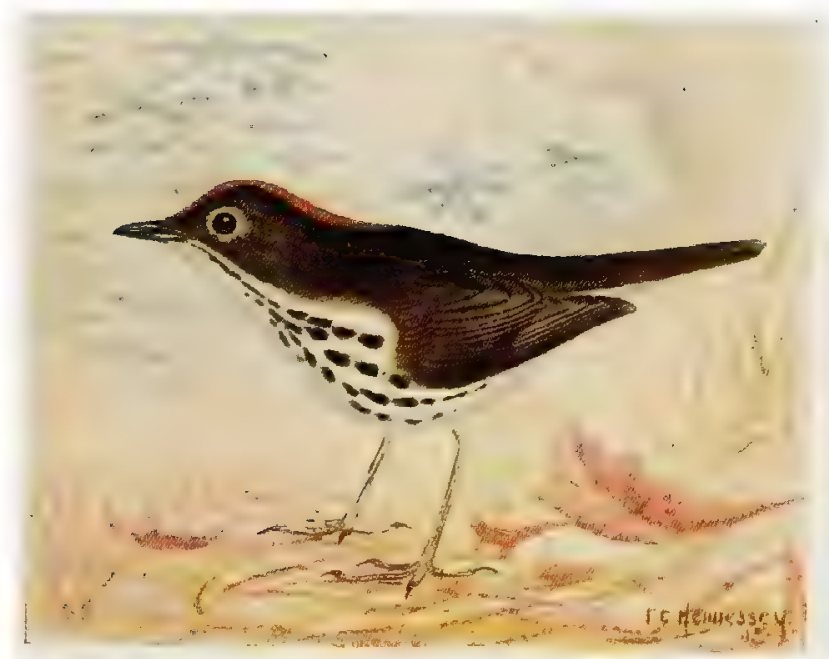

A. Ovenbird (p. 200).

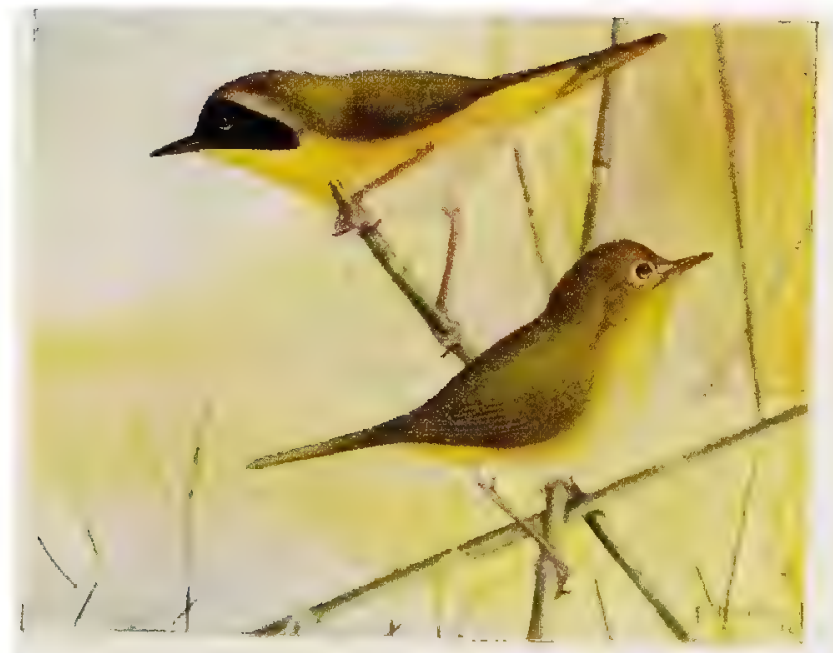

B. Lorthern Yellow-throat (p. 202).

Male Female 
Plate XliV.

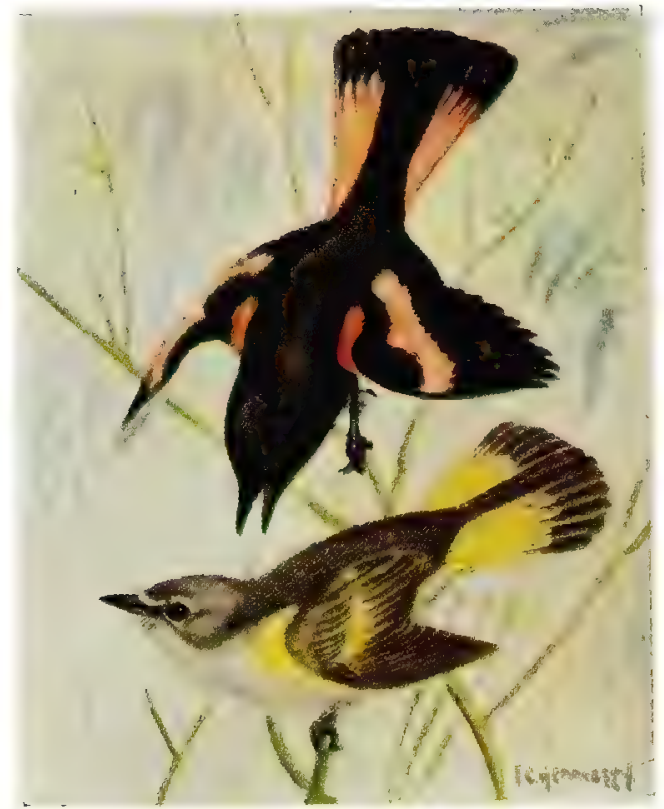

A. Redstart (p. 204).

Male Female

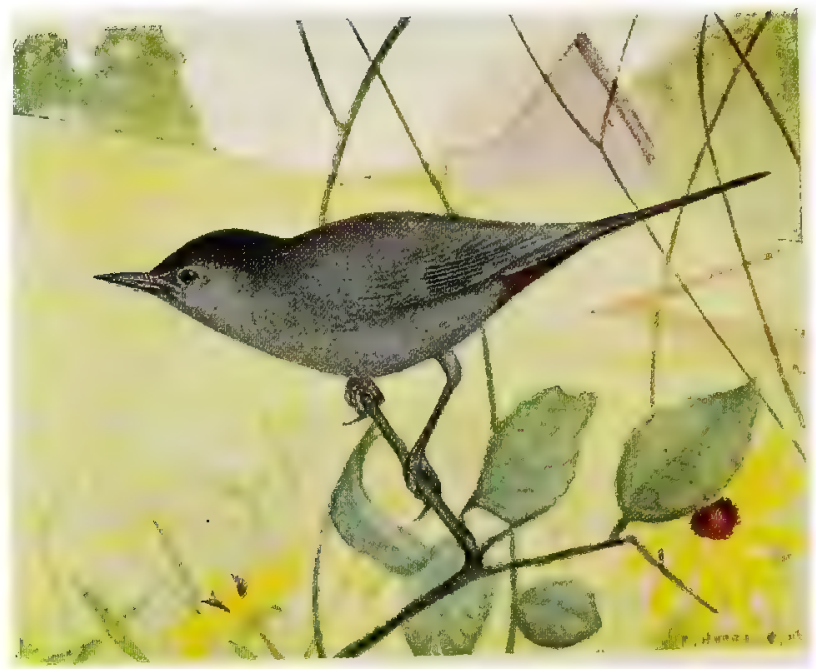

B. Catbird (p. 206). 
Plate XlV.

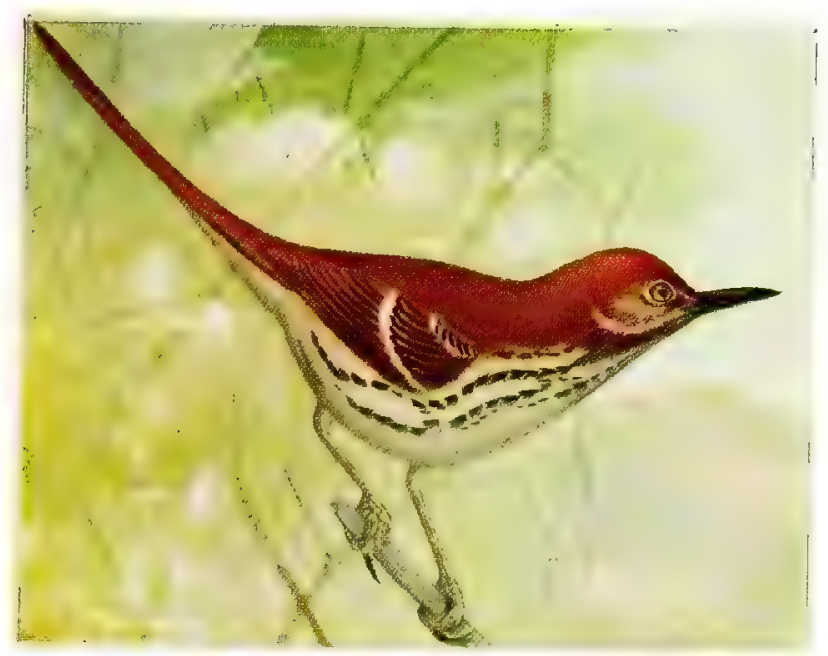

A. Brown Thrasher (p. 207).

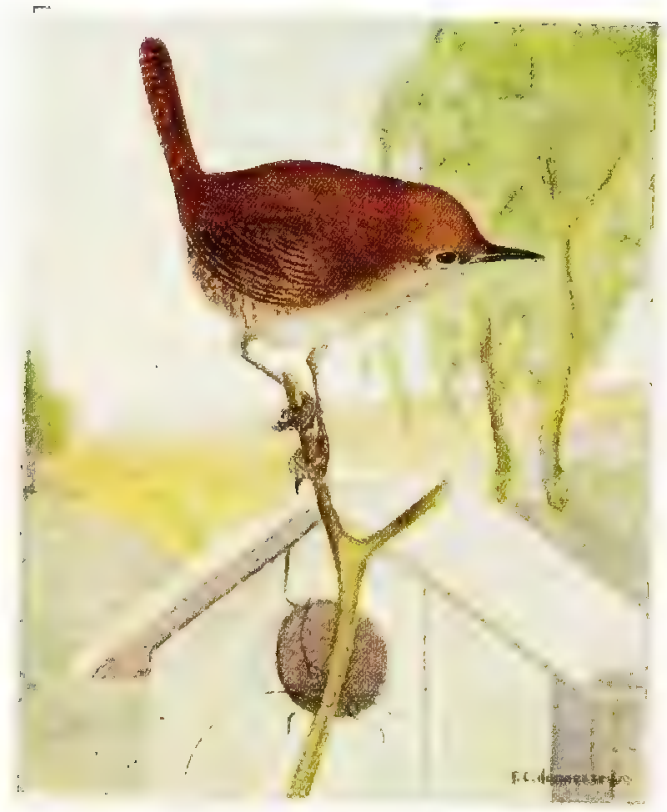

T3. Housc Wren (p. 208). 


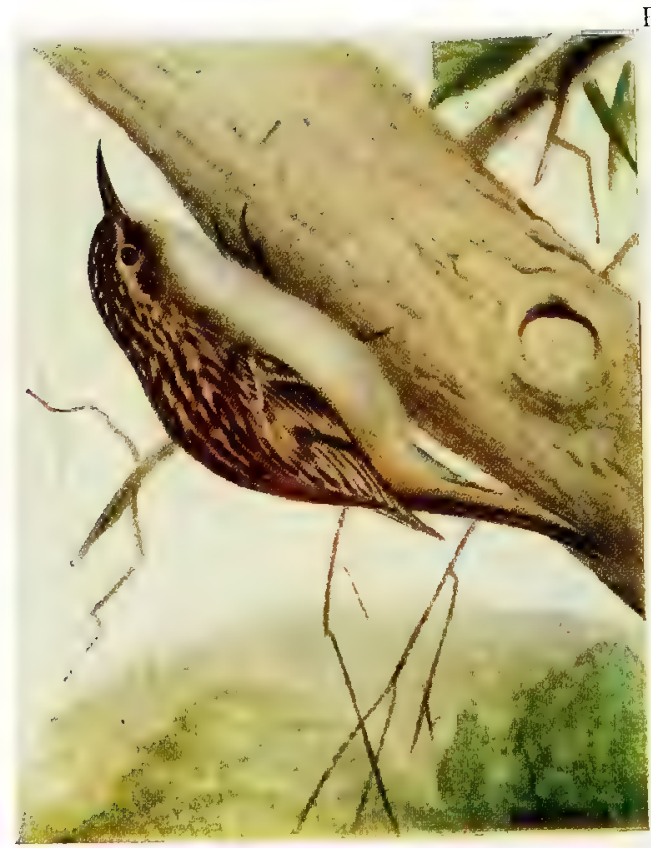

Plate NLTi.

A. Brown Creeper (p, 210).

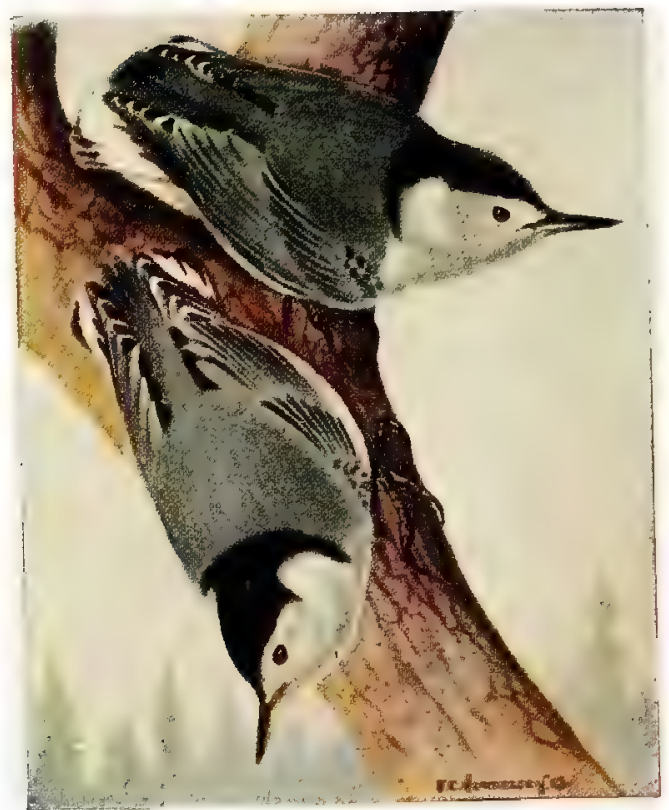

B. White-breasted Tuthatch (p. 211). 


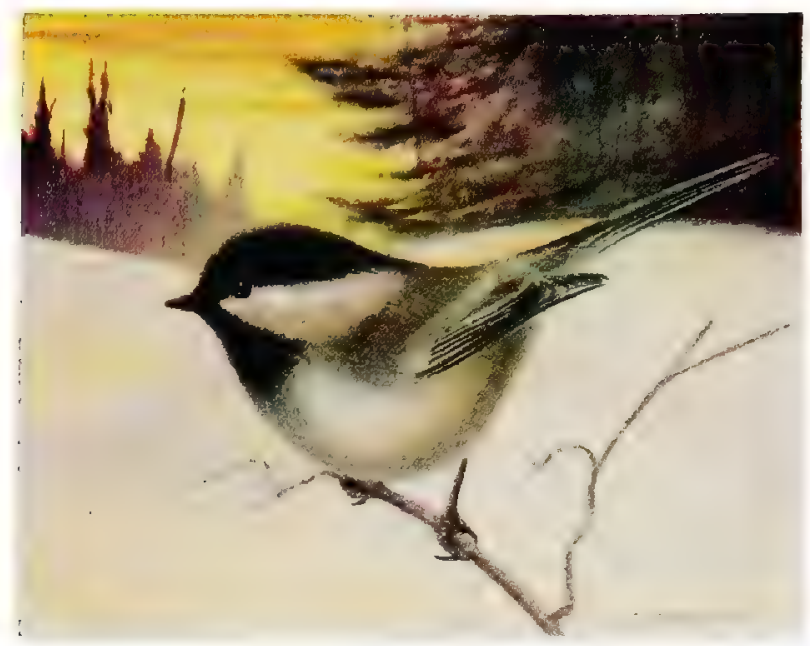

A. Chickadee (p. 212).

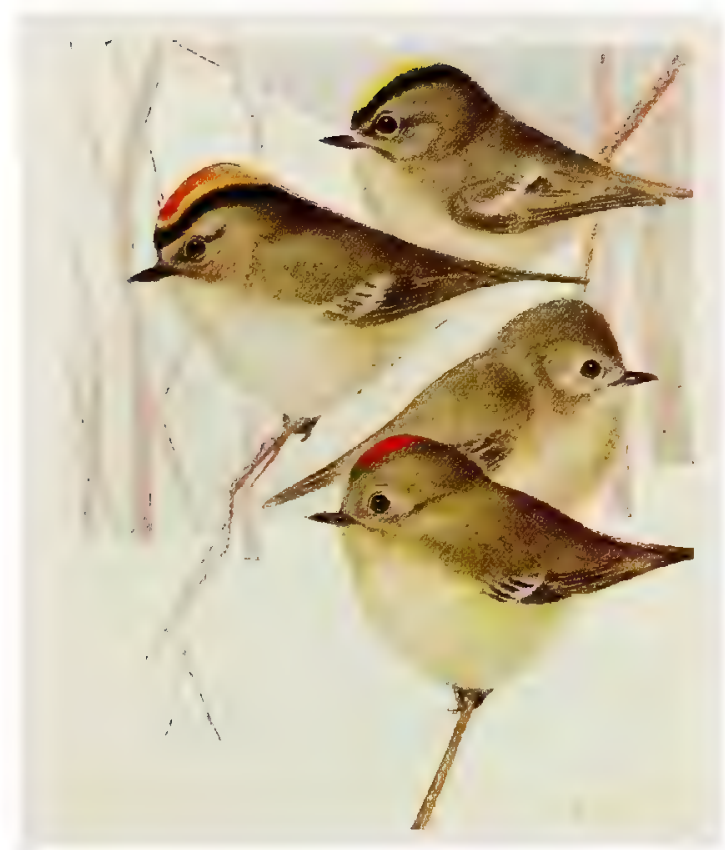

B. Golden-crowned Kinglets. Ruby-crowned Kinglets (p.214).
Male
Female 


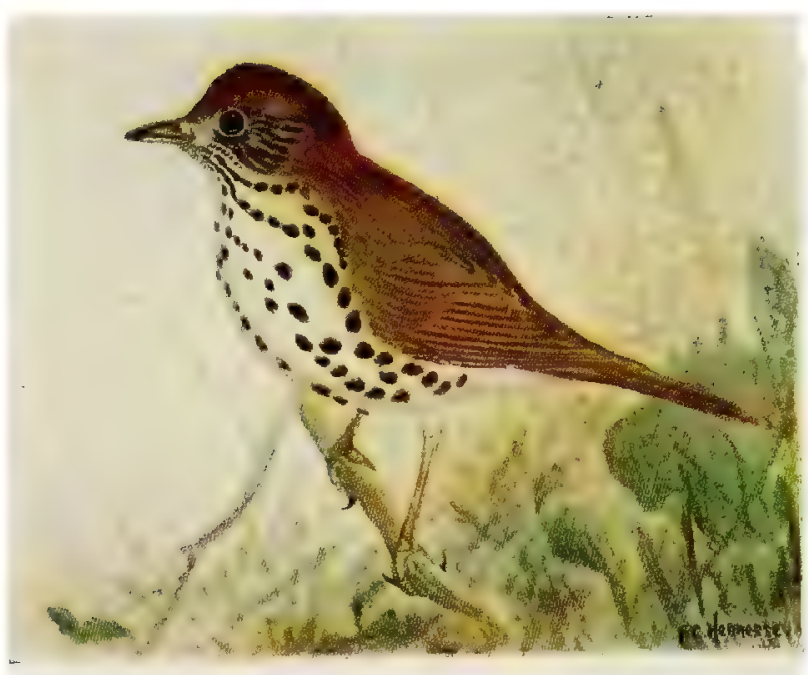

A. Wood Thrush (p. 216).

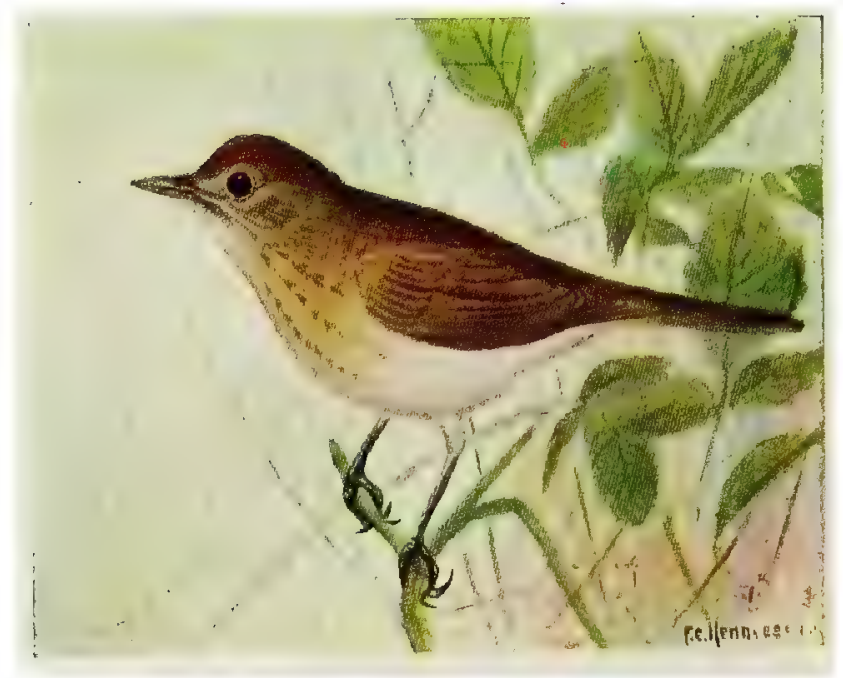

B. WVilson's Thrush (p. 216). 
Plate Xlix.

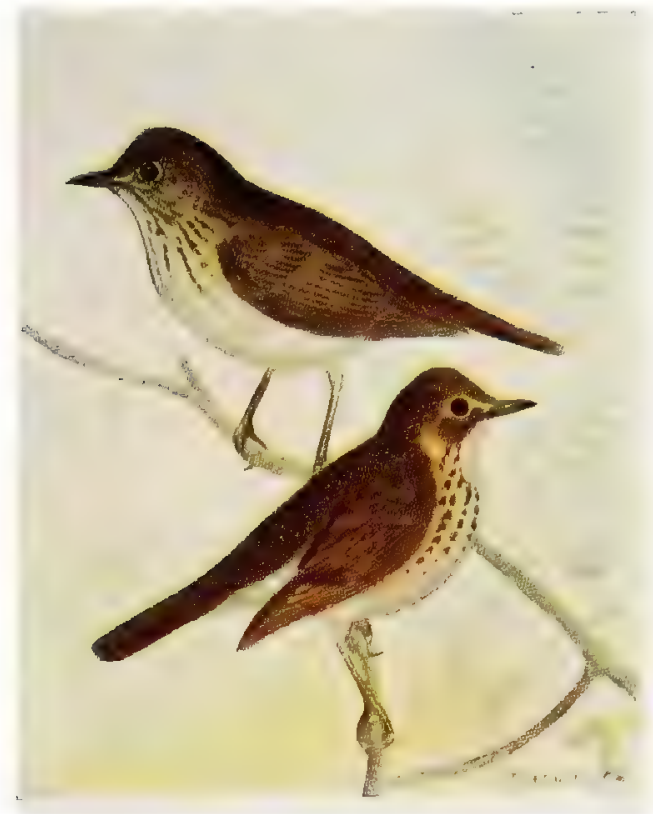

A. Grey-cheeked Thrush (p. 216),

Olive-backed Thrush (p. 217).

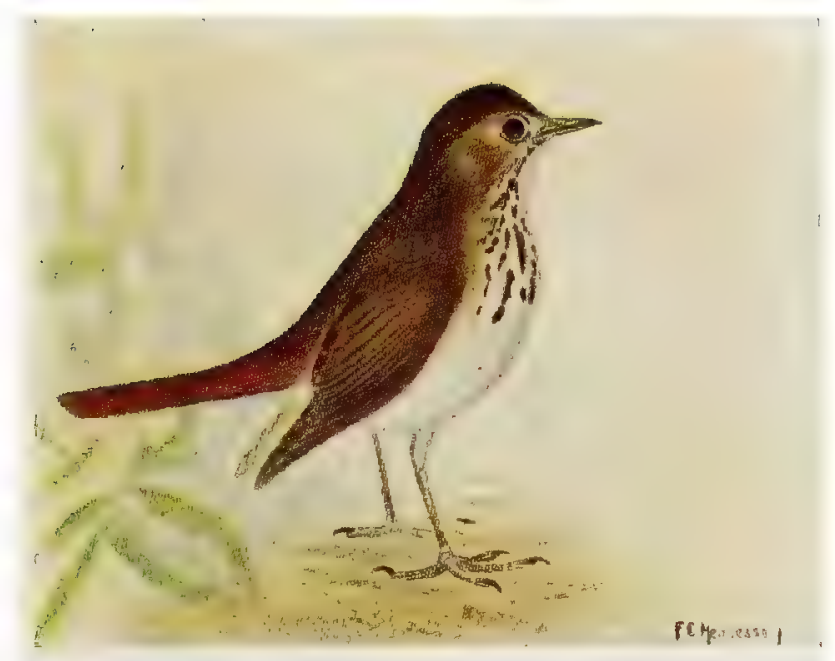

B. Hermit Thrush (p. 217). 
Plate L.

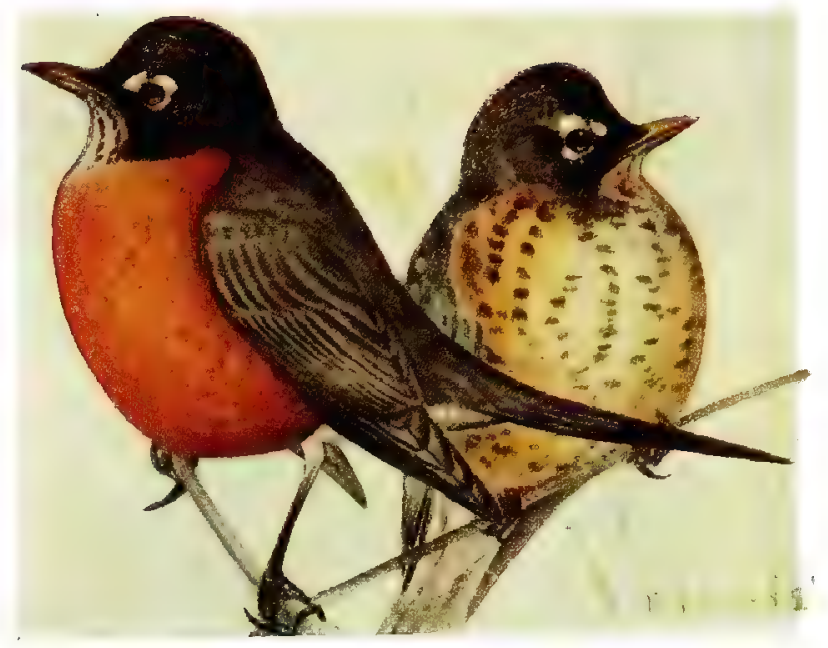

A. American Rohin (p. 217).

Adult Juvenile

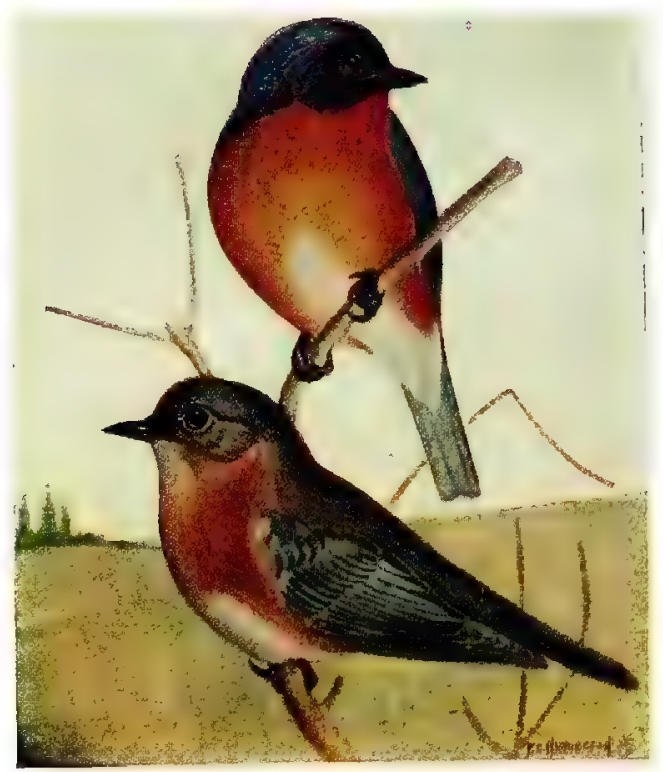

B. Bluebird (p. 218). 


\section{INDEX.}

Page.

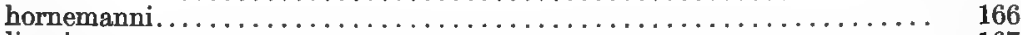

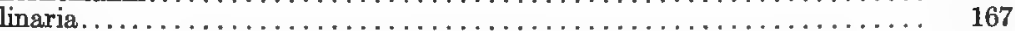

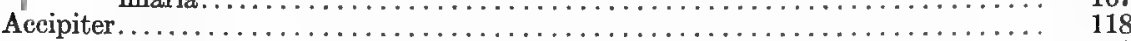

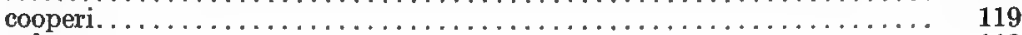

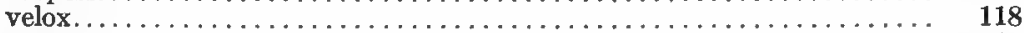

Accipiters.

Actitis macularia. . 100

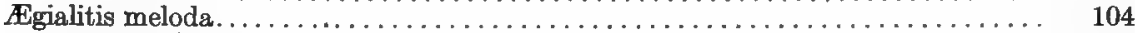

semipalmata..................................... 104

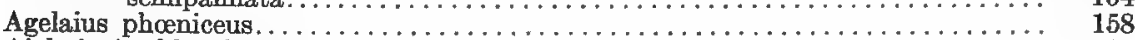

Aigle à tête blanche...................................... 124

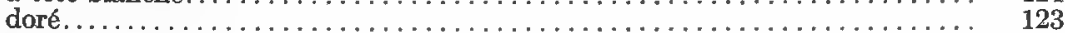

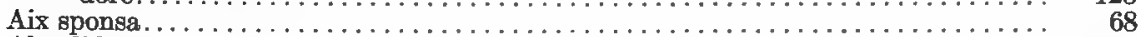

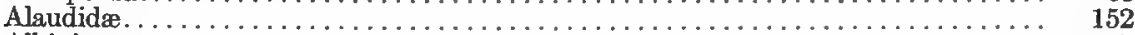

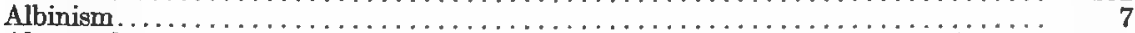

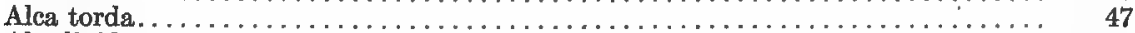

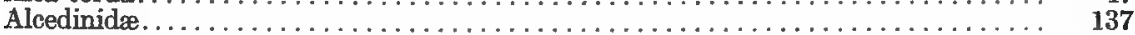

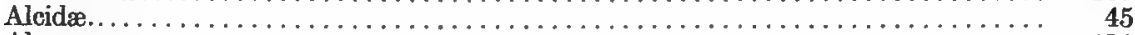

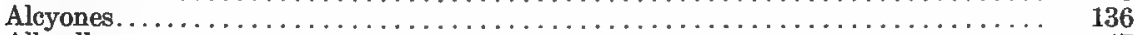

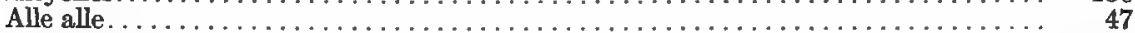

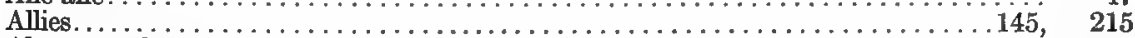

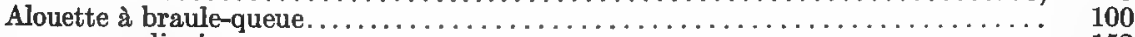

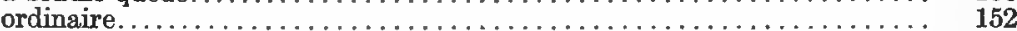

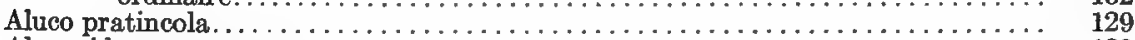

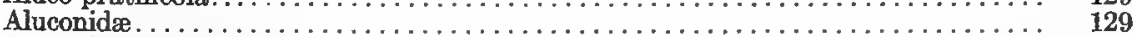

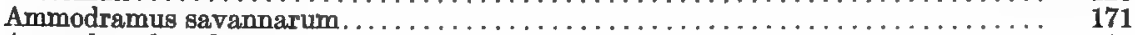

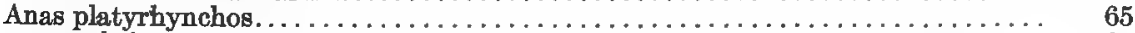

Anatidæ

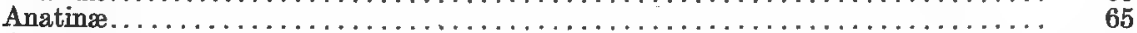

Anser albifrons. . . . . . . . . . .

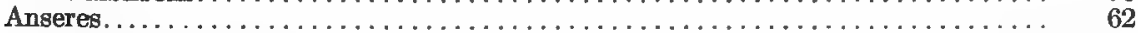

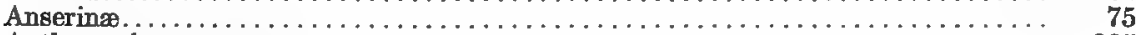

Anthus rubescens. . . . . . .

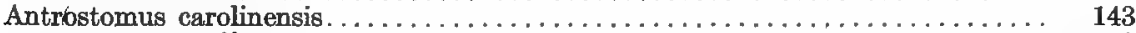

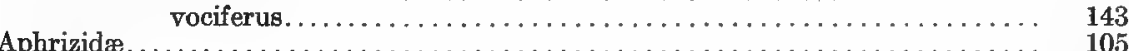

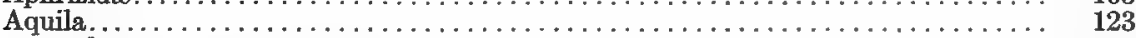

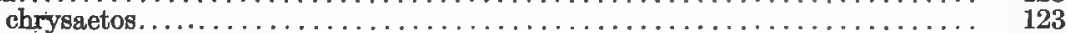

Archibuteo ........................................... 120

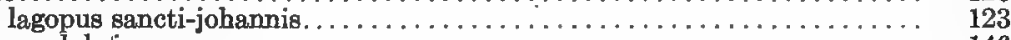

Archilochus colubris................................................ 146

Ardea herodias. . . . . . . . . . . . . . . . . . . . . . . . . . . . . . . 82

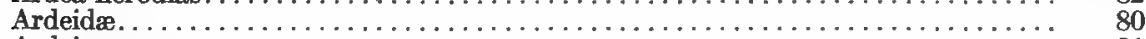

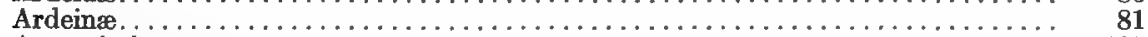

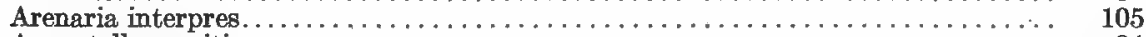

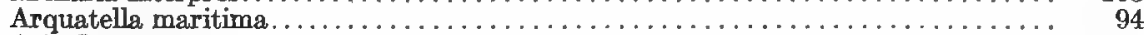

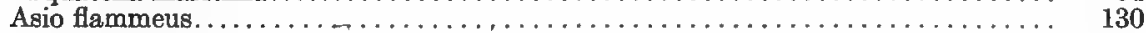

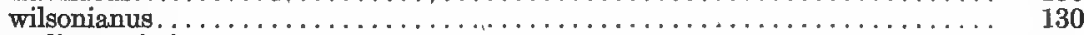

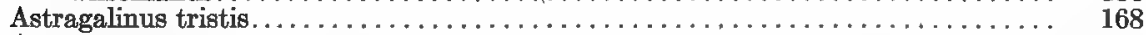

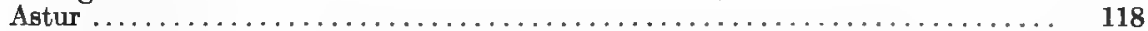

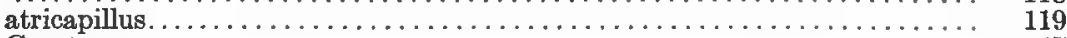

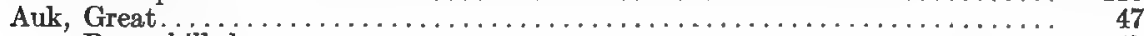

Razor-billed.................................... 47 
Auks.

Austral region.

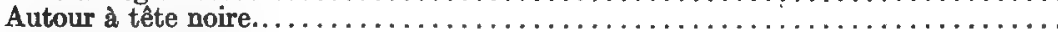

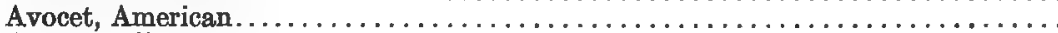

Avocette d'Amérique.

B.

Bæolophus bicolor

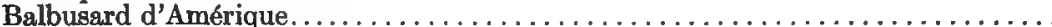

Barge de la baie d'Hudson.

Marbrée.

Bartramia longicauda.

Bec-croisé à ailes blanches.

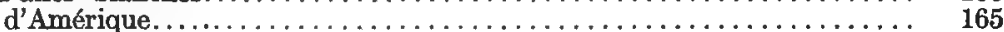

Bec-scie.

Bécasse d'Amérique

Bécassine.

de Wilson

Rousse.

Bernache commune.

du Canada Outarde.

Birds of Prey diurnal.

Birds, scrutching

Bittern, American.

Bittern

Blackbird, Cow. See Cowbird.

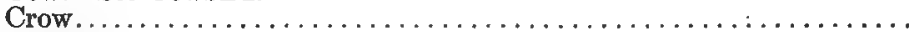

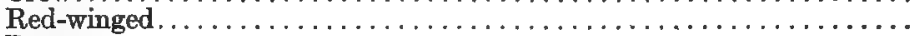

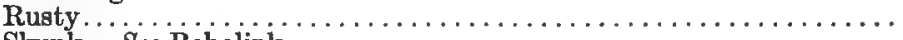

Skunk. See Bobolink.

Soldier. . . . . . . . . . . . . . . . . . . . . . . . . . . . . 158

Yellow-headed

Bluebill, Greater or Lake. See Duck, Greater Scaup.

Little or Marsh. See Duck, Lesser Scaup.

Bluebird .

Litle or Marsh. See Duck, Lesser Scaup.

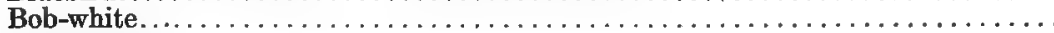

Bobolink.

Bombycilla cedrorum.

Bombycillidæ

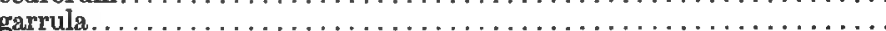

Bonasa umbellus. . . . . . . . . . . . . . . . . . . . . . . . . . . . .

Boobies. .

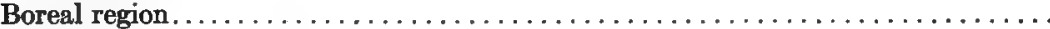

Bo'sn.

Botaurinx. . . . . . . . . . . . . . . . . . . . . . . . . . . . . .

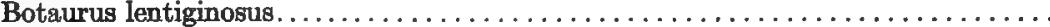

Brant. . . . . . . . . . . . . . . . . . . . . . . . . . . . . . . . .

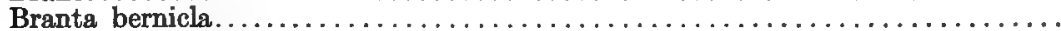

canadensis..........

Bride, The. See Duck, Wood.

Broad-bill. See Duck, Greater Scaup.

River. See Duck, Lesser Scaup.

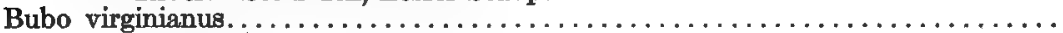

Bucéphale d'Amérique....................................... 70

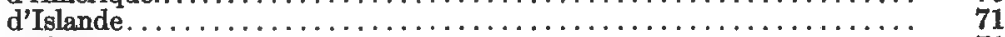

Buffle-head.

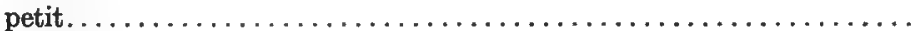

Bull-bat. See Nighthawk.

Bull-head. See Plover, Black-bellied. 


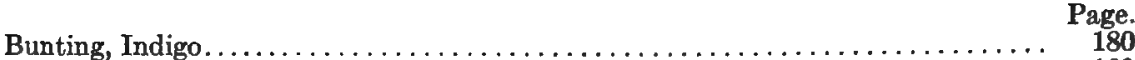

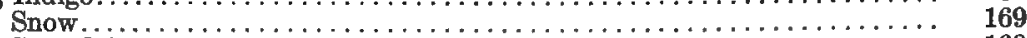

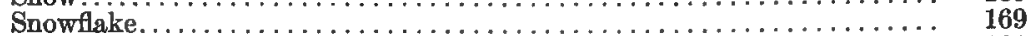

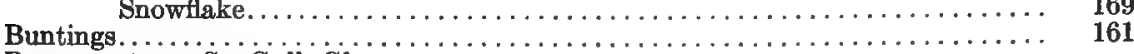

Burgomaster. See Gull, Glaucous.
Busard des marais.....

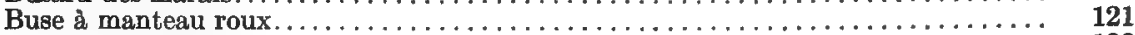

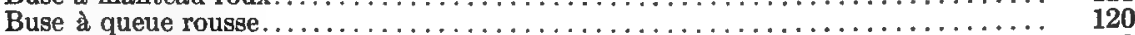

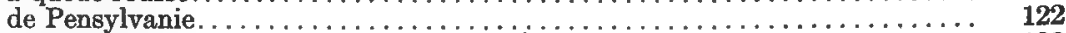

de Swajnson.................................................. 122

pattue d'Amérique............................................. 123

Butcher-bird. See Shrike, Loggerhead, and Shrike, Northern.

Butcher-birds. .................................................. 186

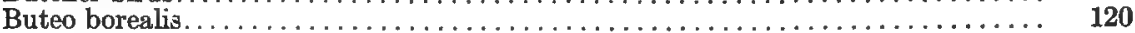

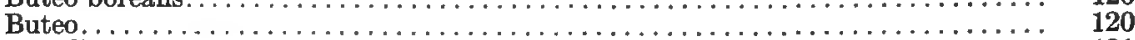

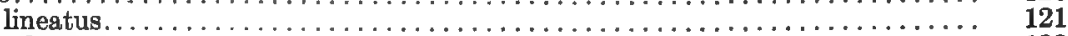

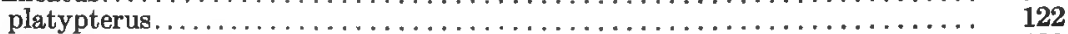

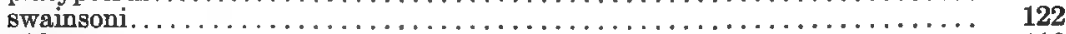

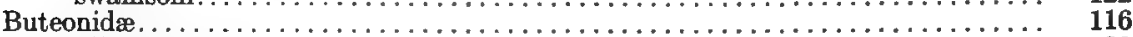

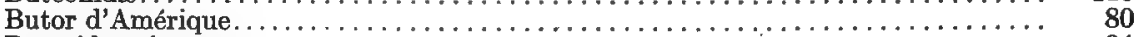

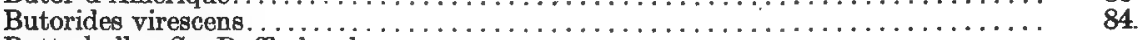

Butterball. See Buffle-head.

Buzzard, Turkey. See Vulture, Turkey.

Buzzards

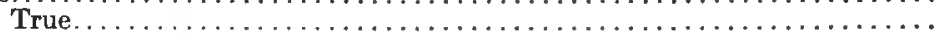

C.

Calcarius lapponicus....................................... 169

Calidris leucophæa .......................................... ${ }_{97}$

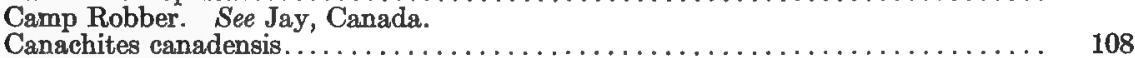

Canada White-throat. See Sparrow, White-throated.

Canard a longue queue ........................................ 72

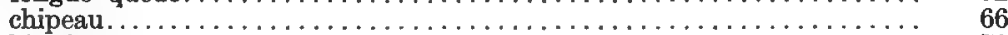

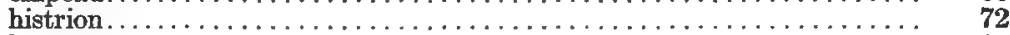

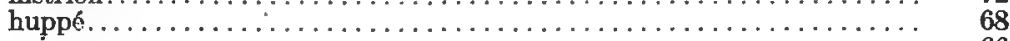

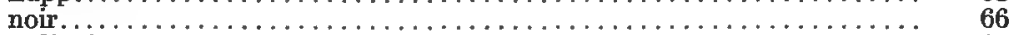

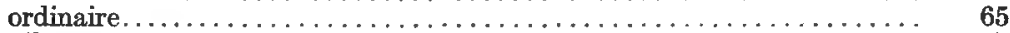

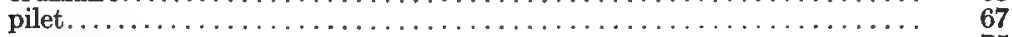

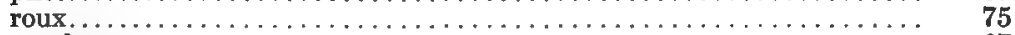

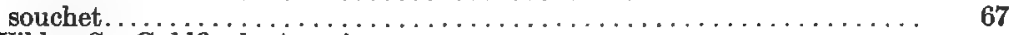

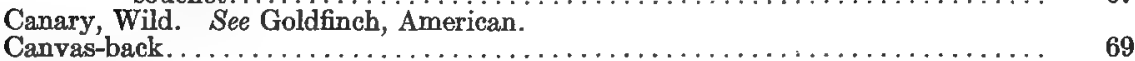

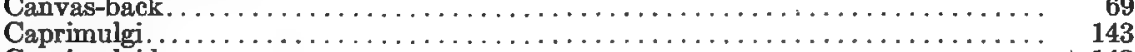

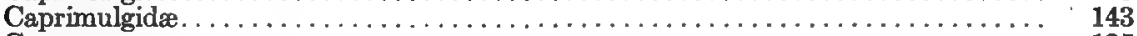

Caracaras................................................. 125

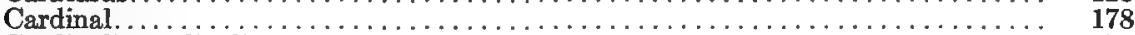

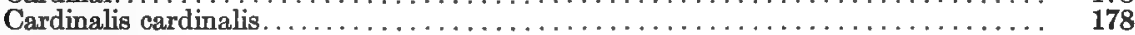

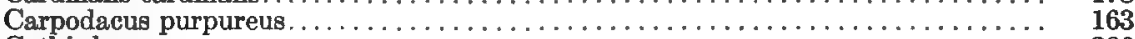

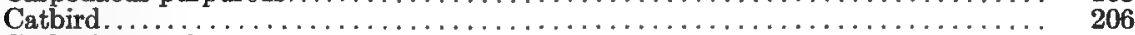

Catharista urubu.............................................. 116

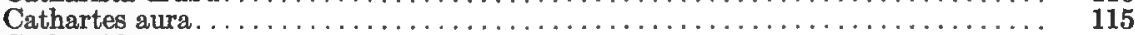

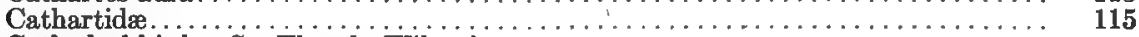

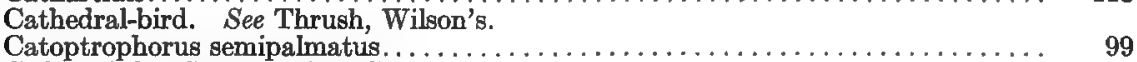

Cedar Bird. See Waxwing, Cedar.

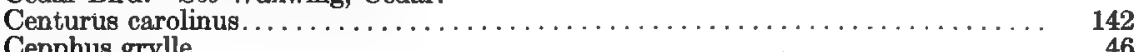

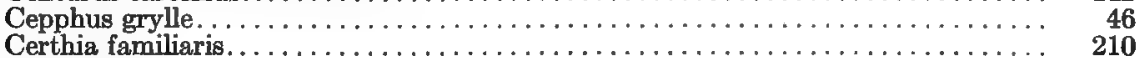

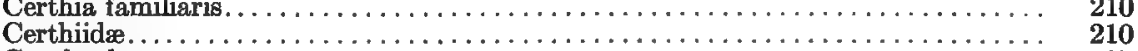

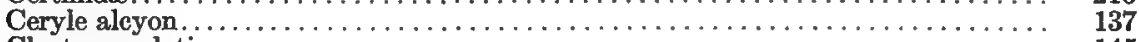

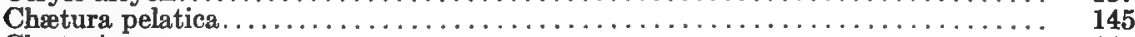

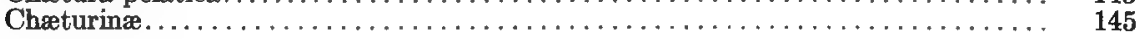


Chapman, Frank.

Charadriidæ.

Charadrius dominicus. . . . . . . . . . . . . . . . . . . . . .

Chardonneret des pins.

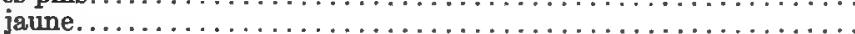

Charitonnetta albeola

Chat, Yellow-breasted.

Chatterer, Wandering. 'See Waxwing, Bohemian.

Chaulelasmus streperus.................................... 66

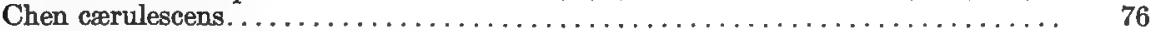

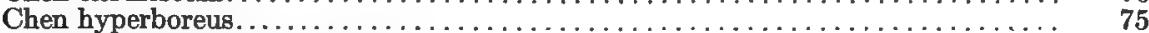

Cherry Bird. See Waxwing, Cedar.

Chevalier ou pattes jaunes.

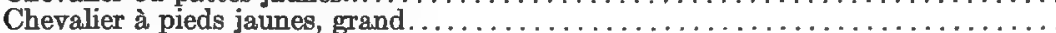

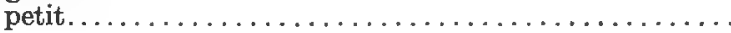

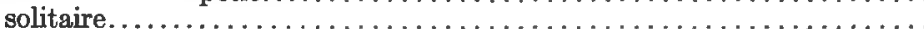

Chickadee

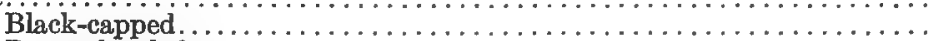

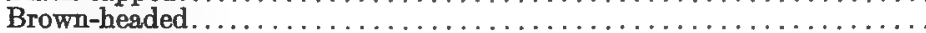

Hudsonian. ..

Chicken, Mother Carey's. See Petrel, Wilson's.

Prairie.

Chippie. See Sparrow, Chipping.

Chondestes grammacus.

Chordeiles virginianus.

Chouette cendrée. du Canada.

éperviere d'Amérique.

Chuck-will's Widow

Circus.

hudsonius.

Cistothorus stellaris.

Clamatores.

Clangula Clangula.



Classification.

Coccyzus americanus

Cock-of-the-Wood. See Woodpecker, Pileated.

Cockawee. See Old Squaw.

Coffin-carrier. See Gull, Great Black-backed.

Colaptes auratus.

Colibri à georges rubis.

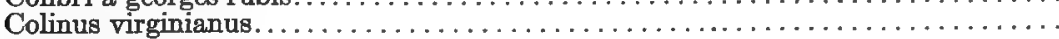

Columbæ.

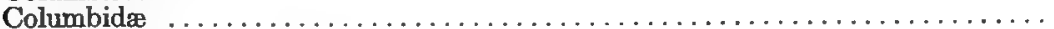

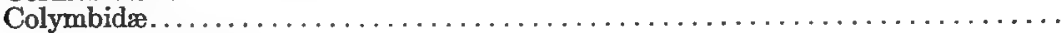

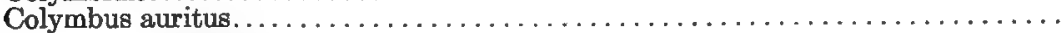

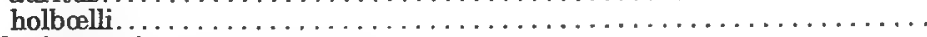

Compsothlypis americana

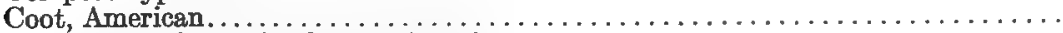

Black Sea. See Scoter, American.

Butterbill. See Scoter, Surf.

White-winged. See Scoter, White-winged.

Coots.

Corbeau.

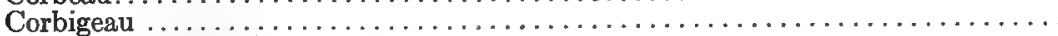
des Esquimaux........................................ 102

Cormoran à aigrettes 


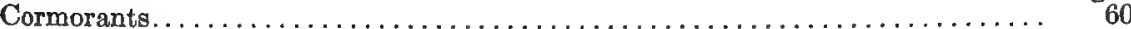

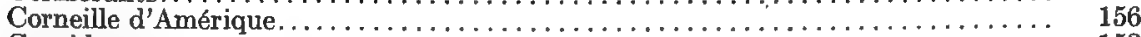

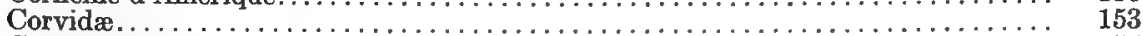

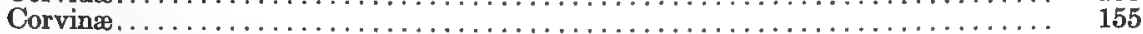

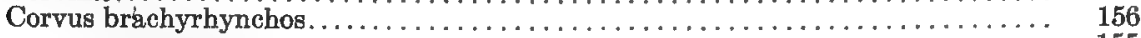

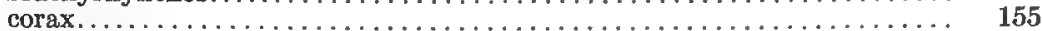

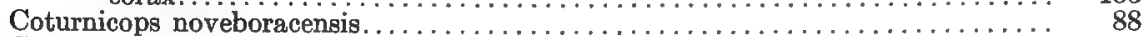

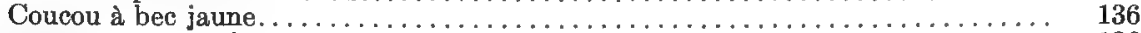

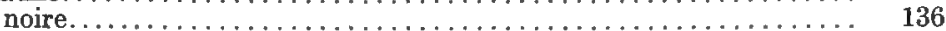

Courlans................................................ 85

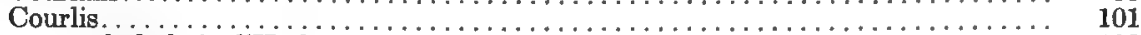

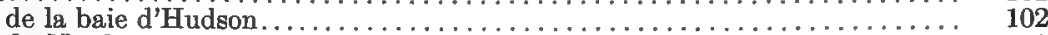

du Nord.......................................... 102

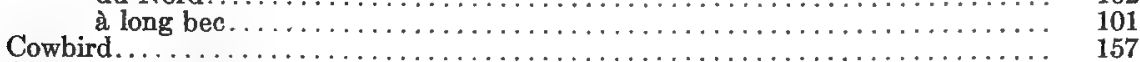

Coween. See Old Squaw.

Crane, Blue. See Heron, Great Blue.

Sandhill .......................................... 85

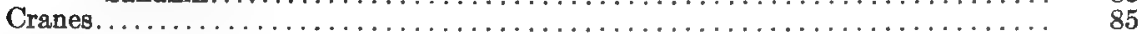

Creeper, American Brown................................................. 210

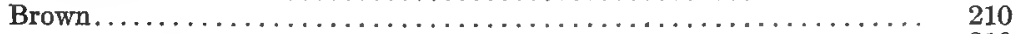

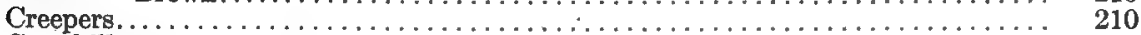

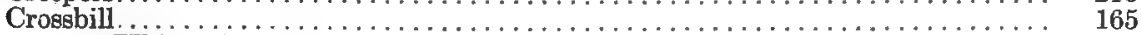

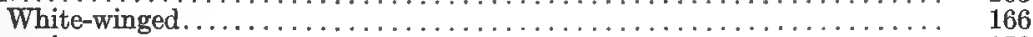

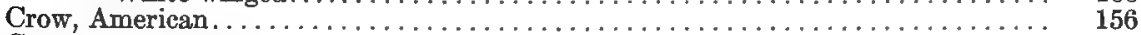

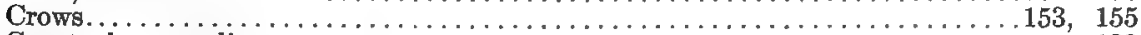

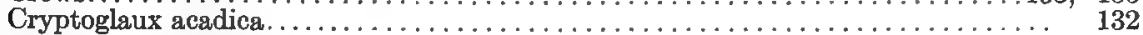

funerea............................................. 132

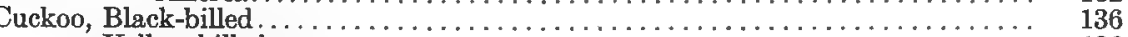

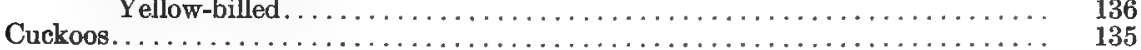

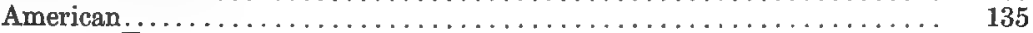

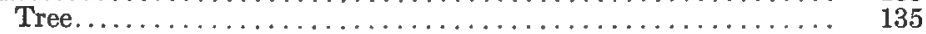

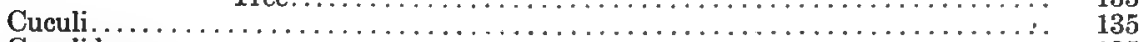

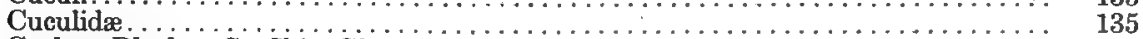

Curlew, Black. See Ibis, Glossy.

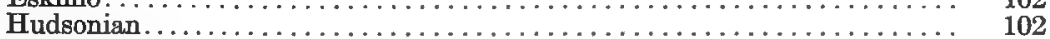

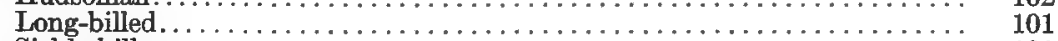

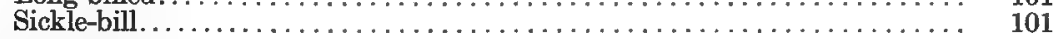

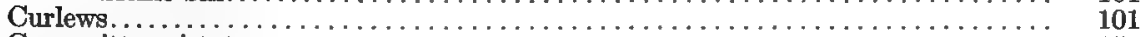

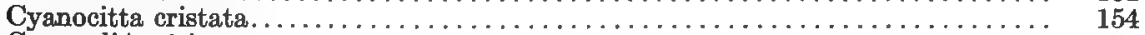

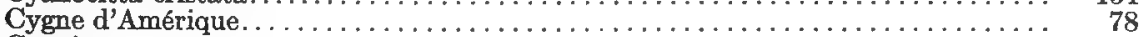

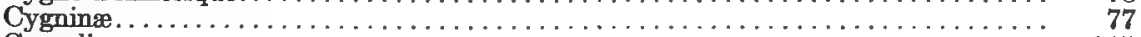

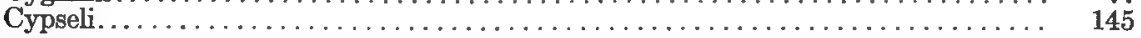

D.

Dab-chick. See Grebe, Pied-billed.

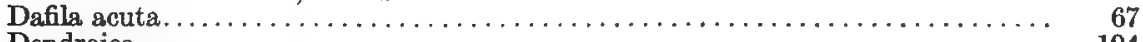

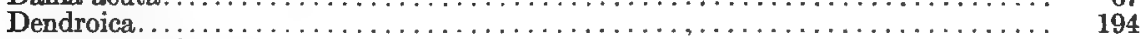

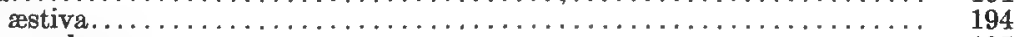

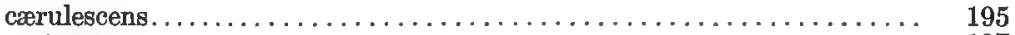

castanea............................................. 197

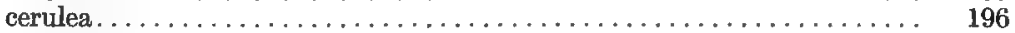

coronata........................................... 195

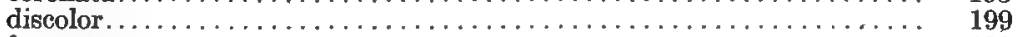

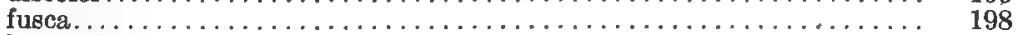

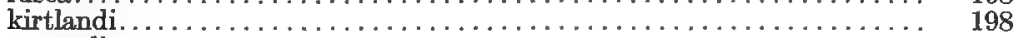

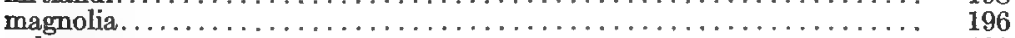

palmarum...................................... 199

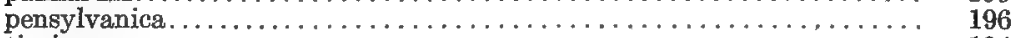

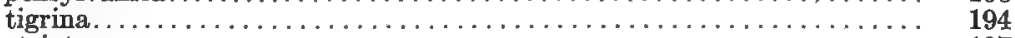

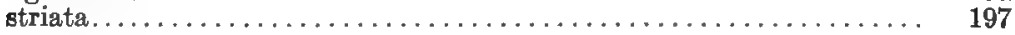




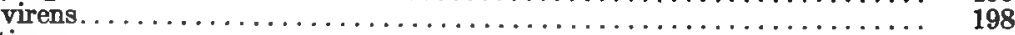

Dichromatism . . . . . . . . . . . . . .

Dickcissel. .......................................... 180

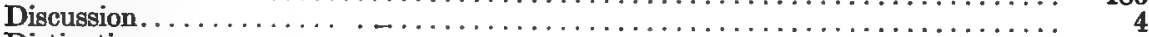

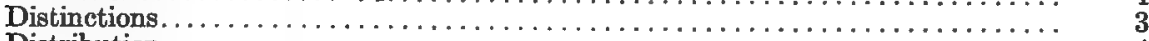

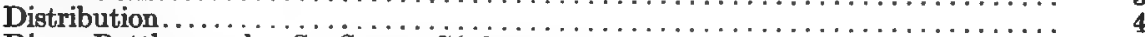

Diver, Bottle-nosed. See Scoter, Sürf.

Brass-Winged. See Scoter, White-winged.

Diving birds.

Great Northern. See Loon, Common.

Dolichonyx oryzivorus. . . . . . . . . . . . . . .

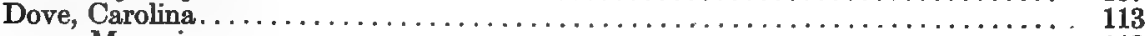

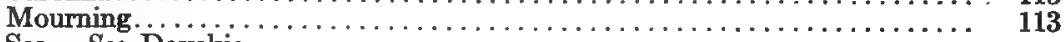

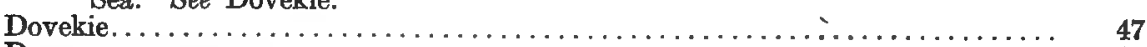

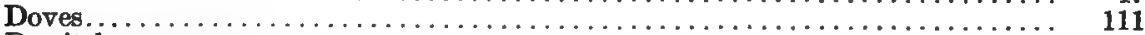

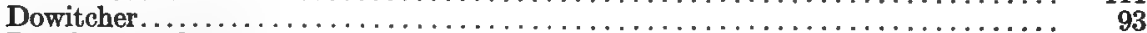

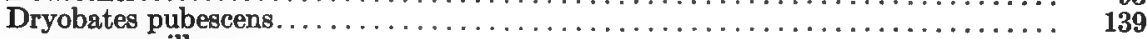

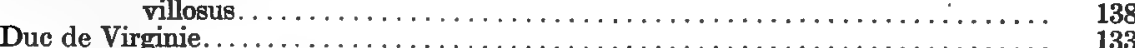

Duck

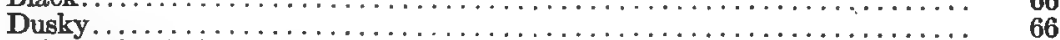

Eider. See Eider Duck.

Grey. See Gadwall and Mallard.

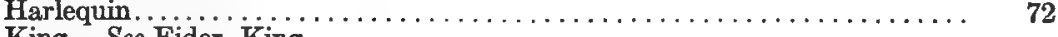

King. See Eider, King.

Lesser Scaup.................................. 70

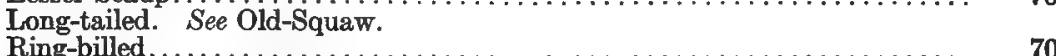

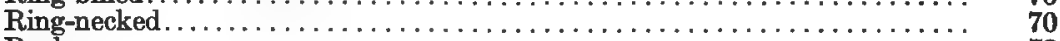

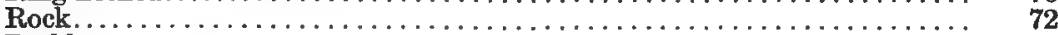

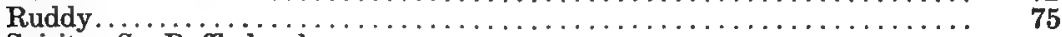

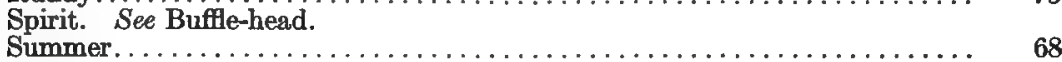

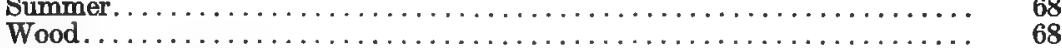

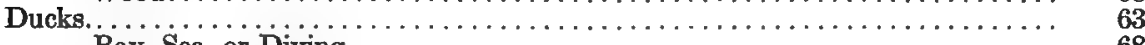

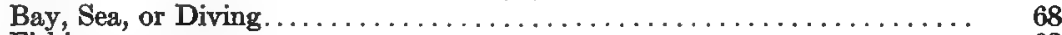

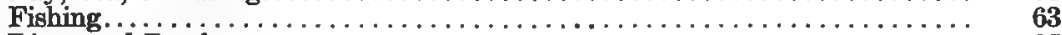

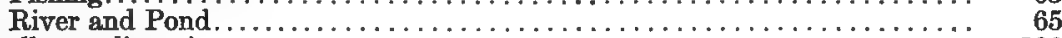

Dumetella carolinensis............................................ 206

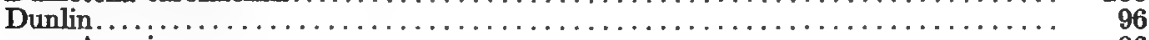

American. ................................ 96

E.

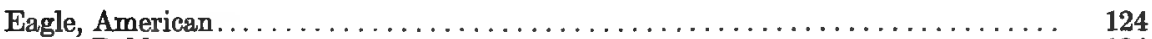

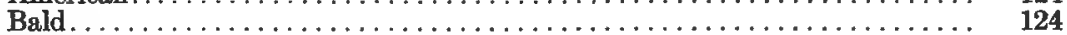

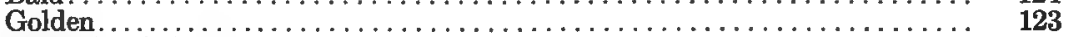

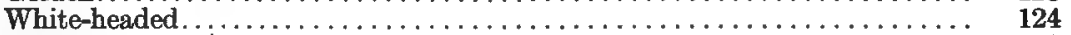

Eagles.............................................. 123

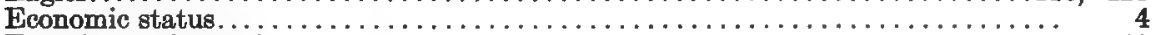

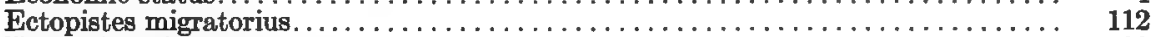

Egret, American.................................. 83

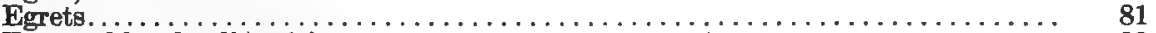

Egrette blanche d'Amérique . . . . . . . . . .

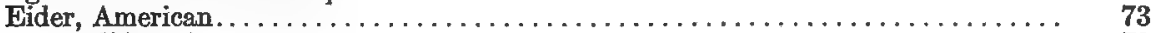

d'Amérique . . .

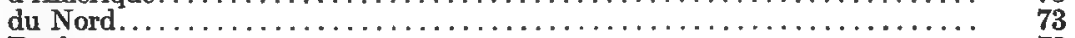

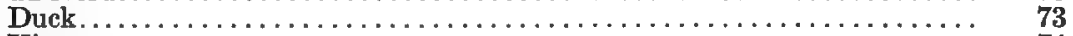

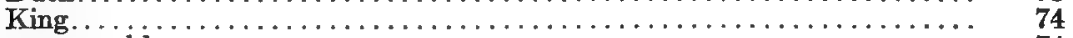

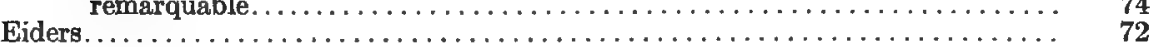


Planoide.

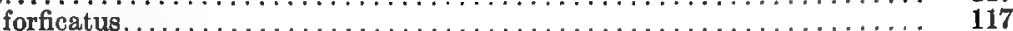

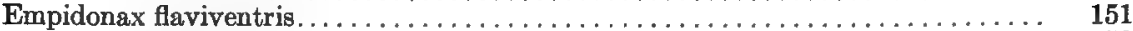

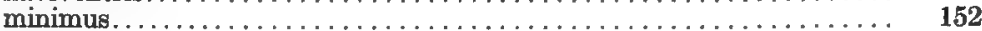

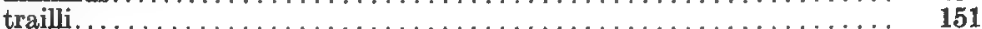

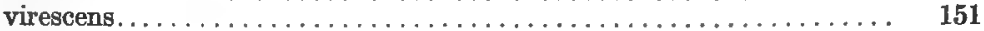

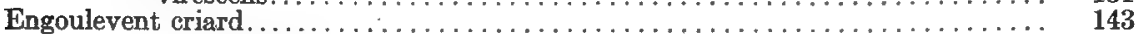

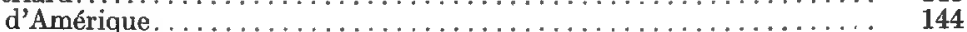

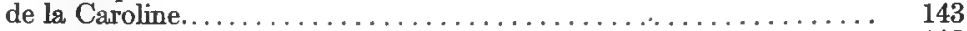

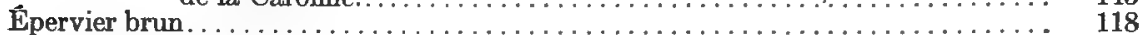

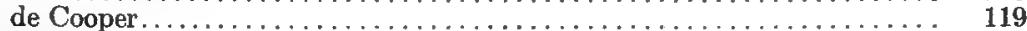

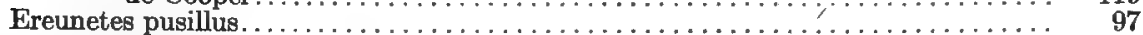

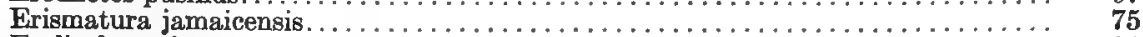

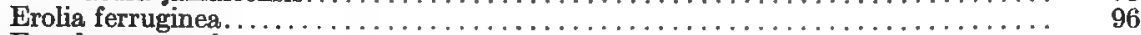

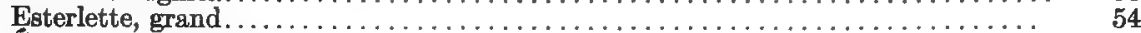

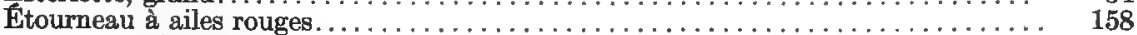

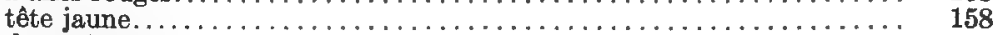

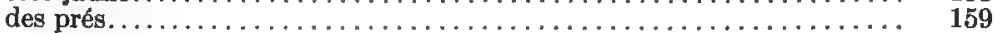

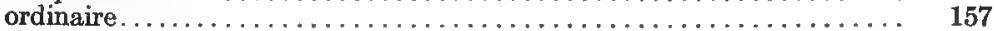

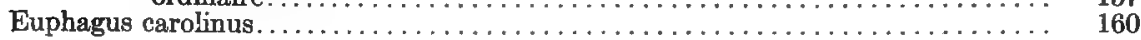

F.

Falco columbarius. .................................... 127

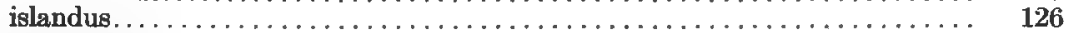

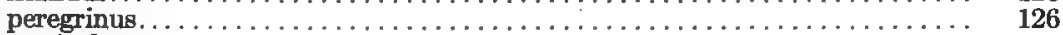

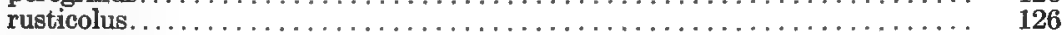

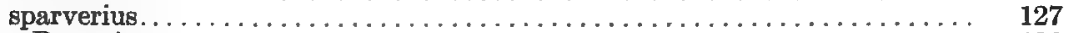

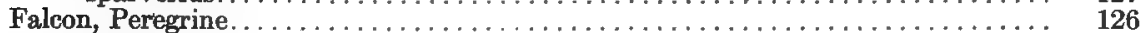

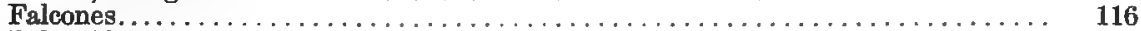

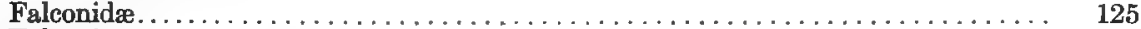

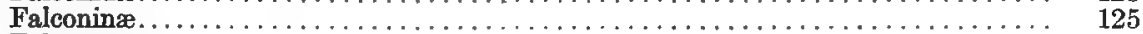

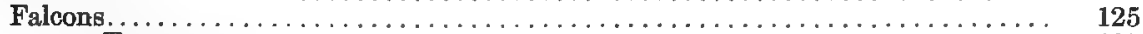

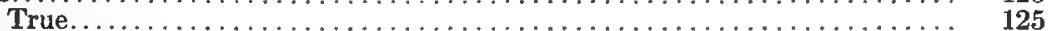

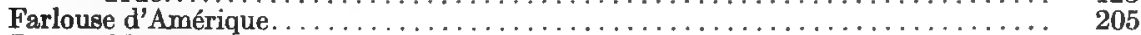

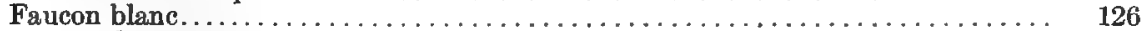

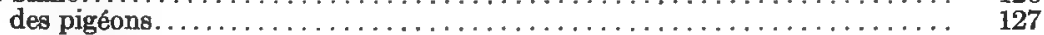

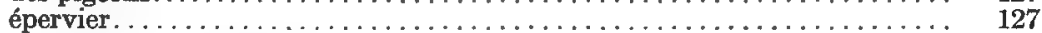

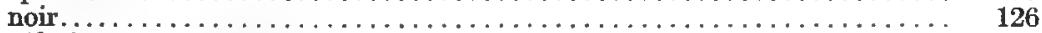

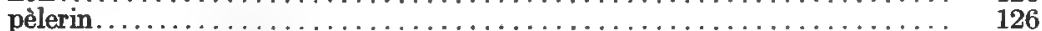

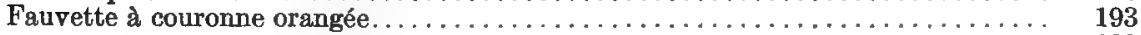

rousse................................ 199

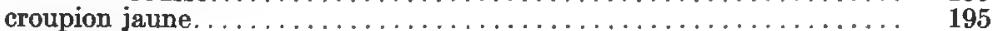

queue rousse. . . . . . . . . . . . . . . . . . . . . . . . . . 204

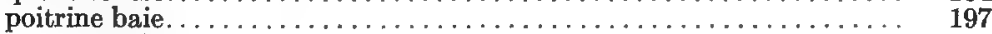

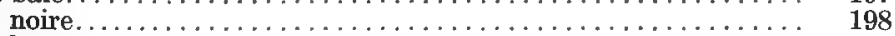

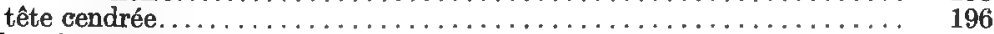

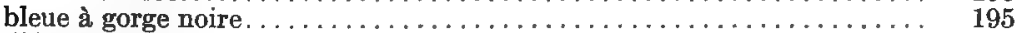

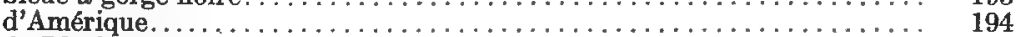

de Blackburn. . . . . . . . . . . . . . . . . . . . . . . . . . 198

Nashville. . . . . . . . . . . . . . . . . . . . . . . . . . . . . . 193

Pensylvanie. . . . . . . . . . . . . . . . . . . . . . . . . . . . . 196

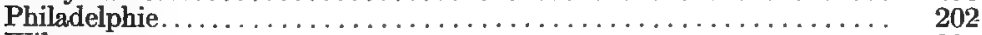

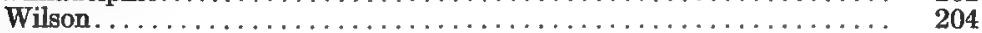

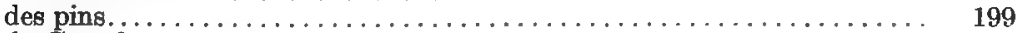

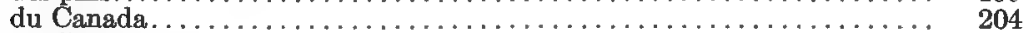

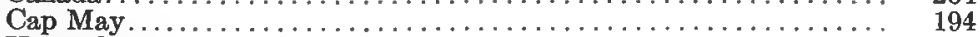

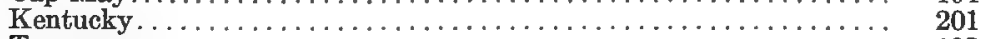

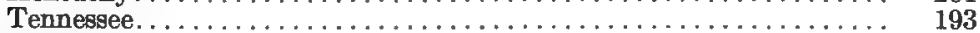

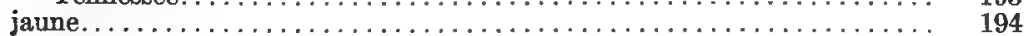

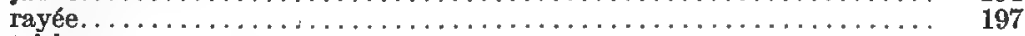

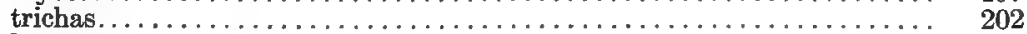

Field marks. 
Finch Grass. See Sparrow, Vesper.

Finches.

Purple. .

Fire Bird. See Tanager, Scarlet.

Page.

Fishduck. See Merganser, Red-breasted.

Fleming, J. H.

Flicker.

Florida cæulea.

Flycatcher, Acra

Canadian. 'See Warbler, Canada.

Chebec.

Crested.

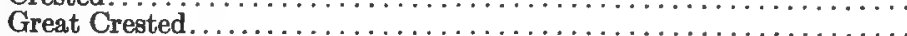

Least.

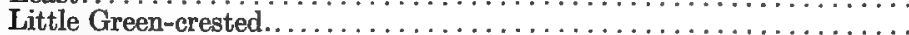

Olive-sided.

Scissor-tailed.

Fly-up-the-creek. See Heron, Green.

151

Fou de Bassan.

Foulque d'Amérique.

Fowls, True.

Fratercula aretica.

Fringillidæ

161

Fulica americana. . .

Fulicine.

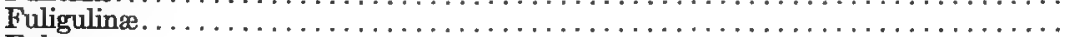

Fulmar. . . . . . . .

Fulmars.

Fulmarus glacialis.

G.

Gadwall

Gallinæ.

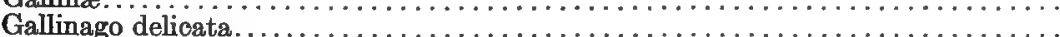

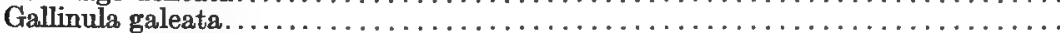

Gallinule de la Floride.

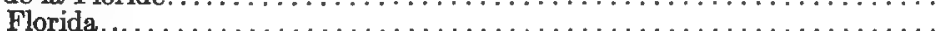

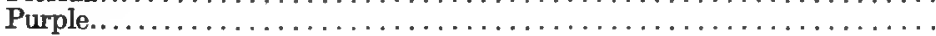

Gallinules.

Gannet

Gare-fowl. See Aü, Great.

Garrulino.

Gavia immer...

Gaviidæe

Geai du Ca............

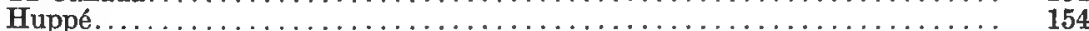

Geese.

Gélinotte a Fraise.

Geothlypis.

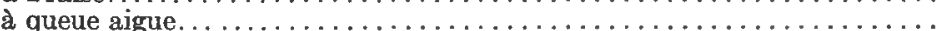

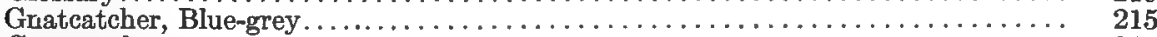

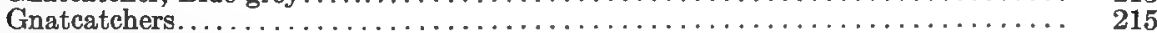

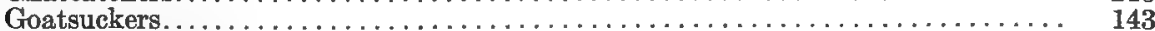

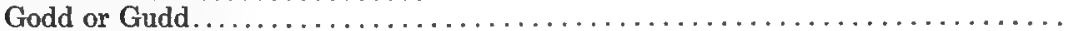

Godwit, Hudsonian . . . . . . . . . . . . . . . . . . . . . . . . . . . . . . . . 


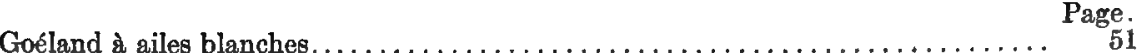

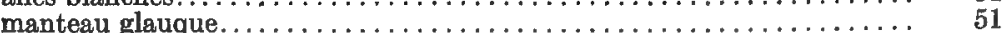

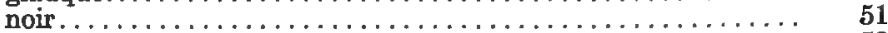

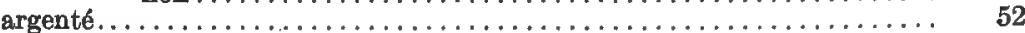

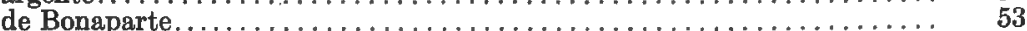

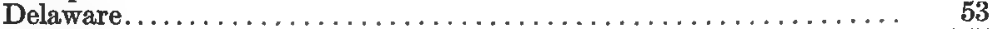

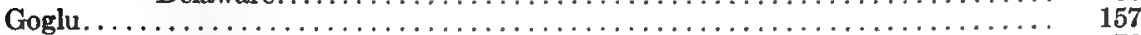

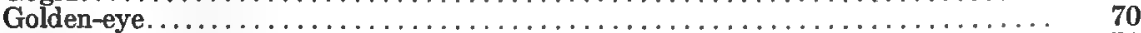

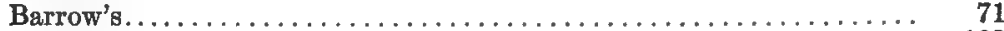

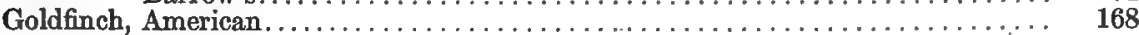

Goosander. See Merganser, American.

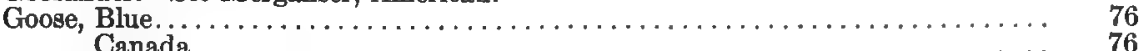

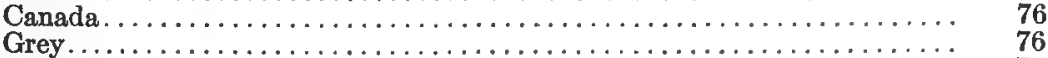

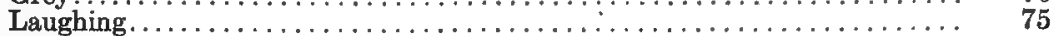

Solan. See Gannet.

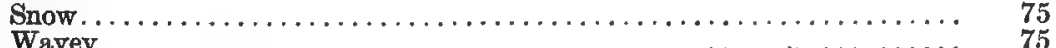

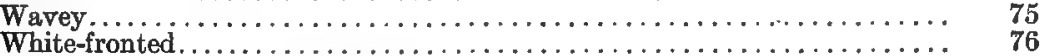

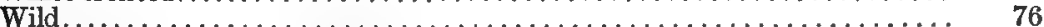

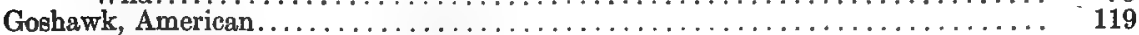

Grackle, Bronzed. See Crow, Blackbird.

Rusty. See Blackbird, Rusty.

Graybird. See Junco.

Great Head. See Golden-eye.

Grebe à bec bigarré. . . . . . . . . . . . . . . . . . . . . . . . . . . . . . . . 43

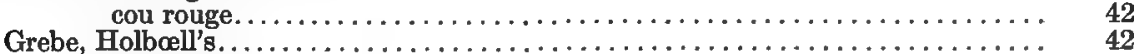

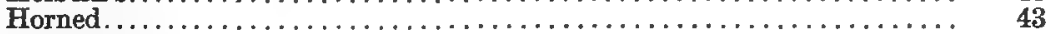

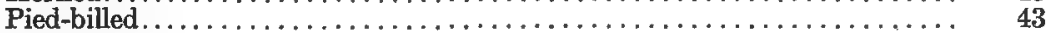

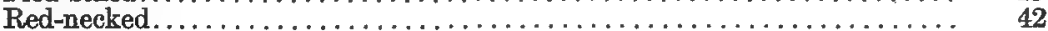

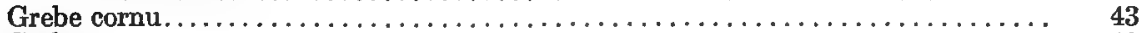

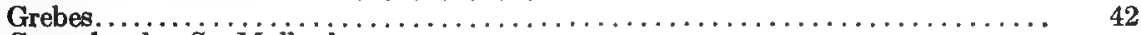

Green-head. See Mallard.

Greenlets........................................... 188

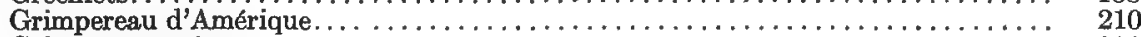

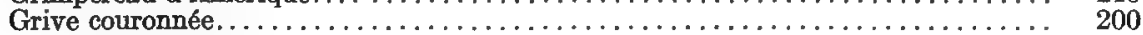

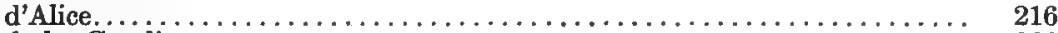

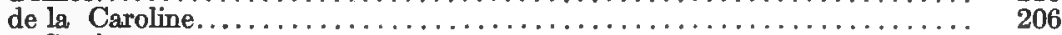

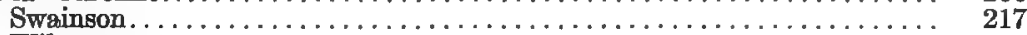

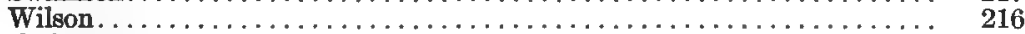

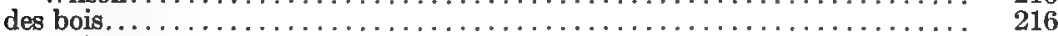

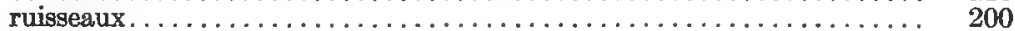

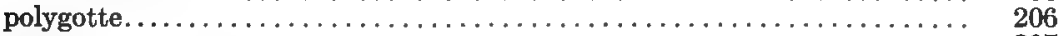

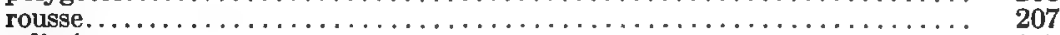

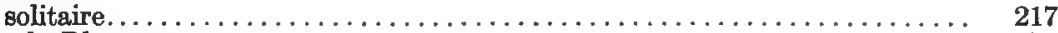

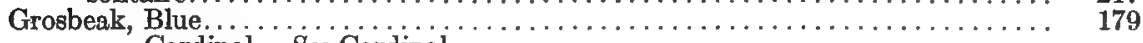

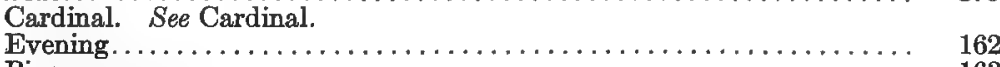

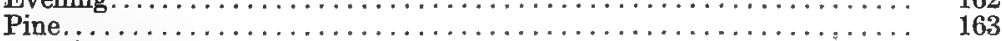

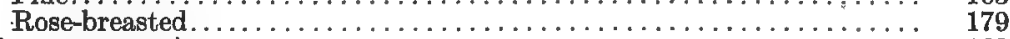

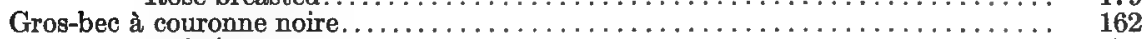

poitrine rose...................................... 179

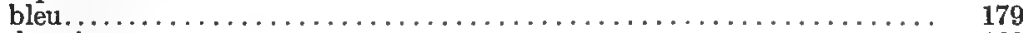

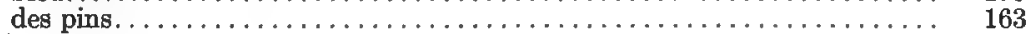

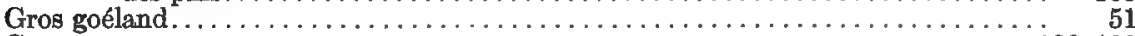

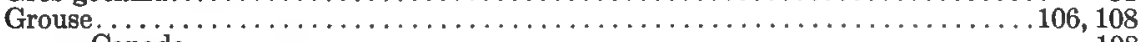

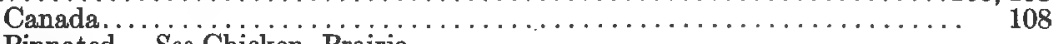

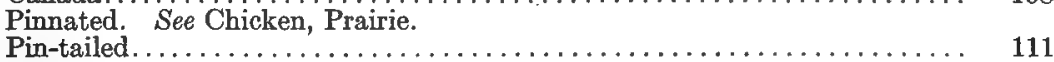

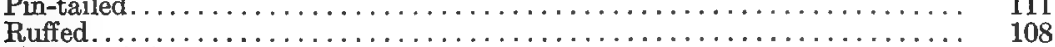

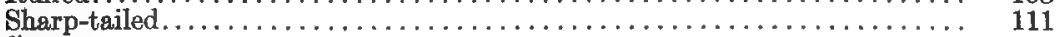

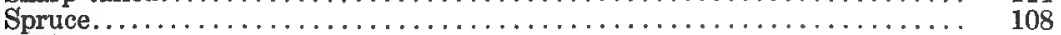

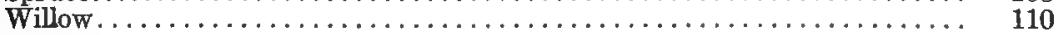




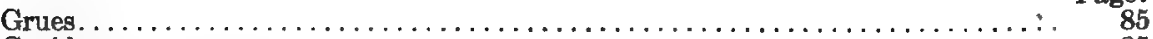

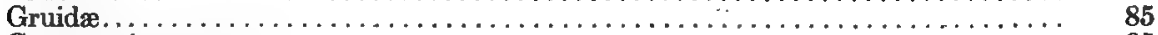

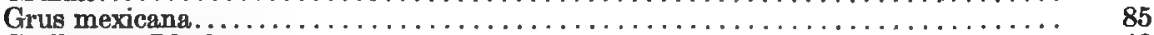

Guillemot, Black. . . . . . . . . . . . . . . . . . . . . . . . . . . .

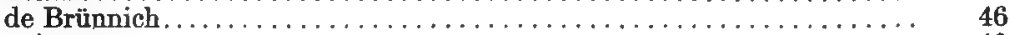

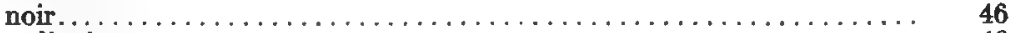

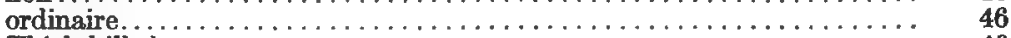

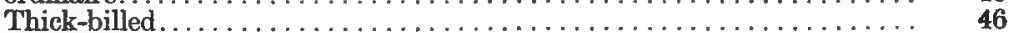

Guiraca cærulea. ...................................... 179

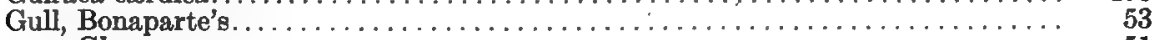

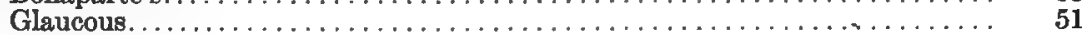

Great Black-backed................................ 51

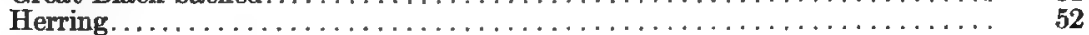

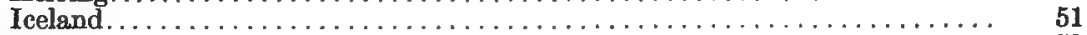

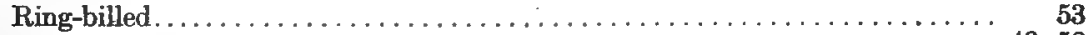

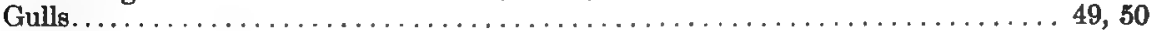

Gyrfalcon . . . . . . . . . . . . . . . . . . . . . . . . . . . . . . . 126

Gyrfalcons

\section{H.}

Hæmatopodidæ.................................. 105

Hair-bird. See Sparrow, Chipping.

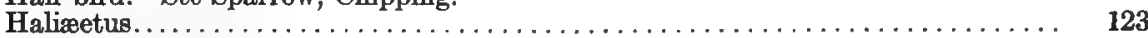

leucocephalus. ............................. 124

Hang-nest. See Oriole, Baitimore.

Harelda hyemalis. . . . . . . . . . . . . . . . . . . . . . . . . . . . . . 72

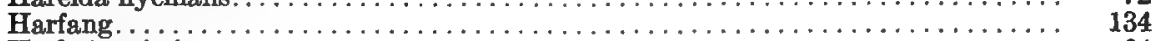

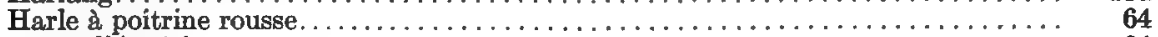

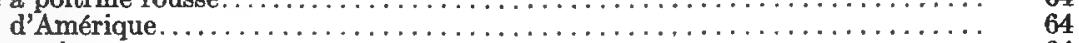

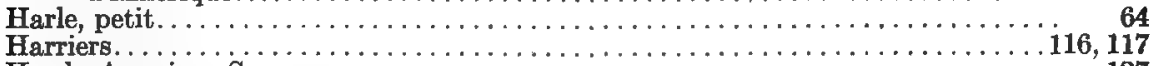

Hawk, American Sparrow. ................................ 127

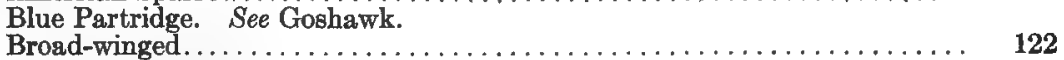

Bullet. See Falcon, Peregrine. 119,121

Cooper's. . . . . . .

Duck. See Falcon, Peregrine.

Fish. See Osprey.

Hen. See Goshawk, American.

Hen. See Hawk, Red-tailed.

Marsh. . . . . . . . . . . . .

Mosquito. See Nighthawk.

Pigeon . . . . . . . . . . . . . . . . . . . . . . . . . . . . .

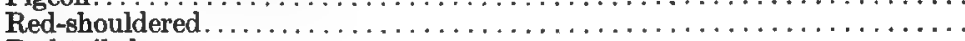

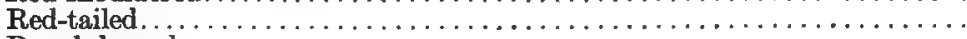

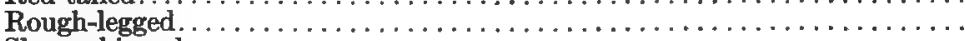

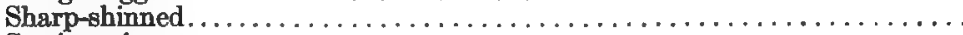

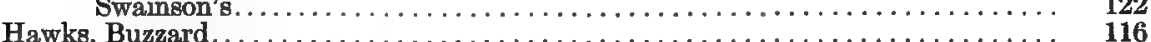

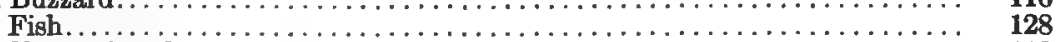

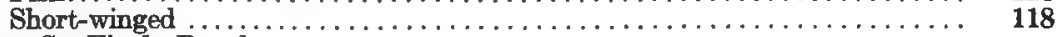

Hefling. See Finch, Purple.

Hell-diver. See Grebe, Pied-billed.

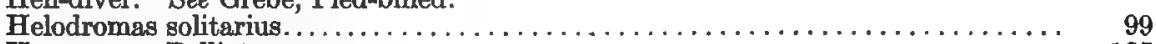

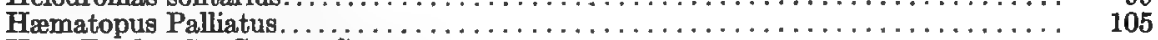

Hen, Fowl. See Grouse, Spruce.

Marsh. See Bittern, American.

Prairie. See Chicken, Prairie.

Hennessey, Frank. . . . . . . . . . . . . . . . . . . . . . . . . . . . . 4

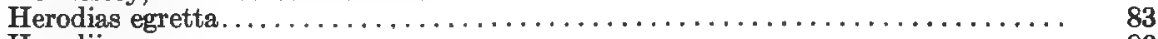

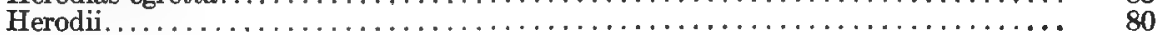


Herodiones.

Heron, Black-crowned

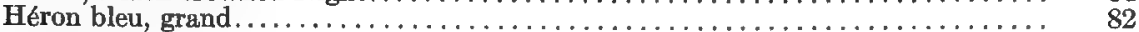

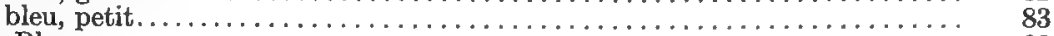

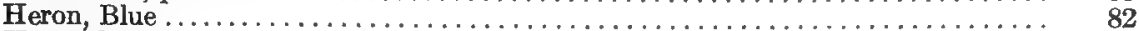

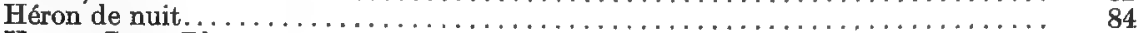

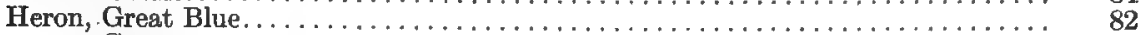

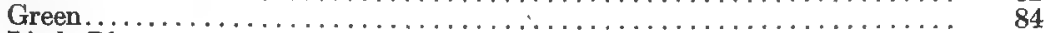

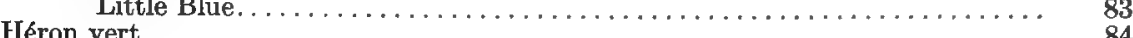

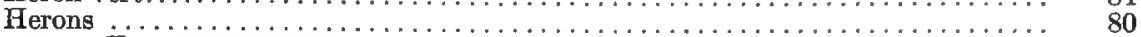

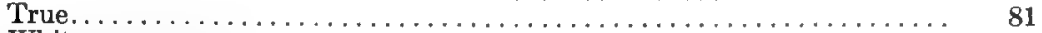

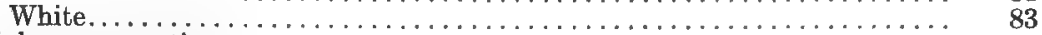

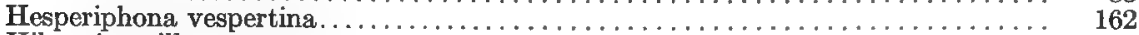

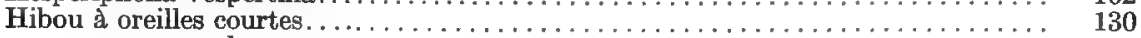

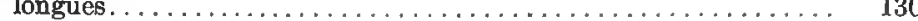

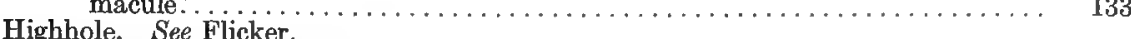

Highholder. See Flicker.

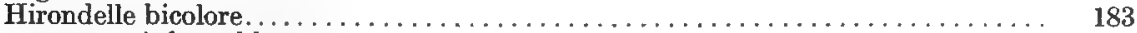

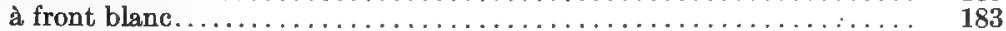

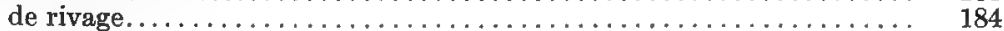

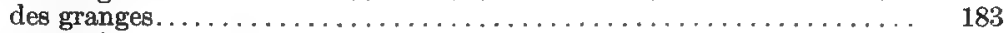

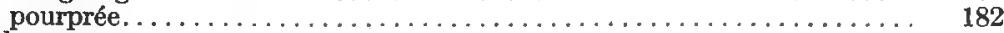

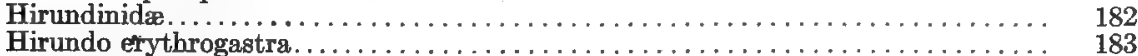

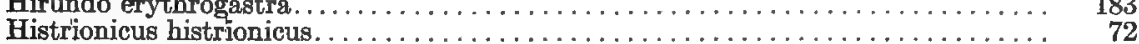

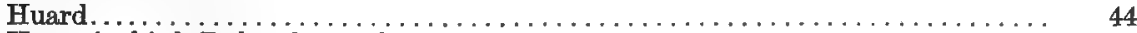

Hummingbird, Ruby-throated. . . . . . . . . . . . . . . . . . . . . . 146

Hummingbirds . . . . . . . . . . . . . . . . . . . . . . . . . . . 143, 146

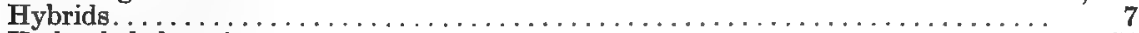

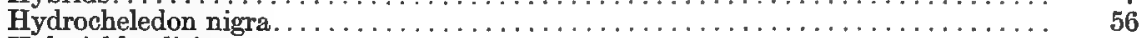

Hylocichla alicie. . . . . . . . . . . . . . . . . . . . . . . . . . . 216

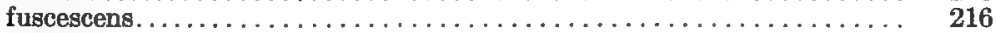

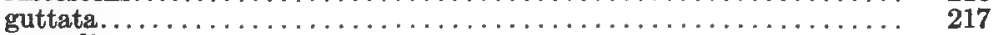

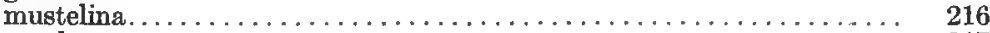

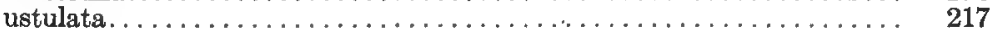

I.

Ibides. . . . . . . . . . . . . . . . . . . . . . . . . . . . . . .

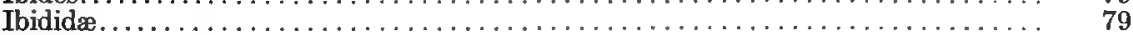

Ibis, Glossy . . . . . . . . . . . . . . . . . . . . . . . . . . . . . . . . . . . .

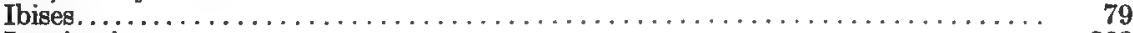

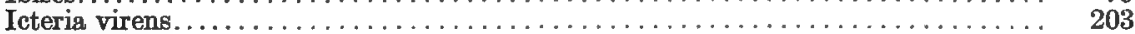

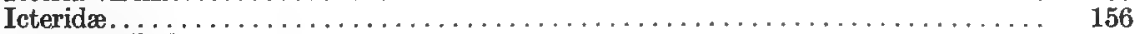

Icterus galbula . . . . . . . . . . . . . . . . . . . . . . . . . . . . . . . 160

Icterus spurius . . . . . . . . . . . . . . . . . . . . . . . . . . . . . . . . . . 159

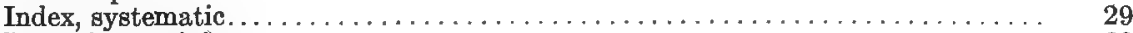

Ionornis martinicus. . . . . . . . . . . . . . . . . . . . . . . . . . . . . 89

Iridoprocne bicolor . . . . . . . . . . . . . . . . . . . . . . . . . . . 183

J.

Jaeger, Long-tailed . . . . . . . . . . . . . . . . . . . . . . . . . . . . 49

Parasitic.................................... 49

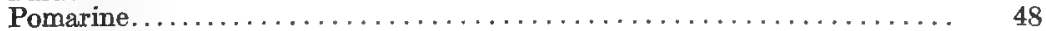

Jaegers. . . . . . . . . . . . . . . . . . . . . . . . . . . . . . . . . 48

Jaseur de Bohême. . . . . . . . . . . . . . . . . . . . . . . . . . . . . . 185

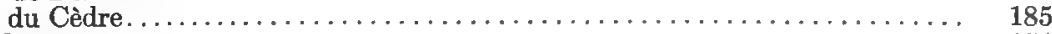

Jay, Blue. . . . . . . . . . . . . . . . . . . . . . . . . . . . . . . . 154

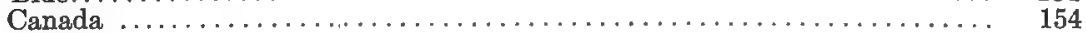

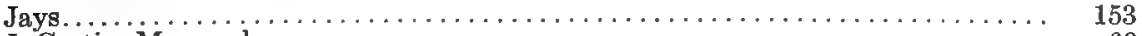

J. Cartier-Morgaud..................................... 60 
Johnson, Claude

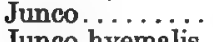

K.

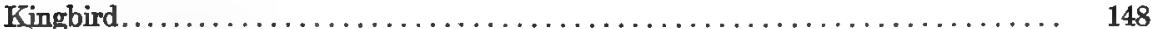

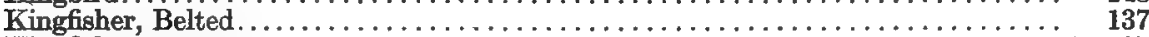

Kingfishers.................................................. 136, 137

Kinglet, Golden-crowned................................... 214

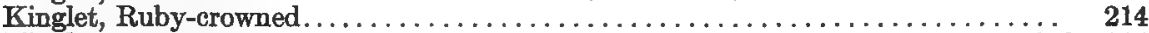

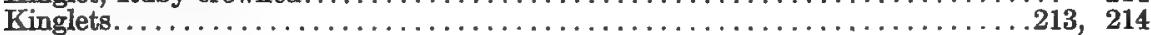

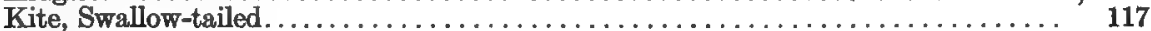

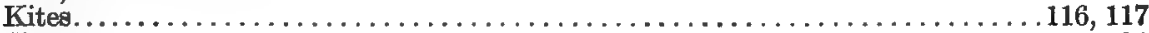

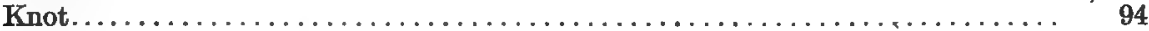

L.

Labbe à longue queue. . . . . . . . . . . . . . . . . . . . . . . . . . 49

parasite.................................... 49

pomarin.......................................... 48

Lagopède des rochers.............................. 110

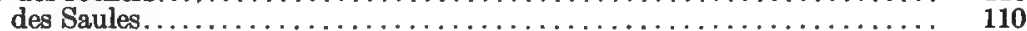

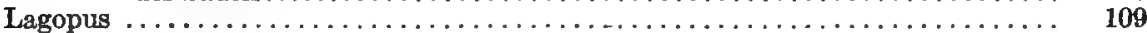

Iagopus....................................... 110

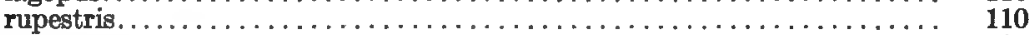

Laniidæ............................................ 186

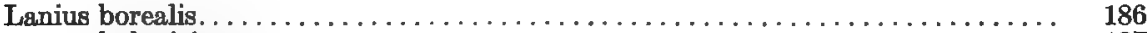

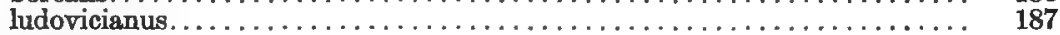

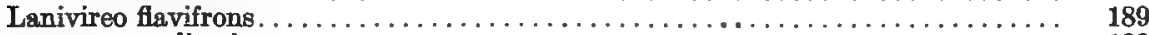

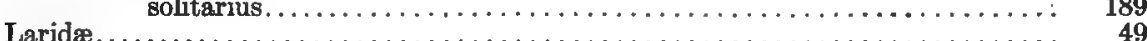

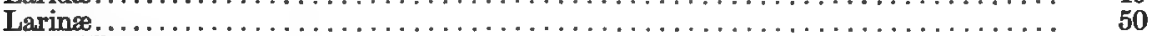

Lark, Horned. . . . . . . .

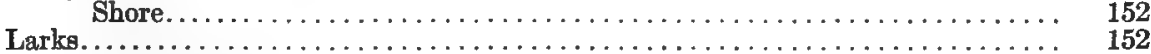

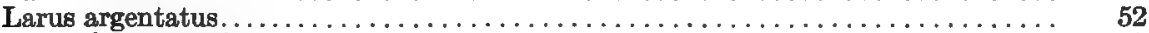

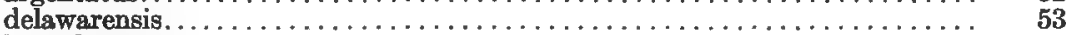

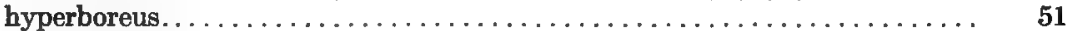

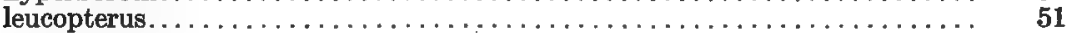

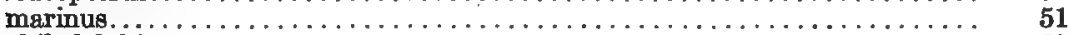

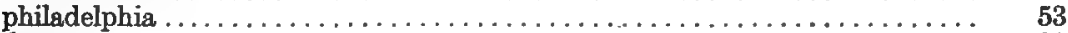

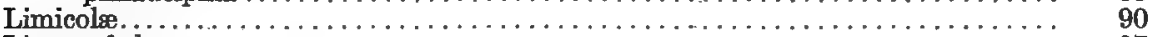

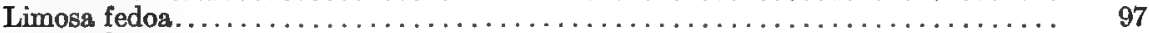

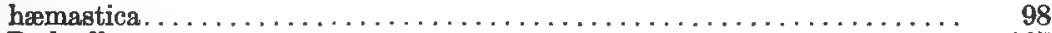

Linnet, Redpoll. . . . . . . .

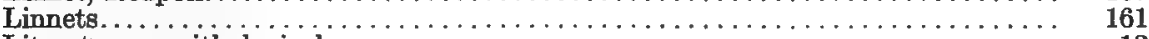

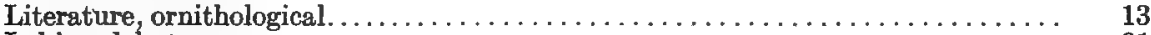

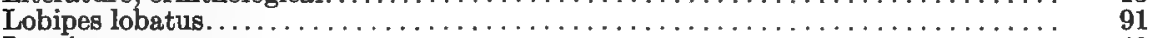

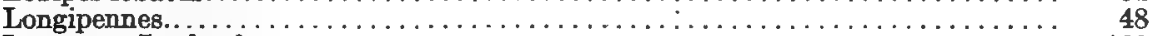

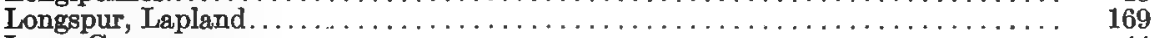

Loon, Common............................................. 44

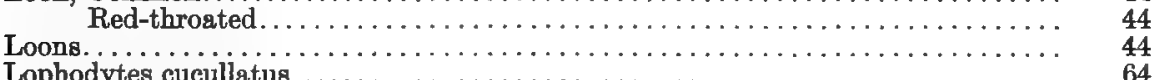

Lord and Lady Algy. See Duck, Harlequin.

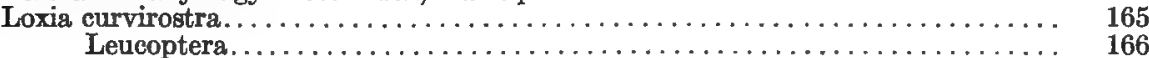

M.

Macareux arctique.

Macoun, James M.

John. 
Macreusè à large bec.

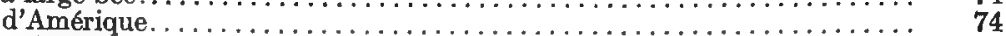

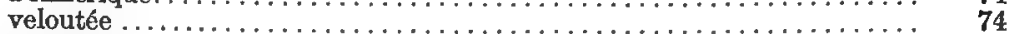

Macrochires........................................ 143

143
93

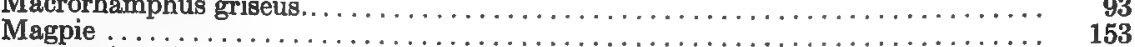

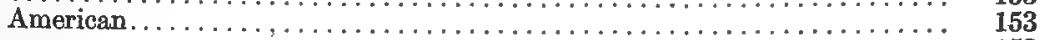

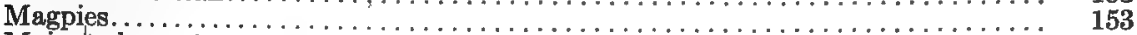

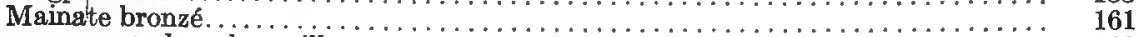

Mallard couleur de rouille. . . . . . . . . . . . . . . . . . . . . . . . . 160

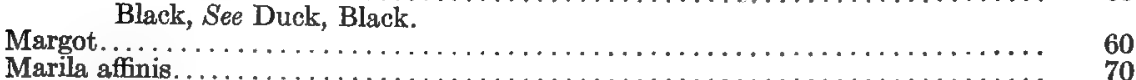

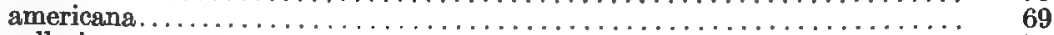

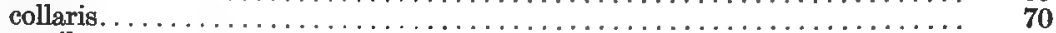

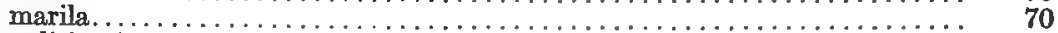

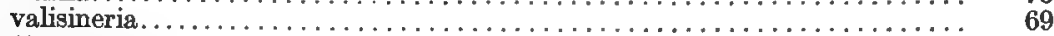

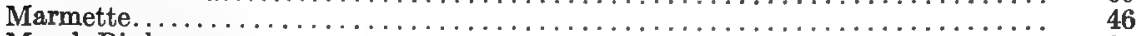

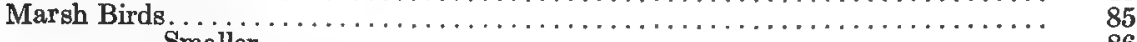

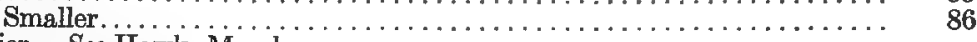

Marsh Harrier. See Hawk, Marsh.

Martin, Bee. See Kingbirt.

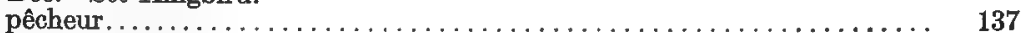

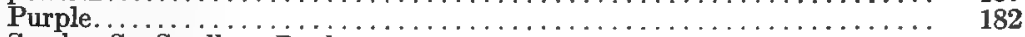

Martinet des chemines................................ 145

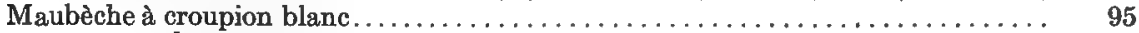

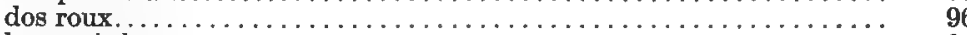

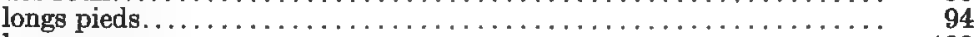

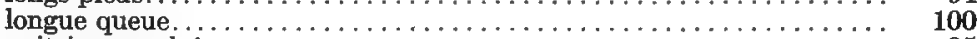

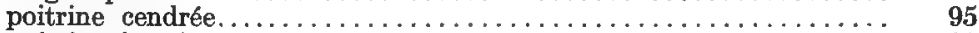

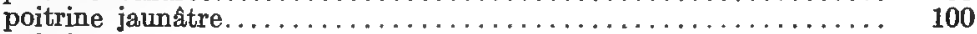

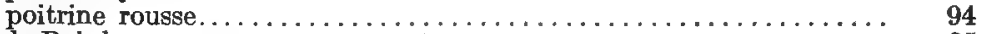

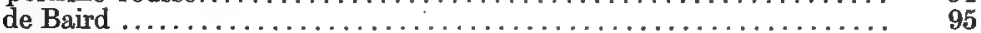

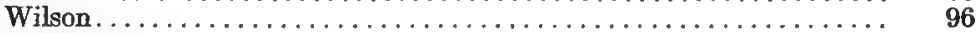

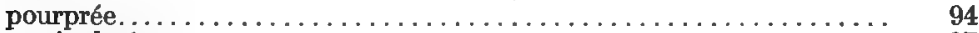

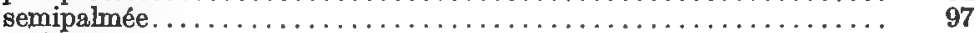

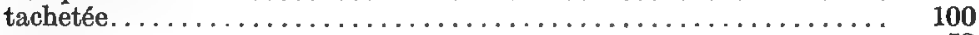

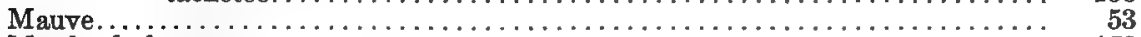

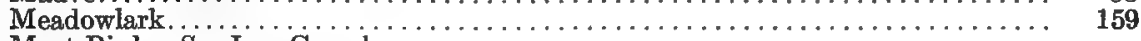

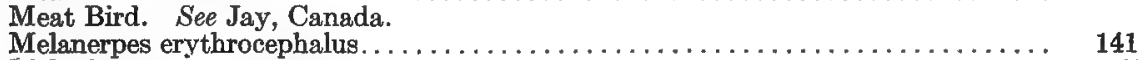

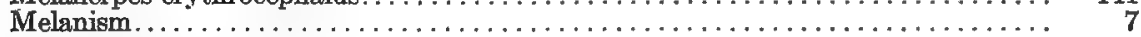

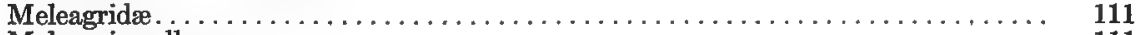

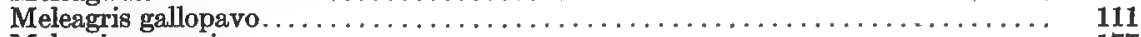

Melospiza georgiana. . . . . . . . . . . . . . . . . . . . . . . . . . . . . . . 177

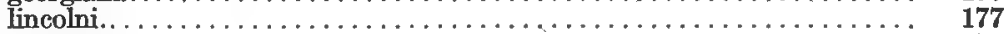

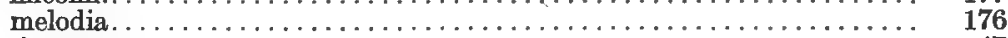

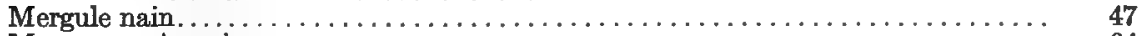

Merganser, American. . . . . . . . . . . . . . . . . . . . . . . . . . . . . 64

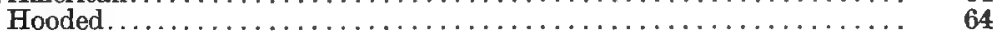

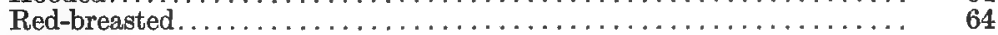

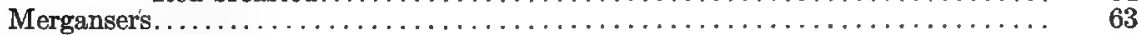

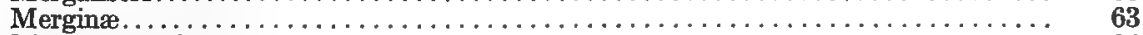

Mergus americanus. . . . . . . . . . . . . . . . . . . . . . . . . . . . . . . 64

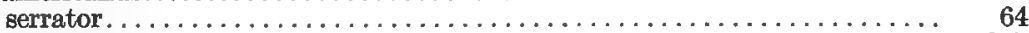

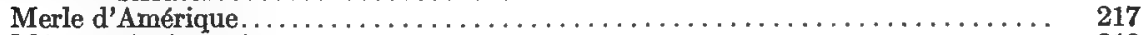

Mésange à tête noire. . . . . . . . . . . . . . . . . . . . . . . . . . . . . . . 212

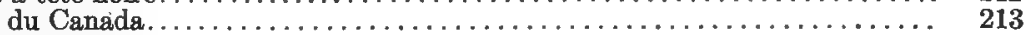

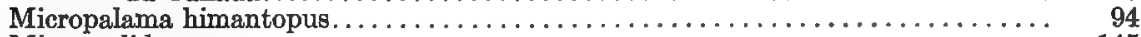

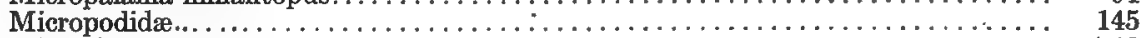

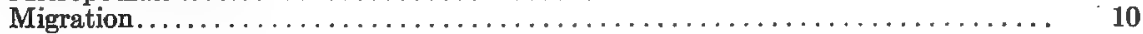


Milan à queue d'aronde.

Page.

Milouin à tête rousse. aux yeux rouges. . . . . . . . . . . . . . . . . . . . . . . . . . 69

Mimidæ.

Mimus polyglottos....................................... 206

Mniotiltidæ.............................................. 190

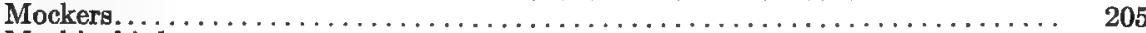

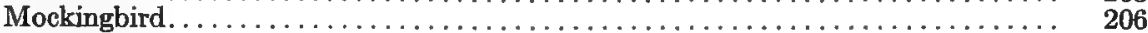

Moineau domestique. . . . . . . . . . . . . . . . . . . . . . . . . . . . 164

Molothrus ater............................................. 157

Moose Bird. See Jay, Canada.

Morillon à collier......................................... 70

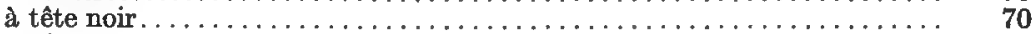

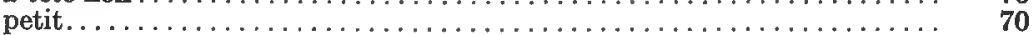

Motacillidæ........................................... 205

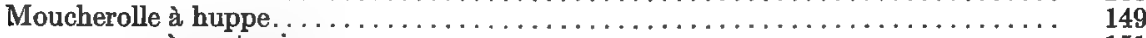

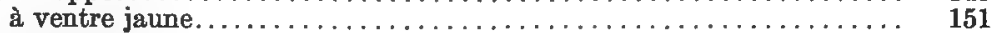

aux côtés olive................................. 150

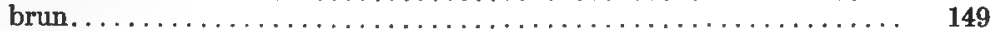

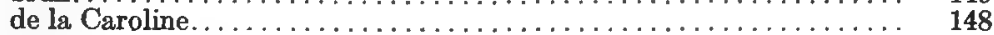

des aulnes............................................ 151

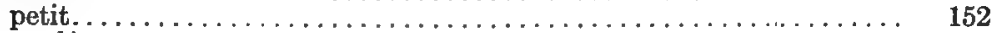

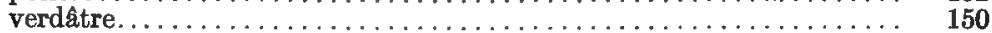

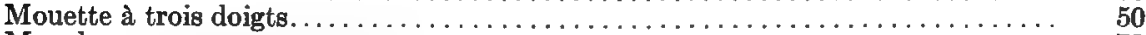

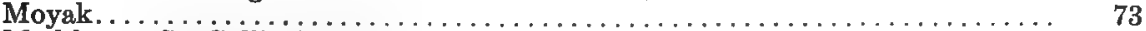

Mud-hen. See Gallinule, Florida.

Red-billed. See Gallinule, Florida.

White-billed. See Coot, American.

Mud-hens

Murre, Brünnich's. See Guillemot, Thick-billed.

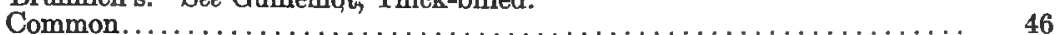

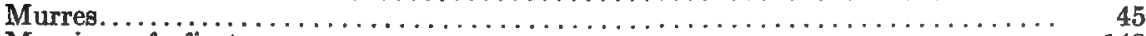

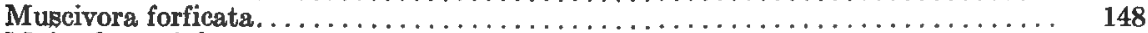

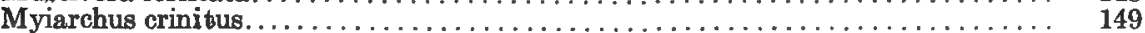

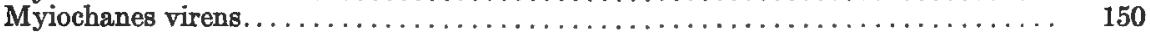

N.

Nannus hiemalis...................................... 209

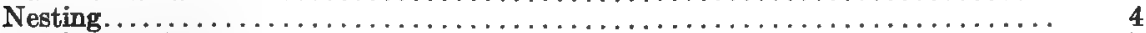

Nettion carolinense........................................... 67

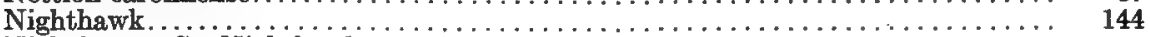

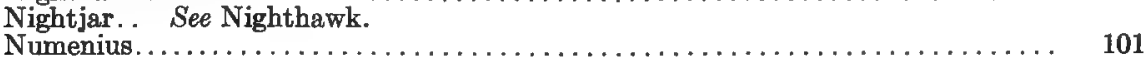

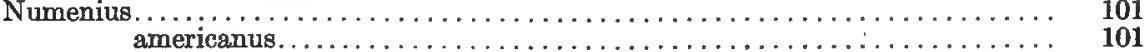

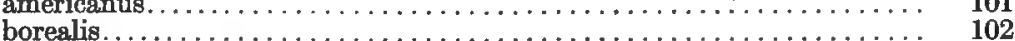

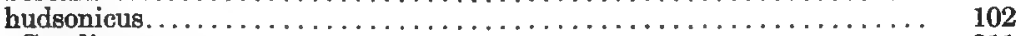

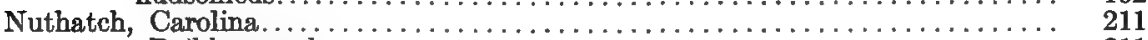

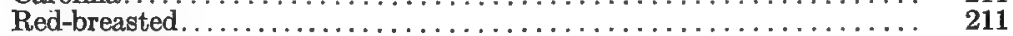

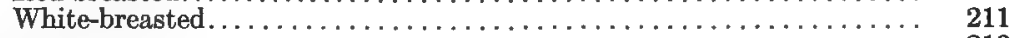

Nuthatches. ......................................... 210

Nuttallornis borealis. . . . . . . . . . . . . . . . . . . .

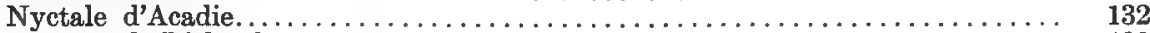

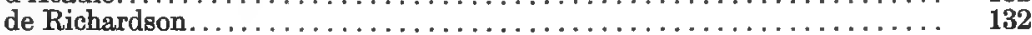

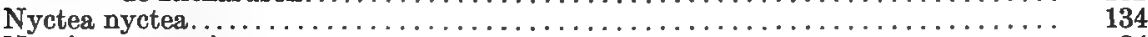

Nycticorax nycticorax.......................................... 84

o.

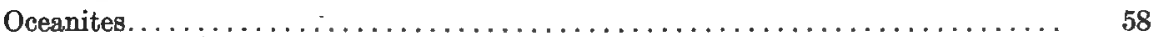

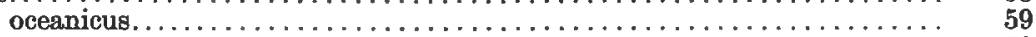

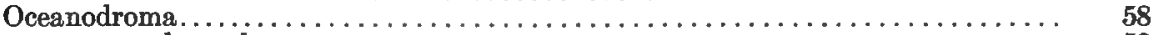

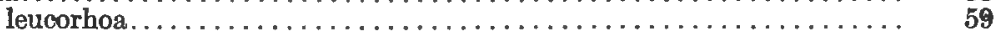

Odontophoridæ....................................... 106 


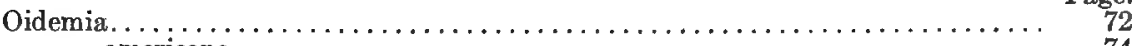

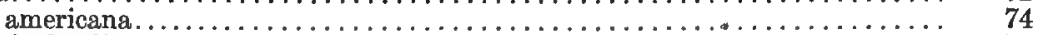

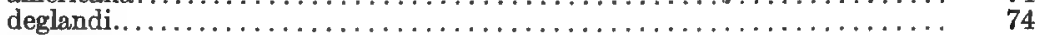

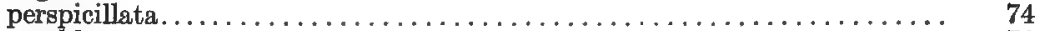

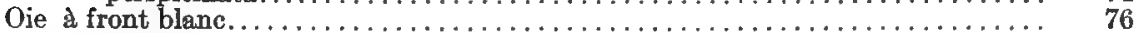

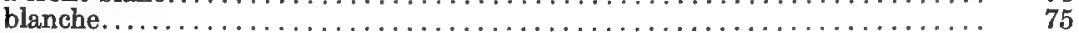

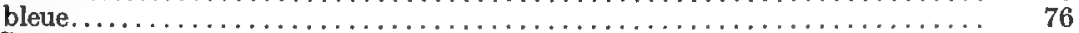

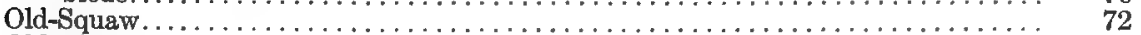

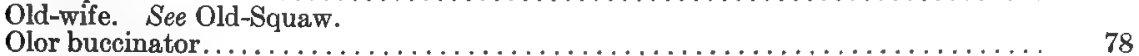

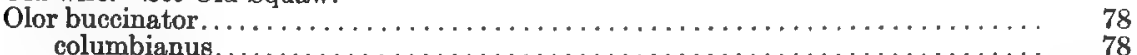

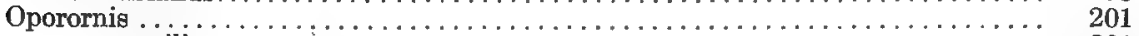

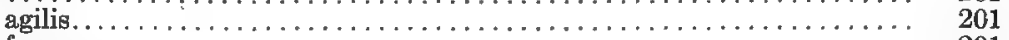

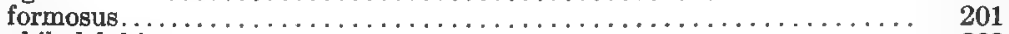

philadelphia...................................... 202

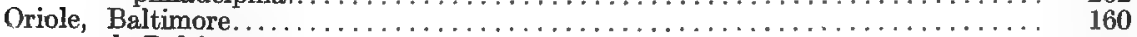

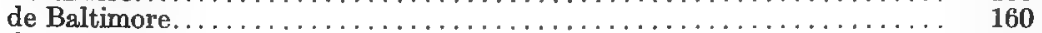

Orchard. . . . . . . . .

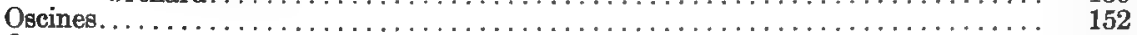

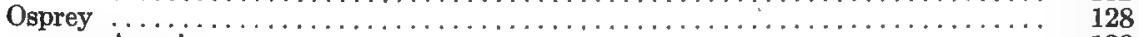

Osprey American. . . . . . . . . . . . . . . . . . . . . . . . . . . . . . 128

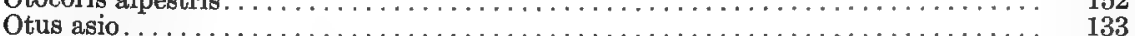

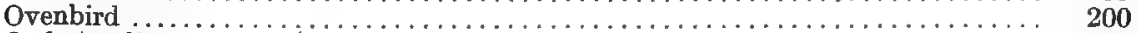

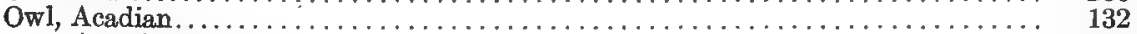

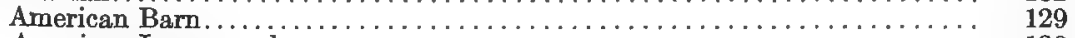

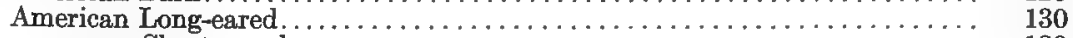

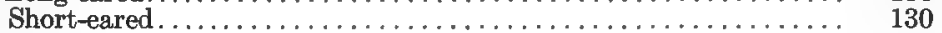

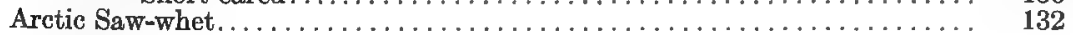

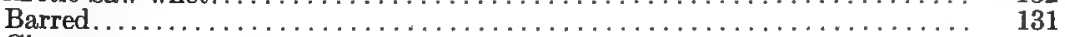

Cinereous................................................... 131

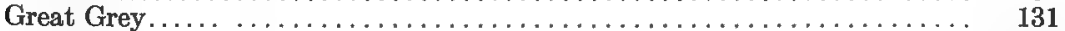

Great Horned . . . . . . . . . . . . . . . . . . . . . . . . . . . . . . . . 133

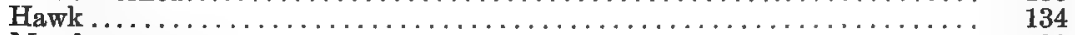

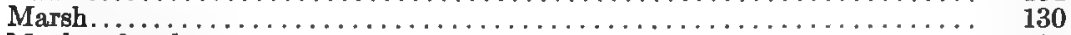

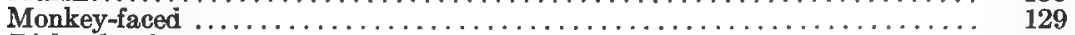

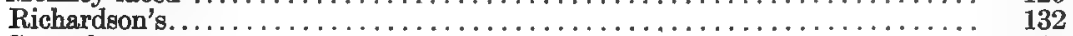

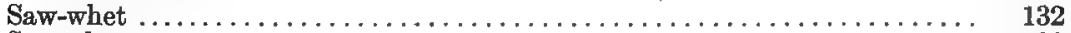

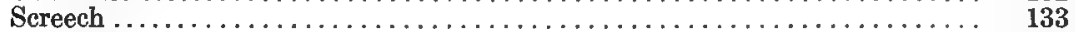

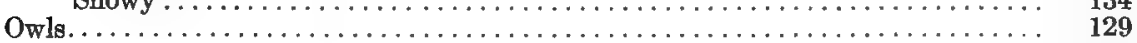

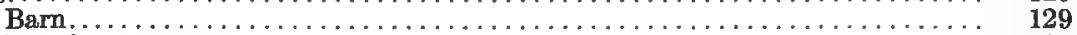

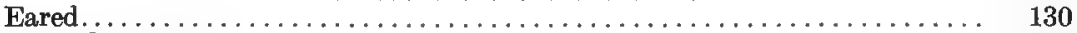

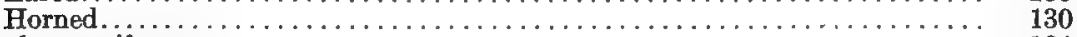

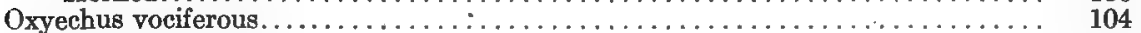

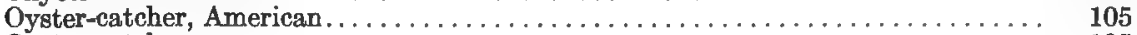

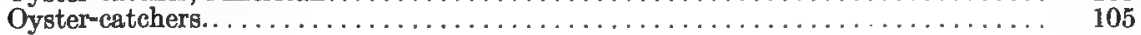

P.

Pandion haliætus carolinensis............................ 128

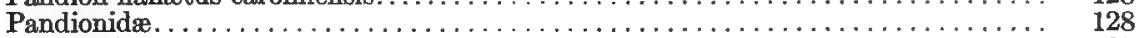

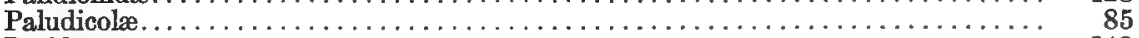

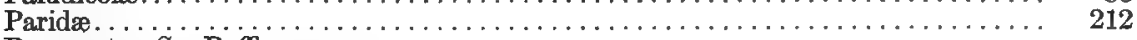

Paroquet. See Puffin.

Parrot, Sea. See Puffin.

Partridge. See Grouse, Ruffed.

Birch. See Grouse, Ruffed.

Spruce. See Grouse, Spruce.

Passer domesticus...................................... 164

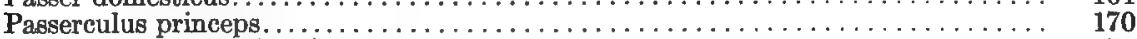

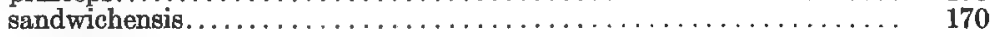

$57172-16 \frac{1}{2}$ 
Passerella iliaca.

Passeres.

Passerherbulus henslowi. . .

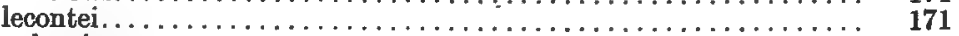

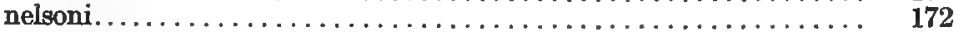

Passerina cyanea...................................... 180

Peabody-bird. See Sparrow, White-throated.

Pedixcetes phasianellus.

Peep, Black-legged. See Sandpiper, Semipalmated.

Green-legged. See Sandpiper, Least.

Mud. See Sandpiper, Least.

Pelecanidæ

Pelicans

Pelidna alpina.

hud

Perchers, Songless.

Perching Birds

Perisoreus canadensis.

Perroquet.

Petrel de Leach.

Wilson

Leach's.

Wilson's.

Petrels.

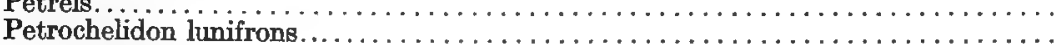

Pewee, Bridge. See Phoebe.

Wood.

Pewit. See Sandpiper, Solitary.

Phalacrocoracidæ

Phalacrocorax auritus.

Phalarope de Wilson. . . . . . . . . . . . . . .

Phalarope, Grey.

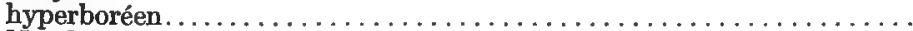

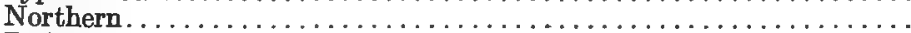

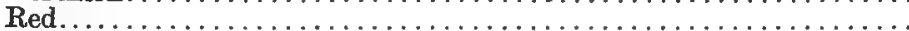

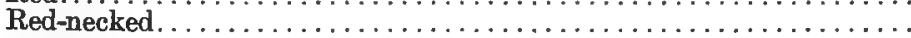

Phalarope roux.

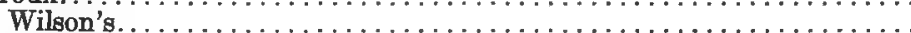

Phalaropes.

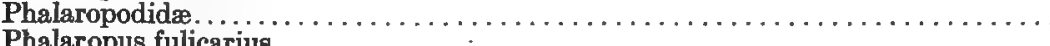

Phasiani.

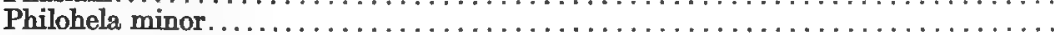

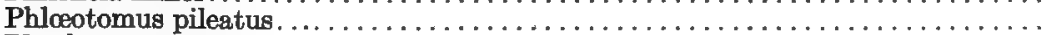

Phoebe.

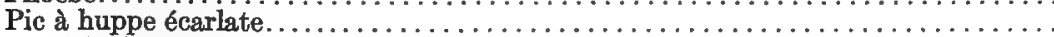

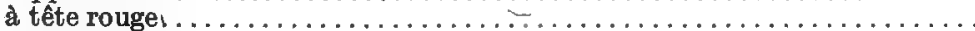

arctique.

chevelu.

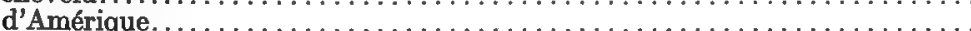

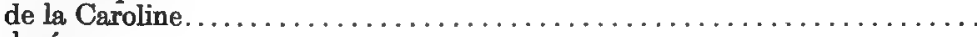

doré Caroline..................

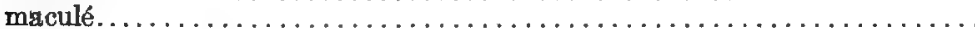

minule.

Pica Pica.

Picidæ.

Picoides americantus.

Pie d'Amérique.

Pie-greiche boréale.

Pigeon. See Guillemot, Black. 
Pigeon, Passenger $\ldots \ldots \ldots \ldots \ldots \ldots \ldots$

Sea. See Guillemot, Black.

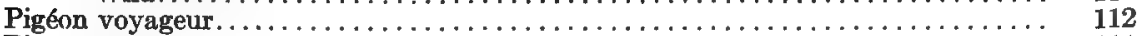

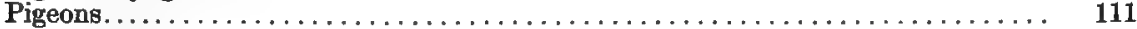

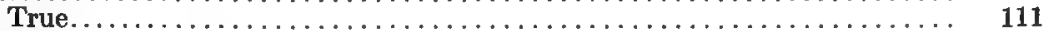

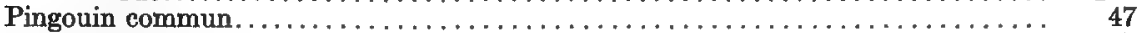

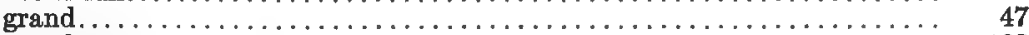

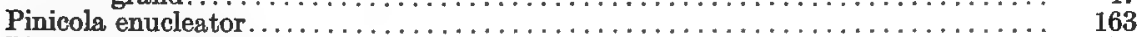

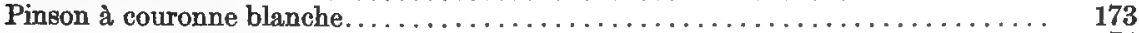

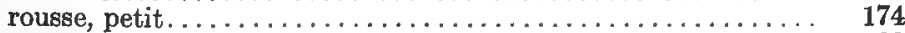

ailes baies.......................................... 169

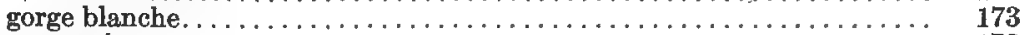

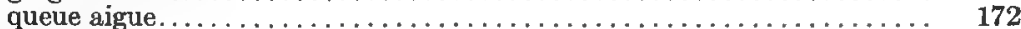

aux yeux rouges........................................ 178

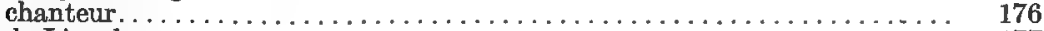

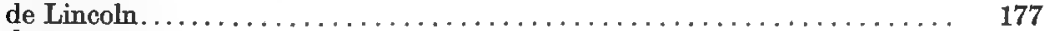

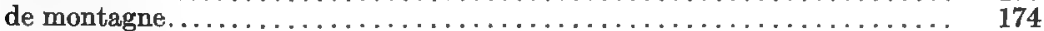

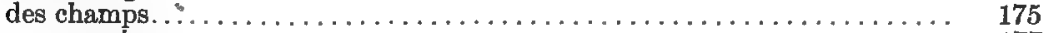

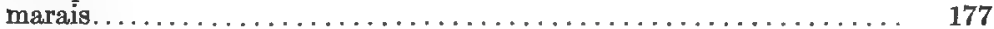

prés................................................. 170

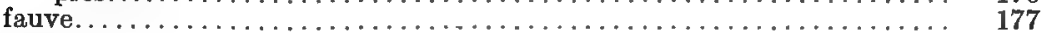

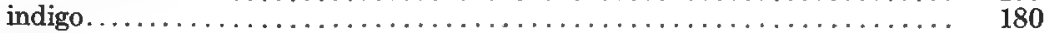

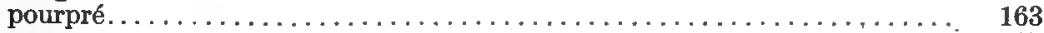

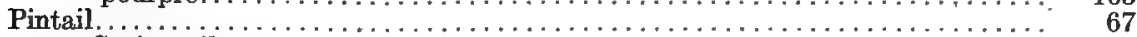

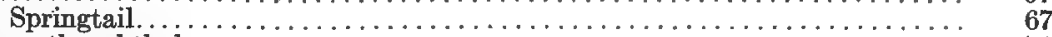

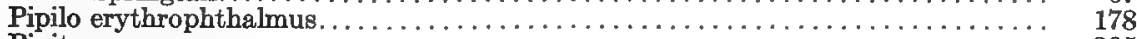

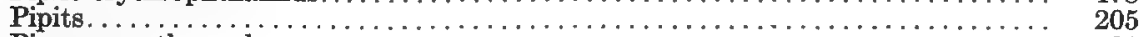

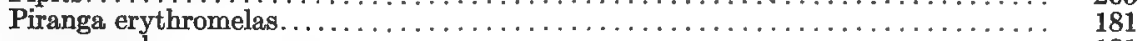
rubra.............................................. 181

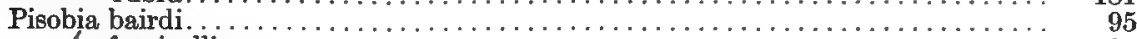

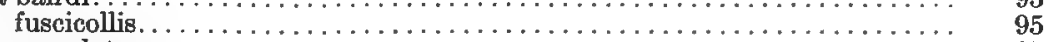

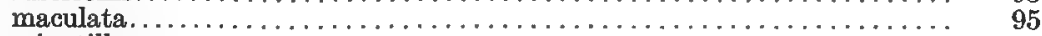

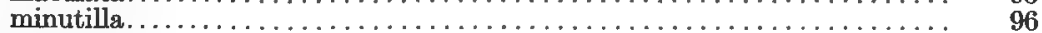

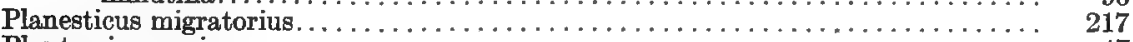

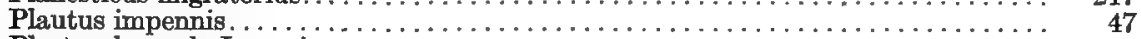

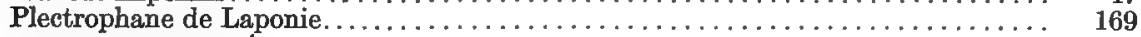

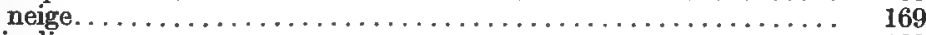

Plectrophenax nivalis. . . . . . . . . .

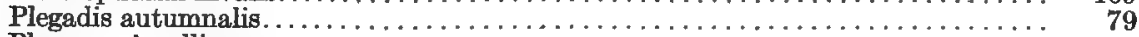

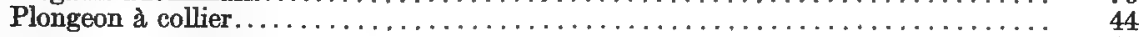

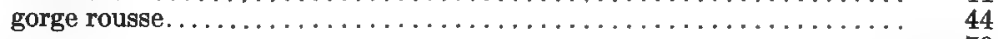

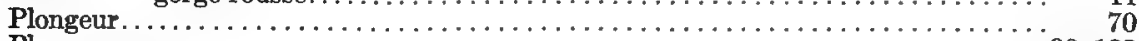

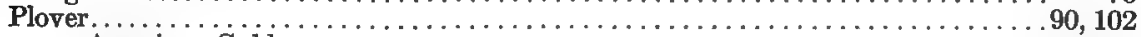

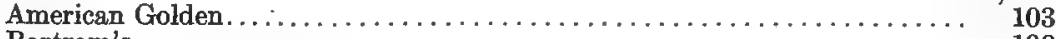

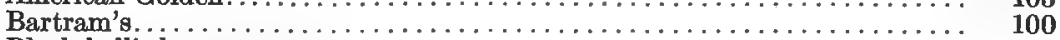

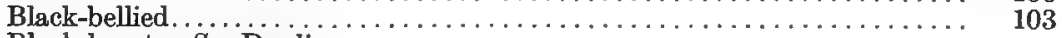

Black-heart. See Dunlin.

Calico. See Turnstone.

Carriquet. See Turnstone.

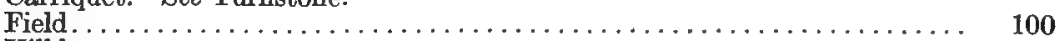

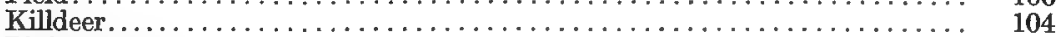

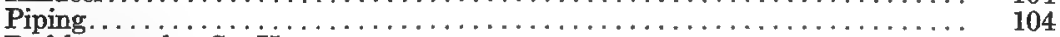

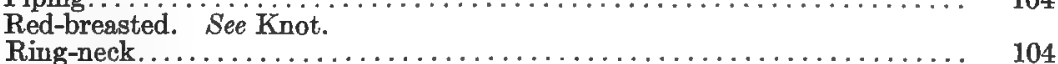

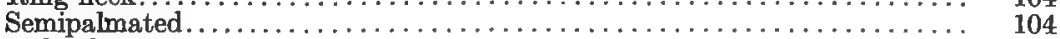

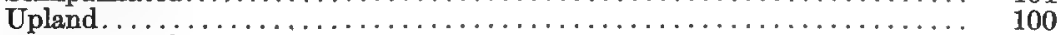

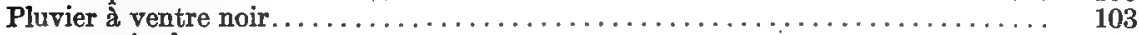

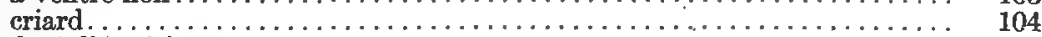

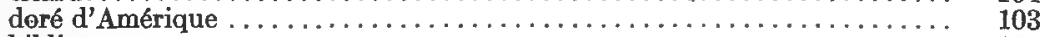

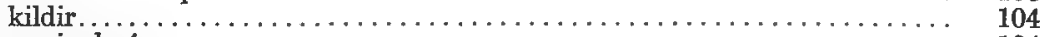

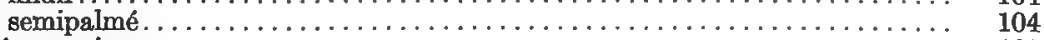

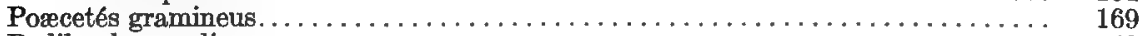

Podilymbus podiceps.................................. 43 
Polioptila cærulea

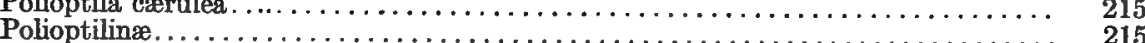

Porzana carolina........................................ 88

Preacher-bird. See Vireo, Red-eyed.

Procellariidæ........................................ 57

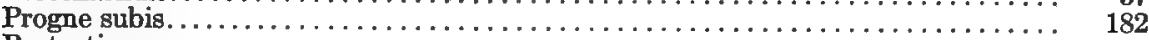

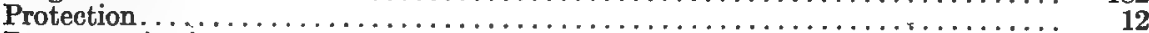

Protonotaria citrea........................................ 192

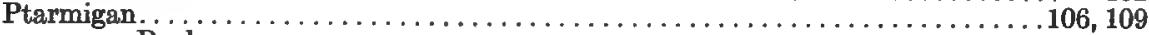

Rock...................................., 110

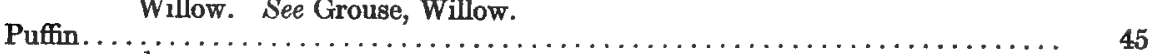

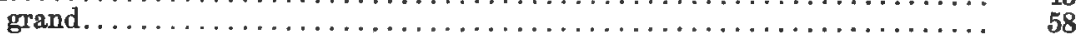

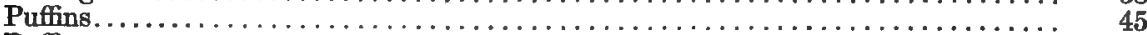

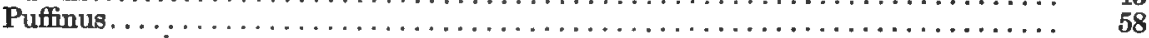

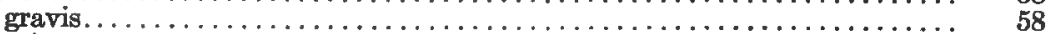

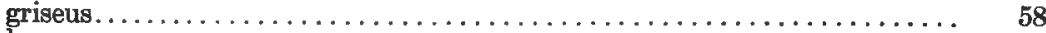

Pygopodes........................................ 41

Q.

Qua-bird. See Heron, Black-crowned Night.

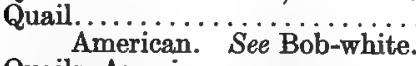

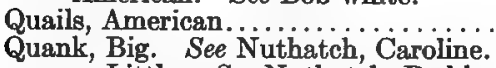

Little. See Nuthatch, Red-breasted.

Querquedula discors.

Quisculus quiscula.

R.

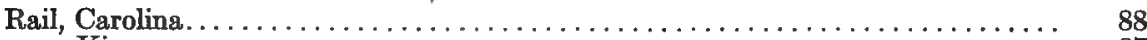

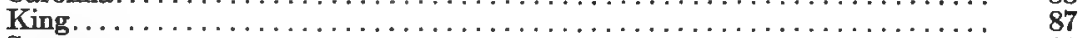

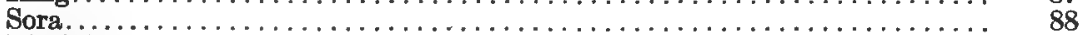

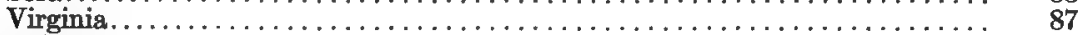

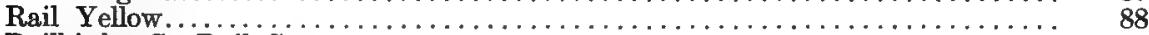

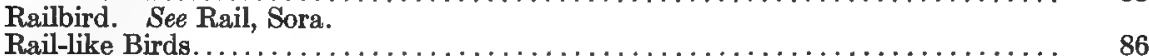

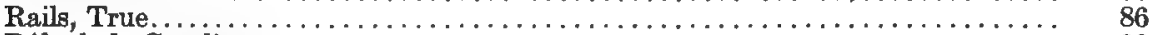

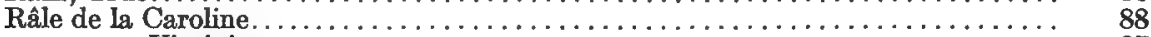

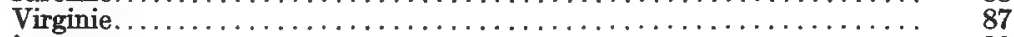

jaune........................................ 88

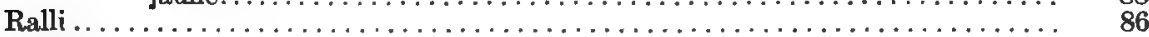

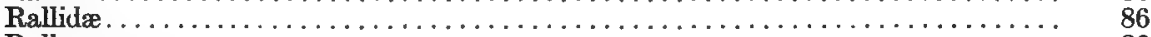

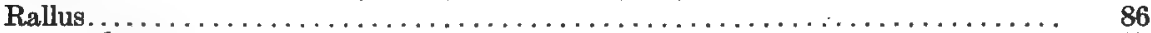

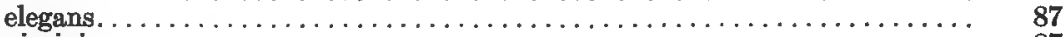

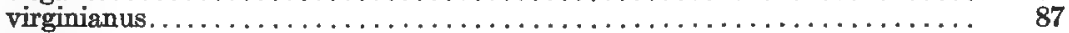

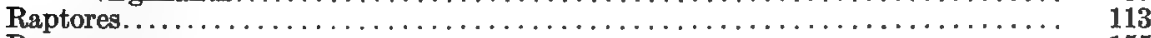

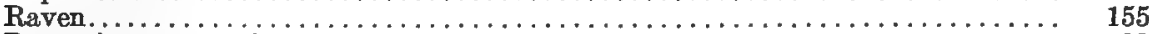

Recurvirostra americana.................................... 92

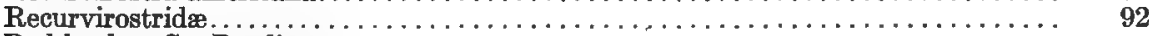

Red-back. See Dunlin.

Red-bird. See Cardinal and Tanager, Scarlet.

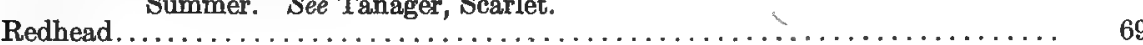

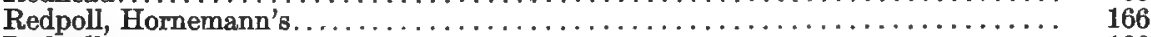

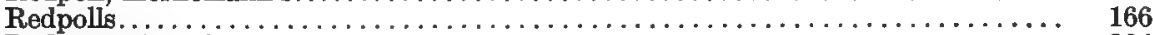

Redstart, American. . . . . . . . . . . . . . . . . . . . . . . . . 204

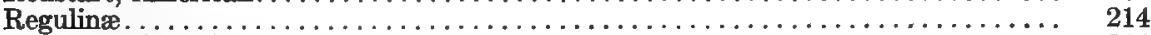

Regulus calendula.................................... 214

Ricebird. See Bobolink.

See Gallinule, Florida. 
Ring-neck. See Plover, Killdeer.

Riparia riparia.

Rissa tridactyla.

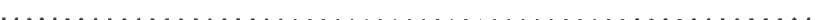

Golden. See Oriole, Baitimore.

Roitelet à couronne rubis. . . . .

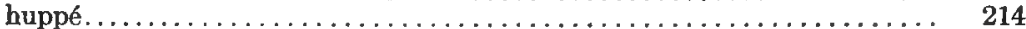

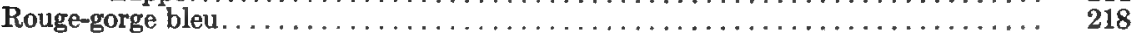

S.

Saddle-back. See Gull, Great Black-backed.

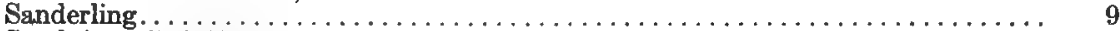

Sandpiper, Baird's. . . . . . . . . . . . . . . . . . .

Bartramian. See Plover, Upland.

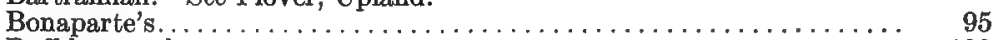

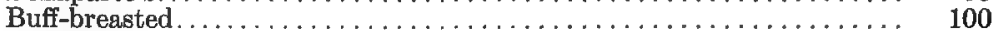

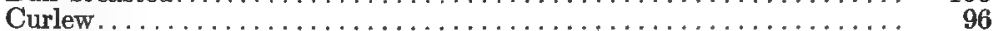

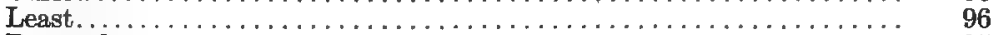

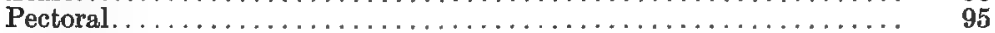

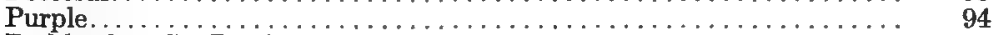

Red-back. See Dunlin.

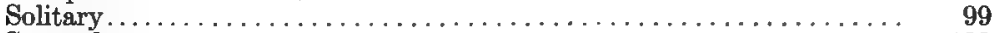

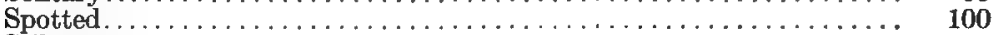

Stilt...................................... 94

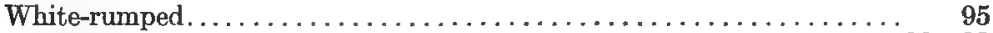

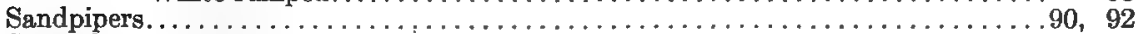

Sapsucker, Yellow-bellied............................... 140

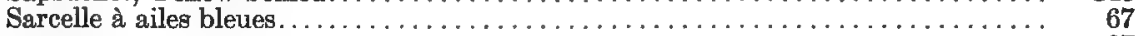

Sarcorhamphi vertes. . . . . .

Saunders, W. E........................................ 4

Saw-bill. See Merganser, American, and Merganser, Red-breasted.

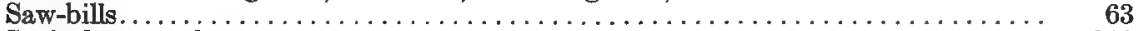

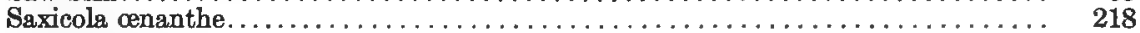

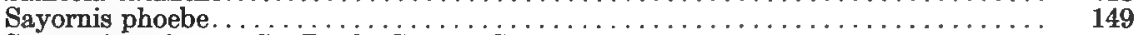

Scaup, American. See Duck, Greater Scaup.

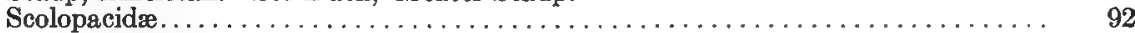

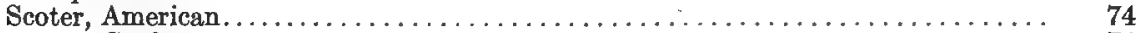

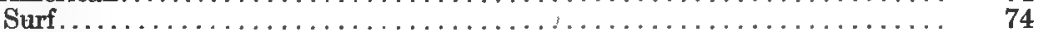

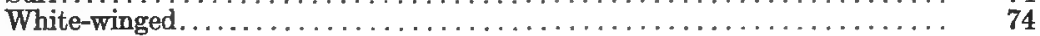

Scoters.............................................. 72

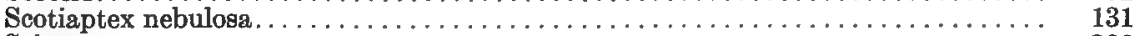

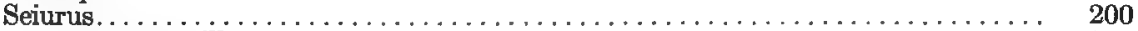

aurocapillus.......................................... 200

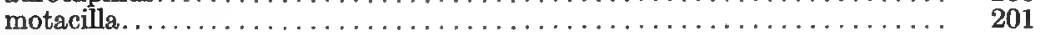

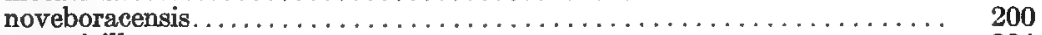

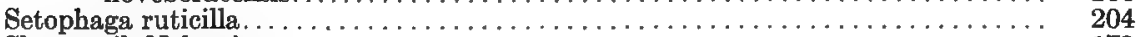

Sharp-tail, Nelson's. . . . . . . . . . . . . . . . . . . . . . . . . . . 172

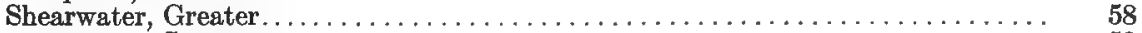

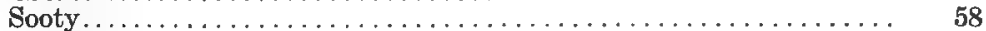

Shearwaters.................................. 58

Shelldrake. See Merganser, American, and Merganser, Red-breasted.

Shellduck. See Merganser, American, and Merganser, Red-breasted.

Shore Birds ........................................ 90

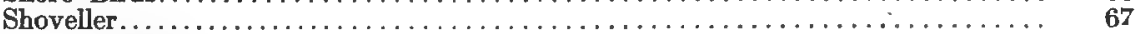

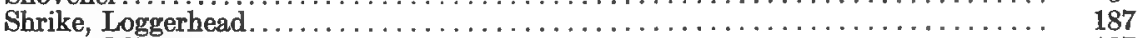

Migrant........................................ 187

Northern .......................................... 186

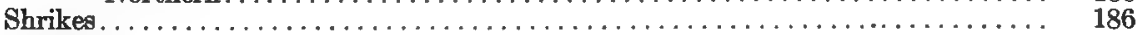

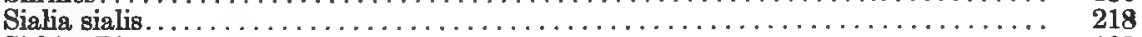

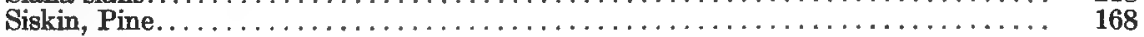




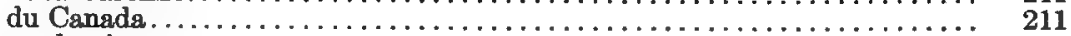

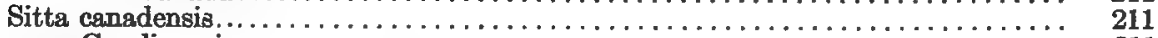

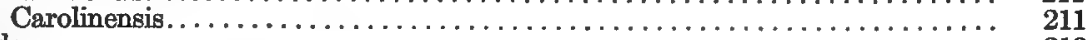

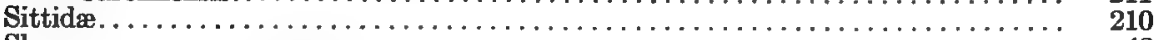

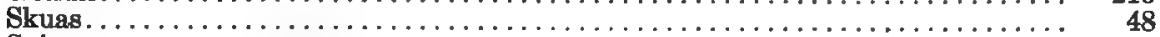

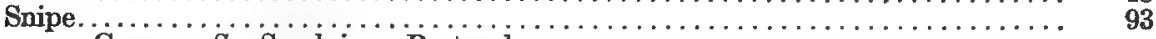

Grass. See Sandpiper, Pectoral.

Jack $\ldots \ldots \ldots \ldots \ldots \ldots \ldots \ldots \ldots \ldots \ldots \ldots \ldots \ldots \ldots,{ }_{93}$

Red-breasted. See Dowitcher.

Robin. See Dowitcher and Knot.

Rock. See Sandpiper, Purple.

Wilson's...............................

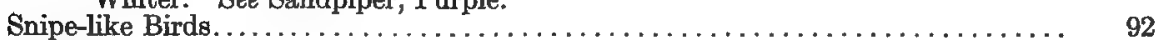

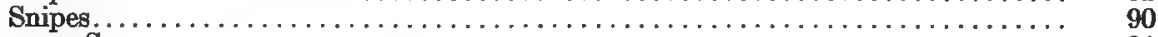

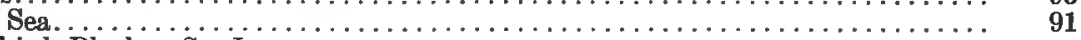

Snowbird, Black. See Junco.

Somateria............................................ $7_{72}$

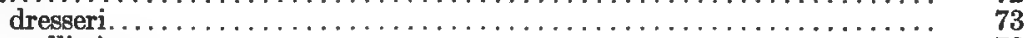

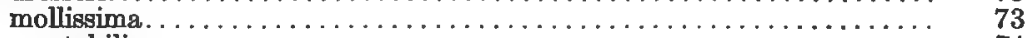

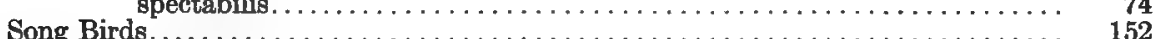

Sora. See Rail, Sora.

South-southerly. See Old-Squaw.

Sparrow, Bay-winged....................................... 169

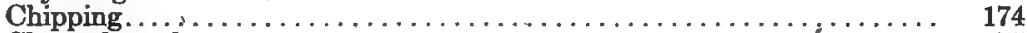

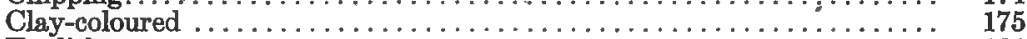

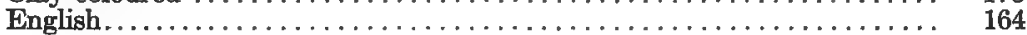

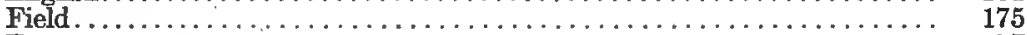

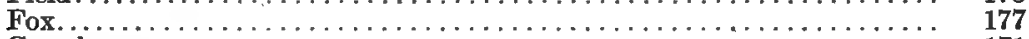

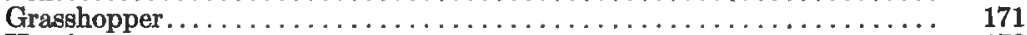

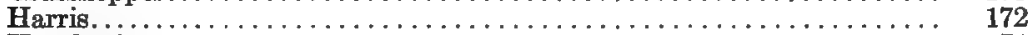

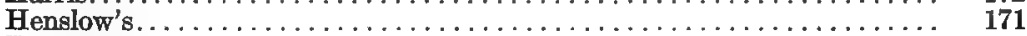

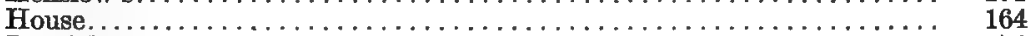

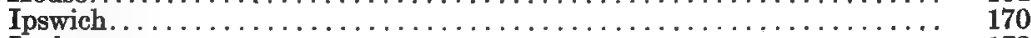

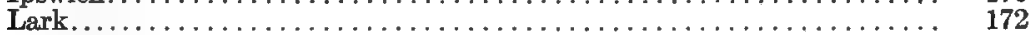

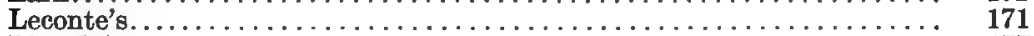

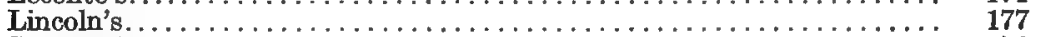

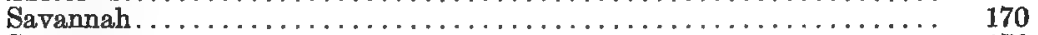

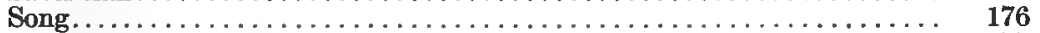

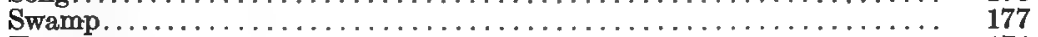

Tree............................................ ${ }_{174}$

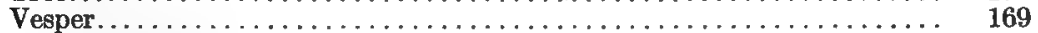

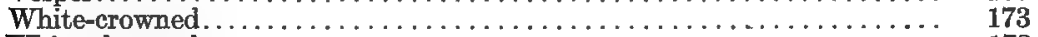

White-throated.............................................. 173

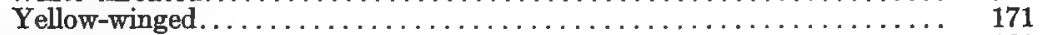

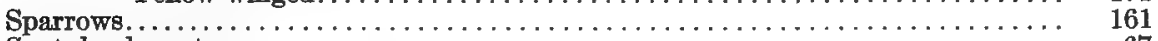

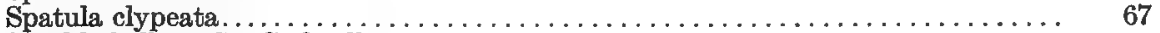

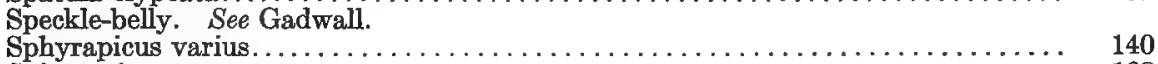

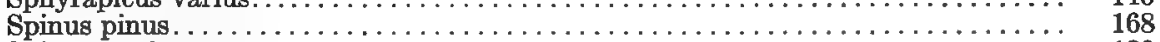

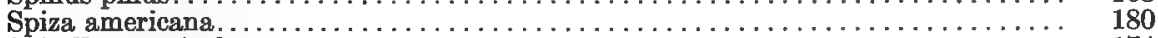

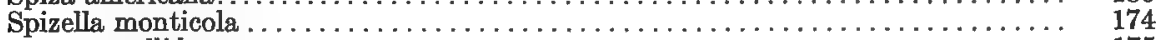

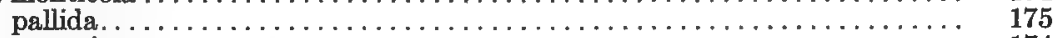

passerina......................................... 174

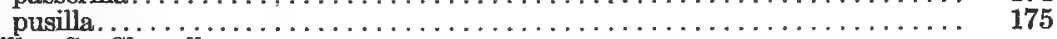

Spoonbill. See Shoveller.

Squatarola squatarola ..................................... 103

Squawk. See Heron, Black-crowned Night.

Stake-driver. See Bittern, American.

Starlings, American . ........................................ 156

Steganopodes............................................... ${ }_{59}$

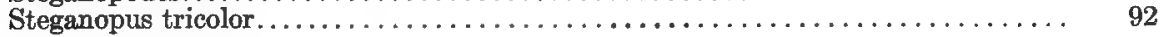


Stelgidopteryx serripennis................................... 184

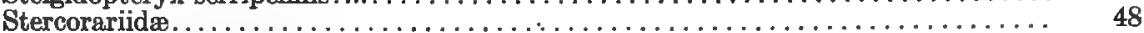

Stercorarius longicaudus. . . . . . . . . . . . . . . . . . . . . . . . . . .

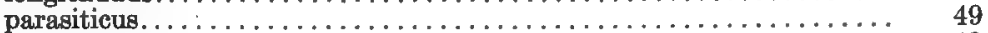

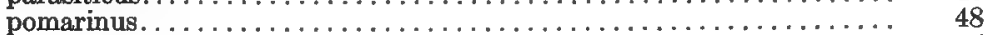

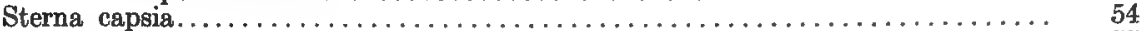

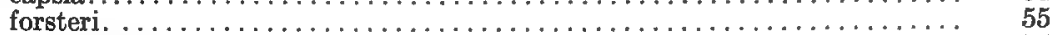

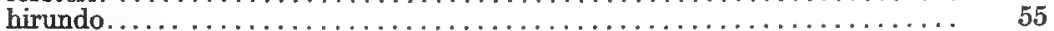

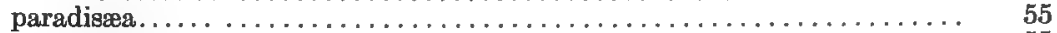

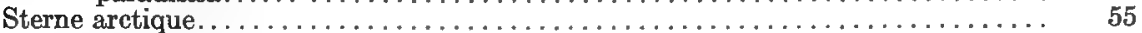

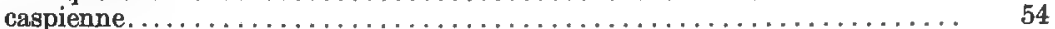

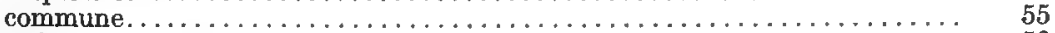

noire. 56

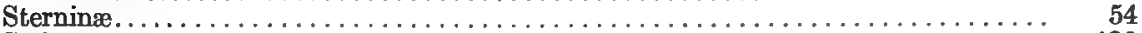

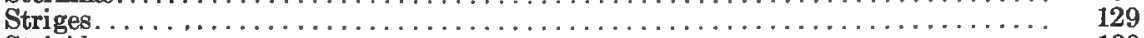

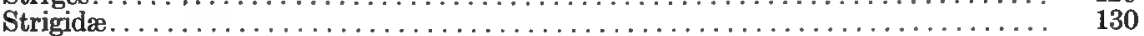

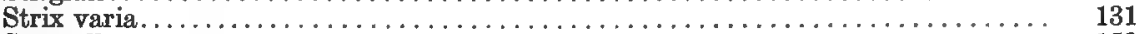

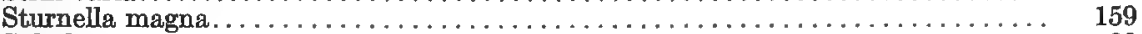

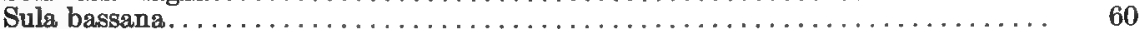

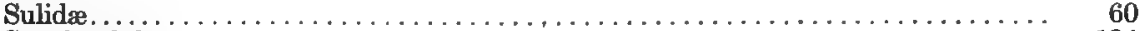

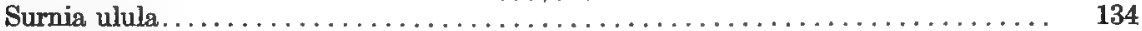

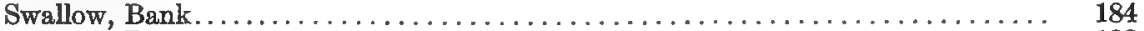

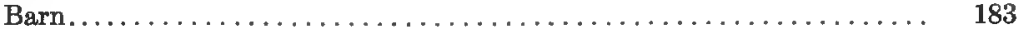

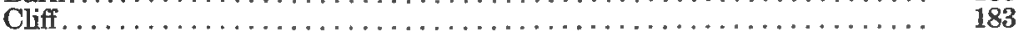

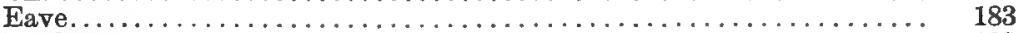

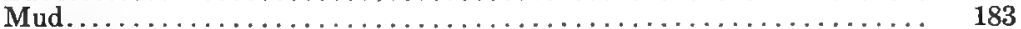

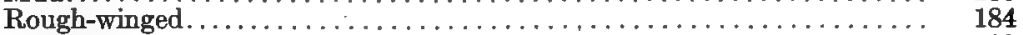

Tree............................................ 183

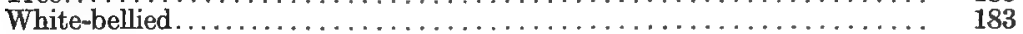

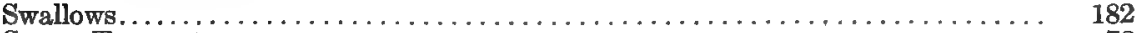

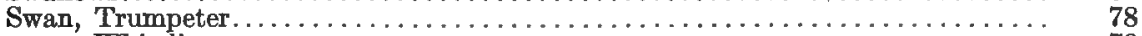

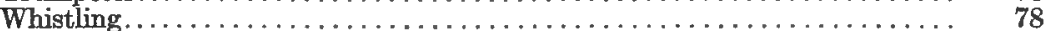

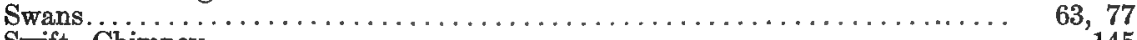

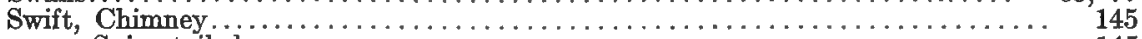

Spine-tailed........................................ 145

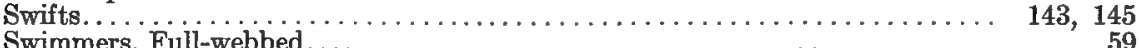

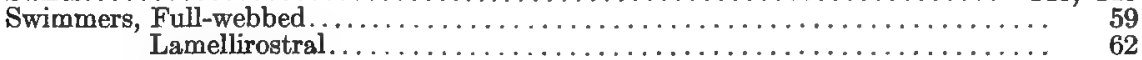

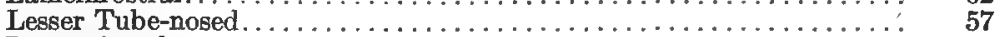

Long-winged......................................... 48

Sieve-billed....................................... 62

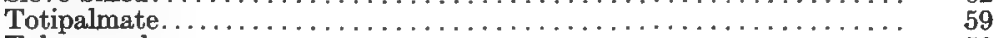

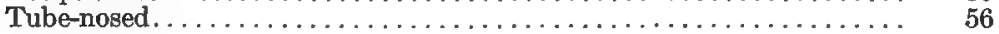

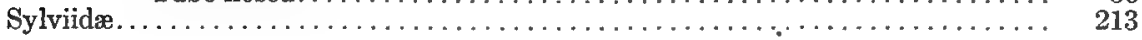

T.

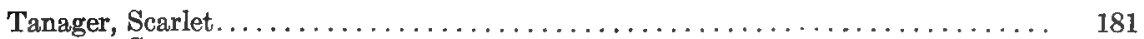

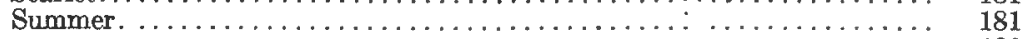

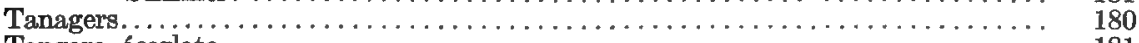

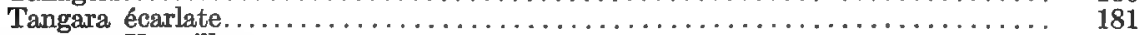

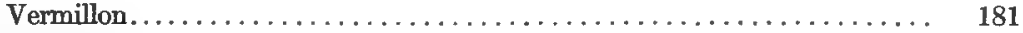

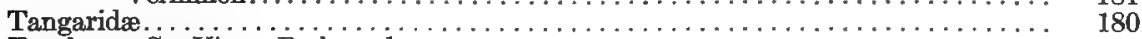

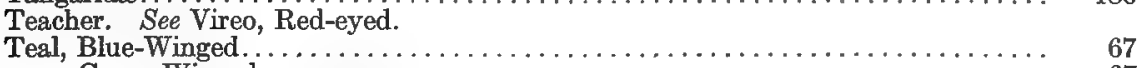

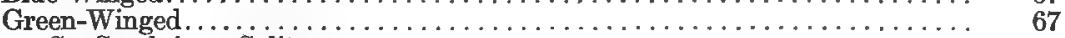

Teeter. See Sandpiper, Solitary.

Tell-tale, Greater. See Yellow-legs, Greater.

Little. See Yellow-legs, Lesser.

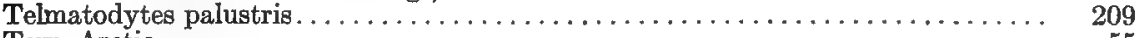

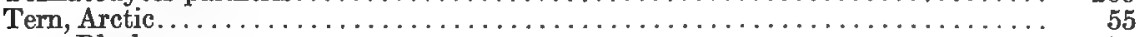

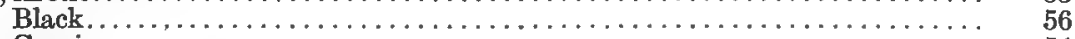

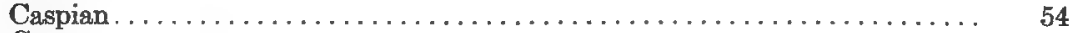

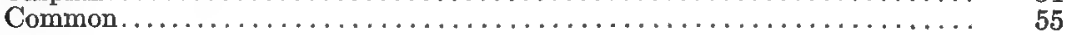


Tern, Forster's

Wilson'

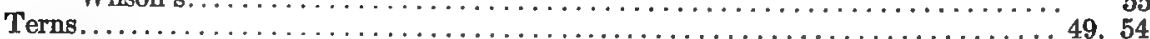

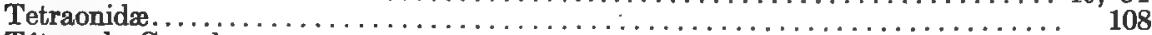

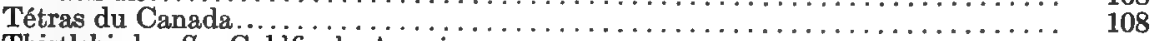

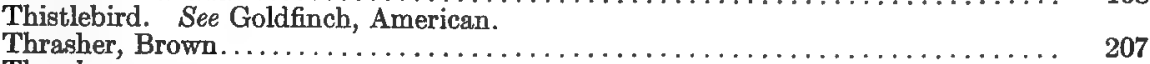

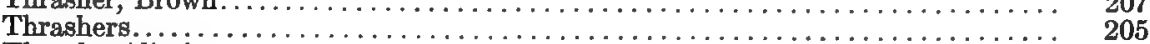

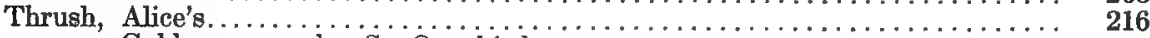

Golden-crowned. See Ovenbird.

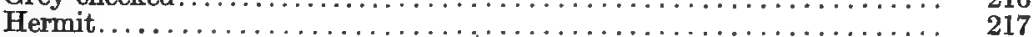

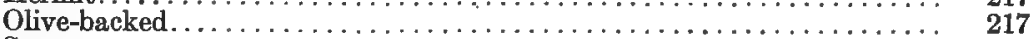

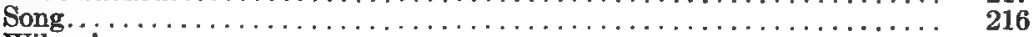

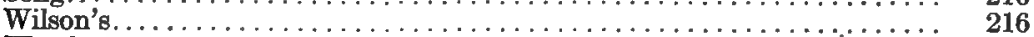

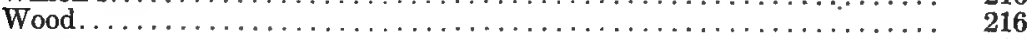

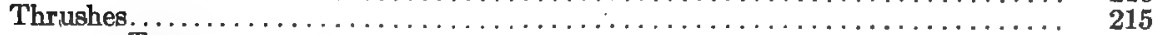

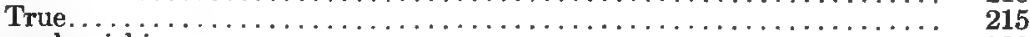

Thryomanes bewicki . . . . . .

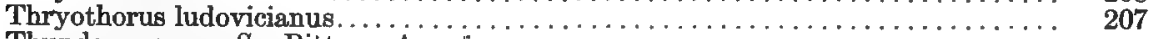

Thunder-pump. See Bittern, American.

Tinker. $\quad$ See Auk, Razor-billed.
Tip-ups. See Sandpiper, Solitary. $\ldots \ldots \ldots \ldots \ldots \ldots \ldots \ldots \ldots \ldots \ldots \ldots \ldots \ldots \ldots \ldots \ldots \ldots \ldots \ldots \ldots \ldots \ldots \ldots \ldots \ldots$

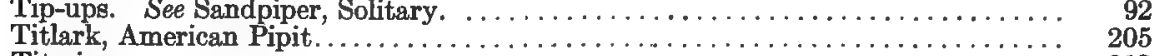

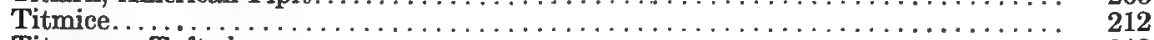

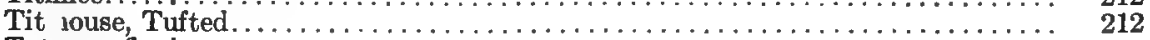

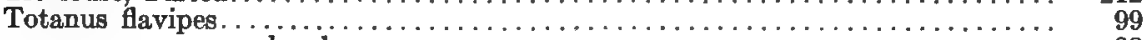

melanoleucus............................ 98

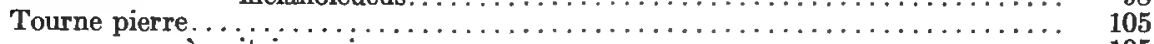

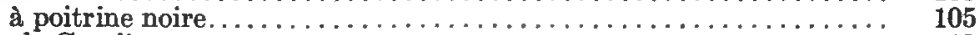

Tourterelle de la Caroline. ................................... 113

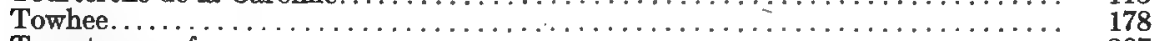

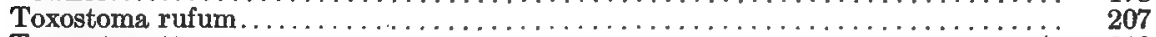

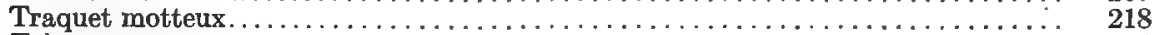

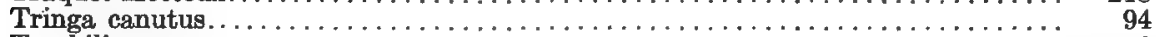

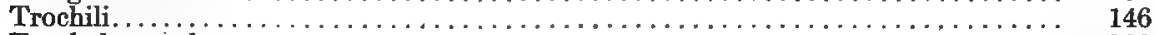

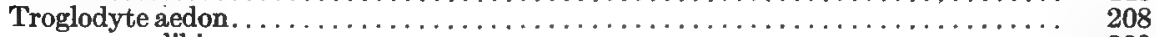

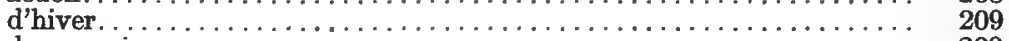

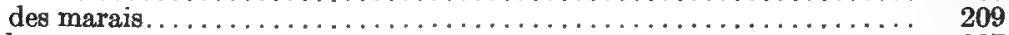

Troglodytidæ.......................................... 207

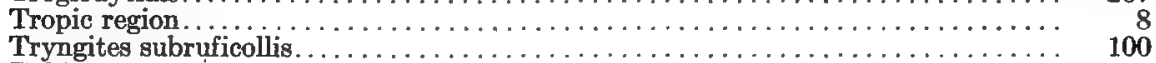

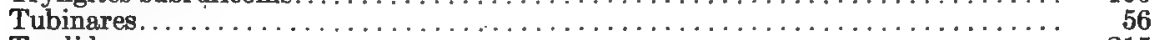

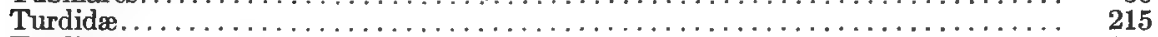

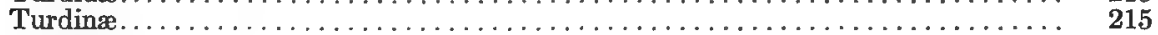

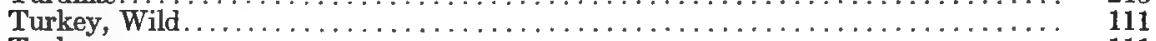

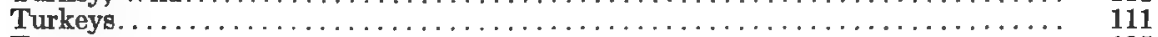

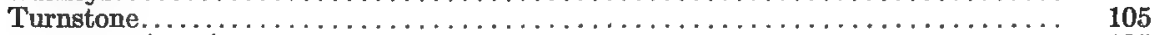

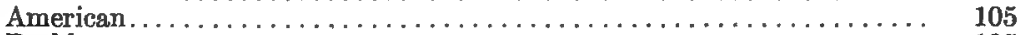

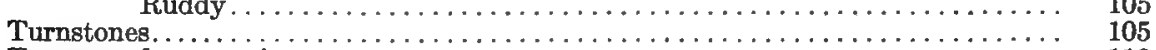

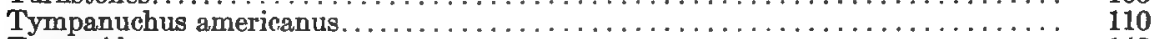

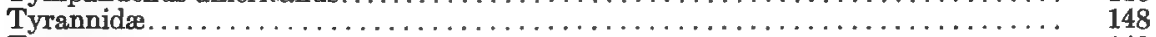

Tyrannus tyrannus........................................ 148

U.

Uria lomvia.................................... 46

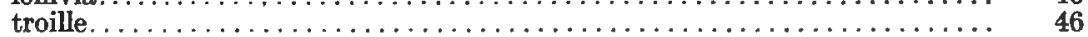


Vanneau gris

Veery. See Thrush, Wilson's.

Vermivora.

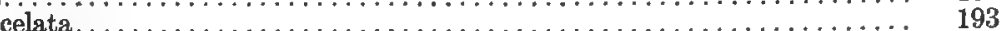

chrysoptera. . . . . . . . . . . . . . . . . . . . . . . . . . . . . . 192

peregrina........................................ 193

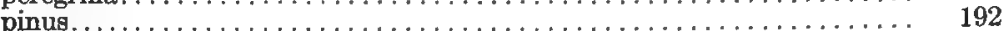

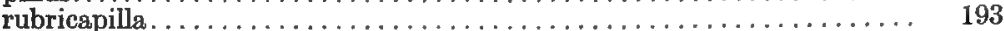

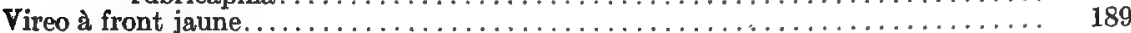

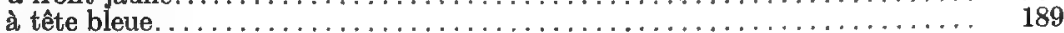

aux yeux rouges. . . . . . . . . . . . . . . . . . . . . . . . . . . 188

Blue-headed.

de Philadelphie........................................ 188

gris-olive.............................................. 189

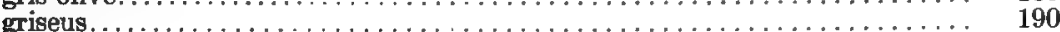

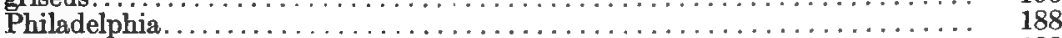

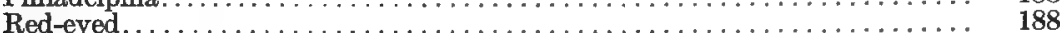

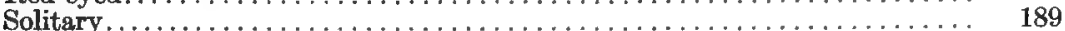

Warbling. . . . . . . . . . . . . . . . . . . . . . . . . . . . . . . . 189

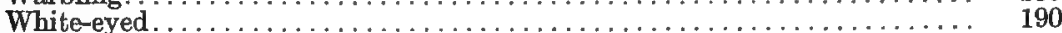

Yellow-throated . . . . . . . . . . . . . . . . . . . . . . . . . . 189

Vireonidæ

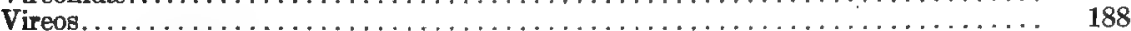

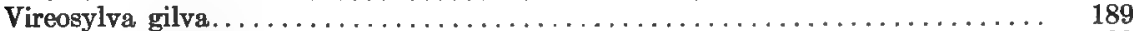

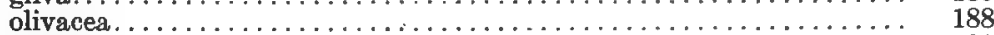

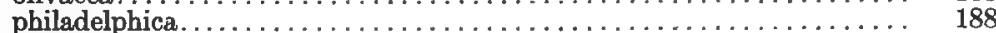

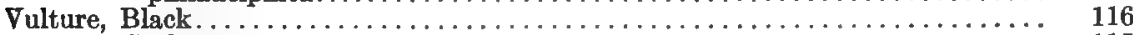

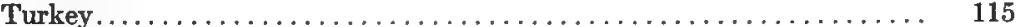

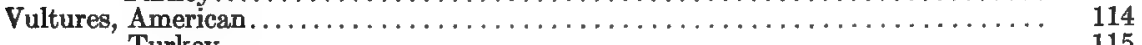

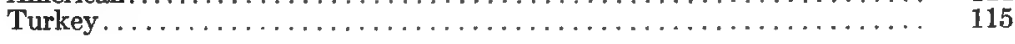

W.

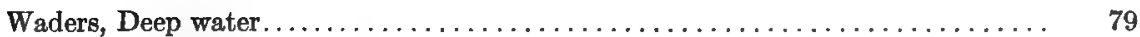

Wagtails............... Scarlet.

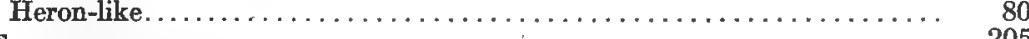

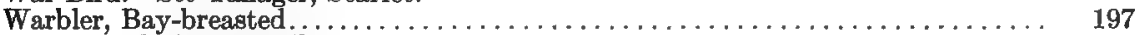

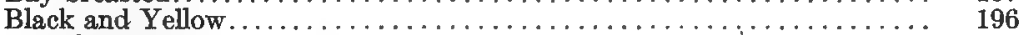

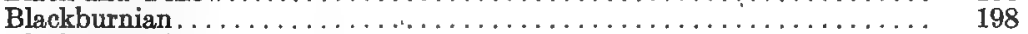

Black-capped.................................... 204

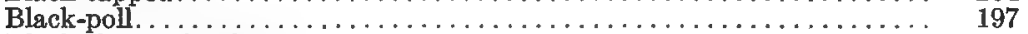

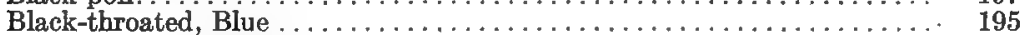

Green.............................. 198

Blue-winged. . . . . . . . . . . . . . . .

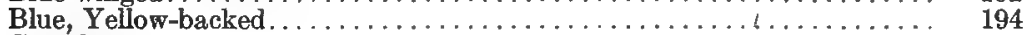

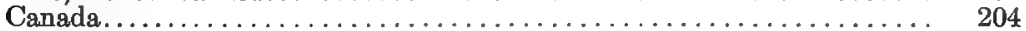

Cape May.......................................... 194

Cerulean........................................... 196

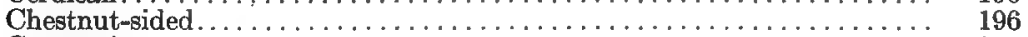

Connecticut......................................... 201

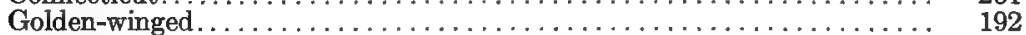

Ground ............................................. 201

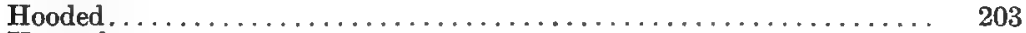

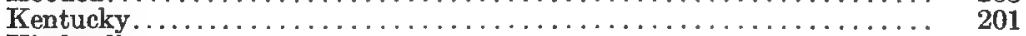

Kirtland's....................................... 198

Magnolia....................................... 196

Mourning........................................ 202

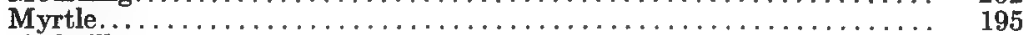

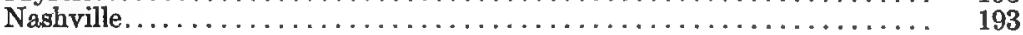




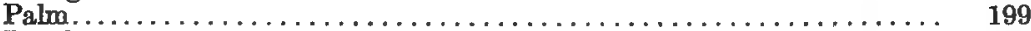

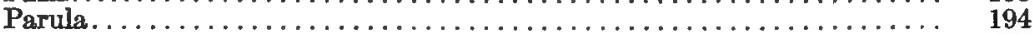

Pine............................................ 199

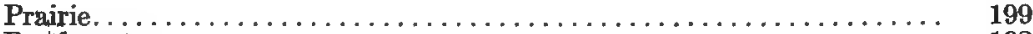

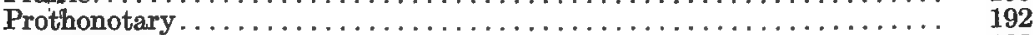

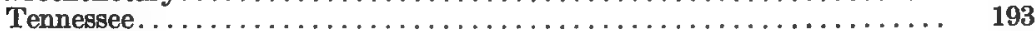

Wilson's........................................ 204

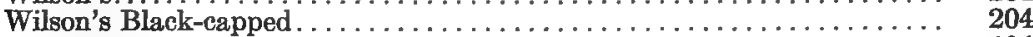

Yellow......................................... 194

Yellow-rumped...................................... 195

Warblers, Flycatching. . . . . . . . . . . . . . . . . . . . . . . . . . . 203

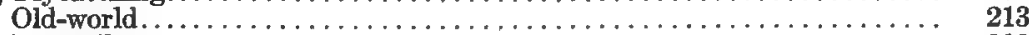

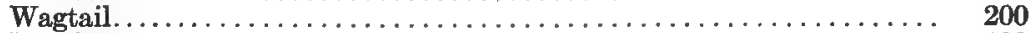

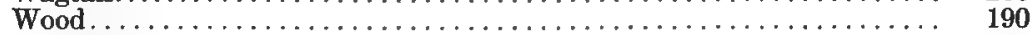

Woodland...................................... 194

Worm-eating....................................... 192

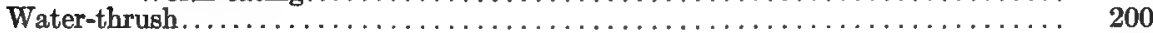

Louisiana.......................................... 201

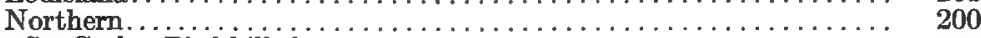

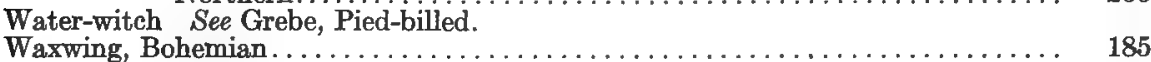

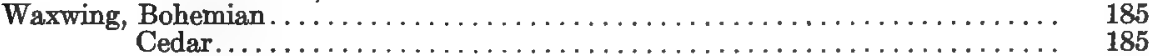

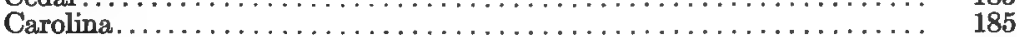

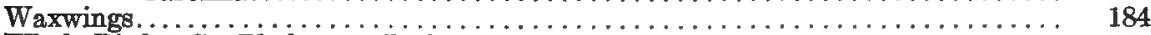

Whale Bird. See Phalarope, Red.

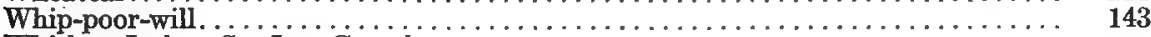

Whiskey Jack. See Jay, Canada.

Whistle-wing. See Golden-eye.

Whistler. See Golden-eye.

Willet...

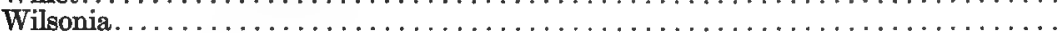

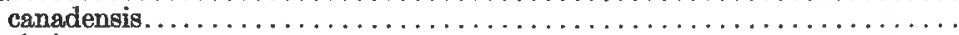

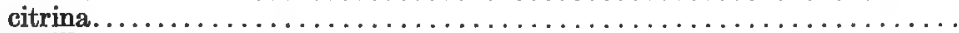

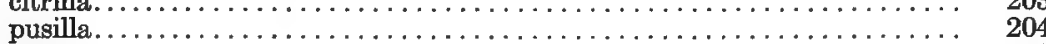

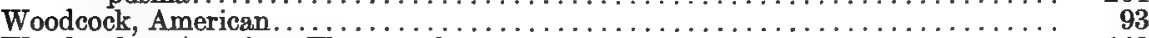

Woodpecker, American Three-toed........................................ 140

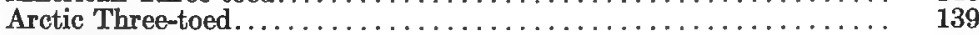

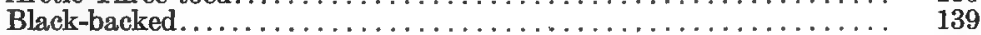

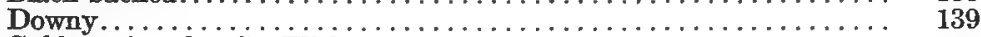

Golden-winged. See Flicker.

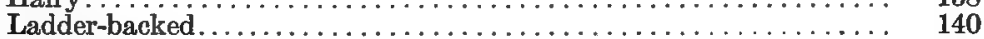

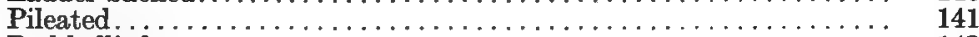

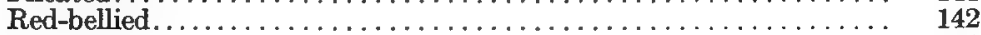

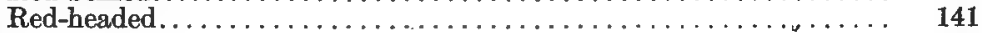

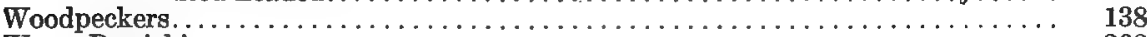

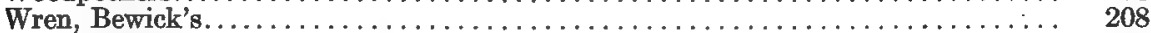

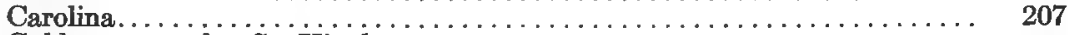

Golden-crowned. See Kinglet. 208

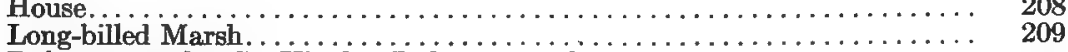

Ruby-crowned. See Kinglet, Ruby-crowned.

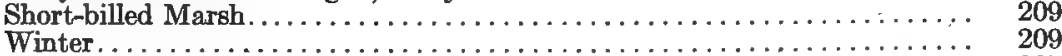

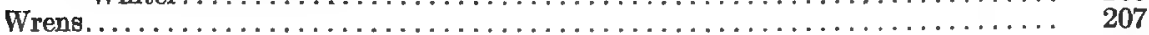

$\mathbf{X}$.

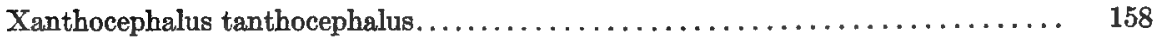


Y.

Yellow Bird, Summer. See Warbler, Yellow.

Yellow-hammer. See Flicker.

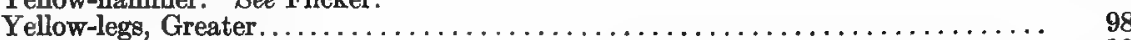

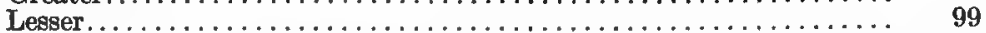

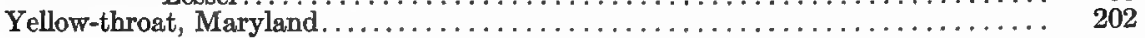

$\mathbf{Z}$.

Zamelodia ludoviciana...................................... 179

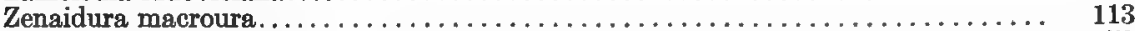

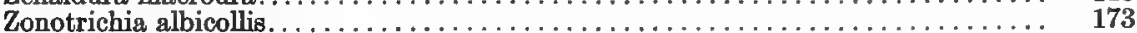

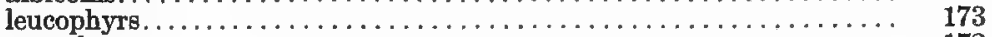

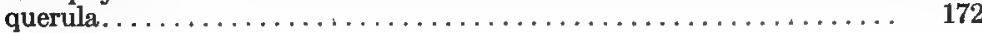










